UC-NRLF

||||||| || || || || ||| ||| ||||

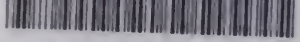

\$B 25081 


\section{GIIT OF}

President's Office

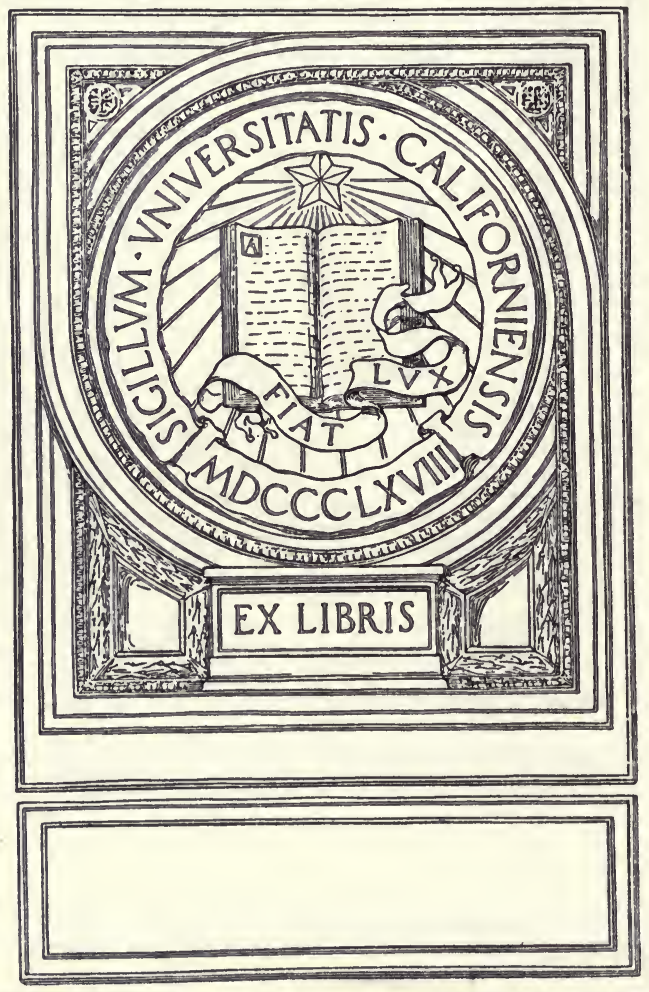








\section{OFFICIAL, REPORT OF THE SESSION OF THE}

\section{INTERNATIONAL CONGRESS OF VITICULTURE}

HELD IN RECITAL HALL AT FESTIVAL HALL PANAMA-PACIFIC INTERNATIONAL EXPOSITION, SAN FRANCISCO CAL., JULY 12 and 13, 1915

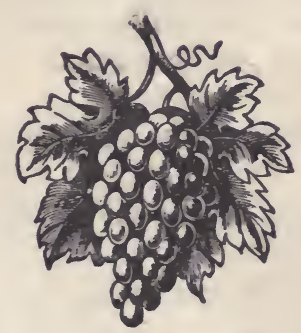

UNDER THE AUTHORITY OF THE PERMANENT INTERNATIONAL VITICULTURAL COMMISSION, BY RESOLUTION VOTED JUNE 11, 1913, AT GHENT, BELGIUM 


\section{PERMANENT INTERNATIONAL VITICULTURAL}

\section{COMMISSION.}

\section{HONORARY PRESIDENTS :}

MM.

Le Ministre d'Agriculture d'Autriche;

Le Ministre d'Agriculture d'Espagne;

Le Ministre d'Agriculture de France;

Le Ministre d'Agriculture de Hongrie;

Le Ministre d'Agriculture d'Italie;

Le Ministre d'Agriculture de Portugal;

Le Ministre d'Agriculture de Russie.

\section{BUREAU:}

Président:

M.

Méline (Jules), Sénateur, ancien Présiđent du Conseil, ancien Ministre de l'Agriculture, Président de la Commission Internationale d'Agriculture;

MM.

\section{Vice-Présidents:}

Buhl (Franz), Président de l'Union allemande des Viticulteurs, viticulteur à Deidesheim (Bavière rhénane), (Allemagne);

Karl Portele, Conseiller aulique, Inspecteur de l'Agriculture, à Vienne (Autriche);

Garcia de los Salmones, Directeur du Service Agricole de la province de Pampelune (Espagne);

Viala (Pierre), Inspecteur Général de la Viticulture, Professeur à l'Institut National agronomique (France);

Victor Kosinsky, Directeur de l'Ecole de Viticulture d'Arad (Hongrie);

Edoardo Ottavi, Député au Parlement italien, Secrétaire général du VIe Congrès international d'Agriculture, à Rome (Italie);

Cincinnato da Costa, ancien Député aux Cortès, Professeur à l'Institut Agronomique de Lisbonne (Portugal);

Basile Taïroff, Consultant au Ministère de l'Agriculture et des Domaines, Directeur du Westnik Vinodélia, à Odessa (Russie);

Muller-Thurgau (Prof. Dr), Directeur de l'Establissément fédéral d'essais pour l'arboriculture, la viticulture et l'horticulture, à Waedensweil (Suisse);

\section{PERPETUAL SECRETARY :}

M.

Prosper Gervais, Morchre de la Sosistế nationale d'Agriculture, Vice-Président de la Société des Agriculteurs de Fránce, et de la Société des Viticulteurs de France (Frappel. 


\section{INTRODUCTION.}

\section{INTERNATIONAL CONGRESS OF VITICULTURE} SAN FRANCISCO, CALIFORNIA.

July 12 and 13, 1915.

The International Congress of Viticulture of 1915 was held at San Francisco under the authority of the Permanent International Commission, in accordance with a resolution of that body voted on June 11, 1913, at Ghent, Belgium. At that time no one anticipated that by reason of a world-wide war the European members would be unable to attend.

The international character of the Congress was preserved as much as possible by the co-operation of the various countries concerned, whose governments accepted the invitation to furnish representatives from among their European commissioners. The members attending the Congress and the papers presented were almost entirely American. The absence of most of the active members of former Congresses, and the lack of their valuable papers and discussion, were serious deficiencies. The Congress, however, was valuable as an indication of the progress and extent of viticulture in the United States and the report should be of interest to the viticulturists of the world as a symposium of American viticulture.

The activities of the Congress consisted of meetings in San Francisco, at which the papers were presented and discussed, and of excursions to some of the most important viticultural centers of California.

The papers presented covered a wide range of viticultural interests. They included seven addresses on historical, educational and commercial aspects of viticulture; five on various cultural topics; seven special regional studies representing most of the grape-growing regions of the United States; fifteen studies of fungous diseases, injurious insects and of methods of control; nine papers on the chemistry, technics and products of viticulture and several miscellaneous papers. 


\section{PATRONS.}

The Governor of the State of California.

University of California.

Permanent International Viticultural Commission.

American Pomological Society.

California State Board of Viticultural Commissioners.

California Grape Protective Association.

American Wine Growers' Association.

\section{COMMISSION ON ORGANIZATION.}

His Excellency, the Governor of California.

Dr. Benjamin Ide Wheeler, President University of California.

M. Jules Meline, Senator of France, former Minister of Agriculture, President of the Permanent International Viticultural Commission.

M. Prosper Gervais, Perpetual Secretary of the Permanent International Viticultural Commission, member of the Superior Council of Agriculture and of the National.Agricultural Society of France.

M. Henry Sagnier, Questeur of the International Agricultural Commission and Perpetual Secretary of the National Agricultural Society of France.

Herr Franz von Buhl, Senator, President of Viticultural Society of Germany.

Karl Portele, Superior Councillor, Inspector of Agriculture, Vienna, Austria. Garcia de los Salmones, Director of the Agricultural Service, Province of Pampelune, Spain.

Pièrre Viala, Inspector General of Viticulture, Professor of the National Agricultural Institute of France.

Victor Kotinsky, Inspector of Agriculture in the Ministry of Agriculture, Budapest, Hungary.

Hon. Dr. Edouardo Ottavi, member Italian Parliament, President of the Society of Agriculture of Italy.

Cincinnato Da Costa, former Deputy in the Cortez, Professor in the Institute of Agronomy, Lisbon, Portugal.

Basil Tairoff, Councillor in the Ministry of Agriculture and Domaines, Director of the Journal Westnik Vinodelia, Odessa, Russia.

Prof. Dr. Müller-Thürgau, Director of the Federal Experiment Stations for Forestry, Viticulture and Horticulture, Waedensweil, Switzerland.

Dr. Clemente Grimaldi, Professor of Agricultural Science, Modica, Sicily.

Dr. Salas Y. Amat, Agricultural Engineer, Malaga, Spain.

Dr. E. W. Hilgard, University of California, Berkeley, Cal.

Hon. L. A. Goodman, President American Pomological Society, Kansas City, Missouri. 


\section{OFFICERS OF THE COMMISSION.}

President-Prof. William B. Alwood, Charlottesville, Va. First Vice-President-Walter E. Hildreth, Urbana, N. Y. Second Vice-President-Clarence J. Wetmore, Livermore, Cal. Third Vice-President-Sophus Federspeil, San Francisco, Cal. Secretary-Lee J. Vance, 302 Broadway, New York, N. Y. Assistant Secretaries-H. F. Stoll, 216 Pine Street, San Francisco, Cal. E. M. Sheehan, State Capitol, Sacramento, Cal.

Treasurer-William Culman, 410 West Fourteenth Street, New York, N. Y.

\section{ACTIVE MEMBERS.}

Appointed by the Commission on Organization.

Benjamin R. Kittredge, San Francisco, Cal.

Clarence J. Wetmore, Livermore, Cal.

Walter E. Hildreth, Urbana, N. Y.

Hiram S. Dewey, Egg Harbor, N. J.

Edward R. Emerson, Washingtonville, N. Y.

Prof. William B. Alwood, Charlottesville, Va.

William Culman, New York, N. Y.

Lee J. Vance, New York, N. Y.

H. F. Stoll, Secretary California Grape Protective Association, San Francisco, California.

Andrea Sbarbaro, San Francisco, Cal.

S. Guasti, Los Angeles, Cal.

E. M. Sheehan, Secretary California State Board of Viticulture, Sacramento, California.

Prof. F. T. Bioletti, University of California, Berkeley, Cal.

Dr. Oberlin, Director of the Viticultural Institute, Colmar, Germany.

Herr Auguste Dern, Inspector of Viticulture, Neustadt, Germany.

Baron de Schorlemer, Viticulturist, near Treves, Germany.

Dr. L. Mathieu, Director Enological Station, Beaune, Cote d'Or, France.

Dr. Emile Manceau, Director Enological Laboratory, Epernay, France.

Prof. A. Mareschati, Director of Viticultural Station, Casale, Montferrato, Italy. Claudio Oliveras Masso, Agricultural Engineer, Reuss, Tarragone, Spain.

Alfredo Mesquita, Diario de Naticios, Lisbon, Portugal.

Amadeo Serafini, Buenos Aires, Argentine Republic.

Prof. E. R. Lake, Secretary American Pomological Society, Washington, D. C. Prof. George C. Husmann, Department of Agriculture, Washington, D. C.

Prof. U. P. Hedrick, Horticulturist, New York Agricultural Experiment Station, Geneva, N. Y.

Prof. A. L. Quaintance, Entomologist, Washington, D. C.

Sophus Federspiel, San Francisco, Cal.

C. E. Bundschu, San Francisco, Cal.

Walter S. Lenk, Toledo, Ohio.

A. C. Krudwig, Sandusky, Ohio.

O. G. Stark, St. Louis, Mo. 


\section{CONTRIBUTING MEMBERSHIP TO THIS CONGRESS.}

\section{CALIFORNIA.}

F. Albertz, Cloverdale, Cal.

Charles Ash, The California Wine Association, San Francisco, Cal.

J. A. Barlotti, 1234 Palmetto Street, Los Angeles, Cal.

George W. Barry, 453 Second Street, San Francisco, Cal.

J. E. Beach, Fair Oaks, Cal.

Beringer Bros., Inc., St. Helena, Cal.

R. G. Bettoli, Italian-Swiss Colony, Battery and Greenwich Streets, San Francisco, Cal.

George P. Beveridge, The California Wine Association, Fresno, Cal.

Prof. Frederic T. Bioletti, University of California, Berkeley, Cal.

William F. Bornhorst, St. Helena, Cal.

John Bosch, The California Wine Association, San Francisco, Cal.

George Bourland, Winters, Cal.

J. B. Bradford \& Sons, Bruceville, Cal.

Bismarck Bruck, St. Helena, Cal.

Carl E. Bundschu, 20 California Street, San Francisco, Cal.

Charles Carpy, Oakville, Cal.

Chauche \& Bon, 319 Battery Street, San Francisco, Cal.

E. S. Ciprico, Lachman \& Jacobi, 112 Main Street, San Francisco, Cal.

J. E. Colton, Martinez, Cal.

Joseph J. Concannon, Livermore, Cal.

John A. Corotto, 560 N. Fifth Street, San Jose, Cal.

J. A. Covick, The California Wine Association, San Francisco, Cal.

W. V. Cruess, College of Agriculture, U. C., Berkeley, Cal.

Edward L. da Roza, Elk Grove Winery, Elk Grove, Cal.

G. De Latour, Beaulieu Vineyard, Rutherford, Cal.

P. De Veaux, Mission San Jose, Cal.

A. G. Dondero, Ciocca-Lombardi Wine Co., Battery and Green Streets, San Francisco, Cal.

Henry Dufour, Oakville, Cal.

F. Estrade, Madrone, Cal.

S. Federspiel, Italian-Swiss Colony, Battery and Greenwich Streets, San Francisco, Cal.

E. I. Field, Mt. Hamilton Vineyard, San Jose, Cal.

Prof. F. Flossfeder, University Farm, Davis, Cal.

M. J. Fontana, Italian-Swiss Colony, Battery and Greenwich Streets, San Francisco, Cal.

George W. Foulks, Elk Grove, Cal.

French-American Wine Co., 15th and Harrison Streets, San Francisco, Cal.

F. Frohman, The California Wine Association, San Francisco, Cal.

J. Frowenfeld, The California Wine Association, San Francisco, Cal.

E. H. Frye, Franklin, Cal.

F. Gianinni, Tulare, Cal.

Theodore Gier, Oakland, Cal.

Ralph A. Gould, The California Wine Association, San Francisco, Cal.

The Granz Estate, Fresno, Cal.

Grau \& Werner, Los Amigos Vineyard, Irvington, Cal. 
Secondo Guasti, 1234 Palmetto Street, Los Angeles, Cal.

Secondo Guasti, Jr., 1234 Palmetto Street, Los Angeles, Cal.

H. R. Gundlach, 20 California Street, San Francisco, Cal.

William Hoelscher \& Co., 1873 Mission Street, San Francisco, Cal.

C. E. Humbert, Cloverdale, Cal.

Fred L. Husmann, Viticultural Superintendent, Second and Seminary Streets, Napa, Cal.

J. J. Jacobi, Lachman \& Jacobi, 112 Main Street, San Francisco, Cal.

A. L. Jacobi, Lachman \& Jacobi, 112 Main Street, San Francisco, Cal.

Rudolf Jordan, Jr., A. Repsold Co., 104 Pine Street, San Francisco, Cal.

W. S. Keyes \& Co., St. Helena, Cal.

B. R. Kittredge, The California Wine Association, San Francisco, Cal.

H. Landsberger, Sheldon Building, San Francisco, Cal.

Leo Korbel, Guerneville, Cal.

Louis Kunde, Glen Ellen, Cal.

Arthur Laçhman, 453 Second Street, San Francisco, Cal.

Henry Lachman, Mission San Jose, Cal.

Landsberger \& Sons, Sheldon Building, San Francisco, Cal.

Herman Lange, B. Arnhold \& Co., 116 Townsend Street, San Francisco, Cal.

G. E. Lawrence, Lodi, Cal.

W. Leichter, C. Schilling \& Co., Twentieth and Minnesota Streets, San Francisco, Cal.

Tracy Learnard, Gilroy, Cal.

E. Light, Calistoga, Cal.

P. F. Lint, Los Gatos, Cal.

W. W. Lyman, St. Helena, Cal.

E. G. Lyons \& Raas Co., 535 Folsom Street, San Francisco, Cal.

Stiles McLaughlin, Lemoore, Cal.

Frank Malcolm, The California Wine Association, San Francisco, Cal.

F. T. Malesani, Madera, Cal.

Louis Mangels, Cordelia, Cal.

Margherita Vineyard, Fresno, Cal.

Paul Masson, San Jose, Cal.

A. Mattei, Malaga, Cal.

Louis Mel, Livermore, Cal.

F. J. Merriam, Chula Vista Winery, St. Helena, Cal.

C. O. G. Miller, The California Wine Association, San Francisco, Cal.

A. R. Morrow, The California Wine Association, San Francisco, Cal.

Leon Munier, Italian-Swiss Colony, Battery and Greenwich Streets, San Francisco, Cal.

J. O'Meara, Oakley, Cal.

R. L. Nougaret, Walnut Creek, Cal.

Dr. H. Ohrwall, Hollister, Cal.

Len. D. Owens, Aetna Springs, Cal.

William Palmtag, Hollister, Cal.

Sheridan Peterson, Santa Rosa, Cal.

E. C. Priber, 79 Scott Street, San Francisco, Cal.

Andrew Rasmussen, Napa, Cal.

John G. Ritter, Palmdale, Cal.

E. H. Rixford, 105 Montgomery Street, San Francisco, Cal. 
F. M. Roessler, Fresno, Cal.

Rosenblatt Co., 300 Second Street, San Francisco, Cal.

E. A. Rossi, Italian-Swiss Colony, Battery and Greenwich Streets, San Francisco, Cal.

R. D. Rossi, Italian-Swiss Colony, Battery and Greenwich Streets, San Francisco, Cal.

H. C. Rowley, Publisher "California Fruit News," San Francisco, Cal.

F. Salmina \& Co., St. Helena, Cal.

Paul Samuel, 247 Bush Street, San Francisco, Cal.

A. Sbarboro, Italian-Swiss Colony, Battery and Greenwich Streets, San Francisco, Cal.

C. Schilling, C. Schilling \& Co., 20th and Minnesota Streets, San Francisco, California.

Ernst Schraubstadter, A. Finke's Widow, 809 Montgomery Street, San Francisco, Cal.

E. M. Sheehan, Sacramento Valley Winery, Sacramento, Cal.

A. B. Shoemake, Modesto, Cal.

A. H. Siegfried, C. Schilling \& Co., 20th and Minnesota Streets, San Francisco, California.

M. H. Simons, U. S. N., Rancho Manzanita, St. Helena, Cal.

Mrs. Sara B. Smith, Livermore, Cal.

W. Sommer, Lachman \& Jacobi, 112 Main Street, San Francisco, Cal.

T. J. Stevenson, Elk Grove, Cal.

Alfred Stern, Chas. Stern \& Son, I. N. Van Nuys Building, Los Angeles, Cal. H. F. Stoll, 216 Pine Street, San Francisco, Cal.

M. F. Tarpey, La Paloma Vineyard, Tarpey, Cal.

Arthur B. Tarpey, La Paloma Vineyard, Tarpey, Cal.

Burton A. Towne, Lodi, Cal.

E. H. Twight, Italian Vineyard Co., Guasti, Cal.

W. P. Valsangiacomo, Columbus Wine Co., 150 Columbus Avenue, San Francisco, Cal.

G. W. Van Sicklen, The California Wine Association, San Francisco, Cal.

M. Viera, Antioch, Cal.

N. V. Walsh, The California Wine Association, San Francisco, Cal.

William Wehner, Evergreen, San Jose, Cal.

C. H. Wente, Livermore, Cal.

C. J. Wetmore, Cresta Blanca Wine Co., 166 Eddy Street, San Francisco, Cal.

L. S. Wetmore, The California Wine Association, San Francisco, Cal.

John H. Wheeler, St. Helena, Cal.

\section{CONNECTICUT.}

Albert Bernhard, Meriden, Conn.

James W. Booth, G. F. Heublein \& Bro., 196 Trumbull Street, Hertford, Conn. G. F. Heublein, G. F. Heublein \& Bro., 196 Trumbull Street, Hartford, Conn.

\section{DISTRICT OF COLUMBIA.}

H. J. Bock, Scientific Assistant in Viticulture, United States Department of Agriculture, Washington, D. C.

Charles Dearing, Scientific Assistant in Viticulture, United States Department of Agriculture, Washington, D. C.

Geo. C. Husmann, United States Department of Agriculture, Washington, D. C. 


\section{ILLINOIS.}

John Crerar Library, Chicago, Ill.

Jan. J. Fucik, F. Korbel \& Bros., Inc., 1621 West Twelfth Street, Chicago, Ill.

INDIANA.

The Houppert Wine Co., 801 East Maryland Street, Indianapolis, Ind.

\section{MARYLAND.}

Mrs. H. H. Klingel, 2925 North Charles Street, Baltimore, Md.

\section{MASSACHUSETTS.}

Bernard J. Joyce, The Sonoma Wine \& Brandy Co., 115 Broad Street, Boston, Mass.

Edward J. Joyce, Boston, Mass.

\section{MISSOURI.}

Jacob Brenner Wine Co., 115 South Third Street, St. Joseph, Mo.

\section{NEW JERSEY.}

S. Oberst \& Son, Egg Harbor City, N. J.

Felix N. Renault, Renault Importing \& Exporting Co., Egg Harbor, N. J.

\section{NEW YORK.}

Mrs. Hale Braybrook, New York, N. Y.

L. G. Bennett, Roualet Wine Co., Hammondsport, N. Y.

M. Carbone, Italian-Swiss Colony, 719-721 Washington Street, New York, N. Y. William Culman, The California Wine Association, 410-412 West Fourteenth

Street, New York, N. Y.

J. Cushing, Vine City Wine Cellars, Hammondsport, N. Y.

Mrs. Margaret Farrell Conlon, 115 Maiden Lane, New York, N. Y.

J. W. Davis, Urbana Wine Company, Urbana, N. Y.

Alfred de Montebello \& Co., 110 Broad Street, New York, N. Y.

Elmer De Pue, Cresta Blanca Wine Co., 41 East 41st Street, New York, N. Y. Mrs. Elmer De Pue, Cresta Blanca Wine Co., 41 East 41st Street, New York, N. Y.

Geo. E. Dewey, H. T. Dewey \& Sons Co., 138 Fulton Street, New York, N. Y. Hiram S. Dewey, H. T. Dewey \& Sons Co., 138 Fulton Street, New York, N. Y. Mrs. Hiram S. Dewey, H. T. Dewey \& Sons Co., 138 Fulton Street, New York, N. Y.

Geo. F. Dewey, H. T. Dewey \& Sons Co., 138 Fulton Street, New York, N. Y. Ralph C. Dewey, H. T. Dewey \& Sons Co., 138 Fulton Street, New York, N. Y. Mrs. Ralph C. Dewey, H. T. Dewey \& Sons Co., 138 Fulton Street, New York, N. Y.

S. Bradford Dewey, H. T. Dewey \& Sons Co., 138 Fulton Street, New York, N. Y.

Wm. H. Dewey, H. T. Dewey \& Sons Co., 138 Fulton Street, New York, N. Y. A. C. Douglas, Brotherhood Wine Co., Washingtonville, N. Y.

M. A. Eiseman, Eiseman \& Co., Inc., 68 Cortlandt Street, New York, N. Y. 
Mrs. M. A. Eiseman, 68 Cortlandt Street, New York, N. Y. Evelyn Eiseman, 68 Cortlandt Street, New York, N. Y.

Edward R. Emerson, Brotherhood Wine Co., Washingtonville, N. Y. Mrs. Annie Thompson Farrell, 115 Maiden Lane, New York, N. Y.

-William J. Farrell, 115 Maiden Lane, New York, N. Y.

Miss Helen Thompson Farrell, 115 Maiden Lane, New York, N. Y.

Edward Frowenfeld, The California Wine Association, 410-412 West Fourteenth Street, New York, N. Y.

W. E. Hildreth, Urbana Wine Co., Urbana, N. Y.

J. S. Stubbs, Columbia Wine Co., Hammondsport, N. Y.

B. Kahnweiler, The California Wine Association, 410 West Fourteenth Street,

New York, N. Y.

George A. Kessler \& Co., 20 Beaver Street, New York, N. Y.

Henry Koch, Lachman \& Jacobi, 65 North Moore Street, New York, N. Y.

D. H. Maxfield, Naples, N. Y.

Hiram Maxfield, Naples, N. Y.

Miss Helen L. Maxfield, Naples, N. Y.

Miss Jane S. Maxfield, Naples, N. Y.

J. Oesterlein, E. L. Spellman \& Co., 792 Washington Street, New York, N. Y. James Olwell \& Co., 181 West Street, New York, N. Y.

Frederick E. Palmer, Hammondsport Wine Company, Hammondsport, N. Y. Louis Profumo, Cella Bros., 528 West Broadway, New York, N. Y.

Frederick Renken, Munn Champagne \& Importation Co., 35 West Thirty-ninth Street, New York, N. Y.

E. C. Romano, Italian Vineyard Co., 492 Broome Street, New York, N. Y. Guido Rossati, 226 Layfayette Street, New York, N. Y.

E. L. Spellman, E. L. Spellman \& Co., 792 Washington Street, New York, N. Y. ('harles Schueler, California Winery, 74 Cortland Street, New York, N. Y.

Munson G. Shaw, Alex D. Shaw \& Co., 76 Broad Street, New York, N. Y.

L. W. Southwick, Sonoma Wine and Brandy Co., 18 Hamilton Avenue, Brooklyn, N. Y.

L. G. Stelzle, 861 Sixth Avenue, New York, N. Y.

Charles Stern \& Sons, 153 Hudson Street, New York, N. Y.

Fred U. Swarts, Penn Yan, N. Y.

Walter Taylor, The Taylor Wine Co., Hammondsport, N. Y.

Lee J. Vance, American Wine Press, 302 Broadway, New York, N. Y.

Mrs. M. P. Van Dyke, Hotel Seymour, 44 West 45th Street, New York, N. Y. Michael Volz, Brotherhood Wine Co., Washingtonville, N. Y.

Carl von Bergen, The California Wine Association, 410 West Fourteenth Street, New York, N. Y.

W. L. White, New York, N. Y.

Jacob Widmer, Widmer Wine Cellars, Naples, N. Y.

Alfons Wile, Julius Wile Sons \& Co., Ninth Avenue and Fifteenth Street,

New York, N. Y.

OHIO.

John G. Dorn, Sandusky, Ohio.

The Lenk Wine Co., Toledo, Ohio.

Charles F. Miller, The A. Schmidt, Jr. \& Bros. Wine Co., Sandusky, Ohio.

W. H. Reinhart, Sweet Valley Wine Co., Sandusky, Ohio. 
J. J. Schuster, The Schuster Co., Cleveland, Ohio.

George M. Zimmerman, Duroy \& Haines Co., 1422 Columbus Avenue, Sandusky, Ohio.

\section{RHODE ISLAND.}

John H. Caton, Jr., 70 Arnold Avenue, Edgewood, R. I.

Mrs. John H. Caton, Jr., 70 Arnold Avenue, Edgewood, R. I.

TEXAS.

Will B. Munson, Munson Nurseries, Denison, Texas.

VIRGINIA.

William B. Alwood, Charlottesville, Va.

Adolph Russow, Charlottesville, Va.

\section{REPRESENTATIVES OF FOREIGN COUNTRIES PARTICIPATING.}

Mr. Ernesto Nathan, Commissioner General from Italy to the Panama-Pacific International Exposition.

Mr. Otto Wadsted, Resident Commissioner of the Danish Government.

Mr. William Hutchinson, Commissioner General of the Canadian Government.

Mr. Henri Hains of the Canadian Commission to the Panama-Pacific International Exposition.

Mr. Manuel Roldan, Commissioner General for Portugal.

Mr. A. D. Duffner, Assistant Commissioner for Portugal.

Mr. L. Clifton, Commissioner for New Zealand.

Mr. James A. Robertson, Commissioner for Queensland.

Mr. Jiro Harada, Member of Commission for Japan.

Mr. H. Yamaraki, Member of the Commission for Japan.

Mr. Eduardo Perotti, Commissioner General for Uruguay.

Mr. C. Vassadarkis, Commissioner General, Greece. 


\title{
REPORT OF THE PROCEEDINGS
}

\author{
OF THE
}

\section{INTERNATIONAL CONGRESS OF VITICULTURE}

\author{
HELD IN RECITAL HALL, FESTIVAL HALL, \\ PANAMA-PACIFIC INTERNATIONAL EXPOSITION, \\ SAN FRANCISCO, CALIFORNIA, \\ JULY 12 AND 13, 1915.
}

The Congress was called to order at 9:30 A. M. by President William B. Alwood of Charlottesville, Virginia.

President Alwood called upon Mr. E. M. Sheehan of Sacramento, Cal., to introduce the representative of the Governor of the State of California, Mr. Chester H. Rowell of Fresno, California.

Mr. Rowell. "I am very sorry indeed that Governor Johnson cannot be present in person to welcome you this morning, but he requested me to take his place on account of his unavoidable absence. It is necessary for him to be absent on most occasions of this kind at the Exposition.

"It is a pleasure for me to welcome you here, and I wish I had had time to prepare a speech or to dig up an old one-one that I delivered some years ago on the subject of sweet wine-a speech in praise of wine. Fortunately for you, perhaps, but unfortunately for me, I have not had the time to dig into this old matter or to prepare a new address.

"The viticultural industry, not only the wine part of it, but with all of its branches, has been a very proud possession of California from the beginning of its history. The Mission Fathers, who brought Western civilization here, brought also the vine, and there is the closest association between wine and occidental civilization. We have had for years a viticultural department in our State University, as well as a State Viticultural Commission and many experimental stations and vineyards are located in California.

"Every grape-growing country is pleasant and beautiful. The grape does not grow in the jungles of the tropics or in the frozen North. The grape was the basis of the original international industry, and as long as there has been any commerce in the world two things have been carried-wine and raisins-and frequently very little more. In the blackest pages of European history all the commerce that was left was commerce in silks, pearls, wine and raisins.

"As the representative of Governor Johnson, I welcome you to California and to the Exposition. May your sessions be pleasant and profitable and your stay with us enjoyable."

In his response to Mr. Rowell's address of welcome, President Alwood said:

"I want to say on the part of the Eastern people, that our hearts are so full of gratitude and happiness over all that we have already experienced in 
California that we cannot properly express our appreciation of this welcome. I only wish that our brethren might have been here from that other Continent across the Atlantic and have seen what we people of the East have seen -the wondrous development of this Western land. I have never seen anything in all my travels that at all compares with the wonderful development in this State in one generation.

"I cannot reply to this address of welcome without saying a few words for our absent brethren. For four years I have been laboring over the preliminaries of this Congress. Many of the best men of Europe interested in viticulture were anxious to come to California, the land of wonder.

"M. Prosper Gervais, of the National Agricultural Society of France, in a letter a few days ago stated to me: 'My son, my only son, is dead on the plains of Flanders. I cannot come.' Baron von Buhl, President of the German Wine Association, hoped to take part in the Congress. He wrote a long letter of regret. 'We cannot leave the Fatherland now; it is impossible,' he says. Dr. Ludwig Basserman-Jordan of Neustadt, Rhein Pflaz, Germany, is dead. Dr. Clemente Grimaldi of Sicily is dead. Mr. M. Battanchon, Inspector General of Agriculture of France, is dead, and others whom I have not time to mention.

"Thus many of our former colleagues have fallen, and on the part of this Congress I wish to express our sincere sympathy."

President Alwood named the members of the following committees:

\section{COMMITTEE ON ENTERTAINMENT.}

Mr. C. J. Wetmore, Chairman.

Mr. S. Federspiel.

Mr. H. F. Stoll.
Mr. V. Walsh.

Mr. F. Frohman.

Mr. R. C. Dewey.

COMMITTEE ON PUBLICATION.

Mr. William B. Alwood.

Mr. E. M. Sheehan.

Mr. U. P. Hedrick.

Mr. H. F. Stoll.

Mr. F. T. Bioletti.

COMMITTEE ON PUBLICITY.

Mr. H. F. Stoll.

Mr. L. J. Vance.

COMMITTEE ON RESOLUTIONS.

Mr. C. Bundschu, Chairman.

Mr. S. Federspeil.

Mr. Lee J. Vance.
Mr. E. M. Sheehan.

Mr. L. W. Southwick.

\section{COMMISSION ON ORGANIZATION.}

Mr. Dewey moved that the commission now sitting be elected as officers of the permanent organization. Unanimously carried.

\section{COMMITTEE ON ORDER OF BUSINESS.}

Mr. Hiram Dewey, Chairman.

Mr. D. H. Maxfield.

Mr. F. T. Bioletti.
Mr. C. J. Wetmore.

Mr. H. Gundlach.

The presentation, reading and discussion of papers submitted to the Congress followed. 


\section{HISTORICAL, EDUCATIONAL, COMMERCIAL.}

The Work of the California Viticultural Commission.

E. M. Sheehan, Secretary California Viticultural Commission,

Sacramento, California.

Probable Effect of the Federal Tax on Brandy upon the Horticultural Interests of California.

R. D. Stephens, $1210 \mathrm{~N}$ Street, Sacramento, California.

A Campaign of Wine Education.

H. F. Stoll, 216 Pine Street, San Francisco, California.

Early California Wine Industry.

Henry Lachman, Mission San Jose, California.

Love of the Vine.

Lee J. Vance, New York, New York.

Grape Breeding.

R. D. Anthony, Agricultural Experiment Station, Geneva, New York. Introduction of Viticulture into the Schools.

A. W. Miller, Principal Benicia High School, Benicia, California.

\section{CULTURAL.}

Resistant Vines.

George C. Husmann, Pomologist, U. S. D. A., Washington, D. C.

Pruning and Training American Grapes.

F. E. Gladwin, Vineyard Laboratory, Fredonia, New York.

Commercial Fertilizers for American Grapes.

F. E. Gladwin, Vineyard Laboratory, Fredonia, New York.

Some Tests of Resistant Stocks in California.

F. Flossfeder, University Farm, Davis, California.

Vitis Vinifera in Eastern America.

U. P. Hedrick, Experiment Station, Geneva, New York.

\section{REGIONAL STUDIES.}

Viticultural Regions of the Pacific Slope.

F. T. Bioletti, University of California, Berkeley, California.

Grape Growing in the Idaho-Washington District.

E. H. Twight, Guasti, California.

Grape Growing in Oregon.

C. J. Lewis, Corvallis, Oregon.

Grape Growing in New Mexico.

Fabian Garcia, State College, New Mexico.

Grape Growing in Utah.

A. B. Ballantyne, Provo, Utah.

Grape Growing in the Imperial Valley.

W. E. Packard, El Centro, California. 


\section{DISEASES AND INJURIOUS INSECTS.}

Grape Onthracnose in America.

C. L. Shear, Bureau of Plant Industry, Washington, D. C.

Powdery Mildew of Grapes and Its Control in the United States.

Donald Reddick, Cornell University, Ithaca, New York, and

F. E. Gladwin, Fredonia, New York.

Studies in "Plasmopara viticola" (Downey Mildew of Grapes).

C. T. Gregory, Cornell University, Ithaca, New York.

Action of Fungicides on Plants.

O. R. Butler, New Hampshire College, Durham, New Hampshire.

Sulfur Fungicides.

G. W. Gray, Insecticide Laboratory, University of California,

Berkeley, California.

Insects Injurious to the Vine in California.

H. J. Quayle, Citrus Experiment Station, Riverside, California.

Phylloxera in California.

R. L. Nougaret, Walnut Creek, California.

\section{Some Injurious Grape Insects}

F. Z. Hartzell, Vineyard Laboratory, Fredonia, New York.

(a) The Grape Root Worm.

(b) The Grape Leaf Hopper.

(c) The Grape Flea Beetle.

(d) The Rose Chafer.

The Grape Berry Moth.

W. H. Goodwin, Assistant Entomologist, Wooster, Ohio.

Two Destructive Grape Insects of the Appalachian Region.

Fred E. Brooks, Entomological Assistant, United States Department of Agriculture, Washington, D. C.

\section{CHEMICAL AND PRODUCTS PAPERS.}

The Engineer's Part in the Advancement of the Viticultural Industry.

E. T. Meakin, 409 Sixth Street, San Francisco, California.

Results of the Application of Pure Yeast and $\mathrm{SO}_{2}$ in California Wineries in 1913-1914.

W. V. Cruess, University of California, Berkeley, California.

A Rapid Method of Volatile Acid Determination.

Cruess and Bettoli, University of California, Berkeley, California.

Influence of Composition on Effervescence of Champagne; Preliminary Investigations.

R. W. Bettoli and E. J. La Belle, Laboratory Italian-Swiss Colony, San Francisco. 
Chemical Composition of Native American Grapes.

W. B. Alwood, Charlottesville, Virginia.

On the Normal Composition of Eastern Wines.

W. B. Alwood, Charlottesville, Virginia.

Important Factors Governing the Successful Transportation of Table Grapes.

A. V. Stubenrauch, University of California, Berkeley, California.

The Intelligent Blending of Wines.

Hiram S. Dewey, President American Wine Growers' Association.

A New Utilization of a By-Product of the Grape.

Guido Rossati, Enotecinco Governative Italiano, New York, N. Y.

Relation of the Stage of Maturity of the Grapes to the Quality and Quantity of the Raisins.

F. T. Bioletti, University of California, Berkeley, California. 


\title{
THE WORK OF THE STATE VITICULTURAL COMMISSION.
}

\author{
By E. M. SHEEHAN,
}

Secretary of the California State Board of Viticultural Commissioners, Sacramento, California.

There are 150,000,000 grape vines growing in the valleys and on the hillsides of this great State of California and there are 150,000,000 of dollars invested in the viticultural industry within her borders. Seventy-five thousand people depend for livelihood on the product of our California vineyards, and ninety per cent of that product brings outside revenue into this State. The annual gross income is found to be $30,000,000$ of dollars and of this, $27,000,000$ of dollars come into the State from food product markets all over the world.

It is little wonder, therefore, that California has seen fit to maintain a State Viticultural Commission and a department of viticulture in her State University and State Farm, and that theory has gone hand in hand with practice in the development and culture of the vine to an extent that places this Commonwealth in the forefront of all the sections of the North American continent in matters viticultural.

It is little wonder, therefore, that the Federal Government has concerned itself with the establishment of many experimental nurseries and vineyards in this State for the propagation of new and choice varieties of grape vines and for keeping abreast of the countries of the Old World where viticulture is one of the chief vocations of the vast population.

I recall the general viticultural condition prevailing in California at the present time, as above briefly outlined, for the purpose of bringing forcefully to the minds of every member of this International Congress of Viticulture and particularly those who reside in the United States of America, the question of the perpetuity and future of the vineyard business in this State and in every State in this Union.

I shall speak of California alone and shall ask you to endeavor to grasp and appreciate the position of this State in the vastness of her viticultural interests and in her desire to be accorded just consideration at the hands of our Federal Government.

Until recently, and for many, many years, we have seen nothing but the fostering spirit from Federal sources; but suddenly California is confronted with regulation and most unusual burdensome taxation of her wine-making institutions that fairly threaten to destroy at least seventy-five per cent of her viticultural activity. The same new scheme of Federal taxation affects, it is true, some other states of our Union that grow grapes; but in those states the industry represents investments comparably small with that of ours. Here we lead and excell in vineyard products; there the production is merely an incident in a maze of agricultural pursuits. It means much to many thousands of our people; in other sections it means much to a comparatively few; and, therefore, I plead that because a Federal taxation hardship does not affect most sections of our Country, those sections should not remain passive and permit of destruction of vast interests of their neighbors. 
Though thinking of our wine-grape vineyards now and of our winemaking industry, I shall endeavor to show you later how confiscatory Federal taxation on wine will affect our raisin and table-grape growers unless this new tax law is repealed at Washington, and repealed promptly with the assistance of every fair-minded member of our National Congress.

Permit me to give a brief recital of what has happened to the wine-grape interests of California.

Nine years ago and for years prior, the sweet wines were made without Federal tax. As the industry grew and the expense of Government supervision increased, a tax of three cents per proof gallon on brandy used in fortification of the sweet wines was levied and it more than offset the expense of the Federal employes in the gauging service. This tax or the necessity for it has not been questioned these nine years. A maker of sweet wines in California to the extent of 200,000 gallons has paid, in addition to all other expense, $\$ 1,500$ to the United States Government as his part of the three-cent tax on brandy which he made and added to his fermented wine to preserve a certain degree of sweetness or sugar. Suddenly the United States Government needs money to meet deficiencies in customs and decides to tax sweetwine makers 55 cents per proof gallon on fortifying brandy instead of three cents per gallon, and demands that the manufacturer who makes 200,000 gallons of wine shall pay a fortifying tax of $\$ 27,000$ instead of $\$ 1,500$. Moreover, we are now informed that after the coming vintage season the fortifying tax will automatically become $\$ 1.10$ per proof gallon (the same as has always applied to commercial brandy when taken from bonded warehouses), and consequently the Government tax on the winemaker who produces 200,000 gallons of sweet-wine will after January 1,1916 , be $\$ 54,000$ instead of the original tax of $\$ 1,500$, or about 35 times what he has been paying.

This means practically prohibition of the sweet-wine industry, or the imposition of a tax from the Federal Government of over four and a half millions of dollars annually on California's normal output of sweet wines-a tax prohibitive in the extreme and one under which the winemakers individually or collectively could not exist.

The layman asks, "What has this to do with dry wines? How are they affected? What have the table and raisin-grape growers to fear? It does not concern them, does it?"

And the answer is, "They are affected tremendously."

Just consider first of all the plight of the maker of sweet wines. On top of the cost of his grapes, his labor, his investment in plant, tools and machinery, and his administration, taxes and insurance, the wine he produces must yield the Government from 25 to 30 cents per gallon-a figure as much as a wholesaler would pay a manufacturer for sweet wine a little more than a year ago. Indeed, sweet wine sold in California for two years at prices ranging from 12 to 20 cents per gallon.

Then what is there for the sweet-wine maker to do? He cannot afford to make more than 10 per cent of his normal output and he promptly uses his plant for the production of dry wines such as Claret, Hock, Zinfandel and other types of dry wine. He converts $17,000,000$ gallons of sweet-wine production into $30,000,000$ gallons of dry wines, which, added to California's normal dry-wine production of $22,000,000$ gallons, makes a total seasonal output of $52,000,000$ gallons of dry wine. 
What is the result? The market is glutted with dry wines. The great bulk meets a common price level in the selling markets, the law of supply and demand comes into play, and selling prices of dry wines are ruinous to the producers. There is loss on every hand-the dry-wine producer is engulfed along with the sweet-wine maker.

And now to consideration of the table-grape and raisin-grape vineyardists. Here in California normally, 40 per cent of their tonnage is not fit for tablegrape and raisin markets. These are the culls and second-crop grapes and they have always brought money because the wineries could use them.

What winery will want these grapes now? Who will pay the cost of even picking them? What winery can afford to make them into brandy for fortifying purposes when it will cost that winery more than $\$ 40.00$ per ton for those grapes in tax money alone, not considering the cost of the grapes? Why should wineries buy grapes when dry wines are a drug on the market? The answer is simple. This 40 per cent of the table and raisin grape crop will yield nothing to the owners of the vineyards. It will be a total loss. Markets for unfermented grape juice and grape syrup offer practically no relief. They are not big enough and the possibilities of enlarging them are very remote.

California's State Viticultural Commission has tried to avert this crushing blow to her vineyard interests. The Commission intends even yet to use every powerful, plausible and honest effort to make Congress see what an injury it has done to millions of dollars worth of property in California and many thousands of her people. It is inconceivable that the Federal Government should decide within one year's time to levy a tax on California wines amounting to 36 times what it was before.

To correct an injustice of this nature is a task in which the California Viticultural Commission must have the enthusiastic support of all who are interested in vineyard work not alone in our own State but in New York, Ohio, Missouri, Virginia and every other State in the Union where the grapevine thrives. We should be successful if we have hearty co-operation, and the work to be undertaken is in the opinion of our Commissioners the most important that has come to the notice of the Board. Let us not think of failure in our effort. Fair-thinking men in Congress who have no pecuniary interest in viticulture or in agricultural pursuits will surely see the error in such an act of the Government and will not be ashamed to right a great wrong that has been done to viticulture and particularly to those vast interests in California.

There is endless work for a Board of Viticultural Commissioners in this State, and the present Commission is going about the task before it in a systematic manner. With insufficient financial means at its command, it is gradually completing a roster of the vineyardists of the entire State. This will be an office adjunct of invaluable importance and it will be renewed constantly to keep pace with changes in ownership of these vineyard properties. There will be available in our office the name and postoffice address of every man who grows grapes. In addition, the extent of his vineyard will be known as well as the varieties of grapes he grows. I need not explain to you of how much importance and value this data will be to the office of the Board as well as to each of the individual growers. We shall then be able to reach every vineyard with advice as often as we wish and need not depend on general publicity mediums. 
This Board has worked hand in hand with the table-grape producers of California and has accomplished by appeal to reason and a citation of benefits to be derived, a sugar standardization for table-grape shipments. We also obtained the complete co-operation of all of the marketers of our table grapes in the United States and Canada, and a highly meritorious pack of table grapes was noted during the last vintage. Unfortunately the crop was abnormally large, and meeting as it did, an Eastern crop of similar proportions, the results of sales were disappointing and the season as a whole was discouraging to the table-grape growers.

The situation among the raisin-grape producers is satisfactory. Co-operation in marketing through central exchanges has brought order and profit out of chaos and loss. The whole production is not now rushed to market at one time or within a short period. Intelligent distribution and exploitation of the markets is the order of the day, and raisin affairs are so well in hand that the producer receives needed money throughout the year whether his crop is sold or unsold. Care should be exercised to control the disposition to over-produce in this branch of viticulture, and your Board is so advising those who contemplate going into raisin producing.

The Viticultural Commission is busily engaged in studying plans of relief for the table-grape growers. With only 50,000 acres of table varieties, California either produces too many grapes for her legitimate markets, or the marketing system is faulty. We are greatly interested in the easement which may be afforded by packing large quantities of our table grapes in a sawdust preservative in drums or kegs. These grapes so packed will keep for winter marketing and we are endeavoring to place our product in competition with the Almeria grapes of Spain. The departure being somewhat new to us, has not yet been mastered successfully, but with perseverance we shall surely win in the end.

I might enumerate an endless number of interesting subjects which are keeping our Viticultural Department busy these days, but time will not permit of it at this Congress, and I shall conclude by thanking you for the privilege of mentioning our work in a general way, and by inviting all of you who may be interested to consult us as often as you please for general or specific information you may desire regarding California's vineyards. We have 330,000 acres of vines in our State. 170,000 of these acres are in wine-grape vines; 110,000 acres in raisin grapes; and 50,000 in table grapes. We are qualified to answer your questions correctly and will be pleased to do so. 


\title{
PROBABLE EFFECT OF THE FEDERAL TAX ON BRANDY UPON THE HORTICULTURAL INTERESTS OF CALIFORNIA.
}

\author{
By R. D. STEPHENS, \\ 1210 N Street, Sacramento, California.
}

Read by Mr. E. M. Sheehan.

In replying to your request for an expression of opinion as to what effect the Federal Tax on brandy used in fortifying sweet wines will have upon the horticultural interests of California will say, that I do not know how I can better illustrate how it will affect the interests of the table or shipping grape growers than to give my personal experience which practically has been the experience of all other table grape growers in the State.

I had a very heavy crop in common with all other growers and as the demand was not equal to the supply, I sold to the winery over 220 tons which amounted to about 45 per cent of my entire crop.

While the price I received for these 220 tons was not sufficient to cover all cost of production, picking and delivery, yet the result was profitable to me, for the reason that I received a profit over the cost of picking and delivery-in other words salvage; and, by disposing of over 220 tons to the winery, which were manufactured into brandy and used to fortify sweet wines, I was enabled to put up a superior pack for Eastern shipment. Had I not had an opportunity to dispose of this 45 or 50 per cent of my crop, at a price, which, while it did not cover the total expenses for the year, yet brought a profit over the cost of picking and delivery, it would have been a total loss, which would have materially reduced my income.

\section{Growers and Manufacturers.}

Growers can no more afford to sacrifice 45 per cent or 50 per cent or 60 per cent of their products than can manufacturers afford to sacrifice an equal proportion of their products.

There is a great difference between the products of the manufacturer and those of the growers, for the reason that one is perishable, while the other is not. If the manufacturers have an excess supply, they can hold it until there is a demand for it at a price which will bring them a good profit, for they have the power to fix the price at which they will sell to the growers, but the growers have to sell at a price fixed by the buyers.

\section{The Tax and Its Effect.}

If the tax is permitted to remain on California manufactured brandy which is used for fortifying sweet wines, it will mean the financial ruin of many who have built up this industry through the teachings of experts sent to California by the Federal Government, which now, through a system of taxation if it is permitted to remain, will destroy this industry; an inconsiderate action on the part of the Federal Government. 
It is for this reason that the people of California have the right to ask and demand that the power and authority that has been so instrumental and potent in developing an interest of so great a magnitude, as is the horticultural interest of California, of which the viticultural interest is an important factor should give to it the protection that justice and equity demand.

\section{Magnitude of the Interest.}

There are about $1,100,000$ acres planted to fruit in California representing at a minimum estimate a financial investment of from $\$ 650,000,000$ to $\$ 700,000,000$. The percentage of this acreage that is planted to fresh shipping varieties of fruit, when all is in full bearing will produce from 240,000 to 250,000 carloads per annum and if the tax on our brandy is permitted to remain, it will either force the shipment of 40,000 to 50,000 more cars, or the uprooting of vineyards in which men and women have the earnings of generations invested.

\section{Transportation Rate Problem.}

As the cost for transportation on fresh fruit shipments is such as to absorb in many instances from 55 per cent to over 60 per cent of the gross sales of cars, which means heavy loss, it will make additional shipments prohibitive, unless they be made at an increased loss. I repeat that the Federal Government is responsible to a great degree for the building up of the wine industry of California to its present magnitude, by the establishment of Government Experiment Stations and the importation of scores of varieties of grapes from all parts of the world, and testing their adaptability for successful culture in California, and distributing them to the growers. Therefore, we FEEL JUSTIFIED IN DEMANDING THAT NO ACTION SHOULD BE PERMITTED ON THE PART OF THE GOVERNMENT THAT WILI, RESULT IN IMPAIRING AND DESTROYING AN INTEREST IT HAS BEEN SO INFLUENTIAL AND SUCCESSFUL IN PROMOTING.

\section{A CAMPAIGN OF WINE EDUCATION.}

By HORATIO F. STOLL, Commissioner, State Viticultural Board.

While this Congress is primarily interested in the technical side of viticulture, we must not overlook a pest far more dangerous than phylloxera or any of the diseases that infect our American vineyards. I refer to Prohibition, which aims to wipe out the wine industry in this and every other State in the Union.

It is, of course, necessary that our winemakers and grape growers should strive to keep up the standard of our wines and grapes, but I fear that they will have very little enthusiasm for the industry unless they are given some assurance that after they have produced the choicest grapes and made the finest wines, the growers will be able to sell their grapes to the wineries, the wineries dispose of their product to the dealers and the dealers reach the consumer. Something must be done to assure permanency to the industry. 
For years, our bulk wines have gone to the Atlantic and Middle West States, but our efforts to popularize bottle goods have been confined pretty much to the States immediately contiguous to California.

Hundreds of thousands of dollars have been spent in the Northwest and Southwest by leading wine firms, and an excellent demand for bottled California wines has been created. But almost over night, these markets, which it took years to develop, are being wiped out by Prohibition.

Only recently Washington, Oregon, Colorado, and Arizona have gone dry. Our winemen took little, if any, active interest in the campaigns waged in those States. The saloon was the only question discussed. If competent speakers had spread the gospel of the grape in those four States, I am sure a considerable number of votes would have been swung into the proper column.

It is a pity the voters did not understand more about wine, through a previous campaign of education. I believe that if the merits of wine drinking had been properly placed before the people of Oregon and Washington, they would not have put it on the same basis as whiskey, viz., a half gallon only to be imported, thus encouraging the use of the stronger beverage, as, with a supply once a month, a good many people will pick the most condensed form. Wine was not placed on the same basis as beer, because the voters there just didn't understand.

Our winemen must inaugurate a campaign of education in all the wet States in the Union, and in order to wage an effective campaign, we should employ trained writers to secure at first hand authorative facts and figures showing the sobriety of the wine-producing countries of Europe, and the fallacy of Prohibition in the United States.

So many conflicting stories about the emergency prohibition measures adopted by the nations at war have been printed in the American press that it is time the public was told the truth. The dry leaders would have us believe that Europe is about to adopt Prohibition. Russia and England are cited as the great examples. Neither are wine-drinking or wine-producing countries and I am sure that if we investigate matters carefully, we will find that neither country is warring on wine-but on vodka and whiskey.

The French Government, while it has outlawed absinthe, is giving wine to its soldiers at the front.

In the December 12 th issue of the Revue de Viticulture, the most important viticultural publication in the world, appears an article headed, "Wine for the Army," in which the editor writes:

"The five months of hard fighting that our army has so valiantly waged against the enemy, confirms the hygienic information that other wars have brought to light.

"How many of our soldiers have died from impure water! Thirsty soldiers are tempted to drink water from doubtful sources during forced marches-with the result of dysentery or typhoid.

"The results in the army have demonstrated new proofs of the energetic anti-microbian action of wine.

"The Balkan war demonstrated that in the Greek army, the regiments using wine always showed better military energy and a superior resistance of typhoid fever over those not using wine and far superior to that of the Turkish army. 
"Our doctors, both civic and military, sustain the tradition that wine has a decidedly efficient influence on sick and wounded convalescents.

"In the trenches, when the soldiers suffer from cold and wet, wine is proving of the greatest use.

"The Government and its prefects make appeal to the patriotic generosity of the grape growers for supplies for the soldiers. The Department of the Herault pledges $3,750,000$ gallons. A total of fifteen million gallons of wine would supply the army. Even $8,000,000$ gallons would be very useful to help protect $2,000,000$ soldiers against cold, diseases, typhoid and dysenteric contagion-four gallons per capita during the campaign would materially help."

Needless to say, the army has been well supplied with wine.

I think that a campaign of education as to the merits of wine as a temperance beverage, when used in the home, in the hotels and in the cafés with meals, will not only create a demand and a wider consumption of California wines, but will also have a powerful influence in shaping and moulding public opinion in the desired direction-that of excepting wines in any prohibitory legislation which may be enacted.

Heretofore, only the prohibition side has been presented. This point was emphasized by a visit we had the other day at our wine exhibit in the Food Products Palace, from an eminent professor of an Eastern University.

He called at our "Grape Temple" and after having been shown around, entered our moving picture room where he listened carefully to the talks that accompanied the pictures, and asked questions now and then so as to understand the points made by the speaker.

At three o'clock he announced that he must keep an engagement in one of the other buildings; but at four o'clock he was back in his seat in the moving picture room, listening and studying.

After the last picture had been shown, at five o'clock, he approached me and said: "This has been a very profitable afternoon for me, but I have one criticism to make. Why do you keep this wonderful story and these wonderful pictures all to yourself?"

"What do you mean?" I asked.

"Why, no one outside your own State knows anything about this wonderful industry. Why don't you educate the public? I knew that wine was produced in California, but had no idea of your achievements or possibilities; your ability to make dry wines, sweet wines and champagnes; the great acreage you have devoted to grapes; and the fact that a large proportion of the profit of your raisin and table grape growers comes from wineries that use their surplus production.

"I believe that you should let people beyond your own borders know all this. You should emphasize the purity of your wines and show the outdoor, lives of the grape growers and winemakers. I am sure the plain, unvarnished facts would create a profound impression."

The gentleman went on to say that nearly all the big universities are provided with moving picture facilities; that they would be glad to welcome pictures such as he had seen in the collective wine exhibit; and that something should be done to put forward arguments in favor of wine, in the universities. The other side-the Prohibition and Anti-Saloon League forceshe pointed out, never miss an opportunity to address classes and supplement 
their arguments with anatomical charts, showing the harm done to the different organs of the body by the use of alcohol, and displaying large maps to pruve that the whole United States is going dry.

"Take your pictures East," said this enthusiastic professor. "Show them in our universities, in the public schools. Reach the coming men who will decide the destiny of our nation. You will find that you will soon be able to create a sentiment that will spread from person to person until hundreds of thousands of people outside of California will know of your wonderful grape industry and will hesitate to destroy it with Prohibition."

I believe this Eastern professor is right and that we should at once send our moving pictures on missionary work throughout the Atlantic and Middle Western States, where the people know little about out great wine industry. But we should supplement these pictures with able speakers, educational literature and newspaper articles and advertisements urging the use of wine not only as a substitute for spirituous liquors, but for tea and coffee at the dinner table because wine is more hygienic, nutritive and wholesome.

I am satisfied that there are hundreds of important papers in the United States that would espouse the use of wine in the home, even though they might be in favor of closing the saloons and opposed to running a whiskey advertisement.

The constant drumming of the slogan of this campaign that the drinking of pure, honest California wines, builds temperance, and is the best means to true temperance, is bound to have its effects on the public mind.

We should use quotations from authoritative writings of noted men like Dr. Parkhurst, Professor Münsterberg, Cardinal Gibbons, as well as physicians of national fame, physical experts, famous food experts, writers of books, big men in politics and industry-persons in fact who enjoy public confidence and whose word carries weight.

Alternating with these, should be articles showing the value of wines in cooking, in the preparation of beverages suited to the various seasons, such as delicious cooling beverages for summer, hot drinks for winter, and the proper use of wines at the table.

These articles should also give an idea of the different types of wines. It is a fact that not one out of a thousand knows the character of wines by name.

It has often been said that the wine makes the dinner, and it is very true; but it is likewise quoted that often the dinner makes the wine, which is equally true. There are certain classes of dishes that strikingly bring out the characteristic taste and flavors of wine, and other dishes mar such tastes and flavors. Therefore, to bring forth the full appreciation of the finer qualities of any special wine, the public should be taught to select carefully either such dishes of food as will make these peculiar qualities more perceptible, or at least not clash with them and leave on the palate, through this harmony, a full appreciation of both wine and food.

We must teach the American people that the only way to enjoy wines is to drink them intelligently. In other words, the food or dishes offered should be made to harmonize with the general taste, flavor, and bouquet of the wines served. For instance, as Arphad Haraszthy once pointed out, a heavy wine like port, or even a heavy claret, to a lover of good food, would not be enjoyed if drunk with oysters or eggs. These tastes do not harmonize; there- 
fore, as this rule applies to white wines, to claret, and to champagne, the utmost discrimination is necessary, and considerable experience or education is required to select wines that harmonize with the different dishes offered.

During the Prohibition campaign in California last fall, I visited the Café Marcel in Los Angeles and was discussing with the proprietor the disastrous effects prohibition would have on his establishment. To my surprise, he said, "I don't care if the State goes dry and I cannot serve liquor with my meals. I will live just the same. But if they will not permit me to use wine in my sauce and special dishes, my reputation as a chef will be gone. No one can cook the dishes I offer without wine."

Those who have traveled abroad will tell you of the charming home cooking they have tasted, and how the skillful and thrifty French, Italian and German housewives make the commonest dishes attractive by the skillful use of wine.

It has been suggested that a comprehensive cook book be compiled, giving such recipes, within the reach of the average family. I believe this would be an admirable means of interesting people throughout the United States in California wines, for it would give many valuable hints to the housewife who is always ready for suggestions that will enable her to give variety to the dishes she is offering the family.

Thousands of dollars are spent each year during the hot summer months in an effort to get the public to use grape juice, pineapple juice and other fruit juices in cold punches. Why not advertise wine as a summer drink? Is there anything more thirst-quenching than a claret lemonade-plain lemonade with a flavoring of claret, which gives the beverage a delicious taste and a ruby coloring that is particularly pleasing to the eye?

Many a family that to-day does not use a drop of wine could be induced by attractive copy, illustrated with tempting colored drawings, to use our light red and white wines in punches and lemonades.

The viewpoint of the prohibitionist is so narrow that it is a waste of time to attempt to make him realize the distinction between drinking our light wines at the table with meals and gulping down highly spirituous beverages over a bar.

I am satisfied, however, that if a comprehensive campaign of education is worked out, the bulk of the nation, the millions of moral persons who live a righteous, sober life, and practice moderation, will see things in the right light.

We have friends and they are numerous. But Prohibition is just now fashionable. Our friends, the true temperance people, do not choose to trouble themselves about the progress or the absurdities of prohibition. They treat the subject lightly and dismiss it, with the assertion that "a reaction will soon set in," or that "prohibition will never carry in California."

Nothing is further from the truth. We know the experience of Oregon and Colorado. Both States defeated Prohibition, but eventually the Prohibition element triumphed.

In 1914, we in California had a taste of how bitter a Prohibition campaign can be made and in 1916, we will have to undergo another fight for the life of the industry. 
Elections are to be held in half a dozen other States, so I say we ought to start shaping public opinion NOW, start creating new markets for our California wine NOW.

Every day brings us nearer to the time when the whole country will be face to face with the prohibition problem.

We have a just cause and I believe that if the grape growers and winemakers of California-yes, and of the whole United States-will prepare for the crisis and give as much time and thought and energy to this great question as they do to the technical and commercial side of the industry, they will come through the trying ordeal with flying colors.

\section{EARLY : CALIFORNIA WINE INDUSTRY. BY HENRY LACHMAN,}

San Francisco.

Having been invited to prepare a paper on "Early California Wine Making," it is necessary to state that I will not be able to carry you back any farther than" the seventies, " 76 being my first recollection of California wines.

At that time I knew how difficult it was to introduce California wines to the general wine drinker, who was either a tourist or a wine drinker accustomed to the European taste.

Most wines in those days were principally a blend of Bordeaux wines that came out as ballast, the return cargo then being principally grain. The wine handled in those days was distributed by wholesale whiskey dealers. In putting a wine on the market and supplying our French restaurants, even though we sold them as California wines, we used a portion of our French cargo wine in the blend when selling in bulk. Later there was a demand for bottle wines. The California label was not accepted for a fine wine.

There were also skeleton cases in those foreign bottoms that made the trip-that is, the case, the bottle, the straw cover, the wrapper, the cork, the cap, and more often the label. Before bottles were manufactured in America they were shipped out here in crates, as were also the straw covers. The making of cases in California began about that time.

As California wines began to improve, instead of giving them a half blend of foreign wine the blend was reduced to possibly about 80 per cent California and 20 per cent French. The demand in wine at that time was for a French label, mostly fictitious brands. As we found that our California wines were being consumed, it was in 1886 that we decided, if California wines could be drunk under a foreign label they certainly could be drunk under their own, and it was at this time that we refused to bottle any more wine other than under a California brand and made an exposé through the "Chronicle" by Tom Vivian, which was printed broadcast, as "American People Drinking Label," and from that time our California wines have been 
considered as the only standard wine in the new world as of the European type.

When we were experimenting with our different grapes we were watching the development of each variety. The business at that time was an interesting study; in fact, we would bring out different types of foreign wines and see how closely we could produce wines of the same type. I recollect when Mr. Tubbs brought back from Europe the Merlots, Beclans and Cabernets, which we would ferment and blend to the types of the wines produced in the Château Leoville district, keeping each variety intact. We would also use a Cabernet Sauvignon and a Cabernet Franc in a blend with a Gamay, and I remember where we experimented with the Semillon, Sauvignon Blanc and Muscatelle de Bordelais, producing a wine equal to any of the Sauterne type.

In handling each one of two different varieties, we would use a screen for a stemmer and would have a han crusher, watching the fermentation even in barrels. After the vintage we always wanted to see each variety kept by itself and wanted to do our own blending. In fact, wines at that time were being made along lines similar to those in small cellars of Europe to-day. The Beam Presis was also in vogue at that time and doubtless could still be found in use in some of the grape-growing centers of Sonoma.

There was a certain infatuation to wine making in those days and also in the blending and maturing of wines; there was also a certain individuality along the lines of working. Old oak casks we would look upon as old acquaintances, and if we wanted to mature a wine in a cask that previously contained an old flavor, we would always treasure that package. The advent of the large blending redwood tank has taken away the picturesque and the sentiment out of the wine business, but we will have to admit that the average of the California wines as produced to-day is far in advance of the many sour tanks that we encountered in the olden times.

The Mission grape, which was no doubt transplanted to this country by the padres, was found to adapt itself to our soil and climatic conditions and from this grape was produced the first wine that made California known as a wine-producing section. The Angelica made from this grape has never been excelled by wine produced from any other variety, and as a general utility grape we have never had any other to take its place. The white wine produced from it, while taking longer to mature, developed qualities equal to some of the finest German types, the saccharine in these grapes always maturing to not less than 24 degrees sugar. The Sherry made from these grapes also produced a fine quality, and the Brandies were always considered desirable. In a blend as a Port wine it always met with favor. In fact, the only wine that we could not produce was a Claret. I can safely say that even to-day these Mission grapes should be replanted in the sweet wine district.

In former days when our cellars, fermenting houses and machinery were not so perfected, nor the control of fermentation so well in hand as it is at present, many mistakes were made and as a consequence the introduction of California wines to the Eastern market was not an easy task. Another fault found with our wines in those days was the complaint on red wines, or clarets, they being criticized as having an "earthy" taste. Whether this was due to the newness of the soil or the variety of the grapes planted in those 
days, which consisted of Charbonos, Malvoisies, along with Zinfandels, the writer has never been able to find out, but in recent years this objectionable taste seems to have disappeared and also some of those early varieties of grapes.

I don't believe that at any time we ever made a scientific investigation into the varieties best suited to our climate and soil, nor had we paid much attention to soil analysis and never to fertilizers. The early wine-maker gained his experience in experimental work and watching his local conditions. At one time the European wine merchant or the European wine dealer, after studying our conditions, would tell us that our wines were simply grape juice and only fit for immediate consumption and did not believe they would mature. Occasionally we would find a few bottles that had been set aside in a corner for ten or twelve years and which upon sampling we found they had developed the fine taste shown by aged wines, and on many occasions I have sampled properly matured wines against some of the finer types in Europe and was convinced that wines properly selected, carefully bottled and properly stored, would command the same praise as the finer qualities we were always able to find in Europe and sold in our own country.

It seems a pity that the old fashion of private cellars and setting aside wines to mature has gone out of date. The trouble with California wine heretofore has been due to the distribution end of it, that is, educating the people to the collection of wines as they would stamps or coins, as there is no line of merchandising that has as much infatuation as that of the maturing of wines.

I suppose one of the hard rows that the early California wine man had to hoe was that the business was setting itself as a general wine introduction. We did not have the white wine dealers such as you find in Germany, nor did we have the man handling only Clarets, nor the man only introducing Sherry, nor a Champagne line nor a Brandy line. The California wine dealer was supposed to acquaint himself with all kinds of grape products and in those days we were even turning out a Vermouth, and, as a consequence, grapes that were suitable only for certain varieties were being used for all kinds of wine making.

The California wine business has not reached the stage to which it properly belongs and we are unquestionably about ten years behind in the marketing of our wines. We cannot understand why we have not had a world market when we know our grapes are equal to any grapes grown. Probably one of the reasons that can be advanced is lack of our shipping commerce.

Through scientific research and the present control of fermentation, as well as the improved wine-making machinery and more care in the selection of grapes, we have created a good general demand for all kinds of wines. The improved Champagnes that are being put on the market to-day have opened the eyes of many who thought California would never be able to perfect this style of wines. We are still lacking, though, in producing a brandy similar to the cognac type, and won't be able to do so until the Government permits the blending of brandies in bond as done in France.

There is no question in my mind but that taking the general average of the entire output of our various wines throughout the States, from an analytical test we can show a higher standard than will be found in most 
European countries, and I hope that more attention will be paid to the selection and maturing of finer qualities, that is, aging in old cooperage that has contained nothing but the better types. Sherry responds quicker, I believe, to showing age than any of the sweeter wines. A white wine matures and shows its finer qualities sooner than a red wine.

Within the time up to the fire, I have had old wines that I knew to be twenty years of age (having known them at the time of their making) that wouldn't be accepted by any European wine drinker as a California product, which goes to show that by giving the same care and attention as is done in proper aging, we can equal the wines of the old country.

I am inclined ta believe that the prohibition movement will educate the American people to the use of wines as a household food product and I contend that a white wine, or even a red wine, drank with about 50 per cent of water, makes a more palatable drink than taking the wine in its merchantable state when drinking, assists the digestion and quenches one's thirst, at the same time being more healthful than many of our waters. I don't believe carbonated waters are healthful.

\title{
LOVE OF THE VINE.
}

\author{
By LEE J. VANCE,
}

Editor American Wine Press, New York.

At this, the first International Congress of Viticulture in America, it seems appropriate to refer to that deep and tender feeling which animates and unites grape growers all over the world. If we were not lovers of the vine we would not be meeting here to-day.

This love of the vine was born when the human race was created. It thus antedates civilization itself. And so at the beginning of civilization we find man planting the vine, cultivating it with care and skill, gathering, treading and pressing its luscious clusters of fruit, and drinking the juice of the grape at his religious ceremonies and on all social occasions.

I need only mention, in passing, how the love of the vine inspired the people of ancient Greece to celebrate the vintage, or grape harvest, with song and music in honor of Dionysus, the god of vine and wine. Out of these festivals was evolved the magnificent Greek drama. From the choral hymn, called the dithyramb, sprang both tragedy and comedy; tragedy meaning the "goat song," because a goat was sacrificed to the god before the hymn was sung; comedy meaning the "village song," as it was marked by the rude jests of the rustic carnival.

The Romans had a deep love for the vine, as all readers of the old Latin writers well know. This strong feeling for viticulture has persisted as a notable characteristic of people of the Latin race down to this day. It has had a great influence upon their daily life and activities. It appears in their wonderful art and in their splendid literature. 
Wherever they settled, the Romans planted the vine as well as their civilization. And so the culture of the vine spread from Italy to the south of France, and thence north to the banks of the Rhine. In the course of time Europe became covered with vineyards, particularly in France, where there are now 4,000,000 acres of vines, and the grape growers are the backbone of that country.

In Europe the love of the vine extends from nobleman to peasant. Some of the oldest and best known vineyards on the continent are the properties of the nobility. Every gentleman there, with a farm or an estate which is adapted to grape growing, has his vineyard, and he mrkes his own wine, which he offers with pride to his guests and friends.

The early immigrants to America, who came from the vineyard districts of Europe, brought with them the love of the vine. Some carried a few vines as a precious part of their small possessions, and some had sent to them vines which they planted here.

The Spanish explorers and settlers first brought foreign vines into Mexico, and the Spanish Fathers set out vines about their Missions in Southern California, the first plantings being at the Mission of San Gabriel in 1770. The popular variety thus came to be called the "Mission grape," and it was extensively cultivated in the early days of California viticulture.

The original promoter of grape-growing in the New World, according to Prof. Hedrick, was Lord Delaware, who in the year 1616 wrote to the London Company urging the culture of the grape in the new colony (Hedrick, Grapes of New York, page 6). In 1619 the company sent a number of French vinedressers and collection of the best varieties of French vines to Virginia. In that year the Colonial Assembly passed an act compelling every householder to plant ten cuttings, and stated that the landowners were expected to acquire the art of dressing a vineyard. Later on many other acts to induce grape-growing in the Colonies and States were passed. Thus we see that legislative encouragement to viticulture began at an early date in the United States.

However, the early efforts to grow foreign grapes in the Eastern States were not successful. The story of these efforts forms one of the most interesting and important chapters in the history of American horticulture. It is a long story of constant disappointments and failure, and only an intense love of the vine could have inspired these pioneer growers to persist in the face of loss and possible ruin.

It was not until our horticulturists turned their attention to improving the native American varieties of grapes that they attained a large measure of success. To them we owe most of our best varieties of native grapes, such as Catawba, Concord, Delaware, Iona, Ives, Norton, Noah, etc.

A long list of faithful workers helped to make Eastern viticulture what it is to-day. It includes the names of William R. Prince, whose treatise on the vine was one of the earliest and best on the subject for many years; Judge Nicholas Longworth of Cincinnati, O., who spent forty years and a large fortune in establishing vineyards in the Ohio Valley; Dr. E. W. Bull, the originator of the Concord grape; George W. Campbell, the originator of the Delaware grape; Edward S. Rogers, the originator of forty-five seedlings known as Roger's hybrids; Dr. C. W. Grant, who originated the Iona; James H. Ricketts, who produced many hundred seedlings; Jacob Rommel, who also 
produced many seedlings of value; Prof. T. V. Munson, who introduced more hybrid grapes than any other viticulturist in America, if not the world. These men devoted their lives to the vine. Their work was largely a labor of love. Few of them ever received any reward or profit commensurate with their merit and ability.

So, too, with the pioneers of California viticulture. They planted that others might reap. Few of them were successful in a financial sense.

I think few people, outside of the viticultural industry, fully understand and appreciate what the vine grower must undergo before he takes a load of grapes to the winery, or sends a basket of grapes to the table of the faroff consumer. It may safely be said that vine culture demands more care, skill or expert knowledge than any other branch of agriculture. Hence the vine growers are, as a class, the most industrious and intelligent of all men who till the soil. This is true not only in this country, but in the vineyard districts of Europe.

Again, what other branch of agriculture, what other industry compares with viticulture as regards the variety of difficulties to be overcome and the number of enemies to be met and conquered? The troubles of the vine grower begin in the early spring and last until the crop is safely gathered in the fall. He has to contend with the elements, with nature, and even with man. A sharp spring frost may nip the buds and blast the hopes of the grower for a good vintage. In summer may come hail and thunderstorms to damage the vines and their growing fruit. Even when the time of the vintage is at hand, and the grower is ready to gather a full crop of grapes, if there come early frosts or heavy rains and storms, he may lose 10, 20 or 30 per cent of his crop.

Then the grower has to combat vegetable diseases and insect pests. They are the parasites of the vine, for they feed on the roots, leaves, buds or fruit, according to the nature and habits of the class to which they belong. The list of vegetable parasites is quite long and includes mildew, black rot, oidium, anthracnose, etc. The list of animal parasites is also long. The worst is the phylloxera, which is a terrible scourge. In California, as in all the vineyard districts of Europe, the ravages of the phylloxera have caused widespread disaster and ruin to many thousands of growers. In the last fifty years in France alone the phylloxera has destroyed more than two million acres of vines, representing a total loss of about one billion dollars.

Last but not least, the vine grower has, sorry to say, human enemies. The professional prohibitionist is one of the worst of these. He is, in a way, a parasite. He lives on his work of destruction. In many places and States the grape growers have been the innocent victims of unjust and destructive legislation. They have had the value of their vineyard properties injured and depreciated by prohibitory laws. They have sometimes seen the fruits of their labor turn to ashes. In no other civilized country of the world has grape growing, which is recognized as one of the most ancient and honorable pursuits of man, suffered more from harsh and oppressive legisaltion than it has here in the Unied States. It is time now for the growers to insist upon their rights and to demand in no uncertain voice and tones to be let alone.

In spite of numberless difficulties, in spite of animal and vegetable pests, and in spite of the attacks of many sleepless enemies, the vine grower has abiding faith and confidence in his vineyard. He loves it, as has been well 
said, with that deep, unreasoning affection which a mother bears to her child, and the greater the difficulties in his way, the harder the struggle to keep the vine's enemies at bay, the stronger does his love for his vineyard seem to grow.

The love of the vine is one of the noblest attributes of man. It is as strong to-day as it ever was. You can no more drive the love of the vine out of the heart of man than you can expel from it honor, duty, patriotism, and religion.

\title{
GRAPE BREEDING.
}

\author{
By R. D. ANTHONY, \\ Agricultural Experiment Station, Geneva, N. Y.
}

Read by Frederic T. Bioletti.

It was only after a hundred years of failure that American grape growers could be induced to abandon the European grape and seek for desirable kinds among our hardy native species. Even then, the first native grape extensively grown was decéptively introduced as a Vinifera. The marked success of the Alexander and the fortunate discovery of the Isabella and Catawba revived interest in grape growing and started many vine enthusiasts searching the woods for better sorts. Although this resulted in the production of the Concord, but little else of value was secured for nearly forty years.

The second milestone showing the progress of grape breeding is engraved witl the date 1851 and marks the pollinating of Rogers' hybrids. Valk and Allen had both used Vinifera blood in crossing previous to this, but their results were not so promising nor so extensive as those at Salem and they did not arouse the flood of enthusiastic amateur breeders which followed after Rogers' work and which has left a very considerable impression upon our grape industry. In the fifteen years following the dissemination of Rogers' seedlings, nearly one-quarter of all the grapes cultivated in northeastern United States were introduced. Although many of the Vinifera hybrids were disappointments, nevertheless the introduction of this blood was an epoch-making event.

The last sixty years have produced many new varieties, yet, from a breeding standpoint, they have been a disappointment. Concord and Catawba, poor as they are, still remain very important commercial varieties and few, if any, hybrids have surpassed Rogers' first attempts. To be true, Jaeger and Munson did much to improve the grapes of the Southwest, but, in general, breeders have worked without plan and have kept only meagre records of results.

The rediscovery of Mendelism and the light which has been thrown upon the laws of inheritance since then have shown breeders the necessity of a thorough knowledge of the fundamentals before any considerable success can be hoped for. To gather such information requires years of painstaking effort and the study of a large amount of material. 
The North Carolina Station reports a start along this line with the Rotundifolia grape, and it is the purpose of this paper to discuss briefly certain results which have been secured at the New York Agricultural Experiment Station during some twenty-five years of grape breeding.

During this quarter century some 200 varieties have been studied more or less extensively, and about 10,000 seedlings have been grown. One of the unexpected results was the failure of many of our commercial sorts to transmit desirable qualities, some of the best results being secured from little known varieties. This is why it has seemed best to test such a large number of kinds.

As a means of analyzing the genetic composition of the varieties more than 3,000 selfed, or pure, seedlings have been grown. While these have given much information about the varieties used as parents, they have been so uniformly lacking in vigor as to lead to the conclusion that improved sorts should not be sought through this method.

The large number of cases in which Vinifera blood is found in the grapes which are ranked as high in quality, points to the desirability of adding some of this blood to our native species. About 100 varieties of this species have been grown on the station grounds and several of the best have been used in the breeding work.

Of the factors which are being studied, only a few have sufficient data available as yet to show results which are at all trustworthy. These are discussed below.

\section{Self Sterility.}

Grape flowers may be divided into three classes: true heraphrodites, hermaphrodites functioning as females because of abortive pollen, and pure males with the pistil absent or rudimentary. Among these classes there are two types of stamens: those with upright filaments and those in which the filaments bend backward and downward soon after the calyx cap falls off.

Results so far secured would seem to indicate that all pure males have upright stamens and that among the two classes which produce fruit, the true hermaphrodites which are self fertile possess upright stamens, while the self sterile sorts have reflexed stamens. As apparent exceptions to this statement there are a few varieties with reflexed stamens which can set a small amount of fruit when self sterilized.

From a practical standpoint it is undesirable to grow self steriıe sorts since they require interplanting with other varieties in order to secure pollination. From a breeding standpoint, then, one of our problems is to eliminate the reflexed stamens. In studying this problem the following results have been secured:

\section{The Cross.}

Ratio of Seedlings.

Upright stamens $\times$ upright stamens $=4.3$ upright: 1 reflexed. Reflexed stamens $\times$ reflexed stamens $=1.2$ upright: 1 reflexed. Reflexed stamens $\times$ upright stamens $=1$ upright: 1 reflexed.

The cross upright stamens $\times$ reflexed stamens has failed to give a sufficient number of seedlings to show the ratio.

While these results do not show us any way in which to eliminate those varieties with reflexed stamens they do show that we may decrease the proportion by the use of varieties for parents having upright stamens. 


\section{Inheritance of Sex.}

Fifty-one pure male seedlings have been produced at the station from known parents. A study of these makes it seem reasonable to assume that hermaphrodites pollinated by pure males will give both types in equal number, while hermaphrodites pollinated by hermaphrodites give only hermaphrodites.

\section{Skin Color.}

It is not easy to differentiate grape colors since they grade from the so-called "white" through many shades of red and purple to black. This wide range has greatly complicated the problem of determining the color composition of the various varieties. The several thousand seedlings which have been fruited have made possible the formulation of but two general laws: (1) White is a pure color and (2) it is recessive to both black and red.

Tables I, II and III give the results from the various color combinations which have been made and show what wide variations have been secured even from varieties of the same color. A careful study of the varieties is being continued to bring order out of these conflicting results.

Table I-Crosses of Similar Colors.

\begin{tabular}{|c|c|c|c|c|}
\hline \multirow{2}{*}{ Parental Types } & \multicolumn{4}{|c|}{ Color of Seedlings. } \\
\hline & Black & $\begin{array}{l}\text { Purple to } \\
\text { Dark Red }\end{array}$ & $\begin{array}{l}\text { Medium to } \\
\text { Light Red }\end{array}$ & White \\
\hline $\begin{array}{l}\text { White } \times \text { white............. } \\
\text { *Light red } \times \text { light red.. } \\
* \text { Dark red } \times \text { dark red.... } \\
\text { Black } \times \text { black............... }\end{array}$ & $\begin{array}{r}- \\
88 \\
407\end{array}$ & $\begin{array}{r}- \\
43 \\
49\end{array}$ & $\begin{array}{l}\overline{13} \\
45 \\
13\end{array}$ & $\begin{array}{r}166 \\
8 \\
42 \\
54 \\
\end{array}$ \\
\hline
\end{tabular}

Table II-Color Groups of Pure Seedlings of Black Varieties.

\begin{tabular}{|c|c|c|c|}
\hline \multirow{2}{*}{ Number of Parental Varieties } & \multicolumn{3}{|c|}{ Color of Seedlings } \\
\hline & Black & Red & White \\
\hline ....... & 52 & 16 & 29 \\
\hline - & 128 & 31 & - \\
\hline 10 & 71 & - & 25 \\
\hline 15 & 132 & 一 & 二 \\
\hline
\end{tabular}

Table III-Combination of Colors.

\begin{tabular}{|c|c|c|c|c|}
\hline \multirow{2}{*}{ †Parental Combinations } & \multicolumn{4}{|c|}{ Color of Seedlings. } \\
\hline & Black & $\begin{array}{l}\text { Purple to } \\
\text { Dark Red }\end{array}$ & $\begin{array}{l}\text { Medium to } \\
\text { Light Red }\end{array}$ & White \\
\hline $\begin{array}{l}\text { *White } \times \text { dark red......... } \\
\text { *White } \times \text { black........... } \\
\text { "Black and dark red...... }\end{array}$ & $\begin{array}{r}5 \\
41 \\
100\end{array}$ & $\begin{array}{r}44 \\
3 \\
52\end{array}$ & $\begin{array}{r}14 \\
3 \\
40\end{array}$ & $\begin{array}{l}50 \\
12 \\
32 \\
\end{array}$ \\
\hline
\end{tabular}

*Includes also the reciprocal cross.

tLight red varieties were not used to an extent sufficient to make the results of value. 
Quality.

The final verdict on the worth of a seedling depends largely upon its quality, yet quality is made up of so many factors and its interpretation depends so much upon the tastes of the observer that it is a very, difficult factor to study.

When seedlings are grouped according to quality it is immediately seen that even when parents of the highest quality are used, only a low percentage of the progeny rank as high as good while few reach as high as very good and none could be graded as best in quality. When we consider the ancestral history of these seedlings the results are not discouraging. Our native grapes now under cultivation are but one or two generations removed from the wild and represent the very few possessing sufficient quality to stand out from the many which have been rejected. The low quality of the seedlings is probably due to the leveling influence of the large number of ancestors of poor quality. The importance of breeding only from varieties of the highest excellence is shown by the rapid decrease in the quality of the seedlings as we use parents of poorer quality.

Pure seedlings have proved uniformly poorer in quality than cross-bred seedlings-another reason for not attempting to grow improved grapes by means of selfed seedlings.

\section{Size of Berry.}

A study of the seedlings at Geneva has failed to show any indication of dominance of any one size. This probably means that size of berry is the result of the interaction of several factors. There is, however, a steady decrease in the seedlings as we use parents of smaller size, thus showing that each variety has a tendency to produce seedlings approaching its own size.

\section{Form of Berry.}

The greatest difficulty in studying this factor has been the inability to find varieties which are pure for any particular form. It may be that the extreme oval of certain pure Viniferas is a pure form but certainly the less pronounced oval of Vinifera hybrids gives nearly as many round seedlings as oval. When round varieties are selfed or crossed, seedlings of all shapes are secured with, however, a very large predominance of the round form.

The only indication of purity of form has been found in an oblate variety. Few grapes possess this form, one of the most pronounced of these being Goff, a seedling produced by this Station. Selfed seedlings of this variety would seem to show it to be pure for oblateness. The oblate form is probably recessive to round, in fact there is a very strong tendency for roundness to predominate over both the other forms.

\section{Season of Ripening.}

The period of ripening of a variety depends so much upon the vigor of the vine, the season, cultural methods and environmental conditions that it is difficult to secure accurate data. When seedlings are grouped according to season of ripening and then compared with the season of the parents no pure varieties are found but it is seen that the season of the parents influences to quite a marked extent the average season of the progeny though individual seedlings may show wide variations. 


\title{
The Outlook for Grape Breeding.
}

Twenty-five years of work at the Station at Geneva, involving a study of thousands of seedlings, has resulted in the production of but six seedlings worthy of naming. This would seem to be a discouragingly small percentage as, indeed, it would be were it not for the mass of information which has been gathered from these discarded seedlings. We cannot hope to make consistant progress until we have established more clearly the fundamental lawsno easy task but one which is well started and whose successful conclusion may be confidently expected.

Perhaps it would not be wise to close this paper without a word of encouragment to the amateur breeder. The private grower can not hope to carry on this work to the extent and with the continuity that can be secured at our Experiment Stations. On the other hand practically every variety now under cultivation has been found or produced by the lover of grapes working in a small way, frequently, as Rogers worked, with only a backyard at his disposal for growing his seedlings. For the true grape lover the pleasure of the work is its own reward but there is always the hope that a fortunate combination of parents may produce varieties superior to those now under cultivation. Each addition to our knowledge of varieties and of breeding laws brings this end so much nearer.

\section{INTRODUCTION OF VITICULTURE INTO 'THE SCHOOLS.}

\author{
By A. W. MILLER,
}

Benicia High School, Benicia, Solano County, California.

Read by Frank T. Swett.

Before discussing viticulture as a subject of instruction in the schools I wish to say a few words about the conditions that would tend to make it a success or a failure.

Like everything else of any value, its beginnings will be halting and counted a failure. Suppose some school man introduces viticulture into a high school in a grape-growing region. The farmer's boys themselves will know more about grapes than their instructor and the average man "Would sink with bubbling groan, uncoffined, unknelled and unknown."

Yet the average high school work in language, literature, mathematics, science, history, etc., is no better. We can only measure the high school's inadequacy when it tries something in real life. Our schools may as well undertake a few things that have a bearing on every day life and flounder around until they succeed, instead of expending all their energies upon academic lines.

While the farmer would laugh at the meager results of the fellow trying to teach agriculture, he does not realize that the school does not reach a higher degree of efficiency in any other line.

The community itself must make the school. The teacher can but interpret the attitude and ideals of the community. That place in which the 
people demand and do their best to have an efficient school will attain it, particularly if the patrons sympathize with the difficulties of the teachers and help overcome them.

The grape industry, like every other agricultural industry, depends more for its success upon the mechanical, business and executive ability of the man in charge than upon his knowledge of the purely technical phase of the work.

The Government experts are always at hand to give the theoretical instruction, but the man himself must run his own machinery, keep his own cost accounts and get the work out of his men. The great trouble in carrying on all farm work is that the laborers are so indifferent to their work. They need to be inspired with a desire to make the most of their time and labor. They decidedly need training in efficiency.

The mere introduction of viticulture itself into the high school curriculum will not produce any result of value. The whole course of instruction must be properly reorganized so as to bear as completely and intelligently as possible upon the life and work of the people who use it. A properly worked out course of viticulture in such a school will be of use to a community. Instruction should be given in accounting and business life. Bookkeeping and every day business transactions should be thoroughly given. Economy and efficiency should be constantly emphasized. Good shop and manual training courses should be given, finished off with a course in applied mechanics, involving the use of gas and steam engines, and electric apparatus and machinery. Every course in the high school should consider as much as possible the problems of the people's lives.

An elementary course in general science could use the grape to illustrate much of its principles, so could botany, physical geography, chemistry and physics. In most high schools it would not be advisable to introduce a course in viticulture separate from other studies, mainly because of the jealousy of farmers themselves and the resenting of a mere school man telling their sons what to do, when the farmers know more about it than the teacher.

But if the courses in general science, botany and physical geography will use all the data they can that comes into the farmers' lives not only from viticulture but from horticulture, animal industries and so on, the school will aid the community very materially.

While the individual farmer with the vineyard may laugh at the green school man, the community at large needs training in its own industries. Take the pruning of grape vines. Where is there a large vineyardist that can get a reliable force of men to prune his vines? Every season it is a recurring problem. Yet there is not a country high school that may not either in botany or general science or in both subjects touch upon the subject of pruning in general and that of grapes in particular. If such was done and the farmers helped the green school man with a few kindly suggestions, the community would have plenty of young men with a correct knowledge of pruning, and then if the farmers required a knowledge of this from those they hire, how quickly the course in pruning would be attended and in a few years how efficient it would become.

And so on in many other phases of the subject.

Of course the school man must be a capable fellow. The misfits will fail at first, while only the capable will succeed, but after such courses be- 
come well established even the ordinary school men will be able to serve the community well.

In a country high school general science, while treating of the ordinary scientific knowledge of every day life, can best be taught by taking plant life as its basis. Much of its material can be taken from grape growing, for example: the varieties of grapes and their origin, the budding, grafting and growing of cuttings, diseases, phylloxera, resistant stocks, the principles of wine making, the study of yeasts, bacteria, and molds, and so on. Many of these subjects have a bearing on other things as well as on the grape industry.

Botany would naturally study plant life, in which the grape could be used as much as possible, and the fruiting habits of the grape studied and pruning emphasized.

Physical Geography could treat of the soils and climatic conditions.

Chemistry should take up the composition of the wines, the changing of the sugar to alcohol, the other elements contained in the wines, and the subjects of sophistification and amelioration.

Physics would treat more of the mechanical operations of farm work and there is an unlimited amount of material for illustrating its principles.

If in any high school, anything of an agricultural nature is given, the study of the grape should be included. In those places where the grape is grown either for home consumption or for commercial purposes, viticulture should be strongly emphasized.

Of the whole horticultural group, it is the easiest to be handled in regard to cost, ease of operation and establishment, and the shortness of the time in which it can be covered. It is particularly fitting in California because of the magnitude of the grape industry in its several fields of wine making, raisin growing, and the production of table grapes. If our schools are to present courses in various vocational lines, viticulture should be given its place.

It is also valuable as a representative subject. Most of the work in the schools must be general in type, giving foundation principles that can be applied specifically after the pupils get out in life. In teaching viticulture in the school, the foundation principles of the whole fruit and vine industry will be covered. The first thing to be considered is the requirements and preparation of the soil for planting a new vineyard. While the grape can be profitably raised on a wider range of soil than any other single product, yet the variations due to the different soils are very important and the grape can be used as the means of their study and their preparation and care. The adaptation of different varieties of grape to different soils and climate is a good illustration of the variation due to soil and climate and if the subject is well treated in viticulture, one will have a good conception of it for any other product of the soil.

The propagation of the grape is easy, quick and interesting. 'I'he same results with any kind of fruit trees would take much longer and for this reason such work can be done with the grape to an advantage in high school courses. The grafting, budding, and raising from cuttings can all be done easily by the high school pupils. The subject of resistant varieties and their development is a fascinating study, and it is easy to have the different resistant varieties growing on the school grounds for study. 
At the high school age it is often easy to develope in young people a love for the study of the processes of plant life. The grape is a fine subject to treat. The budding, the grafting, planting, staking, pruning, and shaping of the vine are all things that awaken their interest and the pupils take a pride in seeing the result of their own work develope before the four years are out. With the ordinary fruit trees very little results would be obtained in so short a time. Nor does it take a large piece of ground to carry on the work.

The system of pruning could be illustrated on a few vines and visits to vineyards in the community could be made. This should be done both during the pruning season in the winter and the ripening season in the fall. The effects of pruning upon the vines could be shown and studies of the bearing habit of the grape could be made.

The varieties of grapes could be studied, their names, time of ripening, appearance, quality and use. The subject of the ripening and gathering of the grapes could be treated under the general head of the ripening and marketing of all California fruits. The chemical changes could be emphasized and the effect of marketing too green or too ripe could be easily and fully brought out.

The use of saccharometers in testing ripeness bears upon physics and chemistry. In fact there is hardly an operation but what has some general bearing that may be brought out as well as its special application to viticulture.

The transportation and conservation of the grapes is intimately related to the subjects for all the ripe fruits, and the marketing problems of one are also the marketing problems of all.

The drying of raisins may be treated under the subject of dried fruits in general. Some experiments as to the food value of raisins would be very interesting and helpful.

The wine making might or might not be introduced into the school. It is a subject that would open up a vast field of technical knowledge and if properly given should be interesting and instructive even to those who are opposed to the use of alcoholic beverages.

The mechanics and construction of a winery bring in the problems, which are common to all our agricultural work, of mechanical efficiency and elimination of costs. It is a large field and there is no end to its study both for the college man and the practical farmer. Anything further, or more detailed and specialized in the study of viticulture should be taken up in the advanced schools and departments of agriculture in the colleges.

It would be hard to give a year's course of pure viticulture in high school, but it could be included in the course of horticulture. The writer taught agriculture for one year in the Armijo Union High School at Suisun-Fairfield. One half year was given to horticulture and one half year to the study of general farm conditions, emphasizing the animal industry. In this work the study of the grape was emphasized very much.

If the grape has been studied as indicated through the various courses of general science, botany, physical geography, chemistry, physics and horticulture, there would hardly be a place in the high school curriculum for a course in pure viticulture. But if such courses are not given, the whole sub- 
ject might be combined into a single full year course of viticulture. It would be best to take up the work as it actually takes place in the vineyard.

The subject matter would follow about the following sequence:

a. The ripening and gathering of grapes, the means of testing ripeness and the transportation and conservation of grapes. Study of the fruiting habit of the grape. Some study of pests and diseases.

b. Varieties of wine, table and raisin grapes.

c. The marketing and handling of table grapes.

d. The making of raisins, marketing and handling of the same.

e. The principles of wine making, the mixing and blending of grapes.

f. The winery, general plan, crushing, steming and conveying of grapes, fermenting and storage vats.

g. Red and white wines, areation, temperature, and the extraction of color, tanin and body.

h. The pruning of the grapevine.

i. Cuttings, bench grafting, field grafting, and the planting of cuttings and rooted vines.

j. The soil, preparation, cultivation and fertilization. Laying out the vineyard.

k. The Phylloxera and resistant stocks.

1. Protection from frosts. Green manuring and suckering of vines.

m. A repetition of the study of the fruiting habits of the grape and the subject of pollination.

n. Budding and field grafting.

o. Pests and diseases.

It is hard to write out an exact and full outline, for so many different parts of the subject interlap and can be studied and illustrated at the same time in the vineyards.

The students should be continually taken to the vineyards to study the subject at first hand as well as from text-books.

\section{DISCUSSION}

Discussion of Mr. Stoll's paper was called for by the President.

Mr. Hiram Dewey, of New York City: “In reference to Mr. Stoll's suggestions regarding the moving pictures, I want to say that at the banquet of the American Wine Growers Association at the Waldorf-Astoria last winter in New York, one of the gentlemen who sat next to me, who were the president and vice-president of the Board of Education of the City of New York, said, 'This is the most entertaining banquet I have ever attended in my life,' after the showing of the vineyard scenes in California and in other parts of the United States. I wish you would let us have for our meeting and banquet next winter, other reels of vineyard scenes in California. I want to encourage you in California in regard to what Mr. Stoll said in relation to the part the moving pictures play, and I believe they should be increased and shown to the people all over the country as nothing will impress them so strongly."

President Alwood announced the death of Mr. Henry Lachman, of Mission San Jose, California, a few days previously. The paper which Mr. Lachman had prepared was read by Mr. Sophus Federspiel of San Francisco. 
President Alwood announced that thirty minutes would be given for a discussion on the question of the Federal Tax on brandy used in the fortification of sweet wines.

Mr. C. E. Bundschu, of San Francisco, spoke of the work the California Viticultural Commission has inaugurated in the hope of getting relief from Congress, and invited the Eastern delegates to give their views on the subject.

Mr. E. M. Sheehan, Secretary of the Board of Viticultural Commissioners, told of the circulating of a petition throughout the State by the Commission, the petition to be presented to Congress at the first opportunity. Told of the opportunity given to Californians to reach the ears of the Congressional party that had been in the State recently on its return from Honolulu. Spoke of the possibility of there being an extra session of Congress in September, and the hope that in any call made for a special session the matter of this tax might be included so that the ears of the National Government might be reached at that time. The Commission expects to have 6,000 or 7,000 names signed to the petition by that time, and said that all of the California delegation in Congress is alive to the situation and most of them have promised to do all in their power to get relief from the present conditions.

"We have the hearty support of Senator Phelan and Senator Works," said Mr. Sheehan, "and of Congressmen Kahn, Curry, Nolan, Church, Raker, and, in fact, all of our Representatives in Congress with the possible exception of one from Southern California. This State is very weak so far as representation goes in Congress, and we do not seem able to get anywhere in matters of legislation in Washington, and I think it is timely for me to say to the Eastern delegates present that we would like to have the support of their Representatives. We are not asking anything unreasonable, but want to protect this enormous viticultural industry of our State."

Mr. Lee J. Vance, of New York: "On behalf of the American Wine Growers Association, I believe that this Association is composed about equally of California and Eastern wine grape growers, and you will have no trouble in the matter. Our legislative committee will be only too glad to cooperate. We have members in New York, Ohio, New Jersey; Michigan and other States, and they can bring pressure to bear greater than any other part of the United States."

Mr. Hiram Dewey, of New York: "In speaking for the East, I will say that we were very much hampered by this law going into effect so suddenly last year. We make our wine in September and October, and we do not fortify it until April. When this bill was being drafted, the Eastern and Western wine makers had representatives in Washington. We endeavored to have the passage of this bill deferred until after the fortifying was done. When we went to the office of Senator Johnson, of Maine, chairman of the committee on framing this bill, he showed us the bill they had been working on and to our utter surprise we found a clause in which there was a tax of $\$ 6.00$ per case on champagne. Most of the champagne made in the United States, as you know, is made in New York.

"With reference to the brandy tax, we are suffering in connection with you people in California as most of our brandy comes from your State. We have to pay the transportation and then the tax besides. We should use our 
best efforts to have this brandy used for fortifying wines put under the same regulations as denatured alcohol. The brandy put into sweet wine is not to make it more valuable, but simply to satisfy the demands of the public. Some people like a dry wine, but some cannot drink it and prefer a sweet wine. A great percentage of the sweet wine manufactured is used in the preparation of medicines.

"Why should we be taxed any more than the man who uses alcohol in the manufacture of other articles?

"I assure you that I shall interest our Eastern legislators as much as it is in my power to do and in connection with those who are associated with me to bring about a rational change in this law during the next session of Congress."

President Alwood: "I have had considerable experience before legislative bodies. I have been successful sometimes, and sometimes not. You should be able to make it perfectly clear to a committee just what you want when you go to Washington. If you want to use the spirits for preserving the sugar in sweet wines, make them understand it. Get the matter before them simply and plainly, and I have no doubt you will achieve your object." The Congress adjourned at 12:30 to meet again at half-past one o'clock.

\title{
AFTERNOON SESSION, JULY 12, 1915.
}

\section{RESISTANT VINES.}

\author{
By GEORGE C. HUSMANN,
}

Pomologist In Charge of Viticultural Investigations, United States

Department of Agriculture, Washington, D. C.

The subject "Resistant Vines" was assigned me. I infer Phylloxera Resistant Vines was implied and will treat it thus. In the Vinifera regions of this country the expression "Resistant Vines" has so long been thus applied that unless a qualifying term is used it is understood to mean "Phylloxera Resistant Vines". In the United States Department of Agriculture the expression has a broader meaning, as it has in other countries.

Thus, for instance, from 1858 to 1862 , when the destruction of the vineyards of France was feared through Oidium for which there was then no remedy known, American Euvitis varieties were imported to see if they would resist it. This was before anything relative to their resistance to phylloxera was known.

Records show that cuttings of Catawba and Isabella were sent to France as early as 1825, but no rooted plants of American Euvitis were sent until 1858 to 1863 , and then, by a singular coincidence, introductions of such were made about the same time into France, Germany, Portugal, England and Ireland. It is more than likely that phylloxera was introduced on some of these vines. 
Phylloxera injury was first noticed in France in 1863, in Austria and Hungary in 1868, in Switzerland in 1874, in Australia in 1875, in Spain in 1877, in Italy in 1879, in Russia in 1880, and in Turkey in Europe and Asia in 1885 .

Mr. Laliman of Bordeaux, France, was the first to notice and announce in 1869 the resistance to phylloxera of American grape species. Prof. C. V. Riley, then Chief Entomologist of the United States Agricultural Commission confirmed the statements of Laliman in 1870 , especially in regard to the Aestivalis species.

M. Gaston Bazille of Herault, France, is said to have been the first to attempt to utilize their resistance, and in 1869 tried grafting vinifera on American stocks. In 1871 he succeeded in growing American varieties on Vinifera, and in 1872 he, Planchon and Lichtenstein succeeded in grafting Vinifera on American stock.

In 1873, M. Planchon was sent from France to this country to study American vines. After his return to France the use of several American grape species as stocks for vinifera spread rapidly. The writer recalls heavy shipments of resistant cuttings made to France in 1873 to 1876 by his father, George Husmann, from Hermann, Missouri.

Prof. Viala, on his mission to this country in 1887, did most valuable work in directing attention to the value of the different species on the different soil types.

Space and time prevent mentioning the particular services rendered by other investigators actively participating at that time.

The foregoing explains why the early attempts at grape growing in the eastern states of this country, which were with material of Vinifera varieties the settlers brought with them, resulted in failures. These, unknown to the settlers, were doomed to destruction by phylloxera, and no permanent success was had until attention was given to the improving and growing of our native grapes.

Therefore, we find America in her native grapes has not only given the world new fruits but, because of their resistance to the phylloxera, has through them saved the viticultural industry of the world.

Why should we not, therefore, also be able to grow Vinifera varieties on resistant stock in many of the States of this country where they are not grown now? In fact the United States Department of Agriculture has proved this more than ten years ago in experiment vineyards it then had on the Atlantic Coast.

\section{Phylloxera in Vinifera Regions of the United States.}

The phylloxera, which is not a native of California, was probably introduced into that State from east of the Rocky Mountains. In 1880 it was found to exist in Sonoma, Napa, Solano, Yolo, Placer and Eldorado counties. No careful investigations had been made at that time of much of the region farther south in the State. It probably existed in Sonoma County as early as 1873, and possibly occurred in Sonoma Valley and on the Orleans Hills twenty years previous to that.

Innumerable remedies have been suggested and tried to eradicate phylloxera from vineyards, but it is still conceded that the only way to suc- 
cessfully combat it is to reestablish the vineyard on resistant stocks, except in the case of the vineyards which can be flooded cheaply and sufficiently to kill the insect.

\section{Early Attempts at Resistant Stocks in This Country.}

The varying soil, climatic and other conditions on the Pacific Coast which makes it possible to grow such a diversity of products in that region, has proven a great stumbling block in the reestablishment of the vineyards on resistant stocks.

Records show introductions and plantings of resistants were made in California as early as 1876. In the winter of 1880 to 1881 several large orders were placed for resistant vine cuttings from east of the Rockies.

Some of the earliest introducers accidentally chose varieties well adapted to their locations and soil. For instance, near Sonoma, Vulpina, (Riparia) introduced from Missouri, not only showed adaptability to soil and climatic conditions, but also proved congenial stock for the Riesling and Chasselas varieties which were principally grown there.

At the lower end of Napa Valley, the Vulpina also did well. As a result of such instances as these, Vulpina as a stock was planted indiscriminately in high and low localities and on various soils, particularly in the Sonoma and Napa valleys, the vineyards of which were the first to be destroyed by the phylloxera. There being but few localities suited to Vulpina in California, failures with them predominated.

Then again, it was thought Vitis Californica might be resistant. Without any substantiation of this by 1883 at least three hundred thousand of these had been planted.

A few years later the Lenoir, having done remarkably well on some soils, all who could secure them planted such. Had more vines been available more would have been planted.

Since then, Rupestris St. George is being as indiscriminately used and similar mistakes made with it.

The resistant stocks mentioned and all others of merit, a number of which had been introduced by the California State Experiment Station can be expected to prove valuable only under conditions and soils suited to them.

Furthermore, the work of selecting and breeding resistant stocks in European wine countries has been largely influenced by their relative ability to endure an excess of lime which is rarely met with in regions of this country where the viniferas are commercially grown at present, so that the resistant standards established by the French cannot be accepted as infallible, or in fact serve more than as a general guide for American viticultural investigators and vineyardists.

The waste of money spent in reestablishment of vineyards in California from the first appearance of phylloxera to the present time cannot even be approximately estimated. It is more than likely, however, that at least two hundred and fifty thousand acres of once flourishing vineyards have been destroyed by phylloxera and other agencies during the last decades. The claim is made that there are but few vineyards in California that are more than ten years old at the present time, and we are sorry to say a large percentage of these are not on resistant stock. 


\section{Factors in Resistance.}

For the benefit of those not familiar with the subject it should be stated that the resistance of vines depends on (1) the inherent resistant character of the vine, and (2) its adaptation to soil, climatic and other conditions. These are greatly influenced by the cogeniality of the graft with or to the stock.

The inherent characters pertain to the nature of the plant, which more or less enhance or restrain attacks of the phylloxera; causing the punctures of the insect more or less rapidly to produce swellings, nodosities and tuberosities, varying in size and number, upon roots of different texture, causing such swellings to rot more or less easily, rapidly and deeply, and by that rot determining the extent and rapidity of the enfeeblement of the roots and, where it is sufficient, the death of the vine.

The roots of the different grape species vary greatly in the effects the insect injury has on them, as well as in the likes and dislikes the insects seem to have for them. Thus, on vinifera varieties, the nodosities usually rot quickly and are about three times as large as those on the most resistant American species. Vines upon the roots of which the phylloxera does not remain and produces no injury at all would be called "immune". Varieties of some of the American species are not injured any further than the forming of a few nodosities on their roots. Such vines have a very high resistance.

In fact, on a determination of the relative number and size of nodosities found on the roots of the different species, the resistant ratings of these species are based.

The necessary degree of resistance for the production of good crops varies with the character of the soil and the congeniality of scion to stock; otherwise stocks rating 16 , being considered sufficient for all soils; 14 to 16 , for fairly good soils, and 10 to 14 for rich, moist, sandy soils.

\section{Adaptation to Soil, Climatic and Other Conditions.}

The ability of a vine to withstand the attacks of the phylloxera without serious injury is influenced greatly by the climatic and soil conditions in which it is grown. This may either increase or diminish the vigor of the plant and retard or favor the reparation of the insect injury.

The soil and climate also affect the resistance by being favorable or unfavorable to the approach, dissemination or activity of the phylloxera. For instance, sand of a certain fineness hinders the insect in traveling from the root of one vine to that of another, etc. Climatic variations also affect the multiplication of the insect.

Then again, a vine variety which resists splendidly in one locality perishes in another having the same soil but a different climate, or in another having the same climate but a different soil. This is due not only to the adaptability of some species to a moist and others to a drier soil or to a moist or dry climate, but also largely to the root systems of the species, which vary from horizontal to vertical, from thick to thin, and from soft to hard with intermediate grades between these extremes.

For instance, how could a horizontal root system thrive in a dry, hot climate and what could a deep rooting system do in a shallow, hard soil, or a moisture loving variety where there is but little moisture, or vice versa. 
A variety under congenial conditions of soil, climate, etc., will frequently prove more resistant than one having greater inherent resistance, but which is not adapted to the particular conditions.

The congeniality existing between scion and stock also influences the resistaice of phylloxera.

Causes like these and many others affect the resistant qualities of vines.

\section{Department Researches in Vinifera Regions.}

In a survey made by the writer in 1902 to 1903 of the region in which the vinifera is commercially grown in this country, it was found that exceedingly serious conditions prevailed. As all efforts to check the devastation of the phylloxera had failed, the United States Department of Agriculture was looked to for aid and in 1904 undertook a comprehensive investigation of the entire subject.

To afford facilities for systematically prosecuting these and other problems coming up for solution, the United States Department of Agriculture has located and maintained experiment vineyards at Brawley, Colfax, Chico, Elk Grove, Fresno, Geyserville, Guasti, Livermore, Lodi, Mountain View, Oakville, Sonoma and Stockton, California.

These were located with special reference to different soil and climatic conditions, higher and lower altitudes, nearness to and distances from ocean, bays and other bodies of water, and to bring out the typical differences of grape products derived in different sections under varying conditions. A mechanical analysis and correlation of the soils in each of these vineyards has been made, and weather records are kept in them to enable us to usefully apply results for the benefit of intending growers.

To obtain additional data on such minor differences of soil, climatic and other conditions not found in any of the experiment vineyards and to encourage others to research work, distributions of vines and cuttings are made to persons willing to report results had with them.

\section{Species and Varieties of Grapes Under Test in the United States Department of Agriculture Experiment Vineyards.}

All vinifera varieties of importance are being tested on all stocks considered valuable. Of the twenty-three species of grapes native to North America, fourteen have been found sufficiently important to have special attention given them. These are: Vitis aestivalis; v. berlandieri; v. bicolor; v. candicans; v. champini; v. cinerea; v. cordifolia; v. doaniana; v. Iabrusea; v. linsecomii; v. longi; v. monticola; v. rupestris and v. vulpina.

These, amongst other reasons, have been selected with special reference to the conditions under which they thrive as natives.

A description of these species and where they are found native is given in Bureau of Plant Industry Bulletin No. 172. As our researches progressed a number of other species have become represented in the vineyards. In the quest of resistant stocks suited to soil, climatic and other conditions and that are at the same time congenial and lasting stocks on which to graft vinifera varieties many difficulties are encountered.

For instance, a stock might be suited to the soil, but be so hard to root as to make its commercial use impracticable; again the stock might be suited 
to the soil, root easily and be resistant, but not be congenial to the vinifera varieties it is desired to graft; or the congeniality might otherwise be good but the fruitfulness of the graft be impaired. Then again, in many cases, no species of resistant is entirely suited to the soil and climatic conditions.

In order to overcome such and other difficulties, hybrids are being produced, using as parents, in breeding, native American species possessing the various qualities desired. A number of the best resistant stocks are hybrids of this nature. We are testing an extensive assortment of such hybrids and so called direct producers, hybrids between vinifera and American Euvitis, some of which it is hoped will produce sufficient fruit of desirable qualities and prove resistant, thereby eliminating considerations of congeniality and cost of grafting.

It has been ascertained that the same vinifera varieties grafted on different resistant stocks are sweeter on one, more acid on another, ripen earlier on some, later on others, are more productive on some stocks than on others; in fact often are entire successes on some stocks and failures on others. This shows the ideal conditions are the best adapted resistant stock, tops producing the finest fruit of sufficient quantity, and congeniality between tops and bottoms permanent and good.

There are more than nine hundred varieties under test in the Department's Pacific Slope Experiment Vineyards. Bureau of Plant Industry Bulletin No. 172 gives full account of the Department's Viticultural researches in vinifera regions up to the time the bulletin was written. United States Department of Agriculture Bulletin No. 209 gives a full account of such researches since then to date.

March 27, 1915.

\section{PRUNING AND TRAINING AMERICAN GRAPES.}

\section{By F. E. GLADWIN.}

Vineyard Laboratory Fredonia, N. Y.

The questions of how a variety should be pruned, long or short, when the pruning should be done, and how the canes should be disposed upon the trellis are ever recurrent. They come not only from the beginner in commercial grape growing, the garden grape fancier but, in large numbers, from vineyardists of many years' experience. It is probable that no one phase of grape growing is so little understood in its fundamentals as this subject. One of the causes that has contributed to this condition in a large measure, in certain sections of eastern United States, is the all too common practice of leaving the pruning to professional pruners, who see the vineyard at but the one season of the year and hence are unfamiliar with it during the growing period. The sole basis in this instance, for determining the amount of fruiting wood to be left, is the amount of wood made during the previous season. It is a well-known fact that the Concord may, in some cases, make a very vigorous growth of wood and yet fail to mature its fruit properly. Without this information the professional pruner cannot prune intelligently. We have growing on our Experiment Grounds a Concord vineyald eight years set. Each year the vines make a large wood growth, and if one were to judge from this alone, it would appear that at least ten 
buds more per vine could be left without injury to them. Yet in this vineyard the fruit matures poorly unless the fruiting wood is reduced much below what, the season's growth would indicate, should be put up.

In the Chautauqua Belt a crop of four tons of Concord to the acre is considered a very good one. As the more recent plantings are made in rows eight feet apart and the vines are spaced eight feet in the row, this yield would be borne by about 680 vines at an average of 11.8 pounds per vine. In order to return this yield, from forty to fifty clusters will be required from each vine. The buds for furnishing this amount of fruit may be on canes, on spurs or a combination of both. As each shoot bears from two to three clusters, usually two, and as some buds may be imperfect, be broken off in the tying, or the shoots injured later, it is well to leave more buds than is actually required to furnish the desired amount of fruit. Under unfavorable conditions, the same number of buds will not produce equal amounts of grapes in any two seasons, so that the principle advantage in a consideration of the number to be retained is in gauging overbearing rather than as a forecast of the crop. In some seasons, the secondary buds produce at least one marketable cluster in addition to the two or three returned by the primary ones. It is to be preferred that the vines be underpruned rather than over.

The time for pruning American varieties varies considerably with vineyardists, varieties and localities, but as a rule, the period extends from the falling of the leaves in the fall to just before the swelling of the buds in the spring. Some vineyardists even prune after the sap flow has become vigorous, claiming no injury therefrom. It has been observed that when this late pruning is done, and the sap flows down over the lower buds, that a freeze severely injures and often kill those covered with sap. And from this standpoint alone, late pruning is not to be recommended. As there is a considerable sap flow within the vine even before there are external evidences of it, it is best not to delay the pruning in order to lessen frost injury, through retardation of the exfoliating buds. Thus far we are not able to see any favorable affects on fruitfulness from late pruning. It is good practice to delay the pruning until after one or more severe freezes in the fall and early winter, as an index of the maturity of the wood. The immature canes will wither, and the poorly ripened tips will be killed back, thus making it possible to discard any such for the next years' supply of fruiting wood. Late fall or early winter pruning are desirable from the fact that a large amount of food from the canes will have undergone translocation to the stem and lower parts of the vine and hence is not lost to the vine by their early removal. It is quite probable that under ordinary conditions translocation has been completed at the end of the second or third week after leaf fall. As soon as sap flow begins in the spring the food in the stem and larger roots is carried to the canes and arms again and if the pruning be delayed till this time, it will be removed with the wood cut away. There is no reason physiologic or otherwise why American varieties cannot be pruned to the best advantage any time between these periods of translocation if the vines have well matured wood. But if the wood is not such, the work should not be begun until after severe freezes. In sections where snow covers the ground, a greater part of the winter, the pruning. should be done as far as possible when the least amount is on, so that access can be had to the growth 
springing from the ground level or just above it. The axiom "Never prune when the wood is actually frozen" has some foundation in fact, for frozen canes are brittle and are easily broken during handling.

In the fall of 1911 an experiment was started in a Concord vineyard eight years set to determine the affects of pruning at two widely separated periods of the dormant stage. Five rows consisting of about 68 vines each, trained on five different systems were pruned in the fall, approximately three weeks after the leaves had fallen. Five other rows immediately adjacent to, and representing the same five systems were pruned in the spring a short time previous to the starting of sap flow. In the fall of 1912 records of fruit yields from the five pairs of rows were taken. As these vines were planted in rows eight feet apart with the vines six feet apart in the rows, there are 907 vines to the acre as against 680 when ordinarily planted eight feet.by eight feet. The following table shows the yields for the two periods:

$\begin{array}{cc}\text { Fall pruned } & \text { Spring pruned } \\ \text { Tons per acre } & \text { Tons per acre } \\ 6.98 & 6.98 \\ 6.9 & 6.75 \\ 6.2 & 5.98 \\ 2.76 & 4.3 \\ 6.3 & 5.94\end{array}$

The variations appearing between the fall and spring pruned vines in this table are by no means consistent and are those that are common to any acreage of grapes or other fruits, grown under commercial conditions.

The following table is a compilation of the yields for 1913 in the same vineyard:

Fall pruned
Tons per acre
2.48
2.75
2.82
3.33
2.24

Spring pruned

Tons per acre

2.94

2.5

2.96

2.03

1.64

Here again it is seen that while three of the plats of the fall pruned, returned somewhat larger yields than the companion spring pruned rows, nevertheless two of the spring pruned in turn yielded the higher. In practically all of our experiments this natural variation has shown prominently. Certainly the data as here given does not warrant the drawing of conclusions pro or con.

The yields for the season of 1914 are as follows:

$\begin{array}{cc}\text { Fall pruned } & \text { Spring pruned } \\ \text { Tons per acre } & \text { Tons per acre } \\ 6.2 & 7.4 \\ 6.4 & 7.0 \\ 5.6 & 5.9 \\ 5.8 & 6.5 \\ 7.1 & 7.3\end{array}$

For the first time since the beginning of the experiment we see that all the spring pruned plats yielded slightly higher than the fall pruned. The increase ranges from 1.2 tons per acre down to the minimum 0.2 tons. If 
we leave the experiment with but the three years' results, we are not able to draw definite conclusions, even though those of 1914 point to the superiority of the spring pruned. It will require a number of years of experimentation to prove satisfactorily the superiority of one period over the other so far as the pruning of Concord is concerned.

Judicious pruning of the grape is more essential than the training to any particular system, but there does necessarily exist a relationship between pruning and training. It is quite obvious that varieties short pruned, will have their fruiting wood disposed somewhat differently on the trellis from those that are long pruned. Where the vigor of a variety permits and its fruiting habits are consistent with, it may be pruned for training to one or more of the common systems, but in many instances a variety is such a poor grower that it cannot be adjusted to a preferred system. There is no doubt that certain varieties do best when pruned to conform with the training of some particular type. Further the disposal of the fruiting wood, as made possible with some systems, favors the development of fruit of better quality, and wood for the following crop so placed on the arms and stem that it can be utilized to the best advantage. Other systems favor the best development of wood at points unsuitable for future use, although the fruit may be of good character. We have found that the sugar content of the Concord fruit, when pruned to the Chautauqua System, varies from different parts of the same vine. The fruit from the higher half gave for an average thirteen per cent more sugar than from the lower portion. While the amount of acid was greater in grapes from the lower portion of the vine than from the upper. Some of the systems now in common use favor this difference in even greater degree than the Chautauqua. Others operate to lessen the differences by promoting a more equable sap flow.

It is generally agreed that strong growing varieties like Concord, Niagara, and Clinton do their best when trained according to the drooping type, while weaker, slower growing ones, like Delaware, Dutchess, and Iona, can best be trained to some form of the upright type, all conditions being the same. The terms here used refer to the position the bearing shoots assume, rather than that of the canes. The drooping and the upright types are commonly used to-day, while the horizontal type has generally been discarded.

The drooping type is best represented by the Kniffen system and its various modifications. The growing shoots of the season are not tied but are allowed to hang free. Thus there is but one tying at a time previous to the starting of the buds. The type is characterized by a relatively long stem, and two to four short arms or branches. In all the modifications of the type the fruit is carried at a considerable distance from the ground and well disposed between the two wires and just below the lower one.

In our experiments we have used three forms of the Kniffen type, namely, the Single-Stem Four-Cane, the Umbrella and the Two-Stem FourCane. Inasmuch as the trellis is practically the same for each, it will be described at this time for the three. Two wires are employed, one placed at a height of about three, or three and a half feet above the ground level, and the other above it two or two and a half feet. Posts eight to eight and a half feet in length are required to allow for this height of wires. They 
may seem to be unnecessarily long but after they have been driven several years it will be found that they are not.

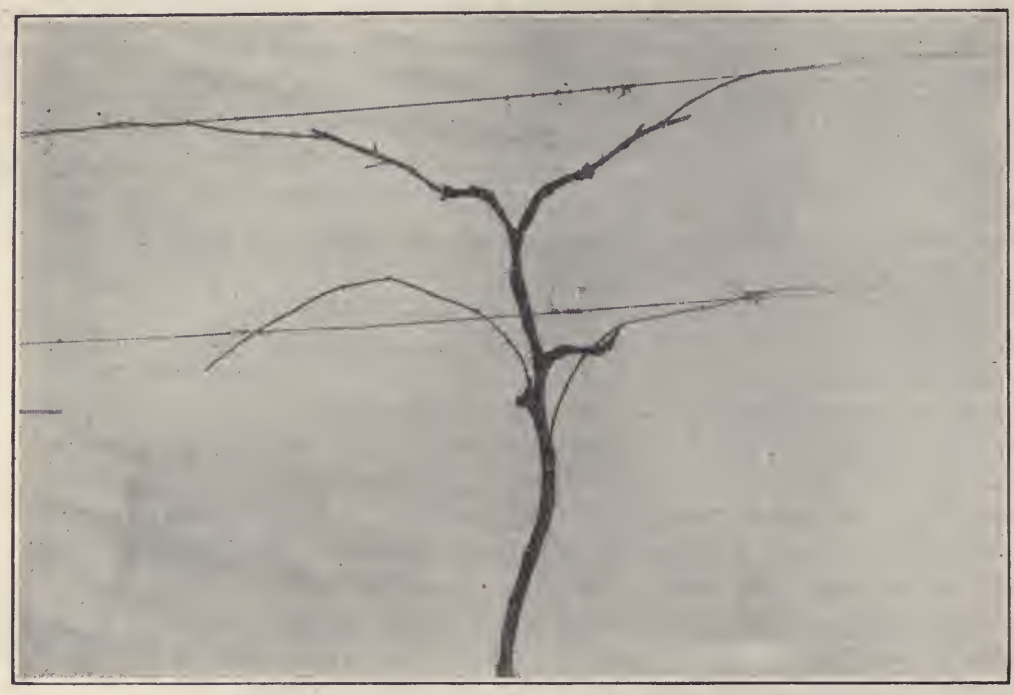

Fig. 1. Single Stem Kniffen System.

With the Single-Stem Kniffen.(Fig. 1), a single trunk or stem is carried directly to the top wire the third year after planting, or if the growth is not long enough at this time it is carried to the lower wire and there tied. The following year a cane from this is extended to top wire, thus the stem is formed for a period of years. In event of a complete stem to the upper wire in the third year, it is good practice to break out many of the developing shoots, and allow only the strongest to grow, and those that arise close to both the lower and upper wires. The stem should be tied tightly to the top wire and somewhat loosely to the lower. The girdling resulting at the top is not objectionable as the head of the vine is preferred somewhat below rather than at or above the wire. This facilitates the bending and tying of the canes. When the shoots have become sufficiently hardened those that are growing in proximity to the wires should be loosely tied to them in order that they may not be broken off during cultivation. At the beginning of the fourth year a typical vine should consist of a stem extending from the ground to a point just below the top wire. From this all but four canes and four spurs of two buds each have been cut away. Two canes and two spurs are therefore located below each wire level. As the sap flow is most vigorous at the top of the stem from four to six buds more are left on the upper canes than on the lower. A vine that has made sufficient growth so that the stem goes to the upper wire the third year will probably support the fourth season canes aggregating twenty-two buds with eight additional buds on the spurs. If the growth has been slight, only a half of this number should be left. It is far better to err with the lesser number. The tying at this time consists of fastening the stem rather loosely, with ordinary grape twine, to the lower wire, and with the same material the canes are tied down to and 
along the two wires to the right and left of the stem. The canes are tied tightly and just in from the last bud. When thus tied they cannot slip out of the twine and the girdling does not interfere with the fruiting wood of the following year. The two upper canes support the head of the stem so that no tying of it is necessary. In ordinary seasons tying at this time is sufficient for the year, however, if the conditions for rapid growth are unfavorable, the twine may rot away before the tendrils have firmly taken hold of the wires, and a partial second tying may be necessary. Where the acreage is not extremely large, it is a good plan to break off all clusters on the shoots growing from the spurs shortly after they are formed. The primary purpose for their retention is not for fruit this year but to furnish the fruiting wood for the following.

After the close of the fourth season, the pruner has a considerable choice of fruiting wood for the following year. It may be chosen from the basal canes of the preceeding year's fruiting wood or the canes that have developed from the spurs may be used. The choice depends upon the relative accessibility and maturity of the wood. At each pruning, the possibilities for obtaining fruiting wood for the following year should receive careful consideration, and provision made for it. It is possible to use the same spurs for two or three years but after this time they should be entirely cut away and new ones obtained. As far as possible after the first spurring, the spurs should be selected from the stem or wood that is older than two years. The shoots from such wood bear but little fruit, and hence make good fruiting canes for the next year.

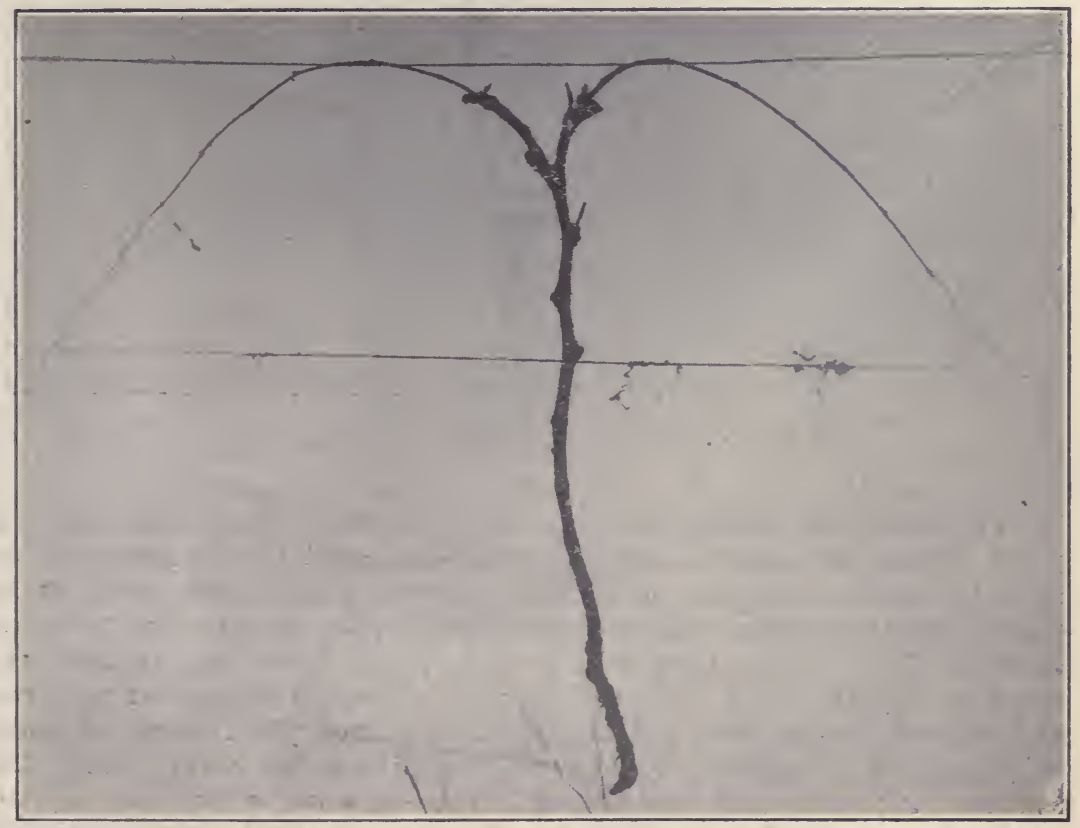

Fig. 2. Umbrella Kniffen System. 
With the Umbrella Kniffen (Fig. 2), the stem is brought up to the top wire in the same manner as with the Single Stem and a head formed just below it. When the vines are pruned at the close of the third year, all the canes are cut away, but two at the head of the vine and two renewal spurs. The canes are left long enough so that they can be carried up over the top wire and then obliquely down to the lower, where they are tied to it just above the last bud. The carrying of the canes over the upper wire lends considerable support to the stem and firmly fixes the canes, so that they are rarely blown down. The renewal spurs may furnish the canes for the year coming, or they may be gotten from the basal shoots of the canes of the previous year. The same attention to the maintenance of a goodly supply of renewal spurs should be given as in the Single Stem Kniffen. The amount of fruiting wood put up each year with this system is considerably less, however, so that the yield will be somewhat less.

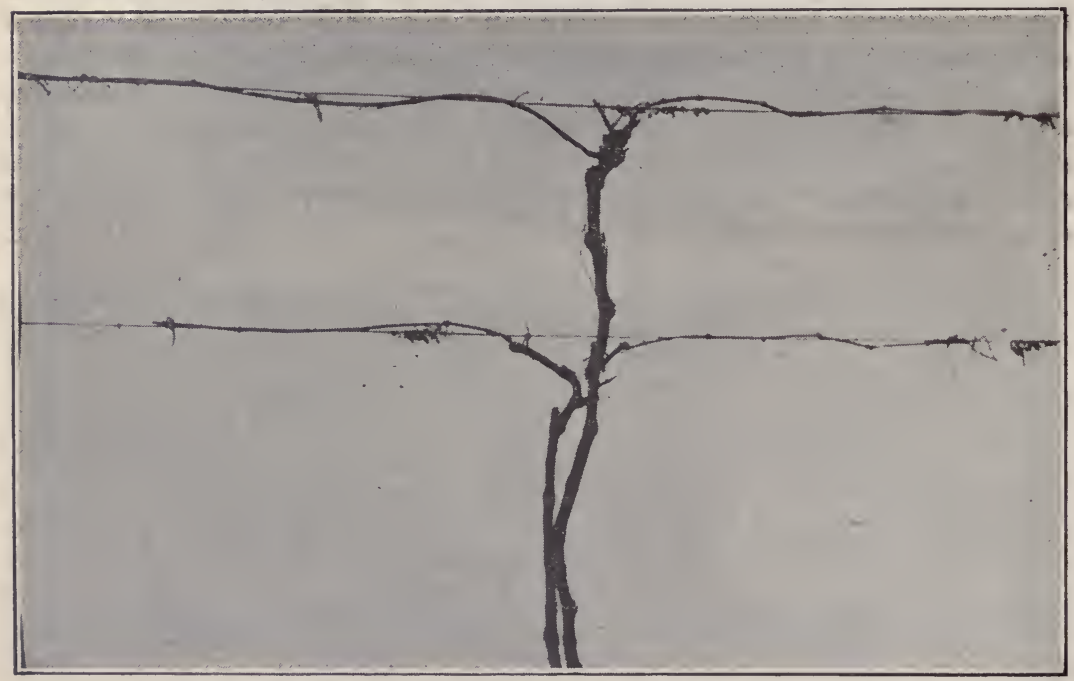

Fig. 3. Two-stem Kniffen System.

The Two-Stem Kniffen (Fig. 3), as the term implies, maintains two stems instead of one, as in the preceding systems. One is carried to the top wire as before described, where the fruiting canes are taken off in exactly the same manner as with the others. The second stem, however, reaches only to the lower wire or preferably just below it. At this level two canes are tied to it. In a typical vine both stems arise at or near the ground level. In another modification of the Kniffen, the Y stem, the point of divergence is midway between the ground and the lower wire. The methods for pruning and maintenance of fruiting wood is the same as with the Single-Stem Kniffen, except that each stem supports but two canes and two spurs. The canes are tied to the two wires exactly the same. 
A consideration of the values of the three systems for grapes of equal vigor with Concord will not be out of place at this time. The Single-Stem Kniffen has proven a very desirable method of training. The wires being some distance from the ground serves to keep all the tender growing parts out of the way of tillage tools. The same statement applies to the Umbrella and the Two-Stem Kniffen. With all three the canes are spaced for good air drainage, the growing parts are not crowded together in such a manner as to make conditions favorable for Powdery Mildew. The pendant position of the shoots disposes the leaves and clusters so that they are readily reached by spray mixtures. All three systems facilitate pruning, tying and harvesting, as all the fruit is borne practically between the two wires and but slightly below the lower. The Single-Stem Kniffen has produced the largest yield of the three for the four years that the experiment has been conducted, a yearly average of six tons per acre. The Two-Stem Kniffen follows with 5.3 tons, which is in turn followed by the Umbrella with 5 tons.

The Umbrella has, however, produced the best fruit, not only as to ripeness, but also in size of cluster, size of berry and compactuess. The Single-Stem falls short in these respects, while the Two-Stem is very much below the last named. It fails particularly in the ability to mature its fruit, much of it remaining red and unmarketable for dessert purposes.

The availability of fruiting wood has been greatest in the Umbrella Kniffen as it has also been the most mature. The Single-Stem Kniffen ranks second, while the Two-Stem Kniffen is a poor third. If the fruit is to be used entirely for dessert purposes the writer recommends the Umbrella Kniffen as a very desirable system. If the grapes are for unfermented juice or wine the Single-Stem possesses many advantages. The Two-Stem Kniffen can probably be discarded as an unsatisfactory system of this type of training. It should be kept in mind that these statements are made for the Concord growing under the best conditions of soil, fertilization and tillage. These conditions, however, are met in a great many vineyards in eastern United States. The vines, however, have in no way been pampered.

The upright type of training includes those systems in which two or more canes or arms are carried along a horizontal wire or obliquely across two or more such wires. The different systems of this type naturally fall into two classes, characterized by the terms Cane Renewal and Spur Renewal, according as the fruiting wood is obtained. The Spur Renewal, so far as the training of Concord is concerned, may be eliminated from a consideration, commercially. The Cane Renewal further separates into two groups, the High Renewal (Fig. 4) and the Arm (Fig. 5). The High Renewal, as the name implies, eliminates practically all of the old wood each year back to the stem. While in the Arm system more or less permanent arms are maintained. The High Renewal carries no wood over one year old, except the stem and spurs, while with the Arm system, in addition to the old stem, arms two years of age and over are maintained, according to the wishes of the vineyardist. 


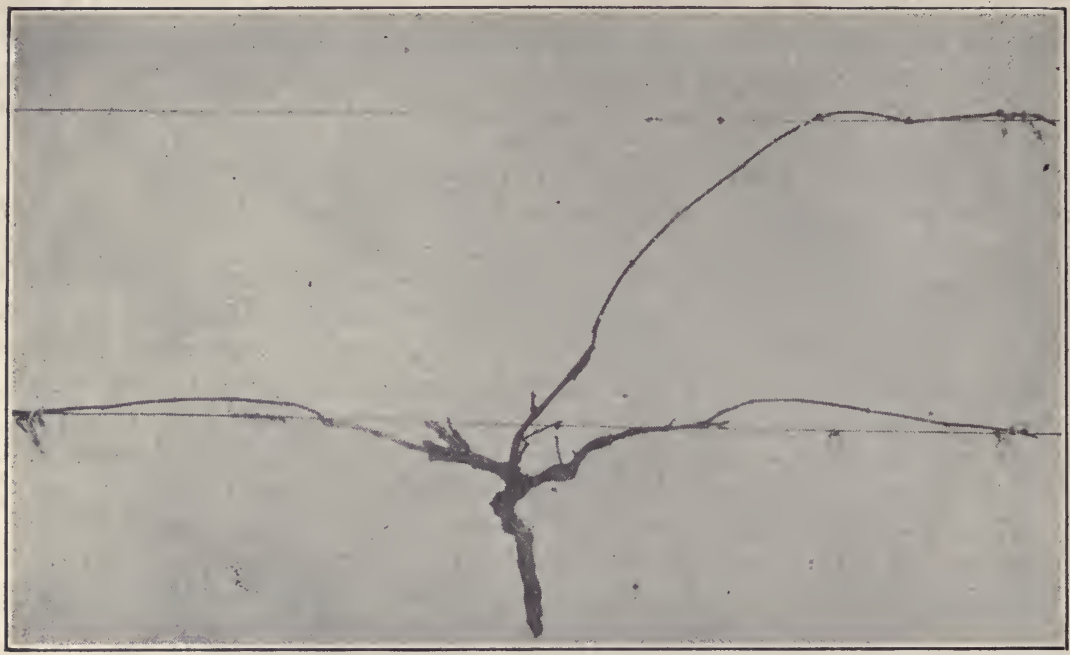

Fig. 4. High Renewal System.

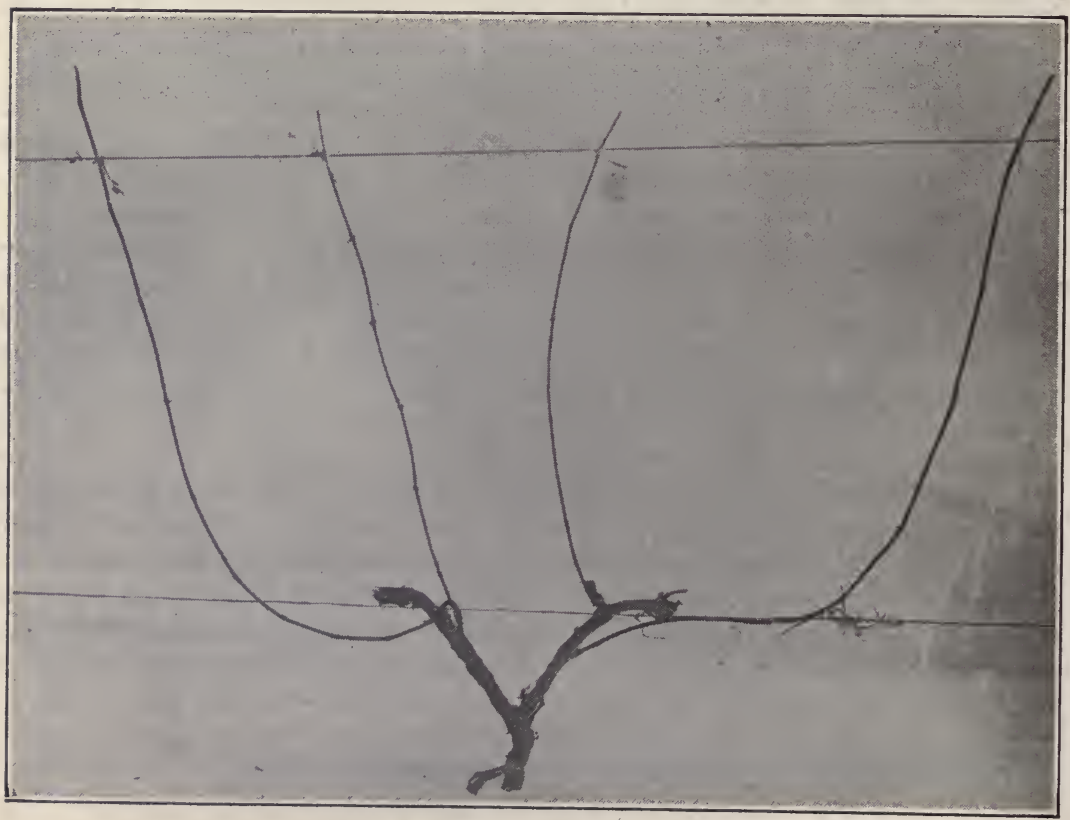

Fig. 5. Arm System. 
With both the High Renewal and the Arm system the wires are situated at practically the same heights. With the former three wires are required while with the latter two is the usual number although three may be used, and in many cases is preferable. In eastern United States the Arm system is generally the common one employed in growing the Concord, especially in the Chautauqua "belt". Here it is known as the Chautauqua or Tree system. The High Renewal is in general use for training the Catawba in the Keuka Lake District of New York.

The lower wire, with the two systems, is placed from eighteen to twenty inches above the ground level, and with the Arm, if but two wires are used, the second is about thirty-four inches above the lower. If three are employed the wires stand about twenty inches apart with both systems.

With the Arm training two canes are tied up at the beginning of the third year, if the vines be vigorous. If growth has been but scant, but one cane is left, while with extremely unfavorable growth it is cut back again to two buds. The canes are carried obliquely to the upper wire when the growth permits and there firmly tied either with twine or fine wire. The latter is more commonly used now. They are loosely tied to the lower. The pruning for the fourth year consists in cutting away all but two or three canes and a number of spurs on the canes of the previous year. The vine now consists of two arms, arising from near the ground, with two or three canes of the previous year, and several two-bud spurs at intervals along the arms. As far as possible those canes that have arisen but a short distance above the lower wire are selected, other conditions being equal. All the old wood projecting beyond the last cane on each of the arms is cut away. The canes (now arms) of the third year are bent down from their oblique position and tied firmly to the lower wire, to the right and left of the center of the vine. These are now the more or less permanent arms. The vine at this time consists of two arms, arising from near the ground, tied to the lower wire to the right and left of the center, and on these are two or three canes, pruned long enough to reach to the middle wire at least, and in the majority of cases to the upper. They are tied so that they stand in a vertical or oblique position. Along the arms at intervals of a few inches are spurs, consisting of two buds. If the vineyardist maintains the arms permanently these furnish the fruiting wood for the succeeding year. At the pruning for the fifth year one of the arms is cut away entirely, close to the point of its origination. The remaining arm, reaching from the ground to a point a few inches below the level of the lower wire, now becomes the permanent stem. The vineyardist has two options for selection of the fruiting wood. But first he must provide for the arm cut away. This is done by the selection of a cane, arising from the remaining arm at a point below the lower wire, either directly, or from a spur left for the purpose. This is pruned to reach the top wire and is tied obliquely to it. This cane at the next pruning is tied down to the lower wire and becomes the second arm. Then the same selection of canes and spurs is made from it as was made at the previous pruning, and the canes tied up as before. However if the grower desires to retain the arms of the preceding year for a few years, canes that have grown from the spurs, may be tied up and provision made for the following year through further spurring. Spurs may be obtained from cares that have arisen from dormant buds on the arm, or by spurring 
in the basal canes of the fruiting wood of the year previous. A combination of both methods of renewal will in the long run work out the better, as the repeated spurring in of the basal canes will result in greatly lengthened spurs that will require frequent cutting out. While the canes that arise directly from dormant buds on wood two years and over are not fundamentally the best fruiting ones, they can, however, be utilized for renewal purposes. The ideal vine pruned to this system now consists of a stem reaching from sixteen or eighteen inches above the ground level. From the head two arms arise, one extending to the right, the other to the left and tled along the lower wire, each arm not extending for more than two feet and a half to either side of the head. From the arms two canes on each are tied vertically or obliquely to the top wire. In addition there are left two or three spurs, growing from the upper side of each arm, located at well spaced intervals and preferably in proximity to the head.

One of the chief faults of the Arm system is the tendency of the best matured, and most desirable, canes to be developed at or near the upper wire, while those lower down are often too short, or so pcorly matured as to be unfitted for fruiting purposes. When the wood, bearing the well-developed upper canes, is brought down for arms, a considerable interval of the arm from the head to the point where the canes arise is without fruiting wood. Under such conditions the growth will be again thrown to the extremities. If spurring on the arms has been practiced, this undesirable condition is eliminated. With either type of renewal, spurring should be practiced. The fruit from vines trained to the arm system reaches its highest development at or near the level of the upper wire, that on the lower shoots is, as a rule, quite inferior. This, from the fact that sap flow is more vigorous at these points, resulting in more and healthier leaves. These in turn influence the fruit for the better.

In the vineyard of Concord given to a test of the various modes of training, the Chautauqua (Arm system) has returned an average yield of 5.7 tons annually for the past four years.

With the High Renewal system the trellis always includes three wires, placed as has already been described. At each pruning for the first two years the vines are cut back to two buds. However with strong growing varieties like the Concord, Niagara and Isabella, and under good soil conditions, the stem may be formed the second year. With moderate growers and under average conditions the formation of the stem is left till the third year. The cane that is the most direct and straightest as well as the best matured is chosen for the purpose. This is carried to the lower wire and there firmly tied. As soon as the shoots have made sufficient growth they are loosely tied to the wires so that they are kept away from the tillage tools. The fourth year the head of the vine is formed. This should stand a few inches below the lower wire. Two canes that have grown from the stem near this position are selected, and one is tied to the right and the other to the left of the stem along the lower wire. In the Keuka Lake District, the canes are tied with willows. In addition, at least two spurs of two buds each are retained near the head. With the Concord, the canes may carry about ten buds each, but with the Catawba as grown on the hillsides of the Central Lakes Region of New York, the canes should not carry above six buds each. As the shoots develop from the horizontal canes, they 
are tied with rye straw to the middle and upper wires. This summer tying is almost continuous after the shoots are long enough to reach the middle wire.

The following year all the wood is cut away except two or three canes that have developed from the basal buds of the canes put up the previous year, or that have grown from the spurs. In the event of a third cane being retained, it is tied to the middle wire. Spurs are again maintained close to the head for renewal purposes. The other two canes are tied along the lower wire as before. If the same spurs are used for a few years they so lengthen that the canes arising from them reach above the wire and cannot be so well managed in the "willowing". It is desirable to provide new spurs annually, selecting those canes for the purpose that arise from the head of the vine or near it. It is possible by careful pruning to so cut away the old wood that, practically all that remains after each pruning is the stem. Thus the vine is renewed almost to the ground. When the stem approaches the end of its usefulness, a shoot is allowed to grow from the ground, and the old one cut away. This system of training is especially adapted to slow growing varieties, or those situated on poor soils, where but little wood growth is made. It is ideally adapted for the growing of Catawba on the hillsides of the Keuka Lake District. It is well adapted to late maturing varieties that are planted out of their zone. Concord, growing under average conditions, is too vigorous to be trained to this system. It makes a tremendous growth of wood out of all proportion to the quantity of fruit, which is inclined to be very inferior. The chief objection to the system is the amount of summer tying involved, which comes at a time when attention to tillage should be given. It might prove profitable in the growing of dessert varieties, that have been discarded for lack of vigor and which command a fancy price. On thin hillside soils, the Catawba requires training modeled after this system, but on the heavier upland ones, with shorter pruning, it can be grown on the Arm plan. In our test vineyard, Concord trained to this system, has yielded a yearly average of four and three-tenths tons per acre during the past four years. Here we have put up from two to four canes per vine, excepting in 1911 when an average of but two was used. These canes carried from six to ten buds. Those tied along the lower wire having the first number, while the longer ones were tied to the middle one.

So far as the data is now available, it indicates that the Concord can be successfully grown, under judicious pruning, when trained to the Single-Stem Kniffen, the Umbrella Kniffen or the Chautauqua or Arm. The Kniffen systems possess several points of superiority over the Arm, as has already been described, yet the fact remains that the latter, when the vines are well pruned, is proving a successful method.

Niagara, Hartford, Champion, Clinton, Diana, Hernito, Noah, Mo. Riesling, Agawam, Lindley, Herbert, and Lucile can be trained very satisfactorily to either of these three systems.

Catawba, Delaware, Iona, Dutchess, Campbell, Eumelan, Jessica, Vergennes and Regal are, as a rule, grown to better advantage when trained to the High Renewal.

Other varieties of vigor, ranging between the two, of which Worden is a good example, should be pruned somewhat longer than the last named group and trained to the High Renewal. 
Any system of training to have merit must be so adapted to the variety, as grown on the particular soil type, that it will conserve the energies of the vine from year to year. Any system can be abused in the hands of the incompetent pruner.

\section{COMMERCIAL FERTILIZERS FOR AMERICAN GRAPES.}

\section{By F. E. GLADWIN.}

Vineyard Laboratory, Fredonia, N. Y.

This paper presents the results of six years' study on the role of commerical fertilizers in grape growing for New York. The data here presented is not to be considered conclusive kut rather suggestive in pointing the way towards a reasonable standard cf production, and at the same time maintaining the vines in good vigor. Fertilization and manuring of vineyards has been a hit or miss operation, no well-defined plan having been followed out. Vineyardists of New York are generally of the opinion that stable manure or potash in some form are all important. Of the potassium carriers, Kainit is the möst popular. Commercial Nitrogen and Phosphorous have generally been applied only in factory-mixed goods and these are usually low in quickly available Nitrogen.

No long time fertilizer experiments have been conducted with the grape in the United States under commercial conditions. The French and Germans, however, have made numerous tests, yet because of the dissimilarities of species and cultural practices they are of little use to American grape growers. A few are worth brief mention. Sannino2 reports "that he used 356 pounds per acre of sulphate of potash and no differences in wood growth were to be seen between the fertilized and the unfertilized. At harvest time, however, the fertilized grapes were seen to be a little larger and sweeter than the unfertilized." No differences in the amounts of fruit are recorded.

Stoklasa, J.,3 reports the following yields from .08 acre: Plats

Check $4600 \mathrm{Kg}$.

Acid phosphate, 17 per cent, 814 pounds per acre

Kainit, 1430 pounds per acre. $5500 \mathrm{Kg}$.

Acid phosphate, 814 pounds per acre.

Ammonium sulphate, 616 pounds per acre.

Kainit, 1430 pounds per acre. $7100 \mathrm{Kg}$.

This experiment seems to show that nitrogen was the limiting factor.

Zeissig 4 obtained much heavier wood growth from the use of 160 pounds of nitrate of soda put on in three applications than from plats where nitrate was omitted. The development of fruit and the yield were most satisfactory. Nitrate of soda was more effective with some varieties than with others.

2 Sannino, F. A. (Revista) Conegliano.

3 Stoklasa, J. Wiener Londw. Ztg. 59.1909. No. 18, p. 182.

4 Zeissig, Ber. K. Lehranst Wien, Obst. u. Gartenbau, Geisenheim, 1902, pp. 59-64. 
Zacharewicz, E.̃ concluded that nitrate of soda associated with sulphate of potash and superphosphate of lime increased yields, hastened maturity and raised the sugar content of the fruit.

Holloday 6 observed that the only fertilizer that showed on the growth of the vines in a marked degree the first season was dried blood. This was evidenced also in a brighter, fresher green of the foliage. Potash showed little if any effect.

\section{Fertilizer Formulae.}

Most fertilizer formulae for grapes have been suggested from time to time by chemists. Van Slyke 7 recommends liberal applications of a fertilizer carrying 2 per cent nitrogen, 8 per cent phosphoric acid, and 11 per cent of potash. Nearly all formulae seem to be based on the amounts of the principal elements removed in an average crop of fruit and wood. Manufacturers and distributors of fertilizers furnish in their advertising, formulae, taken from experiments carried on under their direction with grape-growers who are not in many cases competent to do careful work.

\section{The Experimental Vineyard.}

In the spring of 1909 this Station leased the 30 -acre farm of H. B. Benjamin, Fredonia, New York. The soil is of three types on the Benjamin farm. Dunkirk gravelly loam, Dunkirk silt loam and Dunkirk clay loam. The fertilizer experiment was located on the gravelly loam as follows:

The Dunkirk gravelly loam is a deep open soil quite inclined to leaching. It is formed of alternating layers of varying degrees of fineness. In the Benjamin vineyard it extends to a depth of approximately 20 feet. It should be said that this type of soil is generally preferred by vineyardists in the Chautauqua Belt, not by reason of superiority in its plant food content, nor because grapes are better grown on it, but rather because it is naturally well drained and more easily worked. It consequently commands a higher price per acre. In 1909 about one-third of the entire acreage of the Chautauqua District was located on Dunkirk gravelly loam. Since then, however, the plantings have been largely on other soil types by reason of the fact that practically all land of this character had been planted to grapes or other fruits.

\section{The Fertilizer Section.}

A section of approximately three acres was selected for the tests of commercial fertilizers. This area is very uniform and with a gentle slope to the south. A slight depression extends across the entire section from east to west. The plats extend at right angles to this depression, so that as far as topography is concerned, they are very uniform. The soil on the north side is possibly a little lighter than elsewhere in the section, but the same extent of each plat overruns this variation. The rows, 46 in number, run north and south and contain 37 vines per row. A few scattering vines have died and not all are yet replaced. The age of the vines in this section is not known but they were approximately 18 years old at the time this experiment was begun in 1909. At this time it was a representative vineyard for this type

5 Zacharewicz, E. Prog. Agr. \& Vit. (Ed. l'Est. 1906.)

6 Holloday, A. L. Virg. Sta. Bull. No. 35.

7 Van Slyke, L. L. New York Agricultural Exp. Station Bull. No. 94. 
of soil and of like age, except that the west portion including about 20 rows was in poorer condition than the remainder of the section.

As far as could be learned no commercial fertilizer nor stable manure had been applied to the vineyard for the last ten years before the beginning of this experiment. The tillage had been that ordinarily given; namely, spring plowing, horse-hoeing, hand-hoeing and cultivation with the spring tooth and disc harrows. Spraying had been done intermittently.

This section as shown in Figure 1 was divided into 11 plats consistipg of three rows each, beginning on the west side. The rows are eight feet apait and the vines stand eight feet in the rows, making 680 per acre. Each plat would contain 111 vines if none were missing, or approximately $1 / 6$ of an acre. In computing the results the actual number of producing vines are counted. Outside of a few scattering vines of Clinton and Catawba the vines are all Concord.

\section{Treatment of Plats.}

Fertilizers were applied as follows:

Plat 1.

Nitrate of soda at the rate of $100 \mathrm{lbs}$. per acre.

Cotton seed meal at the rate of $800 \mathrm{lbs}$. per acre.

Acid phosphate at the rate of $300 \mathrm{lbs}$. per acre.

Sulphate of potash. at the rate of $200 \mathrm{lbs}$. per acre. Lime (air slacked) at the rate of $2000 \mathrm{lbs}$. per acre.

\section{Plat 2.}

Plat 2, separated by a discard row from plat 1, had the same application excepting that no lime was used.

Plat 3.

Nitrate of soda at the rate of 100 lbs. per acre.

Cotton seed meal at the rate of 800 lbs. per acre.

Acid phosphate at the rate of 300 lbs. per acre.

Plat 4.

Nitrate of soda at the rate of 100 lbs. per acre.

Cotton seed meal at the rate of 800 lbs. per acre.

Sulphate of potash at the rate of 200 lbs. per acre. Plat 5.

Sulphate of potash at the rate of 200 lbs. per acre. Acid phosphate at the rate of $300 \mathrm{lbs}$. per acre. Plat 6.

Unfertilized.

Plat 7.

Duplicate of plat 1 .

Plat 8.

Duplicate of plat 2 .

Plat 9.

Duplicate of plat 3 .

Plat 10.

Duplicate of plat 4 .

Plat 11.

Duplicate of plat 5 .

Each plat is separated from adjacent ones by discard rows not considered in the results. 
In $1910,1911,1912,1913$ and 1914 dried blood was substituted for the cotton seed meal owing to the difficulty of obtaining the meal. The amount of dried blood used in 1910 was at the rate of 560 pounds per acre. In 1911 , 1912, 1913 and 1914 but 400 pounds per acre were applied. The difference was made necessary because of the variability of the nitrogen content of the blood in 1910 and the four years following.

The lime applications have been made at three year intervals. Thus far two applications have been made, one of air slacked lime and the other an equivalent amount of ground limestone.

The fertilizers were purchased in the open market at prevailing prices and were "home mixed."

The lime was broadcasted and harrowed in after spring plowing.

In 1909 the cotton seed meal and nitrate of soda were mixed with the other materials, broadcasted and plowed under, but in 1910, 1911, 1912, 1913 and 1914 the dried blood and nitrate of soda were withheld from the mixtures and two applications made of them, one shortly after growth started and the second two or three weeks later. In both cases the nitrogen was broadcasted and lightly harrowed in. The acid phosphate and sulphate of potash were applied early and plowed under.

Using these materials at the rates just given we applied in 1909, 72 pounds of nitrogen, 58 pounds of phosphoric acid and 108 pounds of potash per acre. In 1910,1911, 1912, 1913 and 1914, we applied 56 pounds of nitrogen, 42 pounds of phosphoric acid and 96 pounds of potash.

Chemical analyses 1 shows that about 15 pounds of potash and 8 pounds of phosphoric acid are removed in producing a ton of grapes and 1000 pounds of wood per acre, hence a three ton crop would theoretically require approximately 50 pounds of potash and 24 pounds phosphoric acid.1 If these figures be correct it will be seen that the applications have been sufficient to supply the needs and still leave an accumulation in the soil. However, the six year average for this section has been over three tons and the wood production considerably greater than a 1000 pounds per acre, so the accumulation is considerably less than the figures would indicate.

\section{Gauging Results.}

During the first two years, 1909 and 1910, records were made of the fruit yields from the different plats, and the general coudition of the vines in them, as to their vigor, indicated by the wood growth and the amount and color of the foliage. For the past four years, 1911, 1912, 1913 and 1914, in addition to the above data, weights of the pruned wood, leaf weights (green and dry), amounts of bearing wood put up, and fruit characteristics, as, size of clusters, size of berries, compactness and maturity, were recorded for each plat.

\section{Table 1.}

Yields in tons per acre from the various plats of the commercial fertilizer vineyard for the years:

\begin{tabular}{|c|c|c|c|c|c|c|c|}
\hline Treatment. & 1909 & 1910 & 1911 & 1912 & 1913 & 1914 & 6-yr. av. \\
\hline Complete fertilizer, lime. & 4.48 & 2.10 & 5.37 & 3.46 & 2.14 & 4.90 & 3.7 \\
\hline Complete fertilizer.. & 4.76 & 2.21 & 5.71 & 4.30 & 2.83 & 5.20 & 4.1 \\
\hline Nitrogen and phosphorus.... & 5.17 & 2.14 & 5.61 & 4.00 & 2.25 & 4.00 & 3.8 \\
\hline Nitrogen and potash.... & 4.25 & 2.55 & 5.64 & 4.10 & 2.85 & 5.30 & 4.1 \\
\hline Phosphorus and potash......... & 3.41 & 2.00 & 5.44 & 4.35 & 1.78 & 4.00 & 3.5 \\
\hline Check & 3.38 & 2.10 & 5.32 & 3.60 & 1.24 & 2.90 & 3.1 \\
\hline Complete fertilizer, lime........ & 4.69 & 2.38 & 5.62 & 4.80 & 3.04 & 5.10 & 4.2 \\
\hline Complete fertilizer...... & 4.66 & 2.07 & 5.71 & 4.98 & 2.72 & 5.80 & 4.3 \\
\hline Nitrogen and phosphorus..... & 4.99 & 2.04 & 5.35 & 4.89 & 2.61 & 4.80 & $t .1$ \\
\hline Nitrogen and potash... & 4.79 & 2.26 & 5.91 & 4.89 & 3.07 & 5.70 & 4.4 \\
\hline ot & 4.99 & 1.87 & 5.03 & 4.21 & 1.97 & 4.50 & 3.7 \\
\hline
\end{tabular}




\section{Yield of Fruit.}

In table I are given the amounts of fruit borne the past six years, beginning with 1909. Records of individual vines were not kept. The total production of each plat was recorded and from these the average yield per vine has been obtained. Then the yields have been computed in tons per acre. The table shows that in 1909 the unfertilized check yielded less than any plat in the experiment, ranging from three hundredths of a ton less in one, to one and seventy-nine hundredths tons less in another instance. On either side of the Check Plat, the yields with one exception are much greater than from the Check. The exception is in the plat to which no nitrogen was applied. No differences in wood growth or in the color of the foliage of the vines in the plats were discernible in 1909.

During the winter of 1909-1910 approximately 50 per cent of the buds, that were to produce the 1910 crop were killed. Counts made of injured buds in the different plats showed that the killing was uniform over all and that the fertilizers had not thus far affected favorably, hardiness of bud. This condition was reflected, as Table I shows, in the uniformity of yields from the several plats in 1910. Not only were the yields about equal over the entire section for the year 1910 , but the small crop, by not taxing the vines, probably served also, to equalize the $1911 \mathrm{crop}$, which was uniformally high as the crop of 1910 was low. Thus the season of 1910 may be considered a rest period. Differences in yield between the check and fertilized plats were so slight that they are within the range of experimental error.

The yield records for 1912, however, show marked differences in the several plats. From them it will be seen that only one fertilized plat, No. 1, to which was applied complete fertilizer and lime, fell below the check. The part of the section that includes this plat, it will be remembered, with some adjacent plats, were lacking in vigor at the beginning of the experiment. Their poor condition, probably, is still reflected in the yields of 1912.

The differences in yield between the check and other fertilized plats range from four-tenths of a ton, to one and thirty-eight hundredths tons per acre.

In 1913 the check plat is without exception the low producer. The differences between it and the fertilized plats range from fifty-four hundredths of a ton in the case of plat 5, phosphorus and potash, to one and eighty-three hundredths tons with plat 10 , nitrogen and potash. In this year both phosphorus and potash plats, which up to 1913 have produced crops comparable with any of the others, gave the lowest yields of the fertilized plats. This seems to indicate that the lack of nitrogen in these plats is beginning to be felt.

Again in 1914 all the fertilized plats have yielded crops considerably above the check. These gains vary from 1.1 tons to 2.9 tons per acre over the unfertilized. With but one exception the plats receiving Nitrogen were the high yielding ones. In this instance one Phosphorus and Potassium plat yielded exactly the same amount of fruit as its companion Nitrogen and Phosphorus one. It would appear that the lack of uniformity of the plats on the west side of the section has been somewhat overcome by reason of the treatment given. 
The six year averages for the plats indicate that all have produced more than ordinary crops for the period and while the showing for the check is good, the fact that it dropped behind in 1912, 1913 and 1914 probably means that the fertilizers are beginning to tell in the fertilized plats. We shall see that the fertilized vines show improvement as well.

\section{Fruit Characteristics.}

No differences were to be detected in the fruit in 1909, 1910 and 1911 from the various plats. The grapes in all respects compared very favorably with those in the average well-cared-for vineyard on the same soil type. No better, no worse. Nor were any differences noted in its time of maturing. But in 1912 it began to appear that the fruit from the plats on which nitrogen had been used, was superior in compaciness of cluster, size of cluster, size of berry and matured earlier than the grapes in the check. The grapes in the phosphoric acid and potash plats while superior to those in the check in these respects, were not equal in quality of fruit to those of the plats which had nitrogen. The clusters from the check were scraggly and both clusters and berries were small. In 1913 these differences, with the exception of earlier maturity, were even more marked. The favorable ripening season and the smaller crop probably tended to equalize the time of maturity between the fertilized and the unfertilized plats. In 1912 ripeness was an important consideration and we believe that the fertilizers played an important part in hastening maturity. In 1914 the fruit from the plats that received Nitrogen was superior to all other, while that from the phosphorus and potassium rows was considerably better than the check.

\section{Table 2.}

Amounts of wood pruned per acre for each plat.

\begin{tabular}{|c|c|c|c|c|}
\hline Treatment. & 1912 & 1913 & 1914 & 4-yr. av. \\
\hline lbs. & lbs. & lbs. & lbs. & lbs. \\
\hline plete fertilizer, lin & 1020 & 1088 & 1033 & 1096 \\
\hline lete fertilizer.... & 1196 & 1292 & 1149 & 1256 \\
\hline en and phosphorus.... & 1156 & 1088 & 972 & 1144 \\
\hline gen and potash........................... ${ }^{2}$ & 1258 & 1360 & 1217 & 1299 \\
\hline horus and potash. & 1033 & 816 & 972 & 1011 \\
\hline 1305 & 707 & 734 & 761 & 877 \\
\hline 1734 & 1162 & 1496 & 1278 & 1417 \\
\hline te fertili & 1183 & 1400 & 1339 & 1417 \\
\hline en and phosphorus.... & 1162 & 1190 & 1142 & 1293 \\
\hline (........................... 1720 & 1203 & 1407 & 1258 & 1397 \\
\hline orus and & 1006 & 952 & 938 & 1096 \\
\hline
\end{tabular}

* Weights taken in spring of 1912. All others in the fall of their respective years.

\section{Annual Wood Growth.}

There were no indications either, in 1909, 1910 and 1911 that fertilizers were producing any increase in wood growth, apparent to the eye at least. In the fall of 1911 , as fast as the plats were pruned, the wood was stripped from the wires, forked out to the end of the rows and weighed. The weights included the weights of the canes put up for the year previous in each instance. Owing to unfavorable weather but seven plats were weighed at this time. The remaining five were weighed early in the spring of 1912 . 
These are starred in Table 2 which gives the results. It is quite probable that the wood from those that were not weighed lost weight during the interim between pruning and weighing, as the weights taken for the years 1912-1913 and 1914 do not show the differences in weight between the halves of the section shown in 1911.

From the above data, we conclude that commercial fertilizers for grapes are at this writing having a marked effect upon wood growth, yield and quality. The use the first season, 1909, apparently had a decided effect upon the crop of that year, although normal Plat variations may account for the increased yields of the fertilized over the unfertilized.

Bud injury during the winter of 1909 and 1910 reduced the crop the second year 50 per cent. Both the fertilized and unfertilized plats were equally affected. The crop of 1910 was fairly uniform over all the Plats. The general light crop, no doubt, tended to equalize the yields for the succeeding year 1911.

No differences in the amount or the color of the foliage were apparent till the summer of 1912. Then the nitrogen fertilized plats clearly showed superiority in these respects to those on which no nitrogen was applied and also to the check. The phosphorus-potassium plats appeared superior to the check.

The plats receiving the nitrogen application produced fruit in the years 1912, 1913 and 1914 somewhat superior in size of cluster, size of berry and compactness, to the plats to which phosphorus and potassium had been applied and considerably superior to the check. The phosphorus-potassium plats yielded fruit better than the check in these respects and probably more mature at the time the observations were made. The nitrogen has probably indirectly affected fruit characters through its action in producing more healthy wood and leaf, as well as greater amounts.

It appears that nitrogen quickly available has been the limiting factor with this vineyard. That two applications, one at the time the first three or four leaves of the shoots are out and a second two or three weeks later are preferable to a single application of the total amount used in the two. That the carriers of nitrogen in this experiment, nitrate of soda and dried blood, on this type of soil should be broadcasted and lightly harrowed in and the phosphorus and potassium applied before plowing somewhat earlier.

Thus far lime has proved of no direct benefit in the experiment.

This experiment indicates that commercial nitrogen in connection with good tillage will restore a run-down vineyard on soil of a gravelly nature. That systematic applications are necessary, and immediate results are not to be expected, and that good tillage alone will not accomplish this. 


\title{
PHYLLOXERA RESISTANT STOCKS IN CALIFORNIA.
}

\author{
By F. C. H. FLOSSFEDER,
}

Viticulturist, University Farm, Davis, California.

When the phylloxera appeared in France and after it had done a considerable amount of damage, it was thought the crossing of the non-resistant vinifera varieties with resistant American species would save the industry. This was attempted and we got what is called the direct producer, of which we find a few here and there, grown at the present time. The results obtained in this way were, for several reasons, not satisfactory. The grafting on resistant vines was commenced at about the same time, but this also was not accompanied by the results expected, because a good many stocks used at that time were not resistant enough or not suited to the soil in which they were planted. Very often they were very weak growers, and, as the years passed by, the field grafted vines were pulled up, because they proved to be unsatisfactory in several ways, and experimenters narrowed down their very large collections of species, varieties and hybrids of Vitis to the comparatively small number of stocks used at the present time. After long years of hard and systematic work, it may be said, that at the present time there is in France a resistant stock suited to almost every kind of soil.

Here in California, things are somewhat different. Grape growing in this country is comparatively new, the phylloxera appeared much later and climatic conditious here do not allow the phylloxera to destroy the vineyards so quickly as in Europe. There are Muscat vineyards here, which are known to have been infested with the insect for fifteen years, but are still in existence and giving good crops.

To a certain extent, we do benefit by the experiences gained in Europe. However, very often it happens that a given stock, which does well in France, seems to give no good results under about the same conditions in California.

As no systematic work had been done along this line of investigation, Prof. F. T. Bioletti, of the Division of Viticulture, College of Agriculture. University of California, in the spring of 1910 commenced a series of bench graftings to supply material for the stock testing of blocks " $E$ " and " $F$ " of the Davis, and "A" and "B" of the Kearney Experiment vineyards. Of the 9,750 bench grafts made, 5,612 or 57.55 per cent grew. The variation in percentage of the various combinations which gave successful unions and of their vigor, was very great and indicates, first, suitability of these combinations; secondly, the general suitability of each stock for nursery work; thirdly, the general ease of grafting for each scion.

During the summer of 1910 these bench grafted grape vines received ordinary nursery care. They were dug up in the fall, and planted in March, 1911 , in the field with the unions an inch above the surface of the soil.

During the summer of 1911 they were watered twice; the soil was well cultivated in order to give them a good start, which they made. In November, 1911, we had a very bad early frost, and owing to the fact that the vines were still growing, they froze down to the ground and, in some few instances, even below the union, rendering the plants useless. 
The results are summarized in the accompanying tables:

Table A shows the percentage of successful unions of the various combinations, the average number of pounds per vine of the first crop, the Balling per cent and total acidity of the juice and the relation between the diameter of the stock and scion in June, 1915, of all vines three and four years old.

The percentage of successful unions depends upon various factors. Among the principal are: A, specific vigor of scion and stock, especially of the former; $\mathrm{B}$, the ease of rooting of the stock; and $\mathrm{C}$, the specific capacity of each variety of stock and scion to form uniting tissues. These factors may be modified by the condition of the cuttings and by the health and vigor of the vines from which they are made. Where the latter are defective, the results may be bad through no defect of the varieties nor of the combinations. A single failure must, therefore, be considered as negative and inconclusive. Many failures of a stock or of a scion when grafted with different varieties give strong evidence of unsuitability. Successful results are of more importance and a single good result may be considered as proof of the suitability of the varieties and combinations.

These results indicate the relative ease of grafting and the vigor of the nursery vines. They give no assurance of the behavior of the vine in the vineyard, of their fruitfulness nor of their longevity. A vine which grows well in the nursery, however, is likely to do well in the vineyard, if the conditions are suitable.

Nurserymen consider 60 per cent of first-class unions as very satisfactory, and anything under 40 per cent as unprofitable. The average in practice will be somewhere near 50 per cent. Any of the combinations in Table "A" which show a percentage of not less than 60 per cent may be considered worth trying and fairly sure to give good results if the soil where the vines are planted is suitable to the stock chosen.

This table gives an idea of the relative ease with which some of our commonest varieties can be grafted. Valdepeñs, Sultana and Petite Sirah gave 50 per cent or over on all stocks, with the exception of Berlandieri hybrids. Some gave very high percentages on some stocks and low on others, such as the Gros Mansenc with 95 per cent on Riparia gloire and only 23 per cent on Rip. X Rup. 3309; or the Sultanina with 85 per cent on 3309 and only 23 per cent on Riparia gloire. Such cases as the latter are particularly valuable, as the scion and stock cuttings were the same in both cases and the differences can be safely ascribed to specific peculiarities of the varieties. The excellence of the Valdepeñas as a grafting scion is shown by the high percentage of successful unions on Berlandieri hybrids, 65 per cent on $41 \mathrm{~B}$ and 60 per cent on $420 \mathrm{~A}$.

Similar information is given regarding the various stocks. The high percentage of successful unions with the St. George and their great vigor explains the preference of nurserymen for this stock. The low percentage of the Berlandieri hybrids $41 \mathrm{~B}$ and $420 \mathrm{~A}$, and their relative lack of vigor do not attract the nurserymen, but European experience has shown that the vines become vigorous as they become older and have valuable qualities of fruitfulness, longevity and adaptability to unfavorable conditions. 


\section{A. Table to Indicate Relative Suitability of Various Grafting.} Combinations.

\begin{tabular}{|c|c|c|c|c|c|c|c|c|}
\hline \multicolumn{2}{|r|}{ Scion. } & $\underset{\%}{\text { Nursery }}$ & $\begin{array}{l}\text { Crop } \\
\text { Lbs. }\end{array}$ & Bal. & Acid & $\begin{array}{l}\text { Stem } \\
\mathrm{mm} .\end{array}$ & $\begin{array}{l}\text { Stock } \\
\text { mm }\end{array}$ & $\begin{array}{l}\text { Relative } \\
\text { Diameter } \\
\text { of Stock }\end{array}$ \\
\hline \multicolumn{2}{|c|}{4 Beba.... } & 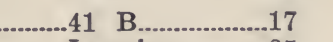 & ......... & ......... & $\ldots$ & 42 & 38 & 90.4 \\
\hline 11 & " .......... & 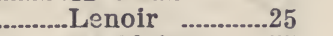 & .......... & .......... & $\ldots$ & 46 & 40 & 86.9 \\
\hline 16 & 6 $\quad . . . . . .$. & $\ldots . . . . . . R$. Gloire........55 & .......... & ........... & $\ldots$ & 36 & 29 & 80.5 \\
\hline 20 & is $\quad \ldots . . . . .$. & $\ldots . . . . .$. St. George......80 & ......... & .......... & $\ldots$ & 45 & 36 & 80. \\
\hline 8 & “ .......... & $\ldots 1202$ & .......... & ......... & $\ldots$ & 50 & 38 & 76. \\
\hline 10 & “ & 35 & .......... & ........... & $\ldots$. & 49 & 37 & 75.5 \\
\hline 7 & “ $\quad \ldots . . . . .$. & 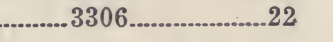 & $\ldots . . . . .$. & $\ldots \ldots . .$. & $\ldots$ & 47 & 32 & 68.1 \\
\hline 7 & Bouschet & t, Al. H., 41 B........50 & 10.82 & 24.72 & .88 & 43 & 35 & 81.4 \\
\hline 9 & " & St. George......75 & 7.91 & 25.26 & .80 & 38 & 30 & 78.9 \\
\hline 5 & “ & $3309 \ldots \ldots \ldots \ldots . . . . . . . . .50$ & 14.20 & 25.06 & .62 & 32 & 23 & 71.9 \\
\hline 8 & “ & 3306_...................37 & 7.79 & 25.72 & .56 & 38 & 28 & 73.6 \\
\hline 14 & “ & $1202 \ldots \ldots \ldots \ldots . . . . . . . .63$ & 15.75 & 24.92 & .72 & 45 & 34 & 75.5 \\
\hline 13 & “ & R. Gloire..........45 & 8.98 & 25.69 & .62 & 33 & 22 & 66.6 \\
\hline 10 & “ & 420 A & 12.86 & 24.36 & .80 & 42 & 29 & 69. \\
\hline 21 & Corinth, & Blk..41 B..............48 & & & & 38 & 38 & 100. \\
\hline 8 & “ & " St. George.....65 & ......... & 30.34 & .79 & 38 & 37 & 97.3 \\
\hline 12 & & “ R. Gloire..........61 & & & & 33 & 31 & 93.9 \\
\hline 9 & Corinth, & Wh..st. George......61 & ......... & 21.46 . & .97 & 31 & 30 & 96.8 \\
\hline 12 & & “ 3306 & -....... & 21.46 & .97 & 36 & 29 & 80.5 \\
\hline 6 & Cornicho & pn......1202 & & ........ & .... & 38 & 37 & 97.3 \\
\hline 5 & “ & .......R. Gloire.........35 & ......... & ......... & $\ldots$ & 35 & 33 & 94.3 \\
\hline 6 & “ & ........st. George.......45 & ......... & ......... & $\ldots$ & 44 & 40 & 90.9 \\
\hline 4 & $“$ & $\ldots . . . . A$ x R No. $9 \ldots 45$ & ......... & ......... & $\cdots$ & 43 & 38 & 88.3 \\
\hline 5 & “ & $\ldots$ & ......... & ......... & $\ldots$ & 44 & 39 & 88.6 \\
\hline 3 & “ & .......R. Martin.......40 & .......... & $\ldots . . . . .$. & $\ldots$ & 46 & 40 & 86.9 \\
\hline 5 & “ & $\ldots 41$ B & ......... & $\ldots$ & $\ldots$ & 49 & 42 & 85.7 \\
\hline 5 & “ & …...101-14 & ......... & $\ldots . . . .$. & $\ldots$ & 43 & 36 & 83.7 \\
\hline 5 & “ & …....3306 & ......... & ......... & .... & 46 & 36 & 78.2 \\
\hline 3 & “ & $\ldots . . . . . A \times$ x No. 1...15 & ......... & $\ldots . . . .$. & $\ldots$ & 61 & 44 & 72.1 \\
\hline 8 & Emperor. & 50 & (a). & ........ & & 40 & 42 & 105. \\
\hline 6 & & ........Lenoir .............35 & .......... & .......... & .... & 41 & 39 & 95. \\
\hline 3 & “ & $\ldots . . . .420$ A._................ & .......... & .......... & $\ldots$. & 39 & 36 & 92.3 \\
\hline 9 & & ........st. George.......65 & ......... & ......... & $\ldots$ & 36 & 32 & 88.8 \\
\hline 9 & “ & .......R. Martin.......55 & .......... & ......... & $\ldots$ & 39 & 34 & 87.1 \\
\hline 4 & “ & ........3306 & -........ & ......... & .... & 43 & 37 & 86. \\
\hline 7 & “ & ........3309 & ......... & ......... & $\ldots$ & 46 & 37 & 80.4 \\
\hline 5 & “ & ........R. Gloire..........65 & ........ & ......... & ..... & 37 & 28 & 75.6 \\
\hline 4 & “ & $\ldots . . . . A$ x $\mathrm{R}$ No. $1 \ldots 45$ & -......... & $\ldots \ldots . .$. & .... & 51 & 39 & 76.4 \\
\hline 10 & G. Manse & enc...Lenoir ...........56 & .67 & 28.20 & .84 & 28 & 29 & 103.5 \\
\hline 7 & & St. George.......50 & 1.33 & 28.86 & .77 & 25 & 26 & 104. \\
\hline 3 & “ & 41 В..................42 & 1.92 & 27.70 & .96 & 31 & 31 & 100. \\
\hline 12 & “ & 420 A & 1.18 & 27.10 & .8 & 26 & 2 & 96.1 \\
\hline 5 & “ & $3309 \ldots \ldots \ldots \ldots \ldots \ldots \ldots \ldots$ & 3.15 & 28.90 & .83 & 29 & 26 & 89.6 \\
\hline 13 & “ & $1202 \ldots$ & 4.37 & 28.00 & .87 & 38 & 34 & 89.4 \\
\hline 6 & “ & K. Gloire $\ldots . . . . . . .95$ & 1.44 & 30.11 & .71 & 24 & 20 & 83.3 \\
\hline 11 & Lagrain.. & 65 & 4.33 & 27.50 & .63 & 32 & 34 & 106.2 \\
\hline 7 & “ & 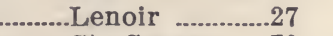 & .54 & 26.76 & .75 & 3 & 31 & 103.3 \\
\hline 5 & “ & $\ldots . . . . . .$. St. George.......70 & 2.20 & 29.00 & .63 & 33 & 32 & 96.9 \\
\hline 10 & “6 & $\ldots 420$ A & 2.50 & 28.10 & .64 & 30 & 29 & 96.6 \\
\hline 9 & “ & 30 & 3.31 & 25.25 & .67 & 35 & 33 & 94.3 \\
\hline 9 & “ & ..........R. Gloire...........42 & 2.59 & 28.16 & .57 & 26 & 23 & 88.4 \\
\hline 9 & “ & 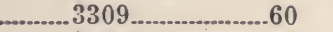 & 3.06 & 28.40 & .66 & 32 & 26 & 81.2 \\
\hline 8 & “ & $\ldots 3306 \ldots$ & 1.56 & 28.70 & .64 & 31 & 25 & 80.6 \\
\hline
\end{tabular}




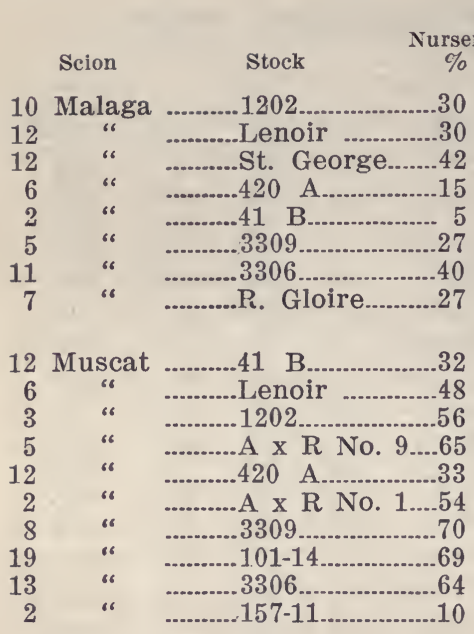

10 Palomino 1202

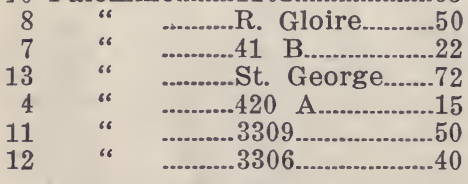

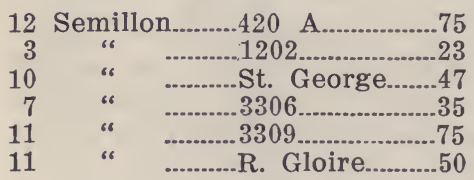

15 Sirah Petite..St. George.......65

\begin{tabular}{|c|c|c|c|}
\hline & & “ & 420 А... \\
\hline & “ & “ & $1202 \ldots$ \\
\hline 8 & “ & “ & $41 \mathrm{~B}$ \\
\hline 21 & “ & “ & R. Gloire.... \\
\hline & “6 & “ & $3306 \ldots \ldots \ldots$ \\
\hline & “ & “ & 3309 \\
\hline
\end{tabular}

11 St. Macaire...41 B...................55

\begin{tabular}{|c|c|c|}
\hline 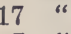 & “ & 1202. \\
\hline 7 & “ & 420 A... \\
\hline “ & “ & St. George.......67 \\
\hline “ & “ & 3309 \\
\hline “ & “ & R. Gloire..... \\
\hline “ & “ & 3306 . \\
\hline
\end{tabular}

6.45

10.43

6.81

9.94

10.45

8.19

11.45

8.63

4.46
13.16

22.00

21.20

7.25
12.71

6.63

6.42

7.17

4.30

8.04

9.38

6.68

6.88

4.13

Bal.

Stem Stock

Relative

Diameter

24.85

.67

$46 \quad 44$

of Stock

23.15

.75

44

42

24.65

.59

24.65

25.03

24.55

24.85

.58

44

40

40

$\begin{array}{lll}.66 & 48 & 42\end{array}$

$\begin{array}{lll}.61 & 52 & 42\end{array}$

$.65 \quad 49 \quad 36$

24.55

$.66 \quad 43 \quad 30$

95.6

95.4

90.9

88.8

87.5

80.8

73.4

69.8

$\begin{array}{llllll}4.48 & 29.47 & .69 & 37 & 35 & 94.6 \\ 4.67 & 28.67 & .62 & 40 & 36 & 90 . \\ 4.70 & 30.41 & .45 & 38 & 32 & 84.2 \\ 8.32 & 29.67 & .62 & 42 & 35 & 83.3 \\ 9.83 & 29.37 & .67 & 41 & 32 & 78 . \\ 5.82 & 30.07 & .59 & 35 & 26 & 74.3\end{array}$

$\begin{array}{lllll}4.15 & 29.26 & .60 & 32 & 33\end{array}$

103.1

$\begin{array}{llllll}5.85 & 27.26 & .60 & 35 & 35 & 100 .\end{array}$

$\begin{array}{llllll}13.92 & 28.02 & .63 & 38 & 36 & 94.7\end{array}$

14.16

10.27

27.86

.60

40

37

28.26

10.32

28.66

.53

92.5

88.5

84.2

$\begin{array}{llllll}7.81 & 28.66 & .56 & 35 & 27 & 77.1\end{array}$

$\begin{array}{llllll}5.18 & 24.69 & .91 & 28 & 31 & 110.7\end{array}$

$\begin{array}{lllll}4.47 & 24.89 & .85 & 30 & 32\end{array}$

$\begin{array}{lllll}4.86 & 25.10 & .96 & 30 & 30\end{array}$

1.53

25.90

$\begin{array}{lll}.79 & 29 & 28\end{array}$

3.83

27.20

66

28

5.20

26.60

.77

26

27

25.29

$.90 \quad 30$

25

106.6

100.

96.5

96.4

88.4

83.3

17 Sultana_..........41 B..................49

6 “ 6 ..........420 A................38

11 ، ….......1202 $12 \ldots \ldots . . . . . . . . . . . . .73$

7 “ ........................ George

101-14_.............65

R. Gloire..........66 


\begin{tabular}{|c|c|c|c|c|c|c|c|c|}
\hline & Scion & $\begin{array}{c}\text { Nursery } \\
\%\end{array}$ & $\begin{array}{l}\text { Crop } \\
\text { Lbs. }\end{array}$ & Bal. & Acid & $\begin{array}{l}\text { Stem } \\
\text { mm. }\end{array}$ & $\begin{array}{l}\text { Stock } \\
\text { mm. }\end{array}$ & $\begin{array}{c}\text { Relative } \\
\text { Diameter } \\
\text { of Stock } \\
\%\end{array}$ \\
\hline & Sultani & 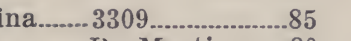 & ......... & ........ & $\cdots$ & & & \\
\hline 8 & “ & .........R. Martin...... 80 & ......... & .......... & .... & 37 & 30 & 87.1 \\
\hline 8 & “ & $\ldots 22$ & ......... & .......... & .... & 46 & 37 & 80.4 \\
\hline 4 & “ & .........R. Gloire..........23 & .......... & ......... & $\ldots$. & 36 & 27 & 75. \\
\hline 12 & “ & $\ldots . . . . .$. St. George.......65 & -....... & -........ & .... & 42 & 32 & 76.2 \\
\hline 12 & “ & $\ldots \ldots \ldots 101-14$ & -........ & ......... & .... & 41 & 30 & 73.2 \\
\hline 11 & “ & $\ldots$ & -........ & -........ & .... & 47 & 35 & 74.5 \\
\hline 11 & “ & .............3306....................... 47 & $\cdots+. .$. & ........ & .... & 55 & 35 & 63.6 \\
\hline 12 & “ & .........A x R No. 1...53 & -........ & -........ & -... & 53 & 33 & 62.3 \\
\hline & Tokay... & $\ldots . . . . . .420$ A & 15.63 & .......... & ..... & 44 & 43 & 97.7 \\
\hline 9 & “ & ...................50 George & 7.09 & .......... & $\ldots . .$. & 38 & 37 & 94.4 \\
\hline 2 & “ & ...............enoir...............37 & 7.38 & .......... & ..... & 44 & 42 & 95.4 \\
\hline 6 & “ & $\ldots$ & 16.46 & .......... & ..... & 44 & 41 & 93.2 \\
\hline 8 & “ & .................................... & 10.94 & .......... & ...... & 44 & 36 & 81.8 \\
\hline 17 & “ & 60 & 14.56 & .......... & ...... & 44 & 35 & 79.5 \\
\hline 9 & “ & $\ldots . . . . . . . . . R$. Gloire.........55 & 11.67 & (......... & $\cdots$ & 36 & 28 & 77.7 \\
\hline 4 & Valdepe & eñas....420 A & 10.25 & 26.90 & .56 & 35 & 32 & 91.4 \\
\hline 14 & " & ....St. George......75 & 8.35 & 28.86 & .46 & 35 & 32 & 91.4 \\
\hline 14 & “ & $\ldots 1202 \ldots \ldots$ & 8.63 & 26.70 & .55 & 40 & 36 & 90. \\
\hline 10 & “ & ....Lenoir .............82 & 5.15 & 28.66 & .43 & 39 & 34 & 87.1 \\
\hline 15 & “ & ....3309 & 8.14 & 28.30 & .51 & 39 & 32 & 82.1 \\
\hline 9 & “ & 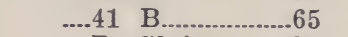 & 5.78 & 27.06 & .58 & 37 & 30 & 81.1 \\
\hline 14 & “ & ....R. Gloire.........75 & 11.54 & 28.16 & .57 & 35 & 28 & 80. \\
\hline 18 & “ & ...3306 & 8.71 & 28.60 & .51 & 39 & 31 & 79.5 \\
\hline
\end{tabular}

Table $B$ summarizes the information of Table $A$, regarding the best stocks for each variety, and Table $\mathrm{C}$ the worst stocks. In chosing a stock for any of the varieties mentioned in Table $B$ it would be safe to take any of the three given, preferably that most suited to the soil and climate. The comparative failure shown in Table $\mathrm{C}$ is less definite, but makes it advisable to avoid these combinations.

\section{B. The Three Stocks Giving Best Nursery Results with Each Scion.}

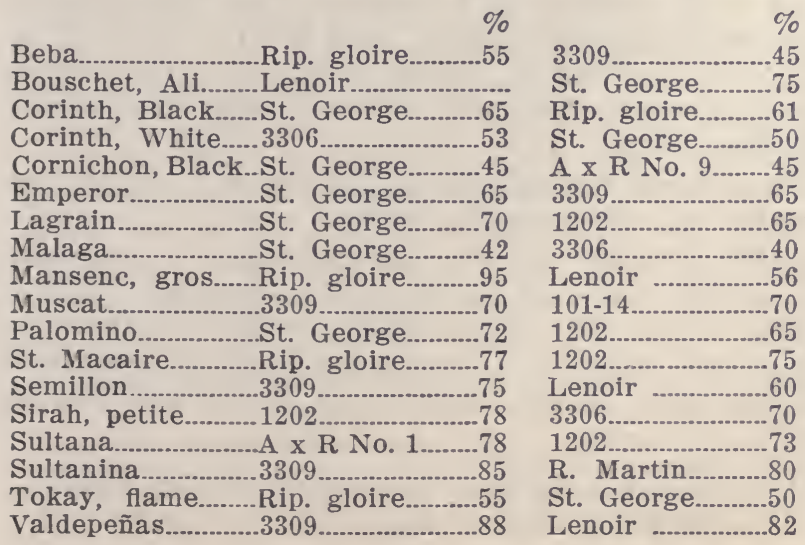

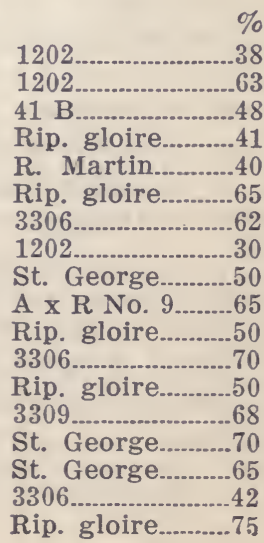


In this list of best stocks

\begin{tabular}{|c|c|c|c|c|c|c|c|}
\hline St. George & occ &. .13 & $\operatorname{tim}$ & Lenoir & ccur & S.................. & times \\
\hline Rip. gloire & “ & ....................10 & “ & Rup. Martin & “ & ..... & 2 \\
\hline 202 & “ & .................. 8 & “ & AXR No. 9 & “ & …................ & .2 \\
\hline & “ & .................. 7 & “ & AXR No. 1 & $"$ & 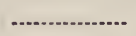 & 1 \\
\hline & “ & .................... & “ & $41 \mathrm{~B}$ & “ & ........ & 1 \\
\hline
\end{tabular}

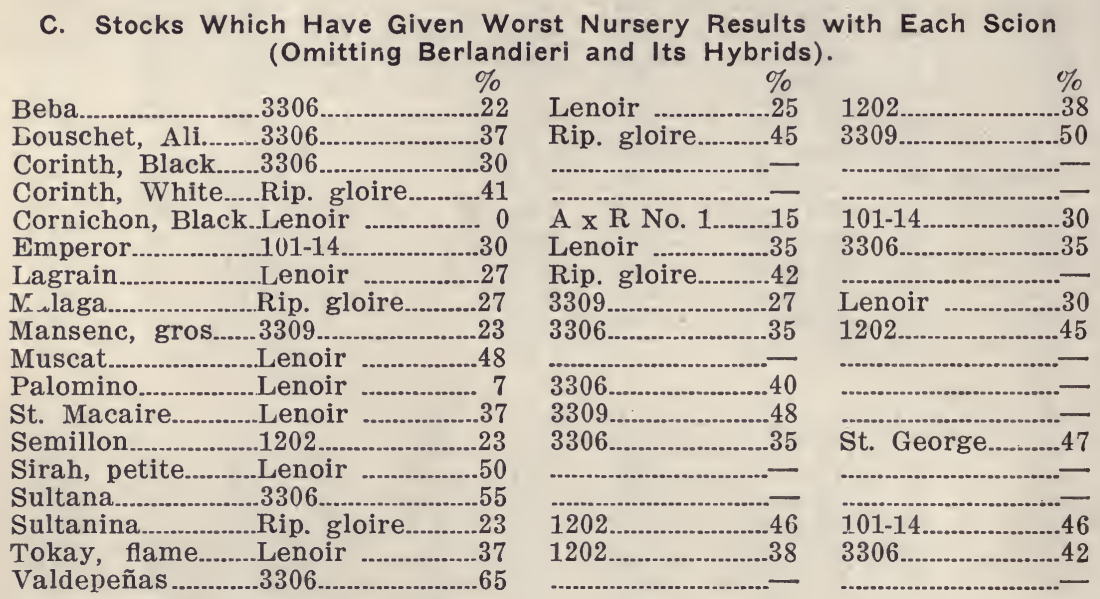

In this list of worst stocks

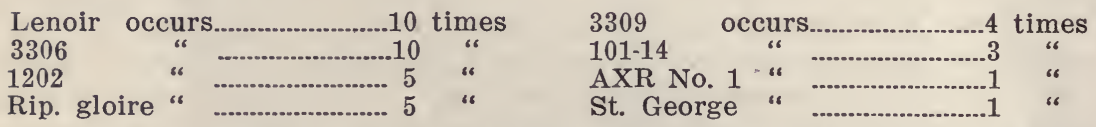

Table D giving a summary of columns 4,5 and 6 of Table A, enables us to compare the influence of the various stocks and scions on bearing. Several interesting tendencies may be observed:

1. Rip. x Rup. 3309 produced the largest crop, 80 per cent more than the St. George, our most commonly used stock. Lenoir was no better than St. George. The soil of the vineyard is a deep, rich loam with sufficient moisture and suitable for all the stocks tested. As this is the first crop, the small crop of the St. George may simply indicate greater slowness in reaching full bearing. The Mourvèdre $\mathrm{x}$ Rup. 1202, however, which is supposed to have this defect, did much better.

2. There was little difference in the time of ripening or in the composition of the grapes on the various stocks.

3. All varieties showed earlier ripening and more sugar when grafted than when growing on their own roots, wherever the comparison could be made. On the average, the increase of sugar was over 20 per cent. With the Muscat, it amounted to over 36 per cent, which would represent a considerable increase of crop of raisins, if the weight of the fresh grapes was the same.

D. Summary of Crop and Composition of Grapes on Grafted Vines. Blocks "E" and "F" Davis. 
Comparison of Stocks With All Scions. Crop Gathered and Weighed October 1, 1914.

\begin{tabular}{|c|c|c|c|}
\hline & Average & Average & Average \\
\hline Stock- & Crop & $\mathrm{Bal}^{\circ}$ & Acidity \\
\hline Rip. X Rup. 3309 & 9.57 & 27.45 & .59 \\
\hline Mour. X Rup. 1202. & 8.35 & 27.03 & .64 \\
\hline Rip. gloire ...................... & 7.73 & 27.47 & .58 \\
\hline Rip. X Rup. 3306 & 7.60 & 27.79 & .58 \\
\hline Rip. X Berl. 420 A & 6.89 & 26.32 & .64 \\
\hline 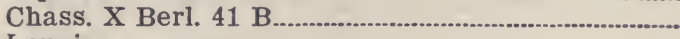 & 6.78 & 25.74 & .66 \\
\hline Lenoir & 5.38 & 26.51 & .63 \\
\hline Rup. St. George ......................... & 5.25 & 27.72 & .58 \\
\hline
\end{tabular}

Comparison of Scions with All Stocks.

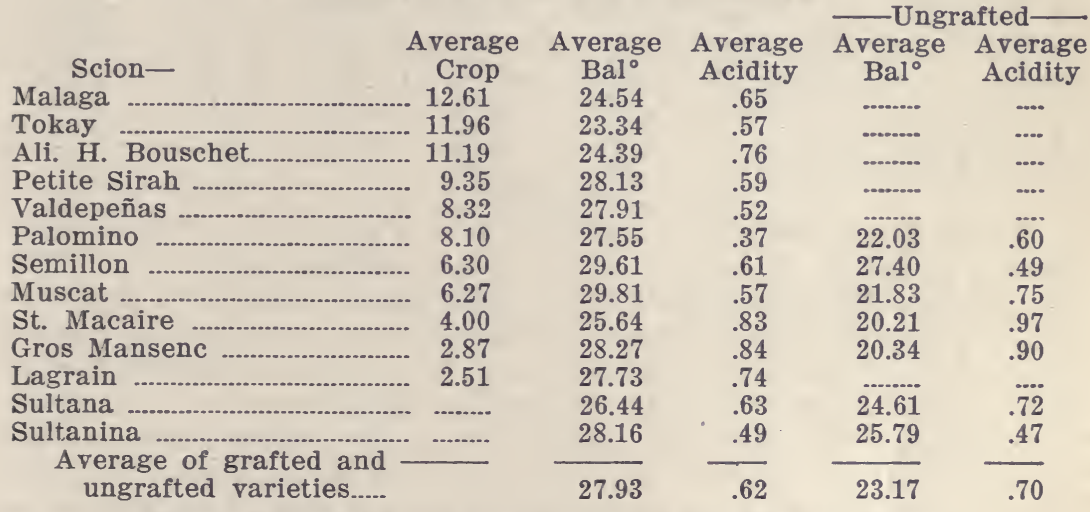

Size of Stock, Scion and Union of All Grafted Vines.

Measurements made June 16-23, 1915.

It is for practical reasons of great importance to have grafted vines with a stock as large and, if possible, larger than the stem or scion in order to dispense with the grape stake as early as possible. However, as a rule, we find that the stock in most cases is the weaker grower of the two; only in a few cases have we been able to observe that a stock and a stem of the vine were of the same diameter. Measurements were taken on 1201 grafted vines. Every vine was measured at three levels. With vines, which were irregular in shape, several measurements were made to obtain average dimensions. The first measurement at the largest diameter of the swelling, and the third measurement two or three cc. below the union. The measurements are shown in Table A, expressed in millimeters. The last column gives the diameter of the stock in percentage of diameter of the scion.

The 1201 vines measured represent 130 combinations consisting of 18 vinifera scion varieties and 10 resistant stocks. The average for all was as follows.

Average diameter of all stems above union $39 \mathrm{~m} / \mathrm{m}$ Average diameter of all stems below union $33 \mathrm{~m} / \mathrm{m}$ Average ratio scion, stock $84.6 \%$ Average diameter of all unions. $56 \mathrm{~m} / \mathrm{m}$

Vines where the stock is smaller than the scion have the disadvantage that they require permanent stakes. An ideal vine would be one which, while making a good, strong and healthy growth every year, ripens its canes well, giving a good average crop of grapes every year and forms a stock strong 
enough to support the above-ground portions of the plant; thus eliminating the expense for stakes, labor and tying material.

Table Showing Average Differences in Diameters of Stocks with All Scions.

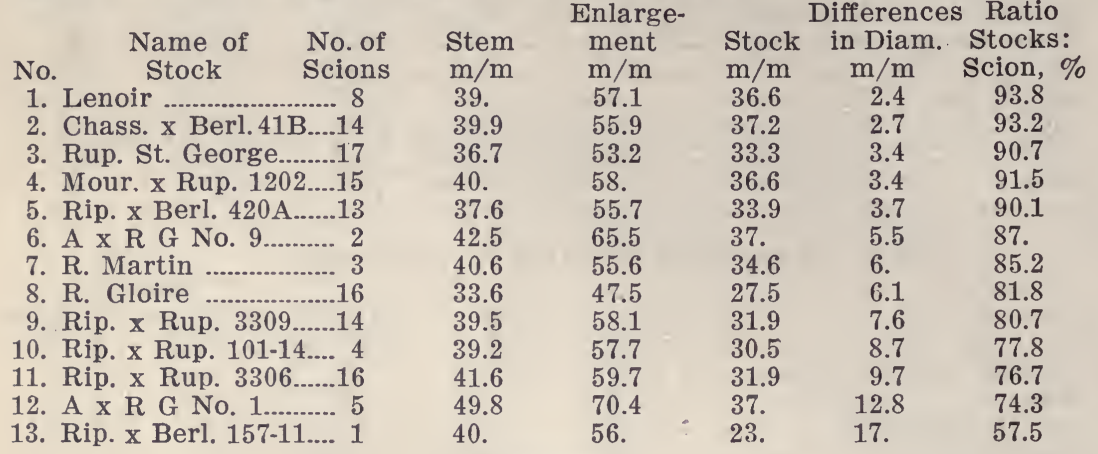

Summary.

Do the above facts and figures place us in a position to recommend the grafting of certain vinifera grapes on certain resistant stocks? No. However, we have found Mourvèdre x Rup. 1202, Riparia x Rupestris 3309, Berlandieri $\mathrm{x}$ Riparia 420, and Chass. $\mathrm{x}$ Berlandieri $41 \mathrm{~B}$ have given very satisfactory results. Rupestris St. George, the most common stock in California, makes a good growth but the crop is deficient in quantity, and whether this bad peculiarity will disappear in time we are not prepared to say. The Lenoir shows the least lack of affinity with the scions, grafted on to it, but its low resistance to phylloxera and the inferior bearing of its grafts make it useless as a resistant stock.

The vines from which the above data have been obtained, are nearly all four years old. We have been able to weigh, test for sugar and acidity but one crop. We do not know whether the crop of certain varieties of grapes on certain stocks will increase or decrease in the future, nor do we know whether the lack of affinity between the stock and scion which always exists to a more or less degree, as evidenced by the differences of diameters in the stocks and scions, will increase or decrease when the vines get older. All these are questions which can be answered in the future only. The "perfect" phylloxera resistant stock which is satisfactory in every way, has thus far not been produced. However, we hope in time to be able to find a suitable stock for every commercial vinifera variety grown in California and every soil condition.

The obseivations of Prof. Flossfeder to the effect that after making practical test $;$ it was found that the crop produced by varieties grafted on Rupestris St. George showed less tonnage brought about an interesting discussion and the experience of many growers was given, and showed the value of the work of the Viticultural Department of the State of California and of the United States Department of Agriculture. Mr. Louis Kunde, of Glen Ellen, California, Mr. Swett, of Martinez, Mr. Sheehan, of Sacramento, Prof. Husmann, of Washington, D. C., Mr. C. J. Wetmore, of San Francisco, Mr. P. F. Goodwin, of Healdsburg, California, Prof. Bioletti, of the University of California, and others took part in the discussion. 


\title{
VITIS VINIFERA IN EASTERN AMERICA.
}

\author{
By U. P. HEDRICK,
}

Experiment Station, Geneva, N. Y.

I need only remind this audience of the many efforts to grow European grapes in America. The various attempts, some involving individuals, others corporations and in early days even colonies, form some of the most instructive and dramatic episodes in the history of American agriculture. All endeavors, it will be remembered, were failures, so dismally and pathetically complete, that we are wont to think of the 200 years from the first settlement in America to the introduction of the Isabella, a native, as time wasted in futile culture of a foreign fruit. The early efforts were far from wasted, however, for out of the tribulations of two centuries of grape-growing came the domestication of our native grapes, one of the most remarkable and one of the noblest achievements of agriculture. It is possible, too, that we may find that the failures of the fathers of American viticulture are the foundations for the success of the sons.

The advent of Isabella and Catawba wholly turned the thoughts of vineyardists from Old World to New World grapes. So completely, indeed, were viticulturists won by the thousand and more native grapes that came trooping in that for the century which followed no one has planted Old World grapes east of the Rockies, while vineyards of native species may be found north and south from the Atlantic to the Pacific.

Meanwhile, much new knowledge has come to agriculture, old fallacies have had many hard knocks and chains of tradition in which the culture of plants was bound, have been broken. In no field of agriculture have workers received greater aid from science than in viticulture! Particularly this is true of the diseases of the vine. The reports of the old experimenters were much the same, "a sickness takes hold of the vines and they die." What the sickness was and whether there were preventives or remedies no one knew a hundred years ago. But we have learned something about the ills grape flesh is heir to, with preventives and remedies for the same. We know that the early wine growers failed in part, at least, because they followed empirical European practices. Is it not possible that in the last hundred years we have advanced sufficiently in our knowledge of plants, soils, insects, and fungi, and that by breaking away from European dictums we can now succeed in growing vitis vinifera in eastern America where old experimenters failed? The Geneva Experiment Station is putting this question to test, with what result I am now to tell

In the spring of 1911 the station rbtained cuttings of 101 varieties of European grapes from the United States Department of Agriculture and the University of California. The object was to obtain European varieties to hybridize with American grapes. I hasten to say that at first there was no thought nor plan to experiment with thesa grapes as a cultivated crop. The cuttings obtained were grafted on the roots of a heterogeneous collection of seedlings five years set representing a half dGzen species of Vitis and hybrids between them then growing on the station grounds. These stocks had little to recommend them except that all were vigorous, well established and all 
were more resistant to phylloxera than the Old World varieties. From four to six grafts of each of the hundred varieties were made and a stand of 380 vines resulted, the percentage of loss being exceedingly small. The success in grafting we believe to be due to the method used, the value of which had been proved in previous work on the station grounds.

In grafting, the earth was removed from the plants to a depth of two or three inches. The vines were sawed squarely off below the surface of the ground. The stock was then split for a cleft graft. Two scions were inserted in each cleft and tied in place with waxed string. 'Grafting wax was not used, the wax being worse than useless because of the bleeding of the wounds in the stock. . The earth was then replaced and enough more of it used to cover stock and scion to prevent evaporation from them. This method of grafting is available to those who have old vineyards. 'It is so simple that the veriest tyro can thus graft grapes. Were young plants or cuttings used as stocks some method of bench-grafting would, of course, be resorted to.

The cultivation and spraying have been precisely that given native grapes. There has been no coddling of vines. The fungous diseases which helped to destroy the vineyards and vexed the souls of the old experimenters have been kept well in check by two sprayings with Bordeaux mixture; the first application was made just after the fruit set, the second when the grapes were two-thirds grown. This year, 1914, a third spraying with a tobacco concoction kept thrips in check. Phylloxera is present in the vineyard but no one of the varieties on the resistant roots is appreciably suffering from the pest. It need hardly be said that the immunity to phylloxera secured by grafting is the chief reason for the success we are having with these grapes-undoubtedly this pest was the chief cause of the early failures. The stocks used in the present work are not those best suited either to the vines grafted on them or to resist phylloxera. Unquestionably some of the standard sorts used in France and California from Vitis rupestris or Vitis riparia, or hybrids of these species, would have given better results. From theoretical consideration it would seem that the Vitis riparia stocks should be best suited to the needs of eastern America.

It was thought by the old experimenters that Vitis vinifera failed in the New World because of unfavorable climatic conditions. It was said that the winters were too cold and the summers too hot and dry for this grape. During the few years the station vineyard of Viniferas has been in existence we have had stresses of all the kinds of weather to which the variable climate of New York is subject. Two winters have been exceedingly cold, killing peach and pear trees; one summer gave us the hottest weather and the hottest day in twenty-five years; the vines withstood two severe summer drouths and one cold, wet summer. These test seasons have proved that European grapes will stand our climate as well as the native varieties except in the matter of cold-they must have winter protection.

To growers of American grapes the extra work of winter protection seems to be an insuperable obstacle. The experience of several seasons at Geneva shows that winter protection is a cheap and simple matter. Two methods have been used; vines have been covered with earth and others wrapped with straw. The earth covering is the cheaper method and the more efficient. The vines are pruned and placed full length on the ground and covered with a few inches of earth. The cost of winter protection will 
run from two to three cents per vine. Since the European vines are much more productive than those of the American grapes the added cost of winter protection will be much more than offset by the greater yield of grapes. Trellising, too, is simpler and less expensive for the European grapes, helping further to offset the cost of winter protection.

It is apparent at once that European grapes must have special treatment in pruning if they are to be annually laid on the ground. Several modifications of European and California practices can be used in the East to bring the plants in conditions for winter laying-down. All methods of pruning must have this in common: new wood must be brought up from the base of plant every second, third, fourth or fifth year in order to permit the bending of the plant. In our experiences we have no difficulties in so training the vines. Briefly, we have maintained for each vine two trunks, one old, the other young, which we have carried up to or just below the first wire in a two-wire trellis system and from each of these trunks we have trained a cane bearing from four to eight buds to right and left on a lower wire. The bearing shoots that grow from the buds on these canes are tied to the second wire. In a commercial vineyard, depending upon the varieties, our simple method might be modified in many ways to meet conditions.

The grower of European grapes grafted on American vines may be prepared to be surprised at the growth the vines make. At the end of the first season the grafts attain the magnitude of full-sized vines; the second season they begin to fruit more or less abundantly, and the third year they produce approximately the same number of bunches as a Concord or Niagara vine, and as the bunches of most varieties are larger than those of the American grapes the yield, therefore, is greater. The European varieties, too, may be set more closely than the American sorts since they are seldom such rampant growers.

It is quite too soon to reason from this short experiment that we are to grow varieties of Vitis vinifera commonly in New York, but the behavior of the vines on the station grounds seems to indicate plainly that we may do so. At Geneva the European varieties are as vigorous and thrifty as American vines and quite as easily managed. Why may we not grow these grapes if we protect them from phylloxera, fungi and cold? In Europe there are varieties of grapes for nearly every soil and condition in the southern half of the continent. In Eastern Europe and Western Asia the vines must be protected just as we shall have to protect them here. It seems almost certain that from the many sorts selected to meet the various conditions of Europe we shall be able to find kinds to meet the diverse soils and climates of this continent. And here, by the way, we have one of the chief reasons for wishing to grow these grapes-that American grape-growing may not be so localized as it now is. Probably we shall find that European grapes can be grown in more kinds of soils and under more various conditions than can our native varieties.

The culture of Vitis vinifera in the East gives us essentially a new fruit. If any considerable degree of success attends their culture then wine-making in Eastern America will be revolutionized, for the European grapes are far superior to the native sorts for this purpose. Varieties of Vitis vinifera have a higher sugar and solid content than do those of the American species and for this reason as a rule keep longer and we may thus expe-t t'vat through 
these grapes the season for this fruit will be extended. The European varieties are better flavored, possessing a more delicate and a richer vinous flavor, a more agreeable aroma, and are lacking in the acidity and somewhat obnoxious foxy taste of many American grapes. Consumers of fruit will like them better and the demand for grapes will thus be increased.

The advent of the European grape in the vineyards of Eastern America ought quickly to bring about splendid varieties of hybrids between Vitis vinifera and the America species of grapes. As all know, we have many such hybrids but curiously enough scarcely more than a half dozen varieties of European grapes have been used in crossing. Most of these have been greenhouse grapes and not those that could be expected to give best results for vineyard culture. As we come to know the varieties best adapted to American conditions we ought to be able to select European parents to better advantage than we have done in the past and thus produce better hybrid sorts.

From the eighty-five varieties of Vitis vinifera now fruiting on the station grounds we may name the following as worth trying on a larger scale: Actoni, a table grape; Chasselas Golden, for the table; Cinsaut, for table or wine; Feher Szagos, another table sort; Kuristi Mici, for the table; Lignan Blanc, a very early table grape and one of the best; Mantuo de Pilas, Muscat Hamburg, Pinot Gris or Ruländer, three of the best table grapes; Poulsard, a wine and table grape; Palomino or Listan, a table and wine grape; Rosaki, a table grape; Sultanina Rosea, a seedless table sort; and Teinturier, Petite Sirah, Franken Riesling and Zinfandel, all wine sorts.

I have briefly set forth the essentials of the work with Vitis vinifera in New York but I shall have missed an oportunity if this simple statement of facts ends here. Permit me to suggest several phases of the work in need of careful experimental attention.

First, it is imperative that we know more about the adaptation of European varieties to American conditions. More than five-thousand varieties of grapes are grown in Europe and Asia but few of which have been tried in Eastern America. Those most promising for the different States should be carefully tried out.

Second, it is very certain that we shall have to grow European grapes on American stocks. We must determine experimentally what stocks are best for Eastern America; here the experience of European countries and California will be most helpful.

Third, a great obstacle in the way of growing European grapes in this region is the difficulty in getting a good stand of grafted plants. Possibly we shall have to modify the methods used elsewhere, and to determine which will be best for us we must do experiment work in grafting and propagating.

Fourth, European varieties will be differently affected by fungi and insects than are our native sorts, and it is possible that we shall have to modify remedial treatments of pests for the foreign grapes.

Fifth, there is a tremendous field for plant breeders in hybridizing European and American grapes. 'The half dozen European sorts that have been used in hybridization are for most part those that would be least expected to give good results, namely, greenhouse grapes. It is probable that the American grapes of the future will be European grapes with a dash of 
American blood in them. Plant breeders have a wonderful opportunity to breed grapes despite the fact that more work has been done with this fruit in the past hundred years than with any other.

In conclusion let me exhort those of you who have the opportunity to carry on experiments with European grapes. The work to be done is so vast that we cannot make an appreciable showing unless the task be divided among a number of workers. If viticulturists in the different States will but concentrate on particular problems in the culture of Vitis vinifera, sifting the experience and knowledge of the world in regard to them for use under our conditions, it is almost certain that we can successfully grow some European grapes in Eastern America. Here, it seems to me, is a splendid opportunity on your part and mine to serve viticulture.

\section{VITICULTURE ON THE PACIFIC COAST.}

By FREDERIC T. BIOLETTI,

Professor of Viticulture, University of California.

The title of this paper is misleading if it calls up visions of luscious grapes bathed in the ocean spray of the Pacific. The cool summer fogs of the Californian littoral art not favorable to grape-growing. The vine does not fear the warm waves of the Mediterranean, but it finds a too close proximity of the Japan current insalutary. A more appropriate title would be "Viticulture on the Pacific Slope."

This is fairly descriptive of the extreme western grape region whose main body lies on low hills, narrow valleys and wide plains from the foot of Mount Shasta to the Mexican border, from the foothills of the Sierras to the edge of the Redwood forest that borders the coast. This body has a numerous progeny of small descendants scattered through neighboring states. Some have extended north through Oregon, Washington and Idaho almost to the Canadian border, shrinking ever further eastward, to escape the humid coast condition which extends ever further inland as we approach the north, but stopping before they reach the regions of zero winters and stormy summers. From the south they have extended to southern Nevada and Arizona and even to Utah, Colorado and New Mexico. Except in a few specially favored spots however, they are weakly children and their precarious existence is assured only by the most careful nursing and protection.

Grape growing on the Pacific Slope differs so much from that of the Eastern States, both in its material and methods, that they have little in common and conclusions drawn from the experience of one region may be misleading if applied to the other. A brief account of western viticulture, with a discussion of the causes of the differences, may therefore be useful and interesting.

Professor L. H. Bailey in "The Evolution of Our Native Fruits," has given an account of the early efforts to grow grapes in the Eastern and Middle States. He has described the numerous attempts to grow the grapes of Europe there and the earlier or later failure of all. It has been shown that the principal cause of these failures was the extreme susceptibility of the 
European vine to certain fungus diseases, especially to Downey Mildew and Black Rot.

The ultimate success of grape-growing in these regions was due to the development of varieties of the indigenous vines of the country which were more or less resistant to the attacks of these fungous parasites. This substitution of varieties was made after repeated trials and failures and at first without a clear knowledge of the reasons for the advantages obtained.

The first attempts at grape growing in California were made also with varieties of the European grape, but unlike those of the East they were successful from the first. For this reason, the Eastern varieties have never been grown to any large extent here and our viticulture is based on European or allied varieties.

The so-called European varieties are all derived from the wild vine which is indigenous or naturalized in all the countries which border the Mediterranean. The species is the Vitis vinifera which was perhaps the first fruit to be thoroughly domesticated. The 5000 or.more varieties of this fruit which we now possess are the result of a millenary selection commencing before the dawn of historic times. The result is that we have such a diversity of characteristics, of form, size, color and flavor in the innumerable varieties, that some observers can account for them only by supposing that they are derived from the hybridization of several species. These species, however, are merely hypothetical, as all the wild forms known can be placed without hesitation in the species Vinifera.

The variations in the fruit of Vinifera varieties are much greater than those of Eastern varieties, although the latter are derived from selection and hybridization of several well recognized species. In consequence, the Vinifera varieties are suited for a much larger number of diverse purposes and for most of these purposes are superior. Vinifera varieties are characterized as a whole by vigor, fruitfulness, wide adaptation to diverse soils and amenability to simple methods of pruning and cuitivation. Their defects are intolerance of all but a narrow range of climatic conditions and susceptibility to many serious fungous and insect pests.

The climatic conditions of the Pacific Slope are exactly those preferred by this species and most of the serious fungous diseases cannot or at least do not exist here.

The excellence of the fruit and the suitability of the climate explain the almost exclusive use of Vinifera varieties here. It is not that we cannot grow the Eastern varieties, but that we have no occasion to do so.

Grapes are grown in California for three main purposes: 1, wine; 2, raisins; 3 , shipping table grapes. These represent three types of viticulture which, while on the whole distinct, are not quite mutually exclusive. The growers of raisins and shipping grapes usually sell a portion of their crop to the wineries. The wineries use the cull, inferior or excess shipping grapes. This material is used for brandy or for a second-class wine and brings a price about 50 per cent lower than that of good wine grapes. This price, however, is remunerative to the growers, as, in the absence of the wineries, a considerable portion of their crop would be wasted, or, still worse, forced on the market in competition with their good grapes, thus depressing the price of all. Second-crop Muscat grapes, which constitute about 15 to 20 per cent of the crop of raisin grapes, are disposed of in the same way. Wine grapes, on 
the other hand, cannot as a rule be used for the other purposes. They are unsuited for raisins or table use with the exception of a few varieties which in the warmer districts are occasionally dried or shipped in small quantities when the demand is greater than the supply.

Each of these great classes of viticulture depends partly on the use of varieties with special characteristics, and partly on special climatic conditions.

The great bulk of the raisins is made from the Muscat of Alexandria, the Sultanina (Thompson's Seedless) and the Sultana. The first produces large raisins of the Spanish type, the last two, the seedless raisins known to commerce as "Sultanas." No other known varieties can be substituted for these, though fair raisins are made occasionally from a few large grapes such as Malaga and Feher Szagos. Currants or seedless raisins of the Zante or Greek type are made in small quantities from the Black and White Corinth grapes.

The business of shipping-grapes deals with a larger number of varieties, though three constitute by far the greater part of the Eastern or distant shipments. These are, in order of importance, Flame Tokay, Malaga and Emperor. A few others, notably Cornichon, Verdal and Black Morocco, are shipped in fairly large quantities. For Pacific Coast markets the raisin Muscat and the Sultanina are used extensively and also, in smaller quantities, Black Prince (Rose of Peru), Black Malvoisie, Black Ferrara, Mission, Luglienga, Golden Chasselas, Pizzutello and Pierce, the last our only variety of Labrusca type, while a score or more of varieties are shipped occasionally, locally and in small quantities.

For wine, the list of varieties used extensively would be too long to give. Zinfandel is still the chief, but a list of even the important names would contain fifty or more. The total number grown commercially would probably exceed a hundred.

Among the better varieties which have been planted largely during recent years, the principal is the Petite Sirah; Alicante Bouschet and Palomino have also been extensively planted, but these are little better than the Carignane, Mataro and Burger which they tend to replace. Many small vineyards of fine varieties, such as Cabernet Sauvignon, Colombar and Riesling, exist which in the aggregate constitute a considerable area.

Among the smaller viticultural industries the manufacture of vinegar and of unfermented grape juice should be mentioned. The former is often of excellent quality, but much of it is made from inferior and waste material and is therefore little better than cider or other fruit vinegars. The manufacture of unfermented grape juice has not on the whole been successful. The reasons for this are that the Concord juice entered the market first and formed the public taste and that methods of manufacture, which are adequate when dealing with the strongly marked Labrusca varieties, are not sufficiently refined for the delicate qualities of Vinifera.

\section{Climatic Factors.}

The chief climatic factors upon which the successful cultivation of Vinifera varieties depends are: 1, Sufficient heat during the growing season; 2 , Dry air during the hotter part of the growing season; 3 , Absence of winter cold sufficient to kill the dormant vine; 4 , Rarity of frosts during the growing season, 


\section{Seasonal Sum of Heat.}

According to the observations of A. Angot* the buds of the vine commence to start when the mean daily temperature reaches $9^{\circ} \mathrm{C}$. From this point until the ripening of the grapes, the sum of the mean daily temperatures above $9^{\circ} \mathrm{C}$. must reach $1130^{\circ} \mathrm{C}$. for the earliest varieties and $1520^{\circ}$ for the latest.

In the accompanying diagram, drawn from data in the reports of the United States Weather Bureau, the seasonal sum of heat for various typical localities is shown graphically. This sum is indicated by a line drawn through points which represent the mean temperatures of every month where these temperatures exceed $48^{\circ} \mathrm{F} .\left(9^{\circ} \mathrm{C}\right)$. Two vertical dashes drawn through this line indicate the average dates of ripening for the earliest, and for the latest varieties according to the data of Angot. Crosses represent the dates of the latest spring frost and of the earliest autumn frost and also the mean dates for both of these frosts where records are available.

\section{Locality}

Sissons, elevation, $3555 \mathrm{ft}$ Redding, Sacramento Valley Stockton, Sacramento Valley. Merced, San Joaquin Valley. Bakersfield, San Joaquin Valley, Salton, Coachella Valley Ukiah, Coast Range Napa, Coast Range Redlands, Coast Range Eureka, Pacific Littoral. Berkeley, Pacific Littoral. Raleigh, North Carolina
Rainfall 37.8 in. 36.2 in. 15.5 in. $10.3 \mathrm{in.}$ 4.8 in. 2.5 in. 35.0 in. 23.7 in. 14.8 in. 45.8 in. 26.5 in. 49.9 in.

\section{Seasonal}

Sum of Heat above $9^{\circ} \mathrm{C}$. Apr. to Oct. $2331 \mathrm{~F} .{ }^{\circ}=1295 \mathrm{C} .^{\circ}$ Feb. to Nov. $5538 \mathrm{~F} \cdot{ }^{\circ}=3077 \mathrm{C}^{\circ}$ Feb. to Nov. $4553 \mathrm{~F} \cdot{ }^{\circ}=2529 \mathrm{C}^{\circ}$ Feb. to Nov. $5592 \mathrm{~F} \cdot{ }^{\circ}=3107 \mathrm{C}^{\circ}$ Feb. to Nov. $6783 \mathrm{~F} \cdot{ }^{\circ}=3768 \mathrm{C}^{\circ}$ Dec. to Nov.10310 F. ${ }^{\circ}=5728$ C. ${ }^{\circ}$ Mar. to Nov. $3703 \mathrm{~F} .{ }^{\circ}=2057 \mathrm{C}^{\circ}$ Feb. to Nov. $3300 \mathrm{~F} \cdot{ }^{\circ}=1833 \mathrm{C}^{\circ}$ Dec. to Nov. $5750 \mathrm{~F} \cdot{ }^{\circ}=3195 \mathrm{C}^{\circ}$ Apr. to Nov. $1406 \mathrm{~F} .{ }^{\circ}=770 \mathrm{C}^{\circ}$ Feb. to Nov. $2842 \mathrm{~F} .{ }^{\circ}=1579$ C. ${ }^{\circ}$ Mar. to Nov. $4822 \mathrm{~F} .{ }^{\circ}=2679 \mathrm{C}^{\circ}$

This diagram indicates that the data given by Angot do not apply precisely to California. In all cases, the actual dates of ripening are from 2 to 4 weeks later than is required by the theory. The greater differences are in the hotter localities. In the Coachella Valley, for example, represented by the record for Salton, grapes should ripen, according to the theory, from May 3 to May 23. Actually the earliest varieties ripen there about May 15 to 30 and the latest about June 15 to 30. For Napa the diagram shows August 12 to September 24 as the dates of ripening. The actual mean dates are about from September 1 to October 15. Undoubtedly other factors enter into the result. It may be that the daily range of temperature affects the rate of ripening. Delay, due to the cool nights of the Californian summer, may counteract the acceleration due to the hot days. It may be, also, that in the hottest regions the temperature of maximum acceleration is passed. The last increments of heat at Bakersfield and Salton, while undoubtedly hastening the ripening, may do so to a less extent than equal increments at lower temperatures.

* Etudes sur les vendanges en France (Annales du Bureau central méteorlogique, 1883). See also, Viala \& Vermorel, "Ampelographie” T. I. p. 636. 


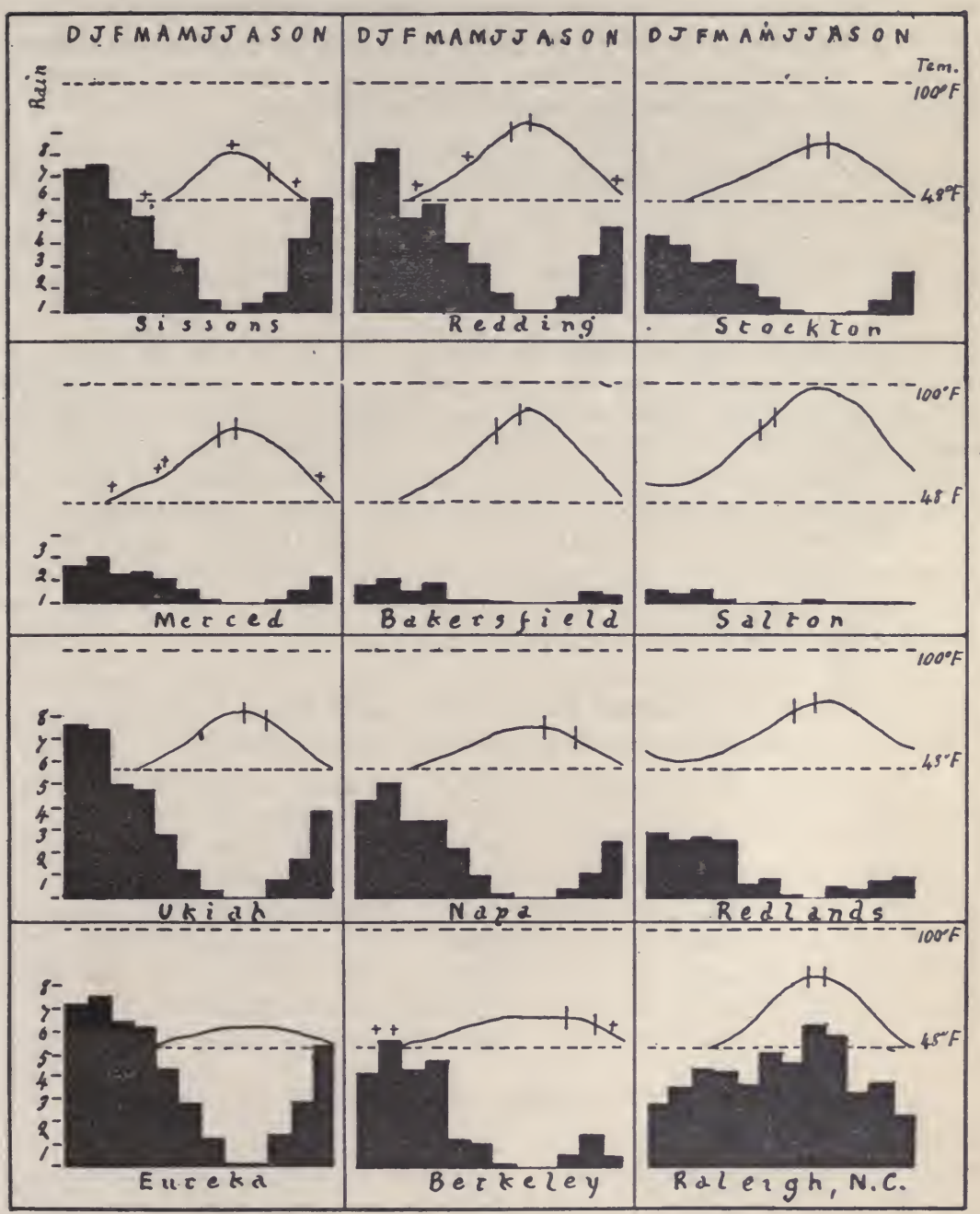

DIAGRAM.

Rainfall and Temperature of various localities on the Pacific Slope compared with a typical region of summer rains. 
A decrease of the difference in the time of ripening between early and late varieties in the hotter localities is shown by comparing the dates for Salton with those for Napa, as indicated by the vertical dashes. In the former the interval between the dashes represents 20 days, in the latter 43 days. This corresponds very closely with the observed facts.

That the conclusions of Angot do not apply exactly to California is shown by data obtained by the California Experiment Station from experiments carried out in Fresno and Yolo counties in 1913 and 1914.

The starting of the buds of the raisin Muscat occurs in both of these regions on the average about the middle of March. The mean temperature for March at Fresno is $54.9^{\circ} \mathrm{F} .\left(12.7^{\circ} \mathrm{C}\right)$ and at Davis, Yolo County, $56.2^{\circ} \mathrm{F}$. $\left(13.5^{\circ}\right.$ C.). This indicates that the mean daily temperature necessary to start the buds in these regions is from four to five degrees higher than Angot's $9^{\circ} \mathrm{C}$.

The seasonal sum of heat necessary to ripen the grapes will depend on the degree of maturity chosen. The most favorable degrees for shipping grapes, for dry wine grapes and for raisin grapes represents three different stages of maturity. Whichever of these we chose, however, it appears that Angot's estimates are too low for the great interior valley of California. This is clearly indicated by the following table, which represents three sets of tests of ripening Muscat grapes, two in the San Joaquin Valley and one in the Sacramento. The data given are the date of gathering and the Balling degree and seasonal sum of heat to that date. The sum is reckoned from March 15, the average date of the starting of the buds.

\section{Seasonal Sum of Heat for Muscat.}

Kearney, Fresno County, 1914. Mean for Year, 17.6

Date of Gathering. Bal. ${ }^{\circ}$

Aug. 12

Aug. 19

Aug. 26

Sept. 3

Sept. 9

Sept. 16

Sept. 23
18.6

20.2

21.8

23.6

24.0

23.8

26.5
Sum above $9^{\circ} \mathrm{C}$. from March 15, 1915.

1858

1983

2109

2231

2360

2486

2612

Kearney, Fresno County, 1913. Mean for Year, 17.6

$\begin{array}{lll}\text { Aug. } 17 & 21.0 & 1917 \\ \text { Aug. } 23 & 23.9 & 2034 \\ \text { Aug. } 30 & 25.5 & 2170 \\ \text { Sept. } 8 & 26.8 & 2317 \\ \text { Sept. } 16 & 28.8 & 2443\end{array}$

Davis, Yolo County, 1914. Mean for Year, 15.1

$\begin{array}{lrrr}\text { Aug. } 26 & 21.4 & 1549 \\ \text { Sept. } 2 & 25.8 & 1612 \\ \text { Sept. } 8 & 26.1 & 1677 \\ \text { Sept. } 16 & 26.5 & 1764 \\ \text { Sept. } 23 & 28.7 & 1841\end{array}$


These figures indicate that the minimum degree of ripeness, that necessary for table grapes, requires about 1900 units of heat or about 400 more than Angot's maximum in the case of Muscat at Fresno. The degree of ripeness necessary for raisin-making similarly requires about 2300 units or 900 more. At Davis the figures approximate those of Angot more closely, being about 1500 and 1700 respectively. This fortifies the conclusion already reached by a different route that in warmer regions more heat is needed than in cooler for the same results. Accepting the minimum degree of ripeness as representing Angot's calculation, the 400 extra units needed at Fresno represent almost exactly the heat of the month of August. Grapes which should ripen according to the theory about August 1, actually ripen at Fresno about September 1, or four weeks later.

The seasonal sum of heat is sufficient in all the cases shown in Fig. I with the exception of that of Eureka, even though we allow an increase of time of three weeks over that required by Angot's theory. The figures, however, represent averages for a term of years and the variations between different years are considerable. No locality is safe for planting, therefore, where the average seasonal sum is close to the minimum. This is the case of Berkeley, where even early grapes do not ripen every year. At Sissons, near the northern border of California, the sum of heat is sufficient for early varieties, but the possibility of the occurrence of frost even in July makes grape growing uncertain.

The temperature curve for Napa shows some of the causes of the superiority of the Coast ranges and valleys for the production of dry wine. The development of the vine and its fruit there requires from seven to eight months, as compared to the five or six months shown for Bakersfield at the upper end of the San Joaquin Valley. This slow ripening results in a higher acidity at maturity and brings the vintage to a time of year when the weather is cool and favorable to proper fermentation.

The temperature curves for Merced and Bakersfield show ideal climatic conditions for the production of raisins. The sum of heat necessary for the ripening of even late varieties, is obtained while there still remain several weeks or hot, dry weather for the drying of the raisins. The temperature conditions for Redding, at the upper end of the Sacramento Valley, are almost identical with those of the corresponding part of the San Joaquin, but the autumn rains are more abundant and occur about a month earlier. This makes the drying of raisins precarious.

\section{Dry Summers.}

The black areas on the diagram indicate the annual rainfall for each locality and its distribution by months. They show apparently that the condition of a dry summer is fulfilled for all the California localities. The absence of rain, however, is not all that is needed. The harm of summer moisture is not due to the wetting of the soil. This may be an advantage and is often brought about intentionally by means of irrigation. Harm results only when the air is both warm and moist for considerable periods. Such a condition is shown by the record for Raleigh, N. C., which shows that the warmest month is also the wettest and that rain falls abundantly during every month of the growing season. So much rain cannot fall without producing excessive moisture in the air for considerable periods. It is this 
combination of high temperature and moist air, which favors the development of fungous diseases and makes their control difficult or impossible.

Even Eureka and Berkeley have two months of almost complete absence of rain and two more months when the rain is too scant to keep the air moist for injuriously long periods. The summers in these localities, in fact, are about as free from rain as in Ukiah and Redding, where all grapes succeed admirably. Lack of heat is a sufficient cause for failure at Eureka but at Berkeley, where the heat is ample for early varieties, the presence of frequent summer fogs is sufficient to make their crops very uncertain. These fogs militate against grape growing to an increasing degree, as we go north from San Francisco, but their effect decreases gradually as we go south. Grapes are grown in favored spots within a few miles of the ocean from Santa Cruz south, but much trouble is experienced in controlling the Oidium.

\section{Winter Killing.}

The killing of dormant vines by cold is practically unknown in California. A thoroughly dormant vine is seldom hurt by temperatures above $10^{\circ} \mathrm{F}$., unless it is of a tender variety or growing in very wet soil. Where the temperature falls to $5^{\circ} \mathrm{F}$. or lower, most varieties will be killed to the ground unless protected. Such temperatures do not occur in California, except at high elevations where the summers are too cool for grape growing. In more northerly and easterly localities, such winter temperatures may occur even where the summer temperature is favorable. In such localities, vinifera varieties may be grown if protected with straw or soil during the winter. Autumn killing occurs occasionally in nearly all parts of California, especially in the wide plains of the interior. It is due to excessively late growth of the vines, which maintains them in a susceptible condition until the first autumn frosts. It occurs most commonly in vineyards of two or three years of age, growing in rich moist soil. Younger vines are shallower rooted and the drying of the upper soil causes them to become dormant earlier. The drain of the crop on the vital activities of bearing vines has the same effect. In all cases it can be prevented by appropriate cultural methods which insure the dormancy of the vine before November.

\section{Extent of the Industry.}

The vineyards of California covered in 1912 about 385,000 acres. Of this total, about 180,000 acres were producing wine grapes. Roughly, 50 per cent of the wine was produced in the great interior valleys, including most of the sweet wines; 35 per cent was produced by the valleys and hillsides of the Coast ranges, including most of the dry wines; the remaining 15 per cent was produced in Southern California and included both sweet and dry.

The raisin-grape vineyards covered about 130,000 acres, of which about 90 per cent were in the San Joaquin Valley, 7 per cent in the Sacramento, and 3 per cent in Southern California.

The shipping-grape vineyards are reckoned at 75,000 acres, distributed about as follows: 40 per cent in the Sacramento Valley, 40 per cent in the San Joaquin, 6 per cent in Southern California, and 4 per cent in the Coast ranges. 


\title{
THE VINEYARDS OF THE COLUMBIA RIVER BASIN.
}

\author{
By E. H. TWIGHT,
}

Guasti, California.

The Grape Growing Districts of the States of Washington and Idaho are found east of the Cascade Mountains on the bench lands overlooking the Columbia River and its affluent, the Snake River (and its affluent, the Clear Water); the Yakima, the Wenatchee and the Okanogan Rivers.

The soil of those benches is either volcanic ash or decomposed granite; these soils have made a reputation in growing some of the best apples in the world and have now added to their laurels by producing grapes, that in color, quality, flavor and even quantity are unsurpassed.

The climate shows the usual effect of the Coast Range on the lands laying east of it; very dry through the growing season and with a rainfall (of 6 to 14 inches) which takes place mostly in winter and in the shape of snow. The Cascade Mountains being higher than the Coast Range further south their effect is more striking and the trade winds from the Pacific Ocean, heavy with moisture when they reach the coast, have abandoned nearly all of it before they have overcome the great barrier of the Cascades. Thus we find that at the mouth of the Columbia at Astoria the mean rainfall is 76.09 inches; at Vancouver, near the junction of the Willamette and the Columbia, and only 90 miles up, the annual average rainfall has dropped to 45 inches, and just across the gorges through which the Columbia forces its way through the Cascades, at the Dalles, 84 miles further up river, the rain fall has dropped to 14 inches. The minimum is met a little further east near Pasco, 300 miles from Astoria, where the Columbia swings north and receives the Snake River from the east; here the mean annual rain fall is about 6 inches. Following the Columbia River north we find at Wenatchee 13.71; at Brewster at the mouth of the Okanogan 13.52. If we follow up the Snake River we find at Lewiston 13.48 .

From these figures it can be readily seen that grape culture in the Columbia Basin can only be carried on with the aid of irrigation. It is true that in many instances grape vines will grow without irrigation for the first two or three years, but when they come into bearing they need water to give a marketable crop.

As regards the seasonal changes, we find that during the growing season the hours of sunshine are probably greater than in the most favored districts in the world. The days are long with hardly ever a cloud in the sky, from early spring until fall. The summers are warm, the temperature reaching sometimes over one hundred, and this insures a good supply of sugar in the grapes.

The fall brings a little rain, usually enough to help plowing, but it is through winter that most of the moisture comes, a good deal of it in the shape of snow.

There are usually two or three cold spells in winter when the temperature may drop around zero, but with well matured wood most varieties stand well; especially when there is a good coat of snow on the ground. 
In some parts of the Columbia River Valley, on the lower levels where very little show falls, there is a very early start of vegetation in the spring; this is frequently followed by a cold snap, and in such locations the vines are frequently not profitable, unless well covered up through winter. This covering can be done without much expense if a low cordon system of pruning is followed. The best locations however are those where, on account of the heavier snow fall this early start does not take place; the vine remains dormant until the late frosts are over. In some of these favored locations no winter protection is needed.

The cold dormant season, followed by a continuous, cloudless warm growing season insures a great perfection in the grapes and results have been very gratifying.

At the Dalles, at Wenatchee and on the Clear Water and Snake Rivers some attempts have been made to plant wine grapes and to manufacture wine. Some of the choicest varieties from Europe were planted and very satisfactory results obtained especially with grapes of the Burgundy and Rhine types. The wines have maintained a fine bouquet while having a good alcoholic degree and fine acidity. One of the pioneers Mr. Schleicher, of Lewiston (Idaho), laid out a regular experimental vineyard of some 35 or 40 acres on a bench a few miles above Lewiston on the Clear Water; most of these varieties were obtained through the writer from the collections of the University of California. Whi'e the great number of varieties only allowed making comparatively small amounts of the different types, it has been sufficient to demonstrate the high grade of the products that can be made here. Connoisseurs from Portland, and from Seattle are anxious to secure the bottled products that Mr. Schleicher has offered from time to time.

It is unfortunate that the Prohibition Movement has not so far separated the manufacture of pure wholesome wines and ciders from the so-called saloon business. If there was a guarantee of protection in the future, there is no doubt that a very important industry could be built up in those districts. There would be practically no competition with California wines, the climate of the Columbia River enabling the grower to make a type of wine that cannot be made in California in the districts at present devoted to grape culture. There would be as much difference between California and the Columbia types as there is between the Rhine and the Languedoc or Provence.

However, on account of the fear of future interference the great bulk of the planting has been done with a view to develope the table grape and grape juice industries. Of possibly 5000 acres in the Columbia Basin not over one tenth is planted to wine grapes.

The most important centers of the table grape industry are Kennewick, Prosser and Pasco.

The European varieties planted have generally been introduced from California and thus we find the Flame Tokay, the Cornichon, the Emperor, Rose of Peru, and Black Hamburg in the lead of the red grapes, while Muscat, Malaga and Chasselas are planted mostly for the whites. All of these ripen well; however, the Malaga and the Muscat lack sometimes in sweetness. The Flame Tokey does wonderfully well, the coloring and size being equal to the very choicest California product. As these grapes usually come into 
the market after the California product is through they receive a good price. With some attention they can be carried until Thanksgiving when excellent prices can be obtained.

The Eastern varieties have been planted more extensively than the European varieties, partly because they stand the winter better and partly because the growers have in mind the manufacture of grape juice for which these eastern varieties are better adapted. The Concord, the Worden, the Moore's Early, and Campbell Early are the favorite varieties. The Campbell Early seems to head the list; a vigorous grower it bears enormously and ripens early in August bringing very satisfactory prices.

Regarding the danger of disease, the experience here seems to be similar to that of California; the dry climate seems to be a protection against fungous diseases, the only one that seems to be troublesome being the Oidium (California Mildew) and that is easily checked with the usual sulphur application.

Phylloxera exists in some of the vineyards of the Clearwater district, and the wholesale importation of rooted vines from California and the East will probably distribute the pest thru the new districts so that the usual problems of reconstruction will come up. There will be no difficulty to find suitable stock for the soils of those new districts. The writer warned repeatedly the growers of the danger of introducing phylloxera but apparently to no avail.

There is no doubt that the grape industry has a great future in the Columbia River Basin, even though at present the wine industry may not be taken up. There has been so much over-enthusiasm towards the apple industry that when the reaction sets in more attention will be given to other branches of horticulture: the fair returns that have been obtained by the grape growers are bound to induce many to plant grapes.

At present few grapes are being shipped outside of the local State markets; with three transcontinental lines close at hand the shipping facilities are excellent to reach the markets of St. Paul, Chicago and Canada.

With the advantages of soil, climate, and transportation certainly in a few years the Columbia River grapes will be as well known as their beautiful red apples are today.

\title{
THE GRAPE IN OREGON.
}

\author{
By C. I. LEWIS, \\ Chief, Division of Horticulture, Oregon Agricultural College, \\ Corvallis, Oregon.
}

Grape growing in Oregon has never reached large proportions. The people of the State have not taken up the culture of this fruit to the same extent as they have that of the apple, pear, prune and cherry. The State, however, stands eighteenth in the Union, according to the last census, and at that time had 381,302 bearing vines. It must be borne in mind, however, that grape growing in this country is highly specialized and that there are only about a dozen states that have an industry of much importance. At the present time the State of Oregon is importing large quantities of grapes. 
They come from two sources: from California, which ships us large quantities of Malaga, Tokay, Muscat and similar varieties, and from New York State which furnishes us principally with Concord.

The State occupies a peculiar position in that it has a range of climate and soil that allow the production of the two great types of grapes, namely, the Vinifera and those of American blood, principally V. labrusca. The consumption of grapes in the State, however, is relatively low and could be increased many fold. The cause of the low consumption is due to the fact that many of our local grapes are of poor quality and that some sections have not determined the types and varieties best adapted to their conditions. As a result much sour or immature fruit is placed on the market. This seems to be the limiting factor as far as consumption is concerned.

There are also limiting factors which determine production in certain parts of the State. First, as regards production of the Vinifera or European type of grapes; east of the mountains, the limiting factor becomes the winter cold making it necessary in many sections to give the vines artificial covering; and in some sections west of the mountains the limiting factor is mildew. Then, with the American grapes, in some portions of the State, such as the coast counties and cooler portions of the State, it has been difficult to mature some varieties. Many of the grapes produced on such locations are too tart to satisfy the trade. There are in this State, however, large areas where the climate and soil are splendidly adapted to grape production, and Oregon should become an exporter of grapes and grape products.

The Vinifera grapes will be limited to about three sections: First, Southern Oregon, especially Jackson and Josephine Counties. Mr. A. H. Carson of Grants Pass has made a signal success of producing both Vinifera and American grapes. On the higher altitudes and red shot soils, the grapes succeed very nicely. In the Columbia Basin, the Vinifera grape will succeed and The Dalles is a splendid location. This section has a moderate winter climate. Further to the east some Vinifera grapes are also produced.

For the American grapes, Southern Oregon-including the Umpqua and the.Rogue River Valleys-is one of the leading sections of the State. The Columbia Basin, especially such sections as Stanfield and Hermiston, are producing grapes of very fine quality and of high sugar contents. Eventually this region should have grape juice factories established to take care of their product. On the warm exposures in the Willamette Valley, these grapes succeed and in the vicinity of Portland, at such points as Milwaukee and Forest Grove, many of the farmers are producing high quality grapes.

The marketing question in the State is a serious one, especially as far as the American varieties are concerned. We have about reached that point where not much expansion can be hoped for until grape juice factories can be established. At the present time the total consumption of grapes produced fresh about equals the supply, but at times the American grape is a drug on the market and the prices received not remunerative. It would certainly pay to have a juice outlet so that this condition could be remedied.

There is not much we can say regarding soils. The grape needs the same type of soil here as it does in any other section. They seem to succeed better in the lighter types of loam or the well-drained types of soil. They also seem to succeed in rather dry solls and in some cases in rather shallow soils provided the roots can get through the cracks and seams in the rock 
and reach the lower strata. Certain varieties and certain stocks demand special soil.

Not much work has been done with stocks for grapes, but at the Umatilla Experiment Station, Hermiston, Oregon, we have inaugurated a number of experiments with grapes and are experimenting with double working. A bulletin is now in press concerning grape growing in that section.

\section{Varieties.}

We find a tremendous range as regards adaptability of the different varieties. The principal varieties of Vinifera grapes for Southern Oregon are Tokay, Malaga, Muscat, Thompson Seedless, Rose of Peru; American varieties: Worden, Concord, Delaware, Moore's Diamond, Niagara.

In the Willamette Valley, we have been growing at this Experiment Station a large number of varieties and find that the following succeed best: blue grapes: Moore's Early, Worden; white grapes: Moore's Diamond, Niagara; red grapes: Brighton, Delaware. There are some other very promising varieties, Campbell's Early meeting with considerable favor and a few of the growers finding Regal one of their best grapes.

For Eastern Oregon the following recommendations and descriptions taken from Bulletin 126 (now in the press) on Grape Growing in Eastern Oregon, by Professor R. W. Allen, will be of interest:

Recommendations:

The Concord and Worden are preferred for the manufacture of black juice. For red juice, the Catawba is preferred.

Early Moore, Winchell and Delaware are promising for early dessert varieties. The Early Campbell, Worden and Diamond are superior midseason varieties. For late season and storage varieties the Concord, Catawba and Niagara are preferable.

But a small number of Viniferas can be recommended for general planting as late varieties do not reach full maturity. The most successful are Sultanina (Thompson's Seedless), Malaga, Muscat of Alexandria, Flame Tokay, Black Hamburg and Black Prince.

Varieties for home use should be selected from this list. It includes a sufficient number from which a succession of hardy and productive varieties can be taken to supply fresh fruit from August to December, or until January with proper storage.

\section{Tillage.}

Very little can be said regarding tillage. The same rules that apply to other fruits apply in grape production. The main point is to sufficiently till the ground so as to maintain the vigor of the plant the first two or three years after planting for if neglected at that time they rarely become heavy producers.

In the irrigated district, great care must be taken in irrigation. The rill system is generally used and on some sandy soils, irrigation will have to be given every two or three days.

Some growers are using cover crops to splendid advantage. There is danger, however, of overdoing the use of cover crops or the application of nitrogenous manures in any form. While the grape is a heavy feeder, too much nitrogen produces a vigorous plant growth at the expense of fruit. 


\section{Pruning.}

American varieties are pruned very much the same as in New York, the renewal system being one in vogue using various combinations of arms, such as the two-arm, the four-arm, the fan shape. The Kniffin, both two and.four-arm, system and occasionally the Munson system are used also. Since these systems are described so thoroughly in various books on pruning and grape bulletins, it would be merely repetition to describe them here.

The system of pruning the Vinifera grape is greatly modified from that used in California. This is owing to the fact that we must give artificial protection. In those sections where artificial protection is not necessary, the California system of pruning the Vinifera is used. Mr. R. W. Allen, Superintendent of the Eastern Oregon Experiment Station, Hermiston, has found the following system of pruning the Vinifera to give very good results:

\section{Training and Pruning Viniferas.}

Vinifera plants require being kept near the ground to facilitate covering for protection in winter. They can be trained to low stumps (the short system) or horizontal arms, that can either be left on the ground during summer or tied up to the lower wire of the trellis. Shoots springing from spurs on older wood of the plants constitute the fruit part and should be tied up to a trellis.

A form of trellis with two wires is in common use. When the horizontal arms are tied up to the lower wire, three wires become necessary.

Pruning should be done as soon as the leaves fall, so the plants may be covered before cool weather occurs.

The Short or Stump System:

Training young plants for the stump system is simple. It consists in pruning back to short spurs near the crown of the plants until a stump, or much branched stem, is established. These stems, or bodies, should be lsept close to the ground to facilitate covering. Pruning is accomplished by cutting back a few strong shoots to spurs having two or three buds, and in removing all the remaining growth. The stump is kept from gaining in height by care. ful selection and close pruning of spurs.

The fruit wood should be tied up to the trellis, and all remaining growth removed. Other shoots or sprouts that come on during the growing season need to be removed to prevent excessive shading of the fruit near the center of the bushes.

Horizontal Arm System:

Young plants are trained to the horizontal arm system by confining the growth to a small number of shoots (one or two) until two strong canes are produced. One cane is made secure in a horizontal position each way in the row from the plant, and the ends removed at a point near the center of the space between the plants. Growth springing from these permanent arms constitutes the fruiting parts of the plant and is tied on to the trellis each year in a vertical position.

The pruning of vines trained to this system is accomplished by cutting the canes back each winter to spurs on the permanent arms. The number of spurs left on each plant should be influenced by its vigor. As many canes as the plant can support should be tied up to the trellis as soon as they are 
large enough, and at the same time-all remaining growth should be removed. This should be done as soon as the new growth gets long enough to reach the top wire of the trellis.

When to Prune:

The heavy annual pruning necessary to regulate the fruit of vines should be done during the dormant season. Plants that require winter protection need to be pruned as soon as they become dormant. Hardy vines can be pruned at any time during the dormant season when the wood is not frozen. It is advisable, however, to prune before February in this region as late pruning frequently results in bleeding and serious weakening of the plants.

Summer pruning to diminish shade and hasten maturity of the fruit appears to be necessary with Viniferas on account of their vigorous growth. The usual practice is to remove all suckers and the ends of bearing canes beyond the last bunches of fruit. Summer pruning should be carefully done to not expose the fruit as sunscald might result. No definite system is adopted for this work, nor is its effect upon growth and production at all well understood.

\section{Winter Protection of Vines.}

The tender Viniferas, not being capable of withstanding low tempera. tures, require covering to guard against injury or loss during the winter. Not all varieties are affected by the same temperature, but as all suffer in occasional seasons, covering becomes necessary.

Some of the so-called American varieties, which are crosses between American and Vinifera parents, although more hardy than the latter, suffer from freezing in cold districts and might be injured here in times of extremely low temperature.

A series of experiments has been carried out to determine the most effective method and best material to use for covering grape vines. The vines should be pruned and laid down, or pruned back close to the ground before covering. Vineyard soil is preferable to straw or litter to cover plants with, and can be put on to the plants with a plow or shovel. When the plants are properly prepared they can be readily covered by running a twelve or fourteen-inch plow along each side of the row and throwing the soil on to the vines. It will be necessary to complete the operation with a shovel, as thorough covering cannot be done with a plow. Plants pruned to the short system frequently stand ten to sixteen inches above the ground and necessitate the handling of considerable soil to completely cover them.

If exposed to the wind the covering is liable to be blown off and should be protected by a light covering of straw or litter.

There are two objections to the use of straw for covering grape vines. Materials of this character furnish agreeable quarters for rodents which frequently injure the vines by gnawing at the body or roots. It frequently begins to decay in early spring and heats before the proper time for it to be removed. Covering materials upon heating cause the buds and wood to be killed or badly weakened.

Grape vines should be uncovered when danger of frost is past. Plants covered with soil are frequently left in place and the new growth allowed to come through it. The liability of late frosts renders uncovering hazardous before growth begins, and to leave the plant covered causes new growth to 
be small and weak underground. Neither method is entirely successful, but for greatest safety to the vine, it is preferable to allow the new growth to come up through a small amount of soil. Part of the covering should be removed when severe weather is past, and when the new growth is well advanced, the remainder of it can be taken off. Arms of plants trained to the horizontal system can be raised out of the covering by the time warm weather occurs while p'ants that are laid down must be uncovered and tied up to the support as soon as danger of frost is past so the new growth will not be disturbed by a change of position.

\section{Planting.}

The distance of planting varies tremendously. In Western Oregon our plants are from seven to eight feet apart and eight feet apart in the row. In Eastern Oregon we find, with such varieties as Moore's Early and Delaware, that eight feet is ample, but most of the other American varieties require about ten feet in the row. The Viniferas are generally planted about ten or twelve feet apart.

\section{Insects.}

While insects have not become a menace to the grape industry, there are a few which I would call your attention to.

The grape leaf mite has been reported in one valley of the State, and while it makes the leaves conspicuous it does not seem to cause any serious damage. No opportunity has been given the Experiment Station for experiments with control of this mite, but we believe that lime-sulphur applied in the spring when the buds swell should be effective.

The branch and twig borer which attacks a variety of fruits also at times attacks this fruit.

The shot-hole borer has also at times been troublesome. The treatment for these pests here is the same as generally recommended elsewhere.

\section{Diseases.}

There are a number of diseases which prove troublesome, mildew being the worst. In fact, mildew is so bad in some sections that it will probably never be controlled on certain varieties of the Vinifera grapes. In other sections, however, control is fairly easy with dry sulphur applied intelligently.

Another disease which is very bad at times is the crown gall or black knot of the grape. In some localities it has become so serious as to cause considerable loss to our growers. A discussion of this disease is not necessary at this time, as it is very well known and has been splendidly described in much of our literature and bulletins on plant pathology.

\section{Marketing.}

The Vinifera or California grapes are marketed in four-basket crates, each basket holding approximately five pounds of fruit. This is a very acceptable package on our market and meets with ready sale generally bringing about $\$ 1.00$ and $\$ 1.25$ a crate to the grower. However, much inferior fruit sells for less. 
The American grapes are nearly all marketed in Climax baskets.

Some attempt has been made to manufacture juice, but most of this juice, while pronounced by some as of fair quality, has usually been of rather low grade. In a neighboring state, a juice of high-grade has been manufactured of Worden grapes. There is no reason why some sections could not produce grapes in large enough quantities to supply a juice ctory. It seems to us that it would be a good proposition for some of sur Eastern juice manufacturers to establish a branch factory to take charga of the local distribution of grapes.

\section{GRAPE GROWING IN NEW MEXICO.}

By PROF. FABIAN GARCIA,

Director Agricultural Experiment Station, State College, New Mexico.

New Mexico has a history which is probably not surpassed in antiquity and interest by that of any other State. Some of the more interesting features of the early history are the peculiar Pueblo and Aztec civi'izations, remains of which are to be found in the ruins in many parts of the State; the antiquity of the State under the old Spanish rule, for New Mexico was the first of the states to be occupied and governed by a European people; the overthrow of the Spanish rule and the Mexican form of government from 1820 to 1848; the peculiar circumstances under which this section became a part of the United States. Its salubrious climate; its large grazing prairies; the picturesque mountain ranges traversing the central and western parts of the State, and the fertile irrigated valleys dotted here and there with orchards and vineyards add materially to the interest of the State.

However, in searching for information relative to the early horticultural development in the State, the investigator finds it no easy task to get reliable data on the subject. In all of our histories we find the records of different political events that have taken place since New Mexico was discovered by the Spaniards, but for some reason or other the historians have failed to record any agricultural or horticultural data. It is probably safe to say that for one or two hundred years after the Spaniards discovered this land there was little or no effort made in the growing of fruits of any kind. Prior to 1880 it is found that there was little progress made in the horticulture of the State. From 1750 to 1800 it is recorded that the New Mexico industries consisted largely of barter, stock raising, and a limited growing of farm crops. About this period the Spaniards made a slight beginning in the growing of inferior varieties of fruits for home use. From about 1822 to 1845 , during the Mexican rule, New Mexico started to develop its agriculture somewhat more rapidly than it had in the past. In 1823 the value of the agricultural and horticultural exports, mostly to Chihuahua, amounted to about $\$ 12,000$, while in 1845 they had increased to about $\$ 450,000$. While these exports were mostly of agricultural crops and live stock, it is perhaps safe to conjecture that as other branches of agriculture developed, fruit growing must have started to develop also, though perhaps in a smaller pro- 
portion on account of the perishable nature of the products and the long distances to large markets.

Another factor, which no doubt was responsible to some degree for fruit growing not coming to the front more in the early history of the State, was the lack of interest and inclination of the Spaniards and Mexicans for this line of agriculture. The people of both of these two races were not particu'arly horticulturally inclined. However, these people had some knowledge and training in viticulture and the grape was probably the most popular fruit among the early settlers in the valleys.

\section{American Grapes.}

The American grapes may be grown in almost all of the irrigated districts of the State. They are, as a rule, hardier and more resistant to the cold than the European varieties. The American grapes are to be found growing mostly in the higher and cooler districts of the State. In the lower and warmer valleys, while they grow well, they are not grown nearly so much as the European grapes nor are they so popular.

There are only small vineyards to be found and these are usually in home fruit plantations. As a rule, these small vineyards are composed of a number of varieties, such as Ives, Moore's Early, Delaware, Niagara, and Concord. Some of these American grapes are also used for arbors, as some of them seem to be well adapted for such purposes. These varieties, being hardy, do not require any winter protection. The method of growing them is practically the same as that used in grape growing districts in Missouri and New York.

They are trained on different kinds of trellises and pruned according to Eastern methods.

\section{European Grapes.}

The European grapes are not nearly so hardy as the American varieties and are more or less subject to winter injury. While they may be grown in the higher and cooler districts in the State, the large vineyards are to be found in the lower and warmer valleys. For best results they prefer warm conditions and a more or less mild winter. The European grape is, at the present, the commercial grape in New Mexico. It is grown, trained and pruned in practically the same way as in California.

\section{Grape Growers.}

From the early history of grape growing in New Mexico it is found that this industry has been carried on by the Mexican or native farmer. The American farmers do not seem to care to follow grape growing on any kind of a commercial scale. Even at the present time the larger vineyards in the different parts of the State are owned and managed by the Mexican farmers.

\section{The Rio Grande Valley.}

The Rio Grande Valley has been the agricultural backbone of New Mexico from its early history. It has produced food for a large per cent of the people who have controlled and ruled the State from time to time. The 
southern part of the Rio Grande Valley, particularly the Mesilla Valley, has been noted for its fine fruit, especially the Mission grape. The Mesilla Valley is one of the largest irrigated districts in New Mexico and during the latter part of the Mexican and the early part of the American rule the Mexicans made an effort to develop the grape-growing industry. As a matter of fact, the history of grape growing in New Mexico may be reduced to the history of the Rio Grande Valley.

During the 50's and 60's much interest was manifested in the cultivation of this crop, since this fruit could be manufactured into wine and dried into raisins. The wine was sought after quite extensively by the United States soldiers who furnished a market for this product. In 1866 Judge J. G. Knapp, a resident of Mesilla, the county seat of Dona Ana County, in the early 60's wrote as follows: "Two kinds of grapes were grown, the El Paso (Mission) and the Muscatel. Both are sweet grapes. The origin of these grapes is shrouded in mystery. No trace of them can be found beyond El Paso (now Cuidad Juarez, Mexico), though they are of Asiatic origin and probably were produced from seed of dried grapes from Spain or even further east, planted by some of the Spanish missionaries."

In 1868 one of the first large vineyards was started by Mr. T. J. Bull of Mesilla. Others were started by Messrs. Thomas Casad, Ramon Gonzales, Rafael Ruelas and Rafael Bermudes. These men played quite a part in the early development of grape growing in the Rio Grande Valley. From 1880, after the A. T. \& S. F. Railroad came through, the grape industry developed very fast, as there were facilities for shipping the grapes to outside markets.

\section{Other Districts.}

There are in New Mexico a number of districts in which the Vitis vinifera grape does well. As has already been stated, these grapes prefer the lower and warmer valleys. The best grape growing districts are to be found in the lower and warmer valleys at altitudes ranging from 3000 to 6000 feet, the Rio Grande Valley being the principal and largest grape growing district. Large plantations are also found in the Pecos Valley, Tularosa Basin, in the Mimbres Valley, and on a smaller scale around Santa Fe and Las Vegas. Vitis vinifera is the grape that has been grown and is being grown for commercial purposes in New Mexico.

\section{Propagation.}

The propagation, soil, irrigation, pruning, etc., in this paper refer to the Vitis vinifera grape. The New Mexico grape grower propagates his vines by cuttings. These cuttings may be taken in the fall, winter or at the time when the vineyard is being pruned. If taken in the fall or winter, the cuttings are hilled in until spring. If taken in the spring, when the vineyard is being pruned, the cuttings are then placed in the field where the vines are to grow. Hardly ever are the cuttings taken and rooted in nursery rows the first year. This method has been used by all of our native grape growers for many years and if the work is properly done and the cuttings are well taken care of during the summer it is surprising how large a percentage of them will root. As a rule, if the vineyard is propagated in this way, it comes into bearing about one year earlier than if the cuttings are 
first rooted in nursery rows. The cuttings are made about twelve or fifteen inches in length. Two cuttings, as a rule, are placed in each hole in the field. Most of the old time grape growers bend the lower end of the cutting almost at right angles when placed in the hole. Immediately after the cuttings are planted they are irrigated. If the ground cracks around the cuttings it is customary to go over the field and throw a little dirt around them. Sometimes a second irrigation is given, which tends to prevent the cracking of the soil. This method of propagation is followed almost altogether by the Spanish-American vineyardists. The American grape growers, as a rule, prefer to use the rooted cuttings which they can purchase from California nurseries.

\section{Soils.}

The European grape is quite cosmopolitan in its soil requirements. The best all-round soil, however, for European grapes is a sandy to a sandy loam. This grape makes too rank a growth and is liable to ripen its fruit more or less irregularly and later when grown on heavy adobe soils. A soil that may be considered almost too sandy for any other fruit or vegetable may be used very satisfactorily for the Vinifera grape. The sandy to sandy loam will produce, other things remaining favorable, a better, earlier, sweeter and larger berry and the bunches will ripen more uniformly than on the heavy adobe soil. Wet or alkaline soils are not considered desirable for grapes. Soils which have the water table close to the surface should be avoided in grape culture.

\section{Distance to Plant.}

There is some difference of opinion among the grape growers as to the best distance between the vines, and this distance depends, to some degree, on the variety, but more particularly on the kind of soil. If the soil is a sandy to a sandy loam the distance between the vines is less than when a heavy adobe soil is used.

When the stump system of training the vines and heavy pruning are practised, and if a light soil is used, the distance may vary from seven by seven to ten by ten. Most of the vineyards are planted seven by seven or eight by eight feet apart.

\section{Staking the Vines.}

It is a good practice, after the first season's growth, to tie the small vine to the stakes driven down in the soil close to the plants. The stakes may be made out of any durable wood and vary from two and one-half to three feet in length. The vines are kept tied to these stakes until the stump has been formed which is from two to three seasons. The staking of vines encourages a more upright and straighter stem or stump.

\section{Cultivation.}

The cultivation of the New Mexico vineyard consists of one plowing in the fall and one in the early spring before the vines are trimmed, fol owed by shallow surface cultivations to keep down the weeds and to keep more or less of a soil mulch. The summer surface cultivations will vary from four to six. depending on the character of the soil and the season. The heavier the soil, as a rule, the more cultivations and the harder it is to keep a good soil mulch The weeds are also worse on the heavy adobe soil. 


\section{Irrigation.}

The grape is one of the most drought-resisting fruits grown in New Mexico. On sandy soil from three to four irrigations during the season will be enough to mature the crop. It is not a good practice to irrigate late. It tends to produce too rank a growth of canes and retard the ripening of the fruit. During the winter, if it is very dry, it is advisable to irrigate the vineyard once. This may be done just before or immediately after the vines are hilled up. The first irrigation in the spring is given just immediately after the pruning is done. The frequency of the subsequent irrigations will vary somewhat according to the nature of the season and the kind of soil. As a rule these irrigations are given from four to six weeks apart. The last irrigation is usually given in the early part of August. The flooding system is practiced in the irrigation of grapes.

\section{Winter Protection.}

The vinifera grape in New Mexico is somewhat tender and is subject to winter injury. It is necessary to cover the vines up every winter. While the vines may not be injured every year, the vineyardist cannot tell just when the vines may be winter killed and in order to be on the safe side it is advisable to cover them up every year. If the winter is very moist, and if it rains or snows considerably, the chances are that there will be little or no winter injury to the vines. On the other hand, however, if it happens to be a dry winter it is almost certain that the canes will be killed back.

The winter protection of the vines consists in drawing the dirt up to the vines and building a mound to the proper height. If the soil is quite sandy it is advisable to irrigate before covering. If it happens to be a pretty heavy soil, it is better to do the irrigating after the covering of the vines. Early in the spring the dirt is removed from the vines by first plowing as much of it away as possible and then using a hoe or shovel to remove what is left.

It is also advisable to uncover the vines early before they bud out and the base buds have started to swell. If the uncovering of the vines is delayed until the season begins to warm up, the base buds will swell so much that when the soil is removed they are quite likely to be injured. It is customary to uncover the vines about a month before pruning.

\section{Pruning.}

The method generally practiced by the vinifera grape growers is the one commonly known as pruning to a stump. In the spring, the canes are cut back very severely, leaving from two or three buds. This operation is also delayed just as late as possible in the spring. It is not a good practice to prune early, because the earlier the vines are pruned the more liable they are to be injured by the late spring frost.

\section{Insects and Diseases.}

At the present time the vineyards have been comparatively free from serious pests and diseases. The worst insect pest that the vineyardist has to deal with is the grape leaf hopper, which sometimes causes considerable trouble. This, however, can be eradicated by the proper use of the "Black Leaf 40 " solution, together with the use of the hopper-doser. 
During recent years in some of the grape growing districts some trouble has been experienced from the grape crown-gall. This disease seems to attack some varieties more than others. Fortunately the better commercial varieties are somewhat resistant to it and those that are attacked by this pest are not materially injured.

\section{Varieties.}

The old El Paso or Mission grape is the one that has been grown ever since grapes were first planted in New Mexico. There are more vineyards of the Mission than of any other grape. This variety has been quite popular throughout New Mexico, as well as throughout Texas and Louisiana. It is a very hardy variety, and withstands considerable drought, neglect and cold. It is a good bearer and of fairly good quality.

During more recent years the Muscat of Alexandria has displaced many of the Mission vineyards. This is one of the best varieties that is being grown at the present time. It begins to ripen about the 15th of August, about ten days earlier than the Mission. The Black Cornichon, Purple Damascus, Flame Tokay and Black Ferarra are varieties that are being planted quite extensively in the State. The Thompson Seedless and Chasselas are becoming popular early varieties.

\section{Use.}

Grape growing does not compare in importance with apple, pear or peach growing. Most of the grapes that are raised are shipped locally in the State, some are shipped to Colorado, to Oklahoma, to Texas and to Louisiana. A large per cent of the grapes grown by the native farmers is converted into wine.

April 2, 1915.

\section{GRAPE GROWING IN UTAH.}

\section{By A. B. BALLANTYNE,} Provo, Utah.

\section{General Conditions.}

Lying mostly within the Great Basin, Utah, as a whole, possesses the climatic characteristics of this vast semi-arid region. The warm usually dry sunny days are followed by cool crisp nights, the total daily range of temperature at almost any season being very great.

In surveying the climate of this State with reference to the grape industry, cognizance must be taken of the two geographical areas into which it is divided-The Great Basin region lying west of the Wasatch Mountains and north of the Pine Valley Mountains at the southern end of the State, and the Colorado River Drainage Basin including the eastern and extreme south. orn portions. The southern portion of this latter basin is commonly called Utah's Dixie and includes that section lying around St. George. It is here that most of the grapes are grown. 
The mean annual temperature of the Great Basin section is $49.3^{\circ}$; that of the sections most favorably situated for grape production $49.6^{\circ}$ to $52.2^{\circ}$. Winter temperatures of $10^{\circ}$ to $15^{\circ}$ below zero and summer temperatures of $95^{\circ}$ to $100^{\circ}$ are common.

In the St. George district the mean annual temperature is $58.9^{\circ}-4^{\circ}$ the 'owest and $116^{\circ}$ the highest temperatures recorded in thirty years. The sommon low winter temperatures from $15^{\circ}$ to $32^{\circ}$ occur through December and early January, and normally occur only during the early morning hours, the day temperatures nearly always registering $35^{\circ}$ or above.

The St. George district is not only warmer but also has a growing season three to four weeks longer than Bear River, Salt and Utah Lake Valleys of the Great Basin enjoy.

The rainfall of these valleys ranges from 14 to 19 inches, that of the St. George district is 8.3 inches, so that in each section irrigation is necessary to mature crops properly.

The above mentioned valleys range from eight to eighteen miles in width, their lengths from thirty to sixty miles and have their long axis in a north and south line. They are typical of the valleys lying within the Great Basin and like many of the others were once occupied by prehistoric Lake Bonneville. The benches left by this lake as it receded make up the most valuable fruit lands, the soils ranging through coarse and fine gravels, sands and loams and clay loams, with almost every type of subsoil.

The St. George district is made up of a low broken valley with irregular benches and bottom land. The soils are made up of decomposed granites, sandstones and basalt with some river silts-all more or less impregnated with gypsum and white alkali.

The Mormon pioneers of 1847 found clear streams issuing from the Wasatch Range and these they used to irrigate their crops. In time these streams have been made to irrigate practically all of the valleys lying immediately at the foot of this range, though the valleys to the westward have less water and a great proportion of their lands will probably never be irrigated.

Likewise the Mormon pioneers of 1862 found a few small streams and springs in Utah's Dixie and while these have been developed wonderfully there is still water enough for greater areas of land. Their chief source is the Rio Virgin River which sometimes carries half its weight of silt.

The pioneers of 1847 brought with them the seeds of fruits and vegetables and it is probable that grape seeds were among them. The first grapes brought into Utah's Dixie were from California and arrived some time before 1870. Here the industrious pioneers gave the grapes more atten. tion than they received in the north, probably because they thrived better and because the fruit and its products found ready sale in the northern settlements.

Since those early days the Utah grape market has been captured by the California grower, mainly because the local supply was inadequate and because the fruit was presented in a more attractive form and cheaper than it could be secured by wagon and rail from the distant Dixie settlements. California ships in, according to the most reliable estimates, about thirty carloads ( 900 crates to the car) of Vinifera grapes in four-basket twenty. pound crates. About twenty thousand eight-pound baskets of Concords are 
shipped in from the East, the local vineyards supplying our markets with about thirty-five thousand of the same sized baskets.

With the increase in acreage the problem of the Dixie grower has been to find a suitable market for his grapes. The district as a whole is seventy to eighty miles from the nearest railroad point and, with poor roads, the p'acing of grapes on the Salt Lake market in a condition to compete with the California grapes is almost beyond possibility. So that what little is marketed fresh is usually hauled to the pearby mining camps; the bulk of the crop being made into raisins.

\section{Statistics of Crop.}

The 1910 census gave a total of 204,445 vines in Utah and of these 124,827 were in the St. George district. At 700 vines per acre the total acreage at that time was 292 acres. The yield was given as $1,576,363$ pounds and of this 985,400 pounds were accredited to the St. George district. The average yield for the State was then 7.7 pounds; for the Great Basin section 7.3 pounds and for St. George district slightly under 8 pounds per vine. This census also shows that eight of the twenty-seren counties grew no grapes at all.

Since 1910 several large Concord vineyards have been planted so that the total area for the northern part is about 275 acres and for the St. George district about 185 acres all told. In the north about three-fourths of the acreage is Concord or other varieties of that type, the remainder Vinifera varieties mostly Muscat. In the St. George section probably nine-tenths of the grapes are Vinifera.

\section{Treatment of the Soil.}

Planting. Very often in the past the sites chosen for grapes have been on gravelly slopes, where proper care in preparing the soil and in planting were either difficult to give or were lacking. Partial or total failure came in many instances, thus discouraging the industry. The general practice in later years has been to plow the land deeply in the fall, thoroughly pulverize it in the spring and after marking the rows each way to plow the furrows with the slope of the land. From this point the practice differs, some men placing the stakes before planting the vines, others planting the vines, the usual care in heeling in and using the proper soil being exercised, then the soil is hilled around the plant and a small irrigating stream turned in at the head of the row and allowed to soak the soil about the newly set plants.

After the soil has dried sufficiently in the furrow, it is plowed in and the soil cultivated at intervals to conserve the moisture and to keep the weeds down. Where the stakes are not set before planting they are usually left until the second or third year.

Irrigation. The first year two to five irrigations are required-depending upon the season and locality. In all of the vineyards visited by the writer (most of those within the State), two irrigation furrows for each row are used. In the north on moderately open soils one or two irrigations will normally be sufficient to mature the crop and enable the vine to prepare for winter. However, some growers have found that more water applied will produce larger grapes, consequently a great yield. This is true of soils with a shallow surface soil and a loose gravelly subsoil. These grapes are not so 
sweet, well-flavored or firm or highly colored as those grown with less water. The amount of water applied will vary from two to six acre inches, depending upon the subsoil.

If one irrigation is given it is applied about two weeks before the fruit ripens. If the fall is a dry one, another irrigation is given after the leaves fall.

In the St. George district if clean culture is practised, three irrigations per year will be ample, unless extremely hot dry winds prevail for protracted periods, or the fall, winter and spring are unusually dry, in which event another irrigation will be necessary in February or March. These irrigations are applied at blooming time, one or two weeks before ripening and after the leaves fall.

Drainage. In most Utah sections, the vineyards are so located that artificial drainage is not necessary. In one section, however, it has been found that on deep, sandy soil where grapes have grown for five or six years, that their roots have gone down over eight feet. Under these conditions it can be seen that ordinary drainage measures would not save a vineyard, unless the drains were placed very deep.

Fertilization. No fixed or universal system of manuring has been adopted, though many receive barnyard manure at irregular intervals. This is true in parts of the St. George district, especially where light sandy soils are found. Here it has been found, especially on Thompson Seedless, that by leaving two or more canes the vines can be manured heavily and large quantities of grapes will be produced without an excessive wood growth.

Alfalfa, crimson clover, sweet clover and rarely hairy vetches are the green manures used.

\section{Treatment of the Vine.}

The Concord is the variety mostly grown in the north, while small areas are devoted to the Black Pearl, Sweetwater, the various Muscats, Thompson Seedless, Flame Tokay, Black Cornichon, Malaga and Feher Szagos about in the order named.

In a few instances the vines have been propagated by cuttings. Most of them, however, have been imported.

Pruning. Throughout the State most of the pruning is done in the spring, the amount depending upon the grower and to some extent on the variety. The largest growers in the north prune their Concords to fifteen or twenty spurs of three buds each. Other growers advocate the leaving of more wood and where the soil is rich it unquestionably gives greater yields with but slight difference in the size of the berry.

About half of the vines in the north are trained on trellises, the rest to a low stump form barely a foot above the soil.

In the St. George district, practicalıy all of the vines are trained to the stump form, the crown being one and a half to three and a half feet from the surface. Here spurs of two or three buds are left and as many as the vigor of the vine will justify.

In a co-operative pruning experiment at St. George, the writer increased the yield of Thompson Seedless grapes from 12 to 24,27 , and 29 pounds per vine by leaving two, four and six canes of 10 buds each on the vines in addition to the spurs that would normally be left. 
In the same experiment, summer pruning was found to reduce the crop, the earlier prunings reducing it more than the latter ones. In that section this practice is followed to some extent to enable late cultivations to be given without tearing the vines.

Diseases. The only serious diseases we have are Black Knot and Powdery Mildew or Oidium. The first of course is not as yet controlled other than by removing affected vines, the latter by the usual applications of sulphur, during the summer.

Frost. In the northern section, Vinifera grapes are frozen down about every third or fourth winter unless they are given special protection. Occasionally early fall frosts catch part, rarely all, of the crop.

Winter killing by frost sometimes occurs in "Dixie" on the low, damp soils where especial care is not taken to ripen the wood. Rarely the early fall frosts injure the crop, especially of the late varieties like the Emperor.

Pests. Phylloxera as yet has not been reported from any section. The grape moth is present in some parts of the St. George district, otherwise the only serious pest is the grape leaf hopper Typhlocyba comes (Say) var. Coloradensis, mainly. Considerable loss has occurred from its presence in the various cycles. They are readily controlled by spraying with nicotine sulphate solution ("Black Leaf 40 ") strength 1-1200, just before the oldest nymphs of the first brood moult for the last time. At the Southern Utah Experiment Farm it cost $\$ 5.59$ per acre in 1911 and $\$ 2.47$ per acre in 1912 to apply this spray.

\section{Treatment of the Crop.}

In the largest Concord vineyard in the State, the grapes are picked directly into eight-pound baskets, which are properly filled and faced at the packing house. This about represents the common practice. The four-basket twenty-pound crate is almost universally used for the Vinifera grapes. These are usually packed with selected fruit and either sold on the local market or to peddlers.

In the St. George district most of the grapes are made into raisins and are marketed in that form, otherwise the four-basket crate is much used in disposing of the fresh fruit.

The manufacture of grape juice is yet in its infancy, only one or two firms attempting it. These are producing an article equal in every way to the best standard juices.

The large Concord grape crops bring ten cents to twenty-eight cents per basket, the Vinifera grapes four to eight cents per pound. In Dixie the price is one to three cents per pound.

Reviewing briefly the condition of the grape industry in Utah, we may say that it is far from being in a position to supply the present demand for fresh grapes, not mentioning the creation or a greater demand, or the stimulation of the manufacture of grape juice, for the State's trade of something over 18,000 gallons.

With her ideal sunshine, soil and water, Utah should not only be doing these things, but will be in the near future, because it will be found profitable. 


\title{
GRAPE GROWING IN IMPERIAL VALLEY.
}

\author{
BY WALTER E. PACKARD,
}

El Centro, California. Read by Mr. F. T. Swett.

The extreme climatic conditions in Imperial Valley constitute a natural resource which makes possible the development of a practical monopoly in the production of certain specialties. The early springs, high summer temperatures, low humidity and abundant sunshine favor the planting of eariy fruits and vegetables, out-of-season crops and special crops, such as dates, which are especially adapted to the particular conditions of this section. Early table grapes hold an important place in this list of favored crops. From the beginning of the settlement of the valley much attention has been given to the table grape industry, which promises unusually profitable returns.

The first commercial planting was made in 1904 by Mr. W. S. Corwin. The vineyard, which ultimately consisted of fifty-five acres, included twenty different varieties of grapes common in California. The vineyard plantings rapidly increased until the total area in vines in 1910 approximated 1000 acres. Since that time the acreage has not increased materially, as the number of new plantings has been about offset by the acreage pulled out. In 1914 one hundred and fifty-two cars of grapes were shipped out of the valley.

It seems strange, at first thought, that the plantings should decrease at all in a section so generally favorable to the industry. A broad statement, often made, that these vineyards which have been dug up did not pay, is partially true but very misleading. Several contributing factors to the failure of the vineyards to yield a profit should be named as the primary causes of their abandonment. The vineyards under good management and favorable conditions have proved to be very profitabie, perinaps more proitable than any other industry estaplished in the region up to the present time.

A vineyard to be a success in Imperial Valley should be planted on sandy or sandy loam soil free from alkali. Choice of unsuitable soil in the early planted vineyards has been the main obstacle to the develcpment of a profitable enterprise in certain cases. There are several types of soil in this section, some being well adapted to the production of fruits and vegetables and others only suited to the production of field crops. Grape vines growing on clay or clay loam soils produce an abundant vegetative growth, a growth which is really remarkable as compared to the growth of vines in otiner parts of the State. A one-year-old cane will often be as large as a twoyear growth in other sections. This vigorous vegetative growth is quite naturally accompanied by a dense mass of green leaves, much darker in color than those found on sandy soil with the same variety. The grapes are usually a darker green also, and often lack the attractive amber color desired in white table grapes. The setting of first crop is comparatively small, although the second and third crops are often quite large. Three and four crop settings are quite common with most varieties tried. The grapes on these large vines are usually later than on the vines grown c n 
sandy soil and the proportion of "water berries" is larger. On sandy or sandy loam soils the vines are comparatively small, the leaves light green and not dense, the grapes are early and of good quality and the yield of first crop, although not large, is satisfactory. These facts are quite evident to any one comparing the appearance of fruit and vines on different soil types, either on the same or on different ranches.

Many of the early vineyards were planted on the harder types of soil, with consequent poor results, which discouraged many of the growers, some of whom came to the erroneous conclusion that Imperial Valley was not adapted to the production of a good quality of early table grapes. It can be quite definitely said, therefore, that the best profits can be made when grapes are planted on sandy or sandy loam soils.

The production of "water berries," which has been a decidedly important factor in the failure of some vineyards to produce a satisfactory profit, is closely associated with the soil type, as already suggested. In some cases fully fifty per cent of the grapes had to be discarded on account of these poor berries. The "water berry" can be described as a soft b'uish berry occurring in whole bunches or as individual berries in a bunch. They are semi-transparent and have very poor shipping and keeping qualities. The following observations have been made in connection with this undesirable condition. Water berries are found more abundant on young than on old vines. They are much more common on vines growing in hard or medium hard soils than on a sandy type. They are usually found on soils too dry for successful vine growth. Too much water does not seem to produce this condition unless it is applied just before or during the sugaring period on vines which have previously been too dry.

Alkali is of course injurious and has done some damage in some of the valley plantings, although as a general rule the vineyards have been planted on soils comparatively free from injurious salts. Common salt or sodium chloride is the common so-called alkali in this section. The salts have usually only caused damage in small patches in the vineyards, and often have done no damage until the vines are three or four years old, when the roots have penetrated to some sub-stratum containing more alkali than the overlying soils. This spotted condition is characteristic of the occurrence of alkali here as in other parts of the State. Continuous irrigation through furrows has caused a concentration of alkali in the row which has frequently killed old vines. On this account it is quite a general practice to flood the vineyards during the winter, after pruning, in order to distribute these salts.

In a section where the average rainfall for the year totals less than three inches, irrigation is, of course, a very important operation. Overirrigation is seldom practiced in the vineyards of this section, although on the very sandy types too much water has been applied to the detriment of the vineyard. On the other hand too little irrigation is not infrequent. Cases have been noted where water has not penetrated more than eighteen inches to two feet, with the natural result that the roots were all near the surface and affected by the least drought. Hundreds of dollars have been spent in treating for disease vines which needed nothing but a thorough irrigation. Every irrigator should know how far the water penetrates in his soil type and should irrigate in such a way that a fairly constant supply of moisture will be maintained, through the growing season. The method or time of 
irrigation apparently makes little difference in either yield or quality, provided plenty of water is added to keep up a good growth. Some practice and advocate winter irrigation, with no spring or summer irrigation until the grapes have been harvested. Others advocate the app ication of water at more or less frequent intervals during the spring and early summer. Both methods, with others half-way between, have given good results.

Pruning undoubtedly has an important bearing upon the results secured in the vineyards. Pruning methods for this section must be studied before the best work can be done. The tendency of the vines to make a very rapid vegetative growth at once suggests longer pruning, leaving three buds instead of two, or leaving more canes. This applies particularly to the early Persian varieties, which make a very large growth but so far have produced a very poor yield. This can be overdone, however, as clearly evidenced in one instance where twelve to fifteen canes were left, with the hope of securing a larger yield. The total yield was larger than at any previous time but the quality was poor. Where before a large part of the crop had been sold as fancy grapes, the percentage of good bunches was very small, and the profits less. Some of the varieties which are normally pruned short, will probably be improved by long pruning and trellising. This is being tried with all of the Persians and some other vigorous varieties.

The practice of shipping grapes which are too green has been practically stopped in Imperial Valley, on account of the poor results secured from these green shipments and on account of the campaign of education along this line. Some still tend to pick before the sugar content is as high as desired, but the practice is diminishing.

The question of varieties is a live issue among the vineyardists. As previously stated, the first vineyard planted contained twenty varieties of grapes. Some of these proved to be quite well adapted to conditions, while others proved to be quite inferior. Needless to say the mixture of twenty varieties in one small vineyard was not profitable and as a result the whole patch was dug up in 1913. Alkali patches in this vineyard formed a really important contributing cause for the digging up of the vineyard however.

Malaga grapes form a large part of the grape acreage in the valley, and are well adapted to the conditions. The earlier ripening grapes, however, are the varieties which are receiving the greatest attention at the present time, and very few Malagas are now being planted. The Thompson Seedless is, perhaps, the favorite grape at present, as it bears well, ripens early and is easily packed. Persian No. 23 and Persian No. 21 are very promising grapes but so far have not borne well. Long pruning may remedy this unfavorable feature, in fact, if the blossoms on the vines at present are any criterion the yield will be very satisfactory on the vines which were pruned long. Persian No. 23 is slightly earlier than No. 21. Both varieties are large white grapes. The bunches are large and loose and the grape is a good shipper. The Khalili is the earliest grape grown in this section. It ripens in the latter part of May and may prove to be a very desirable variety for this section. The grapes are slightly larger than the Thompson Seedless, are almost seedless and are fair shippers.

Many of the colored varieties do not succeed. In most cases they do not color well. The Flame Tokay, for example, is shipped as White Tokay. The first crop of Emperors is very light, although the second and third crops 
are quite well colored. For a late grape, this is quite a satisfactory variety. Of other varieties of promise the Almeria, Chavushi, Paykani Razui and Rish Baba, may be mentioned.

The yield of grapes in this section has been rather light, but the prices have been very good indeed. The present interest in early table grapes seems to indicate that the acreage will increase rather rapidly in the next few years. The experience of the pioneers forms a solid basis for a healthy development of this industry, which will form one of the most profitable enterprises in the valley.

Mr. Vance: I wrote to a number of men in the different States in order to get expressions in relation to the growing of grapes all over this broad land. It is certainly wonderful for men to try to grow grapes in such a terrible region as I was told the Imperial Valley is while down in San Diego. It shows the persistence of man.

President Alwood: I want to ask Professor Flossfeder about his statement regarding the increase of sugar in certain varieties when grafted on different stocks. Did not you say that the increase in sugar was 25 per cent or 30 per cent when grafted on different stocks?

Prof. Flossfeder: Yes, sir. Of course these experiments must be run for at least ten years and then we can say for certain that such is the case.

Prof. Hussman: You will find data in this connection in Bulletin No. 209 of the United States Department of Agriculture, which is in press now.

Mr. Frank Henry, private farm adviser for the San Joaquin Valley, in speaking of conditions in the Imperial Valley, said that in some cases too great an amount of water is used, and sometimes insufficient water is used. In the San Joaquin Valley, too much water is the cause of failure. Water properly applied at the right season is very essential, but when improperly used, the crop is lessened. The people in the San Joaquin Valley should be educated as to the proper time to use water. In the lower end of the valley, the vineyards being near the river, the conditions are good, but back from the river the conditions are bad through a wrong system of irrigation.

Prosident Alwood: It certainly appears to a person not familiar with California conditions that you have many problems. 


\title{
GRAPE ANTHRACNOSE IN AMERICA.
}

\author{
By C. L. SHEAR, \\ Pathologist, United States Department of Agriculture, \\ Washington, D. C.
}

Grape anthracnose is a fungous disease caused by Sphaceloma ampelinum De Bary.1 It is called "Charbon" by the French, and "Schwarzer Brenner" by the Germans. The name anthracnose was first applied to it by Fabre and Dunal2 in 1853.

This disease was first reported with certainty in this country, so far as known to the writer, by Professor Burrills of Illinois. He says he found it in Central Illinois in 1881 and had also seen it in Indiana, Michigan and Ohio. The native home of the fungus is apparently in Europe. It was probably introduced into this country some time before this. As it is such a conspicuous and destructive disease it does not seem that it could have escaped observation long if it had been present in our commercial vineyards. It was first accurately described in Europe by Fintelmann 4 in 1839 and Viala5 says specimens are preserved in the herbarium of Dunal at Montpellier collected in October, 1839. It is quite probable, however, that earlier European descriptions of grape diseases than those mentioned above refer to this. H. Marès, according to Viala, cites a passage in Theophrastus which he believes refers to this disease and L. Portes, according to the same author, cites a passage in Pliny's Natural History, Books XVII and XVIII, which agrees with the appearance of this disease. According to certain French traditions reported by Prillieux 6 the disease was prevalent in certain parts of France before the French Revolution and before any American vines had been introduced into that country. All the evidence thus far discovered, therefore, seems to indicate that the disease is native in Europe and has probably been introduced into America. It has never been found, so far as the writer knows, on the wild grape vines in this country. It, however, attacks American varieties derived from our native species.

Meyen, 7 1841, also described the disease but did not determiue the organism causing it. In 1873 De Bary ${ }^{1}$ investigated the disease, determined and named the fungus producing it, and gave an accurate description of the organism.

The effects of the disease are so characteristic and noticeable that when once seen it is easily recognized. The fungus attacks practically all of the green parts of the grape. It is first noticed on the young leaves and shoots. In the case of vinifera varieties the leaves are seriously affected, becoming

1De Bary, A. Annalen der Oenologie 4.165.2 1873.

2Fabre, Esprit. Observations sur les Maladies regnantes de la Vigne, mises au jour par Felix Dunal, Montpellier $4^{\circ}, 48$ pp. 6 tab. 1853.

3Burrill, T. J. Grape Rots. Proc. 20th Session Amer. Pomol. Soc. 1885:

48. 1886.

4 Fintelmann, G. A. Allegemeine Gartenzeitung, 7:273-276. 1839.

5 Viala, P. Les Maladies de la Vigne. Ed. 3, 206. 1893.

6 Prillieux, E. E. L'Anthracnose de la Vigne observée dans le centre de la France. Bull. Soc. Bot.-France, 26:187, 1879.

7Meyen, F. J. F. Pflanzenpathologie, Berlin. 1841.

IDe bary, A. Loc. cit. 
distorted, curled and spotted, with small, dead areas which soon drop out, leaving irregular holes, as shown in Figs. 1 and 2. On the shoots small, dark spots at first appear which enlarge rather rapidly, causing sunken cankers with a more or less reddened margin (see Fig. 2). As the fungus develops and produces its spores on the surface of the cankers the sunken portion becomes ashy gray in color. Under favorable weather conditions the cankers multiply rapidly, and finally destroy the whole shoot. In case of American varieties the young foliage is not so seriously affected and the disease is restricted almost entirely to the under side of the ribs of the leaf. The fungus also attacks the berries during all stages of their development. The most striking and characteristic appearance of the fungus occurs in the lesions produced upon the berries, especially the varieties having light colored fruit. A light brown spot first appears; this increases in diameter and soon becomes surrounded by a bright red zone, while the central portion of the spot becomes ashy gray as the spores of the fungus are developed. These bright colored spots on the fruit have given rise to the common name, "bird's eye" rot, in some sections, owing to their fancied resemblance to the eye of a bird. Fruit affected by this fungus soon dries up and is worthless.

Three kinds of anthracnose of the vine have been described by French writers, Anthracnose maculée, spotted anthracnose; Anthracnose ponctuée, punctate anthracnose, and Anthracnose déformante, causing malformed leaves and shoots. The spotted anthracnose is the only form known to be caused by Sphaceloma. The punctate anthracnose has recently been investigated by Schellenberg 8 who states that he produced the characteristic effects of the disease by inoculation with Valsa Vitis (Schw.). The cause of Anthracnose déformante is unknown.

The spotted or true anthracnose is widely distributed in America east of the Rocky Mountains but seems to be rather erratic in its appearance and behavior. A serious outbreak will occasionally occur in a certain locality or in a certain vineyard and become very destructive for a few years and then apparently disappear more or less completely for a period. Its development and spread apparently depend upon particularly favorable combinations of weather conditions. Hot, wet weather during the early part of the season seems to be most favorable for it. Several very serious outbreaks have occured the present season in Southern Texas upon vinifera grapes and also on varieties derived from Vitis borquiniana, such as Black Spanish (Lenoir). The accompanying reproduction of photographs shows the effect of this disease on leaves and shoots of vinifera grapes (Tokay) from Texas. As this is in a semi-arid region little trouble from this disease would ordinarily be anticipated, but the past season has been unusually wet and this is probably the primary factor in accounting for the unusual development of this disease in that region. While some of the vinifera varieties very widely grown in California are subject to this disease in humid regions no cases have yet been reported so far as we know from the irrigated regions of California.

Certain American varieties appear to be generally more susceptible than others. Champion, Diogenes, Moore's Diamond, Missouri Riesling, Norton, Salem, and Vergennes, are particularly liable to attacks of this disease, while the Concord is rarely affected by it. Of the vinifera grapes, Thompson's

8 Schellenberg, H. C. Uber die Schädigung der Weinrebe durch Valsa Vitis (Schw.) Fckl. Ber. d. Deutsch. Bot. Gesellsch. 30.586:593. 1912. 


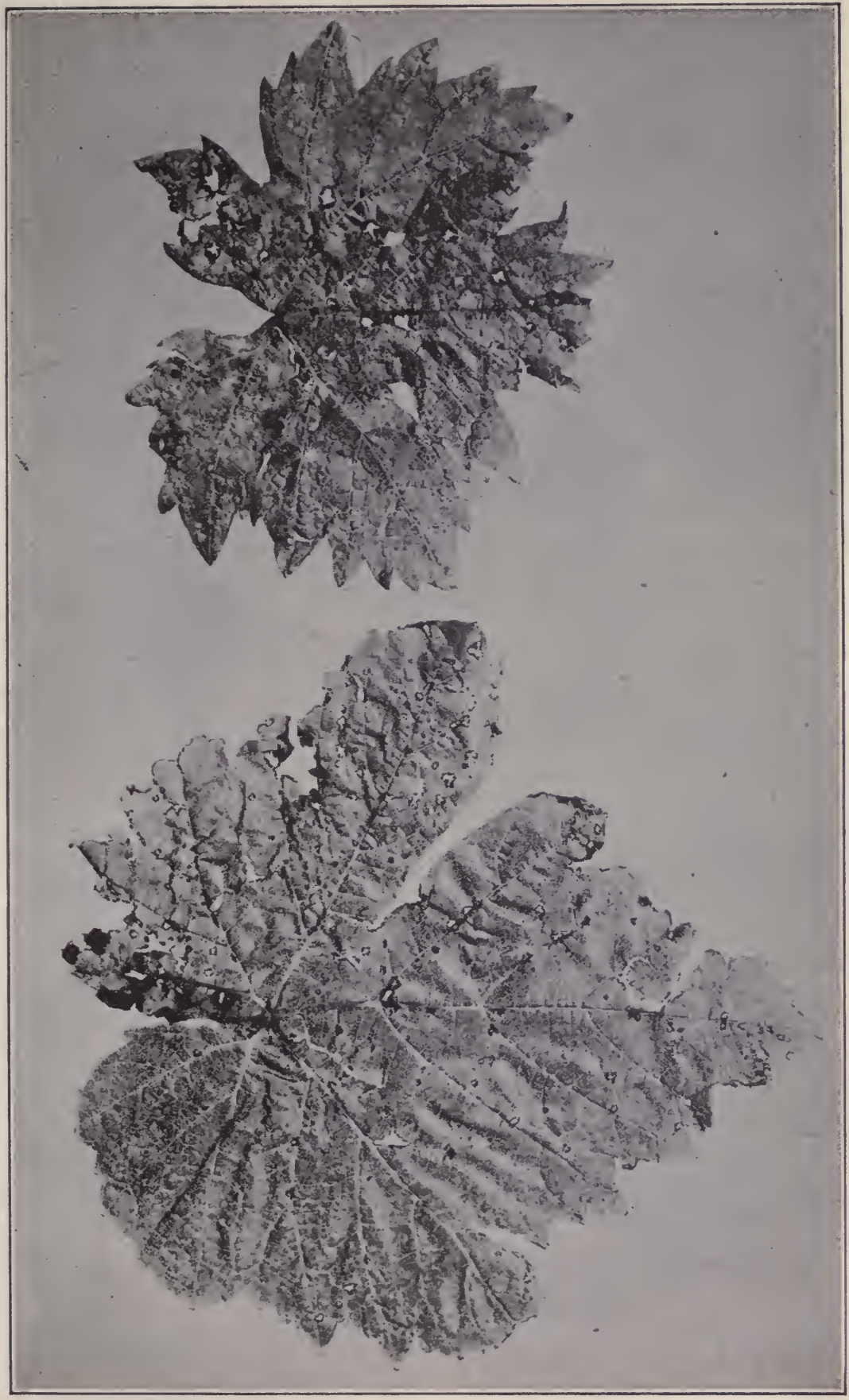

Figs. 1 and 2.

Fig. 1. Flame Tokay grapes from Texas, showing injury caused by Anthracnose fungus, Sphaceloma Ampelinum. 


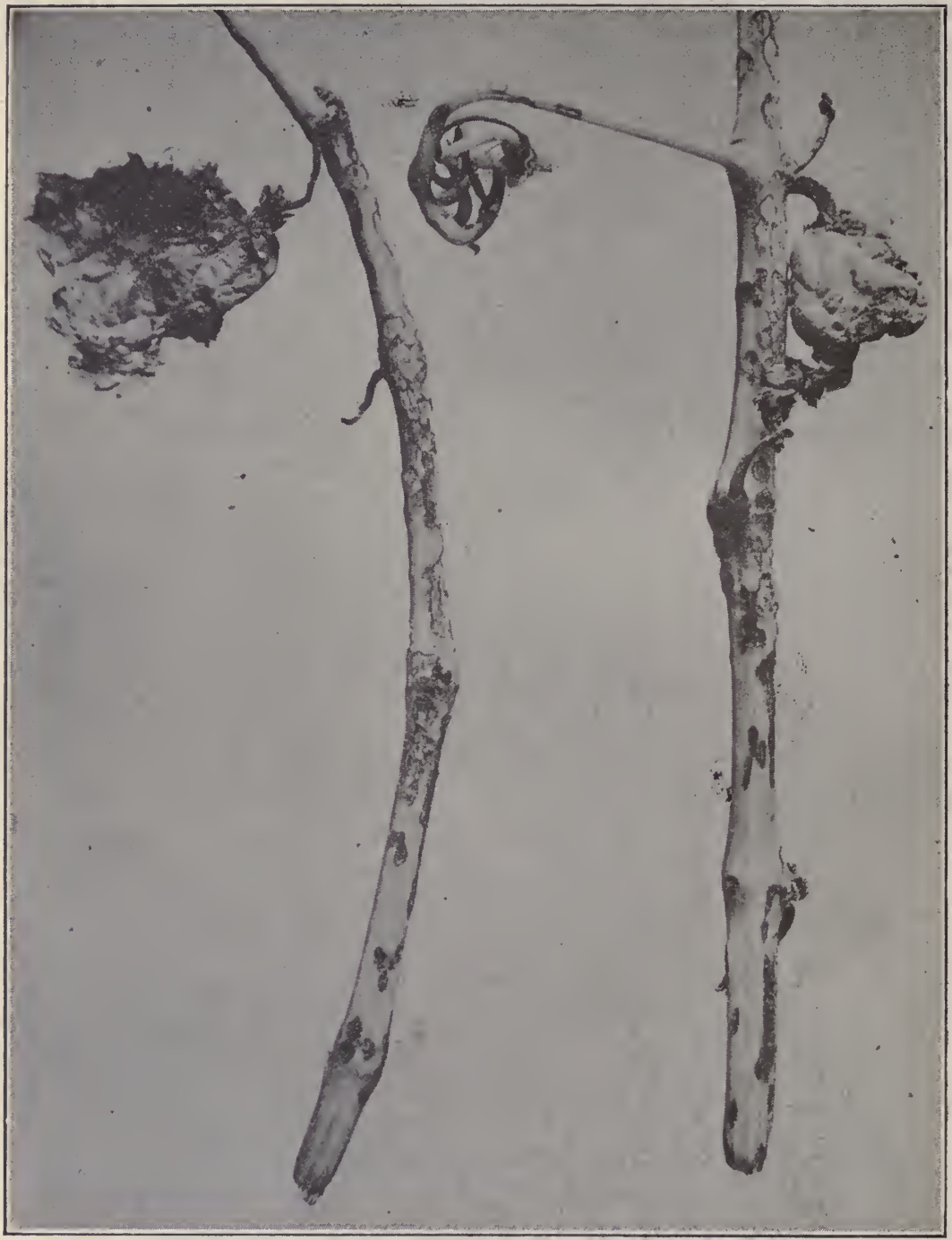

Fig. 2. Shoots, leaves and tendrils of Tokay grape from Texas, showing injury caused by Sphaceloma Ampelinum. 
Seedless, Malaga, Tokay and Black Hamburg are the most seriously injured in Texas. Vialas gives a list of susceptible and resistant varieties of European grapes.

The fungus Sphaceloma ampelinum De Bary has been renamed and described by other mycologists and pathologists and transferred at different times to different genera. One of the latest researches on the morphology and biology of the fungus is that of Viala and Pacottet. 9 These authors have decided as the result of their investigations that the fungus is an Ascomycete and have established for it a new genus, Manginia. They describe several different spore forms which they obtained in cultures. These include what they call a yeast form which produced asci and ascospores. They also describe various forms of resting spores and cysts; also a spermogonial form; and a macroconidial form arising from sclerotia but no perithecia were produced. These results have not yet been verified by other investigators. This would seem desirable, however, in view of the remarkable diversity of the various spore forms described and the present lack of knowledge of any organism having a similar variety of metagenetic stages or spore forms. The writer has grown Sphaceloma in pure culture on agar at various times for long periods but has not yet observed any of the various spore forms described except the ordinary microconidia and bodies resembling clamydospores, or resting spores of various shapes and sizes. This however, is not offered as evidence that other forms do not occur under other conditions or on other media.

Assuming the accuracy of their work the need of a new generic name for the organism is still not clear to us.

It is interesting in this connection to note the recent report by Burkholder 10 of the discovery of the ascogenous form of the anthracnose of raspberries and blackberries. This has been shown to be a Discomycete closely related to Plectodiscella piri Woronichin.11 A very close resemblance in pure cultures between the anthracnose fungus of the grape and that of the Rubus species has attracted our attention and suggested the possibility of a close relationship, if not identity of the organisms. Cross inoculation experiments have been planned by the writer to determine whether these organisms will pass from one host to another. The appearance and morphological characters of the two organisms in culture are so similar that it is difficult to separate them in this condition. There is also considerable similarity between the cankers produced on the different hosts. No fructifications of an ascomycetous fungus resembling the Plectodiscella on raspberry has yet been discovered on grape vines affected with anthracnose. If the anthracnose of grape and of Rubus species should prove to be the same it would have an important bearing upon studies of the distribution and control of the disease. The raspberry and blackberry anthracnose appears much more common than that of the grape.

5 Viala, P. Loc. cit. p. 216.

9Viala, P. and Pacottet, P. Culture et developpement de l'Anthracnose. Revue de Viticulture 22:117 and 145. 1904.

Viala, P. and Pacottet, P. Nouvelle Recherches sur l'Anthracnose. Revue de Viticulture, 24:1905; 25:1906.

10 Burkholder, W. H. The perfect stage of the fungus of raspberry anthracnose. Abst. Phytopathology 4:407. 1914.

11 Woronichin, N. N. Myc. Centbl. 4:225-233. 1914. 


\section{Methods of Control.}

Spraying with ordinary fungicides during the growing season only does not prove effective in preventing the disease. The treatment of dormant plants with a mixture of iron sulphate and sulphuric acid has been successfully applied in Europe. This, however, is a very unpleasant mixture to prepare and use on account of the corrosive action of sulphuric acid. As a result of experiments conducted by Dr. Hawkins12 under our direction in

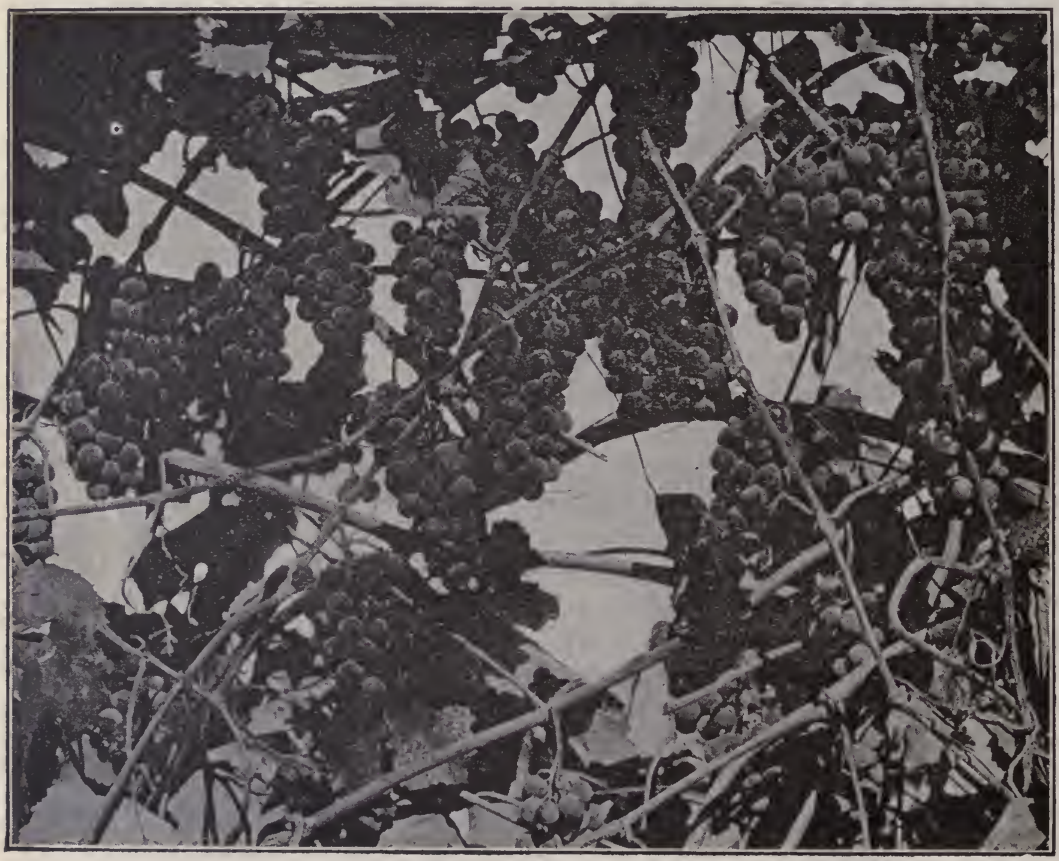

Fig. 3. Treated vine.

Michigan on Champion grape vines, very seriously affected with anthracnose, it was found that a treatment less troublesome to apply than the sulphuric acid mixture was entirely successful. In connection with any treatment by spraying it is of course necessary to eradicate and destroy as much of the disease as possible. All the diseased wood should be pruned out and burned; then spray the dormant vines thoroughly with concentrated lime-sulphur solution, 1 to 9 , after which thorough treatment with four or five applications of 4-3-50 Bordeaux mixture has been found to reduce the injury from this disease to the minimum. Figure 3 shows treated and figure 4 untreated vines. The first spraying with Bordeaux mixture should be done when the

12Hawkins, L. A. Experiments in the Control of Grape Anthracnose. Circ. 105, Bureau of Plant Industry. Feb., 1913, pp. 1-8. 
shoots are from 8 to 10 inches long; the second, just before the flower buds open; the third immediately after the blossoms fall; the fourth ten days to two weeks after the third. The addition of two pounds of resin fish-oil soap to fifty gallons of the spray mixture in the last two applications is desirable in order to increase the adhesiveness of the fungicide.

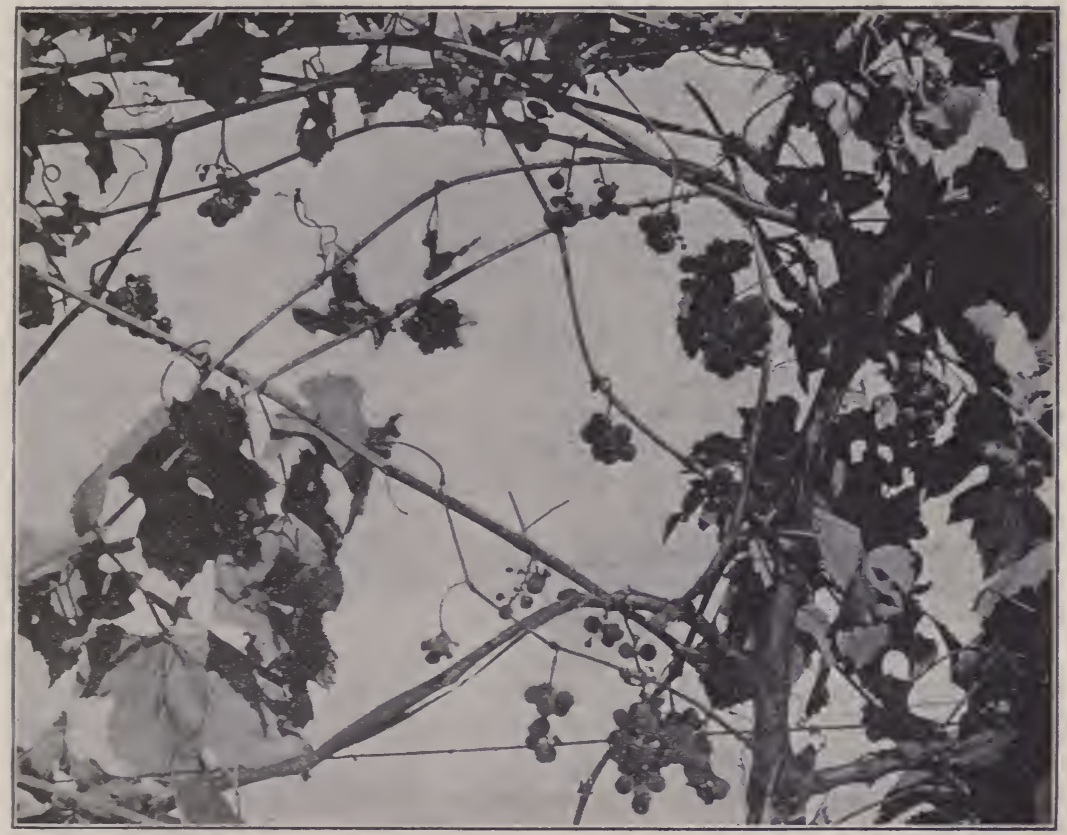

Fig. 4. Untreated vine.

\section{POWDERY MILDEW OF GRAPES AND ITS CONTROL IN THE UNITED STATES.}

By Prof. DONALD REDDICK, Cornell Univ., Ithaca, N. Y. and F. E. GLADWIN, Fredonia, N. Y.

Abstract read by Prof. Frederic T. Bioletti.

By far the largest continuous area of land given to the culture of grapes in Eastern United States is that lying in a narrow belt along the southern shore of Lake Erie. This belt is often referred to by residents of New York and others as the Chautauqua grape belt, owing to the fact that some 30,000 acres of a possible 50,000 are located in Chautauqua County, New York. The records and observations that follow have been made at a vineyard laboratory located near Fredonia, New York. They cover a period of five years and have been made possible in part by a special legislative commission to 
the New York Agricultural Experiment Station to investigate the cause of the decline in the grape industry in Chautauqua County.

The geology, physical geography and meteorology of the "grape belt" are presented by Tarr, 1 and it is easy to see from his account why it is that this "belt" is so admirably adapted to grape culture. While the meteorological conditions can be described, it is really necessary to undertake infection work under vineyard conditions to fully appreciate the dryness of the atmosphere and the fact that there is a constant air current in one direction or another. One of the writers (R.) has expressed the opinion2 that the two most destructive fungous diseases of the grape, downy mildew and black rot, are held in check by an unusual combination of meteorological conditions. At any rate it is a remarkable circumstance that neither of these diseases has ever seriously menaced the Chautauqua belt, although both have occurred in certain vineyards to a certain extent. It is noticeable that the vineyards in which black rot has occurred are in small depressed areas having poor air drainage, or in vineyards far up or over the ridge, left by the sudden lowering of the lake level during glacial recession, and that downy mildew does occur generally, although as a rule to a limited extent, on such susceptible varieties as Delaware and certain of the Rogers Hybrids, notably Agawam and Lindley. This freedom from disease may be attributed in part to the resistance of the variety Concord which comprises perhaps 99 per cent of the total acreage, but varietal resistance can be only a partial explanation for, in other sections of the State, this variety may suffer severely although never so severely as the varieties just mentioned.

So far as these diseases are concerned, therefore, there is no object in applying a fungicide to the vineyards. At a conservative estimate not one-tenth of the vineyardists in the Chautauqua belt own a spraying outfit of any description, and scarcely half of those could be operated if there were a desire to do so. The grape root-worm (Fidia viticida) exists throughout the belt and the sprayers in use are employed in fighting this insect. The time for effective application against this pest is near the first of July. If two applications of poison are made the second treatment is rarely applied later than July 15 th.

\section{The Mildew.}

In the French vineyards, as is well known, the powdery mildew, caused by Uncinula necator, is likely to be very serious at blossoming time. In the Chautauqua belt, on the other hand, mildew rarely appears before the middle or end of July, and sometimes even a trace of it can not be found before mid-August.

It is at about this time of year that heavy dew forms at night. Whether the occurrence of dew has anything to do with the appearance of mildew is not known. The method of hibernation of the fungus is not definitely known although it is assumed to be by means of ascospores in perithecia. The conditions for infection by ascospores and conidia have not been de-

1 Tarr, R. S. Geological history of the Chautauqua grape belt. Cornell Univ. Agr. Exp. Sta. Bul. 109:121.

2 Reddick, Donald. The black rot disease of grapes. Cornell Univ. Agr. Exp. Sta. Bul. $293: 342-345$. 
termined by the writers nor apparently by anyone else. It is not even known how long a time is required for conidia to germinate under field conditions, nor what degree of moisture is most favorable for their germination. The mildews are sometimes regarded as dry weather diseases, although the experience of Blodgett3 in hop yards seems definitely to correlate infection of the hop mildew fungus with periods of rainfall. Admittedly there are here some interesting points in the life-cycle of the Uncinula which need investigation. The first spots of mildew appear promiscuously on the green parts. Secondary infections occur in rapid succession and in a surprisingly short time leaves can be found that are entirely overrun with the fungus. Berries here and there begin to show the dwarfing effect of mildew. But the point where the fungus seems to spread most rapidly is on the peduncles and pedicles. By harvest time, in early October, the peduncles are dwarfed and withered, the berries of some of the clusters frequently have a grayish, powdery appearance and the foliage may appear almost white from the abundance of conidia. By this time perithecia are exceedingly abundant on the peduncles and on the older spots on the leaves.

A canvas of fifty men, average or better than average vineyardists, made in 1914 elicted the fact that mildew is not regarded by growers as of any particular consequence, and that in their opinion the amount of damage is negligible or very slight. Unfortunately the grower rarely if ever sees his baskets of fruit after they have been subjected to shipment and carting. In all probability he would disclaim his package and charge fraud if he were to see his fruil as it is offered for sale two weeks later by the retail grocer. In cases of severe infestation the peduncles are commonly withered and black and as high as 50 per cent of the berries may have shelled. The percentage of shelling from healthy clusters treated similarly is relatively small.

So far as basket grapes are concerned, therefore, the mildew disease does not appeal to the average grower as a disease worth fighting. The springing up of unfermented grape juice and grape product factories, however, lately has brought a stimulus for the production of a better quality of fruit. This stimulus is largely from the very high standard of quality demanded by some of the largest consumers.

\section{Control.}

Since the margin of profit on grapes is not very great, all of the above factors enter into consideration in planning a system of mildew control that will be accepted and put into practice by grape growers. That the mildew is relatively easy to control is attested by the fact that the disease is usually dismissed by compilers of information with the statement that treatments for black rot and downy mildew will serve to hold this disease in check. That the disease commonly is not controlled is attested by the conditions in the largest grape section east of the Rocky Mountains as presented above and by the examination of a few packages of Concord grapes on any of the large markets.

3 Blodgett, F. M. Further studies on the spread and control of hop mildew. New York (Geneva) Agr. Exp. Sta. Bul. 395.41-43. 


\section{Spraying.}

Since the Chautauqua grower can use a spray with profit in fighting the root-worm, some of the first efforts in mildew control were to combine a fungicide with the poison. Bordeaux mixture has been used commonly where any spraying has been done and, in fact, some of the men who use the mixture believe that it is a part of the insect poison. The amount of mildew in Bordeaux-sprayed vineyards is considerably reduced even though the applications are made a month or more before the first appearance of the disease. Extensive spraying experiments were performed, the entomological features of which have been published in detail by Hartzell.4 As a general summary of those experiments it may be said that the degree of mildew control obtained by making applications at the time when the Fidia beetles could be killed barely warranted the use of a fungicide. Bordeaux mixture gave best results where the foliage was sparse and where it was possible to cover the clusters thoroughly. In cases where the foliage was very dense any of the sulphur sprays proved superior. The mildew fungus did not grow where there was a film of Bordeaux mixture but if a leaf received a coarse sprinkling of the mixture the fungus grew between the individual spots. With any of the su'phur sprays the leaves remained entirely free from the fungus until all the sulphur had been washed away.

In one of the experiments, which was followed up a second year by the owner of the vineyard, it developed that the sulphur sprays positively injured the set of fruit for the next year; in one instance the crop was reduced onethird on that account. Hartzell4 states that a lime-sulphur spray cannot be used on grapes. He also finds that Bordeaux mixture interferes with effective spraying for the root-worm when molasses is used with the poison. It appeared, therefore, that if mildew was to be controlled at all, the applications should be specifically for that trouble and at the most opportune times and in view of the general apathy of growers with respect to mildew, it seemed that if any treatment were made at all it must be one quickly, easily and cheaply applied.

\section{Dusting.}

Even before the trouble with sulphur sprays and with Bordeaux had developed, some preliminary experiments were performed (in 1909) by Dr. F. M. Blodgett, with sulphur dusted over the vines with a French "puffer". These experiments were continued in a desultory manner by the writers but some work has been done every year since 1909. Dusting sulphur over the vines late in the season proved effective in controlling the disease. Even when the fungus was well established it could be killed by the use of sulphur, although more satisfactory results were secured if an application was made at the time when the first traces of the disease were evident, and was folfowed by another application in the course of two weeks or more, depending on meteorologic conditions.

4 Hartzell, F. Z. A preliminary report on grape insects. New York, (Geneva) Agr. Exp. Sta. Bul. 331:579-581. 


\section{Dusting and Spraying Experiments in 1911.}

In 1911 the writers began a series of experiments with sulphur as a possible control for powdery mildew. Bordeaux, while very effective in holding the disease in check in its early period (August 1st), does not protect late unless other applications are made. Late applications are undesirable, as they stain the fruit, if the rainfall is deficient, and thus render it open to the suspicion of the consumer. In certain seasons one application of Bordeaux has so persisted that the pedicels and peduncles have been practically free from mildew at harvest time. It was for the purpose of controlling the disease during the ripening period, and up to the harvest without the staining attendant upon late applications of Bordeaux, that the tests were carried out.

A vineyard consisting of Concord, Worden and Lindley was selected for the early tests. The presence of Lindley in considerable numbers made this vineyard particularly desirable, as this variety is very subject to powdery mildew. The fifteen rows of vines included in the experiment were all sprayed in the dormant state on April 27, 1911, with commercial limesulphur solution at the dilution of 1 part of solution to 11 parts of water. Rows 1, 4, 8, 10 and 11 were sprayed July 1st, July 21st and July 31st with Atomic sulphur5 2 pounds and arsenate of lead 2 pounds to 50 gallons of water. Rows 2, 5, 9 and 14 were dusted with flowers of sulphur with a knapsack duster on July 14 th and 31st. Row 13 was given one application of Atomic sulphur and arsenate of lead July 21st. Rows 3, 6, 7, 12 and 15 were left as controls. The dust applications were made on warm days as far as possible. Comparison of the various treatments a short time before harvest, showed that neither the dormant spraying nor the spraying with Atomic sulphur had controlled the mildew satisfactorily. Marked differences were plainly seen between the rows that were sulphur dusted and the controls. The leaves of the latter were fairly white with mildew and the peduncles and pedicels were but slightly less affected. The dusted foliage was green and with a minimum of mildew and the berries were practically free from mildew. No injury to leaf, fruit nor wood was shown at this time nor did later observations disclose any such.

\section{Sulphuring in 1912.}

In 1912 the same vineyard was again used for dusting but no dormant or summer sprayings were given. This year the experiment was limited to 6 rows of Lindley of 22 vines each. The dusted rows alternated with the controls, there being three that were treated and three left as controls. The first dusting was done July 11th, and this application as well as the later ones were made with a traction duster. The weather on this date was warm, cloudy and humid. The second application of dust was made July 29th, the weather being humid and cloudy. The third application was made on August 12th. The forenoon of this day was humid and cloudy, changing to clear in the afternoon with fresh winds.

Just previous to the picking of these rows careful counts were made of the affected and unaffected clusters, and the presence of mildew on the

5Trade name for an exceedingly fine sulphur sold in paste form by Thomsen Chemical Company. 
leaves estimated both for the dusted and control rows. On the 66 vines of the latter there were 34 vines on which there was mildew on 80 per cent or more of the stems or berries. Four vines only had clusters 60 per cent of which were free and no vine of the controls bore clusters 70 per cent of which were free from mildew. Of the 65 vines dusted, 60 showed 70 per cent and above, mildew-free clusters. On 59 vines 80 per cent or over of the clusters were free from disease. The leaves of the control vines were very generally affected so that the entire row had a distinct grayish cast. It was possible to select the treated rows from the controls from a superficial examination, even by the untrained observer. As in the preceding year no injury to any part of the vine by reason of the treatment was to be seen.

During the same season, 6 rows of Delaware were dusted in a neighboring vineyard. The first application was made August 1st with a knapsack machine. Five rows of the same vineyard were left as control. A second application was made August 13th with the traction duster. An examination of the vines during the period preceding ripening, and at the time of harvest disclosed very little mildew even on the control rows, with possibly a trifle less on the treated. However, the slight infection made impossible the securing of reliable data. No injury to the vines was to be seen as a result of the sulphur applications.

In a Concord section of the same vineyard 7 rows of 100 vines each were treated with a dust consisting of 45 pounds of sulphur flour and 5 pounds of powdered arsenate of lead per acre. This application was made July 11, 1912. The weather on this day was hot and clear. A control of several rows containing the same number of vines was left. Owing to the slight infection of mildew on the control vines no data were obtainable as to the efficacy of the treatment. To all appearances the dusted and untreated vines were practically alike. Each matured a good crop of fruit.

\section{Dusting in 1913.}

During the summer of 1913 the Lindley vineyard was again dusted. Each application was made with the traction machine, the first, July 18th, when the weather was clear and warm; 5 days elapsed before a rain; the second July 30th, a hot, humid day followed by light showers at night. Three rows were left as control, while three and a portion of a fourth immediately adjoining were treated. Through this selection one of the rows that was dusted in 1912 became a control in 1913 while one of the check rows of 1912 received treatment in 1913. The other rows of the vineyard were treated as in 1912. On September 6,1913, a count was made of the clusters of each plat. Of 2101 clusters examined in the three control rows, 2062 showed mildew of some degree while but 29 clusters could be classed as entirely free, i. e., 1.3 per cent of the entire number. 2151 clusters were examined from the 66 dusted vines. 1670 of these or 77 per cent were found to be free of the disease. 481 clusters were affected in some degree. The leaves on the untreated vines were very generally affected while those of dusted ones showed only occasional spots of mildew. The sulphur in no way injured any part of the vines. 


\section{Experiments of 1914.}

In 1914 the Lindley vineyard was again treated as in 1913. The dusted and control rows remaining the same. The first application was made. July 6th. The weather on this day was clear with a maximum temperature of $82^{\circ}$. The second treatment was given July $27 \mathrm{th}$, the day being partly cloudy with a maximum temperature of $84^{\circ}$. But .54 of an inch of rain had fallen between the two applications. The temperature average for the six days immediately following the first dusting was $88^{\circ} \mathrm{F}$., while the average for the entire intervening period was $83.5^{\circ}$. The third dusting was made August 10 th immediately after a shower. Only general observations were made this year to determine the effects of the sulphuring. From this examination it was plainly evident that the treatment had proved as effective as in the preceding years. The first indication of injury was noted at this time. A few leaves showed burned areas, but not enough to interfere in the ripening of the fruit.

On July 6th, a vineyard consisting of 125 varieties, located on the experimental grounds of the Vineyard Laboratory at Fredonia, N. Y., was sulphured with the traction machine. Four weeks after the application was made it was evident that considerable injury had been done. Cynthiana, Norton and Wine King were entirely defoliated. The first two belong to the species aestivalis while the last-named contained aestivalis blood. Cottage, Carman, Early Ohio, Little Wonder, Lutie, Martha, Caco, Geant, and Blue Black were burned badly, so that the fruit and wood did not mature well. Beacon, Banner, Moore, Eaton, Ives, Geneva, Lukfata, King, Northern Muscadine, Rega!, Rockwood, Worden, Woodruff and Gold Coin were affected to a less degree, although the maturity of the fruit was interrupted. In this vineyard Lindley nor any of the Rogers varieties were in the least injured. As there was no Concord in this vineyard, the effect could not be determined for this variety. In another vineyard, Winchell was partially defoliated so that fruit and wood did not mature properly.

The excellent results with Lindley for the three years previous, and the freedom from injury, both of this variety and Concord, pointed to the conclusion that a cheap, effective and safe treatment presented itself in the application of powdered sulphur. Approximately 100,000 tons of sulphur are used every year in France, largely in dusting vineyards. With these facts in mind it seemed perfectly safe in 1914 to undertake a final large demonstration experiment of the effectiveness, ease, simplicity and cheapness of an application of dry sulphur for the control of mildew. A French traction dusting machine was secured and sulphur of two degrees of fineness, ordinary ground brimstone or flour sulphur and an exceedingly finely ground flour sulphur, used. The plan of the dusting campaign had been announced through the columns of the Grape Belt and Chautauqua County Farmer. The plan was that at the proper time a man should come with outfit and material and dust a block of four to five hundred vines. The only requirement imposed upon the grower was that he should agree to examine the treated plat at picking time, compare it carefully with adjacent untreated vines, and furnish a statement of his opinion of the effectiveness of the treatment. As everything was free, even the labor involved, there was no objection on the part of anyone and the number of individual experiments 
was limited only by the quantity of material and the time available in which to do the work.

Some difficulty was experienced with the feeding mechanism of the duster, and the experiment was finally performed by distributing nearly 50 per cent less sulphur per acre than had been planned originally for some of the tests. A maximum of 40 pounds of either grade of sulphur was applied per acre. Mildew was showing to a limited extent in all the vineyards. In some cases it was necessary to search carefully to find spots and in others small spots, particularly on the peduncles, were easily found.

A half acre or more in each of 47 vineyards was dusted. These were scattered over a territory about eight miles in length, and represented several soil types. Nearly all the vines treated were Concord. It was planned to make two applications, but subsequent happenings interrupted. The first vineyard dusted was on July 20 th and all were completed by July 31st. The average maximum temperature for the 22 days following the treatment was $84^{\circ}$, while the total precipitation for the same period was but .83 of an inch.

When the second application was begun it was seen that several of the vineyards previously dusted were showing marked indications of injury on the leaves. This in the form of burned areas over the blade or a drying out of the margins. The second application was then abandoned. As the time of maturity approached the injury showed more abundantly and in some instances practically all of the leaves were functionless on one or more canes of a vine. The fruit on such vines did not color and at harvest time it was still red and unmarketable. In many instances the season's wood growth did not ripen so that it was a problem to find fruiting wood for the crop of 1915. In order to learn to what extent these conditions obtained for all the vineyards, the growers were requested to report on the effect of the sulphur to leaf, wood and fruit. Of the 30 from whom such information was obtained 25 reported severe injury to leaf, fruit, and wood. "The leaves had the appearance of having been burned and in extreme injury, the vines were practically defoliated." "Wood growth and fruit development was consequently checked." One vineyardist reported "that the most damaging effects upon the foliage and wood appears to be on eight or ten rows adjoining, and on either side of the dusted area." "In no other of my vineyards is such a condition to be found." The extent of injury with these vineyards made impossible the securing of reliable data as to the control of the mildew. One grower of the thirty reported slight injury, but owing to the slight amount of mildew present in the untreated sections, he was unable to detect material results from the dusting.

Four of the thirty reported no injury. Of this number three saw no beneficial effects from the sulphuring. One of these, however, had sprayed thoroughly with Bordeaux. One grower of the four reported almost complete control.

Just what factors entered to bring about these conditions is difficult to say. Three of the four vineyards uninjured were dusted with fine sulphur, yet a large number of those injured were treated with the same grade. Leaf hopper injury to the foliage cannot be considered as a factor for very little trouble was experienced the past year with this insect. Weather conditions at and following the application seems to offer a possible explanation, at 
least in part, for the injury. As has been stated previously a relatively long period of high temperatures followed the sulphuring and there was little precipitation. It is possible that sulphur particles became heated sufficiently to cause a mechanical burning, aside from any chemical reaction with the leaf tissues. The heat concentrated on the leaf surfaces may have resulted in excessive transpiration, which could not be met by the roots owing to the drought at the time. One of the writers 6 has been studying a leaf affection of the grape, that is apparently dependent upon the amount of moisture in the soil at critical periods. Examination of the injured dusted vineyards showed the leaves affected in much the same manner as with the leaf trouble due to a lack of moisture. In fact it was only after several observations that this writer was led to believe that the sulphur was a contributor to the injury present. That four of the vineyards were uninjured may be due to the availability of a greater amount of soil moisture, or to the fact that demands of the growing wood, leaf and fruit were not so great, due to less fruiting wood having been retained at the winter pruning.

This unexpected turn of affairs leaves the practical control of mildew where it was years ago. It is possible that much smaller quantities of sulphur may be used per acre. It is equally possible that such a combination of circumstances may not exist again in many years. At any rate the desirability of dusting the vineyards of the Chautauqua belt is such that renewed experiments on a small scale will be continued in 1915 .

Prof. Bioletti remarked that the paper showed that the control of this disease in the eastern portions of the United States is very different from its control in California. They sulphur many times during the summer, while in California the sulphur should be applied principally during the spring.

President Alwood: "If someone here has had experience with Oidium, he may state that experience."

Mr. Henry: "It has been very hard to control mildew in the San Joaquin Valley. It has been very bad this season. Sulphur prevents mildew just as long as it lasts on the vines, but no longer."

Prof. Bioletti. "In regard to the mildew in the San Joaquin Valley this year, I went through a large part of Fresno, Tulare and Kern counties and I was told that there was a great deal of mildew in these sections. I visited forty or fifty vineyards and did not find a single indication of mildew. In every case it was something else. It was alkali, or some other trouble of the vine. I have never seen so little at this time. There is a great deal of worrying in this region about something that is not mildew at all. Many growers haven't learned to recognize it when they see it."

Mr. Henry: "When you go into a vineyard one day, and two days afterward you go back and find the vines are gray, I think it is plain that it is mildew."

Mr. P. F. Lint, Los Gatos, Cal.: "I want to say a word about sulphuring. The great secret is to sulphur just as soon as the leaves come out."

Prof. Flossfeder asked Mr. Henry if the vines were totally covered with leaves or not when he found what he says was mildew.

Mr. Henry: "There were bunches of grapes on the Thompson Seedless vines right out in the open. We often find mildew on the second crop and not on the first crop." 


\section{STUDIES ON PLASMOPARA VITICOLA (DOWNEY MILDEW OF GRAPES).}

By C. T. GREGORY,

Cornell. University, Ithaca, New York.

\section{Historical.}

Early writers frequently mention the "mildews" and "blights" which "sickeneth" the vines but these troubles were attributed to some visitation of Providence or to atmospheric disturbances. As late as 1870 the disease was not supposed to be caused by any organism, although a conjunct fungus was always found. Saunders (1862) r:as of the opinion that the vine was previously injured and partially decayed before the fungus was able to gain foothold.

Lippincott (1866) in a summary of the various theories of the origin of the disease held at that time, states that they were essentially as follows: that it is spontaneously developed, that the spores are inhaled through the stomates and distributed throughout the plant and that during moist weather the plants become gorged with water resulting in an incipient stage of decomposition so weakening the plants that they are unable to prevent the formation of the mildew. Lippincott, himself, offers the explanation that ozone in the air prevents the formation of the mildew and that during moist weather this prophylactic gas is not present, hence the abundance of the disease during such periods.

Farlow (1876) described the disease and correctly attributed it to the fungus, Peronospora viticola De Bary.

\section{Name and Classification.}

The fungus was first collected in America by Schweinitz, in 1834, but was erroneously referred by him to Botrytis caca Link. It was studied by Berkeley and Curtis (1848) who described it as a new species, Botrytis viticola. De Bary (1863) later studied the fungus carefully, described and figured the sexual as well as the asexual stage and referred it to the genus Peronospora, naming it Peronospora viticola.

Schroeter (1886) subdivided the genus Peronospora into Peronospora and Plasmopara. The differences may be briefly stated. The conidiophores of Plasmopara are monopodially branched, never clearly dichotomously as in Peronospora. The ultimate branches or sterigmata of Plasmopara are dichotomous or trichotomous and after the dissemination of the conidia their ends are flat or concave. In Peronospora the sterigmata are always dichotomous and the ends are acutely or obtusely pointed but never flat. Finally the germination of the conidia of Plasmopara is typically by means of zoospores or by the entire contents of the spore slipping out and then producing a germ-tube. Rarely a germ-tube may be produced directly. The conidia of Peronospora always germinate by means of a germ-tube.

Berlese and de Toni (1888) redescribed the fungus as Plasmopara viticola. 


\section{Characterization.}

The mycelium is cœnocytic and pleuroblastic. Istvanffi (1913) states that it may sometimes be intracellular and figures it so. The writer has never observed the mycelium in a position which might be interpreted as intracellulár. Since all observations were made from stained sections which were not more than $10 \mu$ thick all possibility of mistaking hyphae passing

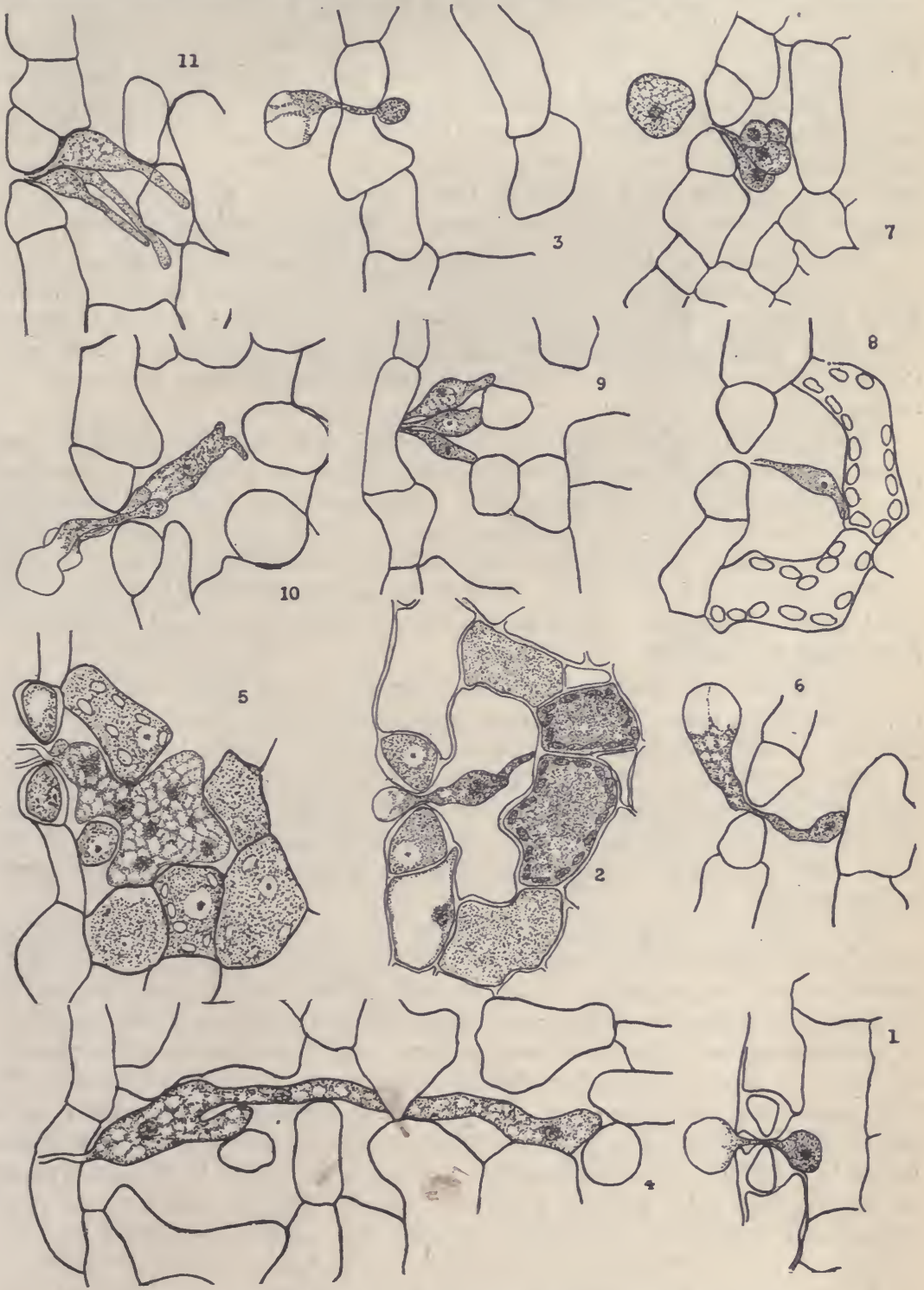

Plate 1. Infection of grape leaf by Plasmopara viticola. 
above or below the cell, as being intracellular, is obviated. In the writer's opinion the mycelium is always intercellular.

The diameter of the hyphae varies considerably with the conditions of temperature and moisture and with the character of the tissue in which it is located. Where the germ-tube and the conidiophore pass through the stomate it is about $1 \mu$ in diameter ( $\mathrm{Pl}$. I, fig. 1). In certain cases the diameter of the mycelium may be as much as 40 to $60 \mu$ (Pl. I, fig. 5). In the canes where the tissues are firm and the cell walls relatively thick, the hyphae are smaller and of more uniform diameter. In the leaves the hyphae tend to fill the large, irregular, intercellular spaces and hence are of greater diameter. In general it may be said that in young tissue the mycelium is of greater diameter and more abundant than in the more mature parts. Indeed, in the very old, diseased areas, particularly after the period of oospore formation, the mycelium seems to disappear almost entirely.

The younger parts of the mycelium are filled with a dense, finely granular protoplasm which, with age, becomes coarser and profusely vacuolated. When carefully stained the protoplasm exhibits a netted structure seemingly made up of numerous fine strands. At irregular intervals upon these strands occur deeper staining granules whose exact nature is not evident.

The mycelial wall is very thin and according to Mangin (1890), is composed of a mixture of cellulose and callose. The action of various stains may serve as an indication of its nature. When untreated mycelium is stained with chloriodide of zinc there appears after a short time a brown color. If previously boiled in potassium hydroxide the mycelium becomes a deep reddish purple with this stain. This is in accordance with Mangin's statement to the effect that boiling potassium hydroxide will dissolve the masking callose leaving the pure cellulose.

The nuclei are commonly globose but in certain places they may be oval or at times almost linear. They are especially abundant in the younger portions of the mycelium. Istvanffi states that they divide karyokinetically.

The haustoria are produced very profusely and occur in all parts of the plant in which the mycelium is to be found. In the leaves of the resistant varieties the haustoria are similar in every respect to those found in the more susceptible vines except that they are usually smaller and are never so abundant.

The method of haustorial formation is similar to that described by Grant Smith (1900) for the Erysiphae. At first a very small tube is produced laterally from the mycelium into the host cell-wall which becomes greatly thickened at this point. The exact cause of this thickening is not apparent. It would seem that, if it is caused by some enzyme producing gelatinization of the wall, as is suggested by Cuboni (1889), the adjacent portions of the wall would also swell but this is not the case. The other possible view is that it is an indication of an attempt of the host to exclude the haustorium hence is the result of additional depositions at this point by the protoplasm of the irritated cell. Be this as it may, the haustorium continues to grow inward still enclosed in its sheath of host wall. After reaching a variable length the end of the tube gradually swells into a globose sac accompanied to a certain point by the swelling of its sheath (Pl. II, fig. 1). After attaining about one-half of its mature size the terminal portion bursts or dis- 

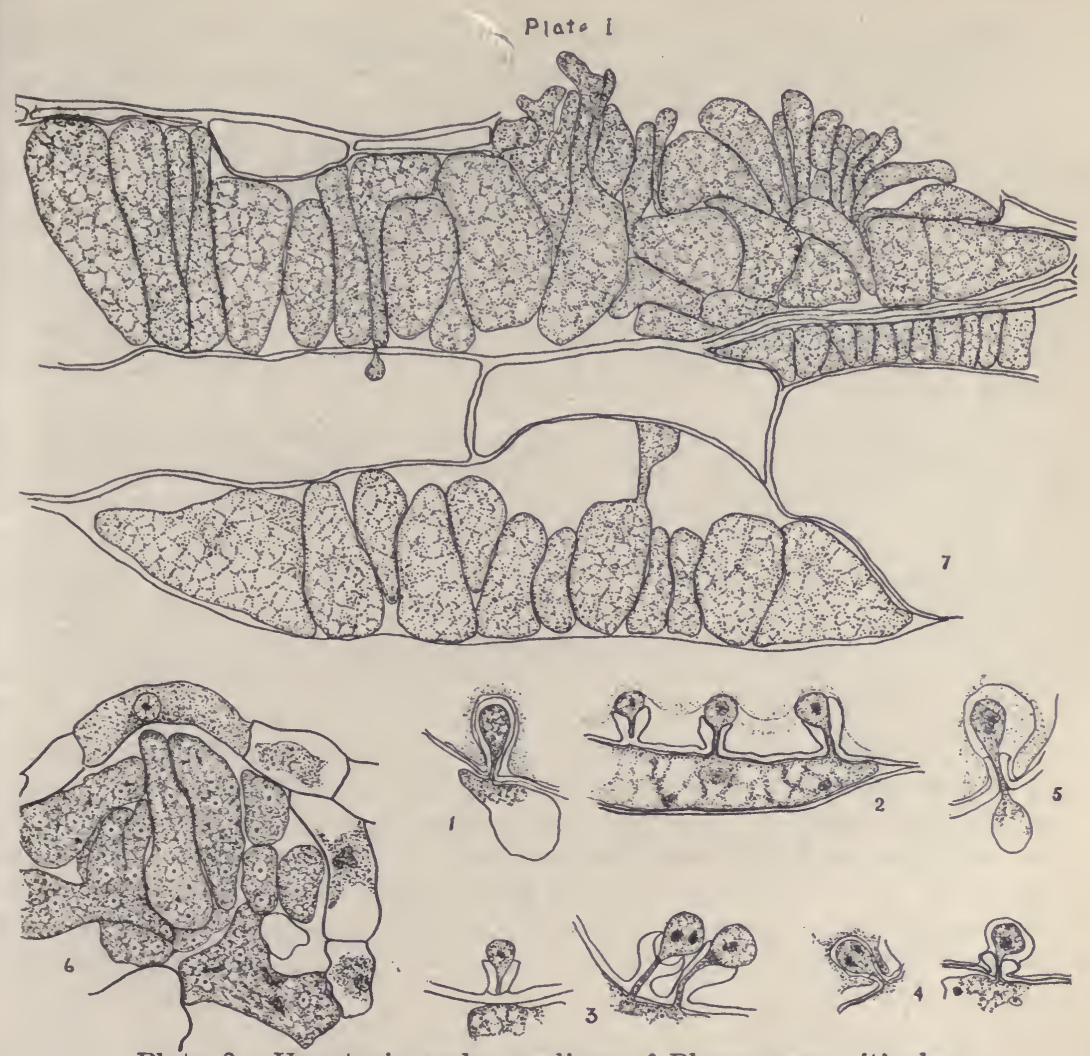

Plate 2. Haustoria and mycelium of Plasmopara viticola.

solves the sheath. Thus in many of the mature haustoria there may be seen about the base a goblet-shaped collar pierced by the greatly attenuated stem of the haustorium (Pl. II, figs. 2 and 3). After penetrating the cell wall, the terminal portion continues its growth for a certain period, never, however, completely filling the cell as is sometimes the case in certain of the Erysiphaceae. It is this terminal, globose portion which constitutes the absorbing area of the haustorium.

In the meantime the plasma membrane of the cell is gradually pressed back by the advancing haustorium and often may be very closely appressed to the latter but never penetrated by it (Pl. II, figs. 2 to 5 ).

The haustorium is thin walled. The presence of the host cell wall about the partially swollen tip or the space between the plasma membrane and the haustorium may give the impression that the wall is thick as has been stated by Istvanff (1913) and others. The former states that the wall is sometimes thin and sometimes very thick. It is evident that in the first instance he has observed the condition in which the plasma membrane is closely appressed to the haustorium and in the second, the encompassing sheath of host cellwall. 
Within the haustorium is a small bit of protoplasm in which is imbedded a nucleus. In certain cases the writer has observed two nuclei (Pl. II, figs. 3 to 5). Istvanffi (1913) has reported as many as four. In his estimation these are produced by the division of a single nucleus which entered the haustorium during the early stages of its development.

The size of the haustoria is exceedingly variable. According to Istvanffi they are 4 to $10 \mu$ (rarely 15 to $20 \mu$ ) at their largest diameter by 4 to $12 \mu$ (rarely 20 to $25 \mu$ ) long. These measurements correspond very closely with those made by the writer. The stems may attain nearly one-half of the total length of the haustorium, varying from 1.5 to $5.5 \mu$ in length and from .4 to $1.0 \mu$ in diameter.

The method of differentiating the cell wall from the haustorium was by the combination of certain stains. After some experimentation, it was found that ruthenium red and methyl green gave the clearest coloration. In this way the cell walls were tinted a deep red and the mycelium green. The safranin-gentian violet-orange stain also gives very good differentiation showing the relation to the plasma membrane but since it leaves the cellwall practically unstained it is unsuitable for that aspect of the problem. A study of sections stained by both methods gives an excellent idea of the relation of parts.

The formation of conidiophores commences after a sufficient period of mycelial development, the time varying with the organ attacked, the temperature and the humidity. The mycelium begins to mass beneath the stomata forming what has been termed the cushion (Pl. II, fig. 6). From these hypae arise many other smaller ones which push upward through the stomata. In order to traverse the small opening they must become greatly attenuated but immediately after their egress they abruptly swell to the normal size of the conidiophore. As many as twenty such branches may arise through a single stomate but more commonly there are from four to six.

In certain cases the fruiting mycelium may burst directly through the epidermis. This has been observed frequently on flower peduncles which were heavily infected (Pl. II, fig. 7). In such cases it appears that the epidermal cells are killed, then crushed by the pressure of the mycelium beneath and finally disrupted. There is no evidence that it is a process of solution. On the young fruit the mycelium takes advantage of the lenticle-like structures for its egress.

The conidiophores are produced most readily in the absence of light, in relatively humid conditions and at a temperature of $18^{\circ}$ to $20^{\circ} \mathrm{C}$. The other conditions being favorable the temperature is of rather minor importance. The method ordinarily employed to obtain an abundance of conidia for germination studies is to enclose infected leaves, on which there is no evidence of conidiophore formation, in a moist chamber during the night (about 12 to 20 hours). A smaller percentage of conidia frequently have been obtained during the day by a similar treatment. The light was in such cases very subdued. This is in accordance with the statements of Istvanffi (1913), Cuboni (1889) and others to the effect that conidiophores are produced only during the night or in subdued light.

The conidiophores are from 300 to $500 \mu$ in height and 7 to $9 \mu$ in diameter. Istvanffi states that they average 800 to $1200 \mu$ in height and that occasionally one may attain the height of $1500 \mu$. There are usually about six monopodial 
branches which are in turn branched several times. Each branch is terminated by two to four, short sterigmata whose ends, after the dispersal of the conidia, are concaved. The sterigmata are about 5 to $12 \mu$ long and 2 to $3 \mu$ in diameter.

The walls of the conidiophores are thicker than those of the mycelium and are composed at least partially of cellulose, staining a bluish purple with zinc chloriodide. At irregular intervals in the primary axis, branches or the sterigmata, there occur septa which are very much thicker than the walls. These are claimed by Mangin (1890) not to be true cross-walls but merely plugs of callose. When stained with zinc chloriodide they are not tinted but, as in the case of the mycelium, do so after the conidiophore has been boiled in potassium hydroxide.

To determine whether the conidiophores are composed of pure cellulose they were treated with a cellulose solvent, cuprammonia (Schweizer's reagent). A preliminary observation was made of the action of this Solvent upon cotton fibers (pure cellulose). The first evidence of its action is a swelling of the fibers to at least double their original diameter, followed shortly by their rapid disappearance. The walls of the conidiophores, when treated in the same manner, also swelled to about twice their normal thickness but they do not then rapidly dissolve (Pl. III, fig. 1). The basal portion exhibits a peculiar reaction, seeming to burst outward and to disintegrate except for a thin inner sheath (Pl. III, figs. 1 and 3). Sometimes the large proportion of the conidiophore assumes this aspect, but in practically every case the distal end remains apparently intact. A logical interpretation of these reactions is that the conidiophores are composed of cellulose or a cellulose-like substance but are lined with another material, possibly callose.

Before the formation of the conidia, the conidiophore is filled with protoplasm which is abundantly provided with nuclei. The conidia are formed by the swelling of the end of the sterigmata into which a portion of the protoplasm passes. After the mature size is attained a septum is laid down separating the conidium from the sterigma. According to Istvanffi (1913) a single nucleus passes into each spore at this time and its division produces the multinucleate condition obtaining in the mature conidium. He also states that the cross-wall is laid down when the conidium is from onehalf to two-thirds its mature size.

The mature conidia are extremely variable in size and shape. Some are almost globose, others are long and narrow, but the majority are ovoid. They are attached to the sterigmata at their smallest end. Disarticulation occurs very easily, being produced by the breaking or solution of a small lenticular area which separates the conidium from the sterigma (Pl. III, fig. 5). The ease with which this substance is broken is shown by the fact that only a slight jarring is necessary to release the spore. It is also very readily soluble in water hence the exceeding difficulty of obtaining a mount in water of the attached spores for microscopic examination. One may observe many conidia still fastened to their sterigmata when in the dry state but if a drip of water is placed upon the mass in a moment all of the conidia will be freed.

Cornu (1882) mentions this substance and states that it is due to its extreme solubility that the conidia are freed during moist weather. $\mathrm{He}$ figures it, however, as a wall which is so tightly compressed between the 

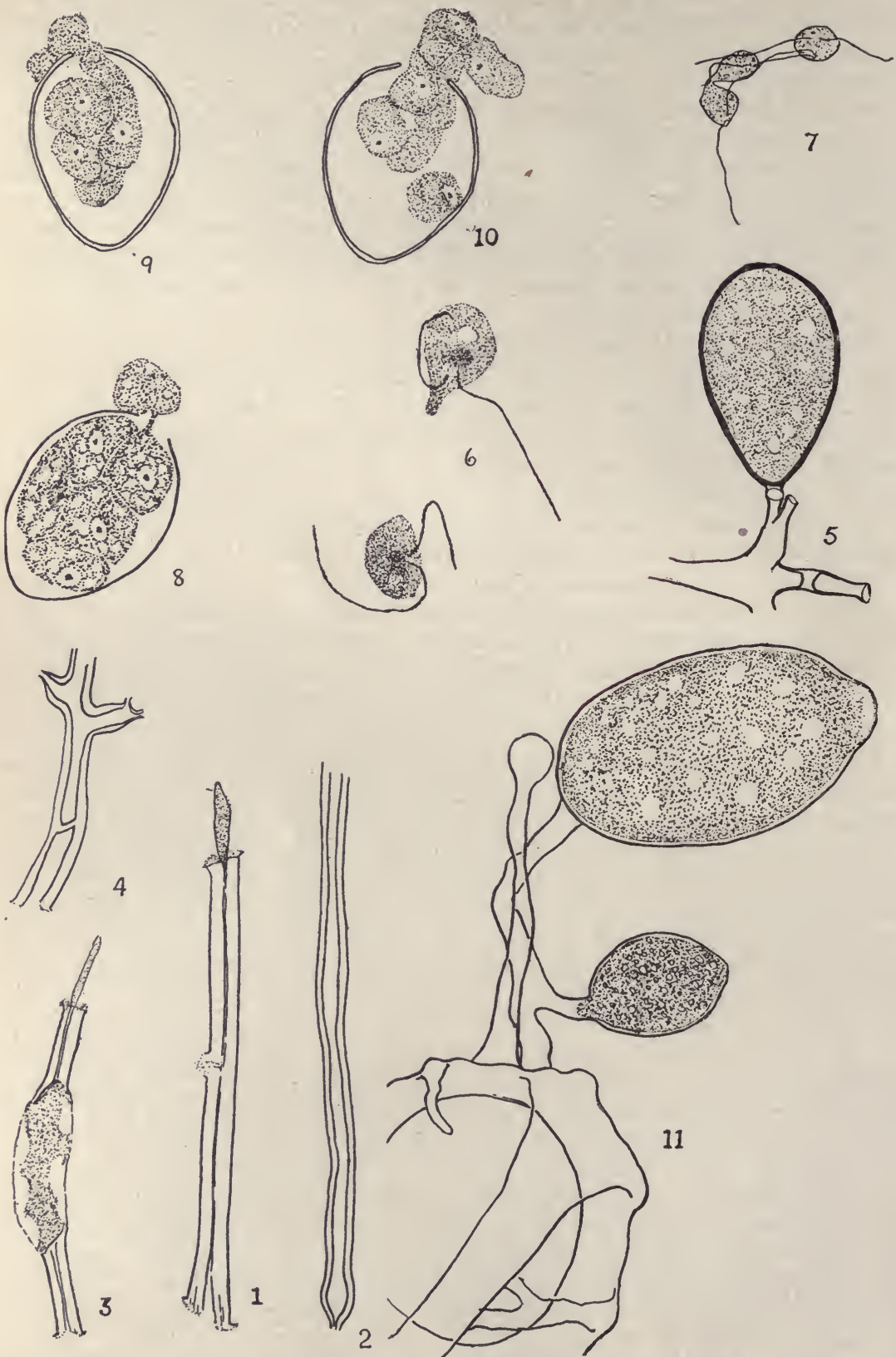

Plate 3. Fructifications of Plasmopara viticola. 
conidium and the sterigma that it bulges out on either side. Mangin (1.891) on the other hand, having made' a complete study of this subject, figures this disjunctive wall as lenticular. He claims that it is composed of callose which is, however, insoluble in water but explains this anomaly by the theory that there is some chemical change in the composition which renders it soluble.

In size the conidia average from 11 to $18 \mu$ by 15 to $31 \mu$ but in certain cases are much larger than this. Istvanffi (1913) distinguishes three types, the microconidia, which are of the size and shape usually observed, the macroconidia, having a size of 25 to $35 \mu$ by 40 to $55 \mu$ and finally the megaloconidia which are much larger than the macroconidia, more or less globose, contain 15 to 20 nuclei and which are produced without the intervention of a sterigma.

At the small end of the conidium there are usually two minute projections, the remnants of the attachment to the sterigma. At the opposite, larger end is a papilla or projection through which germination occurs.

The thickness of the wall of the conidium lies between that of the conidiophore wall and the mycelium. It is practically uniform except at the papilla where it is very thin and delicate. The composition is the same as that of the conidiophore, staining reddish-purple with zinc chloriodide except at the papilla which remains colorless. Within each conidium there are several nuclei corresponding to the zoospores which are ultimately formed in it.

On susceptible varieties, like the Delaware, Niagara and V. bicolor, the downy mass of conidiophores and conidia is usually very dense and when disturbed, a tiny white cloud of spores arises. On the more resistant forms the growth is only slightly developed even under the most favorable conditions, appearing most frequently in isolated clusters which correspond to the brown punctations on the upper surface.

The Sexual spores, oospores, are formed in the intercellular spaces largely within the palisade or spongy parenchyme tissues of the leaf, and almost invariably closely adjacent to the principal veins. The writer has very seldom found them in the tissue about the margin or in the blade of the leaf. Bailion (1888), Istvanffi (1913) and Lamson-Scribner (1886) have reported finding them in the cortex of the stem and in the berries.

The development of the oospores has not been clearly followed but several different stages have been observed and in order that these may be correctly interpreted and arranged in their proper sequence, a comparison is made here with the oospore development of Plasmopora alpinum, described by Rosenberg (1903).

The oogonium is multinucleate (Pl. IV, fig. 1) and number of nuclei counted in one case being about forty. This is very similar to the oogonium of $P$. alpinum which Rosenberg states has forty-five. In the case of $P$. alpinum the antheridia are clavate and contain about four or five nuclei. Though many hundreds of stained sections have been examined, the writer has only once observed a structure which might be interpreted as an antheridium. It was much smaller than the oogonium, clavate and arose from the hyphae immediately beneath the former (Pl. IV, fig. 2). Both Viala (1893) and Cornu (1882) figure similar structures but Farlow (1876) 

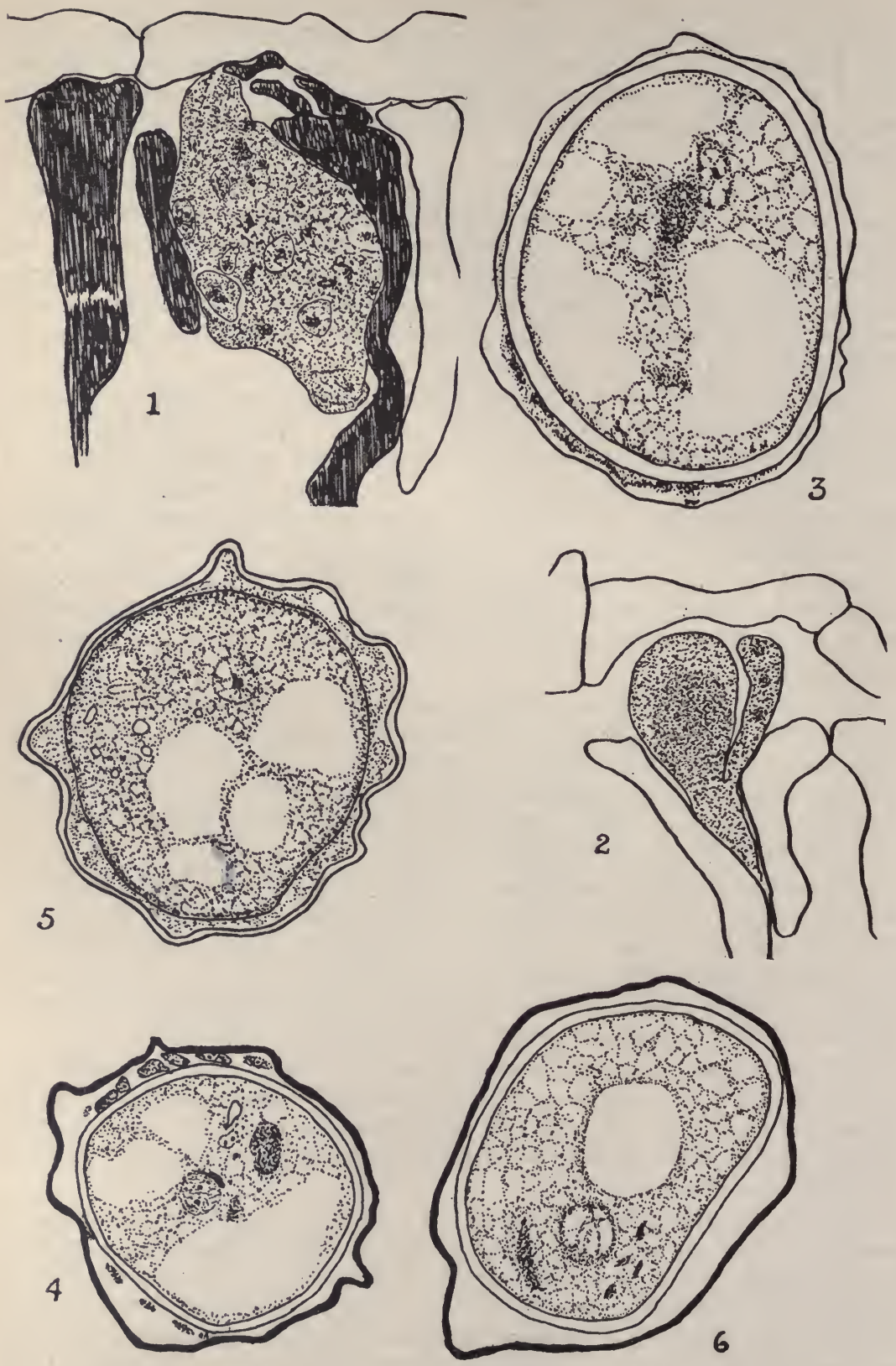

Plate 4. A few stages in the development of the oospore. 
represents the antheridium as à long, slender thread partially encircling the oogonium.

Briefly stated the nuclear history of the oogonium of $\mathrm{P}$. alpinum is as follows. First, there is a single mitotic division, after which all of the nuclei but one migrate to the periphery. Simultaneously there appears at the center a small dense body which seems to attract the single remaining nucleus to it. This is considered by Rosenberg to be the coenocentrum. Following this, another mitosis of the central nucleus occurs, which does not, however, occur in all of the nuclei at the periphery. One of the sister nuclei at the center then migrates to the periphery and gradually disintegrates. At this time one nucleus from the antheridium passes to the center of the oogonium and after a time fuses with the female nucleus.

In Plasmopara viticola, certain of these stages have been observed. In many instances a single, well-developed nucleus occurs at the center near a well-defined, denser, body, the coenocentrum (Pl. IV, figs. 3 and 4) while outside of the partially developed oospore wall are numerous irregular, darker-staining bodies which may be interpreted as disintegrating nuclei (Pl. IV, figs. 3 and 4). At times there may be seen two or more nuclei within the developing oospore but the fully matured oospore contains only a single nucleus without the accompanying coenocentrum (Pl. IV, fig. 6).

The writer has never observed an antheridium in connection with the more advanced stages of development of the oospore in the many hundreds of sections obtained. This fact is amenable to two interpretations, either that these oospores develop apogamously or that the antheridia very quickly disintegrate.

The protoplasm of the oospore is granular, rather yellowish brown and filled with numerous, refringent globules. At times the entire center is occupied with a large, round, hyalin area, having the appearance of a large vacuole. The oospores are from 25 to $35 \mu$ in diameter. The inner wall or endosporium of the oospore is smooth, colorless and relatively thick. This wall is formed about the oosphere immediately following fertilization. It is apparently a deposition from the protoplasm (Pl. IV, fig. 5). Surrounding the endosporium are the disintegrating remnants of nuclei lying in the periplasm. It is probable that the periplasm contracts about the endosporium thus forming the irregular, brown exosporium. The oospore lies within the thickened persistent, oogonial wall. The writer has seen many oospore-like bodies, having spiny walls but since they are as frequently on the outside of the leaf as within it is apparent that they are not spiny forms of the oospores of Plasmopara viticola.

As has been pointed out by the writer (1913) there were many unsuccessful attempts to germinate the oospores of Plasmopara viticola but, notwithstanding these failures, two theories were evolved as to the probable method of germination. On the one hand we find Millardet (1883), Frechou (1885), Richon, Viala (1893) and others who considered that zoospores were formed directly from the protoplasm of the oospore. On the other hand, Cornu (1882) and Prillieux (1883) were equally certain that the oospores produced a typical conidiophore bearing conidia.

The writer (1913) published an account of germination by means of a promycelium bearing a single conidium (Pl. III, fig. 11). Shortly afterwards, 
Ravaz and Verge (1913) also described an exactly similar method fully corroborating these observations.

Oospore germination may begin as early as the latter part of February, though at this time it is not as abundant as later in the spring, March till June.

The oospores will retain their vitality for at least a year. Leaves containing oospores were collected in October, 1912, allowed to remain on the ground during the winter of 1912-13 and then kept in the laboratory in a thoroughly dried condition until March, 1914. At this time they were moistened and after being maintained about three weeks in these conditions germination occurred in a small percentage of the oospores.

Freezing seems to be necessary, since germination has only been obtained from those oospores which have been allowed to remain on the ground until at least January or February.

The conditions essential for germination are very similar to those necessary for conidial germination. A temperature of about $23^{\circ} \mathrm{C}$. and an abundant supply of moisture seems to be optimum. The leaves are allowed to rot for a week or more in a warm moist place and thereafter it requires usually about five to eight days in order to obtain germination.

The time necessary for the complete formation of the primary conidium and the emission of the zoospores is about 24 hours. The germination of two oospores was followed from the time that the conidia were $8 \mu$ and $11 \mu$ respectively in diameter at 12:35. The promycelium was still completely filled with protoplasm. At 4.45 both conidia were full size, being $27.3 \mu$ and $39 \mu$ respectively in diameter and the septum separating them from the promycelium was formed. The next morning they were in a similar condition but at $12 \mathrm{~m}$. germination, by means of zoospores, occurred.

Numerous motile bodies have been observed in cultures which apparently contained no germinating oospores and it was at first thought that possibly germination might occur by zoospores directly but when these motile bodies were fixed in osmic acid and stained with methylene blue it could be seen readily that they possessed but one flagellum. Furthermore, their globose shape and size $(10$ to $13 \mu)$ preclude the possibility of their being zoospores of Plasmopara viticola. Melhus (1914) has observed a parasite of oospores which produces similar zoospores, hence it may be that we are also dealing here with such a parasite.

With these points in mind it appears certain that early spring infections arise from the oospores. Though the process has not been followed, certain observations have indicated that this is the case.

The leaves lying on the ground about the vines during the winter, are in an advanced stage of decomposition by spring, thus only a short period of warm, rainy weather is necessary to complete this process. The driving rains, also occurring at this time, aid in breaking up the thoroughly rotted leaves, thus more or less completely exposing the oospores and facilitating conidial formation and dissemination.

The conidia may germinate in the soil water or may themselves be spattered to the lower leaves of the vine during heavy rains. Arbois de Jubainville (1883) has stated that he has seen mildewed spots on the leaves opposite bits of mud. The writer has also observed the mildew in the season on the mud-bespattered leaves. This would indicate that some spores, either 
zoospores or conidia were carried there through the agency of the rain. It is, moreover, well known that the first spots to appear in the early spring or summer are on the lower leaves.

Millardet thought that the seedlings growing through the layers of oospores-filled leaves are infected by the zoospores produced in the oospores and the conidia resulting from these primary infections serve as sources of infections upon the surrounding vines. This hypothesis, with the exception of the oospore germination by zoospores, may be tenable in France, but in this country where seedlings never, or at least very seldom, appear in the vineyards, we must search for some other explanation.

Noack (1899) states that in Brazil the oospores are unnecessary since the leaves are green the year round and the summer stage is constantly present.

At one time the writer thought that possibly the mycelium of the fungus could hibernate in the roots or canes of the diseased vine and, producing conidia in the spring, serve as a source of infection. During the autumn of 1912 roots and canes of certain vines which were known to be badly infected each year were planted in the greenhouse, care being taken not to bring in soil which might contain oospores.

These vines grew until the following July without any evidence of the mildew, though they were well watered and an attempt made to induce a succulent growth which would probably favor any mycelial development.

Istvanffi (1913) found the mycelium and conidia within the bud scales in autumn but was not able to prove that a diseased cane or leaves develop from these buds, as Cuboni (1889) thought possible.

Frechou (1885) states that the mycelium may hibernate in the leaves which do not become moist enough to rot. After five or six months this mycelium may produce conidiophores bearing conidia. He points out that it is extremely rare that there will not be enough moisture during the autumn, winter and spring to rot the leaves, hence this method need hardly be seriously considered.

During the winter of 1914 the writer had an opportunity to test the possibility of such a method of hibernation. Leaves of a wild vine which were known to have been badly infected, were found in a fine state of preservation, showing no evidence of decomposition and in every way ideal for hibernation of the mycelium as described by Frechou. They were placed in a warm, moist situation, in the hope that conidiophores would be produced but without success, indicating that the mycelium does not hibernate in this manner.

It is probable that the principal, if not the only, method of hibernation is by means of the oospores.

After the formation of the first crop of conidia from the primary infections the spread of the mildew becomes much more rapid. The conidia are blown to other vines where they readily germinate if proper conditions exist. The principal factors influencing the germination of the conidia, aside from the presence of moisture are, the temperature, and the proper age of the conidium.

Viala (1893) gives three types of germination of the conidia, namely, by zoospores, by the emission of the entire contents of the conidium and by a germ-tube directly. Istvanffi (1913) also figures the same types and states 
that germination by means of the germ-tube occurs only in moist air. The writer has never observed this type. In the great majority of cases zoospores are formed. Very rarely the entire contents of the conidium emerges, forms a wall about itself, and eventually produces a tube.

In one case a number of conidia were observed which produced several amoeba-like bodies, emerging in each case from the apical end of the conidium. After a short period, during which they moved about in the typical amoeba-like manner, they came to rest and became globose as do the zoospores.

According to Viala (1893), the optimum temperature for germination is from $28^{\circ}$ to $30^{\circ} \mathrm{C}$. At this temperature the zoospores are produced in about one-half hour. At temperatures from $10^{\circ}$ to $17^{\circ} \mathrm{C}$., germination only occurs after two or three days and a temperature of $2^{\circ}$ to $5^{\circ} \mathrm{C}$., prevented germination entirely. Istvanffi (1913), on the other hand, states that the optimum temperature for germination is from $20^{\circ}$ to $22^{\circ} \mathrm{C}$, while at $28^{\circ}$ to $30^{\circ} \mathrm{C}$. germination practically ceases, being feeble at the end of six to ten hours. He found that after two or three hours there is profuse germination at a temperature of $14^{\circ}$ to $15^{\circ}$ becoming slight at $8^{\circ} \mathrm{C}$. Melhus (1911) states that a temperature of $10^{\circ} \mathrm{C}$ : is most favorable to conidial germination.

During the summer of 1912 numerous attempts were made to germinate the conidia at room temperatures, $70^{\circ}$ to $80^{\circ} \mathrm{F}$, and often as high as $90^{\circ} \mathrm{F}$. In some cases there was absolutely no germination after two or three days. All variety of condition were given except to change the temperature because at this time facilities were lacking for that type of experiment.

In 1913 an ice-box was used in which a temperature of $50^{\circ} \mathrm{F}$. easily could be maintained. At this temperature fully 95 per cent germination was always obtained in two to six hours, averaging about three hours. At $70^{\circ} \mathrm{F}$. only 40 to 50 per cent of the conidia germinated, in about one-third of the time, however, while at $80^{\circ}$ to $90^{\circ} \mathrm{F}$. there was no germination. When the slides holding the spore-laden drops were placed directly upon the ice, thus obtaining a temperature of $35^{\circ}$ to $41^{\circ} \mathrm{F}$., a slight germination by means of zoospores occurred in about twenty-four hours. Another point which was observed concerning the spores maintained at low temperature is that the zoospores continue active for a much longer time than at the higher temperatures. In the latter case the writer (1913) has found that it is common for them to rest in about thirty minutes and to have completely germinated in three to twelve hours. In the former, the zoospores are still active from twenty-four to thirty hours after germination. In the opinion of the writer the optimum temperature for germination lies between $50^{\circ}$ and $60^{\circ} \mathrm{F}$.

Speaking of the effect of light upon the conidia Cuboni (1889:33) says: "the conidia which have been exposed to an intense light for some time, according to my observations, are sterilized and unable to germinate." Istvanffi (1913) makes a similar statement to the effect that conidia placed in water in the morning and maintained in obscure illumination germinate during the afternoon while those which were placed in strong light did not germinate until the following morning. Melhus (1911) states, however, that if the temperature is low, light will have no effect on germination.

In this connection the writer has conducted experiments and made certain observations. Conidia were placed on ice in a glass chamber and 
exposed to strong sunlight but so far as could be observed the germination was as rapid as in the case of spores placed in an ice-box. Furthermore, conidia have been placed in a drop of water suspended from the cover of a Van Tiegham cell and the culture placed on the stage of the microscope, for continuous observation. In this case a strong light continually passes through the culture. By this method of procedure germination has been obtained in one-half to one hour. In our opinion the failure to germinate, apparently caused by strong light, may be due rather to a higher temperature. Indeed, Farlow (1876) states that the direct rays of the sun heats the water causing such rapid evaporation that germination could not occur.

According to Istvanff (1913) a certain proportion of the conidia which do not germinate are still immature even though they may be of full-size. He says . . (free translation) "the conidia in which karykinesis is already completed are not necessarily mature even though they have attained their full size. We have observed that the conidium still undergoes certain transformations if they are maintained in a moist atmosphere, namely, that the plasma becomes more reticulated in structure. These changes occupy about three or four hours. During this period the vacuoles become larger . . . and if examined in water the plasma appears granular."

It is certain that one who has studied conidial germination for some time will be able to state readily and with a fair degree of certainty, which conidia will not germinate. To describe this distinction is difficult but in general it may be said to be that the protoplasm of immature conidia appears more finely granular, denser and to have a much deeper greenish color. Before germination the protoplasm becomes more hyalin and less dense probably due to the appearance of the numerous vacuoles, noted by Istvanffi.

On the other hand the conidia may be too old to germinate, as has been pointed out previously by the writer (1913). Such conidia are characterized by the coarsely granular, brown protoplasm.

A third type of conidia, to which Istvanffi takes exception, has also been described by the writer, as "partly or wholly filled with a highly refractive drop which appears to be oleaginous in nature". Istvanffi admits that a conidium treated with osmic acid becomes a deep brown indicating the posslble presence of some oily substance but he claims that the oil is present as minute drops. In this same connection both Viala (1893) and Patrigeon (1887) state that there are numerous brilliant or refringent drops present in the conidium. At the same time, Istvanffi states that the supposed error may be due to the fact that vacuoles are very abundant in the conidium and that these, being clear, "may resemble the ordinary refringence of the drops of oil." It will be noted that the writer stated that these refringent bodies remain in the conidium after germination. If vacuoles had been mistaken for independent bodies in the protoplasm, would they remain as such in an empty conidium? There is no question that in some cases, a clear, highly refringent, and well-defined body or "drop" remains in the conidium after germination. Its exact composition has not been determined but the possibilities are either oil or glycogen.

The vitality of the conidia varies with the conditions of humidity and temperature. Istvanff states that at a temperature of $8^{\circ}$ to $10^{\circ} \mathrm{C}$. they will retain their vitality for two or three weeks and if placed directly upc. 
1ce may be germinated after sixty days if optimum conditions be afforded. In warm, dry air they perish in five days.

The writer has germinated conidia which have been kept for two weeks at a temperature of $10^{\circ} \mathrm{C}$, , while those kept in a moist chamber at room temperature lost their vitality in from seven to ten days. It seems safe to assume that the conidia will retain their vitality in nature about a week.

The season makes no apparent difference in the germinative power of the conidia. As good germination has been obtained in October from conidia collected on wild vines as during the summer.

The germination of the conidia has been described by the writer (1913) but will be rewritten at this time in order that changes in certain details may be more intelligibly indicated. "At first the protoplasm is finely granular but about an hour after being placed in water there appear lighter hyaline spots in the protoplasm, which at the same time becomes a little denser and more granular." When stained with methylene blue it will readily be seen that the "hyaline spots" are the nuclei. "This continues until there is a dense granular mass with clear, distinct spots arranged at regular intervals. In a short time there appear in the protoplasm dark lines which mark out portions about each nucleus. These lines become more and more distinct and finally there are slight indentations along the margin of the previously smooth protoplasm. The content of the conidium is now very rough and irregular. By focusing, the individual swarmspores can be made out. In a few minutes the spores break apart and become distinct bodies. out until the opening becomes maximum in size when the entire mass of At this point there is a pause during which it seems that the spores must burst forth immediately and, coincidently, there seems to be a slight movement among them. Suddenly through the tip of the conidium there appears a bit of protoplasm of one of the swarmspores which slowly forces its way spores, jerkily but rapidly, slips out. it is quite certain that the opening is at the papilla, and is probably brought about by the dissolution of the wall at this point and not by its breaking, since no remnant of the wall can be found after evacuation." Istvanffi (1913) claims that the papilla is a cap-like structure which is pushed off when the zoospores emerge. The writer watched this process very closely and has fixed and stained conidia in all stages of germination but has never seen anything which might possibly be interpreted in this way.

During the preliminary stages of germination the conidium swells slightly, as Farlow (1876) has already intimated, probably due to the imbibition of water. Ordinarily the increase in size is about $1 \mu$ in both length and breadth. After the evacuation of the zoospores the size decreases about $2 \mu$, becoming much smaller than the original conidium. Ultimately the conidial wall becomes greatly wrinkled and shriveled.

"The swarmspores remain for an instant at the end of the conidium and then pull apart and swim away." In this connection Farlow states, "They passed out rather slowly, usually one at a time, and paused for a moment in front of the cpening, where they remained as if not yet quite free from one another. In a short time each segment began to extricate itself from the common mass, moved more and more actively, and finally darted off with great rapidity a full-fledged zoospore, furnished with two cilia." The writer states further, "It is quite probable that the flagella are formed 
at this time by the pulling apart of the spores. There is a considerable jerking and wrenching before they separate. At times two spores remain attached for a long time and finally, by dint of much pu'ling, they snap apart and swim away. At other times as many as four or five spores are apparently joined together by their flagella. Thus it would seem that the flagella are s'ender threads of protoplasm pu'led from the spores as they split apart." Clinton (1906) has made a similar suggestion in the case of Phytophthora phaseoli, videlicet, "The motion is due to a slender thread or a cilium drawn out by the pulling apart of the narrow zone connecting two adjacent bodies . . . Istvanffi (1913.13) claims that the flagella are present on the spores before they emerge from the conidium and infers that there is no hesitation after emergence. He does not, however, figure them in this way. We have never seen the flagella on the newly formed zoospores in the conidium before evacuation though they were very clearly stained on those which were free and upon mature zoospores which were unable to escape from the conidium (vide post). Hence it is the writer's opinion that the flage!la are produced during the period of emergence or while the zoospores are hesitating at the apex. The method of staining with methylene blue and carbol-fuchsin, has also revealed the fact that the spores are not connected by their flagella but by other minute strands of protoplasm (Pl. III, fig. 7).

"Sometimes all of the swarmspores do not escape from the conidium at once, but one or two remain swimming about within. These spores experience considerable difficulty, so to speak, in escaping, seeming to be unable to squeeze their nuclei through the opening. If they do manage to escape they are usually constricted at the center into a dumbbell shape.

"The number of zoospores produced varies greatly. The large conidia may produce as many as fifteen to seventeen while some small ones have only one or two. The normal number is five to eight."

"The conidia containing the oil drop germinate readily at times. In this case the oil drop is left behind in the conidium, the entire mass of protoplasm going to make up the swarmspores."

"The shape of the swarmspores is plano-convex with a keel or ridge along the flat side. In the center near the flat surface there is a light hyaline spot, the nucleus. Near it, and less brilliant, is another spot which by tinting with stains appears to be a vacuole. From two points on each side of the nucleus arise the flagella, which are of unequal length (Pl. III, fig. 6)." Certain of the European investigators, Viala (1903) and more recently, Ravaz and Verge (1913), have stated that the flagella are terminated with a small lobe. According to the writer's observations this lobe is never present but at times the end of the flagellum may form a small loop which gives such an impression. In this connection, Istvanffi says ". . . Treated according to the methods of Zettnow, one may see that the ends of the cilia are not lobed as they are most often represented, their length is about 15 to $20 \mu . "$

"This is the normal shape of the spores but there are many exceptional shapes produced at times. It is quite apparent that when the spores are newly formed and escaping from the conidium, they are very plastic and capable of taking any form, but once they are fixed in any given shape it is difficult for them to change. Thus, if in pulling apart the spore becomes pyriform or some irregular shape it remains so. 
"It has been stated by some authors that the swarmspores are constantly changing their shape when swimming about. It appears to the writer, however, that there is no actual change, the apparent change being due to the rolling motion of the spores as they swim. This, combined with their peculiar shape, produces the illusion."

"The size of the swarmspores varies, being 6 to 7 by 7.5 to $9 \mu$. The flagella are from 27 to $33 \mu$ in length."

"After swimming about for approximately one-half hour the swarmspores gradually come to rest, round up and surround themselves with a thin membrane." It has been previously pointed out that they may continue active for a much longer time if the temperature is low. "They apparently do not immediately 'drop' their flagella but, rather, absorb them, because, after becoming globose, they continue to whirl and move back and forth until they gradually come to rest. They would probably stop abruptly if the flagella were immediately dropped. Staining which has clearly revealed the flagella on the motile forms, has failed to reveal them lying free among the quiescent forms in the same preparation."

"The spores remain globose for fifteen minutes, more or less, and then there appears a slight protuberence from one side. This is the germ-tube. It elongates and the contents of the spore follow. This continues until the contents have passed out into the tube, leaving the thin wall. After the tube reaches a certain length there may be produced an appressorium from which another tube arises later." In certain cases it has been observed that the swarmspores do not germinate but become very much more granular and finally seem to disintegrate entirely. At times this occurs almost to the exclusion of the germination.

"The germ-tube grows parallel to the surface of the leaf until a stomate is encountered when it turns sharply downward, passing through the opening into the leaf but never penetrates the epidermis directly. In order to pass through the stomatal opening the germ-tube becomes very greatly attenuated, being .4 to $.8 \mu$ in diameter but swells immediately after passing into the sub-stomatal cavity forming a structure which, at times, closely resembles the germinating spore (Pl. I, figs. 1 to 11 ).

Pole-Evans (1907) has termed a similar structure in the case of the rusts, a sub-stomatal vesicle. Istvanffi interprets it in this case, however, as a secondary spore. Its assumed function may best be stated in his own words. "The physiological role of the secondary spore is in our estimation to assure the ulterior development of the germinating zoospores, for this reason all the protoplasm of the zoospore passes into the secondary spore which is well protected against all unfavorable exterior factors in the moist sub-stomatal cavity." This explanation of the peculiar behavior of the germtube seems very reasonable. The term "secondary spore" is, in the writer's opinion, also very apt because in many instances, in fact in practically all instances, it closely resembles the spore from which it arose. It germinates by means of one or more slender hyphae (Pl. I, figs. 2, 4, and 11), and according to the writer's observations does not produce haustoria hence does not serve to absorb food except that which may possibly be present in the intercellular spaces.

There are many variations in the size and form of the secondary spores. In some cases, especially in the leaves of susceptible varieties, the entire 
cavity is filled by the irregular mass (Pl. I, fig. 5). In other cases the diameter is hardly more than that of the primary spore (Pl. I, fig. 1). In this case the shape is usually pyriform. The size varies from 6 to 22 by 17 to $27 \mu$.

As has been indicated above there arise from the secondary spore one or more strands of mycelium which radiate in different directions into the tissue of the leaf. These do not average more than 2 to $3 \mu$ in diameter. The exact time elapsing before the haustoria are produced has not been determined but in all material examined by the writer they are not formed on the secondary spore as is figured by Istvanffi, nor are they developed from the mycelium immediately.

The incubation period varies with the weather, the variety, the season of the year and the portion of the plant affected. Istvanffi states that during the spring the incubation period is longest and that it gradually grows shorter until the early part of August after which it again lengthens. The periods as he determined them are May, 15 to 18 days, June, 11 to 14 days, July, 6 to 7 days, August, 5 to 6 days and late August to September, 9 to 11 days. On the fruit the period averages from 2 to 5 days longer.

The varieties Delaware, Niagara, Catawba and Clinton were inoculated during the summer of 1913. It was found that on the first three, which are relatively more susceptible than the last, that the period of incubation was from 7 to 12 days, while on the Clinton under the same conditions, the period was 20 days.

The difference exhibited in the incubation period on the Delaware and Clinton begins to be evident in the earliest stages of infection. Penetration of the germ-tube through the stomatal opening occurs in 3 to 5 hours in the leaves of the Delaware, while on the variety Clinton penetration apparently does not take place until after about 20 hours. In about 36 hours there is a considerable formation of mycelium in the former variety while in the latter the secondary spore has barely germinated (Pl. I, figs. I and II). If this retarding of growth continues it easily explains the great difference in the incubation periods.

Following the method previously described by the writer (1913), numerous infection experiments were performed during the summer of 1913. Sporeladen drops of water were placed at all points on the upper and lower surfaces of the leaves. Notwithstanding the fact that the conditions under which the inoculations were made, were as nearly identical as it was possible to secure, in some cases the inoculations were on the upper and lower surfaces of different leaves in the same inoculation chamber, it was never possiblo to produce an infection through the upper surface of the leaf. The Eur pean investigators report a certain percentage of successful infections on this surface. Istvanffi has shown that this is true because stomates occur along the mid-rib and the principal veins and about the tips of the leaves, while on the lower surface they are very thickly and uniformly scattered over the surface. According to our observations on several different varieties there are no stomates on the upper surface of the leaves of American varieties. This wou'd explain why it was not possible to infect the upper surface of the leaves.

Istvanffi has shown that there are a few stomates on the ovary of the flower of vinifera varieties and that they do not increase in number. When 
the grape attains the size of a pea there are no stomates on its surface but in their place occur a number of lenticle-like structures. Thus we find again the reason that it is not possible to infect the berries except when they are very small. It can be shown without difficulty that the older berries become infected by mycelium which grows down through the pedicles and peduncles into the fruit. This view is further justified by the fact that there are a few stomates on the pedicle and peduncle thus allowing the possibility of infection at these points.

According to Müller-Thurgau (1911) slight tears or injuries may allow infection through the upper surface. He bases this statement on certain experiments in which this surface was punctured with a needle at the points of inoculation. To verify this statement similar experiments were conducted. Spore-laden drops of water were placed on the upper surface of the leaf at numerous points. In some cases the leaf was punctured with a needle through the drop and in other cases injured before the drop was placed upon the leaf. Checks of drops on the uninjured upper surface and on the lower surface were also run. No infections were obtained except through the lower surface. It was then thought that possibly the openings were not large enough. With this in view another series of experiments was conducted in which the leaf was torn as much as possible without allowing the water to penetrate to the lower surface. In some cases jagged tears fully $5 \mathrm{~mm}$. long were made. As before the results were all negative. Hence in our opinion injuries to the upper surface do not permit infection unless the water is permitted to gain access to the lower surface through the opening so that the swarmspores may swim through the opening.

To determine whether the swarmspores produced from conidia which had fallen on the upper surface of the leaf, might be able to produce infection if conditions were such that they could gain access to the lower surface the following experiments were performed. The leaves were held with the lower surface firmly but not tightly against plates of perfectly clean glass. Drops of water were than so placed that there was a continuous layer passing from the upper surface over the margin and between the leaf and the glass. Fresh conidia were then placed in the water on the upper surface as far as possible from the margin. In three cases out of five (60 per cent) infections occured. In the other cases the explanation of the failure lies in the fact that the film of water was broken on the upper surface of the leaf probably before conidial germination. This indicates that this method of infection is possible but that it may occur only in the most favorable conditions because of the ease with which the film is broken. This is an exact verification of the work of Ravaz and Verge (1911) relative to this same question.

\section{Pathological Histology.}

The chlorophyll, the plastids and at times the nucleus of the cell are eventually disintegrated. This process is gradual, being not only confined to certain cells or groups of cells, but even to the individual plastids within a cell, certain of them remaining green while others are entirely yellow. The first microscopical evidence of this change occurs in about three days after inoculation. 
The cells of the spongy parenchyme are first to exhibit the indications of the disease, followed shortly by the palisade cells. The vascular tissue is never affected but the mesophyll cells immediately adjacent are first to be injured. This is particularly noticeable during dry weather. The epidermal cells may finally die, due rather to the death of the contiguous cells than to the direct effects of the mycelium.

Coincident with the loss of color the cell contents become plasmolysed, the wall collapses and finally' the entire cell becomes brown. This effect seems to occur first in the palisade cells bordering the veins rather than in the spongy parenchyme, as one would expect, thus producing the peculiar network of brown lines so prominent on the upper surface within the yellow area. Gradually all the cells throughout the older portion of the spot are killed, causing the dead brown center. The collapsing of the diseased cells reduces the thickness of the leaf within the lesion to approximately onehalf to two-thirds that of the normal.

The cortex, collenchyma, epidermis, medullary rays and pith of the stems are affected. Istvanffi (1913) states that the phloem and rarely the xylem may also be involved. The writer has never seen any evidence of the disease in these tissues. Farlow (1876) also states that all parts of the stem are affected except the wood. In the writer's opinion this difference can only be interpreted as further proof of the greater susceptibility of the European varieties.
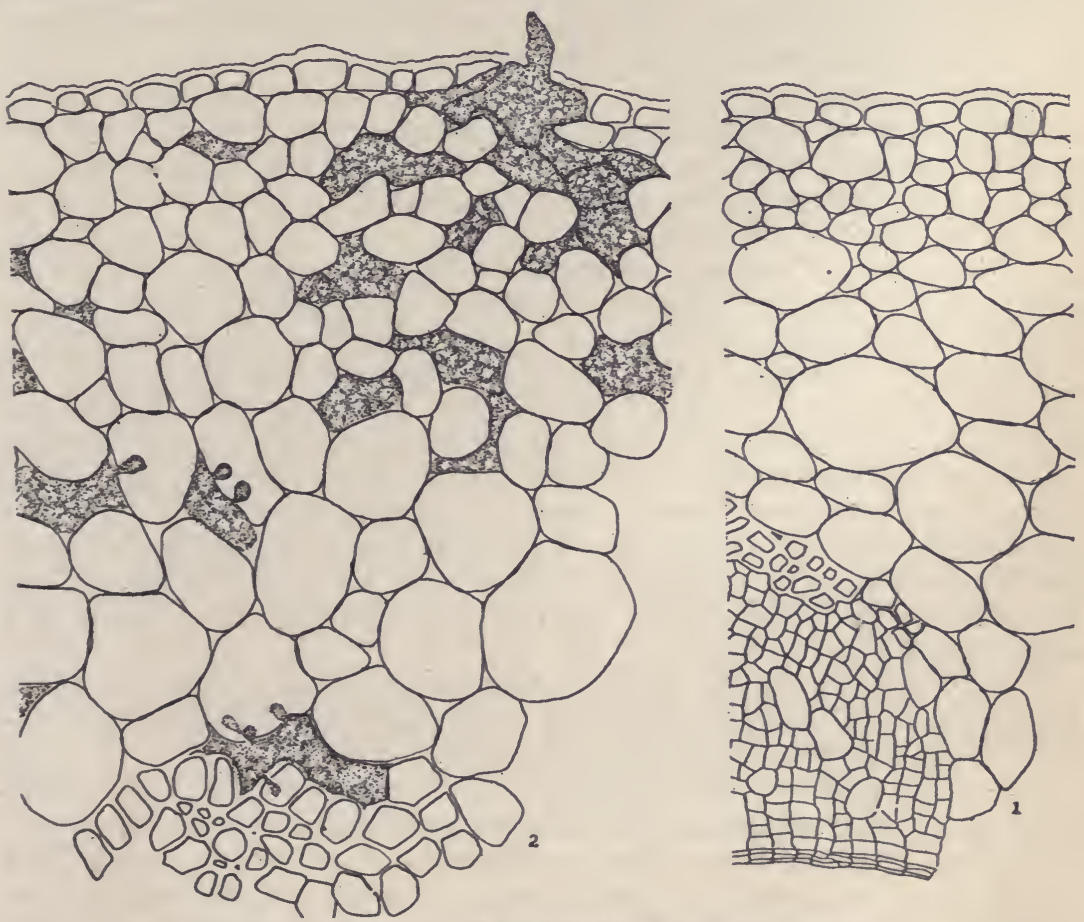

Plate 5. Sections of healthy and diseased shoots. 
The increase in the size of the stem is apparently not due to hyperplasia, but rather to a slight hypertrophy of the cells, and to the intussusception of a large amount of mycelium between the cells. (Pl. V, figs. 1 and 2). The water-soaked appearance of the diseased stems is in all probability the result of an excessive amount of sap in the intercellular spaces. This phenomenon may be caused by a change in permeability of the plasma membrane, possibly induced by the presence of the fungus.

As in the leaf the cells are ultimately killed and collapse, so producing the brown sunken areas in the stem.

In the livid berry the chlorophyll is acted upon as in the leaf and the green color lost, thus giving the peculiar blanched appearance so characteristic of this stage. In a short time the cells begin to collapse; the contents become more or less plasmolysed and the walls brown, resulting in the wellknown soft, brown-rot stage.

The color of the prematurely ripened grapes is located in the outer six or seven layers of cells. It is due to the formation of some red substance in the cell-sap. This may occur in the cells immediately adjacent to the mycelium or several cells distant. It is very similar in appearance to the changes occurring in the normally ripening grape.

\section{Pathological Physiology.}

The question of the resistance or immunity of certain varieties of grapes, of different organs of the same variety, and of the same organ at different ages and seasons has been seriously considered and investigated for some time, particularly during the past five or six years.

Bottini (1909) determined that when leaves of susceptible varieties were immersed in or sprayed with the sap expressed from the leaves of a resistant variety, the former were less easily infected than when water was used. It is his opinion that the concentration of the sap of the resistant variety is the controlling factor in this case.

Laurent (1911) obtained the concentration of the cell sap of different parts of a vine and from different varieties. The method employed was to determine the freezing-point of the expressed juice, the freezing tempeature, according to Livingston (1903) varying inversely with the concentration or the osmotic pressure. In this manner it was determined that the cell sap of the older leaves is much more concentrated than that of the younger leaves and that the sap of the berries is much less concentrated than either. In every case the least resistant parts of varieties contained less concentrated sap. With this as a basis he formulates the theory that resistance is the result of a more highly concentrated cell sap. He points out further that Müntz has stated that resistance becomes greater as the water content falls below 60 per cent.

Cercelet (1912), Capus (1913), Larue (1912) and many other European investigators are of the same opinion concerning the explanation of resistance. Cercelet states that nitrogen, inducing a succulent growth raises the water content and thus tends to render a vine more susceptible. On the other hand, potash and phosphate are said to increase the concentration of the cellsap. Capus has made many interesting observations in this connestion. He claims that vines grown on a gravelly soil are in general more resistant than those on a clay soil. In his opinion there are three stages of resistance in the 
leaves, being susceptible when young, gaining immunity with maturity, and again becoming susceptible in the latter part of the season. The writer has also made a similar observation. This change is most strikingly exhibited in the more susceptible varieties. It does not occur, however, in young vines in a nursery nor is it so apparent in cold rainy seasons. He also claims that, unless the vine is in a receptive state, infection will not occur regardless of how favorable the other conditions may be. It is not clear, however, exactly what is meant by the condition of receptivity.

Istvanffi and Palinkas (1913) are of the opinion that susceptibility depends on the vapor tension in the sub-stomatal cavity and the other intercellular spaces, upon the turgor of the cells and to a certain extent upon the chemical composition of the cell sap, since chlorotic leaves are relatively resistant.

On the other hand, Averna-Sacca (1910) is of the opinion that the composition of the cell sap may be the important factor. To be more specific, he claims that the acidity plays an important part in rendering a vine resistant. In support of this contention he points out that the acidity of resistant forms varied from 4.3 to 10.3 per cent, whereas the acidity of the more susceptible varieties is only .5 to 2.6 per cent.

Resistance to the mildew does not seem to be due to any morphological characters of the leaf. The densely matted hairs on the lower surface of the leaf of certain varieties cannot be a factor, since it has been determined that small drops of water readily permeate them to the surface of the leaf. Furthermore many of our most resistant forms are smooth leaved while certain of those which are most susceptible are densely clothed with hairs. The writer has determined that there are several thousand more stomates per square centimeter on the leaves of certain susceptible varieties than on those of resistant forms but in any case there are amply sufficient to permit ready infection.

Infection experiments may offer some explanation of resistance. In the case of the Delawares the germ tube very readily penetrates the stomate and makes a rapid and prolific growth within the leaf, whereas after the tube has penetrated the stomate of the leaf on a Clinton it seems to encounter some influence which checks its growth, the substomatal swelling is smaller, the secondary mycelium is more attenuated and the growth during a given period is much less.

A consideration of the difference in the abundance of fruiting on the leaves of susceptible and resistant varieties is also significant. It is evident that in order to produce an abundance of spores the fungus must absorb sufficient food material and an insufficient or unavailable supply will reduce the number of spores. Granting this we may say that the food in the resistant forms is not available or that some influence is present which resists the assimilation of the available food, because the fructification on the resistant varieties is strikingly less than on the more susceptible forms.

The apparent immunity of the berries is due to the waxy covering which hinders the adhesion of water to their surface and to the lack of stomates. That this resistance is only apparent immediately becomes evident if the fungus obtains entrance in some other way. The growth of the mycelium is very rapid and the berry is quickly rotted. 


\section{Bibliography.}

Arbois de Jubainville. 1883.-Peronospora viticola de By. Neuchateau.

Averna-Sacca, R. 1910.-L'acidita delle piante in rapporto alla resistanza contro gli attachi dei parassiti. Staz. Sper. Agr. Ital. 43:185-209.

Bary, A. de. 1863.-Recherches sur le développement de quelques champignons parasites. Sci. Nat. France Ann. 4:20:5-148. pls. 1-13.

Baillon, H. 1888.-Sur un mode particulier de propagation du mildew. Mensuel Bul. Linn. Soc. Paris. 96:575.

Berlese, A. N. and de Toni, J. B. 1888.-Sacc. Syl. Fung. 7:239.

Berkeley, J. M. and Curtis, M. A. 1848.-Rav. Fungi Carol. Exsic. Fasc. v. n. 90.

Bottini, E. L. 1909.-La Peronospora viticola. Contributo allo studio delle cause interne chi inducono una diversa resistenza dei vitigni alla peronospora. Agr. Ital. pp. 1-8. Cited from Hollrungs. Gebiet. Pflanzkr. 13:293.

Capus, J. 1913a.-Les avertissements pour le traitement des maladies cryptogamiques de la vigne. Rev. Vit. 39:505-509, 545-548, 613-618, 720-724.

1913b.-Les facteurs des invasions de mildiou. Rev. Vit. 40:228-232.

Cercelet, M. 1912.-Le traitement du mildiou Rev. Vit. 39:629-633.

Clinton, G. P. 1906.-Downy mildew, Phytophthora Phaseoli. Thaxt. of lima beans. Connecticut Agr. Exp. Sta. Rpt. 1905:288.

Cornu, M. 1882.-Etudes sur les Peronosporées. 2:1-89. pl. 2-4.

Cuboni, J. 1889.-Peronospora des grappes. French translation pp. 7-46. pl. 2.

Farlow, W. G. 1876.-The American grape mildew. Bussy Inst. Bul. 1:423.

Frechou, M. 1885.- Sur un nouveau mode de transmission du mildiou de la vigne. Acad. Sci. (Paris) Comp. Rend. 100:396-397.

Gregory, C. T. 1913.-Spore germination and infection with Plasmopara viticola. Phytopath. 2:235-249.

Istvanffi, G. and Palinkas, G. 1913a.-Etudes sur le mildiou de la vigne. Inst. Centr. Ampel. Roy. Hong. Ann. 4:1-122. pls. 1-9.

1913b.-Etudes sur le mildiou de la vigne. Rev. Vit. 40:481-484, 509$513,540-543$.

Larue, P. 1912.-Essais d'infection par le mildiou en Hongrie. Rev. Vit. $37: 416-418$.

Laurent, J. 1911.-Les conditions physique de resistance de la vigne au mildiou. Acad. Sci. (Paris) Comp. Rend. 152:103-106.

Lippincott, J. S. 1866.-Observations on atmospheric humidity. U. S. Dept. Agr. Rpt. 1865:542-550.

Livingston, B. E. 1903.-The role of diffusion and osmotic pressure in plants. Decen. Pub. of Univ. Chicago $2: 3: 37$ and 85 .

Mangin, L. 1890.-Sur la structure des Peronosporées. Acad. Sci. (Paris) Compt. Rend. 111:923-926.

1891.-Sur la desarticulation des conidies chez les Peronosporées. Soc. Bot. France Bul. 38:176-184, 232-236, Pls. 4.

Melhus, I. E. 1914.-A species of Phizophidium parasitic on the oospores of various Peronosporaceae. Phytopath. 4:55-62. pl. IV.

1911.-Experiment on spore germination and infection in certain species of oomycetes. Wisconsin Agr. Exp. Sta. Research Bul. 15:46, 71. 
Millardet, P. M. A. 1883.-Extract of his address to the Society on the oospore infection work. Soc. Sci. Bordeaux Bul. 2:5. XXIX-XXVII.

Müller-Thurgau, H. 1911.-Infektion der weinrebe durch Plasmopara viticola. Centbl. bakt. 2:29:683-695.

Noack, F. 1899.-Rebkrankheiten, in Brasilien, beobachtet. Ztschr. Pflanzkr. 9:1-10.

Patrigeon, G. 1887.-Le mildiou (Peronospora viticola) pp. 9-197.

Pole-Evans, I. B. 1907.-The cereal rusts I. The development of their uredo mycelia. Ann. Bot. 21:441-462.

Prillieux, E. 1883.-Sur la germination des oospores du Peronospora de la vigne. Soc. Bot. France Bul. 30:228-229.

Ravaz, L. and Verge, G. 1911.-Sur le mode de contamination de la vigne par le Plasmopara viticola. Acad. Sci. (Paris) Comp. Rend. 153: 1502-1504.

1913.-La germination des spores d'hiver de Plasmopara viticola. Acad. Sci. (Paris) Comp. Rend. 156:800-802.

Rosenberg, O. 1903.-Ueber die befruchtung von Plasmopara alpina Johan). Kungl. Svenska, Vet. Akad. Bihang. 3:28:3-20. pl. 2.

Saunders, W. 1862.-Remarks on grape culture. U. S. Pat. Off. Rpt. 1861: 495-501.

Schroeter, J. 1886.-Kryptogamen flora von Schliesen. Pilze. pp. 236.

Scribner, F. Lamson. 1886.-Report of the fungous diseases of grape vine. U. S. Dept. Agr., Bot. Div. Bul. 11:7-18.

Smith, G. 1900.-The haustoria of the Erysiphae. Bot. Gaz. 29:153-181. pls. 11-12.

Viala, P. 1893.-Les maladies de la vigne. pp. 57-155.

\section{Plate Legends.}

Plate I. Infection of the grape leaf by Plasmopara viticola.

Plate II. Haustoria and mycelium of Plasmopara viticola.

Plate III. Fructifications of Plasmopara viticola.

Plate IV. A few stages in the development of the oospore.

Plate V. Sections of healthy and diseased shoots.

\section{Plate I.}

Infection of the grape leaf by Plasmopara viticola.

Figs. 1, 2, 4 and 5 are on the leaves of the variety Delaware; the others are on the variety Clinton. $\times 750$.

Fig. 1. Seven hours after inoculation at $50^{\circ} \mathrm{F}$.

Fig. 2. Twenty hours after inoculation at $50^{\circ} \mathrm{F}$.

Fig. 3. Seven hours after inoculation at $50^{\circ} \mathrm{F}$.

Fig. 4. Thirty-six hours after inoculation at $70^{\circ} \mathrm{F}$.

Fig. 5. Thirty-six hours after inoculation at $70^{\circ} \mathrm{F}$.

Fig. 6. Thirty-six hours after inoculation at $50^{\circ} \mathrm{F}$.

Fig. 7. Twenty hours after inoculation at $50^{\circ} \mathrm{F}$.

Fig. 8. Twenty hours after inoculation at $50^{\circ} \mathrm{F}$.

Fig. 9. Thirty-four hours after inoculation at $50^{\circ} \mathrm{F}$.

Fig. 10. Thirty hours after inoculation at $50^{\circ} \mathrm{F}$.

Fig. 11. Thirty-six hours after inoculation at $50^{\circ} \mathrm{F}$. 


\section{Plate II. \\ Haustoria and mycelium of Plasmopara viticola.}

Fig. 1. A haustorium which is still enclosed in the sheath of host cellwall. $\mathrm{x} 650$.

Figs. 2-5. Showing the goblet-shaped sheath about the base of the haustoria. In figures 2,4 and 5 the plasma membrane is pressed inward but not penetrated. x 750 .

Fig. 6. The formation of the mycelial cushion beneath the stomate, previous to conidiophore formation. $\mathrm{x} 750$.

Fig. 7. The mycelium bursting through the epidermis of the petiole to form conidiophores. x 750 .

\section{Plate III. \\ Fructifications of Plasmopara viticola.}

Figs. 1 and 3 show the effects of cuprammonia on the basal portion of the conidiophore. x 300 .

Fig. 2. The basal portion of a normal conidiophore. $x 300$.

Fig. 4. Showing the comparatively slight effect of cuprammonia on the distal end of the conidiophore. $x 300$.

Fig. 5. A conidium attached to the sterigma showing the lenticular disjunctive region. $\times 750$.

Figs. 6 and 7. The zoospores. In figure 7 two of the zoospores are attached by a slender strand of protoplasm. Figure $6 \times 750$. Figure $7 \times 375$.

Figs. 8-10. The germination of the conidia by zoospores.

Fig. 11. Conidia produced by the germination of the zoospore.

\section{Plate IV.}

\section{A few stages in the development of the oospore.}

Fig. 1. A multinucleate oogonium. The nuclei are apparently zonate. Probably following a division since there are disintegrating nuclei occurring abundantly. x 750 .

Fig. 2. An oogonium and antheridium. $\mathrm{x} 300$.

Fig. 3. An oospore containing a single nucleus lying near a dark body which may be interpreted as the coenocentrum. Lying outside of the thick wall are remains of extraneous nuclei. x 750 .

Fig. 4. A single nucleated oospore which contains a coenocentrum and what appear to be remnants of other nuclei lying near. About the margin are other dark bodies, probably the remains of nuclei which migrated from the centrosphere. $x 750$.

Fig. 5. An immature oospore about which the endosporium is being formed. There is an abundant periplasm present. $\mathrm{x} 750$.

Fig. 6. A practically mature oospore, x 750 .

\section{Plate V.}

\section{Sections of healthy and diseased shoots.}

Fig. 1. A cross-section of a healthy petiole of a leaf. $\mathbf{x} 300$.

Fig. 2. A cross-section of the diseased petiole of approximately the same age as that shown in figure 1. This section also was taken from the same position on the petiole. The intussusception of the mycelium very largely explains the hypertrophy of the diseased petiole. $x 300$. 


\title{
METHODS OF PREPARATION AND RELATIVE VALUE OF BORDEAUX MIXTUES.
}

\author{
By O. BUTLER, Ph. D.,
}

Botanist, New Hampshire Agricultural Experiment Station.

I.

Anyone who has perused the literature relating to the copper fungicides cannot but have felt some surprise at the multiplicity of formulae given for the preparation of either Bordeaux mixture of Dauphiny mixture, for instance and at the lack of sufficient ground for this multiplicity. We are, of course, informed by the author of every variant that his formula fulfills certain requirements that justify its publication, though no attempt is usually made to prove the validity of the contention. The characters that a copper fungicide must possess are, however, easily defined; and no formula should be published unless it can be shown to possess in a degree not hithertofore obtained, the essential qualities demanded. I have said that the characters that a copper fungicide must possess are readily defined. They are:

1. The wash must not be toxic to the plant it is destined to protect.

2. The active principle must be efficient, that is, the unit copper must have a high fungicidal value.

3. The active principle must be effective, that is, the unit copper must have a high protective value.

4. The active principle must be adhesive.

5. The active principle must dissolve sufficiently rapidly under the action of the weather to be efficient.

While the literature does not yet afford complete information regarding the manner in which the various copper fungicides meet the five essentials above mentioned, our knowledge has grown sufficiently during the last few years to warrant a brief study of one important fungicide currently used in viticulture, to wit, Bordeaux mixture.

II.

The Bordeaux mixtures used in practice are reducible, as I have pointed out elsewhere, 1 to three types depending on the ratio cupric sulphate to calcic oxide used in their preparation, which three types may be characterized as follows:

1. Neutral Bordeaux mixtures.

2. Slightly alkaline Bordeaux mixtures.

3. Strongly alkaline or basic Bordeaux mixtures.

The neutral Bordeaux mixtures are washes in which the ratio cupric sulphate to calcic oxide is 1:0.2 (Woburn Bordeaux mixture) or approximately 1:0.2 ("acid" Borbeaux mixture). In the former case the copper is

1 Butler, O. Bordeaux Mixture: I Physico-chemical studies, Phytopathology 4:125-180, 1914 . 
precipitated as the basic sulphate $10 \mathrm{CuO} \mathrm{SO}_{3} ; 2$ in the latter $10 \mathrm{CuO} \mathrm{SO}_{3}$ predominates though depending on the strength of the mixture in cupric sulphate and the care with which it was prepared either the next lower or higher basic sulphate may be present to some extent.

The slightly alkaline Bordeaux mixtures are prepared by combining the cupric sulphate and calcic oxide approximately in the ratio of $3: 1$ and are represented by the so-called "neutral" Bordeaux mixture of practice, which consists largely of $10 \mathrm{CuO} \mathrm{SO}_{3}$.

The alkaline or basic Bordeaux mixtures are those washes in which the lime occurs in considerable excess, the ratio cupric sulphate to calcic oxide ranging between the limits $2: 1$ and $0.5: 1$. The copper precipitate in these mixtures, at least when they contain more than 0.5 per cent cupric sulphate, consists largely if not entirely of $10 \mathrm{CuO} \mathrm{SO}_{3}$.

We have seen that in all three types of Bordeaux mixture recognized in practice the copper is precipitated very largely in the form of the basic sulphate $10 \mathrm{CuO} \mathrm{SO}_{3}$. It should, however, be noted that this is only true in general for mixtures that have been recently made, Bordeaux mixtures being, with one exception, i. e., Woburn Bordeaux mixture, quite unstable. while for all practical purposes Woburn Bordeaux mixture may be considered stable, all other forms of Bordeaux mixture deteriorate more or less rapidly depending on their strength in cupric sulphate, the ratio cupric sulphate to calcic oxide used in preparing them, and the temperature at which the washes are kept, as will be seen from the following table:

Table I. Effect of temperature, strength in cupric sulphate, and ratio cupric sulphate to calcic oxide on the rate of deterioration of Bordeaux mixtures.

\begin{tabular}{|c|c|c|c|c|}
\hline $\begin{array}{c}\text { Temperature } \\
\text { of }\end{array}$ & $\begin{array}{l}\text { Strength o } \\
\text { in Cupric }\end{array}$ & $\begin{array}{l}\text { f Mixture } \\
\text { Suiphate }\end{array}$ & $\begin{array}{c}\text { Ratio } \\
\text { Cupric Sulphate }\end{array}$ & $\begin{array}{l}\text { Time Required } \\
\text { for }\end{array}$ \\
\hline Mixture & Per & Cent & Calcic Oxide & Deterioration \\
\hline $25^{\circ} \mathrm{C}$. & & 4 & $1: 1$ & 16 \\
\hline $9^{\circ} \mathrm{C}$. & & 4 & $1: 1$ & 96 \\
\hline $9^{\circ} \mathrm{C}$. & & 4 & $1: 0.5$ & 121 \\
\hline $25^{\circ} \mathrm{C}$. & & 2 & $1: 1$ & 21 \\
\hline $9^{\circ} \mathrm{C}$. & & 2 & $1: 1$ & 192 \\
\hline $9^{\circ} \mathrm{C}$. & & 2 & $1: 0.5$ & 240 \\
\hline $25^{\circ} \mathrm{C}$. & & 1 & $1: 1$ & 8 \\
\hline $9^{\circ} \mathrm{C}$. & & 1 & $1: 1$ & 168 \\
\hline $9^{\circ} \mathrm{C}$. & & 1 & $1: 0.5$ & 192 \\
\hline $25^{\circ} \mathrm{C}$. & & 0.5 & $1: 1$ & 5 \\
\hline $9^{\circ} \mathrm{C}$. & & 0.5 & $1: 1$ & 72 \\
\hline $9^{\circ} \mathrm{C}$. & & 0.5 & $1: 0.5$ & 336 \\
\hline $9^{\circ} \mathrm{C}$. & & 0.5 & $1: 0.2$ & ....... \\
\hline
\end{tabular}

On standing, for instance, the so-called "acid" and "neutral" Bordeaux mixtures gradually decompose with the formation of cupric oxide, while the copper precipitate in the basic Bordeaux mixtures, which is highly gelatinous in the freshly prepared washes, gradually changes over into a copper salt, as yet unidentified, which forms blue sphaero-crystals. The three types of

2 For the chemistry of Bordeaux mixture see:

Pickering, S. U., The Chemistry of Bordeaux Mixture, Journ. Chem. Soc. (Transactions) 91:pt. 2, 1907.

Bordeaux Spraying: Journ. Agr. Science 3.171 et seq. 1908-10.

Bedford, Duke of, and Pickering, S. U. Woburn Experimental Fruit Farm Report 11, 25 et seq. 1910. 
Bordeaux mixture met with in practice differ, therefore, more or less markedly from one another, both as regards physical constitution and chemical composition shortly after they have been made, as is indicated in the following table in which the general characteristics of these washes, both at the time of preparation and after no further change takes place, are briefly shown:

Table II. Chief characteristics of the Bordeaux mixture types when prepared and after standing until a state of equilibrium has been reached.

\begin{tabular}{|c|c|c|c|}
\hline $\begin{array}{c}\text { Type of Mixture } \\
\text { Used }\end{array}$ & $\begin{array}{l}\text { Per cent } \\
\text { Cupric } \\
\text { Sulphate }\end{array}$ & $\begin{array}{c}\text { Ratio } \\
\text { Cupric Sulphate } \\
\text { Calcic Oxide }\end{array}$ & $\begin{array}{c}\text { Color of Mixture } \\
\text { When Fresh }\end{array}$ \\
\hline "Acid" Bordeaux Mixture & e $1 \%$ & 1:0.2 approximately & Cendre blue1 \\
\hline "Neutral" " " & $1 \%$ & $1: 0.25$ approximately & Cendre blue \\
\hline Alkaline & $1 \%$ & $1: 0.5$ & Light cerulean blue \\
\hline Strongly alk. Bordx. Mix & $1 \%$ & $1: 1$ & Light methyl blue \\
\hline
\end{tabular}

Color of Mixture -Form of PrecipitateWhen Old Fresh Mixture Old Mixture Fresh Mixture Old Mixture Deep medici blue......Gelatinous.........Flocculent..........10 $\mathrm{CuO} \mathrm{SO}_{3 . . . . . . C u O}$ largely Light medici blue.......Gelatinous...........Flocculent..........10 $\mathrm{CuO} \mathrm{SO}_{3 \text {............ }}$ Bradley's blue............Gelatinous..........Crystalline.........10 $\mathrm{CuO} \mathrm{SO}_{3} \ldots . .$. ? Light amparo blue....Gelatinous..........Crystalline........10 $\mathrm{CuO} \mathrm{SO}_{3} \ldots . .$. ?

Having obtained a knowledge of the general charateristics of the Bordeaux mixtures met with in practice, we may now proceed to study their relative value as fungicides taking up for consideration first the action of these washes on the plant to be protected, i. e., the grape vine.

\section{III.}

The effect of the Bordeaux mixture 3 on the grape vine may be neutral, beneficial, or more rarely deleterious. I shall not attempt to consider the cause of the beneficial action that follows the use of a Bordeaux mixture as it would lead us too far afield to do so. Suffice it to say that this beneficial action, the most obvious feature of which is the darker green color of the sprayed foliage, appears to be more marked when alkaline Bordeaux mixtures are used then when "acid" or "neutral" Bordeaux mixtures are employed. The toxic action of Bordeaux mixtures, on the other hand, is only produced when alkaline washes are employed and is confined, so far as I am aware, to young and growing leaves. All varieties of the grape are not equally sensitive, however, to the action of alkaline Bordeaux mixture and furthermore, if we are to believe Ewart4 injury is either produced within 24-48 hours, or is not produced at all.

1 Ridway, R. Color standards and nomenclature. Washington, D. C., 1912. The colors are to be viewed on a white ground.

3 The statements I shall make during the course of the present chapter are not to be considered as applying either in whole or in part to the effects produced by Bordeaux mixtures on other plants. Whether they will be the same, or whether they will be different, experiment alone can tell.

4 Ewert K. Die fungicide und physiologische Wirkung der Kupferhaltigen Bruhen mit besonderer Berüchsichtigung der Bordeauxbruhe, Mitteilungen des Deutschen Weinbau-Vereins 2, 1907. 
While the toxic effect of alkaline washes is not very serious, as would be inferred from the general silence of the literature, it is sufficiently marked when it occurs, as on the Clinton for example, to arrest the attention of a keen observer. The intervenium portions of the leaf are the most sensitive and the affected tissues in older leaves not infrequently fall away, which gives the injured foliage a somewhat ragged appearance, while the recently expanded leaves are not only scorched but more or less distorted and curled.

The fact that alkaline washes are injurious while "acid" and "neutral" washes are innocuous indicates that the notion, especially current in the horticultural literature of the United States, that increasing the lime content of a given Bordeaux mixture reduces its injuriousness is not, however justifiable it may be in some instances, a practice to be universally recommended; in the case of the grape vine, injury as I have indicated, may result. The injurious action of the alkaline Bordeaux mixtures, however, is hardly sufficiently marked to warrant disregarding these washes should they be found to possess valuable compensating qualities.

IV.

The literature is unanimous in saying that "acid" Bordeaux mixtures are more efficient than "neutral" or alkaline washes. It should, however, be noted that the literature grounds the distinction on the more rapid solubilization of the copper in "acid" Bordeaux mixture and not on the ground of greater toxicity of the unit copper. We must, therefore, in deciding whether an "acid" Bordeaux mixture is more efficient than a neutral or alkaline wash take under consideration the time when they severally become active and not the total time throughout which they remain active.

Let us first consider the relative rapidity with which the copper becomes toxic in "acid," "neutral" and alkaline Bordeaux mixtures. In order for any copper wash to have a fungicidal value the copper must be in the form of a soluble salt, or, if insoluble when applied, become slightly soluble on weathering. In the case of Bordeaux mixtures, the copper is always insoluble when applied, 5 but gradually yields on weathering small amounts of soluble copper. The rapidity with which the copper becomes soluble will depend on the degree of alkalinity of the mixture. The excess of calcic hydrate present must be carbonated before any copper can go into solution, but it seems doubtful that the interval between the time of appearance of soluble copper in mixtures of various degrees of alkalinity is quite so great as Millardet and Gayon 6 found in one of their experiments. These authors obtained the results shown in the following table: copper.

5It should be noted that "acid" Borbeaux mixtures may contain soluble

6 Millardet, A. and Gayon, U. Les divers procedes de traitement du mildiou par les composes cuivreux. Journ. Agr. Pratique 1, 1887.

7 Millardet, A. and Gayon U., loc. cit., ante. 
Table III. Effect of increasing the alkalinity of Bordeaux mixture on the time of appearance of soluble copper.

Cupric Sulphate

Taken

$\%$

1.6

1.5

1.5

1.5

1.5
Ratio

Cupric Sulphate

Calcic Oxide

100:21.0

$100: 22.4$

$100: 44.8$

$100: 89.6$

100.179 .2
Soluble Copper

Present

After

5 days

7 days

12 days

13 days

18 days

Though the rapidity with which the copper in alkaline Bordeaux mixtures becomes soluble will of necessity always be less than in "acid" mixtures, as no soluble copper can exist in the presence of calcic hydrate, it seems however, quite unlikely that the retardation in its appearance is as material as is sometimes thought. To be sure Millardet and Gayon 7 observed that Bordeaux mixture spots might remain alkaline for five or six six weeks in summer and the data presented in the above table unmistakably show that increasing the lime content of a Bordeaux mixture beyond the amount required to produce a neutral mixture delays the appearance of soluble copper. Nevertheless alkaline Bordeaux mixtures lose their alkalinity usually quite promptly, though the amount of spray applied per square meter as well as the degree of atmospheric moisture prevailing at the time, particularly the latter, are factors of paramount importance, as a glance at the following table will show:

\section{Table IV. Time required for 1 per cent Bordeaux mixture 1:1 to become neutral in dry air and in air saturated with water vapor.}

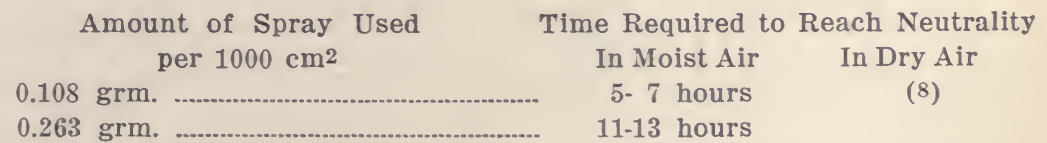

From the-data presented in the above table we gather that the rate at which Bordeaux mixture $1: 1$ becomes neutral is proportional to the amount applied per square meter even under very favorable conditions for carbonation, whereas in absolutely dry air little or no change occurs on long standing irrespective of the quantity used. It is, therefore, clear that the effectiveness of alkaline Bordeaux mixtures will much depend on the weather conditions prevailing during the interim between the time of their application and the period at which protection must be afforded.

While it cannot be questioned that "acid" Bordeaux mixtures are more efficient than alkaline washes when immediate action is required, as in the case of black-rot (Guignardia bidwellii) when the spraying has not infrequently to be carried out during or just prior to spore distribution and germination, this advantage should not in itself be considered of capital importance in preventive spraying, for alkaline Bordeaux mixtures are as efficient as "acid" washes as soon as they have become carbonated. The copper in an "acid" Bordeaux mixture and in a carbonated alkaline mixture of the same age dissolve at approximately the same rate as the data presented in the following table shows:

8 The experiment was discontinued at the end of 14-64 hours. 
Table V. Relative toxicity of neutral and alkaline Bordeaux mixtures to the spores of Phytophthora infestans and Plasmopara Viticola.9

The data presented are for indirect germination, the experiments being carried out according to the method described by Reddick and Wallace.9 The sporangia were placed on the sprayed slides in drops of distilled water and were kept at or near the optimum temperature for germination which usually occurred in the witnesses in about two hours.

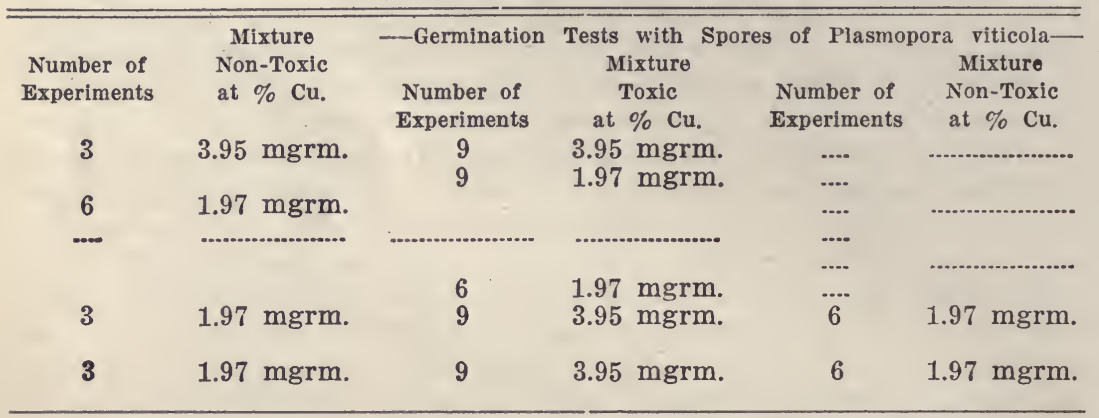

Ratio

Cupric Sulphate

Calcic Oxide

Used

$1: 02$

$1: 03$

$1: 1$

$1: 1.75$

$1: 2$
Amount of Copper Germination Tests With Spores $\left(\mathrm{Cu}_{2}\right)$ Applied per $1000 \mathrm{~cm}^{*}$ (indicative only)

$0.15 \mathrm{mgrm}$.

0.15 mgrm.

$0.075 \mathrm{mgrm}$.

$0.30 \mathrm{mgrm}$.

$0.075 \mathrm{mgrm}$.

$0.30 \mathrm{mgrm}$.

$0.075 \mathrm{mgrm}$.

$0.15 \mathrm{mgrm}$.

$0.15 \mathrm{mgrm}$.

of Phytophthora infestans2
Number of

Expts.

4
7

3

3

3
Mixture Toxic at $\% \mathrm{Cu}$.

3.95 mgrm.

$3.95 \mathrm{mgrm}$.

$7.9 \mathrm{mgrm}$.

7.9. mgrm.

3.95 mgrm.

*The germination tests quoted in this table were kindly made for me by Dr. I. E. Melhus.

From the data presented in the above table we may conclude that the efficiency of the unit copper is the same in all three types of Bordeaux mixtures.

V.

The adhesiveness of the copper fungicides has been studied by various authors whose results for the different types of Bordeaux mixtures currently met with I have gathered together in the following table.

9 Reddick, D. and Wallace E. On a laboratory method of determining the fungicidal value of a spray mixture or solution. Science n. s. 31. 1910 . 
Table VI. Relative adhesiveness of 2 per cent Bordeaux mixtures prepared with various ratios cupric sulphate to calcic oxide.

\begin{tabular}{|c|c|c|}
\hline $\begin{array}{l}\text { Strength in } \\
\text { Copper }\end{array}$ & $\begin{array}{c}\text { Ratio } \\
\text { Cupric Sulphate }\end{array}$ & Adhesiveness \\
\hline Sulphate & Calcic Oxide & Relative \\
\hline Per Cent & & Numbers \\
\hline 2 & 1:0.2 approx. & 64.7 \\
\hline 2 & 1:0.3 approx. & 93.5 \\
\hline 2 & $1: 0.5$ & 100 \\
\hline 2 & 1:0.2 approx. & 64.7 \\
\hline 2 & $1: 0.5$ & 67.8 \\
\hline 2 & 1:0.3 approx. & 100 \\
\hline 2 & 1.1 & 90.4 \\
\hline 2 & $1: 1.5$ & 56.7 \\
\hline
\end{tabular}

Autore
Gastine
"
Guillon \& Gouirand
Kelhofer
"

The data presented clearly show that the ratio, cupric sulphate to calcic oxide, used in the preparation of Bordeaux mixture has a marked effect on the adhesiveness of the wash. A moderate excess of lime produces a more adhesive mixture than either a great excess or minima quantities. To what are these changes due? Let us first consider the case of neutral and approximately neutral mixtures.

The decrease of adhesiveness of Bordeaux mixture as neutrality is approached is not due to the fact that the precipitate formed is less gelatinous than that found in alkaline washes. In fact the rate of settlement of Bordeaux mixtures increases as the ratio cupric sulphate-calcic oxide approaches 1:1 even when the strength of the mixture in copper sulphate is sufficiently high to give rise to the formation of $10 \mathrm{CuO} \mathrm{SO}_{3}$ in all cases as will be seen from the following table.

Table VII. Settlement, in relative numbers, of 1 per cent Bordeaux mixture prepared with different ratios cupric sulphate to calcic oxide.

1\% 1:1 - Settlement after: 1/2 hour, 100; 1 hour, 205; 2 hours, 455. $1 \%$ 1:0.5 - Settlement after: $1 / 2$ hour, $72 ; 1$ hour, 150; 2 hours, 355. 1\% 1:0.25-Settlement after: $1 / 2$ hour, 55; 1 hour, 122; 2 hours, 294. 1\% 1:0.2 - Settlement after: $1 / 2$ hour, $5 ; 1$ hour, 10; 2 hours, 20.

Hence the physical state of the precipitate is not directly the cause of the lesser adhesiveness of "acid" and "neutral" Bordeaux mixtures. The lesser adhesiveness of these washes which is, as we have seen, quite marked, is, however, readily explainable. It will be remembered that the composing precipitate in these mixtures is wholly gelatinous or almost wholly gelatinous, in other words the precipitate is quite homogeneous and in drying will behave like a body, and a stress or strain developed at any point will be accompanied by a reaction in other parts. When, therefore, "acid" or "neutral" Bordeaux mixtures are sprayed on glass, the precipitate dries more rapidly on the surface exposed to the air and in drying shrinks, which results either in fissuring or a curling of the edges, depending on the thickness of the film and the degree of hygroscopicity of the atmosphere. When the washes are sprayed on foliage, the tendency to fissure and curl is greatly augmented owing to the transpiration of the leaves retarding the drying out of the lower surface of the films. I have seen spots of Woburn Bordeaux mixture, for instance, curl up to such an extent that the slightest mechanical 
agency would knock them off. On the other hand, in the moderately alkaline Bordeaux mixtures, i. e., washes in which the ratio cupric sulphate to calcic oxide varies between $1: 0.5$ and 1:1, the precipitate is no longer homogeneous but contains in admixture a considerable number of calcic hydrate particles which effectively prevent the fissuring and curling of the spots on drying; the calcic hydrate particles play a similar role to sand in cement.

Again, in the Bordeaux mixtures in which the ratio eupric sulphate to calcic oxide is greater than 1:1 the spots on drying do not fissure or curl, but their adhesiveness decreases for the same reason, I presume, that an excess of sand weakens cement.

The adhesiveness of Bordeaux mixtures is affected, however, not only by the ratio cupric sulphate to calcic oxide used in their prepartion, but by the length of time elapsed between the time of prepartion and the time of application, the temperature of the water used, the relative dilution of the copper sulphate solution and the milk of lime, and the manner in which the two are combined.

Let us first of all inquire what effect the method of preparation has on the adhesive properties of Bordeaux mixtures. It has been shown by Gastine10 that the method of mixing Bordeaux mixtures affects their adhesiveness as will be seen from the following table.

Table VIII. Effect on method of mixing on adhesiveness of Bordeaux mixture.

Method of Mixing.

Copper and lime equally diluted and poured together simultaneously

Strong lime to weak copper.

Strong to strong.

The method of mixing Bordeaux mixture not only affects its adhesiveness as the above table shows, but we also have abundant evidence to show that the method of mixing employed also affects the rate of settlement of the precipitate formed. It would seem, therefore, that one is justified in assuming that a close relation exists between rate of settlement and adhesiveness, though the data at present available are not sufficiently extensive to warrant one drawing definite conclusions regarding the superiority of any one method of prepartion to the exclusion of all others. If one prepares, for instance, a series of 1 per cent Bordeaux mixtures (1:1) as per the following methods:

1. Strong lime to strong copper

2. Strong lime to weak copper

3. Weak lime to strong copper

4. Lime to copper equal strengths

5. Lime and copper equal strengths poured together simultaneously

6. Copper to lime, equal strengths

7. Weak copper to strong lime

8. Strong copper to weak lime

9. Strong copper to strong lime11

he will obtain the results indicated in the following table, a perusal of which will show that there are at least four methods of mixing 1 per cent

10 Loc. cit.

11 The mixtures were prepared as follows:

In method 1 the requisite amount of a stock solution of cupric sulphate was taken and water added to $30 \mathrm{cc}$; the calcic oxide was freshly slacked 
Bordeaux mixture 1:1 that produce more slowly settling washes than the so-called standard or American method, i. e., diluting equally the copper sulphate and the milk of lime and pouring them together simultaneously. Do these four methods of mixing produce more adhesive or less adhesive mixture than the standard method? As regards one of them, the addition of strong lime to weak copper, the figures obtained by Gastine indicate that it is slightly less adhesive, but in the matter of the other methods we are at present without data.

\section{Table IX. Relative rate of settlement at the end of two hours of 1 per cent Bordeaux mixture $(1: 1)$ prepared in various ways.}

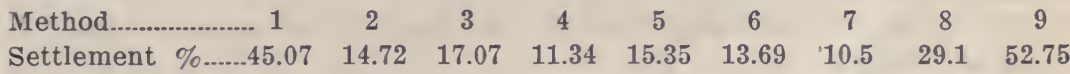

Besides the method of mixing employed, the temperature of the water used in preparing Bordeaux mixture has a marked influence on the rate of settlement of the preciptate. Taking 1 per cent Borbeaux mixture $(1: 1)$ as an example we find that the cooler the water the slower the rate of settlement, the results obtained for a temperature range between $15^{\circ} \mathrm{C}$. and $30^{\circ} \mathrm{C}$. being extremely striking as is shown in the following table:

\section{Table X. Effect of temperature of water on rate of settlement of 1 per cent Bordeaux mixture $(1: 1)$.}

Temperature $15^{\circ}$ C., settlement after: $1 / 2$ hour, $3.5 ; 1$ hour, $8.5 ; 2$ hours, 18 Temperature $24^{\circ} \mathrm{C}$., settlement after: $1 / 2$ hour, $6.8 ; 1$ hour, $14.5 ; 2$ hours, 28.2 Temperature $30^{\circ} \mathrm{C}$, settlement after: $1 / 2$ hour, $9.5 ; 1$ hour, $21.25 ; 2$ hours, 38.2

VI.

I said in the beginning that a copper fungicide must possess to a high degree the following five characteristics:

1. The wash must not be toxic to the plant it is destined to protect.

2. The active principle must be efficient, that is, the unit copper must have a high fungicidal value.

3. The active principle must be effective, that is, the unit copper must. have a high protective value.

4. The active principle must be adhesive.

5. The active principle must dissolve sufficiently rapidly under the action of the weather to be efficient.

and the milk of lime diluted to $30 \mathrm{cc}$; the milk of lime was then poured into the cupric sulphate solution, and water added to $100 \mathrm{cc}$. In method 2 the stock solution of cupric sulphate was diluted to $85 \mathrm{cc}$., the freshly slacked lime to $15 \mathrm{cc}$.; the milk of lime was then poured into the cupric sulphate solution. In method 3 the cupric sulphate solution was made up to $15 \mathrm{cc}$., and the milk of lime to $85 \mathrm{cc}$. The milk of lime was then poured into the solution of copper sulphate. In method 4 the stock solution of cupric sulphate and the milk of lime were both diluted to $50 \mathrm{cc}$.; the milk of lime was then poured into the cupric sulphate. In method 5 the reagents were diluted as in method 4 and were simultaneously poured into a third vessel. Method 6 is the converse of method 4. Method 7 is the converse of method 3. Method 8 is the converse of method 2. Method 9 is the converse of method 1 . 
Using the above criteria in the study of the three types of Bordeaux mixture met with in practice, to wit, "acid" Bordeaux mixture, "neutral" Bordeaux mixture, and alkaline or basic Bordeaux mixture, I have attempted to show in how far these several washes meet the requirements and conclude as a result of this conspectus as follows:

I. "Acid" and "neutral" Bordeaux mixtures are less injurious to the grape than alkaline washes.

II. The toxic value of the unit copper in "acid," "neutral" and alkaline Bordeaux mixtures is the same.

III. The unit copper in "acid" and "neutral" Bordeaux mixtures is more effective when immediate action is required than the unit copper in alkaline washes.

IV. Alkaline Bordeaux mixtures are more adhesive than "acid" or "neutral" washes.

\section{$\checkmark$ SULPHUR FUNGICIDES.}

By GEO. P. GRAY,

Chemist, Insecticide and Fungicide Control Laboratory, University of

California, Berkeley.

The honor of a place on your program was accepted with some reluctance as it was felt that the subject of sulphur fungicides could be far better discussed by one of more practical training and experience. Of recent years, however, the chemist is finding an increasing number of opportunities for usefulness in nearly every branch of human activity. From time to time he has been called upon to contribute his share toward the solution of some of the vexing problems arising in the control of insects and fungi. The examination of materials incident to the administration of the insecticide and fungicide laws of the United States and of a dozen or more states is largely a chemical problem. There has thus been created, especially in the United States, an absolute necessity for a more comprehensive knowledge of the composition and properties of insecticides and fungicides. As a natural consequence, a bond of common interest has resulted between the viticulturist, entomologist, plant pathologist, horticulturist, and chemist.

set In view of the preceding remarks there is offered a chemically flavored discussion of the different kinds of sulphur and of the composition and properties of some of the sulphur fungicides which might be of interest to viticulturists.

It is thought that such a discussion may be an aid toward a more complete understanding of these materials and of their relative merits for the uses to which they may be put to meet various conditions.

The paper is not presented with the intention of offering advice on any phase of viticultural practice nor to recommend any particular substance or 
compound or manner of treatment as a remedy for the ills that may befall a vineyard. The properties and relations of the sulphur fungicides are to be impartially discussed, leaving the choice of materials to those who are better qualified to judge.

Befcre taking up the main part of the paper, a brief survey of the sources of the world's supply of sulphur and particularly that of the United States and an outine of refining methods may be of interest.

\section{SOURCE OF THE WORLD'S SUPPLY OF SULPHUR.}

1Largely abstracted from "Mineral Resources of the United States, Ca'en. dar year 1913." U. S. Geological Survey. Chapter on "Sulphur, Pyrite, and Sulphuric Acid," by W. C. Phalen.

Sicily is the leading sulphur-producing country of the world, the normal production of this country being about 400,000 metric tons annually. Sicily's production for the year ending July 31,1913 was 351,752 metric tons $(346,213$ long tons). The production has been gradually decreasing during the last two years while that of Its nearest rival, the United States, has been increasing. The cause of the decline in the production of the Sicilian sulphur is attributed to "the destruction by explosion of one of the more important mines which had previously produced an average of about 30,000 metric tons a year; the failure to discover new deposits of sulphur during the last decade; the continual deepening of all the existing mines, with consequent increased cost of mining; the working out and inundation of a number of mines; the lack of labor and its increased cost due to the continuous emigration; and finally, the law of June 30,1910 which restricted the granting of sulphur mining concessions. All these causes lead to the belief that the annual output of Sicilian sulphur in the future will not exceed 400,000 metric tons."

The United States is the second important sulphur producing country of the world, having produced 311,590 long tons in 1913. Notwithstanding this notable production, there was imported in the same year some 22,000 tons, the Pacific Coast receiving nearly two-thirds of the imports in the form of crude sulphur. Previous to 1900 the production of sulphur in the United States had not exceeded 5,000 tons. The rapid increase in the production of sulphur in the United States has been due to the development of immense deposits of very pure sulphur in the State of Louisiana. The method of mining the sulphur in this deposit is so novel and the effect upon the sulphur market of the world has been so profound that a description of the process may be of interest.

This great store of sulphur was made available for the use of man by the untiring efforts of Mr. Herman Frasch, who in 1912 was the recipient of the Perkin Medal for distinguished services in the fields of applied chemistry. The following account of the process was given by Professor C. F. Chandler in his presentation address on the occasion of bestowing the medal upon Mr. Frasch:1

"On the 23rd of October, 1890, Mr. Frasch applied for a patent for an epoch-marking improvement in the sulphur industry. It had long been known

1Jour. Ind. Eng. Chem., Vol. 4, No. 2, page 133. 
that there was a large deposit of native sulphur in Calcasieu Parish, Louisiana, at a depth of one thousand feet below the surface. But all attempts to get at the deposit and bring the sulphur to the surface had failed completely, on account of the layers of quick sand above the deposit. Mr. Frasch evolved the idea of melting the sulphur in place, by means of superheated water forced down a boring, and forcing the melted sulphur to the surface, through an inner tube. During the period beginning October 23, 1890, to February 6, 1905, Frasch has applied for ten patents for his inventions of apparatus and processes for accomplishing this result.

"His efforts have been entirely successful. The Union Sulphur Company was organized, he secured control of the sulphur deposit, set up the batteries of boilers, bored the wells, built the railroad to carry the sulphur to the seaboard, and the docks at Sabine Pass for the ships which deliver the sulphur to the seaboard.

"There are seven batteries of boilers, each of which runs a well. A single well delivers about four hundred and fifty tons of sulphur per day. In a two months' test, six wells delivered one hundred and twenty-two thousand tons of sulphur, proving the capacity of the mines to exceed the entire consumption of the world.

"The sulphur is pumped into bins about fifty feet high constructed of planks, where it congeals and forms a block of from seventy-five thousand to one hundred and fifty thousand tons, over ninety-nine per cent. pure sulphur. The planks are subsequently removed, the huge biock is broken up by blasting, and the sulphur is loaded directly into the cars by a scooping derrick which picks up two tons at a time."

In 1912, mining operations began on a deposit in Texas very similar to the Louisiana deposit and also believed to be very large. The mine is operated in very much the same way and it is thought that Texas sulphur will be in the future no small part of the world's output.1

Wyoming also produces a small quantity of sulphur. The sulphur here is mined in open cuts, the ore in places containing as high as 40 per cent. sulphur. The material as mined, however, contains from 15 to 25 per cent. "At the refining plant the sulphur bearing rock is drawn into perforated steel cars which are run in groups of three into a retort. Steam is supplied from two 16-foot boilers, and the liquid sulphur is drawn into wooden tanks, where it is allowed to solidify. The sulphur is broken, crushed to pass through a 20-mesh sieve, and sacked for shipment."

Deposits of easily workable sulphur also exist in Utah and Nevada.1 Their location, however, is too remote for their products to be a factor in any of the markets outside a radius of one or two hundred miles.

Japan is an important producer and it is from this country that practically the whole supply of the Pacific Coast is obtained, amounting to about 20,000 tons annually. In many respects, the method of extracting sulphur from the ore as employed in Japan is similar to the calcerone process which has been used for many years in Sicily. This latter process is described in

1 "Mineral Resources of the United States, 1913," U. S. Geological Survey, page 7 .

Davis, A. W., Min. Sci., August, 1913, pp. 99-102.

Hamor, W. A., Jour. Ind. Eng. Chem., Vol. 5, No. 4, page 337.

1 Private communication. 
Nelson's "Loose-Leaf Encyclopedia." This treats quite fully of this and other processes of extracting sulphur from its ore. In Sicily the ore is placed in ovens and is melted out from the non-sulphur material by the heat produced by burning a part of the sulphur. The melted sulphur runs off at the bottom into the open to cool. The Japanese process is very similar to this but the sulphur there is found intimately mixed with very fine pumice stone. The ore itself very nearly resembles clay. The fine condition of the extraneous matter does not permit the ready separation by heat as in Sicily. The sulphur ore is placed in cast iron retorts and melted out by means of steam heat, a process called leaching the ore.1

It may seem strange that California, having deposits of easily workable sulphur just across its borders, should receive its supply from the far off country of Japan. Freight rates by land have set up an economic barrier which effectively prevents all the States west of the Rocky Mountains and from British Columbia to Mexico from receiving sulphur of domestic production. The cost of sulphur in Japan plus the freight charges to the Pacific Coast is considerably less than the cost of sulphur at a mine in Nevada on the line of the Western Pacific Railway plus the cost of delivery by rail to San Francisco. Whether or not the opening of the Panama Canal, affording a direct water route from the mines of Louisiana and Texas, will change the source of supply for the Pacific Coast remains to be seen. It may be that still other economic factors of deeper significance will prevent any important change in the sulphur markets of the West.

New Zealand. In 1912 work began on the deposits of sulphur on White Island, New Zealand. The production thus far has not been great enough to be of world consequence.

Mexico. Consul Wilbert L. Bonney 1 reported in 1912 that the great bulk of Mexican sulphur is produced at the mines near Cerritos in the State of San Luis Potosi. The deposit is one of the largest and richest in the world. The production of the mines is about 800 tons per month, one third being consumed in Mexico and the remainder shipped to Germany.

\section{REFINING METHODS.}

The refining methods in use are in themselves quite simple, although the construction of the apparatus may be considerably varied by different refiners. In principle, the process is as follows: Su'phur is placed in a retort and sufficient heat applied to vaporize it. The vapors are conducted into a large chamber having a vent at the top. As the heavier fumes of sulphur, mixed with a small amount of sulphur dioxide, fill the chamber, the air is forced out through the vent at the top. After the removal of the air, the vent is closed and the sublimation continued until the walls of the chamber become too warm to condense the vapors. The chamber is allowed to cool and the sublimed sulphur is shoveled up from the bottom.

The finest grade of sublimed sulphur is that which is deposited farthest from the retort. The sulphurs of intermediate fineness are deposited in order from the most remote part of the chamber well up toward the retort.

1 Private communication.

1 Journal of Industrial and Engineering Chemistry, Vol. 4, No. 3, p. 232. 
Directly beneath the inlet from the retort to the chamber there is deposited a considerable quantity of sulphur more or less run together in a compact mass. This lump sulphur is sold as refined lump or "virgin rock." Around the edges of this mass and out in all directions toward the finer grades there is a deposit which is known as "honey-comb" sulphur. This may be thrown back into the retort and resublimed or it may be ground and sold as refined flour sulphur. It is thus seen that the sublimed sulphur which is deposited in the chamber ranges all the way from the very finest particles in the most remote parts of the chamber through the coarser and coarser grades to the lump sulphur which is deposited directly beneath the inlet from the retort.

All of the non-volatile impurities are left in the retort and any impureties found in the sublimed sulphur must be of a volatile nature. Impureties found in crude sulphurs which can not be removed by the sublimation process are arsenic and asphaltum, both of which would be carried over along with the vapor of sulphur. Some crude sulphurs contain an appreciable amount of silicious material which will remain behind in the retort.

Most of the sulphur which is refined in the United States is of a very pure character, being 98 to 99.5 per cent pure and is very free from arsenic and asphaltum so that the sublimation process is chiefly for the purpose of obtaining a desirable physical condition.

\section{KINDS OF SULPHUR.}

Sublimed: This term may be properly applied to any sulphur which has been purified by the process of sublimation. Sublimation may be described as bringing a solid into a state of vapor by means of heat, which, on cooling, returns to a solid state. This definition, therefore, includes the refined lump (or "virgin rock") and "honey-comb" as well as the flowers of sulphur of all degrees of fineness.

Flowers. The word "flowers" shou'd be used to designate the finest and fluffiest grades of the sublimed sulphurs only. It would be a difficult matter, however, to say just when a sulphur is entitled to the use of the word. As a consequence, the coarsest grades of sublimed sulphur have been sold as flowers of sulphur.

All grades of sublimed sulphur contain traces of sulphur dioxide which in time may be oxidized into su'phuric acid. The amount is usually small, but enough to give it a sour taste. It was noted by Blodgett1 that a decidedly acid taste was always noticed in sulphurs which gave trouble in the sulphuring machines. Samples of troublesome sulphur were analyzed and in one case nearly two per cent. of sulphuric acid was found. The lumping of the sulphur was attributed to the presence of the sulphuric acid which attracted moisture from the air and kept the su'phur in a damp condition so that it had a tendency to pack when pressed together in the hands. No sulphurs of such remarkably high sulphuric acid content have been seen by the speaker but an occasional sample has been examined which stuck more or less to the sides of glass containers and upon analysis showed an appreciable quantity of sulphuric acid. Sulphur sacks occasionally rot and this is attributed to the presence of sulphuric acid. It is quite fortunate that instances of this kind are very rare in California.

1 Blodgett, F. M., New York Agr. Exp. Sta., Bu'. 395, 1915. 
Flour: Before the development of the modern grinding and bolting machinery, the process of sublimation was depended upon entirely for the production of sulphur in a very finely divided condition. For this reason, the earlier authorities recommended, without exception, flowers of sulphur for use in the control of surface mildews. The present tendency, however, seems to be in favor of the finely ground sulphur which can be made finer than the former and appear to be fully as efficient, if not more so.1

Pulverized sulphurs produced by means of grinding are now almost universally known as flour sulphur; these may or may not be bolted to insure uniformity. It seems reasonable to suppose that the similarity of preparation of this and wheat flour may have suggested the word. Very likely the similarity in sound of flour and flower may have been used to deceive the consumer. Powder crude sulphur may be purchased as well as refined sulphur in all grades of fineness.

Blown or Ventilated: The rubber industry requires an extremely fine sulphur and a grade of ground and bolted sulphur is supplied to them which is known as "blown" or "ventilated." A very finely ground sulphur is beaten up by machinery through which passes a current of air supplied by a powerful electric fan. The very finest particles are thus separated from the coarser ones. The Insecticide Laboratory has examined samples of remarkably fine sulphur of Eastern production which appear to have been treated in this way. These are being advertised quite extensively in the Eastern States for the dusting of plants, and theoretically ought to be very efficient. They are also the most suitable for the preparation of a wettable sulphur. The cost of these plus the freight charges across the continent would very probably prevent their extended use in this State unless experiments show them to be much more efficient than those of local production. In communicating with the local refiners, it is learned, however, that they could furnish a similar quality if the demand were sufficient to warrant the installation of the necessary machinery.

\section{USE OF DRY SULPHUR.}

The use of sulphur in one form or other antedates the earliest records of man's efforts to control the insect and fungous enemies of cultivated crops. The sulphur of the eighteenth century must have been a very potent substance indeed, for in $\mathbf{1 7 8 7}$ the following recommendation is made: "First wet the trees infested with lice, then rub flowers of sulphur upon the insects and it will cause them all to burst." 1 The extensive use of sulphur in France for the control of surface mildews of grape vines dates from about the year 1850 , although its value for this purpose had been known long before that time. To this day it remains without a formidable rival as a remedy against a great variety of agricultural pests. Factors which have contributed to its universal use are: its cheapness, efficiency, ease of purification, abundant supply, non-poisonous nature, harmlessness to the higher animals, vegetation and soils, and double utility both as an insecticide and fungicide.

\section{Ibid.}

1 Goeze, J. A. E., “Geschichte einiger schadlichen Insecten," Leipsig, 1787, 168. (Cited by Lodeman, "The Spraying of Plants.") 
The continuance of the practice of applying dry sulphur to plants either by hand or by means of various mechanical devices from the very beginning of its use up to the present time speaks well of the efficiency and economy of this method. The cost of material and application in this way are undoubtedly the cheapest. In vineyards located on very uneven land or on steep slopes, this is the only way in which su'phuring can be done. There are certain disadvantages in the use of dry sulphur. This method is the most wasteful of material; the application is best made in the early forenoon while the dew is still on the vines; rain and wind are apt to remove most of the sulphur; in cool weather sulphur is inactive. From time to time the use of liquid sprays have been advocated as a means of avoiding some of the above difficulties. Various attempts have been made to make a spray of sulphur and water or of Bordeaux mixture and sulphur. Dry sulphur, however, seems to have a peculiar aversion to water and when the two are together the sulphur has a perverse way of rolling up in little balls, a part floating on the surface and the remainder sinking to the bottom. As a consequence it is a difficult matter to secure a uniform mixture of the two.

\section{Wettable Sulphur. Sulphur Pastes.}

Various ways have been suggested for the preparation of sulphur so that it will be readily wetted by watter. Vermorel and Dantony1 reported that if sulphur be mixed with 1 per cent. soap solution, it could be wetted by water. It was found, however, that such a preparation could not be wetted with certain salt solutions or acid copper fungicides.

Use of Oleic Acid: The difficulty was overcome by mixing 100 kilograms of sulphur with a solution of 200 c. c. of oleic acid in 2 liters of denatured alcohol and evaporating the alcohol.

Use of Glue: The speakers' attention has also been called to the fact that a weak solution of glue has the property of wetting sulphur.2 The following suggestions were offered for the preparation of a sulphur spray with the aid of glue:

"A. Make an open box without bottom, six or eight inches deep, of such size that it will fit readily inside of manhole opening in top of spray tank and fasten on outside of box, on opposite sides of same near the top, two pieces of wood sufficiently long to support box in opening of spray tank and prevent its slipping into same. Over the open bottom of box tack a piece of wire cloth, preferably of brass, with 18 or 20 meshes to the linear inch, and over this again tack a piece of $1 / 4$ or $1 / 2$ mesh galvanized wire cloth to support and take the strain away from the light wire cloth.

"B. Provide a cheap paint brush, round or flat, two or two and a half inches long.

"For every seven or eight pounds of dry sulphur to be used prepare three gallons of glue solution containing one-half ounce of glue (preferably ground) to the gallon. Place the sulphur in a pail or other convenient recepticle and pour on about one gallon of the glue solution and stir vigorously

1 Vermorel, V., and Dantony, E., Compt. rend., 153, 194.

2 Communication from Mr. F. H. Pough, Manager Research Department of the Union Sulphur Company, New York. 
with a paddle or knead with the hands, breaking up all the lumps as thoroughly as practical. The stirring or kneading should be continued for three or four minutes, until the sulphur is thoroughly wetted and forms a smooth creamy paste.

"Place the box (A) in position in the opening of the spray tank and run into it as much as desirable of the wet sulphur; then work the sulphur through the sieve with the brush, using the remainder of the glue solution to help wash it through. Should more liquid be required for this purpose, water taken from the spray tank may be used."

So far as known, the only wettable sulphurs to come into use in this State are a so-called "iron sulphide" and two proprietary preparations.

Iron Sulphide: The first was devised by Ballard and Volck1 as a remedy against the powdery mildew of the apple. The fungicide is prepared by mixing a solution of iron sulphate with an excess of lime-sulphur solution. There results a mixed precipitate of insoluble iron sulphide (black), free sulphur (yellowish), and calcium sulphate (white). The excess of lime-sulphur is washed out and there is left a paste of the three precipitates which are quite insoluble and inert toward most ordinary reagents. The iron sulphide is black and is present in sufficient quantity to mask the presence of the other precipitates. The precipitated sulphur is believed to be the only constituent of fungicidal value, the others being merely incidental to this economical manner of precipitating free sulphur in a finely divided form. The iron sulphide and calcium sulphate also serve to prevent the minute particles of sulphur from flocculating (i. e., uniting to form coarser grains).

The directions for the preparation of sufficient stock to make five hundred gallons of spray are as follows.

"Fill a 50-gallon barrel about two-thirds full of water. Weigh out 10 pounds of iron sulphate (copperas), place in a sack, and suspend in the water. The iron sulphate will dissolve fairly rapidly, and when it is all in solution measure out carefully $21 / 4$ gallons of commercial lime-sulphur solution testing $33^{\circ}$ Baumé, or 2 gallons and 3 pints of a lime-sulphur solution testing $32^{\circ}$ Baumé. Slowly pour all but 2 pints of the lime-sulphur solution into the iron-sulphate solution in the barrel, stirring the mixture vigorously with a hoe or shovel. The addition of the lime-sulphur solution will produce a bulky, black precipitate, and when all but 2 pints of the lime-sulphur solution has been added the mixture should be allowed to stand for a few minutes, when the black precipitate will begin to settle and a little of the clear liquid at the top can be carefully dipped out with a clean glass or cup. This clear liquid will probably show no yellow lime-sulphur color, which means that an excess of lime-sulphur solution has not yet been added. In other words, there is still some iron sulphate in solution, in which case the addition of a drop of lime-sulphur solution to the clear liquid in the glass will produce a black precipitate. This means that more lime-sulphur solution should be added to the stock in the barrel, and about half of the remaining 2 pints should now be poured in and the contents of the barrel stirred vigorously and allowed to stand. Some of the clear liquid should again be dipped off and tested as before, to determine whether an excess of lime-sulphur solution has been added. If necessary, the addition of small quantities of lime-sulphur solution should be continued until some of the clear liquid dipped from the top, after the contents of the barrel have been well stirred and allowed to settle, shows a pale yellowish lime-sulphur tint. The purpose of using a slight excess of the lime-sulphur solution is to insure all the iron sulphate being utilized. The voluminous black precipitate that is formed consists of iron 
sulphid, precipitated sulphur, and calcium sulphate. After a slight excess of lime-sulphur solution has been added, the barrel should be filled with water and the contents stirred thoroughly, and allowed to stand for several hours. The black iron-sulphid mixture will settle into the lower half or third of the barrel and the clear liquid should be poured off by carefully and gradually tipping the barrel, without allowing any of the black precipitate to run out. The barrel should again be filled with water, the contents thoroughly stirred and allowed to stand several hours, and the clear liquid poured off as before. This operation of washing the precipitate should be repeated until the water poured off no longer shows the yellow lime-sulphur tinge. Probably three or more such washings will be required, depending upon how careful the operator has been in using only a slight excess of lime-sulphur solution. When the washing has been completed, the stock barrel should be filled with water to exactly fifty gallons. . . . care should be taken to stir the contents of the barrel thoroughly each time before any of the mixture is taken out."

The finished spray was made by taking 20 gallons of the stock solution and adding water to make 200 gallons. The cost of the spray is estimated not to exceed fifteen or twenty cents per 100 gallons.

This paste mixes readily with water, is entirely insoluble therein, remains well in suspension, adheres to foliage, and has given excellent results in the control of the powdery mildew of the apple. The chief disadvantages are that it is somewhat tedious to make as a home preparation and is not well adapted to commercial sale on account of a tendency to deteriorate upon standing for any length of time.

As prepared according to the originators' formula, each gallon of the paste would contain in the neighborhood of one-tenth of a pound of precipitated sulphur, and the finished spray, one pound of precipitated sulphur to each 100 gallons.

Proprietary Preparations: Another form of wettable sulphur which might be of interest to viticulturists is a proprietary preparation consisting of between 45 and 50 per cent. of sulphur ground to an impalpable powder in the presence of glue and sufficient water to form a paste. It is readily wet by water, producing a uniform mixture by means of slight agitation so that a very even distribution may be obtained by its use. The finely divided condition of the sulphur makes it very active against fungi which are susceptible to sulphur. It adheres well to the foliage so that its action continues over a long period of time. According to the reports of some of the State agricultural experiment stations, very favorable results have been shown from its use.

Another proprietary wettable sulphur is manufactured by grinding together in a paint mill sulphur and diatomaceous earth (kieselguhr) with sufficient water to form a paste. The percentage of sulphur in this preparation varies from 45 to 50 per cent. The preparation is such that it is easily wet by water and it remains well in suspension. There are also very favorable reports from the use of this material as a fungicide, particularly in the control of powdery mildew of the apple.

\section{SOLUBLE COMPOUNDS OF SULPHUR.}

An excellent class of soluble sulphur fungicides which has been long in use is the alkali sulphides. Their cost, however, has largely restricted their use to small operations, particularly as a fungicide for the home garden 
and in green-houses. Recommendations have occasionally been made for their use in connection with large spraying operations in vineyards to meet certain unusual conditions where quick action is needed. The action of the soluble sulphur fungicides is more rapid than that of sulphur or sulphur pastes. While not advising their use in general practice, Bioletti1 recommends liver of sulphur, alkali polysulphides, or lime-sulphur salt sprays in exceptional cases where "through neglect of proper sulphuring the vines may be badly attacked by mildew, and owing to the coolness of the weather when the trouble is first perceived sulphur may act too slowly."

Another soluble sulphur spray which has gained great popúlarity among horticulturists is lime-sulphur solution. This acts both as a fungicide and an insecticide. Very little success has attended its use for the control of the powdery mildew of the apple in the principal apple growing section of the State for the reason that it has been found impossible to apply it in sufficient strength without fear of foliage injury. Most excellent results have been obtained from its use in the control of apple scab, for which purposes it is rapidly supplanting Bordeaux mixture. It has been advocated for grape vines.

Composition and Properties: The alkali sulphides represent the earliest sulphur fungicides which have been used in soluble form. Caustic soda and caustic potash as well as the alkali carbonates will under proper conditions form a chemical compound with sulphur which is readily soluble in water. The reaction between sulphur and potassium hydroxide in equeous solution has been studied by Professor H. V. Tartar of the Oregon Agricultural Experiment Station.1 He concludes that "the primary reaction of sulphur with potassium hydroxide in heated aqueous solutions takes place as represented by the following equation:

$$
6 \mathrm{KOH}+8 \mathrm{~S}=2 \mathrm{~K}_{2} \mathrm{~S}_{3}+\mathrm{K}_{2} \mathrm{~S}_{2} \mathrm{O}_{3}+3 \mathrm{H}_{2} \mathrm{O} . "
$$

and that "when sulphur is used in excess, a secondary reaction occurs in which it combines, if present in sufficient quantity, with the trisulphide to form the pentasulphide. Potassium tetrasulphide is perhaps formed as an intermediate product. The variation of temperature (below $100^{\circ}$ ) and concentration does not alter the nature of the reaction." This reaction may be taken as typical of what occurs in the making of a similar sodium sulphide or in the making of lime sulphur solution. From the results of analyses made at the Insecticide Laboratory it also appears that much the same products are formed when potassium or sodium carbonate is fused with sulphur. In the case where the hydroxide is used, the by-product is water, but if the carbonate is used, the by-product is carbon dioxide, the final products, however, being almost identical. Interpreting the chemical formula given above, it is seen that the product consists of potassium polysulphide and potassium thiosulphate. This reaction is very similar to the one involved in the preparation of lime sulphur solution, in the latter case the principal ingredients being calcium polysulphide and calcium thiosulphate. According to the best evidence at hand it is thought that in all of the above mentioned

1 Bioletti, F. T., "Oidium or Powdery Mildew of the Vine." California Agr. Expt. Sta., Bul. 186, page 346 (907).

1 Tartar, H. V., "On the Reaction of Sulphur and Potassium Hydroxide in Aqueous Solution." Jour. Am. Chem. Soc., Vol. XXXV, No. 11, page 1741 (1913). 
preparations, the polysulphides are the most active fungicidal ingredients. They are likewise the most caustic. Foliage injury sometimes obtained by the use of these materials may in all probability be attributed to the poiysulphides.

The ingredients of second importance as fungicides are the thiosulphates. Thiosulphates in general have a definite fungicidal value. They are less active, however, than the polysulphides and their causticity is almost negligible.

\section{DECOMPOSITION OF SULPHIDES AND THIOSULPHATES AFTER APPLICATION TO FOLIAGE.}

A knowledge of the decomposition products of the foregoing materials after application may be of value in deciding the suitability of these materials for the various uses to which they may be applied. Haywood 1 has investigated this point in reference to the decomposition products of lime sulphur. His experiments indicate that calcium polysulphides are oxidized to thiosulphates by the action of the air and that the thiosulphates thus produced and those originally present in the wash are further oxidized to sulphites, and that the sulphites are eventually still further oxidized to sulphates. The first two oxidations liberate sulphur in a very finely divided condition. The experiments were made under laboratory conditions and may not show the precise reactions that occur under field conditions. From the data secured in these experiments, it was calculated that it would take about four or five months for a complete oxidation of the wash and it was also shown that the rate of decomposition was very much increased by wetting the material every day simulating the effect of dew. No reference is at hand giving similar experimental data on the alkali sulphides. From a consideration of their chemistry and the miscellaneous facts known about such compounds it seems reasonable to conclude that their decomposition would be in a manner analagous to that of lime sulphur given above; that is, the polysulphides and thiosulphide would be slowly oxidized to su'phites and eventually to sulphates with the liberation of free sulphur during the whole process with the exception of the last stage, the chief difference in the final product being that lime-sulphur solution is finally oxidized into insoluble calcium sulphite and calcium sulphate whereas all of the decomposition products of alkali sulphides are readily soluble in water. It may be well to point out here one advantage in the use of lime sulphur as a spray of general utility. The final decomposition product to which is converted all of the ingredients of lime sulphur is calcium sulphate or gypsum. This material is a natural constituent of many soils, is applied in many cases for the improvement of soils and in no case is it a detriment and in some cases it may be a benefit. This consideration, however, may not be of great significance for the reason that the decomposition products are in such small amount that their effect upon the soil is negligible. There is this thought, however, that the continual application of lime sulphur every year and over an indefinite period of years can not in any possible way add a trace of undesirable material to the soil. The decomposition products of the alkali sulphides, however, are readily

1 Haywood, J. K., "The Lime-sulphur-salt Wash and Its Substitutes," U. S. D. A. Bureau of Chemistry Bul. 101 (1907). 
soluble and if accumulated in sufficient quantity would be an undesirable soil constituent. The quantity is small, however, and would be washed away by drainage water.

\section{THE HOME PREPARATION OF SOME SULPHUR FUNGICIDES.}

Pottassium Polysulphide: In discussing the control of the red spider which in this State is a serious menace to many varieties of fruit trees, Volck ${ }^{1}$ gives the following directions for the preparation of a stock solution of sulphide of potash:

"Granulated, or powdered concentrated lye, 15 pounds; sulphur, 18 pounds; water to make 20 gallons. Stir the sulphur and lye together in a vessel which will allow plenty of room for boiling. When well mixed, add about one pint of water, placing it in a slight hollow in the mixture, and stir in slowly. The mixture will soon begin to melt and boil, forming a red fluid; stir until the boiling ceases, and then add water to make 20 gallons. This stock solution will keep for awhile, or indefinitely when protected from the air."

The finished spray was made up as follows:

"Place 10 to 15 pounds of sublimed sulphur, or 14 to 20 pounds of ground sulphur in the spray tank with 4 gallons of flour paste and 1 to 2 gallons of the sulphid of potash stock solution; add water to make 100 gallons. For summer or spring spraying after the danger of rains is over, the minimum amount of sulphur is sufficient."

Excellent results were obtained by the use of this spray against the red spider on almond trees in full leaf. It was found that "dry sulphur is usually successful as a partial control. Sulphur spraying has been found many times more efficient than other methods of application and is perfectly successful where dry sulphuring has failed." The sulphide of potash stock solution of Volck would contain potassium polysulphides and pottasium thiosulphate as the chief ingredients of fungicidal value. The solids would contain about 54 per cent. of sulphur and each gallon would carry nine-tenths of a pound of sulphur in all forms.

Sodium Polysulphide: In 1907, Haywood1 proposed a substitute for the lime-sulphur-salt wash and gave the following directions for its preparation.

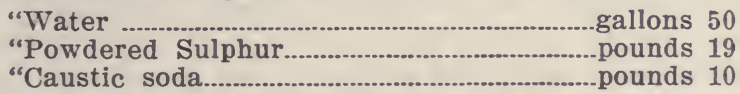

"The wash is mixed as follows: Make a paste of the sulphur with not more than $5 \frac{1}{2}$ gallons of boiling water; at once add all the caustic soda, which has previously been broken up into pieces the size of a hickory nut or smaller, and stir occasionally for one-half hour. At the end of this time add $441 / 2$ gallons of water, stir, and the wash is ready for use.

"An analysis of the liquid portion of this wash for sulphur compound shows the following composition:

Grams per 100 c.c.
"Sulphur as thiosulphates................................ 0.63
"Sulphur as polysulphids and sulphids............... 2.85
"Sulphur as sulphates and sulphites.................... $\quad .01$
"Total sulphur................................................ 3.49"

1 Volck, W. H., "Sulphur Sprays for Red Spiders," Calif. Agr. Expt. Sta. Bul. 154, page 10 (1903).

1 Haywood, J. K., "The Lime-sulphur-salt Wash and Its Substitutes." U. S. D. A. Bur. Chem. Bul. 101, page 28 (1907). 
This wash was doubtless intended as a dormant spray, as it could not be used upon foliage at this strength without very serious injury. The analysis indicates about three-tenths of a pound of sulphur to each gallon of the spray. Three gallons of Haywood's solution would therefore be equivalent to one gallon of Volck's stock sulphide of potash solution. By using the corresponding dilutions, the same results might be anticipated from either spray, both having polysulphides and thiosulphate as the chief ingredients.

\section{COMMERCIAL PREPARATIONS OF THE ALKALI POLYSULPHIDES.}

Liver of Sulphur: This compound is not suitable for home preparation. It is made commercially by fusing potassium carbonate and sulphur together in a crucible. By the action of the heat, carbon dioxide is liberated and the sulphur combines with the potassium. After the fusion is complete, the melt is poured out on to iron plates where it solidifies into a mottled yellow and chocolate colored cake. The sulphur is combined in the form of polysulphides and thiosulphates. Analysis of samples of liver of sulphur show total sulphur to be between 40 and 50 per cent.

Sulphides and Polysulphides: Both potassium and sodium have been used as a base for the combination of sulphur in a form soluble in water. Chemical examination of a number of brands shows a remarkable variation in sulphur content, the range being from 17 to 42 per cent. In all cases, however, the materials consisted mainly of alkali sulphides and thiosulphate. Chemically, sodium is capable of uniting with more sulphur than is potassium, on account of its smaller atomic weight. Except in the case of two proprietary preparations, this fact has not been taken advantage of, for a sample of liver of sulphur (potassium polysulphide) contained more sulphur than any of the sodium compounds. An excess of uncombined sulphur was not shown in any of the samples examined, except in the preparations sold under a trade name.

Proprietary Sodium Polysulphides: Quite recently there have been introduced two commercial preparations of sodium polysulphides sold under trade names. They also consist of a mixture of the polysulphides and thiosulphate but their sulphur content is greater than any of the other materials examined of this character. Analysis indicates an excess of sulphur used in their manufacture so that the maximum amount of sulphur may be rendered soluble. The base being sodium, a greater amount of combined sulphur is possible, and a cheaper product is produced than if the more expensive potassium were used. They are both granular yellow powders readily soluble in water and are advertised as a substitute for lime-sulphur solution. The appearance of the diluted spray is identical in either case so that the impression is quite general that these powders are a dry form of limesulphur. The advertising matter of one of the preparations states that their product is made by the fusion of soda-ash (impure sodium carbonate) and sulphur by a patented process.

The patent under which the other compound is made specifies "forming a water-soluble material for spraying plants, by heating together about equal weights of sulphur and caustic soda to cause reaction and drive off a portion 
of the water liberated but without volatilizing any of the sulphur, and form a final product containing about 37 per cent sulphur."1

So far as indicated by analyses, the resulting product is practically the same in either case, and the diluted spray would be essentially the same as the home-made wash proposed by Haywood in 1907.2 The manufacturers claim from 54 to 62 per cent of total sulphur for their products but the samples thus far examined in the Insecticide Laboratory have had considerably less than this amount, usually running about 50 per cent. The highest official published analysis seen elsewhere reports 58 per cent. of total sulphur.

\section{CCMPATIBILITY CF THE SULPHUR FUNGICIDES.}

Sulphur: So far as chemical action is concerned, sulphur may be mixed with practically any of the sprays which are in common use. Strong alkalies, however, might dissolve enough of the su'phur to cause foliage injury. The aversion of sulphur to water, however, prevents its mixing readily with it or with the sprays, the latter being a physical incompatibility.

Wettable Sulphur-Sulphur Pastes: The addition of oleic acid, glue, or diatomaceous earth as deflocculating agents does not change the compatibilities of sulphur. The constituents of iron sulphide are not affected by the ordinary spray materials. Therefore the preparations described under this heading are both physical and chemically compatible with all of the sprays in general use.

Lime-sulphur: Lime-sulphur solution is chemically incompatible with Bordeaux mixture. It is thought that the fungicidal value of Bordeaux is not destroyed by mixture with lime-sulphur solution, but a part of the soluble sulphur of the latter is looked up as an insoluble copper sulphide which is valueless for the destruction of mildews.

Lime-sulphur solution is chemically incompatible with all arsenicals (excepting basic or neutral lead arsenate), chemically and physically incompatible with soaps and emulsions, and chemically incompatible with acids and alkalies.

It is compatible with tobacco preparations and with basic or neutral lead arsenate.

Alkali Sulphides and Polysulphides. Chemically incompatible with Bordeaux mixture.

Chemically incompatible with all arsenicals (excepting basic or neutral lead arsenate), and with acids.

Compatible with soaps, emulsions, alkalies, tobacco preparations, and basic or neutral lead arsenate.

Summarizing the discussion on compatibility, the following points were shown: (1) Sulphur is unsuited for use in any of the sprays on account of its physical incompatibility with aqueous solutions. (2) Paste sulphurs and wettable sulphurs offer a distinct advantage over the other sulphur fungicides owing to their compatibility with practically all of the common sprays, their compatibility with Bordeaux mixture probably being the most important desirable quality of interest to viticulturists. They are the only type of sulphur fungicide permissible with Bordeaux mixture. (3) If used in the

1 U. S. Patent reissue 13,796, Chemical Abstracts, 8, 3480.

2 Loc. cit. 
vineyard, lime-sulphur must be used alone, unless in combination with tobacco or a special type of lead arsenate. (4) The alkali sulphides and polysulphides have some points of advantage over lime-sulphur solution for the reasons that soap may be used with them as a spreader and that they can be used with a greater variety of sprays.

Prof. Bioletti: "There is a common belief among grape growers that sulphur after being placed on the vine loses its strength. Is there any possible change that the sulphur undergoes that could be interpreted as making sulphur lose its strength?"

Prof. Gray: "There is a great difference of opinion on this subject."

Mr. C. J. Wetmore, Mr. Frank Henry and Mr. Geo. E. Lawrence, of Lodi, California, gave personal experiences of the use of sulphur in their different vineyards.

President Alwood: "In the East we are using sulphur very largely in treating the brown rot in the peach and plum orchards. We use it in a combination of lime solution. We slack the lime and add the sulphur. I do not know whether it has been applied to the vines in the West or not. We use about 16 pounds of sulphur to 100 gallons of wash, and for a second application about 8 pounds of sulphur to 100 gallons of wash."

\title{
MORNING SESSION, JULY 13, 1915.
}

\section{GRAPE INSECTS IN CALIFORNIA.}

\author{
By H. J. QUAYLE,
}

Entomologist, University of California, Citrus Experiment Station, Riverside, California.

While there is more or less injury done to the grape by insect pests every year in California, there is at present no insect that requires such universal treatment as is necessary for the powdery mildew or Oidium. Nevertheless, insect pests have been one of the most important factors in connection with the development of the viticultural industry of the State. The phylloxera has caused probably not only a greater actual loss than any other single thing, but it has necessitated important changes in viticultural methods. The various phases of the question of resistant stock, which have been some of the fundamental viticultural problems of the State for many years, have for their basis the proposition of insect control. The phylloxera has destroyed upwards of 50,000 acres of vines in California, but this loss is now very largely past because of general replanting of the vineyards on resistant stock. Next to the phylloxera, the grape leaf-hopper has been the most injurious insect of the grape in this State, but unlike the phylloxera, the injury by the grape leaf-hopper has not diminished, but rather increased with the 
larger acreage of vines planted. In addition to the two insects mentioned, there are some half dozen other species which do injury in some sections and in certain years.

\section{THE PHYLLOXERA.}

\section{Phylloxera vastratrix, Planch.}

The phylloxera which is an insect native to the United States east of the Rocky Mountains, was introduced from that section into France and from France into California. Since it is in California that most of the vinifera vines occur, it is here the phylloxera has done greater damage than elsewhere in the United States. This damage has occurred chiefly in the Coast counties as its spread has been much more rapid there than in the interior valleys. This difference in the rate of dispersion is due, no doubt, to the fact that in the interior valleys the winged form seldom, if ever, occurs, while in the Coast sections the winged form is common. The spread is also more rapid in heavy soils than in sandy soils, and in soils having a high percentage of sand the vines may be much more resistant or practically immune.

The phylloxera is a minute sucking insect which does injury by feeding upon the roots of the grape. The injury, however, is not due so much to the nourishment taken from the vine as to the decay which follows the feeding. This decay occurs much more seriously on the vinifera vines than on the wild or American vines.

The life history of the phylloxera is somewhat complex where all the forms of the insect occur. In the Eastern States the most evident indication of phylloxera infestation is represented by the galls on the under side of the leaves.

These leaf galls seldom, if ever, occur in California. A colony may arise from a single egg which has over-wintered on the rough bark of the two-yearold wood. While this winter egg has not been actually observed in California, the much more rapid spread of the insect in the coast sections, where the winged form occurs, can scarcely be accounted for unless the winter eggs are laid. Upon hatching, the insect makes its way to the leaves, and becomes a gall maker where it gives rise to a new generation of egg-laying root-feeders. In California, where the gall form is not found it is probable that, in case the winter egg actually occurs, that the insect arising from this egg goes directly to the roots. Generations of this form follow one another throughout the growing period of the vine until there is a total of probably seven or eight. In the interior valleys, this root-feeding form is practically the only form which occurs. In midsummer and later, some of the eggs deposited by the root-feeding form develop into nymphs which finally acquire wings, emerge from the soil, and form new colonies from eggs deposited on the under side of the grape leaf. The eggs from a single individual number from three to six and they are of two sizes, the smaller of which produce the males. The females arising from the larger eggs, after fertilization, move to the rough bark of the two-year-old wood and deposit the single winter egg already referred to.

There have been four principal methods adopted for the control of the phylloxera, namely: 1 , injection of carbon bisulphide; 2 , flooding; 3 , planting in sand; 4, planting vines grafted into resistant stock. The last of these 
methods has been practically the only one followed in California, and since this is a viticultural, rather than an entomological problem, it will not be further discussed.

\section{GRAPE LEAF-HOPPER.}

\section{Typhlocyba comes, Say.}

The grape leaf-hopper occurs in numbers sufficient to be a pest in the Sacramento, San Joaquin and Imperial valleys. It rarely becomes injurious in the Coast valleys or the grape sections of Southern California aside from the Imperial and Coachella valleys. The injury occasioned by the grape leaf-hopper is indicated by the leaf becoming at first a silvery color, later turning to yellow and finally to brown, when it drops from the vine. Leaves thus affected occur most commonly about the crown of the vine, though in cases of serious injury all of the leaves will show this effect. Many of the leaves may become functionless or drop off as early as June or July, and this early loss of foliage prevents the berry from maturing properly. The lack of full foliage to the end of the season also prevents the canes from ripening normally for next year's wood. The buds fail to develop in the following spring, and thus the vine may be more or less permanently stunted in growth in serious cases or hopper injury.

The grape leaf-hopper passes the winter as an adult insect which may feed on various plants growing in the vineyard or the vicinity during the warmer weather. During cold or wet weather the hopper remains under leaves or rubbish or low down on the plants upon which it feeds. When the vine comes into leaf in the spring the hopper leaves its winter food plants and feeds exclusively on the grape leaf until the leaves fall in the autumn.

The young hoppers, or nymphs, begin to hatch about the first of May in the Fresno section, a little later farther north, and two or three weeks earlier in the Imperial Valley, in the extreme south. The young of the second generation begin to appear in the latter part of June, making two generations of the insect in a season.

Probably the most generally satisfactory method of control for the grape leaf-hopper is spraying for the nymphs or young. The adults are almost impossible to kill with the spray, while the nymphs are very susceptible to several different kinds of spray material. The chief difficulty in spraying is to get the material on the urder side of the vine where the hoppers are, and there is a further objection that the eggs which are within the tissues of the leaf, as well as the adults, which are also present, are not affected by the spray. In spite of these drawbacks, spraying for the nymphs will pay when the hoppers are abundant and doing much damage. The spray found most efficient in killing the young, as well as most neutral to the grape foliage and berry, is as follows:

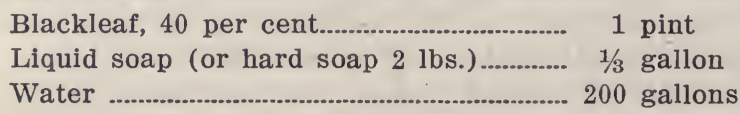

One of the most important factors in hopper spraying is the time of application. If the spray is applied too early, too many eggs which have not yet hatched will escape because the spray cannot reach them; if too late, many young will have become adult winged hoppers which cannot be killed 
by the spray, and which will deposit their full quota of eggs. For the Fresno section of this State in average years, the time of spraying will be from about May 20th to June 10th. The criterion to go by for each year and locality is to begin spraying as soon as some of the nymphs are in the last nymphal stage.

\section{THE CALIFORNIA GRAPE ROOT WORM.}

\section{Adoxus obscurus Fourcroy.}

This pest of the vine occurs in more or less restricted localities in the San Joaquin and Sacramento valleys between Merced and Marysville. It also occurs in the Sonoma Valley, but is not known as a pest on the grape elsewhere in California. This insect injures both the roots and the growing parts of the vine above ground. The most evident indication of infestation of this beetle is in the narrow chain-like strips which are eaten out of the leaves. The beetle also gouges out parts of the petioles, pedicels, berries and shoots. The larva does injury under ground by eating off the small rootlets or by gouging out strips of the bark of the larger roots. In cases of serious injury by this larva, most of the little rootlets will be eaten off and a large part of the bark of the larger roots. Vines thus affected show a stunted condition, the canes fail to attain a normal growth, and in severe cases the vine may be killed outright.

The adult beetles appear in May and June, having emerged from the ground where they have been since the previous year and where they have passed through the larval and pupal stages. This beetle begins at once to feed upon the parts of the vine above ground as already indicated. After feeding for a couple of weeks, egg laying begins, the eggs being deposited on the inner bark or in crevices, usually beneath two or three layers of the old bark. They are laid in clusters of from four or five to twenty-five or thirty. Upon hatching, the young larva crawls or drops to the ground and makes its way to the roots where it begins at once to feed. It continues feeding throughout the growing period of the vine, lies more or less dormant during the winter, and comes to within eight or ten inches of the surface in the spring for pupation, finally transforming to the adult and emerging from the soil about the first of May of the following year.

The adult beetle is very readily jarred from the vine and thus they may be captured on a screen or tray provided for the purpose. This is particularly applicable where the infestation is restricted to small areas in a vineyard. It requires, however, to be repeated several times because new beetles keep emerging from the soil for a month or more. Where the infestation is general over a vineyard, the most satisfactory treatment is to spray the vines with a poison such as arsenate of lead. Here again the application may be required to be repeated because of the new growth continually appearing on the vine.

\section{CUT WORMS.}

Cut worms do more or less damage in certain sections every year, but in occasional years they become very abundant and do serious injury. 1914 was one of the years in which they occurred in great numbers in a large 
section of the country about Fresno. There are several different species of cut worms, but the two most common occurring in the Fresno section are probably "Paragrotis messoria," and "Peridroma margaritosa sauci." Cut worms appear in the early spring and eat off the expanding buds. They also feed upon the young leaves as they appear, but an early attack on the swelling buds is when the most serious damage is done because the removal of the principal buds destroys the fruit and the later buds usually produce sterile shoots. The eggs are laid mostly on the stems of grasses near the ground. The larvae hatching from these feed near the ground, and since they work mostly at night they are not readily seen in their concealed situations during the day. Since there is plenty of vegetation they do not do conspicu. ous injury to the crop. A second generation appears in midsummer and these feed upon the grass and other vegetation similarly to the first genera. tion, and when winter sets in they are but partly grown. It is in this partly grown larval stage which they spend the winter in a more or less dormant condition. When the buds begin to expand on the vines and fruit trees. these partly grown larvae become very active and climb into the vine or fruit tree and very voraciously feed upon buds.

The most satisfactory control measure for these insects is an application of poisoned bait about the ground just at the base of the vine. During the day the worms will be found just below the surface at the base of the vine and come out at night to feed upon the buds or leaves. When they emerge at night they will come in contact with the poisoned bait and will be satisfied with that rather than climbing into the vine. In the case of vines which are pruned high and where there is more or less trunk to the vine, the worms will not always go down to the ground to remain concealed during the day, but will secrete themselves under the bark on the trunk of the vine. In such cases it is necessary to apply the poisoned bait in the crotch of the vine as well as on the ground.

In certain limited sections and during occasional years, vineyardists are obliged to combat the army worm. This is an insect very closely related to the cut worms just mentioned, but is a distinct species, being the well known army worm which occurs more abundantly in the Eastern States than in California. The second generation of the army worm in California appears about the first week in August, and since at this time the grain fields upon which it has been feeding previously, afford very little succulent growth. they leave such situations and acquire the migratory habit, and march off in a definite direction in enormous numbers. Where an outbreak of these army worms is discovered in a neighboring grain field, they can be very completely prevented from entering the vineyard by plowing a furrow with the vertical side of the furrow next to the vineyard to be protected. The army worms marching into this furrow, will be unable to ascend the vertical side and they may be killed in this furrow in any way which seems most feasible. Usually holes are dug every twenty or thirty feet in the furrow and the worms, unable to scale the side, will crawl along the furrow and drop into these holes where they may be destroyed by sprinkling with a little gasoline and dropping in a lighted match. If they are already in a portion of the vineyard, the furrow may be made in the same way to protect the portion not yet reached. The vines already attacked can scarcely be saved from defoliation because of the very great numbers of the worms, but they may 
be checked to a considerable extent by spraying very heavily with a strong poison spray, thus killing themwhere the vines are already infested.

\section{GRASSHOPPERS.}

The most serious injury done by grasshoppers is where outbreaks of these insects occur, coming in from surrounding uncultivated lands. Vineyards most likely to be subject to this attack, occur in new sections wher there is considerable pasture land in the vicinity. The eggs of the grasshopper are laid in the ground in the late summer or fall in uncultivated land. These eggs remain in the ground during the winter and hatch in the following spring.

Grasshoppers may be controlled by a poisoned bait, by spraying heavily a few rows along the border of the field, by the hopperdozer, by burning waste areas, and by the introduction of turkeys into the vineyard. A combination of two or more of these measures may be used to fit particular cases. Of the methods used to virectly protect vineyards, poisoned bait is probably the most common.

\section{GRAPE LEAF FOLDER.}

\section{Desmia funeralis Hüb.}

This insect occurs in scattering numbers over a wide section of California, but important injury is done only in restricted localities and during occasional years. The insects may be detected in a vineyard by the characteristic rolling of the leaves. One edge is rolled up rather tightly to about one-half way across the leaf, making a tube less than the diameter of a lead pencil in which the larva lives. The leaf is always rolled on the under side. The larvae feed by eating off the free edge of the leaf in the interior of the roll, so that they are always protected by the outer layers of the rolled portion. The insect hibernates as a chrysalis, appearing and laying eggs upon the vine in the spring. There are apparently two generations of the insect during the year in California. This same insect is a more or less important pest of the vine in the Eastern States, but there its habits are strikingly different from that of California. In the East the leaf is simply folded over on the upper surface and the edge is sewed down by strands of silk, while in California the leaf is very distinctly rolled. As a general rule the leaf folder does not occur in numbers sufficient to warrant treatment, and the only treatment applicable would be the application of an arsenical spray just after the eggs are hatching and before the rolling of the leaves occurs. Once the leaf is rolled the insect is completely protected from the spray and the only way to rid the vine of them in that stage is to pick them off or crush them within the roll.

\section{HAWK MOTH LARVAE.}

These larvae, while occurring in occasional numbers, are of little consequence as a pest except once in a great while when outbreaks of them occur and they do serious injury to small areas of vines. These larvae are very large worms similar to those which attack tomatoes and tobacco. The insect hibernates in the pupal or chrysalis state and while in the ground, may be distinguished as a large cylindrical object of a dark brown color. about the middle of May they emerge from the ground and deposit their 
eggs on the leaves of the grape. The larvae, upon hatching, begin to feed immediately upon the foliage. There are two generations of this insect in a season. While there are several species of hawk moth larvae, the most common one of the grape is "Pholus achemon." Where there are but occasional specimens of this insect occurring in a vineyard the only practical treatment is to pick them off by hand. Where there is a serious outbreak over a large area, however, the vines may be sprayed with an arsenical while the worms are still very small.

\section{LEAF CHAFERS AND FLEA BEETLES.}

Insects having the above common names appear on the grape occasionally in California but are not generally serious pests. The larvae of the leaf chafers usually feed upon the roots of grasses growing in the vicinity, while the injury to the vine is due to the attacks of the adult beetle. The two most common species of leaf chafers attacking the vine in this State are "Serica mixta" and "Hoplia pubicollis." Since these insects appear usually in immense swarms they are very difficult to control. They may, however, be jarred off the vines or the vines may be sprayed with an arsenical spray.

While there are several species of the flea beetle occurring in the State, probably the most common one on the grape is "Haltica carinata." These beetles have often been confused with the grape root worm discussed in the earlier pages of this paper. They may, however, be distinguished from the root worm because of their bluish color and the fact that they are capable of jumping. The flea bettle also eats out irregular holes in the leaf which may differ in size and shape, while root beetles eat out narrow strips of very uniform size and shape. The flea beetle passes the winter among the leaves or in other situations affording protection for the adult beetle. They emerge in the early spring and begin to feed upon the buds of the vine. The buds may be entirely eaten away or they may have the centers gouged out so that they are completely destroyed. After thus feeding for some time they begin depositing their eggs, generally in the crevices of the bark or at the base of the buds. The larvae hatching from these attack the leaves or eat holes in the buds as already indicated. After feeding for three or four weeks and becoming full grown larvae, they drop to the ground, make a little cell just beneath the surface and change to pupae. Beetles emerge a week or two later and feed upon the leaves. There are thus two generations a year. Since flea beetles feed upon the foliage both as larvae and adults, they may be readily controlled by means of an arsenical spray such as arsenate of lead.

\section{THE MEALY BUG OF THE GRAPE.}

During recent years in certain sections of Fresno and Stanislaus county there has appeared a mealy bug which attacks the grape and which has given more or less concern to grape growers. The particular species concerned has not been positively identified but the evidence seems to indicate that it is probably new. This insect over-winters very largely in the egg stage, the egg masses being secreted under the layers of the old bark. The 
most important injury is done in midsummer when the insects congregate in large numbers in the grape clusters. The presence of the insects themselves together with the honey dew which is secreted by them, renders the cluster unsightly and unattractive and also makes the berry much more susceptible to decay infections.

The only remedy which seems feasible at present is to take off and burn all of the loose bark of the vine during the winter season and afterwards spray the vines thoroughly with distillate emulsion.

\section{PHYLLOXERA IN CALIFORNIA.}

By R. L. NOUGARET,

United States Bureau of Entomology, Walnut Creek, California.*

\section{Phylloxera vastatrix Planchon.}

The Bureau of Entomology of the United States Department of Agriculture, for the past few years, has been making an investigation of the grape phylloxera under existing California conditions. This work is about conpleted, and a report on the results of this investigation, which is being conducted by Mr. W. N. Davidson and the writer, will shortly be published. This paper, in abbreviated form, presents such extracts of this report as are of interest, considered from a viticultural viewpoint.

The difference which apparently seems to exist in the degree of injury caused to the vineyards of California, compared to that which affected those of Europe, prompted this investigation. In France the devastation of vineyards progressed uninterruptedly. Once infested, the vines died in a short time. The spread of the insect was alarmingly rapid in its course from one vineyard district to another, and mostly due to its natural habit. In the course of twenty-two years' time, from 1863, when the phylloxera's injury was first noticed, to 1885 , the infestation had spread over an area of one million hectares (approximately two million and a half acres), a good portion of which was completely dead. In California the great boom in vineyard planting, which occurred from 1880 to 1883, was chiefly responsible for the spread of the pest by vines being used from infested vineyards for planting out the new ones, rather than to the natural spread of the insect due to its biological traits. The affected vineyards also differ essentially, inasmuch as the vines withstand the injury for a much longer time than vinifera varieties did in France. It is not uncommon to find in California vineyards known to have been infested fifteen or twenty years and still bearing crops that justify the expense of cultivation. The vines comprised in the characteristic "oil spot," or primarily infested area, gradually become stunted in growth, then cease bearing grapes, or the very few produced are worthless, but coritinue for years to put forth a stubby growth before dying. The

* Published with the permission of the Chief of the Bureau of Entomology. 
appearance of a phylloxera spot in a vineyard generally means an infestation of several years standing, perhaps as many as ten years or more. Throughout the vineyard, on the roots of many apparently vigorous vines, inspection will reveal the presence of the insect. Eventually other well defined spots will be noticeable, but even in this advanced stage there are but comparatively few dead vines. This applies to vines eight to twelve years old before being infested. Young vines, infested from the beginning, last a much shorter time, and the injury of the insect produces a more pronounced effect.

As a result of this investigation, both from a viticultural as well as an entomological standpoint, a most important fact pertaining to this subject has been placed on record. It is also of economic interest, because of its bearing upon the mode of spread of the insect, and its consequent relation to the severity of the damage to the viticultural industry. The leaf-gall form of the phylloxera does not exist in California. This is true for the American varieties of grapes, which are most susceptible to this form of the insect, as well as for the varieties of the Vitis vinifera. To establish this fact with certainty, a careful canvass has been made, and correspondence exchanged with the entomologists of this State, and with persons professionally and commercially identified with California viticulture; with but one exception all observations concur to prove the absence of the phylloxera leaf-gall form in the California vineyards. This exception deserves special mention, because of the authority of the statement and the peculiar circumstances pertaining to the production of the galls.

Dr. F. W. Morse of Oakland, Cal., then Assistant in the General Agricultural Laboratory of the University of California from 1881 to 1886, carried on investigations of the phylloxera in said State. Late in August, 1884, he found a few galls on the ends of three canes of a Canada vine growing in the vineyard plot on the University grounds. Quoting him from Bulletin No. 19 of the Agricultural Experiment Station of the University of California, he found "few peculiarly formed galls, containing egg-laying mother-lice, as well as eggs, and numerous larvae. A few isolated and abandoned ones were found on the old leaves nearer the stock of the vine." Evidently these were lice of a progeny of the ones which produced the galls on the older leaves. They had increased but little, and struggled along for existence since spring, contrary to their habit under Eastern condition, when they are very prolific; they were never observed before that time, nor afterwards; their presence on this occasion can, therefore, be considered as accidental.

\section{Life History.}

Space in this paper does not permit giving a detailed description of the different forms of the grape phylloxera. It will suffice to point out in what respect its life history differs under California conditions from that influenced by existing conditions of its original habitat.

In California the life cycle of the insect is restricted to parthenogenetic reproduction, and to the radicicole or root form only. It comprises this form in the two stages of Hibernant and Radicicole mother-louse. The Radicicole of spring passes through the pupa or nymph stage to become the alate form, also a root form, or Winged Migrant, which emerges from the ground only to oviposit, and is also parthenogenetic. A great number of the Winged Migrants 
are sterile, in the meaning that these do not deposit eggs. However, when mounted for microscopic examination, generally two large eggs are discernible in the bodies of these sterile migrants. This sterility may be ascribed to incomplete parthenogenesis. A relatively small number only of the winged migrants oviposite-one to five eggs being the number; two, a fair average. The eggs lack vitality; they fail to give issue to healthy active sexed forms. Most of the eggs do not hatch, and when they do, the young die in the act of molting. Hence, in California the winged migrant stage is the end of the progress in the insect's life cycle towards the production of the gallicole or leaf-gall form. This corroborates field observations and explains why grape phylloxera leaf-galls are never found in California vineyards, not even when composed of varieties of American grape.

Hibernants differ in no respect of structural form from the radicicole young larvae. The latter attain maturity the same season, on an average from eighteen to twenty-one days after hatching, while the former make their way up along the roots in search of a place to settle down on, and pass the winter in a dormant state. They neither molt, nor increase in size before they settle down. They awaken about the middle of March, and after four molts attain maturity, in five weeks' time on an average. These adults are the first radicicole mother-lice of the year. Hibernation begins in September; by December there are no more active young larvae, all are hibernants; adults are very scarce and no longer oviposit. From March to December there are from four to five generations of the radicicole apterous form. From late June to October a small proportion of the young larvae, the number depending upon the nature of the roots and on their more or less healthy condition, differentiate after the second molt, and become pupae or nymphs; these after two more molts attain the adult stage of winged migrants, which live from one to four days, rarely more. The nymph works its way up toward the surface of the ground; after transformation, the winged migrant emerges from the ground.

In late June or July a very marked migratory movement of the recently hatched larvae takes place from the roots in the deeper soil towards the surface of the ground, some traveling on the roots, but many more abandoning them for cracks and crevices in the soil by which they gain egress to the surface. This is in fact a true migration, and these young active apterous radicicole larvae furnish the only means by which the phylloxera spreads in California. The term "wanderer" is a suitable designation for these wingless migrants, and avoids confusion with the winged form to which the term migrant is usually applied.

The wanderers, if not exposed to the direct heat of the sun, can live for several days upon the surface of the ground. They can reach neighboring vines, as yet not infested, by crawling to them, or by the aid of the wind, be carried to different parts of a vineyard. Infestation from vineyard to vineyard, or from one viticultural district to another, can possibly happen by the exchange of grape-picking boxes, into the cracks or joints of which wanderers have crept, they thus being transported from one place to another. 


\section{Spread.}

As there exists in California no aerial form of the insect, there is consequently neither sexed form, winter eggs, nor gall louse, as far as present investigations have been able to discover, although these may at rare intervals accidentally occur; there is, therefore, practically no danger in spreading the pests if cuttings be used for planting vineyards in uninfested districts, even though obtained from an infested one; providing, however, they be made late in the fall of the year, and not buried in infested ground while awaiting shipment. Cuttings are very safe if free of adhering soil, and especially if submitted to the warm water method of disinfection. Rooted vines are dangerous, and require a careful cleaning of the roots for disinfection to be effective.

The wanderer, apterous migratory larvae, is the only means of spread due to the natural effort of the insect.

As already mentioned, the reason the phylloxera is so widely distributed over the State is because of the great activity in planting of vineyards in different districts which occurred during a period of years extending from 1880 to, and as late as, 1892. First, in the southern portion of Sonoma Valley, and Napa Valley, then in Livermore Valley, and later in the Santa Clara Valley.

Vineyard troubles in Southern California were due more to other causes than to phylloxera. In Fresno, the Muscat Raisin District, the phylloxera has been present for more than twenty years. The spread is slow, and the vines show a remarkable resistance before dying. In the. Stockton district infestation dates back to the early 80 's. While in the raisin district of Sutter County, where Thompson Seedless (Sultanina) grapes are almost exclusively used for raisins, the infestation is of more recent date, probably twelve years or so and due to one of the few wine grape vineyards.

In every instance the spread is slow, and the Vinifera varieties in general give evidence of a longer resistance to the injury of the insect than in Europe.

\section{Centers of Early Infestation.}

The grape phylloxera is not a native of the Pacific Coast. It was imported to California, and contrary to the current impression that the early European importations of grapes to the State are responsible for the introduction of this pest, there is greater probability that it was brought over from its native habitat east of the Rocky Mountains prior to that.

Without consulting any other source of information than the first annual report of the California Commission of Viticulture published in 1881 , this fact can be made evident.

During the early settlement of California the Mission fathers brought over with them, among other European plants, a Vitis vinifera variety of grape, now known as the Mission Grape, and the first cultivated grape to be grown on this Coast. There may have been other varieties brought over during the same period; if so, this one proved itself of superior adaptability, gave better satisfaction and was the only one propagated. The fruit has a delicate flavor, is very sweet and very palatable. The vine is prolific and but little subject to fungus diseases. For years it answered all requirements of both table and wine grape. 
When the first excitement of the gold discovery was waning, because of the travel across the plains being seconded by that across the Isthmus of Panama, rapidly increasing the population to such an extent that gold mining was no longer the sole pursuit, the pioneers branched out into commerce and agriculture. Viticulture soon grew in importance because of the favorable climate and soil of the country.

Vineyards of Mission grapes increased in acreage, and as the economic status of the grape industry proved to be a success, the growers desired to improve upon the Mission grape. American varieties were introduced from the East, for table grapes, and from Europe, Vinifera varieties, for the wine industry. Prior to this, there is no doubt that pioneers crossing the plains brought over with them American varieties from their Eastern homes without giving any thought to insect infestation.

Quoting from the report already mentioned: 1In the southern part of the County of Sonoma, the Buena Vista Company planted "a vineyard of about one thousand vines in 1834-35 ... in 1850-52 the vineyard was increased; in 1857 one hundred acres were put in vines. Again in 1860 fifty acres were laid out; in 1862 Colonel A. Haraszthy planted seventy thousand European vines. The Buena Vista Company again planted in 1864 one hundred thousand vines."

Prior then to 1862 , when mention is made of European vines, most vines planted must have been of the Mission variety.

Quoting again, "As early as 1860 decayed and dying vines were noticed in the vineyard." Although this was attributed to alkali water, "no examination by microscope was made, vines dying from time to time, showing short growth, small and colorless grapes, early yellow leaves, in fact all the symptoms were observed of vines dying from the vine pest. In 1868 about three acres of diseased grape vines were taken up (p?anted in 1850) . . . and new vines were planted, which grew well, showing little signs of decay until they were four years old."

Same report, appendix D, by J. Knauth, relating his personal experience. He imported in 1853 from Nassau on the Rhine, in Germany, fifteen varieties of grape-vine cuttings. These were first planted in his garden near Sutter's Fort. "They flourished splendidly, and were largely propagated while showing not a single trace of any sort of disease." In 1859-60 he established the Orleans Hills Vineyard in Cache Creek Canon, using for that purpose only the vines dug up from his garden. He goes on to say that sometime later some of the vines in less favorable soil of the vineyard began to die; he also states that some Zinfandel vines obtained from Napa, where an early infesta. tion of phylloxera existed, were planted in the same vineyard and does not clearly establish the fact whether the vines showed signs of disease before this planting or not. One thing is certain, the vine cuttings from Germany did not introduce the disease, and infestation was brought about by some cause within the State.

In the same report, the report of G. G. Blanchard, dated Placerville, December 18, 1880, gives us an insight as to what extent American varieties of grapes were grown in California. "In El Dorado County there are between

1Cal. Vit. Comm. An. Rep. 1, 1881, Appendix C, An. Rep. No. 1, 1881, H. Appleton. 
eleven and twelve hundred acres now in bearing vines. . . . The proportions and kinds growing, taking one hundred as the sum are as follows: Mission, sixty-eight; Catawba and Isabella, ten; White Muscat, Muscatella, Malaga, six; Tokay, Black Morocco, Malvoisies, one; Zinfandel, Riesling, two. The other thirteen are made up of numerous other varieties, such as Sweet Water, Black July, Hartford Prolific, Cloantha and Concord and some others." . . . . "The varieties of vines raised in Amador County, Calaveras County, Tuolumne County and Mariposa County are about the same as in El Dorado County." almost one-quarter of the vines grown in these counties are American varieties. Another of his statements gives an idea of the time these vines have been grown: "Very few vines have been planted in El Dorado County for the past five years."

Considering the statements made in these reports, at a time when European importations were of more consequence than any from the Eastern States, and comparing dates therein mentioned with the date $1863^{2}$ when the very first traces of a disease, then unknown to be caused by the phylloxera, even making allowance for the presence of the insect a few years prior to its injury to the vines being noticed, there still remains a probability in favor of the insect being introduced from the Eastern States. This is still more emphasized by the fact that at the time of the early importations from Europe, cuttings were almost exclusively used for shipments, while those from the East were more often rooted vines, many having been brought to California by the women folk of the homeseekers leaving a home in the East for one in the Far West. The danger of introducing the pest by means of Vinifera cuttings compared to rooted American vines is very small.

\section{Damage Done to the State of California.}

Prof. George C. Husmann, Pomologist in charge of Vitricultural Investigations, Bureau of Plant Industry, United States Department of Agriculture, places the damage at an estimate of seventy-five thousand acres of vineyards destroyed by phylloxera in California. Prof. F. T. Bioletti, head of the Viticultural Department of the College of Agriculture of the University of California, considers these figures about right, while Charles C. Wetmore, for many years identified with the Board of State Viticultural Commissioners, considers them as conservative. Placing an average valuation of an acre of vineyard at two hundred and fifty dollars, the loss sustained amounts to ahout nineteen million dollars (less the value of the land).

2Cours complet de Viticulture, G. Foex, p. 549. 


\title{
THE GRAPE ROOT WORM.
}

\author{
By F: Z. HARTZELL, \\ Vineyard Laboratory, Fredonia, New York.
}

The grape root-worm (Fidia viticida, Walsh) is a serious pest to grapes in several of the important grape regions of the northeastern United States. Although this insect has been known to science for more than forty years, it has been found to be especially destructive only during the past twenty years. The facts presented in this paper were observed at or near Fredonia, New York, which is in the Lake Erie Valley and about in the geographical center of the Chautauqua and Erie grape belt. This region extends from Erie, Pennsylvania, to near the suburbs of Buffalo, New York ( 80 miles) and ranges from three to ten mi'es in width. About 50,000 acres of Concord grapes are grown in this locality. It, therefore, can not be expected that such details as the time of emergence of adults, egg laying, hatching, etc., will be exact for other portions of the country where this insect is found but where temperature and humidity conditions differ from those normally occuring where the investigations have been made. Inasmuch as the importance and distribution of this pest will be presented at this meeting in another paper, we will hasten to other phases of the insect.

\section{History.}

B. D. Walsh1 described this species and gave us the first account of its injury. The insect has appeared in literature for nearly a century under other names. The life history of the insect was first described by Prof. F. M. Webster,2 who found it injuring grapes in Ohio. Additional facts regarding its habits and methods of control were given by Prof. M. V. Slingerland 3 of Cornell University, and Dr. E. P. Felt,4 State Entomologist of New York, both of whom made a number of experiments in Chautauqua County. The most recent and extensive work on the life history of the root-worm and the methods for its control has been done at North East, Pennsylvania, by Fred Johnson and A. G. Hammer.5 The insect has been mentioned in the writings of many other entomologists, but the foregoing references to literature deal with the more important contributions to the life history and methods of control.

1 Walsh, B. D., Pract. Ent. 2:87-88. 1866.

2 Webster, F. M., Cinc. Soc. Nat. Hist. 17:159-169. 1894. Ohio Agri. Exp. Sta. Bul. No. 62. 1895.

3 Slingerland, M. V., Cornell Agri. Exp. Sta. Bul. 184:21-32. 1900. Slingerland, M. V., and Craig, J. Cornell Agr. Exp. Sta. Bul. 208. 1902. Slingerland, M. V., and Johnson, F., Cornell Agr. Exp. Sta. Bul. 224. 1904.

4 Felt, E. P., N. Y. State Mus. Bul. 53. 1902. N. Y. State Mus. Bul. 59. 1902. N. Y. State Mus. Bul. 72. 1903. 1910.

5 Johnson. F., and Hammar, A. G., U. S. Dept. 'Agr. Bur. Ent. Bul. 89. 


\section{Origin and Food Plants.}

The grape root-worm is an American insect and, no doubt, its original food plants were the various species of wild grapes indigenous to its range. It frequently feeds on wild species at the present time but shows a decided preference for the Concord variety of cultivated grapes. Although no variety has been found that is entirely immune to its ravages, Clinton and Delaware grapes do not appear to be attractive to the beetle. The writer has never seen a vineyard of either variety seriously infested by this insect notwithstanding the fact that such vineyards were adjoining or even surrounded by Concord vineyards having the root-worm present in considerable numbers.

The question of the degree of immunity of varieties is one of both theoretical and practical interest and here an interesting field awaits investigation. Inasmuch as the control of the grape root-worm is combined with spraying for other insects and fungus diseases it is doubtful whether it would pay to graft Concords on stock which is largely immune to the attacks of this insect. If this would produce other advantages, such as increased vigor, then grafting of roots might prove practical.

\section{Character and Extent of Injury.}

The adult beetles feed on the leaves of grapes eating chain-like areas on the upper surfaces. The insect grasps a portion of the leaf with its mandibles and then lifts its head thus tearing the tissue which it proceeds to devour. A slight advance is made and another portion of the leaf is torn

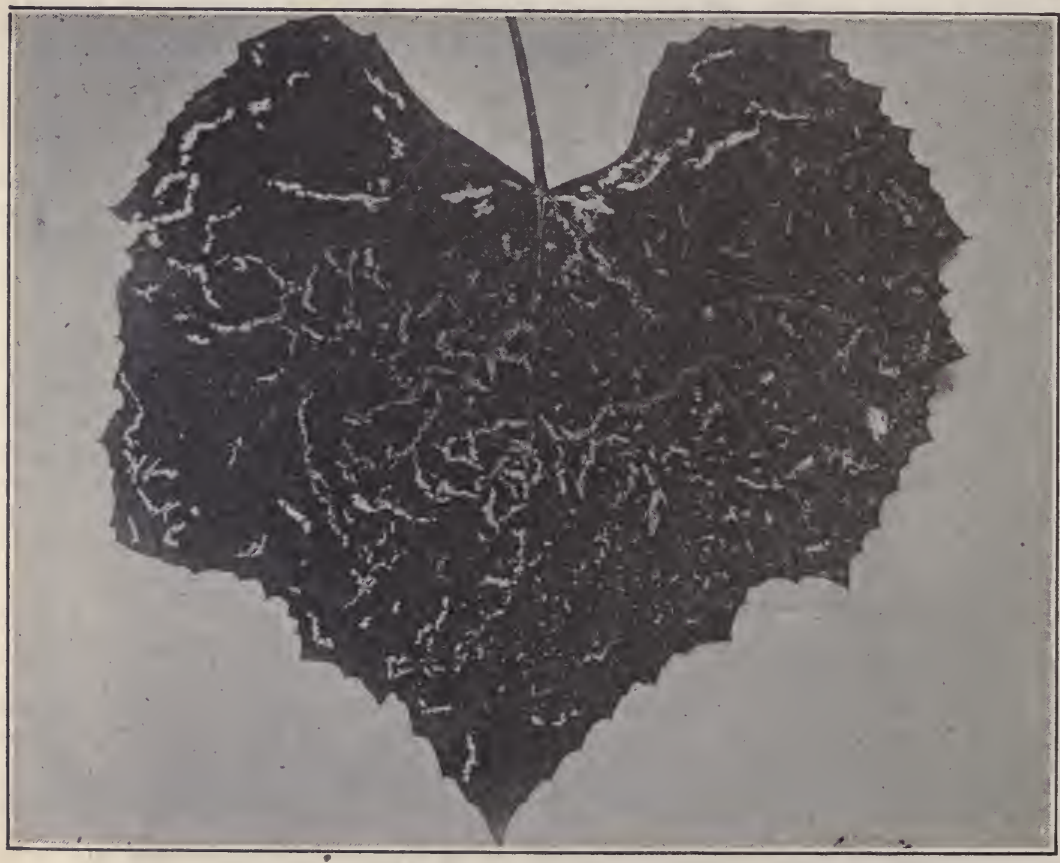

Fig. 1. Effect on leaf of feeding adults (slightly reduced). 
out. If a number of pieces are torn out a chain-like appearance is presented on the upper surface. The feeding on thick leafed varieties usually extends, in depth, only to the small veins near the under surface thus leaving a network of veins exposed but as the leaves grow older these veins die and fall out thus leaving an irregular chain-like hole. If the beetles are very numerous individual leaves may have the tissue eaten so that only shreds remain, but it is very seldom that sufficient feeding occurs on the foliage of a vine to cause injury. The writer recalls only one such instance. In this case a vineyard of three acres had the foliage seriously injured. It happened that the owner had had an adjoining vineyard so severely infested by the larvae that the vines were badly injured and this vineyard was pulled out in May. As the larvae had completed feeding this did not effect their development and after emergence the adults concentrated on the nearest vineyard.

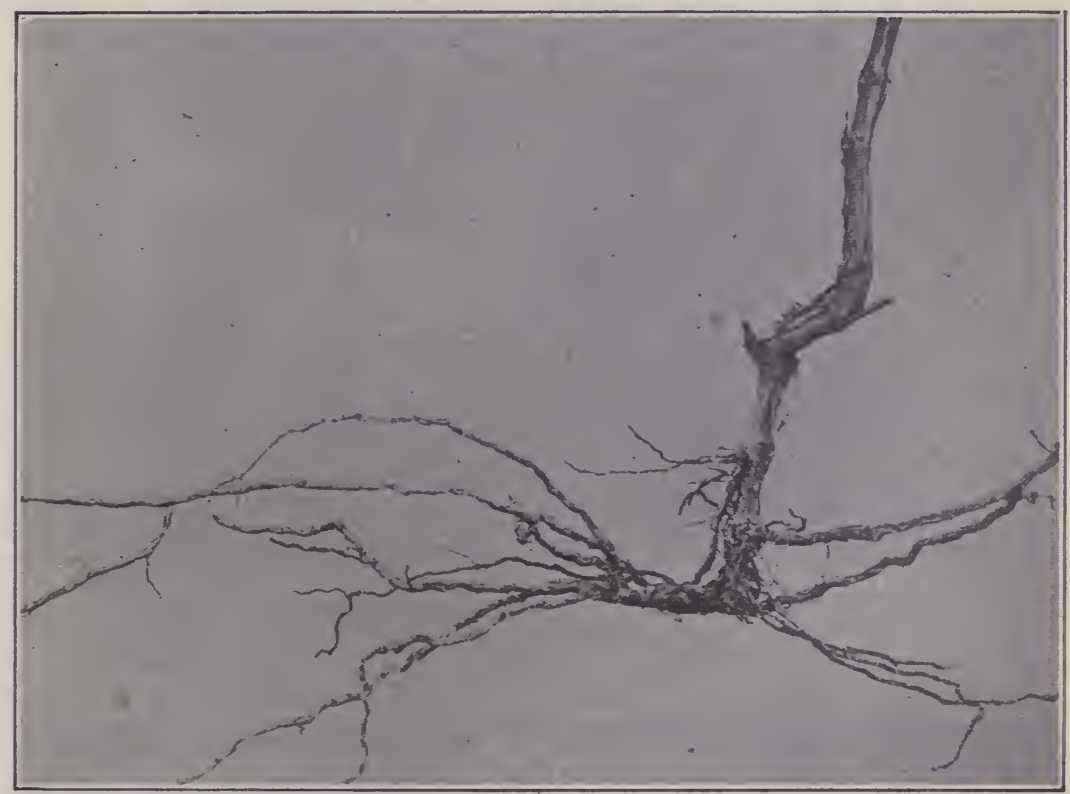

Fig. 2. Effect on roots of severe attack of larvae (reduced).

The greatest damage by Fidia viticida is caused by the larvae, or, socalled root-worms, feeding on the roots of the grapes. The young larvae feed first upon the small fibrous roots usually eating the bark but as the grubs increase in size they gnaw through the small rootlets and channel the bark of the larger roots, often girdling them. This destruction of the root surface decreases the water and food absorption of the plant thus weakening the same. These channeled roots with a scarcity of fibrous roots is the first sign that a grower should seek in a diagnosis of the cause of weakened vines and the presence of these characters would indicate some species of grape root-worm. There are several species of root-worm attacking grapes in the United States and the correct determination of the species must be 
left to the specialist. However, the life histories of the several species are similar so the remedial measures given for $F$. viticida will answer for the control of the other species. The weakening of the vines is the most usual effect of root-worm injury and while this may not always lead to the destruction of the vines, nevertheless they may be so weakened as to produce grapes at a loss.

During periods of severe infestation many vines are killed, sometimes whole vineyards being practically destroyed, but this effect is limited to times of greatest abundance of the insects and is only the exceptional effect during ordinary years.

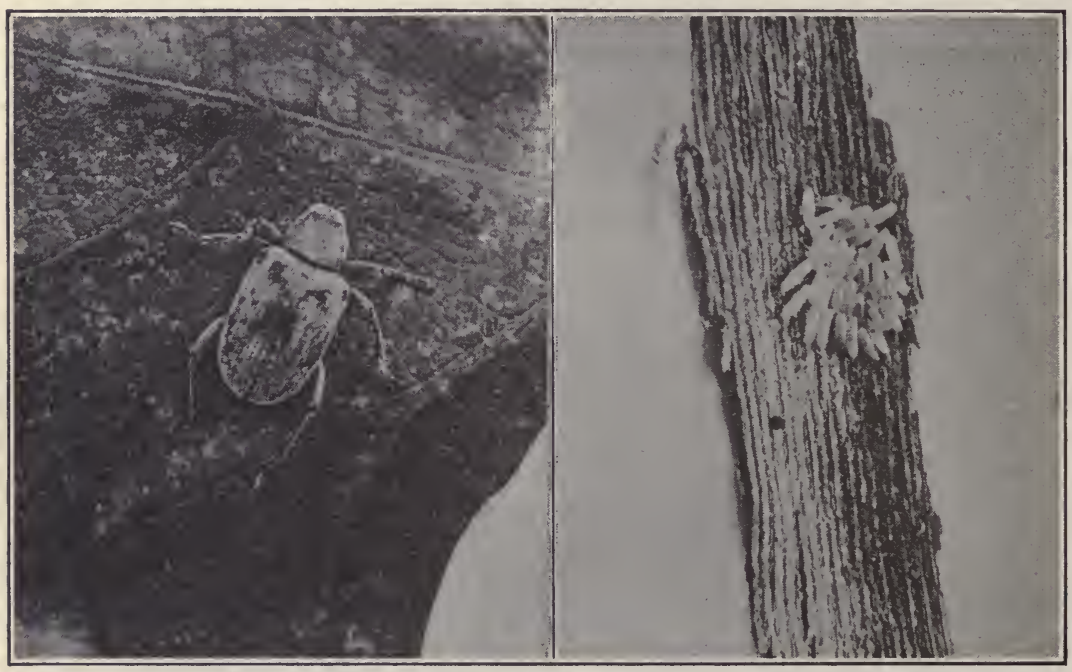

Fig. 3. Adult (enlarged four times). Eggs (enlarged four times).

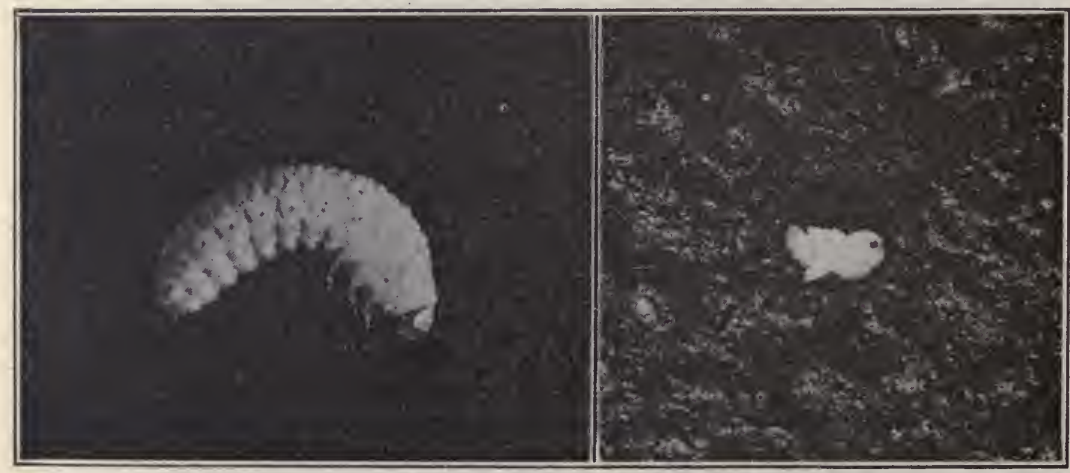

Fig. 4. (a) Larva (enlarged six times).

(b) Pupa (slightly enlarged). 


\section{Description.}

Egg. The eggs of the grape root-worm are small, glossy, semi-translucent, yellow bodies. The means of $416 \mathrm{eggs}$ were $1.05 \mathrm{~mm}$. (.041 inch) in length and $.315 \mathrm{~mm}$. (.012 inch) in diameter. They are cylindrical in form with the ends hemispherical. The stresses produced by the bark, under which they are laid, generally cause the major axis of the egg to be more or less curved.

Larva. When full grown the larvae vary in length being 8 to $10 \mathrm{~mm}$. (.3 to .4 inch). They resemble somewhat the common white grub but are much broader in proportion to their length. The spiracles are brown, nine being visible on each side of the body. The head and thoracic shield are yellowish-brown.

Pupa. The pupae are slightly shorter than the larvae and are cream colored. Hooklike processes are found on the distal ends of the femora and the posterior parts of the body. A number of hairs and setae are found on the body, those on the head and posterior parts of the body serving to support the pupa in its cell.

Adult. The adult beetle is about $6 \mathrm{~mm}$. (.25 inch) in length and all portions of the body have a nearly uniform brown chitin which is densely covered with short gray hairs. The usual color of the adults is gray, due to the abundance of hair. There is considerable variation in individuals as regards color, some specimens having the upper parts of the body and elytra brown caused, in some instances, by the shortness of this hair, in others, by the lack of hair. It seems that the activities of some individuals rub off many of these hairs on the back but all individuals have the under sides of their bodies covered with gray hairs. This is nature's way of protecting them from their enemies for when the beetles drop to the ground and lie motionless this color causes them to resemble the soil and thus they escape being seen by their enemies. The pits bearing the hair are not arranged in any definite pattern but there are larger pits which do not bear hair and these are arranged in rows which run lengthwise and cause the insects to have a finely striated appearance.

The clypeus and mandibles are shining black the former having a number of yellow setae. Each Antenna consists of eleven segments being a light brown with many hairs and setae. The legs are brown with the tarsi slightly darker.

\section{Seasonal History.}

Emergence. During a normal year, the beetles emerge the latter part of June and the early part of July. We expect to find the first adults emerging near the 25 th of June, on gravel soils, but the majority do not appear until almost a week later and certain straggling individuals may not come forth until nearly three weeks later. The time will be a week to ten days later on the heavier soils. The adults have been found as early as June 18th and during late seasons the first ones were not found on gravel soil until July 5th. The occurrence of rains may influence the emergence especially on the heavy soils where the ground has formed a hard crust for here the beetles are imprisoned and cannot emerge until the rain loosens the soil sufficiently for them to dig their way out. 
Emphasis has been placed on the period of emergence for the time of spraying is dependent upon it. This phenomenon together with the time the eggs are deposited constitute an important portion of the seasonal history of the grape root-worm so far as remedial measures are involved. For this reason it is very necessary that these dates be accurately determined by grape growers themselves for they differ with the locality, soil, latitude and humidity. For several years the writer has made an effort to correlate the time of emergence with well marked conditions of the vine, but so far no condition, that is constant has been observed. The size of the berries and the time the fruit has set to the time of emergence of the beetles is found to be variable, depending on moisture and temperature. Nothing so well defined as the relation between the time of spraying for the codling moth and the falling of the petals of the apple has been found for grape spraying. During normal years sprayings made about one week after the fruit has set have been found to be very effective but this will not be true for abnormal years. Fortunately the feeding of the beetles is so conspicuous that grape growers should have little trouble in noting the time of emergence sufficiently accurately for practical purposes. Growers should have sprayers and materials ready for immediate use by the time the fruit has set, then by careful observation the exact time for spraying can be determined and the material applied when it will be most effective.

Feeding habits. The adults usually do not begin feeding until about a day after emergence. During the first two weeks of their life as adult they feed ravenously but later feed much less, especially after dispersion has taken place. The adults feed only during portions of the day, remaining in hiding near the axils of the shoots much of the time. A favorite position is in the axils near the upper wire in the Chautauqua system of training.

Egg deposition. Shortly after mating the females begin to deposit eggs. these eggs are placed chiefly under the loose bark of the canes but are found on all the woody portions of the vine above ground. The eggs are tucked away between the living bark and the loose or corky layers which cover the vine. Seldom do we find eggs laid in exposed situations either on the foliage or on the wood. The number deposited in a cluster varies greatly. In 1914 the numbers of eggs in 164 clusters were counted and the range was found to be from 1 to 66 with a mean of 24 .

The eggs hatch in about two weeks after being deposited although this time varies greatly because of differences in temperature.

Larva. The small larva after hatching crawls about on the bark and soon drops to the ground where it immediately burrows into the soil. It works its way to the roots of the vine on which it feeds. It grows rapidly and often reaches full size by November. If it does not attain its full growth by that time it usually does so the following spring. In several instances Johnson and Hammar found that the larvae lived until the second summer before changing to pupae.

The latter part of October, the larvae burrow into the soil to the depth of about a foot or even eighteen inches where they form cells and thus pass the winter. Early in May they leave these larval hibernating chambers and return to the roots where they feed a short time and change to pupae the early part of June. The normal larval stage is about ten months. 
Pupa. The larvae, when ready to pupate, burrow to a depth of several inches and twist their bodies about to form spherical cells in which to transform to pupae. The depth of these cells is largely influenced by moisture although there is individual variation in the same soil. The first of these pupae are usually found between June 5 th and 10 th. This stage lasts for a period of from two to three weeks depending upon the temperature during the period.

\section{Summary of the Life Cycle.}

The life cycle of the grape root-worm is usually completed in one year although an occasional individual may require two years to complete development. This may occur because the food supply of the larva has not been sufficient for its needs. The eggs are laid in July and August. These hatch in about two weeks and the young larvae, upon hatching, seek the roots and here feed until fall when they burrow deeper, form winter cells and thus hibernate. They leave these in May and seldom resume feeding. Early in June pupation takes place and the adults emerge the latter part of June. Feeding occurs during July but mating takes place the early part of this month and egg laying is in progress during the latter part of July and early August, although a few eggs may be laid as late as the first of September. The adults begin to die the last of July and by the 15th of August very few are to be found. Rarely they have been found late in September.

\section{Remedial Measures.}

Efforts to kill the grubs before they enter the soil or after entrance are not regarded as practical owing to the cost. The efforts of entomologists have been directed toward ridding the vineyard of the adults before they have had an opportunity to deposit eggs and to the destruction of the pupae. The first is accomplished by the use of sprays and the latter by cultivation of the soil in such a manner as to destroy the pupae through the breaking of the pupal cells.

Destruction of the pupae. In New York vineyards it is a common practice to form a low ridge underneath the trellises at the last cultivation of the summer. This ridge is removed, usually during May, after the plowing has been done and it is considered good horticultural practice to remove this early thus avoiding the loss of small roots that might form here were the ridge to remain longer. However, should the grape root-worm be present in serious numbers, the advantage of leaving this ridge undisturbed until the larvae have formed their cells and pupated and then removing it seems to be largely in favor of this latter practice for the deleterious effects to the vine as regards moisture and root injury is more than compensated by the destruction of large numbers of pupae. The average date for this practice is June 10th and the work is done by means of a horse-hoe followed by deep harrowing, preferably with a spring tooth harrow. The ridge serves as a trap for the insects as they are induced to place their cells where they can be reached by cultivation whereas if the ridge be torn away earlier the larvae would form their cells lower and among the roots thus preventing their disturbance. The working of the soil breaks the cells and exposes them to the 
air and sunlight thus destroying them. This practice will not kill all the pupae owing to the fact that some of the grubs will form cells too low for cultivation to reach them. Again all grubs do not form cells at the same time and thus, if disturbed before the cells are formed, will crawl into the soil and form cells lower than the tools penetrate.

Destruction of the Adults. The several entomologists, who have experimented on the control of this species, have used some form of poison as the most effective method of killing the adults, and this is the method of control that is generally recommended.

The most extensively used material is arsenate of lead (6 lbs.) and Bordeaux mixture (8-8-100) 100 gallons. It should be applied as soon as the first beetles appear, using not less than 100 gallons per acre. Where the foliage is dense it will require 150 gallons to cover an acre of grapes properly. A second spraying should be applied in ten days or two weeks. The material just mentioned is most valuable in a vineyard where the foliage is not very luxuriant or where the beetles are not too numerous. In vineyards having excessive numbers of these insects, especially where the foliage is dense, better results are secured by using a spray consisting of arsenate of lead (6 lbs.), cheap molasses (1 gal.), and water (100 gal.), followed in one week by a single spraying of Bordeaux mixture and arsenate of lead in the proportions mentioned above.

The use of the sweetened spray by the writer was brought about through the apparent failure of grape growers to combat the root-worm by means of the Bordeaux mixture-arsenate of lead spray. All workers have found that there is considerable variation, especially some seasons, in the effectiveness of this material. This may have been the result of improper application of the material, due to the interference of wind and dense foliage, or it may have been due to manner in which the poison was made. Our experiments have shown that this material is distasteful to the beetles and this has changed our views regarding the effect produced on the insects. It has usually been assumed that the insects are poisoned but we now hold the opinion that it produces a repellent action on them. In no other way can we account for dead beetles being found under vines where molasses and arsenate of lead was used while in the same field the vines sprayed with Bordeaux mixture and arsenate of lead revealed no dead insects yet the vines were cleared of beetles. Cage experiments have shown that this latter material is distasteful while molasses attracts them.

It seems that too much dependence has been placed upon the idea that a spray to be effective must eradicate the pest in a single season. The cumulative effect of Bordeaux mixture and arsenate of lead upon the infestation is marked when spraying is continued regularly for several years. Although this mixture may not give as decided results as the sweetened spray when used for one season only, especially where the beetles are numerous, still its ise in the same vineyard over a period of years keeps the number below the danger mark. The writer has seldom found a vineyard in the Chautauqua and Erie grape belt that is serlously infested with chewing insects where two thorough applications of this spray have been properly applied for a period of five years.

The great drawback to the sweetened spray is its lack of adhesion. If it should happen to be applied shortly before a rain it will be ineffective be 
cause of being washed upon the ground. Careful forecasting of the weather is necessary if best results are to be attained, but under the proper conditions, this material followed with the Bordeaux mixture and poison has produced the best results of any tried to date.

From the results of many field trials and observations we would recommend that when a vineyard is severely infested the molasses and poison be used for the first spraying and the second application be Bordeaux mixture and poison, while in a vineyard having a moderate infestation two applications of Bordeaux mixture and poison be used.

The fungicidal qualities of this latter spray are needed in most New York vineyards and at least one application should be made whether insects are present or absent.

\section{THE GRAPE LEAF-HOPPER. \\ By F. Z. HARTZELL, \\ Vineyard Laboratory, Fredonia, New York.}

The most common insect found on grape vines in the United States is a small insect commonly, but wrongly, called "thrips" in many localities. This is the grape leaf-hopper and a number of species are found on cultivated grapes. The species most often found is Typhlocyba comes Say of which there are nine varieties. Inasmuch as the other species are similar to this one in life habits and destructiveness and also because this species has been studied by entomologists to a greater extent than the others, this paper will be confined to the life history, habits, destructiveness and control of Typhlocyba comes Say as found to exist in the Lake Erie Valley and throughout the Empire State. Due allowance must be made for differences which exist regarding dates of transformation, etc., in other parts of its range.

The other species and varieties being similar in habits to the typical comes, control measures adapted to the latter form will apply to the other species at least under New York conditions. Certain varieties of grapes are preferred by one species of leaf-hopper and appear to be avoíded by others. Again, several species may infest the same variety in a region but this is not a constant habit, for Concords in one locality are infested by $\mathrm{T}$. comes in another by $\mathrm{T}$. tricincta or a variety of $\mathrm{T}$. comes. Since a detailed discussion of these facts would lead us beyond the limits assigned to this paper we will confine our writing to the life history of $T$. comes and especially to the factors necessary to a knowledge of the proper control of the several species of leaf-hopper found in the northeastern United States.

\section{Food Plants.}

Although the grape leaf-hopper feeds on the foliage of the grape during practically the entire period that this is present, it also feeds on other plants in the spring before the grape foliage has unfolded and during the fall after 
these leaves have dropped from the vines. These insects become active with the first warm days of spring and feed on a number of species of plants. The most important are raspberry, blackberry, strawberry, burdock, catnip, Virginia creeper, currant and gooseberry but they have been found feeding on the foliage of beech, sugar maple and various grasses when their preferred food plants were missing. An interesting succession of plants used for food in the spring has been noted. The leaf-hopper fed on burdock, grasses and wild strawberry until the foliage of the raspberry and blackberry had advanced sufficiently for the young leaves to shelter the insects when they flew to these latter plants, preferring the raspberry (both red and black). They remained on this foliage for the space of nearly one month during which time mating occurred. It may be of interest to mention that when these insects are numerous they severely injure the leaves of cultivated raspberries during May. By the latter part of this month the first grape leaves have grown to a diameter of about two inches and the leaf-hoppers migrate to them. Here they remain during June, lay their eggs and, later, die. The young hatching from the eggs feed and develop on these leaves and remain on them until they drop in the fall. Feeding during the warm days of autumn is confined largely to the leaves of the strawberry and various grasses but they feed on a number of other plants if these are present.

\section{Character and Extent of Injury.}

The grape leaf-hopper is a sucking insect and obtains its food by piercing the tissues of the leaf and sucking the sap. The loss of sap would not interfere with the economy of the vines but since a small area of the leaf dies about each puncture, caused by the drying of the injured area, the presence of many of these punctures interferes with the ability of the leaf to perform its functions. An average sized leaf after being seriously infested until the latter part of July was found to have about 20,000 such dead areas. Such leaves have a yellow appearance, do not produce starch sufficient to meet the needs of the vine and, as a consequence, infested vines do not develop the required amount of wood, nor ripen the same, and the amount of fruit produced is, in time, considerably reduced. The decrease in amount of fruit is greater the season following the infestation. By far the most serious injury is caused by the failure of infested vines to properly mature their fruit. Fruit from such vines is deficient in sugar and flavor and also contains more acid than is found in well ripened grapes. Grapes from vineyards infested with leaf-hoppers will not be used by the manufactures of the better grades of grape juice nor are they suitable for use on the table or the making of wines. They can be used to advantage, however, in the making of jellies but as this industry is only in its infancy very few grapes are used for this purpose.

The actual loss to grape growers from this insect is difficu't to estimate. During years of ordinary infestation the damage caused in New York state is not great; in fact in many regions it is not sufficient to warrant spraying to control the pest. It is during periods of abundance of these insects that vineyards suffer and at such times the injury is sufficient to cause loss. We estimate that this seldom exceeds $\$ 60.00$ per acre for two seasons, and that the injury in infested vineyards averages about $\$ 20.00$ 
per acre. It is necessary to include two seasons' crops in this estimate for these insects usually injure the quality the first season but the effect on the quantity does not appear until the second season. Only two serious outbreaks have occurred in Chautauqua County, New York. And each of these extended over but a few seasons. For this reason the average annual loss is rather small. In other sections of the state, the annual losses from this pest are greater because the outbreaks appear to occur at more frequent intervals. The reasons for this latter condition are: (1) the environment is favorable for hibernating; (2) in some sections, vineyards are grown in proximity to raspberry plantings which we have learned affords the leaf-hoppers both suitable hibernating quarters and (more important) food before the leaves of the grape appear.

\section{Factors Favoring Injury to Vineyards.}

A study of the ecology of this insect has revealed the reasons for the variation in infestation found in a locality during the same season and may explain the causes for the greater infestation found in certain regions. The most severe infestation of vineyards have always been found where they adjoined land having favorable conditions for hibernation of the leafhopper or spring food plants of which raspberry and blackberry plantings seem to be preferred. The locations favorable for winter quarters are dead grass, that has lodged, and leaves, especially those of deciduous trees which are resistant to moisture and to becoming tightly packed by snow. For this reason fences, brush land, waste places grown up with grass, hay fields, when the second crop has been allowed to lodge, and other places in which such rubbish might gather were always found to shelter many of the hibernating adults. During the warm days of autumn myriads of leaf-hoppers fly about and travel short distances alighting in every place they chance to find. Should they find conditions for winter quarters unsuitable they leave them and drift about until suitable places are found. The first warm days of spring cause them to leave their winter quarters and seek food. We again find them on the wing at times and as soon as raspberries are found begin feeding on these. However all leaf-hoppers do not migrate to berry leaves but many continue to feed on grass and weeds which may be present, migrating to the grape leaves as soon as these have grown to be an inch or two in diameter. Weedy vineyards also make excellent places for these insects. Plants which remain green during the winter, such as the several cover crops, do not shelter these pests to any extent although a few of the insects may remain and feed on them. Plantings which are sown to cover crops, which remain green during the winter, or which are kept free from weeds and rubbish and have clear surroundings are not severely attacked by these bugs. The practice of clean culture has given the eastern vineyardists a powerful weapon of defense against the enemy. The writer studied the distribution of these insects in Chautauqua County during the severe infestation of 1912 and at that time few infested vineyards were found on the heavier soils. All observations indicate that either the leaf-hopper seeks dry situations in which to hibernate or the individuals which go into winter quarters on the lower soils die through flooding of these places or on account of the continual dampness. 
True one can find individuals on grapes on all soils but not in the same amount as on the lighter soils.

\section{Description.}

Eggs. The eggs are partially transparent, slightly curved or bean shaped and are between $.7 \mathrm{~mm}$ and $.8 \mathrm{~mm}$ (about $.03 \mathrm{inch}$ ) in length and from $.2 \mathrm{~mm}$ to $.3 \mathrm{~mm}$ (about .01) in diameter.

Nymph. The young leaf-hoppers resemble the adults in general shape but lack wings. In the place of the latter we find thickened areas which are the developing wings, also called wing pads. These increase in size with each moult disproportionately to the other parts of the body. These nympths are yellowish-white in color with red eyes during the first instar. They pass through five stages or instars and at the last moult upon changing to adults the wings unfold. The eyes change to yellow in the second instar.

Adult. The adult insects have a general color of yellow and are variously marked with darker yellow or salmon irregular areas. Several black spots are found on the wings. The variation in color and shape of the colored areas and spots is so great that nine species have been described but these are now regarded as varieties of Typhlocyba comes. The black spots remain constant but the irregular areas change in color from yellow to salmon while individuals having areas of light red have been found. These variations in color vary with the season. The typical color during early summer while the insects are feeding on grape foliage is yellow, but during late summer and autumn they change to a salmon and often to a red. This darker phase is found in the those hibernating and also while they are feeding in the spring, but as soon as feeding is resumed on the grape the color changes to a light yellow. The typical comes is the common variety on Concord vines in Chautauqua County, New York. Although a number of the variety octonotata are also found.

\section{Seasonal History.}

The eggs hatch during the latter part of June and July of a normal season although they have been observed hatching during early August. The nymphs feed by sucking the sap from the leaf, practically all feeding being done on the underside. They require from three to five weeks to reach maturity depending upon temperature. The majority of these nymphs change to adults from July 10 th to July 25 th of a normal year but nymphs of the first brood are often found during early August. If weather conditions are such that a second brood is not produced, the adults appearing in July and August continue to feed on the grape foliage until the fruit is harvested and the leaves begin to fall. We then find them dispersing to other food plants but especially to locations where rubbish and leaves have been collected by the wind and where they remain during the winter. They are active on the warm days of autumn but during cooler weather remain quiet in their shelter. With the warm spring days we find them resuming feeding on the plants previously mentioned. The adults mate during May and early June. The males die before the females, few of the 
former being found after June 15th. The females die during the latter part of June and July.

A second-brood of leaf-hoppers is produced during hot, dry seasons and usually a partial second brood during a normal season. Eggs are laid by the earliest developing adults during August and perhaps September for young nymphs of the first instar have been found as late as October 1st. Most of the nymphs of this brood develop into adults during late September and early October but it is believed that many of the nymphs never develop into adults owing to their late appearance unless they reach maturity on other plants. Nymphs have never been observed hibernating.

The length of life of the single brood insect is about one year but the length of life of the adults during years having a second brood has not been determined.

\section{Natural Control.}

All entomologists who have studied this insect have noted great reductions in the number of leaf-hoppers infesting vineyards but the exact causes of these diminutions in numbers are not known. Climatic conditions appear, however, to be an important factor.

The serious outbreak of 1911 and 1912 terminated rather suddenly during the late summer of the latter year and abnormal weather-low temperatures and excess of rain-is believed to have been the cause. The nymphs did not seem to thrive so that few reached maturity. A worker has reported that high temperatures kill the insect but this has not been the cause in New York vineyards.

Predaceous and parasitic enemies exact their toll but careful observations indicate that these play only a small part in the reduction of the pest. After a study of the literature and personal observations made during a period of decided decrease, the writer must acknowledge that we are ignorant of causes of natural control of these insects.

\section{Remedial Measures.}

Under conditions obtaining in the northeastern United States it appears that several methods of control are practical. The following have been noted or used by the writer: (1) destruction of hibernating places either by clean culture during the summer or by burning over such places during the fall or winter; (2) avoiding the planting of bush fruits close to vineyards; (3) the allowing of the shoots or "suckers" to remain at the base of the vines until early July; (4) spraying with nicotine mixture to kill the nymphs.

Destruction of hibernating quarters. Any practice which will keep vineyards and especially the land surrounding the same clear of weeds and grass will prevent the leaf-hopper from hibernating near the vines and this has been found to keep the vineyards free from serious infestation. If the surroundings have grown up to grass which has died and lodged especially if leaves have been gathered here by the wind, the most practical measure usually is to spray these with kerosene if they will not burn readily and destroy these refuges by means of fire. This method was used by several grape growers with success during the 1911-1912 infestation. 
Keeping bush fruits some distance from vineyards. Along the Hudson river it is customary to interplant grapes with raspberries and such vineyards are seriously infested practically every year. In other sections grape growers often plant raspberries in close proximity to vineyards and the vines near such plantings are often seriously infested. Since we have found that the raspberry is an important spring food of the leaf-hopper the reason for this is obvious. Whenever possible these two fruit p'ants should not be planted near each other.

Retardation of suckering. A common vineyard practice is to remove the shoots which grow near the base of the vines. This is usually done during June-a logical time ordinarily. However, during periods of attack by the leaf-hopper, it is better to allow these shoots to remain until early July. The adults dislike to be disturbed and to avoid this seek the lowest foliage on the vines and here lay their eggs. When this is defiled by excrement and feeding they seek the leaves higher on the vine. Usually this movement to the higher foliage occurs late in June if the suckers are allowed to remain, but if these are removed early in June, the insects injure the foliage which is to remain all summer. By allowing these suckers to remain until the first week of July and then removing them the more permanent foliage is saved from injury and any nymphs and eggs are destroyed by the dying of the foliage after being removed.

Spraying to kill the nymphs. No spraying operations that have been tried have proven practical against the adults but the use of contact insecticides to kill the nymphs has been recommended for a number of years. From the standpoint of safety to foliage, cost of material and effectiveness nothing has been found better than nicotine sulphate diluted so that .02 of one per cent of the material is present in the spray solution. Commercial nicotine sulphate usually contains 40 per cent nicotine and at this strength only one-half pint is required to each 100 gallons of spray material.

The question of application is very important for it is absolutely necessary to hit the bodies of the nymphs with the spray material to be effective. A common method of application is by means of trailing hose having a short extension rod with nozzles set at right angles attached to a power sprayer. This method requires three men-one to drive and two to handle the nozzles. It is a very effective method and in vineyards planted on steep slopes is the only one that can be used. The cost of application by this method as well as the disagreeable effect of the material on the operators, has led to the development of several types of machines which can be used, in level vineyards, to deliver the spray against the underside of the foliage. Space forbids our discussion of these at this time but anyone interested in them can secure illustrations and descriptions of the same in Bulletin No. 19 of the United States Department of Agriculture and Bulletin No. 244 of the New York Agricultural Experiment Station.

In order that spraying to control the grape leaf-hopper be effective, the men operating the apparatus must use care and be thorough in every detail of the operation. 
The use of sticky shields to capture the adults has not proven as practical in eastern vineyards as the several methods of control iust described.

This paper was followed by a discussion, lead by President Alwood, on remedial and preventative measures regarding the grape leaf-hopper, Mr. W. T. Stevenson, of Elk Grove, Cal., and Mr. Frank T. Swett, of Martinez, gave their experiences with the use of atomic sulphur.

Mr. R. H. Roberts, Agricultural Expert with the Santa Fe System. "I use a nicotine mixture together with atomic sulphur in the control of the nymphs. There are very few vine hoppers in the San Joaquin Valley this year. When the nymphs are young, atomic sulphur alone is sufficient to control, and later on nicotine and water, together with whale oil soap as a spreader, will give control. The nicotine will give you a 90 per cent kill. The cost per acre runs from $\$ 2.50$ to $\$ 4.00$, including all labor, supplies and material. tine?"”

Prof. Bioletti. "Do you advocate the use of sulphur without the nico-

Mr. Roberts. "Yes; because it stays on the vine. Used strongly it will give about a 50 per cent kill. It will kill the very youngest nymphs, but the nicotine is the real control."

Mr. Gray. "The atomic sulphur is used preeminently as a control for the mildew, and used with nicotine they mix very well-the sulphur for the control of the mildew and the nicotine for the control of the leafhopper. When nicotine is used alone with water it is not very effective, but when used with something else, as, for instance, whale oil soap as a spreader, it will stick to the leaf."

Mr. Swett to Mr. Roberts. "What form of nicotine do you find best?"

Mr. Roberts. "Sulphate of nicotine, and a spreader of soap is most important to the Emperor vine."

THE GRAPEVINE FLEA-BEETLE.

(Haltica chalybea Illiger.)

By F. Z. HARTZELL,

Vineyard Laboratory, Fredonia, New York.

The first destructive insect to make its appearance in the vineyards of the eastern United States, with first warm days of spring, is a small active beetle of a shining blue color. This coloration has caused it to be given another name-steely beetle. In common with other beetles which have the power of leaping great distances it has been called flea-beetle and from its chief food plant it receives its common name of grapevine flea-beetle. In certain localities it bears the additional appelations: steel beetle and steel-blue beetle. 
This trim blue beetle has been a serious pest in New York vineyards at various times and it is claimed by early entomologists to have caused an immense amount of damage to grape growers. It has appeared in the literature for almost a century and during the latter part of that period it has been mentioned almost annually by many observers. For these reasons this species is one of the best known of our grape pests so far as distribution and feeding are concerned. Many of the details of its life history and habits have been described during the past 35 years. With all these observations there are many facts regarding the life cycle and especially the ecology which will bear careful observation and experimentation before this species becomes as well known as many of our important economic species.

\section{Economic Importance.}

The relative importance of this insect as a grape pest will be given by another. but there are several observations regarding the species in the Chautauqua and Erie grape belt which may be of interest. After careful study of this pest for six years, during several of which there have been severe infestations, it appears that all accounts of the loss of fruit by this insect are correct. However, it is difficult to reconcile the statements of most observers regarding the killing of the vines by the beetles and our own observations. In a very severe outbreak in one locality in 1913 the insects were as numerous as one finds mention of in the literature, yet few vines were killed in a vineyard of six acres (19 vines out of $4020, .4$ of one per cent). The only explanation offered is that it is possible that in former outbreaks a large number of beetles were concentrated on a small number of vines owing to the vineyards being smaller and not in such close proximity to each other as at present. Whatever the explanation, the number of vines killed at present is almost nil when the area of the vineyards is considered. The damage to the crop may be great in restricted areas but it is small when compared with the tonnage of this grape belt. Unfortunately all the loss occurs in a few vineyards and, to the owners of these, this pretty blue insect is a source of considerable financial loss. Under New York conditions, this flea-beetle is found each year in a few localities. The proximity of waste land having wild grapes appears to be the controlling factor in its distribution, for it evidently does not thrive in cultivated vineyards exclusively. In the region just mentioned not more than one per cent of the area is infested.

\section{Food Plants.}

The chief food plants of the grape-vine flea-beetle are the various species of wild and cultivated grapes found in the eastern United States. Most accounts are in connection with injury to cultivated vines. The occasional feeding on other food plants evidently occurs when the beetles have accidentally gotten away from grapes. The writer has made fall and spring observations on the feeding habits of this beetle for several years, including the examination of a number of common plants commonly reported as fed upon by this insect. The following species showed no feed- 
ing: apple, plum, pear, peach, beech (Fagus grandifolia), American elm, sugar maple (Acer saccharum), elder (Sambucus canadensis), raspberry (black and red), blackberry, strawberry, red osier (Cornus stolonifera), Crategus spp., birch (Betulaleadlenta), willow (Salix alba), ash (Fraxinus americana), sumac (Rhus typhina), common chickweed, Virginia creeper, dog tooth violet (Erythronium americanum), and dandelion. The only food plants found during five seasons have been the Concord grape and the wild blue grape (Vitis bicolor). The beetles prefer the Concord during the spring but during late summer and autumn feed almost entirely on the foliage of the wild blue grape. Vitis riparia and V. cinerea are rather rare in this region (Chautauqua Co., N. Y.) and the beetles have not been found on them, but this does not mean that these insects do not use these species for food plants. On the other hand, we believe that it means that the locality in which these two species were found was not infested at the times the observations were made for not all localities in which the wild blue grape grows have been found to be infested.

In the literature mention is made of the following food plants: wild and cultivated species and varieties of grapes (species or varieties seldom given), apple, pear, plum, peach, quince, blue or water beech, elm, and Virginia creeper. The black alder is mentioned but the evidence points to this as an error of mistaking Haltica bimarginata for $\mathrm{H}$. chalybea. The elm has been reported as a food plant a number of times but it appears that where grapes are abundant the elm is not preferred.

\section{Feeding Habits.}

The flea-beetle attacks the vine during three periods of the insect's life, viz., during June and July as a larva, during August and September after emerging from the pupal stage and during April, May and June after hibernating. The larvae, soon after hatching, eat the soft tissues on the upper sides of the leaves, chiefly feeding to the fine network of veins which they leave intact (Fig. 1). This area is always irregular and soon turns brown, giving the leaves a scorched appearance when seen at a short distance. The larvae may be found feeding from near June 15 th until about July 20 th.

The adults upon emerging from the pupal cells may eat sparsley the leaves of cultivated grapes but generally fly to nearby woodland and there feed on the leaves of wild grapes although the amount of food used is very small. At this time the adults are difficult to find, owing, no doubt, to the rather extensive area in which the wild grape grows and also to the lessened activity of the beetles. The writer holds the view that the greater heat and lower humidity of the vineyards is a factor in this movement of the beetles to the woodland where the heat is less and the humidity is higher. Whatever the cause, these beetles disappear as if by magic and are seldom seen by the vineyardist until the following spring.

Although the beetles may be lacking in voraciousness in the fall, this tendency disappears in the spring upon the return of warm weather. They feed almost continuously after their long winter's sleep, especially during the first few weeks after emergence from hibernation. It is at this time they do their greatest damage to cultivated vineyards for, after passing the winter in the waste and woodland, there is a general tendency to disperse after 


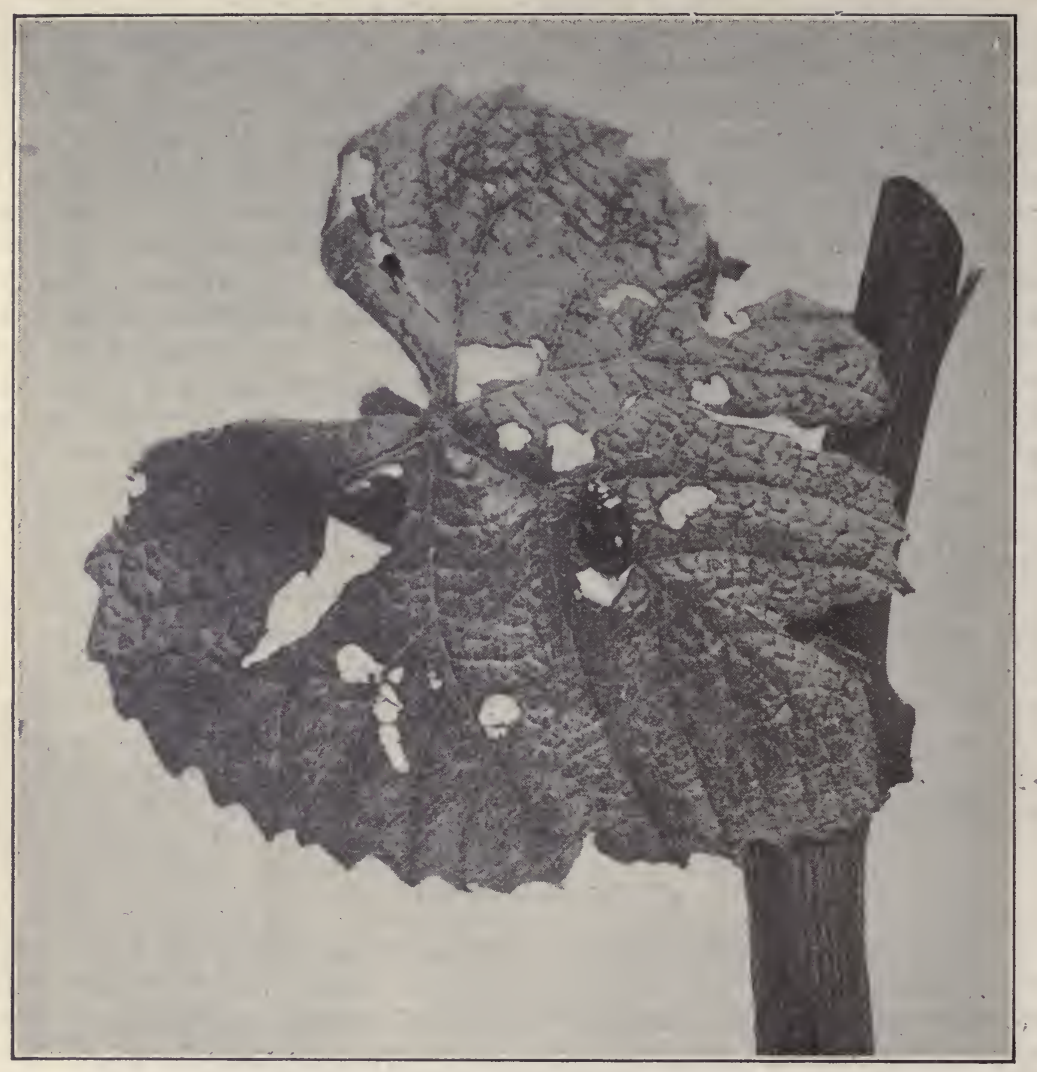

Fig. 1. Larvae feeding on foliage.

they resume feeding. At such times they travel a distance, usually with the wind, and upon entering a vineyard begin feeding on the swelling buds of the grape, eating holes in them (Fig. 2b).

They tear off small areas of the bud scales and eat into the green portion of the bud, tearing the tissues with their mandibles. The circular hole results from the insect eating all the food it can reach without removing any more of the dry bud scales and continuing this process until the interior of the bud is often entirely eaten. The more common effect of feeding is to eat to the center of the bud. By this time the appetitie is satisfied, for a short period at least, and the beetle moves elsewhere. Such injured buds never develop and the crop of grapes, which normally would have developed from them, is destroyed. Later from beneath these buds, new ones usually develop but these seldom, if ever, produce fruit. On severely infested vines, often every bud is destroyed. In fact, we have seen several hundred vines thus injured. Of the 4,020 vines in this vineyard, 1,048 vines escaped injury, but 56 per cent of the fruit was ruined in the buds, making a monetary loss of $\$ 220.00$. When the buds which remain uninjured have opened, the beetles 


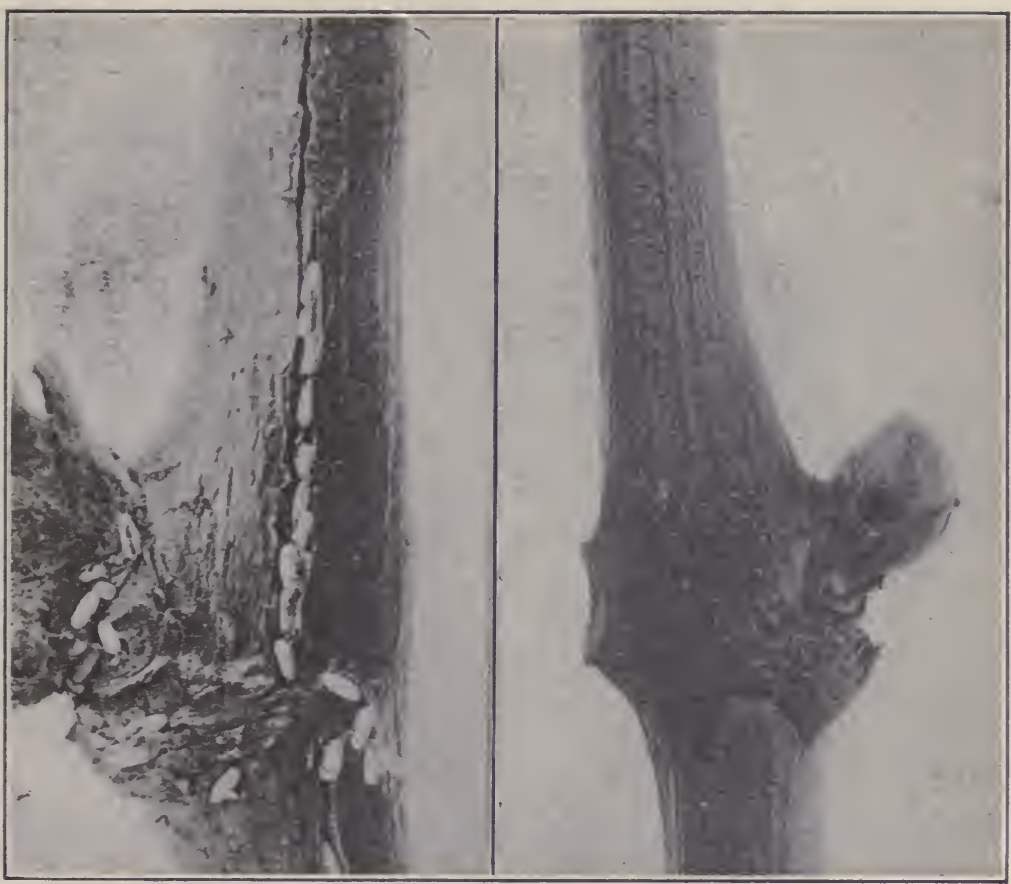

Fig. 2. (a) Eggs of the Flea Beetle (enlarged about six times). (b) Typical injury to the vine bud (somewhat enlarged).

feed upon the foliage, eating irregular holes in it. (Fig. 3.) The greatest injury by the beetles is done during May and early June. After June 10th the foliage has advanced so as to suffer little from the feeding. About this time also the adults begin to die. By July 1st few of the adults remain.

\section{Description of the Insect.}

Egg. The eggs of the grapevine flea-beetle are small orange or saffron colored bodies of a cylindrical shape, having the ends almost hemispherical (Fig. 2a). They vary considerably in size. In 1913, 227 eggs were measured and were found to have a mean length of $1.03 \mathrm{~m} . \mathrm{m}$. (.04 inch) and a mean diameter of $.42 \mathrm{~m} . \mathrm{m}$. (0.165 inch). The range in length was from .76 to $1.22 \mathrm{~m} . \mathrm{m}$. (.03 to .048 inch) while the range in diameter was from .3 to $.54 \mathrm{~m} . \mathrm{m}$. (.012 to .021 inch). The outer covering of the eggs has a uniformily roughened appearance due to small depressions found over the entire surface. If this coating be removed, the inner coating of the egg is seen as an almost transparent membraneous covering and the egg has a light yellow color. These two layers are frequently seen on eggs for in lifting the bark to examine them the outer covering is often ruptured.

Larva. When the larva is in the first instar (i. e. between hatching and the first moult) it is dark brown and the head is very large in proportion to its body. The body tapers gradually to the anal segment and is covered with 


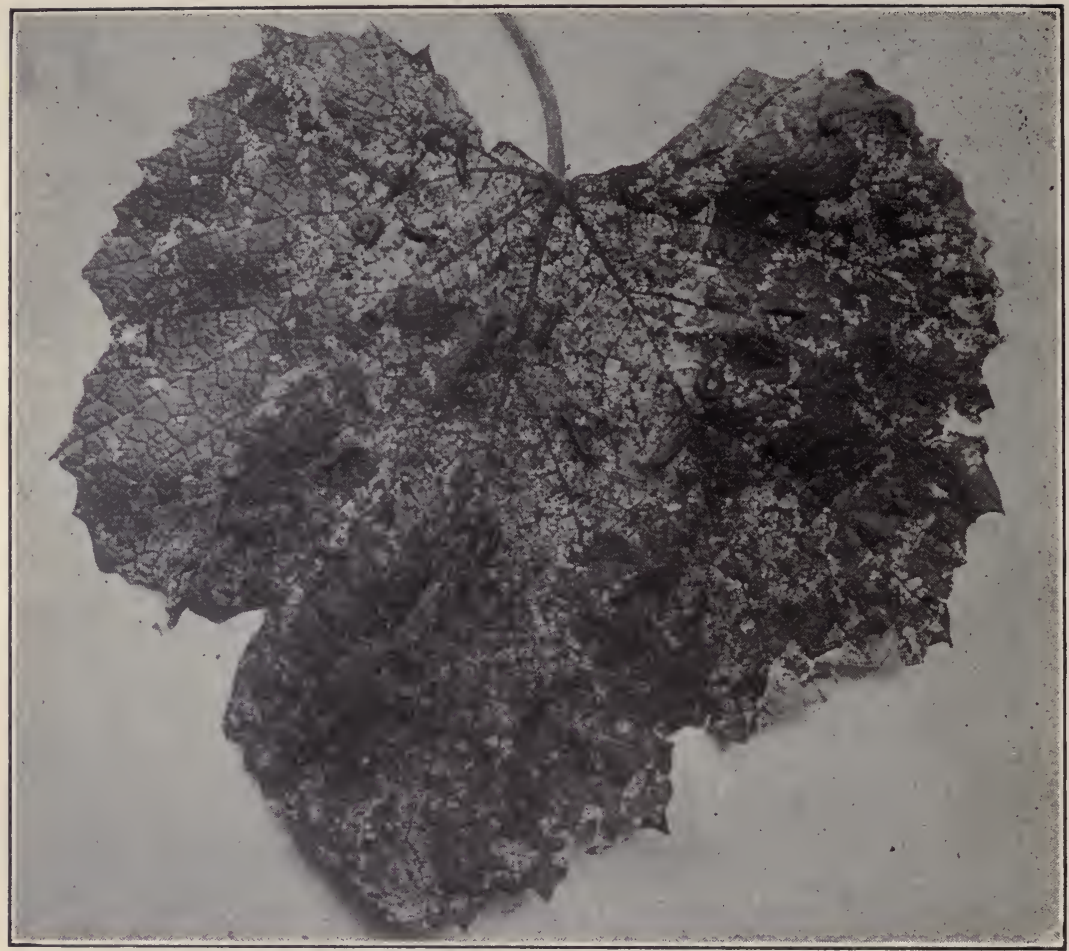

Fig. 3. Adult beetle and work on young leaf (enlarged about twice).

many long hairs. During the later stages the larva is lighter in appearance. The color immediately after a moult is light yellow but soon changes to a dark yellow with numerous dark areas which surround tubercules bearing short setae. The dark areas near the median line join those opposite, thus giving the appearance of dark transverse stripes. The length of the fully developed larvae vary from 7 to $9 \mathrm{~m} . \mathrm{m}$. (.276 to $.354 \mathrm{inch}$ ).

Pupa. The body of the pupa is yellow with the wings and legs almost white. They are from 4 to 6 m.m. (.16 to .24 inch) in length.

Adult. The beetles are about $5 \mathrm{~m} . \mathrm{m}$. (.2 inch) in length and of a shining steel-blue color. The color varies with individuals from a purple to a metallic green. The body and elytra are such as to give the insect a rather stout appearance. The femora of the hind legs are very much thickened by the presence of large muscles which give the capacity for jumping-a very common habit of these beetles to escape danger. The lively habits and the bright color of these adults distinguish them from other pests of the vine.

\section{Seasonal History.}

Hibernation. During the late summer and autumn the grapevine fleabeetles are rather sluggish and retire to the woodland as described above. They seek hibernating places under the rough bark of trees, in the crevices 
of wood, and among deal leaves and rubbish. Here they remain dormant until the warm weather of spring arouses them from their winter's sleep. Entrance into winter quarters takes place about the time the leaves of the grape fall.

Emergence from hibernation. The first few warm days of spring do not arouse these beetles but when there has been an accumulation of temperature sufficient to bring forth the first dandelion blossoms in sheltered places we expect to find the first beetles feeding in places where they are sheltered from chilling winds. For several seasons observations of the first appearance of the adults have been made and the first blooming dates of common wild plants noted. From these observations we learn that the adults may be expected to appear very near the time of the first blooming of several plants, as follows: dandelion, yellow adders tongue (Erythronium americanum), and gill-over-the-ground (Nepeta hederacea). Early in the spring the beetles may appear during a warm day, then a succession of cold, cloudy days will drive them back to shelter. When the temperature is below $50 \mathrm{~F}$. it is useless to look for the beetles on the vines. Feeding seldom takes place unless the temperature is above $55 \mathrm{~F}$. Temperatures above 65 will be sufficient to produce extensive feeding and some dispersion although this latter phenomenon takes place more rapidly the higher the temperature at least up to 80 . This relation of temperature is seen from the direction of spread in the vineyard into which the insects have migrated. Here they will infest the portion which is best protected from cold winds and therefore is warmer.

Mating. After feeding for a day or two the beetles begin to mate and this continues during the greater part of a month, some individuals mating over a period of six weeks. In cages the same individuals were observed mating during this period of time.

Egg deposition. The laying of eggs begins early in May and is continued until near the middle of June. In cages the average length of the egg laying period has been 23 days but one female was observed to oviposit for 52 days. The longest egg laying period for all the females any single season has been 53 days. Eggs are laid during the warmer parts of the day and it has been noted that the variations in temperature affects the rate of laying considerably during the early part of the season, but only slightly after June 1 . The reason for this is found in the fact that by this date the females have laid the greater number of their eggs and the maximum daily temperature is usually above 65. During May we have never found the beetles laying if the maximum temperature for the day was below 60 .

In cages during four seasons in which a large number of beetles were under observation, the mean number of eggs laid by a single female has been 63 , the maximum number 164 and the minimum 55 . The number of eggs laid per day by a female averaged 3 with a maximum of 25 .

The eggs are generally deposited underneath the loose bark of the canes (Fig. 2a) near the buds but âre not tucked under the bark as tightly as are the eggs of the grape root worm. Many of the eggs are placed on the rough area surrounding the buds and some are placed on the growing shoots and even on the leaves. Egg parasites do not attack the eggs to any extent even though exposed. The females place their eggs in these positions so that the young larvae upon hatching will have a short distance to go for food. These newly 
hatched larvae do not have the strength to move far before first partaking of food and if this is not nearby they perish.

Hatching. This occurs during the entire month of June and early July being most active from about June 10 th to July 1st. A very early season may cause a few to hatch the last week of May.

Feeding habits of the larvae. These grubs seek the green tissues either of the shoots or of the foliage but principally the upper surfaces of the latter, although some feeding occurs on the under surface of the leaves also. They are often found devouring the young flower buds and also feed on the blossoms. The extent of injury caused by the larvae is small a'though we have seen a few vines which had the leaves badly eaten by them. Our object in killing the larvae is to destroy the developing crop of beetles which would injure the crop the following season.

\section{Summary of Life History.}

There is only one generation of beetles annually although the generations of two years overlap. The length of life of the insect, counting the egg stage as a part, is slightly more than 13 months. During the latter part of June it is sometimes possible to find all four stages of the insect, but usually all the eggs have hatched before any of the larvae have entered the pupal stage. The egg stage averages about one month in duration, the larval period is slightly over three weeks, the pupae require about two weeks before emerging as beetles, and since the adults emerge about the last week in July and live until the middle of June their life is about 11 months. These are averages and for the Lake Erie Valley, but even here it is possible for the maximum length of life to be 15 months.

\section{Natural Control.}

The grapevine flea-beetle fluctuates in numbers considerably from one season to another, but the exact causes of these variations have not been determined. The eggs are not attacked by parasites to any extent. The larvae, however, are preyed upon by a species of carabid which closely resembles the adult flea-beetle in size and color.

These insects were not found in numbers so their activity does not decrease the number of larvae to any great extent. The writer has found the nymphs of one of the Pentotomidae piercing the bodies of the larvae and sucking the body fluids. Unfortunately the few nymphs found died before reaching maturity thus preventing the determination of the exact species. From the account given by Slingerland, 6 we surmise that these were the

In the vineyards the adults do not appear to be fed upon by birds but we do not know to what extent this takes place in late summer. We have not been able to estimate the number of beetles that are destroyed by climatic. factors and predaceous enemies after leaving the vineyards. This is due to the scattering of the beetles over large areas where their observations is most difficult but it appears that the greatest reduction occurs during the period of adult life.

6 Slingerland, M. V. Cornell Agr. Expt, Sta. Bul. 157, pp. 203, 204. nymphs of Podisus modestus, Dallas. This author also reports finding a common lady beetle, Megilla maculata, De Geer, feeding on the young grubs. 


\section{Artificial Control.}

When these beetles appear in a vineyard in immense numbers it is evident that the owner must adopt means for the eradication of the pest, if he hopes to save the grape crop. Three methods of control are practical against the adults, viz., spraying, hand picking and destruction of wild vines.

Spraying. The bordeaux mixture (100 gals.) and arsenate of lead (6 $1 \mathrm{bs}$. is distasteful to the beetles so that vines sprayed with this material will be avoided by the beetles which seek unsprayed vines. It is true that such a dispersion often saves the vines, but, as it serves to scatter the insects and does not kill them, can hardly be called a method of control. For several years we have known that this beetle is fond of molasses and that this material when added to arsenate of lead serves to poison them owing to its serving as a bait. The lack of adhesion of the arsenate of lead when mixed with molasses makes its use somewhat of a lottery for if rains should appear shortly after spraying, the material will be washed off the vines and thus its benefits lost. Owing to the frequency of rains in New York during May, we do not recommend this material unreservedly, but advise that it be used if rains can be avoided and if the infestation of the vineyard is such as to make spraying practical.

Hand picking. At first thought this method might be considered too expensive but in practice generally it has been found cheaper than spraying. One of the chief reasons for this is the fact that the attack usually is in a restricted portion of the vineyard and in order to spray this the entire length of the rows must be traversed by the spray outfit thus causing much loss of time. A person with a milk pan, having a diameter of not less than 15 inches, on the bottom of which is a shallow layer of kerosene, can knock the beetles into the pan by striking the canes with a short stick, the pan being held a little below the place where the beetle is sitting. The oil kills the insects almost instantly. In this manner several thousand beetles can be captured in a short time and at slight expense. It usually is necessary to repeat this operation several times but even then the expense is less than that of spraying, unless the latter can be done very economically and no bad weather interferes.

Destruction of wild vines. This method of control is based upon the fact that wild vines are necessary for the insects in the autumn and when these are destroyed the insects seek other places to feed and the vineyard usually escapes injury.

Spraying during the time the larvae are feeding. There is no period in the life of the grapevine flea-beetle at which it can be controlled more easily than while feeding as larvae. Since feeding usually occurs on the upper surfaces of the leaves it is very easy to place the material where it will be effective. No trouble is experienced in killing the insects by the use of arsenate of lead (6 lbs.) in water (100 gals.) or if preferred the poison can be used with bordeaux mixture. The application should be made after the maximum number of eggs have hatched. This spraying at times coincides with the first spraying for the grape root-worm but generally a separate application is necessary. The killing of the larvae avoids injury by the beetles the following spring unless a large area of unsprayed vineyards adjoin. Under this latter condition spring migration may cause trouble. 


\title{
THE ROSE CHAFER.
}

(Macrodactylus subspinosus Fabricius.)

\author{
By F. Z. HARTZELL, \\ Vineyard Laboratory, Fredonia, New York.
}

Perhaps no fruit insect is better known to eastern fruit growers than the rose chafer, or rose bug, which not only feeds on grapes and other fruits but by its depredations is a source of annoyance to the growers of flowering plants. Its common name has been applied on account of injury caused to roses. The literature abounds with references to its destructive feeding habits. In the Chautauqua and Erie grape belt (extending from Erie, Pennsylvania, to near Buffalo, New York) it is not common except in several localities but in these local areas it has produced considerable monetary loss.

This paper will be confined chiefly to the investigations and observations of the writer except where otherwise mentioned so all dates given refer to the south shore of the Lake Erie Valley in which the above mentioned belt is situated. For this reason the dates will not be the same as in other parts of the insect's range but it is believed that the relation between the time of flowering of the grape and the emergence of this beetle will be found to hold, judging from the writings of others.

\section{Economic Importance.}

It is difficult to estimate the financial losses caused by this insect. Being almost omnivorous, we must include injury to other fruits and losses to commercial flowers as well as damage to grapes. It injures cherries and grapes to a greater extent than other plants, but occasionally causes serious losses to apples. Nor are its ravages confined to these fruits since much loss has been recorded on raspberries, blackberries, strawberries and florists' plants. The beetles attacking the blossoms can do an immense amount of damage in a short time but it is chiefly owing to its great numbers that it works such havoc.

\section{History.}

The rose chafer was described by Fabricius1 who gave it the scientific name Melolontha subspinosus. Latreille established the genus Macrodactylus (which means great toe) and placed the species in this genus thus giving the insect the present scientific name. The first account of its economic importance was by J. Lowell (1826).2 The following year Harris 3 published a partial account of the life history of the insect. This author gave the first complete account of the life history (1841).4 The writings of other writers occurs in the 1852 and 1862 Eds.)

1 Fabricius, Syst. Ent. 1798.

2 Lowell, J., Mass. Agr. Repos. and Jour. 9:143-147. 1826.

3 Harris, T. W., Mass. Agr. Repos. and Jour. 10:1-12. 1827.

4 Harris, T. W., Insects Injurious to Vegetation. 1841. (The same account 
until 1890 dealt chiefly with the food habits, distribution and destructiveness of this pest. Riley5 (1890) summarized the then known facts regarding the species in an important paper. Smith6 (1891) made extensive studies on the life habits and methods of control which show that the rose chafer is a difficult pest to control. Spraying with arsenical poisons generally with bordeaux mixture was the chief method used by investigators for nearly twenty years after the work of Smith and, as this usually proved a failure, hand picking was the remedy usually recommended.

A new method of attack was used by Taft in 1909 and this has proven to be very useful in killing the beetles. He used molasses as a bait for the insects and mixing arsenate of lead with this secured decided results. The author, 8 in 1910, not knowing of Taft's results found that confectioners' glucose $(25 \mathrm{lbs}$.$) and arsenate of lead (10 \mathrm{lbs}$.$) in water (100 gals.) to be an$ effective remedy. Since that time we have found that cheap molasses (1 gal.) gave just as good results as the glucose (25 lbs.) and this has reduced the cost considerably. The amount of arsenate of lead has been reduced to $6 \mathrm{lbs}$. which, with more care of application, has proven as effective as the larger amount.

\section{Food Plants.}

The rose chafer as adult feeds upon a large number of plants but shows a decided preference for certain species. It also prefers the flowers to either the leaves or the fruit of the plant attacked. The kinds chosen first after emergence are grape, rose, apple, peach, p'um and cherry, of which grapes are always chosen if at hand. After feeding upon the flowers of the grape for a week to ten days they show a tendency to disperse and we find them flying to and feeding upon the blossoms of the stag horn, sumac, elder (Sambucus canadensis) and red osier (Cornus stolonifera). Raspberry and blackberry foliage is also fed upon rather extensively. During this period, the beetles are found on a long list of species, in fact, they seem to feed upon mcst common plants except evergreens and conifers. We are inclined to believe, judging from observations of several years and where many of these so-called food plants grew near the infested vineyard, that a number of the food plants listed are fed upon only accidentally. However, the fact that these insects can subsist on such a number of species of plants makes it obvious that we cannot hope to control them by destroying their food plants.

Food plants of the larvae. The grubs of the rose chafer feed chiefly (perhaps entirely) on the roots of various grasses of which the timothy, foxtail (Setaria glauca) and the several species of bluegrass appear to be preferred. They have never been found feeding on the roots of the grape although the larvae have been found in the soil of vineyards in which the several grasses named were growing.

5 Riley, Dr. C. V., Insect Life. 2.295-302. 1890.

6 Smith, Dr. J. B., N. J. Agr. Exp. Sta. Bul. 82. 1891.

7 Taft, L. R., 48 Ann. Rep. St. Bd. of Agr. of Mich., p. 157. 1909.

8 Hartzell, F. Z., N. Y. Agr. Exp. Sta. Bul. 331, pp. 543-549. 1910. 


\section{Character and Extent of Injury.}

By the adult. Feeding is confined largely to the blossoms of the various plants attacked so that a rather small amount of feeding causes much loss to the crop of fruit (Fig.). It is true that the foliage of many plants is eaten but this loss is insignificant. In fact, the adult seldom injures plants in such a manner as to interfere with their growth. The destruction of the fruit in such a wholesale manner, especia!ly when myriads of these insects emerge, and also the marring of blossoms for florists constitute the chief form of injury by this pest.

In a vineyard of four acres we have seen 90 per cent of the crop destroyed and on two acres of these grapes about 99 per cent of the fruit was taken by these insects feeding on the blossoms. It will be seen that the possibilities for injury which these chafers possess are enormous but in the Chautauqua and Erie grape belt only several rather small areas are infested.

By the larva. So far as that writer has learned, there is no account of injury to cultivated crops by the larvae. The fact that they feed in hay fields and pasture land wou'd indicate that a certain amount of injury would result but generally the larvae are too few to the square yard to cause a loss that could be noted. If these grubs were very numerous per given area (say a square yard) it would be possible for them to cause injury to hay and pasture similar to that produced by the white grub.

\section{Description.}

Egg. The eggs of the rose chafer (Fig.) are small, oval bodies having a glossy, white appearance. They average $1.2 \mathrm{~m} . \mathrm{m}$. (.047 inch) in length and 7 m.m. (.028 inch) in diameter.

Larva. The larva resembles the common white grub except that when each is full grown, the latter is larger (Fig.). They are of a grayish-white color except the posterior portion which usually is dark owing to the remains of food which are seen through the body wall. When full grown these larvae are about $20 \mathrm{~mm}$. (.8 inch) in length. The head is a light brown and bears antennae which are short and consist of four segments. The head and body are rather thickly covered with bristle-like hairs. The feet are dark and have prominent setae.

Pupa. The pupa (Fig.) is of a yellow color and about 15 m.m. (.6 inch) in length. The shrivelled skins are frequently found clinging to the posterior segment. The developing legs and wings are prominent.

Adult. The adult is about $12.5 \mathrm{~m} . \mathrm{m}$. (.5 inch) in length and has a general appearance of yellowish-brown (Fig.). The insect in very awkward because of its long legs, or, to be more exact, its long feet. The legs are of a reddishbrown color and the feet are black. The antennae bear a prominent club-like arrangement at the tips which consist of three thin plates. These may be appressed or separated by the insect and, doubtless serve in the capacity of olfactory organs. 


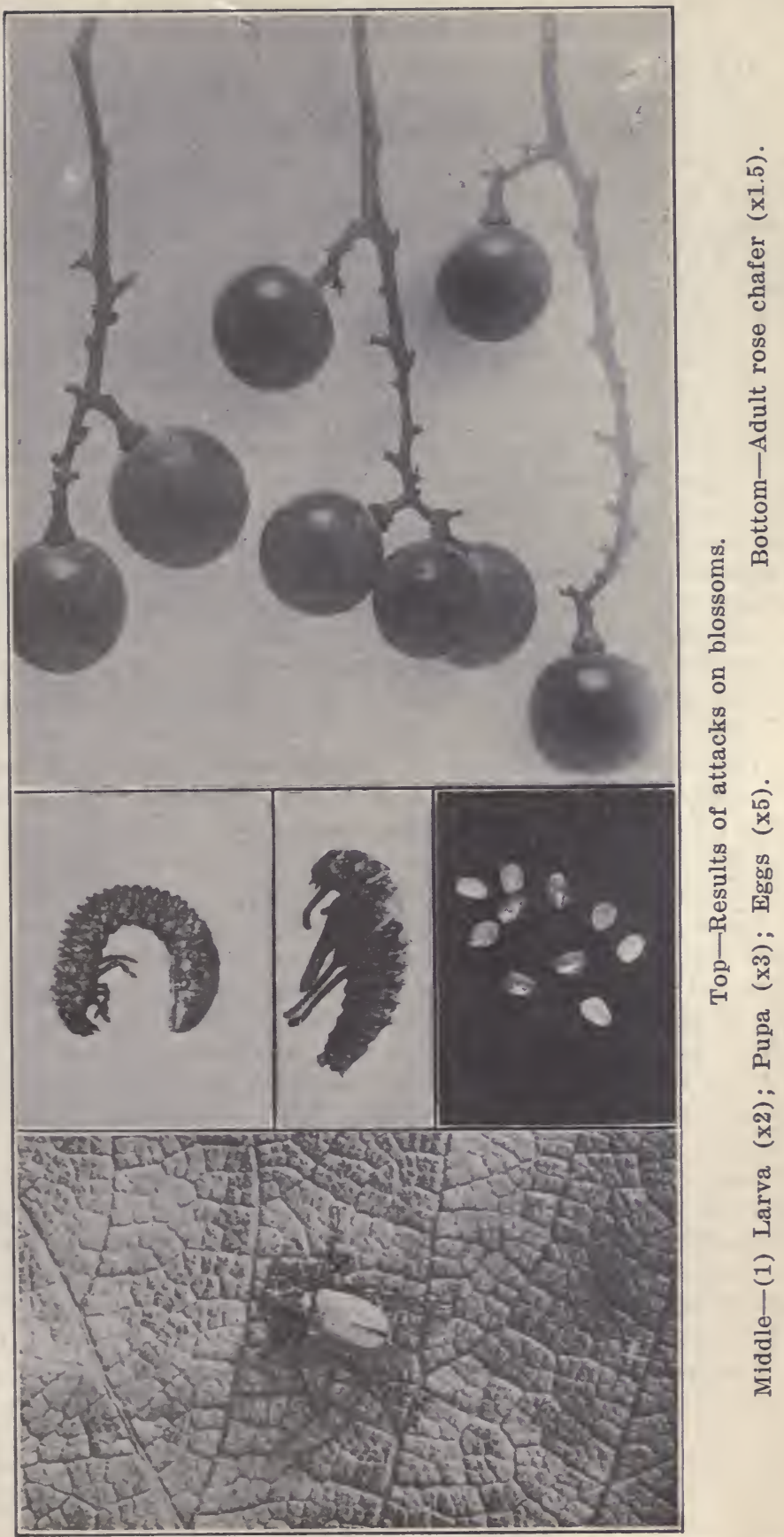




\section{Seasonal History.}

Egg deposition. The females prefer to deposit their eggs in light, sandy soil and our observations indicate that either the females do not oviposit in heavy soil or the eggs (if laid there) do not hatch, for we have never taken larvae from any but the lighter soils. This influence of soil was especially marked in an infested vineyard and hay-land at Westfield, New York, although grapes and grass were on both types of soil on the same farm only the grass roots on the light soil were fed upon by the larvae of the rose chafer. The eggs are deposited near the roots of grass to enable the young larvae to find food in the shortest time.

The question of the number of eggs laid by a single female has been one that we have tried to answer by means of numerous cage experiments but, with the best of attention, the greatest number laid was 25 while the average was so low that it has no value owing to the large number of cages in which no eggs were produced as well as a number in which only several eggs were laid. Dissections of beetles gave various numbers of eggs ranging from 13 to 30 to a female. Dr. Smith secured from females, by dissection, from 24 to 36 eggs. For some reason the beetles do not oviposit freely when confined in cages of any practical size. With all care and precautions to secure as near natural conditions as possible, the number of eggs laid was less than would be expected, judging from dissection records. The evidence indicates that the rose chafer does not lay a large number of eggs-perhaps 50 is the maximum.

The depth at which eggs were placed varied from 3 to 6 inches and all were placed singly. The time of egg laying occupies a period of nearly three weeks, the dates for a normal season being from June 25 th to July 15 th but the finding of copulating beetles as late as July $20 \mathrm{th}$ would indicate that they may lay until near August 1st certain seasons.

Larva. Hatching occurs about two weeks after the eggs are laid and the young grub feeds on the roots of grasses. This feeding is continued until late in the autumn, even a slight breeze seems to be necessary to compel the grubs to seek a lower level and desist from feeding. They dig to a depth of a foot or more to avoid the extreme cold but leave these winter quarters as soon as warm weather appears in the spring, and resume feeding which is continued until the latter part of May. The larvae usually have attained full growth by autumn of the preceding year.

Pupa. The larvae form cavities in the soil from three to six inches below the surface and here change to pupae. These have been found as early as May 19th but the majority, during a normal season, enter this stage near June 1st. Two weeks is the usual extent of the pupal period but cool weather may retard it to three weeks. Very few larvae are found after June 1st and few pupae after June 20th.

Emergence. This coincides very closely with the blooming of Concord and Niagara grapes. In 1911 the first beetles appeared nearly a week before these grapes blossomed and it is claimed by growers that one season the beetles did not appear until the grapes were nearly through blossoming. The earliest appearance noted by us was June $3 \mathrm{~d}$ but the period from June 10th to 20 th is the usual time they have emerged. Emergence is more rapid during the warmer parts of the day. 
Mating. The mating habits of these beetles are conspicuous because they appear to copulate during most of the time they are on the vines, beginning soon after partaking of the first food and extending for several weeks. Unlike most beetles they can be picked off the flowers and upon being placed in a vial will continue to copulate, at least, for a short time.

\section{SUMMARY OF THE LIFE CYCLE.}

The life of one of these beetles occupies a period of about 13 months of which almost 11 months are passed in the larval stage. The egg stage lasts about two weeks, the pupal stage two weeks and the life of the adults about one month. The adults die the latter part of July and early August.

\section{NATURAL CONTROL.}

The most important natural means of holding this insect in check appear to be two: the few eggs laid by the females and the destruction of the larvae by ground beetles-species of the family Carabidae. The abundance of these beetles in soil infested with grubs of the rose chafer led the writer to place them in cages with larvae of the latter insect and here one species of Carabid beetle ate the grubs. Harpalus pennsylvanicus was seen eating grubs in one of the cages but the abundance of other species in the soil infested with larvae of the rose chafer would lead us to expect to find that some of the other species are also enemies of this pest. As this investigation is in progress at the present time we hope to be able to report the same in a later publication.

\section{ARTIFICIAL CONTROL.}

Various methods for the control of this pest have been advocated; three of these appear to be the most practical. They are (1) spraying with arsenical poisons, (2) hand picking, and (3) cultivation during the pupal stage.

Spraying. Entomologists have recommended various poison sprays for this insect but the use of bordeaux mixture and arsenate of lead has been the one most widely used. This material acted more as a repellent than as a poison and while good results have been claimed from its use by some, other workers have failed to control the beetles if numerous. For this reason the rose chafer has always been considered a difficult pest to kill at least in time to save the crop. The use of the sweetened sprays has been attended with success during the past six years and they are the only ones recommended. The mixture consists of cheap molasses ( 1 gal.), arsenate of lead (6 lbs.), and water (100 gals.), and should be used as soon as the beetles appear on the vines. It may be necessary to make a second application within a week after the first one if the insects continue to reinfest the vines. As mentioned previously all sprays containing molasses must be applied so as to avoid rains, and should rain occur the application must be repeated if the beetles have not been poisoned.

Hand Picking. Sometimes the beetles are collected by hand. This is effective but expensive. A practical method is to shake the beetles into a cloth, shaped much like an umbrella and having a can attached to the apex 
of this inverted cone. The can should have a rather deep layer of kerosene to kill the beetles. This method of control requires that the vineyard receive several treatments for unless the vines are kept free from the beetles during this entire period much loss is sure to result.

Cultivation during the pupal stage. Large numbers of pupae will be killed if the land is plowed and harrowed during the period these insects are in their cells transforming to adults. These cells are from three to eight inches below the surface of the soil, usually not lower than six inches and thus can be easily reached by tools used for cultivation.

It will pay even to plow grass land that is severely infested rather than to save it for making hay for under ordinary conditions the infested area is not extensive and the damage to vineyards far exceeds the value of the hay crop that would be gathered from the infested soil. The pupal cells are crushed and the insects die from exposure to the sun and air.

This remedy has a very limited application for frequently these insects do not develop in arable land but inhabit waste land or sand knolls which may have a quantity of scrub trees growing thereon. At other times the cultivated land on which these grubs develop belongs to another person or the conditions are such that tillage is out of the question. For example we know of one instance where the rose chafer larvae occurred in the lawn of a large, well kept cemetery and upon emerging as beetles wrought havoc to a cherry planting near by.

\section{RECOMMENDATIONS.}

From a practical standpoint it is best to use the molasses and arsenate of lead spray when the beetles first appear on the vines and repeat this in a few days if the beetles continue to reinfest the vines. The spraying may come while the grapes are in blossom, which would make little difference so far as the pollination of the flowers is concerned, but in certain States there are laws forbidding the spraying of trees or vines while in blossom. Under such conditions, as law abiding citizens, it would be necessary to adopt the method of hand picking. Whatever method is used emphasis must be placed on the necessity of energetic efforts as soon as the first beetles appear for it requires but a few days for these devastators to destroy the crop. Cultural measures that will decrease the number of chafers are recommended where they can be applied. 


\section{THE GRAPE BERRY MOTH. (Polychrosis viteana)}

By W. H. GOODWIN, Assistant Entomologist, Wooster, Ohio.

The Grape Berry Worm (Polychrosis viteana) has been very destructive in certain localities of New York, Pennsylvania and Ohio, during the past ten or eleven years. It has attracted considerable attention in some other States, but has never done enough damage to be of any great economic interest excepting in the States named. The berry worm is a native species which seems to have almost abandoned its original food plant, the wild grape, and has taken up with the cultivated varieties of grapes wherever they are grown. In Ohio, the chief regions suffering from the depredations of this insect are along the shores of Lake Erie and the outlying islands. It seems to have been especially severe in its attack in the region of Cleveland and Sandusky, and the islands near the Peninsula of Marblehead, but it is not confined to this region by any means. From Dayton, Columbus, Springfield and a number of other points, its injuries have been reported. In the locality of Wooster, this insect destroyed most of the grape crop, especially in grape arbors and small vineyards in and around the city in some seasons. Frost destroyed the grape crop several times so the infestation has almost disappeared some years. The injury done to the grape crop varies from a small per cent of infested berries to 95 per cent of the crop, and many vary from a slight infestation on one side of the vineyard to over 80 per cent infestation on the other side of the vineyard. These points may not be more than onefourth of a mile apart. During 1908 and 1909, the berry worm almost disappeared in the regions of Marblehead and the islands in that vicinity. It was quite plentiful just east of Cleveland in 1908, but had almost disappeared in 1909 and in 1910 it did not seriously damage the crop in this region. In 1912 and 1913 the injury east and west of Cleveland was very severe, and in 1914, although the crop was heavy, the injury was very severe.

The grape berry worm was first recorded about fifty or sixty years ago and being from a practically new country, was recorded as a new species. A few years later, the authenticity of the species was doubted and in 1870 some specimens were sent to one of Europe's specialists who pronounced them as identicai with the European species, Eudemis botrana.

Its species identity was not questioned again until Prof. M. V. Slingerland, in a report of his studies published in 1904, gave a record of its life history and habits. He found that the life history of the American species differed greatly from that of the European moth. These differences had been previously recorded, yet in classifying this moth, the record of its different habits had been entirely ignored. W. D. Keerfoot monographed this genus of tortricids in 1904 and gave the distinguishing characters of the berry worm moth and a number of closely related species, referring it back to the name given by Clemens (Polychrosis viteana). 


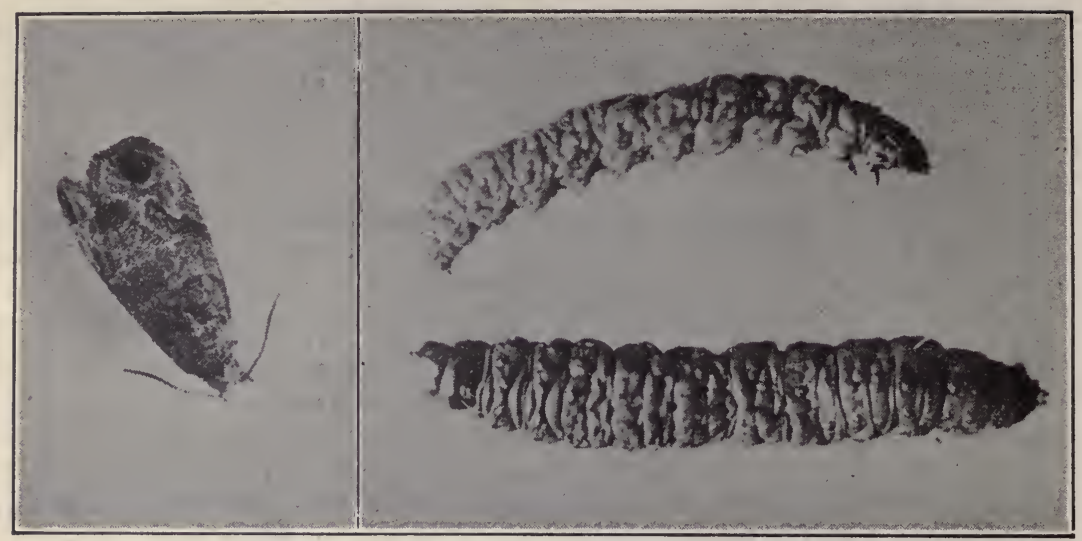

Fig. 1. Moth (x5); Larvae (x8).

The larvae of Polychrosis viteana have often been found feeding in the clusters of wild grapes and as the species is confined in its range to North America, there is little doubt that it is a native species turned pest through the destruction of its original food plant. Riley gives an account of its ravages in Illinois and Missouri in 1868 and 1869. At this time, it was noted that the larvae pupated in a fold, or flap, of the leaf by drawing a section of the leaf over itself and spinning a silken cocoon inside. Eudemis botrana pupates on the posts, trellises or rough vines and never in a fold or pocket of

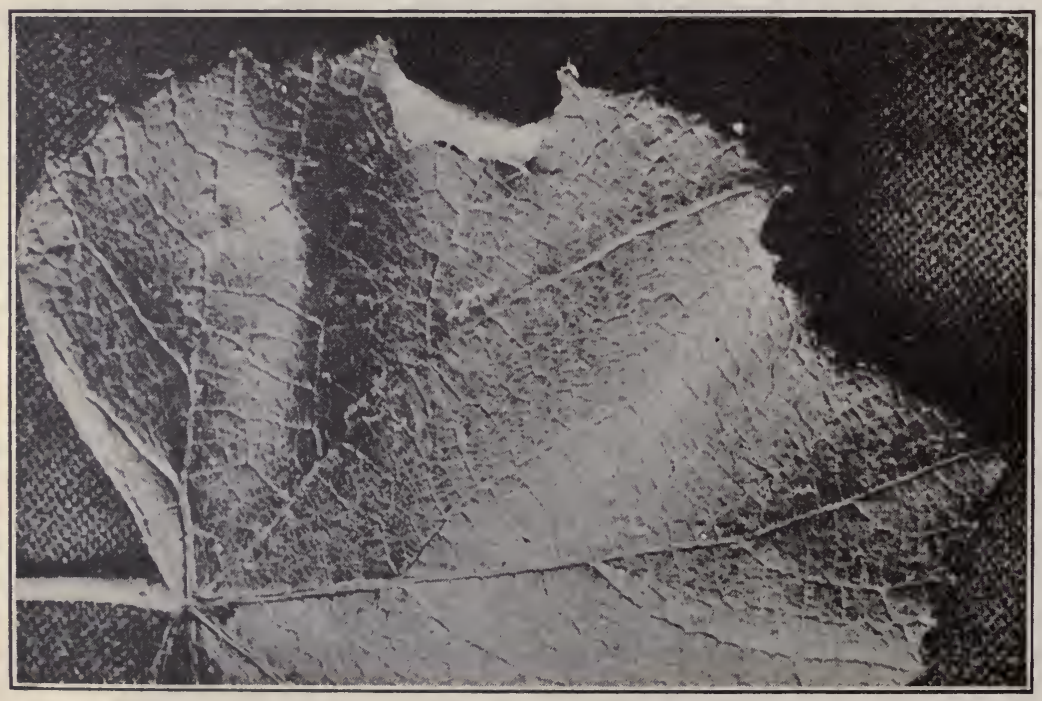

Fig. 2. Pupa in fold of edge of leaf. 

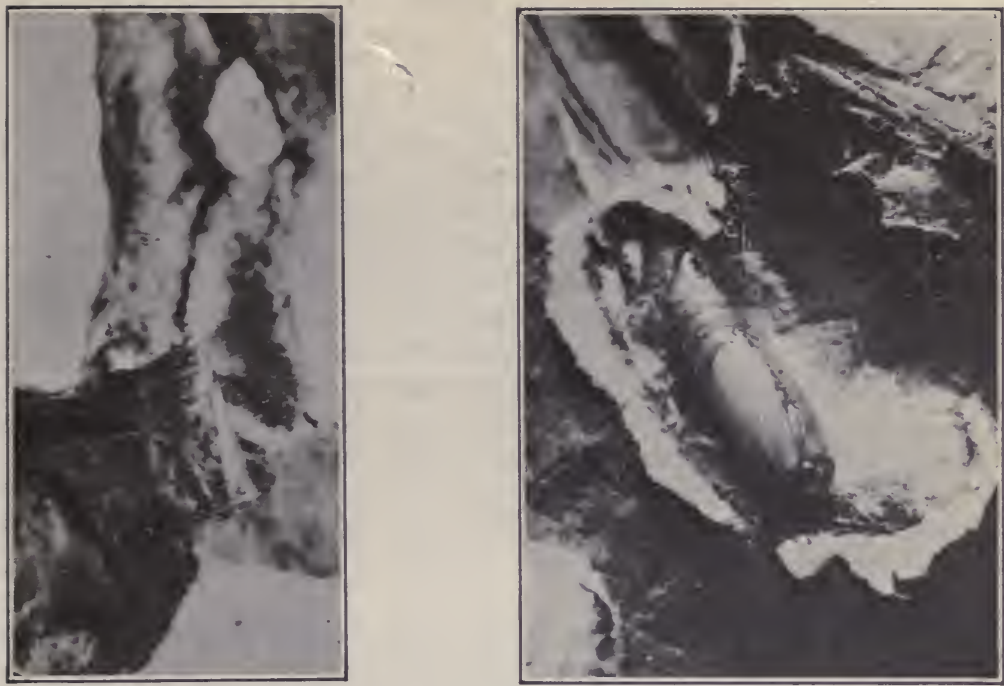

Fig. 3. Pupae in folded flap of leaf $(x 6)$.

the leaf. Saunders gives a brief account of Polychrosis viteana in his Ontario report in 1882. Felt (1904) reports the first beneficial work from spraying with arsenicals. In some experiments for the control of the Grape Fidia (Fidia viticida) beneficial effects were obtained and the berry worm was partially controlled. Polychrosis viteana was reported as injurious in the vineyards of Ohio in 1868, and again in 1881 it did considerable injury to grapes on the islands of Lake Erie. At various times, its occurrence has been reported from New York, Pennsylvania, Illinois, Ohio, Missouri, Delaware, Virginia, North Carolina, Texas, Nebraska and Ontario.

The adult is a small moth, lilaceous and brown in color, and measures from nine to twelve millimeters across its expanded wings. When at rest the moth is triangular in appearance and is scarcely six millimeters long and not more than two and one-half to three millineters broad. They take flight at the slightest disturbance and are rapid flyers and crawl rapidly about the breeding jar when disturbed. Keerfoot describes the moth as follows: "Front wing, ground color, lilaceous or leaden blue. The outer marginal patch is sharply indented above the anal angle by a spur of the ground color, the inner edge is less straight than botrana and bulges inward at the middle of wing; the color is dark brown. The central fascia is more slender than botrana, its outer spur is sharply produced, in some specimens turning upward toward costa and almost joining submarginal patch. The inner fascia is narrower than botrana and the two short inner dorsal fascia are only indicated by a few brown scales. Apical spot is larger than botrana and there are three smaller rectangular oblique spots or costa beyond the central fascia. The inner spot, which in botrana is as distinctly defined as the other four, is in viteana not separable from central fascia. A few short streaks on costa before the middle. A shade of pale yellowish-brown involves the outer half of costa between the central fascia and outer patch, giving the 
outer half of wing this color. Hind wing smoky-brown becoming paler at base. Expanse 10 to $\mathbf{1 1 . 5}$ millimeters."

Very few American collections contain specimens of botrana for comparison with viteana, so Riley's description will be more valuable to the average student. "Perfect insect: Average length 0.17; alar expanse, 0.37. Head, thorax, palpi and basal half of antennae fulvous. Terminal half of antennae darker. Legs fulvous, becoming darker on tarsi. Ground color of forewings, pale slate-blue with slight metallic luster which becomes lighter and somewhat silvery anteriorly and posteriorly. A dark rich brown band, with a light, somewhat silvery annulation, proceeds from the middle of the costa towards the inner margin, becoming paler anteriorly; its basal margin being indistinct but running almost straight across the wing, its outer margin well defined, curving to a rounded point which reaches to the middle of the outer third of the wing and thence running obliquely inwards nearly to the middle of the inner margin. Beyond this middle band is a large, deep brown somewhat oval spot, also lighter below than above and with a pale annula-

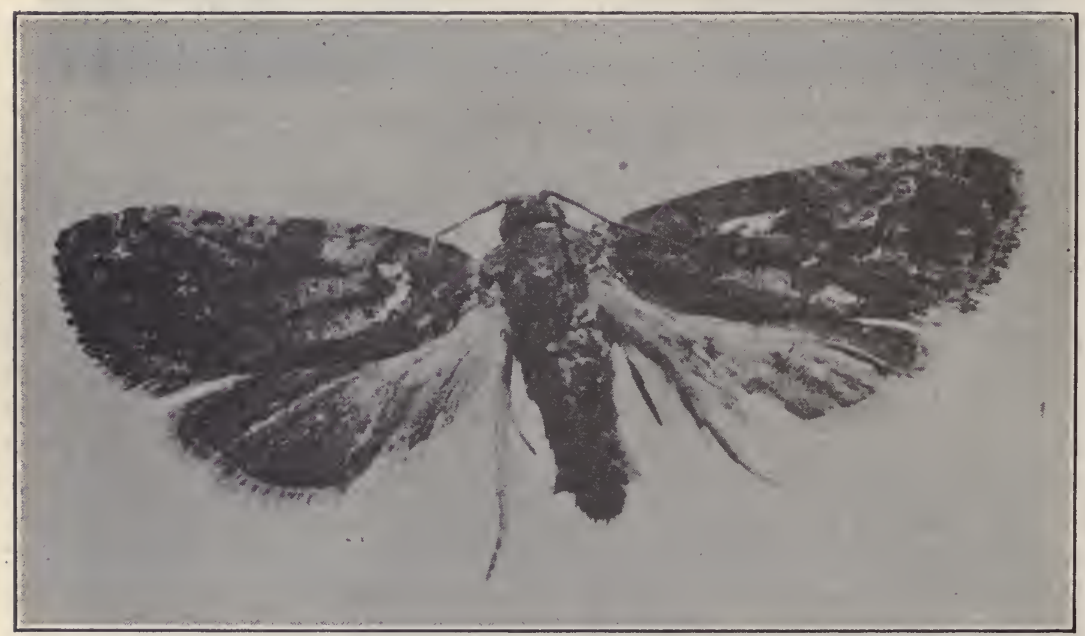

Fig. 4. Adult Moth (x10).

tion, which is broken on the outer side above, allowing the spot to extend to the margin of the wing. Above this large spot at the apex, is a small, perfectly round dark spot, with a bright annulation inclining to orange color. The space enclosed by the middle band, and these two spots just described, are brown above with usually four lighter fulvous costal marks, quite distinct, each mark divided at costa by a slight touch of brown. Another somewhat triangular brown spot with a light annulation above, runs from the posterior angle up between the middle band and a large oval spot. The blue space from the middle band to the base of wing is generally brownish near base, with a brown line across the middle from costa to inner margin, and with two other costal brown marks. The fringes partake of the ground color. Hind wings slate brown, darkest near margin; fringes same color. Body brownish with frequently a clear green tint. The male differs principally in 
its somewhat smaller size, and especially in the smaller size of the abdomen. Individuals vary greatly."

"Larva-average length 0.35 inches. Largest on segments ten and eleven tapering thence gradually to the head, and suddenly to the anus. Color either dark, shiny, olive green, glaucus or brownish. Head and cervical shield honey-yellow, the latter with a darker pcsterior margin. Piliferous spots scarcely distinguishable. Described from ten specimens."

"Chrysalis 0.18-0.20 inches long. Of normal form. Quite variable in color. Usually of light honey-yellow, with a green shade on the abdomen, and black eves, but sometimes entirely dark green with light eyes. The chrysalis skin, after the moth has left, is always deep honey-yeliow, with the green abdominal mark distinct."

The eggs are thin, semi-transparent and much flattened with a finely reticulated surface and are oval in outline. Slingerland describes them as "The thin, rounded, scale-like, semi-transparent eggs, measure six to eight by seven to nine millimeters in size and appear whitish in a few days. The shell is finely reticulated and the egg appears to be glued to the fruit by some substance. The eggs look much like the codling moth's eggs, only smaller."

\section{Life History.}

In northern Ohio, the adults of Polychrosis viteana normally emerge from their winter cocoons during the first or second week in June. Winter is passed in the pupal stage, in cocoons spun in a fold of the leaf the previous fall, on leaves stuck in the wet soil or partially covered with mud, and are seldom found in the piles of leaves or in trash into which leaves have been drifted by the wind. A few days after emerging the moths lay their eggs on the buds or stems of clusters of grape blossoms, or on the young grapes. The larvae hatch in from four to eight days and feed on the tender stems and developing berries of the grape cluster. The work of the larvae is fairly conspicuous at this season of the year, as the entire cluster is often webbed together by delicate white silken threads which the larvae spin around part of the young grape bunch. Inside this web, the larvae devours the flower buds, or young berries, of the grape, often almost destroying the young grape clusters. The idea that the berry worm might have another host plant at this season of the year has been suggested by the size of the brood later in the season, but this is impossible as there is no other plant excepting grapes in many of the worst infested localities. The injuries by the second brood of the European berry moth is partially prevented by going through vineyards when the first brood of worms are attacking the newly formed berries, and crushing the larvae in every infested cluster of grapes. This method cannot be utilized to any considerable advantage in America on account of the cost of labor. The larva is full grown in from 20 to 25 days, and migrates from the bunch of destroyed or injured grapes to young grape leaves, where it draws the edge of the leaf over itself by silken threads attached to the surface and edge of the leaf. This forms a fold, or tube, inside of which it pupates. In from seven to ten days the pupa pushes itself almost out of the cocoon, splits open at the anterior and along the back for almost half its length and the moth of the second brood appears. The normal date of emergence of a large part of the brood of moths is from the 6th to $12 \mathrm{th}$ of 
August in northern Ohio. These moths lay their eggs on the berries of the grape clusters. The berries are almost grown, and at this season of the year the eggs hatch in a very short time, certainly not more than three to five days after they are laid. The larvae bore through the skin of the grape and feed on the cells of the developing berry, sometimes just below the skin of the berry.

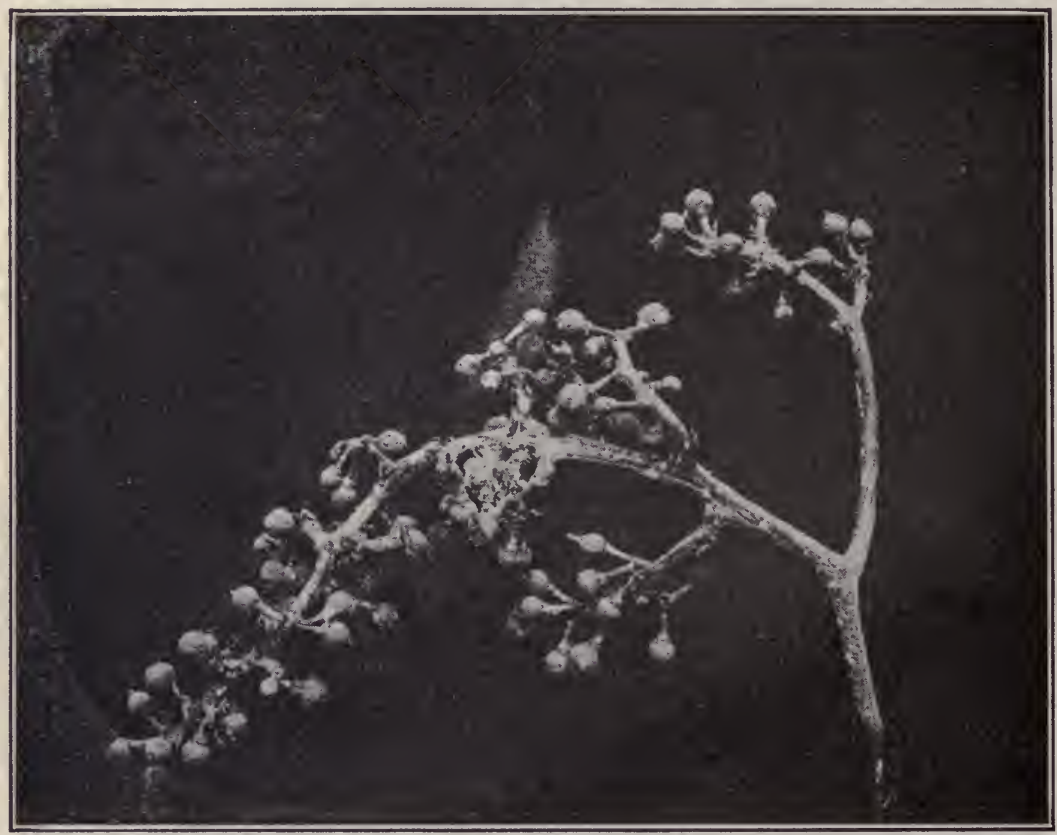

Fig. 5. Injury to young bunch by larvae.

A few berries may have only a purple spot on their sides, but the characteristicly injured berry slits open and is often reddish or purplish along the side of the break. This freshly broken open berry is an ideal place for the spores of the various rots of grapes to settle and grow. In some localities, this injury has been attributed to the grape rots when the real trouble was the first brood of larvae of the grape berry worm, which created ideal conditions for the growth of rot fungi through the injury done to the berries. The second brood of larvae bore into the almost full grown grape berries partially cutting off the supply of nourishment to the cells above the injured portion, and we have the purplish or reddish purple spot surrounding the point of entrance and often extending over one side of the berry. This is the typical injury noted by Riley in his Missouri reports, and in northern Ohio is caused by the second brood of larvae. Riley describes this brood as follows: "Its presence is soon indicated by a reddish-brown color on that side of the yet green grape which it enters. On opening the grape a winding channel is seen in the pulp, and a minute white worm with a dark head is 
seen at the end of the channel. It continues to feed upon the pulp of the fruit, and when it reaches the seeds, eats out their interior. As it matures, it becomes darker, being either of an olive green or dark brown color, with a honey-yellow head, and if one grape is not sufficient, it fastens the already ruined grape to an adjoining one by means of silken threads, and proceeds to burrow in it as it did in the first. When full grown, it leaves the grape and forms its cocoon on the leaves of the vine. This operation is performed in a manner essentially characteristic; the worms cut out a clean oval flap, leaving it hinged on one side, and, rolling this flap over, fastens it to the leaf, thus forming for itself a cozy little house which it lines on the inside with silk. In this cocoon within two days it changes to a chrysalis of a honeyyellow color of a green shade on the abdomen."

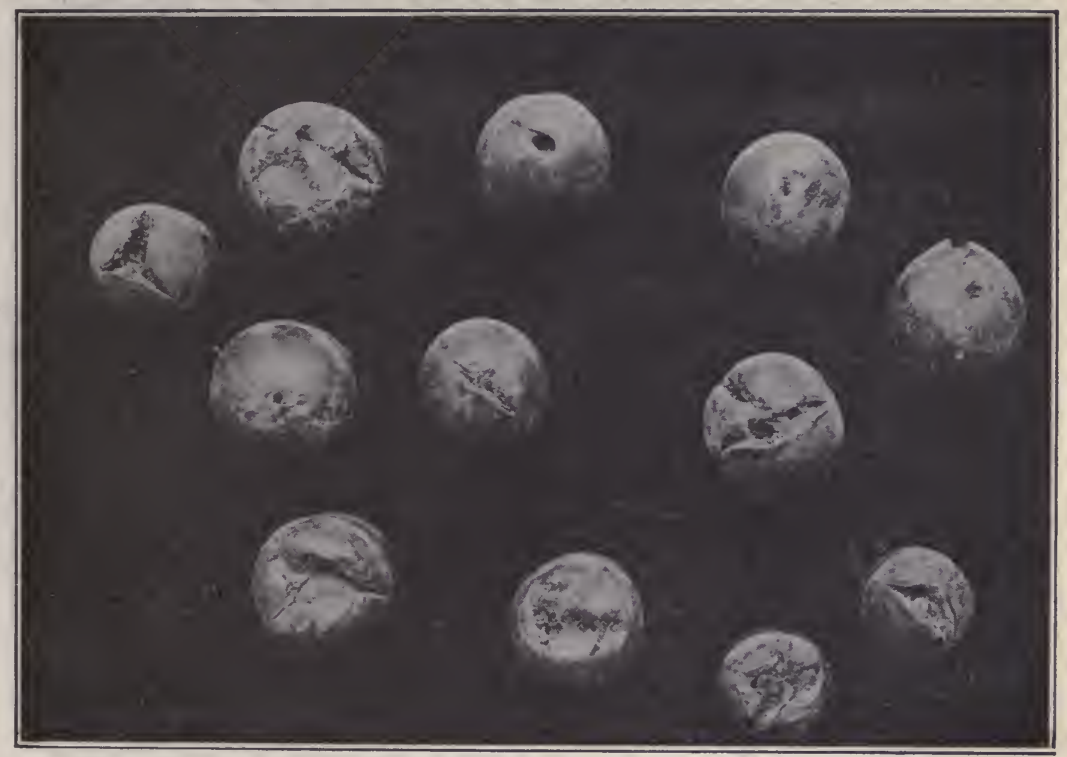

Fig. 6. Wormy berries in July.

The individuals of the second brood of larvae have a tendency to leave the berries in which they are working and attack other berries which are close to, or touching the berry in which the worm has been feeding, leaving each berry as soon as it begins to ferment, for a sound berry. It spins a silken covering between the berries, attaching each newly attacked berry to the preceding one in which it has fed. In this way, as many as five of six berries may be destroyed by one worm. The juice in the injured berries evaporates and frequently a bunch of grapes has half or more of the grapes dried out with only the purple or black dried skins remaining and looking almost like sound grapes. In many vineyards, I have found fully half of the berries in a cluster of grapes, which were only shells.

Many larvae of this brood are not mature until late in October and they are often active after we have had some severe frosts. The earlier maturing 
larvae spin their cocoons before many of the leaves fall. They drop to the ground, or let themselves down by silken threads, often falling with the berry in which they are feeding. These larvae then seek some leaf anchored in the soil, or lodged in the mud; cut the tiny flap and spin a thin white silken cocoon, inside of which they transform to pupae. Here they pass the winter as pupae, and emerge as moths the following June.

The habits of the larvae are distinctive and characteristic of this insect. The dark olive-greenish or bluish-black larvae are very active when disturbed. The individuals of the last brood of larvae will wiggle out of a bunch, if disturbed, and lower themselves rapidly to the ground, on a silken thread. When found in a berry, they will often crawl out and escape capture. The larva, in spinning a cocoon, usually draws over the edge of the leaf and makes a folded pocket inside of which it spins its cocoon. Sometimes it cuts a flap out of the central part of a leaf, but this is not the most common way. These cocoons usually break out of the dried leaf during the fall or winter and lay on the ground until they transform into moths the following June.

In no case could the larvae be induced to spin upon grass or other leaves than grape leaves, when they were introduced into the breeding cages, but a few spun upon moist newspaper. Many larvae transformed to pupae without spinning a cocoon of any kind and the remainder died without attempting to spin cocoons. The little lilaceous brown moths are very inconspicuous when at rest on the bark of a grapevine or on dead wood. When disturbed, they fly with a rapid motion of the wings, with a peculiar zigzagging flight which makes them very hard to follow. They fly low, and usually are most active from 3:30 until dusk. Perhaps they are active during the night, but they are very difficult to follow.

Various methods of control have been tried, but spraying thoroughly with three pounds of arsenate of lead and weak bordeaux mixture to which two pounds of soft soap has been added, is the most effective remedy. Three applications of spray are usually given; one just before the grapes bloom, a second when the grape berries are almost as large as peas, or three to five millimeters in diameter, and a third application in the latter part of July, varying with the season and locality from July 25th to August 6th. Burning all the leaves and trash early in the fall will assist in controlling the berry worm to a limited extent. Gathering all of the leaves, anchored in the soil, in the fall before the frost causes all the leaves to fall, taking care not to allow the cocoons to break out and fall to the ground, putting them in a tight basket and burning them, will help greatly in controlling the berry worm. Plowing fairly deep before the 25th of May will bury many of the cocoons so deep that the moths will never get out. Heavy sprayings with arsenate of lead and soap (the soap makes the spray stick better and helps it to spread around the smooth berries) is the most satisfactory means of control.

In spraying for the grape berry worm a number of poisons were tried as the most promising remedies-arsenate of soda, Paris green and arsenate of lead-and during the season of 1910 arsenate of lead in combination with lime-sulphur, which gives largely an arsenous sulphide as the poison. These poisons were used alone, with bordeaux, with soap, with resin soap, and with bordeaux and soap. Arsenate of lead, bordeaux and soap gave the best results in every case, using three pounds arsenate of lead, two pounds copper 
sulphate, three pounds lime, and two pounds of dissolved soft soap, to each 50 gallons of water. The lime-sulphur combinations almost completely defoilated the grapes and should not be used as a summer spray for grapes.

In treatments, the grapes were machine-sprayed with a traction sprayer by going through between the rows once, and spraying each row, one on each side; by going through the rows twice, giving them a double machine application; by spraying heavily using special spars on a power sprayer, and by spraying the grapes by hand with nozzles directed by the experimenter. Hand work gave the best results by a small per cent, but double machine work was much more rapid and one machine could cover three to five acres per day, going over each row twice. The power sprayer covered the grapes with spray, only one application being necessary, using 135 to 180 gallons per acre. Per cents are as follows for the season of 1907:

\begin{tabular}{|c|c|}
\hline 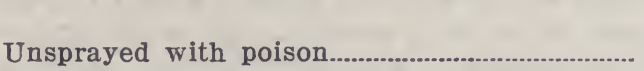 & $\begin{array}{r}\text { Wormy } \\
58.37 \text { per cent }\end{array}$ \\
\hline 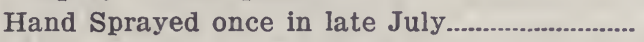 & 2.90 per cent \\
\hline $\begin{array}{l}\text { Single Machine Sprayed twice-June and late } \\
\text { July }\end{array}$ & 20.44 per \\
\hline Sprayed three times, double machine............... & 4.47 per \\
\hline prayed three times by hand.. & 3.00 per \\
\hline
\end{tabular}

These results were for the season of 1907 and show the percentages of wormy grapes. The treatment in July, spraying once with arsenate of lead, shows a very small per cent of wormy grapes, but the yield was smaller than on the other plots. The unsprayed plot yielded at the rate of 1469 pounds per acre, while the hand sprayed and double-machine sprayed plots yielded at the rate of over 6,000 pounds per acre.

In 1908, arsenate of lead only was used as a poison, and bordeaux with soap and iron sulphate as stickers for the poison. The results were as follows.

Wormy

Unsprayed, no poison. $47.43 \%$

Sprayed with arsenate of lead (spraying once before bloom)...... $20.88 \%$

Sprayed with arsenate of lead, bordeaux and iron sulphate, 3 sprayings, double machined.

Arsenate of lead, bordeaux and soap, 3 sprayings, double machined

Arsenate of lead, bordeaux and soap, 3 sprayings, hand sprayed

These results are based on a certain number of pounds of grapes picked at random from each plot and the wormy and sound berries counted in each case.

The average results for two years' work are as follows:

Wormy

Unsprayed with poison $52.90 \%$

Double machine, three sprayings................................................... $4.57 \%$

Hand sprayed, three sprayings................................................................ $1.85 \%$

In this average, soap was used as a sticker (during the last two years of the experiments) in connection with the arsenate of lead and bordeaux. In 1910 , arsenate of lead and bordeaux with soap was tried, in comparison with commercial lime-sulphur, one in fifty, and three pounds of arsenate of lead added to the diluted lime-sulphur. The commercial lime-sulphur injured the 
grape foliage on the young and tender shoots and some varieties were almost defoliated. The bordeaux, arsenate and soap sprayed plot of grapes was only mildly infested, so the results were of little value, as far as the berry worm control was concerned.

\section{Spraying Experiments.}

In the experiments of Euclid in 1908, some eight acres of vineyard consisting of mixed plantings of Concord, Catawbas and Delawares, with a few vines of other varieties, were divided into plots. Each plot was sprayed with a different mixture of spray and one plot was left unsprayed. The machine used in applying the spray was a field type of traction sprayer. A chain gear from the wheels operated the pump by an eccentric and the horses in pulling the machine operated the pump. With six nozzles of the Vermorel type, a pressure of 60 to 95 pounds could be maintained. These nozzles on fixed spars de ivered the spray almost at right angles to the roof of leaves and the results obtained corresponded to the ineffective efforts to entirely cover the grapes with spray with this type of spars. In this series of experiments the plots sprayed carefully directing the nozzle by hand gave results which were much better than on similarly sprayed plots where fixed spars and nozzles were used. In the hand sprayed plots, every bunch of grapes was covered with spray, leaving little opportunity for berry worms to survive.

\section{Comparing the Various Plots.}

Comparing single and double spraying the results are as follows:

Plot 2-Sprayed 3 times, June 2 to 7,15 to 20, July 9 to 14 ; single machine sprayed; sprayed with Bordeaux, 3-6-50; arsenate of lead, 3 pounds; counted September 15, 1908; number of bunches, 28; number of sound berries, 1,195; number of wormy berries, 328; per cent wormy, 21.5.

Plot 5-Sprayed three times, June 2 to 7,15 to 20 , July 9 to 14 ; double machine sprayed; sprayed with Bordeaux, 3-6-50; counted September 15, 1908; number of bunches, 26 ; number of sound berries, 1,369 ; number of wormy berries, 143; per cent wormy, 10.4 .

Poison sprays giving the difference in effectiveness of stickers and spreaders; also machine and handwork:

Plot 8-Sprayed 3 times, June 2 to 7,15 to 20, July 9 to 14; double machine sprayed; sprayed with Bordeaux mixture, 1-6-50; iron sulphate, 4 pounds; arsenate of lead, 3 pounds; counted September 14-15, 1908; number of bunches, 26 ; number of sound berries, 1,341 ; number of wormy berries, 182 ; per cent wormy, 11.9 .

Plot 9-Sprayed 3 times, June 2 to 7,15 to 20 , July 9 to 14; double machine sprayed; sprayed with Bordeaux 3-6-50; arsenate of lead, 3 pounds; hard soap (dissolved), 1 pound; counted September 14-15, 1908; number of bunches, 25; number of sound berries, 1,469; number of wormy berries, 72 ; per cent wormy, 4.7.

Plot 12-Sprayed 3 times, June 2 to 7,15 to 20, July 9 to 14 ; hand sprayed; sprayed with Bordeaux $3-6-50$; arsenate of lead, 3 pounds; hard soap (dissolved), 1 pound; counted September 14-15, 1908; number of bunches, 29; number of sound berries, 1,528; number of wormy berries, 11; per cent wormy, .7. 
Plot 1-Unsprayed; number of bunches, 33 ; number of sound berries, 767 ; number of wormy berries, 692 ; per cent wormy, 47.

Plot 6 was sprayed by going only once between the rows with the traction sprayer with fixed spars. No soap was used in the spray that was put on this plot.

Plot 10 was double machine sprayed; that is, the rows were sprayed twice by going over the rows from opposite directions. In Plot 10 the bunches were much freer from berry worm injury and there was but one of the badly injured bunches of grapes which seemed not to have been reached by the spray, as indicated by the number of injured berries.

This is also typical of the results obtained in latter experiments and indicates how unsprayed bunches of grapes tend to increase rapidly the percentage of wormy grapes.

Comparing bunches as picked at random from different sprayed plots the difference in spraying is very noticeable. Plots 6 and 10 give some striking differences in thoroughness of application and differences in effectiveness of sprays.

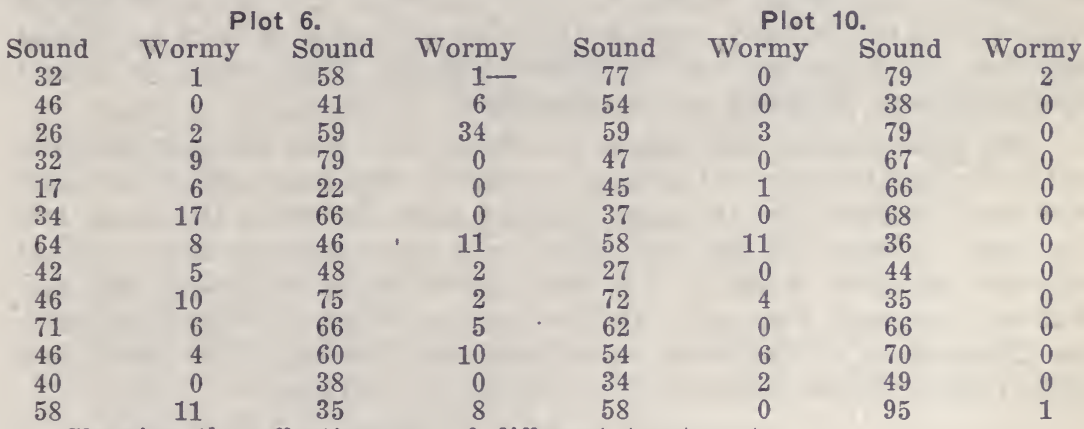

Showing the effectiveness of different treatments.

TWO POISON SPRAYS.

\begin{tabular}{|c|c|c|c|}
\hline \multirow{2}{*}{$\begin{array}{l}\text { No. of } \\
\text { Plot }\end{array}$} & \multicolumn{3}{|c|}{ E OF SPRAYING } \\
\hline & First & Second & Third \\
\hline $3 \ldots$ & June 2-7 & June $15-20$ & July $9-14$ \\
\hline 6... & June 2-7 & June 15-20 & July 9-14 \\
\hline $10 \ldots$ & June 2-7 & June $15-20$ & July $9-14$ \\
\hline 13. & June 2-7 & June $15-20$ & July 9-14 \\
\hline
\end{tabular}

\section{HOW SPRAYED}

Single Machine Double Machine Double Machine Hand Sprayed

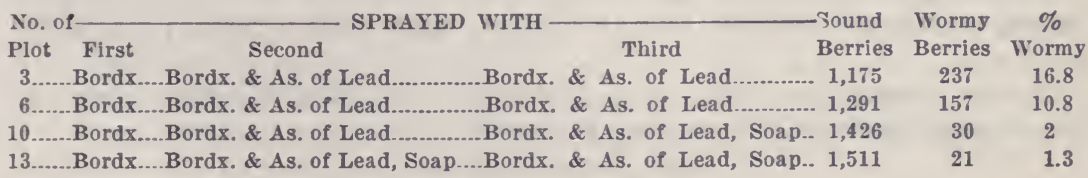

\section{ONE POISON SPRAY.}

\begin{tabular}{|c|c|c|c|}
\hline ...June & $2-7$ & June $15-20$ & July 9-14 \\
\hline ..Ju & $2-7$ & June $15-20$ & July $9-14$ \\
\hline Ju & $2-7$ & June 15-20 & July 9-14 \\
\hline$\ldots \mathrm{Ju}$ & $2-7$ & June 15-20 & July 9-1 \\
\hline
\end{tabular}

Single Machine Double Machine Double Machine Hand Sprayed
4......Bordx....Bordeaux

7....Bordx...Bordeaux.

11.....Bordx ....Bordeaux.

14......Bordx... Bordeaux.
Bordx. \& As. of Lead. 
Some of these results appear almost contradictory, but the infestation in different parts of a vineyard varies considerably. When the grapes receive the two sprayings in June and the third spraying is made early in July, the infestation often seems to be worse where the grapes received the three sprayings. Unsprayed plots will often have scarcely any berries left on the bunch as all of the earlier infested berries split open and fall off. In the sprayed plots many of the injured berries do not fall off and hence count for a much greater infestation than really exists.

1913.

After a lapse of several years experiments for the control of the grape berry worm were made again in 1913 in the East Cleveland district. The grapes in 1913 bloomed at least a week later than they normally do in this. locality. The usual dates being about June 5 to 10 , while they did not bloom until the $16 \mathrm{th}$ to the $20 \mathrm{th}$ of June in 1913. The set of fruit was also very light, which seems to make suitable conditions for a very wormy crop of grapes. Light crops of grapes, when unsprayed, are seemingly always badly injured by the berry worm as there is a full quota of berry moths and only half or less the number of berries to attack. This results in serious injury wherever the berry worm is abundant.

The plots selected were located on almost level land and each plot consisted of about two-thirds of an acre of grapes. The larger part of this section were Concords, but the plots included some Catawbas, Delawares and Niagaras. A series of different sprays was used, applying the poison at different strengths, using it with and without Bordeaux (2-3-50) and also without soap, with soap and with Bordeaux and soap, in order to compare the effectiveness of the poison in different combinations. The results are given below with data concerning the treatment of the plots.

\section{Plot 1-Concords.}

Power sprayer, 200-pound pressure, about 130 gallons of spray per acre.

Sprayed June 9-12: Arsenate of lead, 3 pounds; copper sulphate, 3 pounds; hard soap, 1 pound; lime, 4 pounds; water, 50 gallons.

Sprayed June 24-27, 145 gallons per acre. Same as first application, excepting the heavier spraying.

Sprayed July 15-18, 180 gallons per acre. Arsenate of lead, 4 pounds; copper sulphate, 3 pounds; lime, 4 pounds; hard soap, 1 pound; water, 50 gallons.

Counted September 10-11, 1913. Number of bunches, 31; sound berries, 682 ; wormy berries, 271 ; per cent wormy, 26.7 .

\section{Plot 2-Concords.}

Power sprayer, 135 gallons per acre.

Sprayed June 9-12, 1913. Arsenate of lead, 3 pounds; copper sulphate, 3 pounds; lime, 4 pounds; water, 50 gallons.

Sprayed June 21-27, 145 gallons per acre.

Arsenate of lead, 3 pounds; copper sulphate, 3 pounds; lime, 4 pounds; water, 50 gallons.

Sprayed July 14-18, 180 gallons per acre. 
Arsenate of lead, 4 pounds; copper sulphate, 3 pounds; lime, 4 pounds; water, 50 gallons.

Counted September 10-11, 1913. Number of bunches, 31; sound berries, 546; wormy berries, 271 ; per cent wormy, 33.1.

\section{Pot 3-Concords.}

Power sprayer, 135 gallons per acre.

Sprayed June 9-12, 1913.

Arsenate of lead, 4 pounds; copper sulphate, 4 pounds; lime, 4 pounds; hard soap, 1 pound; water, 50 gallons.

Sprayed June 24-27, 145 gallons per acre. Same spray.

Sprayed July 14-18, 180 gallons per acre.

Arsenate of lead, 6 pounds; copper sulphate, 4 pounds; lime, 4 pounds; hard soap, 1 pound; water, 50 gallons.

Counted September 10-11, 1913. Number of bunches, 34; sound berries, 858; wormy berries, 207; per cent wormy, 19.4 .

\section{Plot 3-Delawares.}

Number of bunches, 28; sound berries, 1,041; wormy berries, 229; per cent wormy, 18.

\section{Plot 4-Concords.}

Power sprayer, 135 gallons per acre.

Sprayed June 9-12, 1913.

Arsenate of lead, 3 pounds; soap (hard), 1 pound, water, 50 gallons.

Sprayed June 24-27, 145 gallons per acre. Same as first spraying.

Sprayed July 14-18, 180 gallons per acre.

Arsenate of lead, 4 pounds; hard soap, 1 pound; water, 50 gallons.

Counted September 10-11, 1913. Number of bunches, 32; sound berries, 499; wormy berries, 421; per cent wormy, 45.7 .

\section{Plot 5-Concords.}

Power sprayer, field spars; 135 gallons per acre.

Sprayed June 9-12, 1913. Arsenate of lead, 3 pounds; copper sulphate, 3 pounds; lime, 4 pounds; flour in paste form, 4 pounds; water, 50 gallons.

Sprayed June 24-27, 145 gallons per acre. Same spray as first.

Sprayed July 14-18, 180 gallons per acre. Same spray as first and second.

Counted September 10-11, 1913. Number of bunches, 33; sound berries, 684; wormy berries, 246; per cent wormy, 26.4 .

\section{Plot 6-Concords.}

Power sprayer; 135 gallons per acre, using fixed spars.

Sprayed June 9-12, 1913. Arsenate of lead, 3 pounds; copper sulphate, 3 pounds; lime, 4 pounds; hard soap, 1 pound, water, 50 gallons.

Sprayed June 24-27; 145 gallons per acre, using fixed spars. Same spray as first. 
Sprayed July 14-18; 180 gallons per acre, applied by hand. Arsenate of lead, 4 pounds; copper sulphate, 3 pounds; lime, 4 pounds; hard soap, 4 pounds; water, 50 gallons.

Counted September 10-11, 1913. Number of bunches, 33; sound berries, 657; wormy berries, 213; per cent wormy, 24.4 .

\section{Unsprayed-Concords.}

Number of bunches, 67 ; sound berries, 221; wormy berries, 1,177; per cent wormy, 84 .

The dates or time of making the different applications was based on the previous experiments made in the grape districts of Ohio and also on the work of the United States Department of Agriculture in Pennsylvania.

The spray was applied with a power machine of large capacity and at 200 pounds pressure. The spars were of the fixed type, but the nozzles were not pointed at right angles to the grape row. The nozzles were placed comparatively low down and were angled so that the spray was thrown upward and outward as well as forward and backward, meeting the roof of the leaves edgewise instead of throwing the spray against the roof-like protecting surface of the leaves. These spars were designed by the author, in order to completely cover the bunches of grapes with spray in as thorough a manner as possible, approaching the best hand spraying in covering capacity without extra labor. The ability to cover a considerable area of vineyard rapidly with a minimum expense for labor was also an important item as directing the spray nozzles by hand adds greatly to the cost of spraying grapes. These spars with the nozzles angled outward and upward saved the labor cost of the two men required to direct the nozzles in hand spraying. The cost of spraying an acre of grapes for the season varied slightly with the different treatments. Basing the cost of the spraying material on the plots having the largest percentage of good grapes, three sprayings cost about $\$ 8.25$ per acre for spraying materials. Labor and wear on machine, repairs, depreciation in value of the machine, and miscel'aneous extras cost close to $\$ 7$ per acre for the season, allowing for three sprayings. These costs are based on the use of a power sprayer under normal vineyard conditions.

In 1914 the experiment work for the control of the grape berry worm was more extensive than in the year previous, as the Dover Fruit Growers' Association cooperated with the Ohio Experiment Station following as closely as possible the program laid out by the author. This permitted the testing out in a practical way of the best results obtained in the experimental plot work of previous years. The different members of the association followed the program laid out as as closely as they could under their circumstances. The results obtained were commensurate with their thoroughness in spraying and caring for their grapes. Four cooperators obtained results approximating 2 to 3 per cent of wormy grapes in vineyards, where on the previous year the crop was more than half wormy. Unsprayed rows in these vineyards had more than 60 per cent wormy berries in the latter part of September. In every vineyard where it was sprayed one or more times, the number of wormy grapes was much less than in the unsprayed sections.

Some of the cooperators put on only the second spraying, about ten to twelve days after the grapes bloomed, and some put on only the third or 
last spraying in the latter part of July. Wherever the July spraying was carefully applied the percentage of wormy grapes was greatly reduced, the results averaging only 11 to 12 per cent of wormy berries. In nearby unsprayed vineyards from 32 to 64 per cent of the crop was wormy and the total weight of merchantable grapes reduced from one-third to one-half.

The experiment plots near Euclid, Ohio, were part of a vineyard of some seventeen or eighteen acres. Each plot consisted of about two-thirds of an acre thoroughly sprayed with its particular kind of spray.

The soil throughout these plots is similar and the cultivation and soil fertilization were practically the same, but the slope varied slightly. The infestation of berry moth the season previous was also fairly uniform throughout the vineyard, so gave promise of a similar condition in 1914 . The set of grapes was much heavier than in 1913, and this usually means that the grape crop will not average quite so wormy as on years when the set is extremely light.

In 1914, various combinations of sprays were used with different methods of application. Arsenate of lead at varying strengths, with and without Bordeaux, with and without soap for a sticker and spreader. Copperas, or iron sulphate, with lime was used as a sticker, spreader and fungicide in combination with arsenate of lead on one plot, and in 1914 flour paste was tested as a spreader and sticker for the arsenate of lead. Syrup or cheap cooking molasses was used in some test p!ots in 1914, in the late July spraying. In a few cases a considerable amount of injury to Ives grapes seemed to be due to the use of cheap molasses for a sticker and spreader with the arsenate of lead. The plot sprayed with this material was also more severely injured by the berry worms than adjoining plots sprayed with arsenate of lead, Bordeaux (2-3-50) and two pounds of dissolved soft soap in each 50 gallons. The plots sprayed with arsenate of lead and soap without Bordeaux had some 8 per cent less of wormy grapes than where molasses was used, hence the decided advantage of using soap, with the poison, as a spreader and sticker.

\section{Check-Unsprayed.}

Number of bunches, 26; sound berries, 749 ; wormy berries, 373 ; per cent wormy, 33.2 .

\section{Plot 1.}

Sprayed June 9, 1914; 140 gallons per acre. Arensate of lead, 2 pounds; copper sulphate, 2 pounds; lime, 3 pounds; soft soap, 2 pounds; water, 50 gallons.

Sprayed same spray June 24, 200 gallons per acre.

Sprayed July 31, 200 gallons per acre. Arsenate of lead, 3 pounds; soft soap, 2 pounds; water, 50 gallons. Added nicotine sulphate, 1 part to 1,000, for leaf hoppers.

Counted September 14, 1914. Number of bunches, 19; sound berries, 1,004; wormy berries, 22; per cent wormy, 2.14 .

\section{Plot 2.}

Sprayed June 9, 1914; 140 gallons per acre. Arsenate of lead, 2 pounds; soft soap, 2 pounds; water, 50 gallons. 
Sprayed June 24, 200 gallons per acre, same material.

Sprayed July 30, 200 gallons per acre. Arsenate of lead, 3 pounds; soap, 2 pounds; water, 50 gallons.

Counted September 15, 1914. Number of bunches, 23; sound berries, 1,005; wormy berries, 77; per cent wormy, 7.1.

\section{Plot 3.}

Sprayed June 10, 1914. Arsenate of lead, 2 pounds; copper sulphate, 2 pounds; lime, 3 pounds; molasses, 2 gallons; water, 50 gallons.

Sprayed June 26. Same spray, except 200 gallons per acre.

Sprayed July 30, 200 gallons per acre. Arsenate of lead, 3 pounds; molasses, 11/2 gallons; water, 50 gallons.

Counted September 15, 1914. Number of bunches, 23; sound berries, 955; wormy berries, 111; per cent wormy, 10.4 .

Plot 4.

Sprayed June 10, 1914; 140 gallons per acre. Arsenate of lead, 2 pounds; copperas, 4 pounds; lime, 4 pounds; soft soap, 2 pounds; water, 50 gallons.

Sprayed June 24. Same spray, except 200 gallons per acre.

Sprayed July 29, 200 gallons per acre. Arsenate of lead, 3 pounds; soft soap, 2 pounds; nicotine sulphate, 1 part in 800 ; water, 50 gallons.

Counted September 15, 1914. Number of bunches, 26; sound berries, 1,149; wormy berries, 54 ; per cent wormy, 4.49 .

\section{Plot 5.}

Sprayed June 10, 140 gallons per acre. Arsenate of lead, 2 pounds; lime, 3 pounds; soft soap, 2 pounds; copper sulphate, 2 pounds; water, 50 gallons.

Sprayed June 25. Same spray.

Sprayed July 29. Arsenate of lead, 3 pounds; copper sulphate, 2 pounds; lime, 3 pounds; soft soap, 2 pounds; water, 50 gallons.

Counted September 15, 1914. Number of bunches, 29; sound berries, 1,186; wormy berries, 24; per cent wormy, 1.98 .

\section{Plot 6.}

Same treatment as Plot 5, except treatments were made by directing the nozzles by hand.

Sprayed June 11 and July 29, 1914. Used approximately 110-135-160 gallons per acre in the different sprayings.

Counted September 14, 1914. Number of bunches, 27; sound berries, 1,264; wormy berries, 11; per cent wormy, .86.

\section{Plot 6A.}

Same spray as Plot 5. Sprayed June 25 and June 29, 1914 . Used 135-160 gallons per acre in the respective sprayings.

Counted September 14, 1914. Number of bunches, 28; sound berries, 1,251; wormy berries, 27; per cent wormy, 2.1 .

\section{Plot 6B.}

Sprayed once, July 29, 1914; 160 gallons per acre. Arsenate of lead, 3 pounds; copper sulphate, 2 pounds; lime, 3 pounds; soft soap, 2 pounds; water, 50 gallons.

Counted September 14, 1914. Number of bunches, 29; sound berries, 1,237; wormy berries, 18; per cent wormy, 1.43 . 


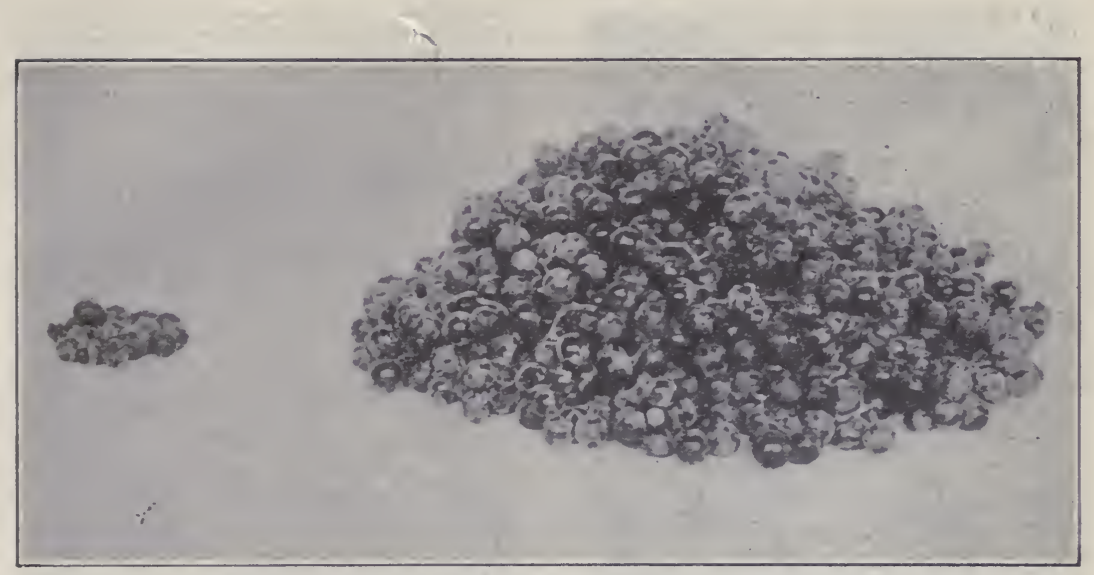

Fig. 7. Machine-sprayed, 1914. Less than two per cent wormy.

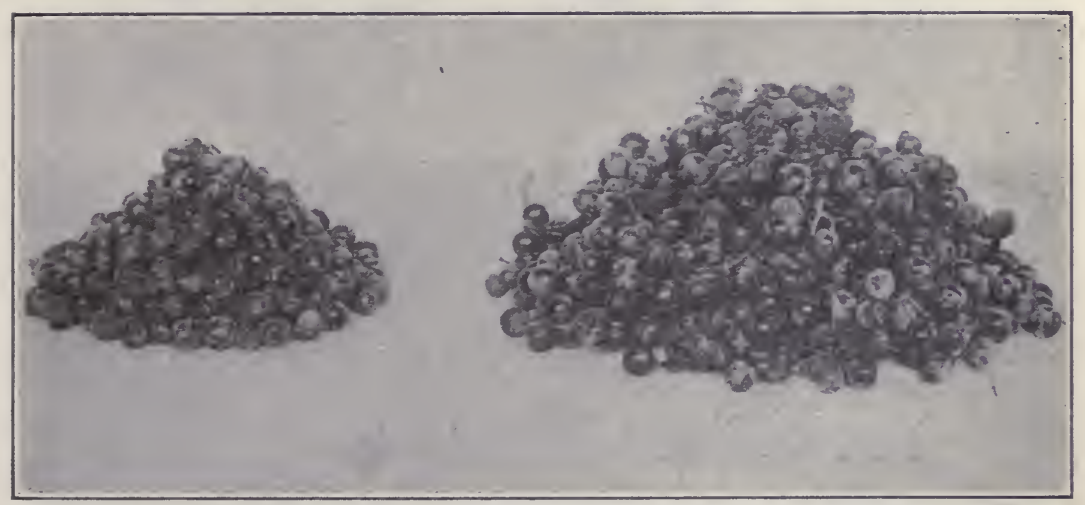

Fig. 8. Unsprayed, 1914. Thirty-three per cent wormy.

Referring to the illustrations, the value of the different sprays can readily be determined. Plots $1,5,6,6 \mathrm{~A}$ and $6 \mathrm{~B}$ all show the value of weak Bordeaux and soap in combination with arsenate of lead. Plot 2 has the Bordeaux omitted and has over 7 per cent of wormy grapes; Plot 3 has molasses instead of soap for the sticker and spreader, with over 10 per cent of wormy berries; Plot 4 has copperas instead of blue vitrol with 4.49 per cent of the wormy berries. All of these applications were made with a power sprayer at 200 pounds pressure, using special spars for all the work excepting the hand sprayed plots. 


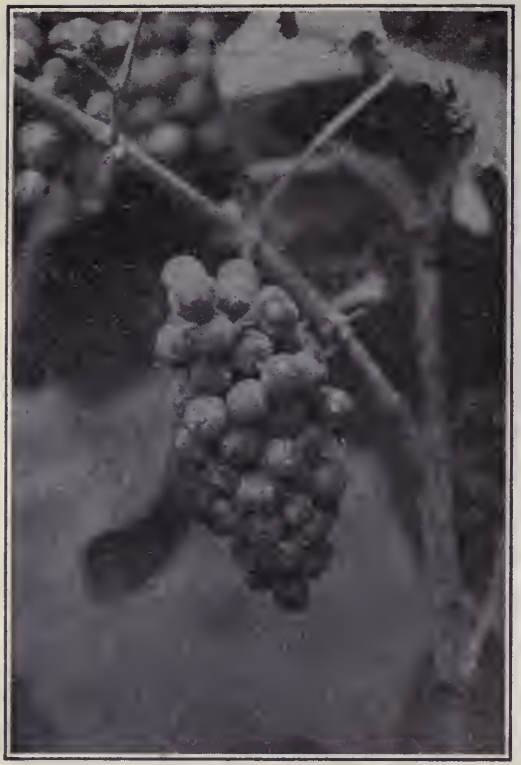

Fig. 9. Sprayed.

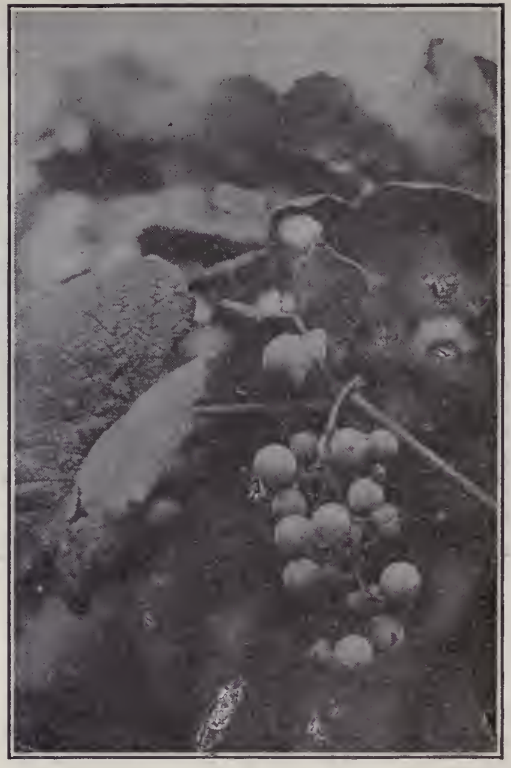

Fig. 10. Unsprayed.

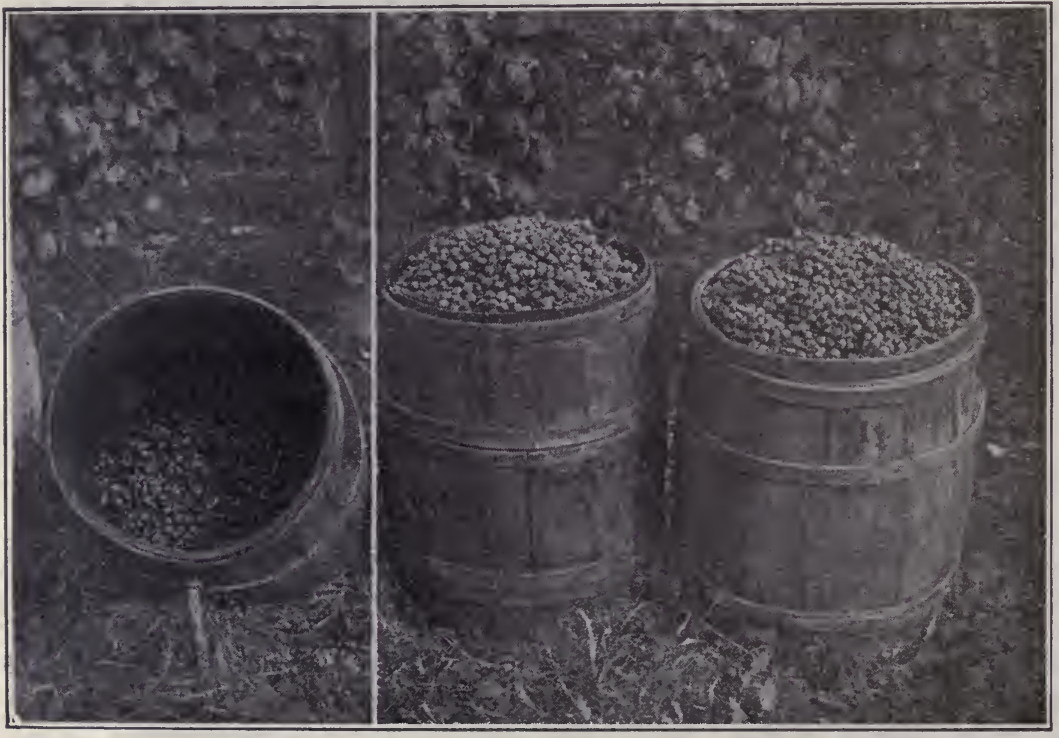

Fig. 11. Left-Barrel from unsprayed row. Right-Barrels from sprayed row. 
In the sprayed plots, one spraying by hand in late July had only 1.43 per cent wormy berries; where two hand applications were made 2.1 per cent of the grapes were wormy, and where three hand sprayings were given only .86 per cent of the harvested crop was wormy. Where the same spray was applied with special fixed spars, making three applications during the season, 1.98 per cent of the crop was wormy. Comparing the results of previous years in similar experiments, these fixed spars approach hand spraying in thoroughness, with a considerable saving in the labor cost of applying the spray.

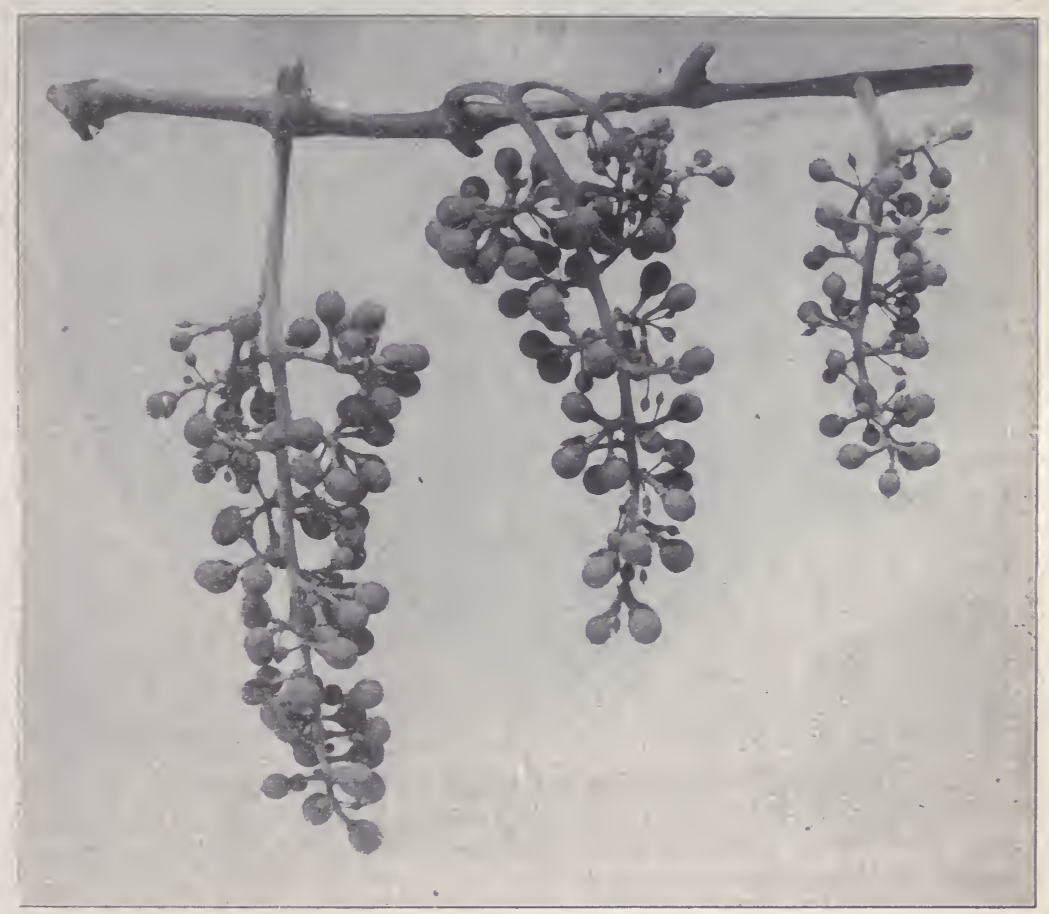

Fig. 12. Stage of bunches at which to spray.

Two thorough applications given at proper times will control the berry worm. The first application should be given just after the grapes bloom, taking Concords as the standard variety, and a second heavy, thorough spraying six or seven weeks later, usually about the first week in August in Northern Ohio. These sprayings just precede the hatching time of the grape berry moth eggs and the newly hatched larvae find a meal of poison awaiting them if the grapes are properly sprayed. Gathering the anchored leaves in the soil, upon which the berry worms have spun up in the fall, and destroying them, will also assist materially in controlling the pest; also plowing in May will crush many of the pupae and bury them so deep that emerging moths cannot reach the surface. 
In cases of severe infestation, careful and thorough spraying at proper times with arsenate of lead, 4 to 6 pounds. Bordeaux (2-3-50) and dissolved soft soap, 2 pounds, is a necessity for controlling the grape berry worm.

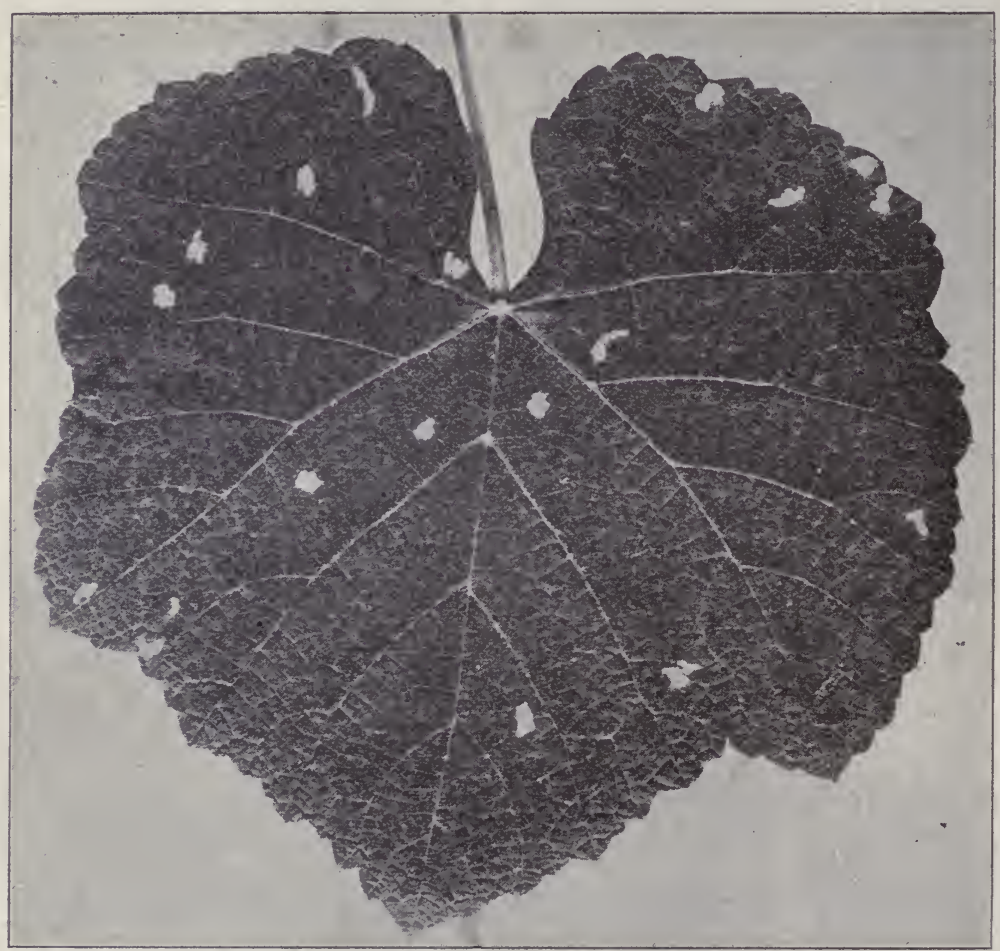

Fig. 13. Cocoons of the grape berry moth on leaf. 


\title{
TWO DESTRUCTIVE GRAPE INSECTS OF THE APPALACHIAN REGION.
}

\author{
By FRED E. BROOKS,
}

Entomological Assistant, Deciduous Fruit Insect Investigations, United States Department of Agriculture.

Several years ago, while the writer was connected with the entomological department of the West Virginia Agricultural Experiment Station, he was called upon to investigate severe injuries which were being done to grapes in various parts of the State by the grape curculio, Craponius inaequalis Say and the grapevine root-borer, Memythrus polistiformis Harris. The accounts of these two which follow are based very largely on information obtained at that time. Both species are prevalent in the Appalachian section although neither is confined exclusively in its distribution to that region of the United States.

\section{THE GRAPE CURCULIO.}

\section{Introduction.}

The Grape Curculio, Craponius inaequalis Say, is a small snout-beetle, belonging to the family Curculionidae, whose larvae develop exclusively within the fruit of the grape. The beetle uses its snout to puncture the skin of partially-grown grapes for the purpose of depositing its egg within a small cavity excavated from the pulp through the opening in the skin. The larva hatching from the egg feeds on the pulp and seeds causing the fruit to drop prematurely.

In many parts of the Appalachian region, and also in some other sections of the Mississippi Valley, the grape curculio is the most destructive of the insects attacking the fruit of the grape. It is not unusual, in some localities at least, for unprotected vines to lose 100 per cent of their crop from this cause. In the region referred to, native grapes of several species abound and there is no doubt that the wild fruit was the original food and breeding place of the insect. The wild grapes are still attacked extensively and are a source from which beetles are produced every year that fly to nearby cutivated vines for the purpose of depositing eggs. Commercial grape growing is not an extensive enterprise at many points within the region under special consideration but practically every home is supplied with vines to furnish fruit for family use and there are numerous small vineyards the products of which supply the local markets. Many of these growers find it necessary every year to protect their crop in some way against partial or entire destruction by this pest.

\section{Distribution.}

Most of the observations on the grape curculio made by the writer have been in West Virginia, but the species has been recorded as occurring, also, in destructive numbers in certain parts of Kentucky, Ohio, Illinois, Missouri and Arkansas. For some reason, which has not been fully explained, the 
insect is apt to be only locally abundant within the area of its known distribution. It has been noticed frequently that grapes in one locality may suffer greatly every year while in other localities, not far distant, injury will scarcely be noticeable. Probably the presence or absence in a given locality of wild grapes, in which the curculios breed, has much to do with this irregularity in the distribution of the pest.

\section{LIFE HISTORY.}

\section{The Egg and Oviposition.}

In the latitude of central West Virginia the adult grape curculio, which is a small, brown, inconspicuous beetle, appears in the spring upon the foliage of grape vines, usually during the latter part of the month of May. The time the beetles first make their appearance corresponds rather closely with the blooming of the grape. Late in June, when Concord grapes are about onefourth grown, the beetles begin to oviposit in the fruit.

The egg is oval in shape, its dimensions being about .015 by .022 inch. The color is translucent white changing to yellowish as incubation advances.

In depositing her eggs the female makes use of her slender snout, upon the point of which the mouth is situated, to form a small opening in the skin of the fruit. She then eats out a cavity in the pulp, about one-tenth of an inch in diameter, and deposits within it a single egg. She then seals the small opening in the skin with a pellet of excrement, evidently for the purpose of securing the egg against natural enemies. The point where the egg is deposited shows as a discolored and slightly depressed spot on the skin of the fruit. The spots have a characteristic appearance and often furnish the vineyardist with his first intimation that the insect is present on his vines. In occasional cases where the eggs fail to hatch a hard tissue forms around the egg-cavity so that the punctured fruit is worthless whether or not the larva develops.

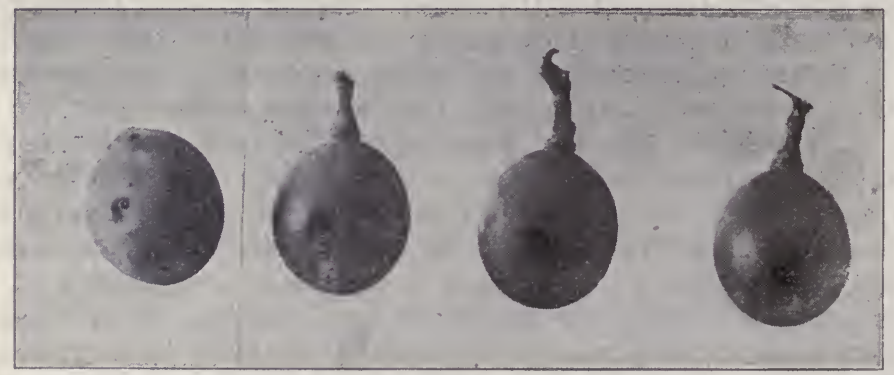

Fig. 1. Egg puncture of grape curculio. T.wo left, punctured. Two right, uninjured.

The females deposit on an average something over 250 eggs each, and, until all available grapes are occupied, the beetle will usually select a sound fruit for each egg. The egg-laying period begins late in June and continues for about eighty days. A single female may deposit as many as fourteen eggs in a single day. The eggs deposited at the beginning of the season 
may develop into mature insects that will themselves produce eggs before the parent beetles have ceased to oviposit. Most of the eggs produced by this second brood, however, are infertile. The eggs hatch in from four to seven days, according to temperature, the average being about six days.
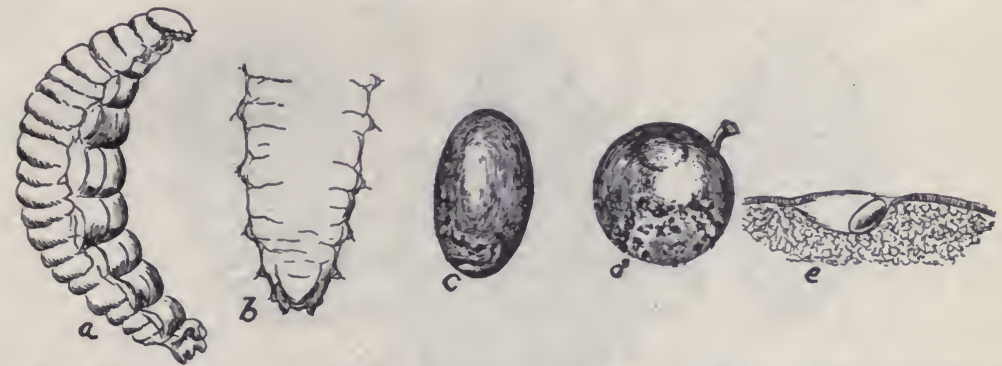

Fig. 2. (a) (Larva; (b) Posterior tip of larva; (c) Egg (greatly enlarged); (d) Grape berry, showing egg puncture; (e) Egg in situ under skin of grape berry.

\section{The Larva.}

The larva of the grape curculio is a small, legless grub, slightly over onefourth of an inch in length, which in color is white with a brown head. The body has a sparse clothing of rery fine, short hairs..

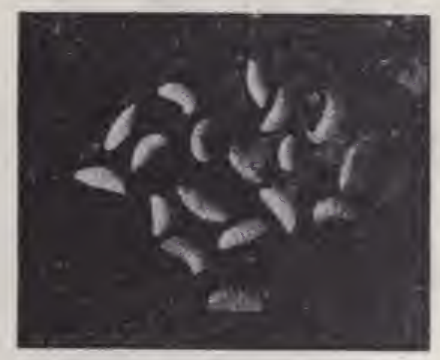

Fig. 3. Larvae grape curculio.

The young larva begins to feed on the pulp of the fruit before it is free from the shell. Within three or four days it attacks the seed and thereafter may be found feeding on either the seed or the pulp so long as it remains in the grape. When full grown it forms a small hole through the skin of the fruit through which it escapes. As soon as it leaves the grape it becomes exposed to ants and other enemies and it hurries under cover with all possible speed. Usually, it crawls beneath a lump of earth, a small stone or fallen leaves, or, if the ground is soft, it will work its way beneath the soil for a short distance. When it chances upon ground that is solid and free from any small objects beneath which it may find protection, it will gather grains of earth and sand and form its cocoon $c n$ the surface of the ground. Most of the larvae leave the fruit early in the morning.

The larvae require about two weeks in which to attain full growth. Twe or three larvae may develop within one grape but usually only one is found. 
Since several eggs are often deposited in a single fruit, it is probable that cannibalism is practiced by the older and stronger individuals. Most of the larvae leave the fruit during the months of July and August; however, a few continue to issue up to the last of September.
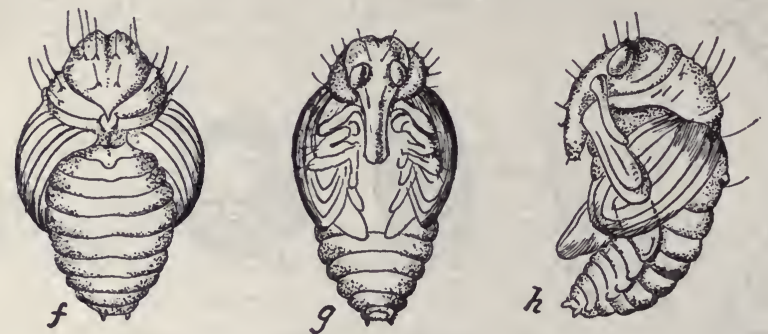

Fig. 4. Pupa.

The Pupa.

The pupa is a delicate, white form of the insect, which is intermediate between the larval and adult stages. It occupies a globular-shaped cocoon composed of grains of sand and earth held together by silk. The cocoon may be formed under any convenient object lying on the ground or it may

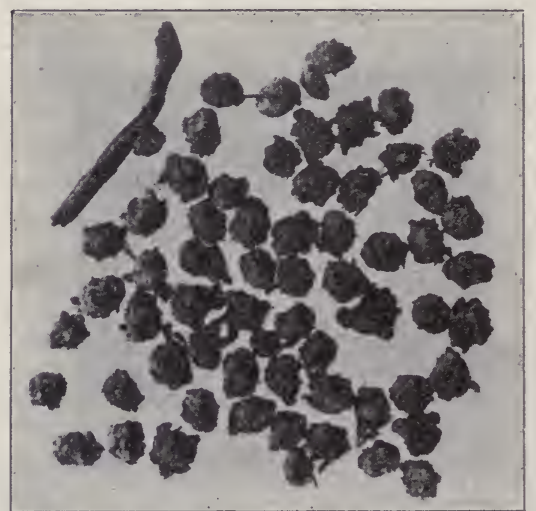

Fig. 5. Cocoons of grape curculio.

be placed just beneath the surface of the soil or in an exposed position on the grolind. The insect remains in the cocoon undergoing transformation anywhere from thirteen to twenty-three days, the greatest numbers emerging as beetles on the eighteenth and nineteenth days.

\section{The Adult.}

The adult grape curculio is a small, robust snout-beetle which measures, exclusive of the snout, about one-tenth of an inch in length. When the beetle first issues from the cocoon it is black with a grayish cast imparted by a sparse covering of minute white hairs. Within a few days the black ground color fades to dark brown. The beetles are inconspicuous and are not often 
noticed by a casual observer, even where they are abundant. They spend much of their time feeding or resting upon the upper surface of the grape leaves and it is in this position that they may be observed most readily.

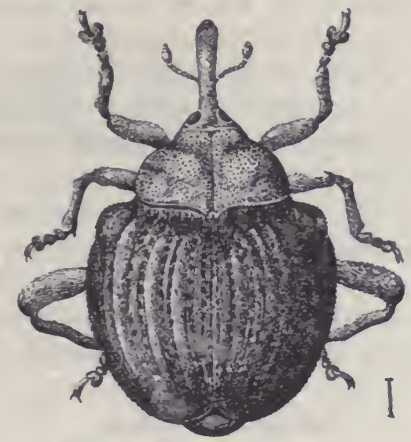

Fig. 6. Adult (x12).

They are quite shy and when disturbed are apt to leap vigorously and take wing before alighting. When captured and confined closely in the hand, they gives forth a distinct squeaking sound, a peculiarity which sometimes serves to distinguish the beetle from a lump of clay or a pellet of excrement dropped by a large caterpillar.

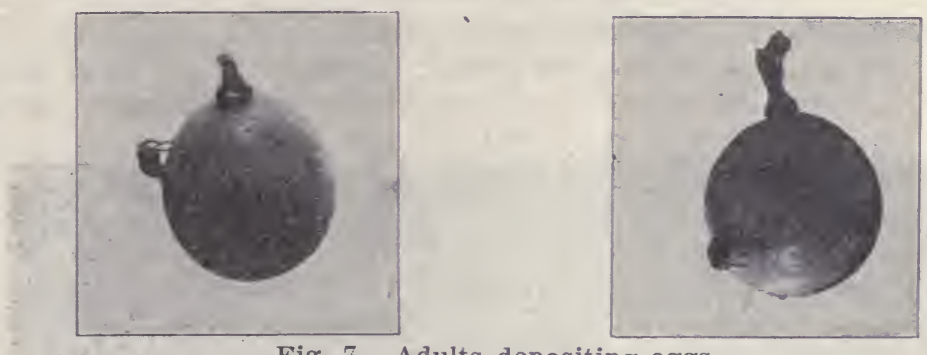

Fig. 7. Adults depositing eggs.

The beetles feed freely upon the upper surface of the leaves and the bark of the fruit stems. The female, also, devours the tissues removed from the fruit in excavating her egg-chamber. In feeding on the foliage only the green, upper layer of the leaf is removed. The mark on the leaf made in feeding is somewhat circular in form and is composed of distinctive zigzag lines with minute transverse ridges. The spots vary in size and shape but average about one-tenth of an inch in diameter. From the practical standpoint of the vineyardist, the habit of feeding on the foliage is of great importance, since it makes it possible to destroy the beetles very readily by spraying the vines. with arsenicals.

The. beetles issue from hibernation in the spring several weeks before egg-laying begins. They are rather inactive when they first appear but food is taken from the leaves about as soon as they ascend the vines. Thereafter, throughout the season, the peculiar feeding marks on the upper surface of the leaves increase in numbers and conspicuousness. Where the insects are 
abundant the foliage in the fall presents a specked appearance that is very noticeable.

A few individuals of the hibernating brood of beetles live and remain upon the vines until as late in the season as the first of October. Most of the beetles, however, that are to be seen on the vines during the fall months belong to a new brood that begins to appear in July. These young beetles may be distinguished for a while from those of the old brood by their darker color and fresh appearance. They feed freely on the foliage and deposit a few eggs which are mostly infertile.

With the coming of cold weather they leave the vines and hibernate, probably under objects of various kinds that they may find scattered on the ground. It is possible a few beetles remain in the cocoon over winter and emerge in the spring. As previously stated, the beetles reappear on the vines during the month of May, or, at about the time grape vines are in bloom.

\section{Natural Enemies.}

Two hymenopterous parasites, Bracon mellitor Say and Stiboscopus brooksi Ashm., commonly attack the grape curculio. The former destroys the larva while in the grape and the latter attacks and devours the larva or pupa while in the cocoon. Ants and other predacious insects destroy many of the larvae, especially at the time they are leaving the fruit to pupate.

\section{Methods of Control.}

As has already been suggested, the application of arsenical poisons to the foliage of the grape is an effective method of destroying the adult grape curculio. The most satisfactory time to apply the poison is in the spring

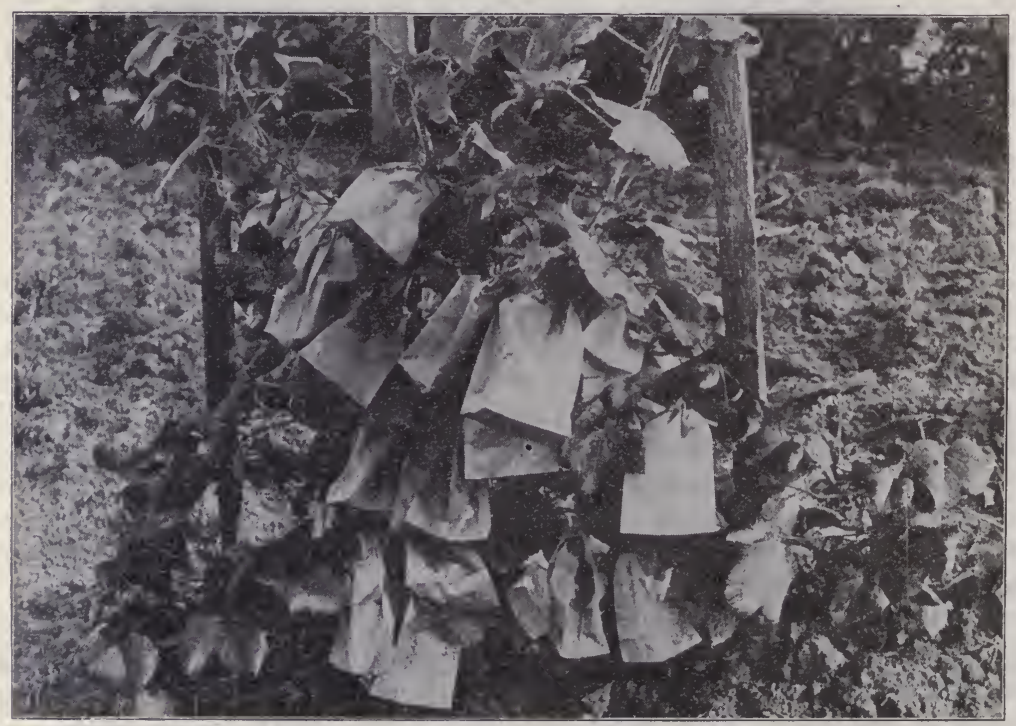

Fig. 8. Grapes protected by paper bags. 
after the beetles have appeared on the vines and before oviposition has begun. The poison may well be applied in the form of a spray and can be combined with materials used against other insects and diseases that are commonly injurious to the grape. The first application in the spring should be made soon after the fruit has set and this may be followed up, if necessary, with other applications at intervals of two weeks. The young beetles may be killed by spraying in August or September. Thorough spraying can be depended upon to almost entirely prevent injury to the fruit by this insect.

Enclosing the bunches of grapes in two-pound or three-pound paper bags soon after the blossoms have disappeared will exclude the beetles and insure perfect fruit. In placing the bags they should be opened and slipped over the young clusters and the mouth folded and pinned around the stems. If properly done, the bags will stay in place until the fruit is ripe. This method is too expensive to be used on a large scale except in cases where fancy fruit is desired regardless of cost. It may be practiced in a small way with excellent results. One person should, with a little practice, place from 1,000 to 2,000 bags in a day.

The cultivation of the soil in vineyards undoubtedly destroys many of the curculios while they are undergoing transformation within the cocoon. The beetles may be collected with fair success early in the morning or on cool days by jarring or shaking the vines over sheets spread on the ground.

Whatever method of control is adopted, it is frequently advisable to supplement the work by the cutting out of all wild and worthless grape vines that may be growing near the cultivated vines. Such wild vines frequently serve as breeding places for the beetles and should either be sprayed with as much care as the vineyards or destroyed.

\section{THE GRAPEVINE ROOT-BORER.}

Introduction.

The grapevine root-borer, Memythrus polistiformis Harris, belongs to a family of moths (Aegeriidae) which is represented in this country by several well known and destructive species. The larvae of various members of the group are commonly designated as "borers" on account of their habit of burrowing through the bark, stems, wood and roots of plants. The different species of the family attack a great variety of valuable trees and smaller plants that grow in the garden, orchard and forest. The grapevine rootborer is not so well known generally as the nearly allied peach borers, squash vine borer, and some other members of the group. This is due in part to the fact that it is not at present so widely and abundantly distributed as the other species mentioned and in part to its habits of concealment during the four stages which comprise its life cycle.

The eggs are small and inconspicuous and can be found only by careful search, even in bad!y infested vineyards; the larvae feed in the roots beneath the ground and throw no castings to the surface as an indication of their presence; the pupa occupies an earth-covered cocoon in the soil; and the adult simulates so closely in form and flight the common wasps of the genus Polistes, that the casual observer does not recognize it as a moth. It thus happens frequently that a vineyard will be quite badly infested by this insect while the owner remains entirely unaware of its presence. 
The injury to the vine is done by the larva, or borer, burrowing through the roots, the attack usually being made a foot or more out from the center of the root system. Badly infested vines will have all or most of the main roots killed except stubs at the base a foot or so in length. These root-stubs will afford the vine a sufficient hold in the soil to retain life but will not permit it to make a satisfactory growth or produce a normal crop of fruit. Vines may thus become stunted and unprofitable without presenting any external symptoms whereby the vineyardist can determine the cause of the trouble.

\section{Distribution.}

The grapevine root-borer is native to North America and is especially destructive in certain localities of the Appalachian region of the United States. The species is known to occur as far west as Missouri, but the most severe injury to grape vines has been reported from West Virginia and Kentucky. It is probable that this borer attacks all varieties and species of cultivated and wild grapes that grow within its range. In the vineyard the insect shows no preference for particular varieties.

\section{LIFE HISTORY.}

The Egg and Oviposition.

In the latitude of West Virginia the adult moths appear during the latter part of July and remain on the wing for two or three weeks. Observations made by the writer show that the females issue from the cocoon early in the day, fertilization, as a rule, takes place in the afternoon of the same day and egg-laying begins on the following day.

The egg is oval in outline, slightly flattened, with one face evenly convex and the other marked through the center with a dẻep longitudinal furrow or groove, the shape of the egg being not unlike that of a grain of coffee. The length is slightly less than .04 inch and the width about .025 inch. The color is chocolate brown, the surface being finely and densely punctured and

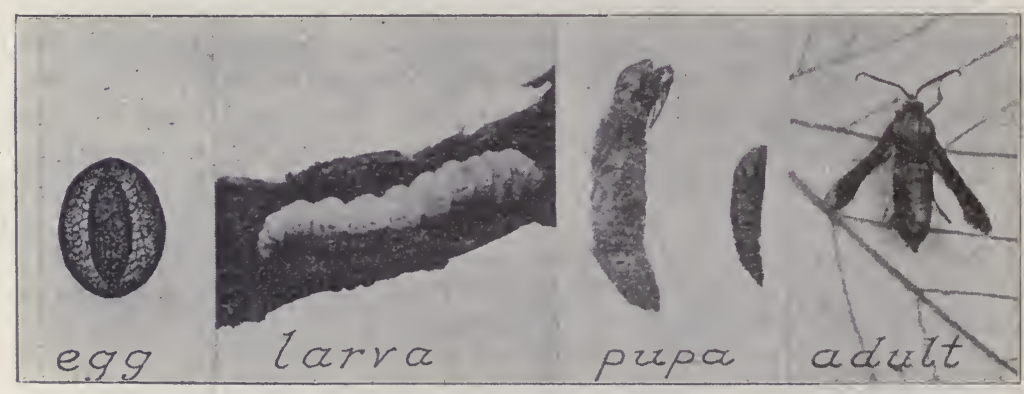

Fig. 9. Larvae of the grapevine root-borer attacking a root.

marked with a network of delicate lines. Eggs are deposited singly, or rarely in pairs, upon the leaves or stems of weeds, blades of grass, straw or any plants that may be growing or lying beneath the vines. Occasionally they are placed upon the leaves or canes of the grape vines. The moth shows 
no inclination to place her eggs on or in close proximity to the base of the cane, but scatters them about promiscuously over a space twenty feet or more in diameter surrounding the vine. The eggs are very insecurely attached and practically all of them fall to the ground before hatching.

About 400 eggs are laid, on an average, by each female, and the eggs require about three weeks in which to hatch.

\section{The Larva.}

The larva is a whitish grub with a brown head which attains, when full grown, a length of about $1 \% / 4$ inches. The body is rather slender, distinctly segmented and has a sparse covering of short, stiff hairs. It is in the larval stage alone that the insect is capable of injuring the vine.

When the borers first appear from the egg they are only about 1/25 of

an inch in length. The egg, as has been explained, is on the ground at the time of hatching and when the borers issue from the eggs they burrow at once into the soil. There they move about until chance leads them to a grape root, which, when found, they attack at once. The little borers are capable of living in the soil for several days without food, but it seems probable that many of them die in a fruitless search for a suitable root from which to obtain nourishment. In arriving at the root in this way, many of the borers enter at a considerable distance from the vine and leave a section of the main part of the root uninjured. The writer found one borer that had evidently penetrated eleven inches of solid clay soil and had entered the root at a point nine feet out from the vine.

The young borer, after finding a suitable root, first eats a hole through the bark and then excavates an irregular burrow, which, at first, is confined to the softer portions of the bark. In the beginning the burrow may encircle the root several times, but later, as the borer increases in size, it is made to run with the grain of the wood and may extend either away from or toward the base of the root. After the borers have been feeding several months their burrows are so large that in roots half an inch or less in diameter all the solid part of the root is converted into frass and only a thin membrane of the outer bark remains intact. In larger roots the burrow will frequently include all the wood on one side of the heart and is most likely to extend along the under side of the root.

The habit of the borer of feeding so far out on the root makes the practice of "worming" with a knife and wire impracticable. It has the advantage, however, of often leaving a stub of sound root to help sustain the vine. Often a root will be found completely severed by the borers and at the wounded end of the remaining stub a vigorous growth of young roots will be developing. Such severe root pruning lessens very greatly the feeding area of the root system and reduces the vigor and productivity of the vine.

The borer probably remains in the root for a period of twenty-one or twenty-two months, the time including two winters. The first winter it evidently feeds more or less during mild weather but remains inactive during the second winter within a silk-lined hibernaculum located in the burrow. 


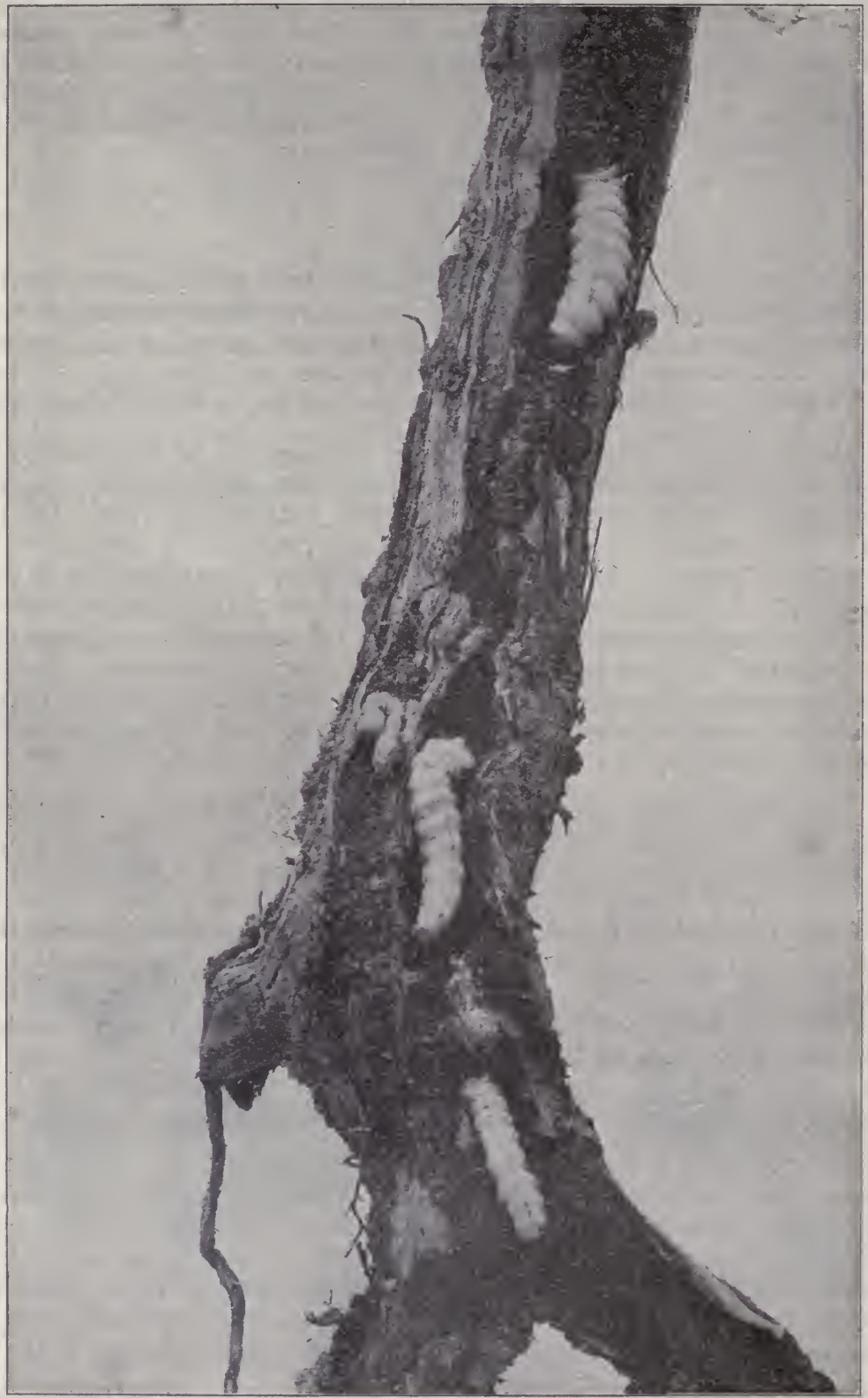

Fig. 10. Various stages of the Grapevine root-borer. 


\section{The Pupa.}

When the larva is full grown and ready to change to the pupal form, it leaves the root and ascends in a more or less direct course to within about an inch of the surface of the ground. Here it constructs a rough, elongate cocoon, of an average length of about one inch. The cocoon is composed outwardly of grains of earth mixed with the borer's excrement and is lined with tough silk. The borer transforms within this cocoon to a pupa of dark brown color with several narrow yellow bands encircling the abdomen. When ready to change to the adult insect the pupa works half its length out of the cocoon and the moth escapes through a slit in the back. The discarded pupa case is left with one end inserted in the cocoon and the other projecting a short distance above the ground. The pupa stage covers a period of four or five weeks.

\section{The Adult.}

The adult grapevine root-borer is a handsome moth, the sexes of which differ considerably in size and appearance. The males vary from five-eighths to three-fourths of an inch in length and from one inch to one and one-eighth inches in expanse. The females are larger, measuring about seven-eighths of an inch in length by one and one-half inches in expanse. The general color of both sexes is dark, lustrous brown. There are bands of orange and lemon-yellow scales encircling the abdomen and spots of similar colored scales at the base of the wings. As the moths grow old and worn with flight these bright colors fade or disappear.

During the investigation of this species moths were first seen on the wing on July 24 th and for about fifteen days thereafter they were abundant. The males appeared a few days in advance of the females and during the period of their flight were more abundant than those of the other sex.

The moth in its color, structure and flight resembles very closely the common stinging wasps of the genus Polistes. Both sexes have a habit of alighting on some object and fluttering their wings with an angry, buzzing sound which adds very greatly to their formidable appearance. They are active by day and oviposition takes place only during the brighter part of the day, usually from 9 a. m. to 4 p. m.

\section{Natural Enemies.}

The larva of one of our common firefly insects, Photuris pennsylvanica, was found devouring a pupa of the grapevine root-borer. The crested flycatcher, Myiarchus crinitus, a common bird in the locality where the investigation was made, was observed to be feeding rather extensively on the moths as they flew about. the vines.

\section{Methods of Control.}

This borer will be found to be a difficult pest to deal with. Methods which are used with success against several species of fruit tree borers are not applicable to the grapevine root-borer. The digging out process, protecting the trunks with mechanical appliances and paints and washes cannot be recommended for the present species. Its habits of burrowing down 
through the soil to the root on which it feeds precludes any method of repelling or destroying the borers at the base of the canes. It is also doubtful if anything can be hoped for from immune varieties.

The use of fumigants in the soil about infested vines has probably not been tried for this species, but some of the borers might be destroyed in this way. Thorough cultivation of vineyards during the months of June and July may be depended upon to destroy many of the insects while they are in the cocoons at the surface of the ground, undergoing transformation.

\section{THE ENGINEER'S PART IN THE ADVANCEMENT OF THE VITICULTURAL INDUSTRY.}

By E. T. MEAKIN,

San Francisco, Cal.

The engineer is very often overlooked when thinking or speaking about viticulture, so that in presenting his side of the,causes of advancement in this important industry to you, gentlemen, he asks for your indulgence.

The first engineer who was called upon for help was probably a poor country blacksmith, who was asked to make a device for digging up the ground so that the vines could be planted. This was some time back about 550 B. C., and at that time he did not realize that his ingenuity was called upon at all.

The next engineer called upon was probably a farmer, who had to devise a way of getting the juice from the berries after they had been pulled off the vines. The first method devised has not been recorded, but certainly this part of the business has received considerable attention from engineers from that date down to the present time.

To attempt to enumerate all the various devices that have been engineered for this part of the business would be impossible.

The earliest type of a grape crusher of which we have any record was a hollow stone, the same as they used to grind corn, the grapes being thrown into the bowl and the juice being pounded out with another stone; the juice was then collected and stored in goat skins.

We also find the early wine makers used the old arastra as a means of crushing their grapes, the grapes being thrown in front of a wheel which was fastened to a central revolving post and drawn around a circular pan by a team of oxen, the wheel crushing all the grapes that were in its path, thus freeing the juice, which was collected, usually in earthenware jars or bowls.

Later we have a long trough about 18 inches deep and six feet long into which the grapes were thrown, and men or women removing their footwear, stepped into the box and tramped out the juice from the grapes. This was a form of a crusher and press, and this same device is used in many places at the present time and with it they make the real genuine foot juice. 
These early engineering methods of crushing grapes, set the juice of the grapes free from the skins, but soon it was realized that the free juice was only a part of the whole juice of the grape, and then engineers set about different ways of extracting the balance remaining in the fruit.

The methods of pressing the grapes were more numerous than those used for crushing. One of the earliest on record was to take the crushed berries, lay them in an old goat skin, punch it full of small holes and twist the ends together. The same method is used by the housewife in making her jellies at the present time. She, however, does not use the goat skin, but a cotton bag.

Another method was to take straw, weave it into a mat, lay the berries in the mat on a flat stone, place logs on top of the mat and pile up stones on top of the logs, the weight causing the juice to flow from the berries, which usually was gathered in earthenware jars. The next step was to select a tree with a forked branch pointing downwards, cut down another tree to make a pole, fastening the pole at one end under the fork, thus making the old log press, which has been handed down from the ages, modified in some details as the times advanced. It can still be found in use at some of the old wineries at the present time.

The early engineers did not have to do their work according to union rules and regulations, therefore time was not the essence of their requirements, and the greatest strides in the development of the viticultural industry from the engineer's standpoint have taken place within our own age or during the last twenty-five years.

The writer had occasion to visit one of the old wineries very recently. The owner had been a poor boy starting as a stranger in a strange land without money or friends, and had amassed a very large fortune before his death. His place was supposed to be the best equipped winery in that part of country when he died, and in looking over the different devices and methods of handling his products, I made the remark that if the place was given free of all incumbrances to any one in the condition in which he left it, with the understanding that they were to operate and keep it running without alteration, that they would starve to death if they had to face present day competition.

In this winery were the two old systems of making wine. In the first apparatus used the grapes were dumped into a crusher which had two wooden rollers, and after being crushed they were immediately pressed in a small hand press very similar to those used as family cider presses; the juice was then fermented in casks or barrels. The pomace after pressing was fed to the stock, only about two-thirds of the available juice being removed. This method had evidently been unsatisfactory, because later the grapes were crushed into tanks, the crusher being placed over the top, and the grapes, including stems, were crushed into these tanks and there allowed to ferment, being removed after fermentation had taken place, to have the juice remaining in the pomace pressed out. While this method gave more color to the wine, it also left a bitter taste which was not there under the former method of wine making. The man who purchased the wine liked the color, but did not like the taste, so the winemaker called upon the engineer to find out which part of the grape this taste came from. It was soon discovered that the greatest part of the bitter taste was caused by the stems 
being in with the grapes during fermentation. The engineer then commenced devising ways and means of extracting the stems from the grapes. One of these early machines was a long tray set on an inclined plane under the crusher rollers, the bottom of this tray being made out of woven wire of about $3 / 4$-inch mesh and the tray provided with a rapid shaking motion. After the grapes were crushed they fell on to this tray, and the loose berries were shaken through the screen, into a receptacle. The stems, being too large to pass through the screen, traveled to the end of the tray and discharged on to the floor.

While this machine did fairly good work, it was very wasteful, a very large portion of the grapes clinging to the stems being thrown away. This device was used in several modified forms for a number of years.

The next machine made for stemming grapes had a long wooden cylinder about four feet in diameter by four feet long, pegs being driven outside this cylinder and allowed to project out about two inches, a metal spiral being formed between these pins to convey the grapes towards one end. This cylinder revolved inside another cylinder made of iron bars placed onehalf inch apart, a square opening being cut in the outside cylinder at one end to allow the grapes to fall on to the central revolving cylinder. The pins on this cylinder pulling in the grapes, the berries were torn from their stems by coming in contact with the iron bars, the spiral being fastened on to the inner cylinder caused the stems to travel outwards while the grapes passed through the bars, some whole and some crushed. These machines were later provided with a conveyor screw to feed the grapes to the stemmer in the right proportion and a grape crusher was placed below which crushed the whole berries that had passed through the bars. This machine was the first successful grape stemmer and crusher and it had the distinction also of removing the stems before crushing the berries. It was made in 1878 and was the forerunner of many different styles of machines for doing this work.

This machine was placed in a winery which was built into a hill, the upper floor coming level with the roadway at the rear. The machine was placed just outside the building and alongside the driveway. The grapes were thrown into this machine, which removed the stems and crushed the berries and discharged the must into four-wheel carts which were used to carry the must to the fermenting tanks.

Soon after the elevator came into use, the first type being a canvas belt on to which wood cleats were securely fastened, two pulleys transmitting the power which delivered the grapes into the crusher. This style of elevator could not work at very steep angles and was soon replaced by the chain and cleat elevator which could work at much greater angles and consequently saved a great deal of room in the building, and increased the elevation to which grapes could be raised. This improvement brought in the gravity flume or chute system. The stemmers and crushers were placed in a central tower discharging the must from that point into a system of flumes which was connected to all the fermenting tanks in the cellar. This was a very great saving, both in cleanliness and labor. The teams did not have to wait while discharging their load, but could work right along, not seeing or caring where the grapes went to. The blocking of the chutes, causing them to overflow, is responsible for many of the gray hairs on the head of the cellar master, who delighted in showing his nice, clean cellar at just the moment 
when the chute was blocked and the must running all over the floor, and the teamster showing the fellow behind how quickly he could get rid of his load.

It was in 1896 that must pumps for handling pomace were first used and this was the first radical change in wine making machinery. The crushers and stemmers before this time had undergone many degrees of improvement and had reached a state whereby a machine could be utilized for removing the stems from the berries, and so perfectly was this work done, at that time, that no difference could be detected between berries removed one at a time by hand from a bunch of grapes, and those removed by the machine. It was the first must pump, however, that created a new era for the winemaker.

The first must pumps used were of the plunger type with a long stroke. The piston was raised past openings in the cylinder, a hopper large enough to hold a quantity of must to cover these openings was fitted around this cylinder, the hopper was placed below the crusher discharge and the must allowed to run into the hopper and through the openings into the cylinder. The plunger then descended on to the must and forced it into the pipe line, which conveyed it to any part of the fermenting cellar.

After this method came in vogue, wineries ceased to be built against a hill and were placed out in the open and could be extended indefinitely as the business grew. The pipes being closed, there was no danger of vinegar flies gathering on the chutes, and many other dangers of the spoiling of wine were removed. About this time the centrifugal pump was tried in many places, but never proved successful as a must pump. Under some conditions it would work, but as soon as the grapes started any fermentation the gas would collect in the runner and the pump would stop operating. The rotary pump was tried later, but it did not have durability, the tartar would wear away the cylinders and their life was too short for economy.

A cross between a centrifugal and a rotary proved fairly successful and can be found in use at the present time, but they are objectionable as their efficiency is only 31 per cent of the power applied. This class of machine was rapidly replaced by the all-closed-in type of a plunger pump which sucks the must from underneath the crusher and delivers it into the fermenting tanks without being further exposed to the atmosphere.

The must pump, therefore, abolished at one stroke the long, costly and unsatisfactory elevators, the expensive and dirty chute system, and did away with the high towers in the buildings, allowing a clean, sweet, light building to be used for fermentation purposes. The pump would handle the grapes at one-quarter of the cost that they could be handled with the elevator and the chute system, in addition to which one man could watch the place where the grapes were discharged in the tanks and also where they were were being delivered to the crusher by the team.

It is by the aid of the must pump that our large plants are now able with one large unit to crush as much as 25,000 tons of grapes during one season.

The must pumps are not alone in their advancement, for the same amount of improvement will be found in all the different branches of the viticultural industry. 
After the grapes are crushed and fermentation has taken place, the pomace is removed from the tanks by various means, and delivered to the presses. I cannot pass this important branch of the industry without mentioning some of these improvements.

After the old log press, already mentioned, came various kinds and styles of screw presses. The one most generally used and giving universal satisfaction is the one which has a central screw secured at the bottom projecting through the bed on which the cage, carrying the pomace, rests. This cage is filled with pomace, blocking is placed over the pomace and the nut screwed down, the bed of the press carrying all of the strains, the pomace being on top of this bed. When the nut is screwed down it presses the pomace in a satisfactory manner.

The hydraulic presses, of which there are several kinds, are also freely used in the wineries. They are provided with two movable cars and baskets, one of which is being filled while the other one is being pressed. These cars are usually arranged so that they can be rolled in between fermenting tanks and the pomace filled directly into them. After being filled they are rolled to the press for pressing.

The hydraulic press is the favorite with all of the wine makers where a dry wine is desired, but in the districts where grapes are cheap, the continuous presses are most commonly used. This type of press will extract 5 per cent to 10 per cent more juice from the grapes than the hydraulic press. This figure is given as a result of numerous tests taken at different wineries covering several years of time where both these types of machines have been in operation.

The juice from the continuous press is not so clear as that delivered by the hydraulic press. This is due to the friction of the screw on the pomace grinding some of the skins while pressing out the juice. There have been many different styles of continuous wine presses, each one having something that appealed to the man who made it, but up to the present moment none of them have entirely overcome the grinding up of the skins and the subsequently cloudy pressed wine.

The continuous press has one fault but many virtues, and with it the pressing of a season's pomace has lost its terrors to the wine maker. It was the continuous press that first caused the conveying systems to be installed to carry the fermented pomace from the tanks to the press.

The first system of conveyors used was built with chain and cleats in much the same manner as the grape elevators. These were placed in the runway between two rows of fermenting tanks and the pomace shoveled out of the tanks into these conveyors which discharged into the press. But as the diameter and height of the fermenting tanks increased, the tanks became too high to shovel over the top, so conveyors were placed under the tanks, and a hole cut through the bottom and the pomace delivered through this hole into the conveyors. Here another trouble was met, all the wine did not flow out as it was supposed to do when the hose was attached, but a large quantity remained in the pomace and as soon as the plug in the bottom was drawn out the rush of wine and pomace could not be stayed and it was soon found necessary to abandon the conveying system below the bottom of the tanks. 
The next step taken in an effort to empty these tanks was a pump which was a cross between a rotary and a centrifugal. A suction pipe of large diameter was placed between the two rows of tanks with an opening for every four tanks and a valve of the same diameter as the suction pipe was fastened on to the bottom of each tank and a piece of hose was connected between the valve and suction pipe. The pump was then started and the free juice and pomace were pumped out of the tank into the press. A smaller sized centrifugal pump returned the free juice to the same tank to keep the pomace well stirred up until the whole tank was emptied. With this system a tank holding 100 tons of grapes could be emptied in one hour's time.

This system also had many disadvantages. It was costly to operate, taking a lot of power and the volume was much too great for the presses, so that the pomace had to be again handled in the presses before it was finally disposed of.

The next method was to introduce a screw conveyor through a manhole in the side of the tank. This was run by the chain conveyor which carried the pomace to the presses when these conveyors were adjusted to the proper speed. Only one shoveling was necessary and very little of this was required, as the conveyor being placed very close to the bottom of the tank, nearly all of the pomace gravitated into it and only the last of the pomace at the bottom of the tank required handling.

To return again to the first operation, namely, crushing, some of our wineries are now arranged so that the railroad cars can run alongside the conveycrs, which are provided with self-feeders which deliver the right amount of grapes to the crusher and no more. The must pump delivers this through a piping system to the fermenting tanks, and after fermentation the conveyors take the pomace from the inside of the tanks and deliver it to the presses. After it is pressed, it is discharged on to another conveyor, which carries it away to the refuse pile, so that after the grapes are once picked from the vine they go through all these processes without ever being touched again.

The time allowed will not permit me to touch upon the other branches such as filtering, pasteurizing, racking, and pumping the wines, each of which has gone through as many styles of refinement as those before mentioned. But let me thank you for the kind attention, and beg for a little better understanding of the engineer, for without him none of these changes could have taken place. 


\title{
SOME RESULTS OF THE PRACTICAL APPLICATION OF SULFUROUS ACID AND SELECTED YEAST IN THE FERMENTATION OF CALIFORNIA WINES, 1913 AND 1914.
}

\author{
By W. V. CRUESS, \\ Division of Viticulture, University of California.
}

Most published data on the effect of sulfurous acid and pure yeast on the quality of wines deal with figures obtained under carefully controlled experimental conditions; very little information is available on the results obtained from their use by practical wine makers. For this reason the composition of wines from California cellars using sulfurous acid and pure yeast in fermentation has been compared with the composition of wines made in the same localities by the old method of "natural" fermentation. The analyses represent thirty-three different cellars and for that reason can probably be taken as being more or less representative of California conditions.

The methods in which the pure yeast and sulfurous acid were applied by the wine makers in the manufacture of the wines discussed in this paper may be described briefly as follows:

A quart bottle containing pure "Burgundy"1 wine yeast growing on agar must is sent by the Enology Laboratory to the wine maker applying for it. He fills the flask with sterile must. When this is in vigorous fermentation, it is used to inoculate two gallons of sterile must, and this, when in fermentation, is poured into 25-50 gallons of must, either sterilized previously by heating with steam, or previously treated with a small amount of sulfurous acid, settled and racked before adding the yeast. The larger lot of inoculated must is aerated and kept warm artificially till in active enough fermentation to be used to inoculate a tank of crushed grapes or white must.

The first tank of crushed grapes is treated at or immediately after crushing with 8-12 oz. potassium metabisulfite $\left(\mathrm{K}_{2} \mathrm{~S}_{2} \mathrm{O}_{5}\right)$ per ton. This amounts to approximately 275-412 milligrams metabisulfite per kilo or 137 to $206 \mathrm{mgms}$. $\mathrm{SO}_{2}$ per kilo, figuring $\mathrm{K}_{2} \mathrm{~S}_{2} \mathrm{O}_{5}$ at $50 \% \mathrm{SO}_{2}$. The sulfited grapes are allowed to stand a few hours (2-4) after crushing. The vat is then inoculated with the 25-50 gallons of yeast. When in fermentation, a portion of this vat is used to start the next vat of crushed and sulfited grapes. This process is repeated successively through the season. This is practically the method advised in Circular 119 of the University of California Station.2

Some of the more careful wine makers maintain a pure yeast apparatus from which each vat is inoculated. The method followed consists in replacing the liquid used from the first 50 gallons of yeast for inoculation by must previously treated with metabisulfite and cleared by settling 24 hours.

1The "Burgundy" yeast was sent the station several years ago by the Ecole Nationa'e d'Agriculture at Grignon, France. It has a high fermenting power and settles rapidly after fermentation.

2Circular 119, University of California Station, "Winery Directions," by Professor F. T. Bioletti. 
In the cellars where the wines were made in the old way by natural fermentation, the crushed grapes were allowed to ferment spontaneously. In some cases fermenting must from one vat was used to inoculate the next vat of crushed grapes, but neither selected yeast nor sulfurous acid was used.

No cooling of the must during fermentation was carried out in the manufacture of any of the wines under discussion.

The analyses were made in most cases of samples taken about the time of the first racking of the wines in December and January.

No notes were taken on the varieties of grapes used, the degree of ripeness in each instance, etc. Therefore, the determinations of most value in judging the relative quality of the wines produced are those which give us a measure of their soundness. These are primarily the volatile acid and sugar determinations. Tables $1,2,3$ and 4 give the volatile acid and sugar content of each sample, while Table 5 gives a general summary of the average general composition of all samples analyzed.

TABLE 1.

Volatile Acid, Sugar and Microscopical Appearance of California Dry Wines, 1913, Fermented with Pure Yeast and Sulfurous Acid.

\begin{tabular}{|c|c|c|c|c|c|}
\hline Dist & rict and & Color & $\begin{array}{l}\text { boratory } \\
\text { Number }\end{array}$ & $\begin{array}{l}\text { Volatile } \\
\text { Acid }\end{array}$ & Sugar \\
\hline Sonon & a Coun & y Red...... & 1076 & .040 & .130 \\
\hline “ & “ & “" & 1077 & .062 & .260 \\
\hline “ & “ & “ & 1089 & .078 & .190 \\
\hline “ & “ & “ & 1091 & .054 & .560 \\
\hline “ & “ & “ & 1092 & .084 & .190 \\
\hline “ & “ & “ & 1088 & .054 & .080 \\
\hline “ & “ & “" & $1017-1$ & .067 & .230 \\
\hline “ & “ & “ & -2 & .045 & .210 \\
\hline “ & “ & “ & -3 & .044 & . 180 \\
\hline “ & “ & “ & -4 & .044 & .200 \\
\hline “ & “ & “ & -5 & .043 & .170 \\
\hline “ & “ & “ & -6 & .043 & .270 \\
\hline “ & “، & “ & -7 & .048 & .160 \\
\hline “ & “" & " & -8 & .048 & .200 \\
\hline “ & “ & “ & -9 & .073 & .070 \\
\hline “ & “ & “ & 1022 & .040 & .220 \\
\hline “ & “ & $"$ & 1023-b & .050 & .140 \\
\hline “ & “ & “ & 1024-b & .041 & .290 \\
\hline “ & “ & “ & $1025-\mathrm{b}$ & .060 & .220 \\
\hline “ & “ & " & 1026-b & .070 & .380 \\
\hline “ & “ & “ & 1027-b & .040 & .250 \\
\hline “ & “ & “ & 1028-b & .062 & .800 \\
\hline “ & “ & “ & 1029-b & .080 & .640 \\
\hline “ & “ & “ & 1045 & .030 & .240 \\
\hline “ & “ & “ & 1046 & .080 & .240 \\
\hline “ & “ & White..... & 1022-a & .046 & .270 \\
\hline “ & “ & " & $1022-\mathrm{b}$ & .040 & .470 \\
\hline “ & “ & “ & $1023-a$ & .051 & .850 \\
\hline “ & “ & “ & $1023-c$ & .038 & .130 \\
\hline “ & “ & “ & 1024-a & .040 & .330 \\
\hline Napa & County & White...... & 1141 & .029 & .080 \\
\hline & “ & & 1148 & .036 & .050 \\
\hline " & “ & Red............ & 1143 & .054 & .050 \\
\hline “ & " & "I & 1144 & .026 & .100 \\
\hline “ & “" & “ & 1145 & .065 & .100 \\
\hline . & " & “ & 1147 & .088 & .079 \\
\hline
\end{tabular}

Microscopical

Examination

Yeast only

c6 is

68 of

66 66

a6 66

66 6

$66 \quad 66$

646

66 66

68 68

$66 \quad 68$

66

$66 \quad 66$

646

68

Y.\& a few Vinegar Bact.

"6 66 6s 66

16 16 68 68

Yeast only

66 c6

66

$66 \quad 66$

66 6

64

$66 \quad 66$

66

66 a

66

64

66

64

c6 6

es 6

$66 \quad 66$

Yeast and a few tourne 
TABLE 1-Continued.

\begin{tabular}{|c|c|c|c|c|c|c|c|c|c|}
\hline \multicolumn{4}{|c|}{ District and Color } & \multicolumn{2}{|c|}{ Laboratory } & \multicolumn{2}{|l|}{ Volatile } & \multicolumn{2}{|r|}{ Microscopical } \\
\hline Napa & Cour & & $\mathrm{Re}$ & d........... & 1148 & .049 & .080 & Yeast & only \\
\hline “ & “ & & " & & 1149 & .046 & .080 & " & " \\
\hline “ & “ & & “ & & 1150 & .040 & .050 & “ & “ \\
\hline “ & “ & & ، & & 1151 & .029 & .050 & “ & “ \\
\hline “ & “ & & “ & & 1152 & .048 & .050 & Yeast & \& a few bacteria \\
\hline “ & “ & & “ & & 1153 & .041 & .070 & Yeast & only \\
\hline “ & “ & & “ & & 1154 & .074 & .110 & “ & "“ \\
\hline Contr & $\mathrm{Cos}$ & & Co. & Red.. & 1174 & .060 & .180 & “ & “ \\
\hline “" & & & " & & 1175 & .090 & .280 & “ & “ \\
\hline “ & $\therefore$ & & “ & “ & 1176 & .050 & .450 & “ & “ \\
\hline “ & “ & & ، & “ & 1179 & .059 & .300 & “ & “ \\
\hline “ & “ & & “ & “ & 1180 & .075 & .220 & “ & “ \\
\hline “ & “ & & “ & “ & 1183 & .055 & .110 & “ & “ \\
\hline “ & “ & & “ & “ & 1214 & .070 & .136 & “ & “ \\
\hline “ & “ & & “ & “ & 1215 & .086 & .190 & “ & “ \\
\hline “ & “ & & “ & “ & 1216 & .090 & .122 & “ & “ \\
\hline “ & “ & & “ & “ & 1217 & .068 & .270 & “ & “ \\
\hline “ & “ & & “ & “ & 1219 & .068 & .156 & “ & “ \\
\hline “" & “ & & “ & “ & 1220 & .048 & .278 & “ & “ \\
\hline “ & “ & & “ & “ & 1221 & 086 & .080 & “ & “ \\
\hline “ & “ & & “. & “ & 1222 & .100 & .334 & Yeast & and a few tourne \\
\hline “ & “ & & 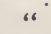 & “ & 1223 & .086 & .360 & Yeast & only \\
\hline “ & “ & & “ & “ & 1225 & .000 & .068 & Yeast & and a few tourne \\
\hline “ & “ & & “ & “ & 1226 & .102 & .136 & Yeast & only \\
\hline “6 & “ & & “ & “، & 1228 & .066 & .129 & “ & "، \\
\hline San I & Diego & Co & & d....... & 1118 & .050 & .070 & “ & “ \\
\hline & " & “ & " & & 1119 & .050 & .050 & “ & “ \\
\hline “ & “ & “ & “ & & 1120 & .048 & .070 & “ & “ \\
\hline “ & “ & ““ & “ & & 1121 & .041 & .060 & “" & “ \\
\hline “ & “ & “ & “ & & 1122 & .050 & .070 & “ & “ \\
\hline “ & “ & “ & “ & & 1123 & .048 & .060 & “ & “ \\
\hline “ & “ & “ & “ & & 1124 & .053 & .060 & “ & “ \\
\hline A & erag & . & 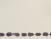 & 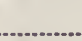 & & 058 & 148 & & \\
\hline
\end{tabular}

TABLE 2.

Wines Fermented Without Sulfurous Acid or Pure Yeast, 1913.

\begin{tabular}{|c|c|c|c|c|c|c|}
\hline \multicolumn{3}{|c|}{ Jistrict and Color } & Laboratory & \multicolumn{2}{|l|}{ Volatile } & $\begin{array}{l}\text { Microscopical } \\
\text { Examination }\end{array}$ \\
\hline & County & Red & 1056 & 213 & .320 & Many tourne bacteria \\
\hline Sonoma & ". & ned..... & $\begin{array}{l}1050 \\
1057\end{array}$ & .060 & $\begin{array}{l}.020 \\
.300\end{array}$ & Yeast only \\
\hline " & “ & “ & 1058 & .175 & .350 & Many tourne bacteria \\
\hline “. & “ & “ & 1059 & .044 & .240 & Yeast only \\
\hline “ & “ & “ & 1060 & .075 & .410 & Many tourne \\
\hline “ & “ & “ & 1061 & .180 & .350 & " \\
\hline “ & “ & “ & 1062 & .148 & .580 & “ \\
\hline “ & “ & “ & 1063 & .120 & .500 & “ \\
\hline “ & “ & “ & 1064 & .080 & .500 & Yeast and a few tourne \\
\hline “ & “ & “ & 1065 & .105 & .080 & Yeast and vinegar bact. \\
\hline “ & “ & “ & 1066 & .057 & .470 & Yeast and a few bact. \\
\hline “ & “ & “ & 1067 & .060 & .790 & Many bacteria \\
\hline “. & “ & “ & 1068 & .080 & .390 & A few bacteria \\
\hline “ & “ & “ & 1069 & .123 & .200 & Many bacteria \\
\hline “ & “ & “ & 1070 & .105 & .480 & “ \\
\hline “ & “ & “ & 1071 & .045 & .100 & Yeast only \\
\hline “. & “ & “ & 1078 & .155 & .370 & Many tourne bacteria \\
\hline “ & “ & “ & 1079 & .120 & .400 & “ \\
\hline
\end{tabular}


TABLE 2-Continued.

\begin{tabular}{|c|c|c|c|c|c|c|}
\hline \multicolumn{4}{|c|}{ District and Color } & $\begin{array}{l}\text { Laboratory } \\
\text { Number }\end{array}$ & $\begin{array}{l}\text { Volatile } \\
\text { Acid }\end{array}$ & \multirow{2}{*}{$\begin{array}{c}\text { Sugar } \\
.990\end{array}$} \\
\hline Sonoma & $\mathrm{Cou}$ & unty & Red...... & 1080 & .260 & \\
\hline “ & & & & 1081 & .290 & .440 \\
\hline “ & & “ & “ & 1082 & .210 & 1.170 \\
\hline “ & & “ & “ & 1083 & .166 & .310 \\
\hline “ & & “ & “ & 1021 & .260 & .270 \\
\hline “ & & “ & “ & $1024-\mathrm{c}$ & .136 & .400 \\
\hline “ & & “ & “ & 1025-a & .150 & .380 \\
\hline “ & & “ & “ & $1025-\mathrm{c}$ & .136 & .400 \\
\hline “ & & “ & “ & $1026-\mathrm{a}$ & .104 & \\
\hline “ & & “6 & “ & $1026-\mathrm{c}$ & .098 & .400 \\
\hline$"$ & & “ & “ & 1029-b & .100 & 1.000 \\
\hline “ & & “ & “ & 1032 & .092 & .540 \\
\hline “ & & “، & “ & 1033 & .050 & .270 \\
\hline “ & & ،: & “ & 1034 & .080 & .430 \\
\hline “ & & “ & “" & 1035 & .056 & .320 \\
\hline “ & & “ & “ & 1036 & .094 & .750 \\
\hline “ & & “ & “ & 1038 & .104 & .210 \\
\hline “ & & “ & “ & 1039 & .090 & .220 \\
\hline “ & & “ & “ & 1040 & .052 & .260 \\
\hline “ & & “ & “ & 1041 & .074 & .30 \\
\hline “ & & “ & “ & $1041-b$ & .060 & .230 \\
\hline “ & & “ & “ & 1042 & .100 & .310 \\
\hline “ & “ & “" & "s & 1043-a & .072 & .290 \\
\hline “ & & “ & “ & $1043-\mathrm{b}$ & .075 & .20 \\
\hline “ & & “ & “ & 1044 & .058 & .360 \\
\hline “ & & “ & “ & 1037. & .106 & .67 \\
\hline “ & & 47 & $=66$ & 1164-b & .130 & .540 \\
\hline “ & & “ & “ & $1165-\mathrm{b}$ & .160 、 & .51 \\
\hline “ & & 66 & “ & 1156 & .114 & .07 \\
\hline “ & & ac & “ & 1157 & .104 & .70 \\
\hline “ & & “، & “ & 1158 & .102 & .15 \\
\hline “ & & “6 & “ & 1159 & .130 & .06 \\
\hline “ & & “ & “ & 1160 & .098 & .09 \\
\hline “ & & “6 & “ & 1161 & .100 & $.14 \mathrm{C}$ \\
\hline “ & “ & s6 & $"$ & 1162 & .052 & .130 \\
\hline Santa & llara & Co. & Red..... & 1084 & .071 & .170 \\
\hline "s & & & s6 & 1085 & .140 & \\
\hline “ & " & “ & “ & $1107-a$ & .060 & .070 \\
\hline “ & “ & “ & “ & $1107 \cdot b$ & .118 & .250 \\
\hline “ & " & $" 6$ & $" 6$ & $1107-c$ & .070 & .130 \\
\hline Sacram & ento & Co. & Red..... & $1027-a$ & .180 & 3.300 \\
\hline 48 & & “ & " & $1028-a$ & .185 & 1.080 \\
\hline “ & & “ & “ & $1029-a$ & .170 & .760 \\
\hline “ & & “ & “ & $1030-\mathbf{a}$ & .230 & 1.590 \\
\hline “ & & “ & $=6$ & $1257-1$ & .160 & 1.440 \\
\hline “ & & “ & $" ،$ & $1257-2$ & .144 & .490 \\
\hline “ & & “ & “ & $1257-3$ & .130 & .180 \\
\hline “ & & “ & “ & $1257-4$ & .134 & .950 \\
\hline “ & & “ & “ & $1257-5$ & .130 & .190 \\
\hline “ & & $"$ & “ & $1257-6$ & .134 & .590 \\
\hline “ & & “ & “ & $1257-7$ & .139 & .190 \\
\hline “ & & “ & “ & 1257- 8 & .204 & .330 \\
\hline “ & & “ & “ & $1257-9$ & .160 & .400 \\
\hline “ & & “ & “ & $1257-10$ & .154 & .980 \\
\hline “ & & “ & “ & $1257-11$ & .171 & .110 \\
\hline “ & & “ & “ & $1257-12$ & .154 & .980 \\
\hline “ & & “ & “ & $1257-13$ & .154 & .410 \\
\hline “ & & “ & “ & $1257-14$ & .070 & .180 \\
\hline “ & & “ & “ & $1257-15$ & .066 & \\
\hline
\end{tabular}

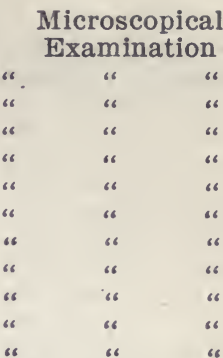

A few tourne bacteria Many tourne bacteria

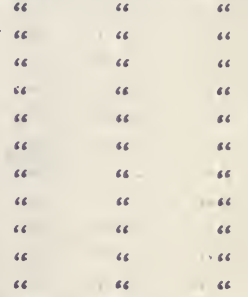

A few tourne

Many tourne bacteria

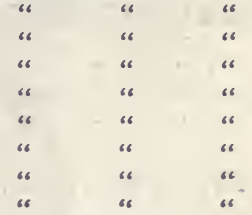

Yeast only

A few bacteria

Many tourne bacteria A few tourne bacteria Many tourne bacteria

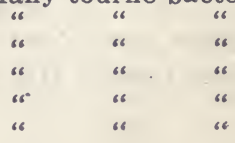


TABLE 2-Continued.

\begin{tabular}{|c|c|c|c|c|c|c|c|c|}
\hline \multicolumn{4}{|c|}{ District and Color } & $\begin{array}{l}\text { boratory } \\
\text { lumber }\end{array}$ & Volatile & Sugar & \multicolumn{2}{|c|}{ Microscopical } \\
\hline Sacr & ramento & Co. & Red...... & $1257-16$ & .080 & ........ & & \\
\hline & " & $" 6$ & "6 & $1257-17$ & .082 & ....... & & \\
\hline & “ & “" & “ & $1257-18$ & .066 & -.... & & \\
\hline & “ & “ & “ & $1257-19$ & .050 & .160 & & \\
\hline & “ & “ & “ & $1257-20$ & .044 & .200 & & \\
\hline & “ & “ & “ & $1257-21$ & .045 & ....... & & \\
\hline & “ & “" & “ & $1257-22$ & .048 & & & \\
\hline & “ & “ & “ & $1257-23$ & .058 & .150 & & \\
\hline & “ & “ & “ & $1257-24$ & .084 & 1.670 & & \\
\hline & “ & “ & “ & $1257-25$ & .149 & 2.950 & & \\
\hline & “ & “ & “. & $1257-26$ & .141 & 1.930 & & \\
\hline & “ & “ & “ & $1257-28$ & .066 & 1.930 & & \\
\hline & “ & “ & “ & $1257-29$ & .129 & 3.020 & & \\
\hline & “ & “ & “ & $1257-30$ & .147 & 2.490 & & \\
\hline & “ & “ & “ & $1257-31$ & .065 & .90 & & \\
\hline & “ & “ & “ & $1257-32$ & .095 & 1.130 & & \\
\hline & “ & “ & “ & $1257-33$ & .088 & .710 & & \\
\hline & “ & “ & “ & $1257-34$ & .082 & .710 & & \\
\hline & “ & “ & White & $1257-35$ & .153 & . 120 & & * \\
\hline & “ & “ & "“ & $1257-36$ & .120 & .150 & & \\
\hline & “ & “ & “ & $1257-37$ & .129 & .420 & & \\
\hline & “ & “ & “ & $1257-38$ & .210 & .140 & & \\
\hline & “ & “ & “ & 1257-39 & .140 & .120 & & \\
\hline & “ & “ & “ & $1257-40$ & .059 & ....... & & \\
\hline & " & “ & “ & $1257-41$ & .087 & ........ & & \\
\hline & “ & “ & “ & $1257-42$ & .068 & 皮 & & \\
\hline San & Joaquin & Co. & Red.... & 1165 & .084 & .050 & Many & tourne \\
\hline & " & “ & $"$ & 1164-a & .134 & .150 & “ & “ \\
\hline “ & “ & $" 6$ & “ & 1165-a & .156 & .150 & $"$ & “ \\
\hline “ & “ & “ & White & 1166 & .130 & .110 & “ & “ \\
\hline “ & “ & “ & & 1167 & .145 & .090 & “ & “" \\
\hline & Average. & ............. & -..-..... & ..... & .114 & .550 & & \\
\hline
\end{tabular}

TABLE 3.

Wines Fermented With Sulphurous Acid and Pure Yeast, 1914.

\begin{tabular}{|c|c|c|c|c|c|c|c|}
\hline \multicolumn{3}{|c|}{ District and Color } & $\begin{array}{c}\text { Laboratory } \\
\text { Number }\end{array}$ & \multicolumn{2}{|l|}{ Volatile } & \multicolumn{2}{|c|}{ Microscopical } \\
\hline Sonoma & County & Red & ...... 1418- 5 & .064 & .400 & Yeast & only \\
\hline “ & "6 & & 1418- 6 & .055 & .350 & “ & " \\
\hline “ & “ & “ & $1418-7$ & .067 & .460 & “ & “ \\
\hline “ & “ & “ & $1418-8$ & .065 & .360 & “ & “ \\
\hline “ & “ & “ & 1418- 9 & .054 & .340 & “ & “ \\
\hline “ & “ & “ & $1418-10$ & .033 & .200 & “ & “ \\
\hline “ & “ & “ & $1418-11$ & .048 & .280 & “ & “ \\
\hline “ & “ & “ & $1418-12$ & .049 & .200 & “ & “ \\
\hline “ & “ & “ & $1418-13$ & .047 & .390 & “ & “ \\
\hline “ & “ & “ & $1418-14$ & .072 & .700 & Yeast & and a few tourne \\
\hline “ & “ & “ & $1418-15$ & .046 & .750 & Yeast & only \\
\hline “ & “ & “ & $1418-16$ & .047 & .320 & “ & $" 6$ \\
\hline “ & “ & “ & $1418-17$ & .042 & .200 & “ & “ \\
\hline “" & “" & “ & $1418-18$ & .041 & .260 & “ & “ \\
\hline “ & “ & $“$ & $1418-20$ & .041 & .380 & “ & “ \\
\hline “ & “ & “ & $1418-22$ & .074 & .210 & “ & “ \\
\hline “ & “ & “ & $1418-23$ & .038 & .260 & “ & “ \\
\hline “ & “ & “ & $1418-24$ & .044 & .380 & “ & “ \\
\hline
\end{tabular}


TABLE 3-Continued.

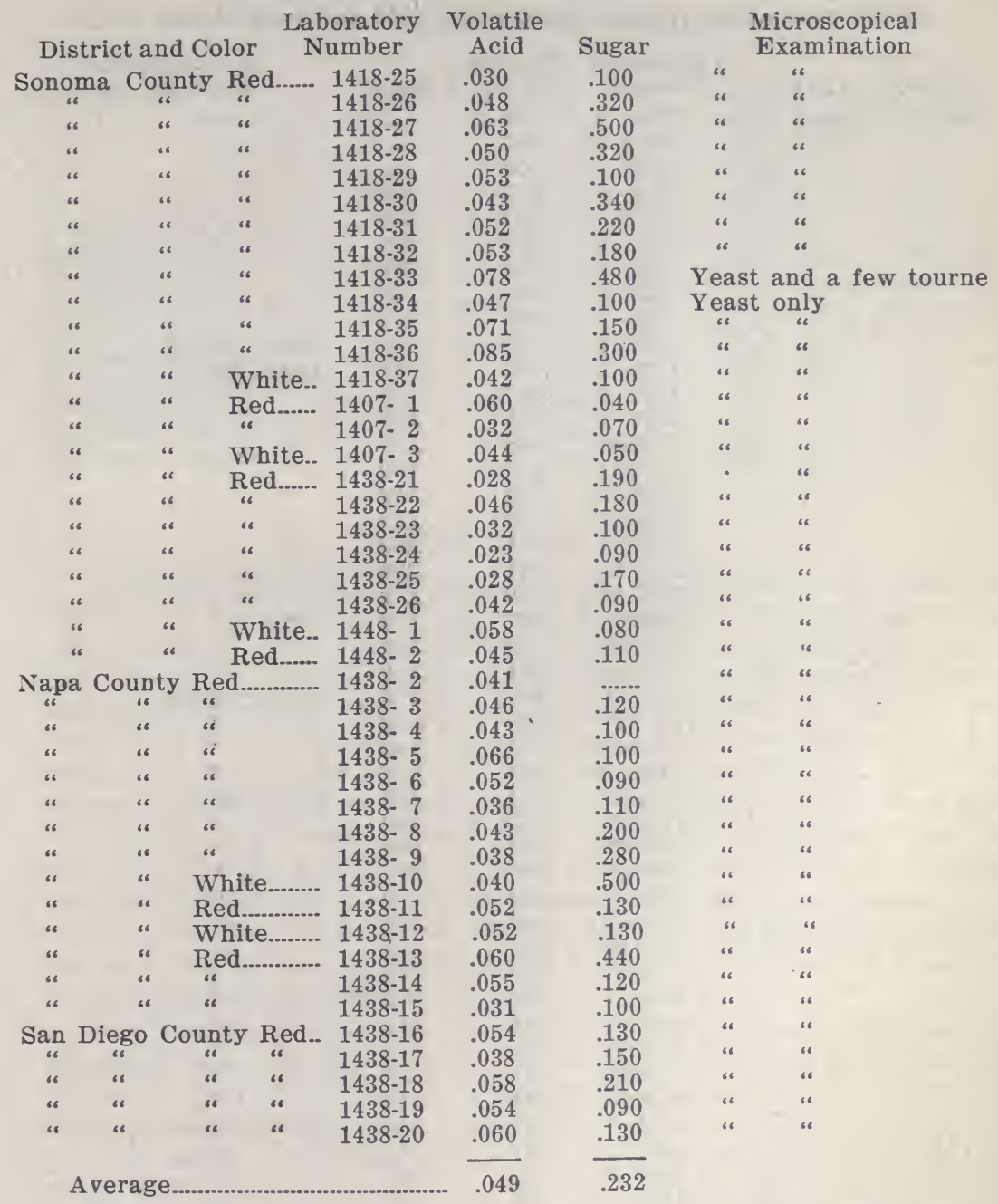


TABLE 4.

Wines Fermented Without Sulphurous Acid and Pure Yeast, 1914.

\begin{tabular}{|c|c|c|c|c|c|c|c|}
\hline \multicolumn{3}{|c|}{ District and Color } & $\begin{array}{l}\text { Laboratory } \\
\text { Number }\end{array}$ & $\begin{array}{l}\text { Volatile } \\
\text { Acid }\end{array}$ & Sugar & \multicolumn{2}{|r|}{ Microscopical } \\
\hline Sonoma & County & Red...... & $\begin{array}{l}1393-2 \\
1393-3\end{array}$ & $\begin{array}{l}.043 \\
.053\end{array}$ & ...... & Yeast & t only \\
\hline “ & “ & “ & $\begin{array}{l}1393-3 \\
1393-4\end{array}$ & .052 & & “ & “ \\
\hline “ & “ & “ & $1418-4$ & .075 & .570 & “ & “ \\
\hline “ & “ & “ & $1425 \cdot 1$ & .047 & .200 & “ & “ \\
\hline “" & “" & “ & 1425- 2 & .063 & .240 & “ & “ \\
\hline “ & “ & “ & $1425-3$ & .058 & .350 & “ & “ \\
\hline “ & “ & “ & $1425-4$ & .081 & .190 & “ & “ \\
\hline " & “ & “ & $1425-5$ & .050 & .210 & “ & “ \\
\hline “ & “ & “ & $1425 \cdot 6$ & .097 & .140 & Many & tourne \\
\hline “ & “ & “ & $1425-7$ & .037 & .100 & Yeast & t only \\
\hline “ & “" & " & 1425- 8 & .048 & .160 & “ & " \\
\hline “ & “ & “ & 1425- 9 & .064 & .240 & “ & “ \\
\hline “ & “ & “ & $1425-10$ & .065 & .170 & “ & “ \\
\hline “ & “ & “ & $1425-11$ & .056 & .100 & “ & “ \\
\hline “" & “ & “ & 1425-12 & .063 & .160 & " & “ \\
\hline “. & “ & “ & $1425-13$ & .051 & .170 & “ & “ \\
\hline “ & " & “ & $1425-14$ & .071 & .290 & “ & “ \\
\hline “ & “ & " & 1425-15 & .041 & .270 & “ & “ \\
\hline “" & “ & “ & $1425-16$ & .058 & .170 & “ & “ \\
\hline “ & “ & “ & $1425-17$ & .067 & .170 & " & “ \\
\hline “" & “ & “ & 1425-18 & .070 & .190 & " & “ \\
\hline “ & " & “ & 1425-19 & .064 & .200 & “ & “ \\
\hline “ & “ & $“$ & $1425-20$ & .100 & .370 & Many & tourne \\
\hline “ & “ & “ & $1425-21$ & .103 & .550 & “ & " \\
\hline “ & “ & “ & $1425-22$ & .274 & .160 & " & “ \\
\hline “ & “ & “ & 1448- 3 & .181 & .080 & “ & “ \\
\hline “ & “ & “ & $1438-27$ & .074 & .100 & Yeast & only \\
\hline " & “ & " & $1438-28$ & .053 & .090 & “ & " \\
\hline “ & “ & " & 1438-29 & .052 & .090 & “ & “ \\
\hline “ & “ & “ & 1438-30 & .070 & .100 & “ & " \\
\hline “ & " & " & 1438-31 & .050 & .100 & “ & “ \\
\hline “ & “ & “ & $1438-32$ & .040 & .090 & “ & “" \\
\hline “ & “ & “ & 1438-33 & .061 & .140 & “ & “ \\
\hline “ & “ & $"$ & 1438-34 & .047 & .140 & “ & “ \\
\hline “ & “ & “ & $1438-35$ & .038 & .100 & “ & “" \\
\hline " & “ & “ & 1438-36 & .044 & .080 & “ & “ \\
\hline “ & “ & “ & 1438-37 & .046 & .100 & “ & “ \\
\hline “ & " & “ & 1438-38 & .048 & .130 & “ & “" \\
\hline “ & “" & “ & 1438-39 & .044 & .110 & “ & “ \\
\hline " & " & “ & $1502-1$ & .163 & .540 & Many & tourne \\
\hline “ & “ & “ & $1502-2$ & .112 & .540 & " & “ \\
\hline “ & " & “ & 1502- 3 & .167 & .580 & “ & “ \\
\hline “ & “ & $"$ & 1502- 4 & .158 & .460 & “ & “ \\
\hline “ & “ & " & $1502-5$ & .157 & .310 & “ & “ \\
\hline San Joaq & quin Co. & Red...... & 1438- 1 & .170 & .710 & “ & “ \\
\hline " & “ & “ & $1452-1$ & .082 & .200 & “ & “ \\
\hline$"$ & “ & $"$ & 1452- 2 & .364 & 4.500 & $"$ & " \\
\hline “" & $"$ & “ & 1452- 3 & .537 & $\ldots . .$. & " & “" \\
\hline " & “ & " & $1452 \cdot 4$ & .309 & ...... & “" & “" \\
\hline Aver & age............. & . & & .098 & .326 & & \\
\hline
\end{tabular}


TABLE 5.

\section{Summary of Analyses 1913 and 1914 Wines.}

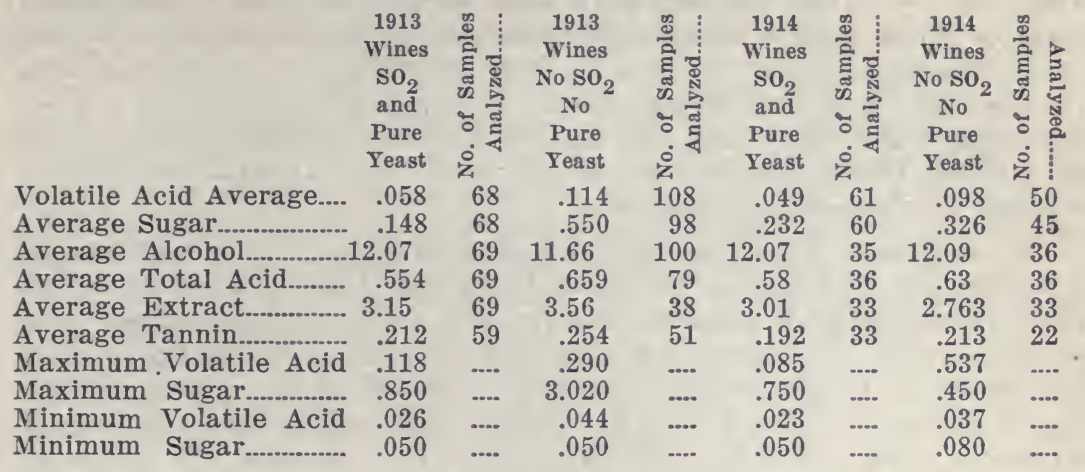

\section{Discussion of 1913 Wines.}

The year 1913 was marked by very hot weather during the fermenting scason. For this reason practically every fermentation rose to a high degree, $100^{\circ}$ to $105^{\circ} \mathrm{F}$. being very common temperatures in the fermenting vats. This, of course, caused a great deal of "sticking" of fermentations and in making conditions favorable for the growth of acid forming bacteria. Fermentations that were made with pure yeast and $\mathrm{SO}_{2}$ reached just as high temperatures as did the "natural" fermentations. The important differences between the two were, however, that the wines fermenting with pure yeast after treatment of crushed grapes with sulfurous acid, did not "stick" with unfermented sugar and did not increase in volatile acid, while the naturally fermented wines "stuck" in many instances and still more commonly developed very high volatile acid. These facts are distinctly brought out in the individual analyses of Tables 1 and. 2 and in the averages of sugar and volatile acid determinations in Table 5.

The average volatile acid for the wines fermented with sulfurous acid and pure yeast was .058 per cent; for the naturally fermented wines, .114 per cent. None of the wines in which $\mathrm{SO}_{2}$ and pure yeast were used were above the commercial limit of .120 per cent (for white wines) or .140 per cent (for red wines). Forty-nine out of 108 samples of the naturally fermented wines were above .120 per cent and 30 out of 108 were above .140 per cent. That is to say, almost 30 per cent of the naturally fermented wines "spoiled" as judged by present commercial standards. On the other hand, the wines made by the improved methods were all well below the limits set for volatile acid, the maximum being .118 per cent, and only four out of 68 were above .09 per cent volatile acid. The average (.058). was far below this figure.

The unfermented sugar in the wines made by the two methods compare in about the same way as do the volatile acid contents. The naturally fermented wines were much higher, on the average, in unfermented sugar than the wines from the same districts made by pure yeast and $\mathrm{SO}_{2}$. The average of .55 per cent of the naturally fermented wines is considerably above the safety limit of .25 per cent for dry wines; that of .148 per cent for the pure 
yeast wines shows complete fermentation. Forty-five out of a total of 98 naturally fermented 1913 wines were above .4 per cent; 7 out of 68 of wines made with $\mathrm{SO}_{2}$ and pure yeast were above .4 per cent. Unfermented sugar is not so good a criterion for judgment of the soundness of a wine as is volatile acid, but is valuable when considered in connection with volatile acid. That may be made plain by examples. A wine with .125 per cent volatile acid and .5 per cent sugar is decidedly unsound; but one with .05 per cent volatile acid and .5 per cent sugar can be gotten dry and can be made into a perfectly sound wine.

A comparison of the miscroscopical examinations of the various samples is instructive. The "tourne" or "lactic bacterium" found in many California wines is an anaerobic organism and the one which probably causes more spoilage than all other organisms combined. It is no doubt identical with or very similar to the bacterium of "tourne" of French wines or the Bacterium Maanitopoeum described by Peltier.3 Wines with high volatile acid and unfermented sugar and badly infected with "tourne" bacteria will almost inevitably spoil completely unless something radical is done to stop the bacterial action.

Fifty-four out of 66 naturally fermented wines examined were badly attacked by tourne bacteria; several more contained smaller numbers, leaving only a very few not visibly infected at the time of analysis. Only 7 out of 68 of the wines made by the improved method showed any tourne bacteria and these exhibited only small numbers.

\section{Comparison 1914 Wines.}

The 1914 fermenting season was very cool and hot fermentations were less common than in 1913. Since hot fermentations cause most "stuck" wines with their attendant high volatile acid and bacterial content, we should therefore expect to find less marked difference in the qualities of the 1914 wines than in the case of the 1913 wines. This is found to be true as an examination of Tables 3 and 4 will show.

Thirteen out of a total of 61 naturally fermented 1914 wines were above .10 per cent volatile acid and 10 were above the commercial limit of .10 per cent. Of the wines made with $\mathrm{SO}_{2}$ and pure yeast none were above .10 per cent and all were very much below .140 per cent. The average in the two cases were .049 per cent and .098 per cent respectively.

Of the naturally fermented wines, 8 out of 45 contained more than .4 per cent sugar. Of those fermented with pure yeast and $\mathrm{SO}_{2}, 8$ out of a total of 60 contained more than .4 per cent sugar.

Microscopical examination showed 15 out of a total of 50 naturally fermented wines to be badly attacked by "tourne" bacteria. The wines fermented with pure yeast and $\mathrm{SO}_{2}$ did not exhibit large numbers of tourne bacteria in any case and in only two instances were any found.4

On the whole, the difference in quality between the wines made by the two methods in 1914 is not so great as in 1913, but is nevertheless distinct

3See Revue de Viticulture, vol. 40, pp. 161-167.

4The microscopical examinations were all made on the non-centrifuged sample; a wine showing large numbers of "tourne" bacteria by this method was considered badly infected. 
and well marked. The averages of .098 volatile acid for the naturally fermented wines and .049 for those made with $\mathrm{SO}_{2}$ and pure yeast prove this statement.

\section{Summary.}

1. The wines made in 1913 with $\mathrm{SO}_{2}$ and pure yeast were very much lower in volatile acid and unfermented sugar and contained a much smaller number of "tourne" bacteria than wines from the same district made in the usual way by natural fermentation. T'he 1913 season was very warm; therefore, the results demonstrate the efficacy of pure yeast and $\mathrm{SO}_{2}$ in producing sound wines under adverse high temperature conditions.

2. The 1914 wines showed less difference in quality and composition, but what difference there was lay definitely in favor of the wines made with $\mathrm{SO}_{2}$ and pure yeast. The 1914 season was very cool and most favorable for sound natural fermentations. The fact that the wines made by the improved methods were superior to the naturally fermented wines demonstrates that the use of $\mathrm{SO}_{2}$ and pure yeast gives better results (on the average) than natural fermentations even under favorable conditions of temperature.

\section{Conclusions.}

1. The quality and soundness of wines made in the ordinary commercial cellars can be raised very materially by the use of $\mathrm{SO}_{2}$ and pure yeast.

2. Special technical knowledge is not necessary for their use and they can be applied by the average wine maker.

\section{A SIMPLE AND RAPID METHOD FOR THE ESTIMATION OF VOLATILE ACID IN WINE.}

By PROF. W. V. CRUESS, University of California, Berkeley, Cal.,

and

R. W. BETTOLI, San Francisco, Cal.

Most of the methods for volatile acid estimation in wine require rather complicated apparatus for the distillation of the volatile acid so that the ordinary wine maker or wine buyer does not feel inclined to master the intricacies of the process in order that he might use it himself. It is the most important chemical determination to be made in judging the soundness of wine and is a great aid in deciding how to handle certain wines during aging. Therefore, any simplification of present methods of making this test would be very desirable.

In the official method a 50 c. c. sample of wine is distilled in a current of steam till 250 c. c. of distillate is collected. This distillate is titrated 
with tenth normal alkali using phenolphthalein as an indicator. The equivalent in terms of acetic acid is then calculated from the c. c. of N/10 of alkali used; 1 c. c. being equal to .006 gms. acetic acid. A method in use in the laboratory of the Italian Swiss Colony and the California Wine Association laboratory depends on distilling a 50 or 60 c. c. sample of wine directly without steam distillation and as the distillation progresses, the liquid distilled off is replaced by distilled water which is allowed to drop slowly into the distillation flask at about the rate the wine distills over, 250-300 c. c of distillate is collected and titrated as in the official method. This apparatus has the advantage of compactness and convenience. Probably, in effect, this may be a steam distillation because as soon as the alcohol of the wine is volatized, the extract of the wine raises the boiling point above that of distilled water. As the drops of distilled water meet this relatively high boiling liquid the water is vaporized and causes bubbles of steam to escape through the liquid and in this way carry over the acetic acid, which boils above $100^{\circ} \mathrm{C}$.

The simplified method to be discussed in this paper is not a strictly new idea but an improvement on an old one. The method is essentially one of estimating the total acid in the untreated wine; then in the wine after driving off the acetic acid and in calculating the volatile acid by difference. Directions for making the test in this way recommend taking a small sample and evaporating to a syrupy consistency several times on the water bath, diluting and titrating with $\mathrm{N} / 10$ alkali. The difference between this and the total acid of the untreated wine represents loss due to volatile acid; taking into account, of course, that total acid is calculated as tartaric and volatile acid as acetic. This method is slow, requires the use of a water bath, and experience has shown it to be inaccurate, especially for red wines, where the color interferes with the titration.

\section{The Method.}

In the modification of this method a 75 c. c. sample, more or less, of the wine is decolorized with bone black free from carbonates. "Eponit," a pure form of vegetable charcoal freed from carbonates and in use in France for commercial decolorization of wines gave the best results. Impure bone black is worse than useless and cannot be used for this volatile acid test. The decolorized wine is filtered and should be water white. A 20 c. c. sample is titrated, using phenolphtholein indicator, and the c. c. of $\mathrm{N} / 10$ alkali used recorded. Call this "a". Then 20 c.c. is taken and mixed with approximately 2 gms. common salt NaCL in a 200 c. c. Erlenmeyer flask. The liquid is boiled down rapidly on a gas flame or alcohol flame until a copious separation of NaCL takes place and the wine begins to spatter. This gives an unmistakable point at which to stop. To the flask is now added 20 c. c. distilled water and boiling repeated till NaCL separates again. The liquid is diluted with distilled water and titrated with $\mathrm{N} / 10$ alkali using phenolphtholein indicator. C. c. used are recorded. Call this figure " $b$ ". Then

(a-b) $\times .03=$ volatile acid gms. per 100 c. c.

The factor .03 comes from a consideration of the following facts:

1 c. c. $\mathrm{N} / 10$ alkali $=.006$ gms. acetic acid. If a 60 c. c. sample were c.c alkali $\times .006$

used the factor would be .01 because $\times 100$ becomes c. c. 
alkali $\times .01$ in calculating the gms. of acetic acid per 100 c. c. wine. Since our sample is $1 / 3 \times 60=20$ c. c. the factor is 3 times as large or .03 .

Samples were analyzed in the laboratory of the Italian Swiss Colony for volatile acid using 50 c. c. samples, distilling to 250 c. c. by the distilled water dropping method described above. The samples were analyzed as soon as possible thereafter in the Enology Laboratory of the University of California, Berkeley, by the NaCL evaporation method. Results were then compared. The figures obtained are given in the following table.

\begin{tabular}{|c|c|c|c|c|c|c|c|}
\hline $\begin{array}{l}\text { Sample } \\
\text { Number }\end{array}$ & $\begin{array}{c}\text { Volatile } \\
\text { Acid by } \\
\text { Distillation } \\
\%\end{array}$ & $\begin{array}{c}\text { Volatile } \\
\text { Acid by } \\
\text { NaCL Mfethod } \\
\%\end{array}$ & $\begin{array}{c}\text { Differ- } \\
\text { ence }\end{array}$ & $\begin{array}{l}\text { Sample } \\
\text { Number }\end{array}$ & $\begin{array}{c}\text { Volatile } \\
\text { Acid by } \\
\text { Distillation } \\
\%\end{array}$ & $\begin{array}{c}\text { Volatile } \\
\text { Acid by } \\
\text { NaCL M Method } \\
\%\end{array}$ & $\begin{array}{c}\text { Differ- } \\
\text { ence }\end{array}$ \\
\hline 1 & .100 & .093 & -.007 & 40 & .044 & .048 & .004 \\
\hline 2 & .101 & .075 & -.026 & 41 & .043 & .054 & .011 \\
\hline 3 & .108 & .111 & .003 & 42 & .043 & .054 & .011 \\
\hline 4 & .099 & .105 & .006 & 43 & .043 & .039 & -.004 \\
\hline 5 & .084 & .081 & -.003 & 44 & .055 & .051 & -.004 \\
\hline 6 & .075 & .084 & .009 & 45 & .068 & .072 & .004 \\
\hline 7 & .091 & .096 & .005 & 46 & .056 & .060 & .004 \\
\hline 8 & .060 & .063 & .003 & 47 & .054 & .059 & .015 . \\
\hline 9 & .113 & .114 & .001 & 48 & .054 & .057 & $.003^{\circ}$ \\
\hline 10 & .076 & .081 & .005 & 48 & .062 & .057 & -.005 \\
\hline 11 & .096 & .099 & .003 & 49 & .080 & .102 & .022 \\
\hline 12 & .096 & .093 & -.003 & 50 & .088 & .099 & .011 \\
\hline 13 & .095 & .087 & -.008 & 51 & .074 & .084 & .010 \\
\hline 14 & .103 & .102 & -.001 & 52 & .174 & .192 & .018 \\
\hline 15 & .097 & .104 & .007 & 53 & .018 & .075 & -.003 \\
\hline 16 & .090 & .084 & -.006 & 54 & .063 & .066 & .003 \\
\hline 17 & .081 & .087 & .006 & 55 & .089 & .091 & .002 \\
\hline 18 & .090 & .099 & .009 & 56 & .070 & .078 & .008 \\
\hline 19 & .114 & .108 & -.006 & 57 & .095 & .093 & -.003 \\
\hline 20 & .085 & .084 & -.001 & 58 & .083 & .082 & -.001 \\
\hline 21 & .148 & .135 & -.013 & 59 & .089 & .084 & .005 \\
\hline 22 & .161 & .159 & -.002 & 60 & .082 & .078 & -.004 \\
\hline 23 & .174 & .165 & -.009 & 61 & .092 & .084 & -.008 \\
\hline 24 & .059 & .041 & -.018 & 62 & .095 & .090 & -.005 \\
\hline 25 & .099 & .102 & .003 & 63 & .087 & .087 & .000 \\
\hline 26 & .055 & .042 & -.013 & 64 & .046 & .054 & .008 \\
\hline 27 & .069 & .072 & -.003 & 65 & .053 & .048 & -.005 \\
\hline 28 & .066 & .066 & .000 & 66 & .101 & .102 & .001 \\
\hline 29 & .055 & .060 & .005 & 67 & .098 & .103 & .005 \\
\hline 30 & .072 & .084 & .012 & 68 & .101 & .100 & -.001 \\
\hline 31 & .051 & .051 & .000 & 69 & .091 & .081 & -.010 \\
\hline 32 & .039 & .042 & .003 & 70 & .071 & .078 & .007 \\
\hline 33 & .049 & .048 & -.001 & 71 & .085 & .084 & -.001 \\
\hline 34 & .040 & .045 & .005 & 72 & .070 & .075 & .005 \\
\hline 35 & .044 & .045 & .001 & 73 & .152 & .141 & -.011 \\
\hline 36 & .055 & .057 & .002 & 74 & .084 & .087 & .003 \\
\hline 39 & .040 & .054 & .014 & 75 & .091 & .087 & -.004 \\
\hline 37 & .042 & .042 & .000 & 76 & .097 & .099 & .002 \\
\hline 38 & .045 & .054 & .009 & & & & \\
\hline
\end{tabular}

\section{Effect of Number of Evaporations.}

A red wine was analyzed by the distillation method for volatile acid. This same wine was then decolorized with Eponit (pure vegetable charcoal for wine makers' use) and filtered. 0 gms. NaCL; $2 \mathrm{gms}$. NaCL; and $5 \mathrm{gms}$. NaCL were used respectively. The samples were evaporated until NaCL separated when NaCL was used and down to 3-4 c. c. where no NaCL was 
used. Cne evaporation and two evaporations were carried out and the loss in acid determined. Where no NaCL was used, there was a tendency for the extract to darken and make titration difficult; where NaCL was used no such difficulty was met.

\begin{tabular}{|c|c|c|c|}
\hline & Gms. of $\mathrm{NaCL}$ & Volatile & Volatile \\
\hline Volatile & used in NaCL & Acid by & Acid by \\
\hline Distillation & $\begin{array}{l}\text { Method for } \\
20 \text { c. c. Wine }\end{array}$ & Evaporation & Evaporations \\
\hline .089 & 0 & .048 & .087 \\
\hline .089 & 2 & .073 & .090 \\
\hline .089 & 5 & .048 & .072 \\
\hline
\end{tabular}

In general, the agreement between the two methods was satisfactory. Better agreement was found with samples containing small amounts of volatile acid than large amounts.

\section{Effect of NaCL Concentration.}

To 20 c. c. samples of decolorized wine were added 1, 2, 5, $10 \mathrm{gms}$. $\mathrm{NaCl}$ respectively and the solutions evaporated twice till $\mathrm{NaCl}$ separated. The samples were diluted and titrated. 1 and 2 grams gave about the same results. 5 and 10 grams gave too low results. This is because the large amounts of $\mathrm{NaCl}$ super-saturate the liquid more quickly as the wine is concentrated and give too short a time for the expulsion of the volatile acid. The smaller amounts increase in concentration more gradually as the volume decreases during boiling. The boiling point is increased and this increased boiling point drives out the acetic acid more effectively than is possible with wine to which no $\mathrm{NaCl}$ is added.

The $\mathrm{NaCl}$ serves as an indicator for the point at which to stop boiling and is useful in this way.

It also checks charring of the sample caused by evaporating too far; the protective action in this respect is very marked.

The figures show that two evaporations are necessary with 2 gms. NaCL and that two evaporations with $5 \mathrm{gms}$. NaCL gives low results.

The method and apparatus needed are simple as the following list of reagents and apparatus necessary and outline of method will indicate:

Apparatus: (1) Gas or alcohol burner; (2) wire gauze for burner; (3) several 200 c. c. Erlenmeyer flasks; (4) two 20 c. c. pipettes; (5) glass funnel, 3-inch; (6) filter paper for funnel; (7) 50 c.c. burette graduated to $1 / 10$ c. c.; (8) burette stand.

Reagents: (1) N/10 alkali; (2) phenolphthalein indicator solution; (3) pure bone black as free from mineral salts as it can be made or pure vegetable charcoal free from mineral salts.

Summary of Methods:

1. Decolorize about 75 c. c. of the sample with bone black or vegetable charcoal free from carbonates. Filter.

2. Titrate 20 c. c. with $\mathrm{N} / 10$ alkali; record c. c. "a"; the titration is made directly in the flask itself; no breaker is necessary.

3. To 20 c. c. add approximately 2 gms. NaCL. Evaporate 200 c. c. Erlenmeyer till NaCL separates and liquid spatters slightly.

4. Add 20 c. c. distilled water and evaporate again till NaCL separates.

5. Add distilled water and titrate. Record c. c. as "b".

6. $(\mathrm{a}-\mathrm{b}) \times .03=\%$ volatile acid. 


\title{
Summary.
}

The volatile acid determination for wines may be determined rapidly and accurately enough for cellar manipulation or buying of wines, by the method described above. The method is simple and the apparatus needed is not expensive or complicated.

(From the Enology Laboratory, University of California, Berkeley, and the Chemical Laboratory of the Italian Swiss Colony, San Francisco, Cal.)

\section{INFLUENCE OF COMPOSITION ON EFFERVESCENCE OF CHAMPAGNE. PRELIMINARY INVESTIGATIONS.}

\author{
R. W. BETTOLI AND J. LA BELLE,
}

Laboratory of Italian-Swiss Colony, San Francisco, Cal.

The effervescence of the gas or "sparkle" is one of the points considered in judging champagnes. The ordinary procedure, as we understand it, is as follows: The various champagnes are poured into separate glasses and closely watched to note the rate and duration of effervescence. The judges then decide which wine has the most life, sparkle and mousse. This method is obviously open to criticism, as it is subject to many sources of error, so much depends on the method of opening the bottle, the pouring of the wine, the cleanliness of the glasses and the close observation of the judges. Furthelmore, the bottles should all be opened at the same time, but when there are many sparkling wines to judge, the wines must be divided into lots which are tested at different times. The results obtained are merely comparative within the lot under consideration, it being a difficult matter to remember the precise action of any bottle of a previous lot. At best, the results are of little scientific value, because they cannot be compared with similar tests conducted by other men.

It is of value to the wine man to know definitely the action of his champagne or sparkling wine on the table of the consumer. He is also concerned in the uniformity of his product. In order to obtain definite and at all times comparable results, we adapted a Lunge's gasvolumeter to accurately measure the rate of gas effervescence.

This apparatus consists of a burette (D), a compensating tube (E), and a leveling tube (F), all connected by means of rubber tubing (G) and partially filed with mercury. By means of the leveling tube the gas is allowed to come off under the same pressure as that of the surrounding atmosphere. This gas is then reduced to standard conditions of $\mathrm{O}^{\circ} \mathrm{C}$. and $760 \mathrm{~mm}$. pressure by means of the compensating tube. A full description of the apparatus will be found in Sutton, Volumetric Analysis, 9th Ed., p. 594.

A tap (B) very similar to that used on manometers for measuring the internal pressure of champagnes was connected directly to this apparatus. In this way there was no loss of gas. 


\section{Lunnges Masvolnumeter.}

as used in Experiments.
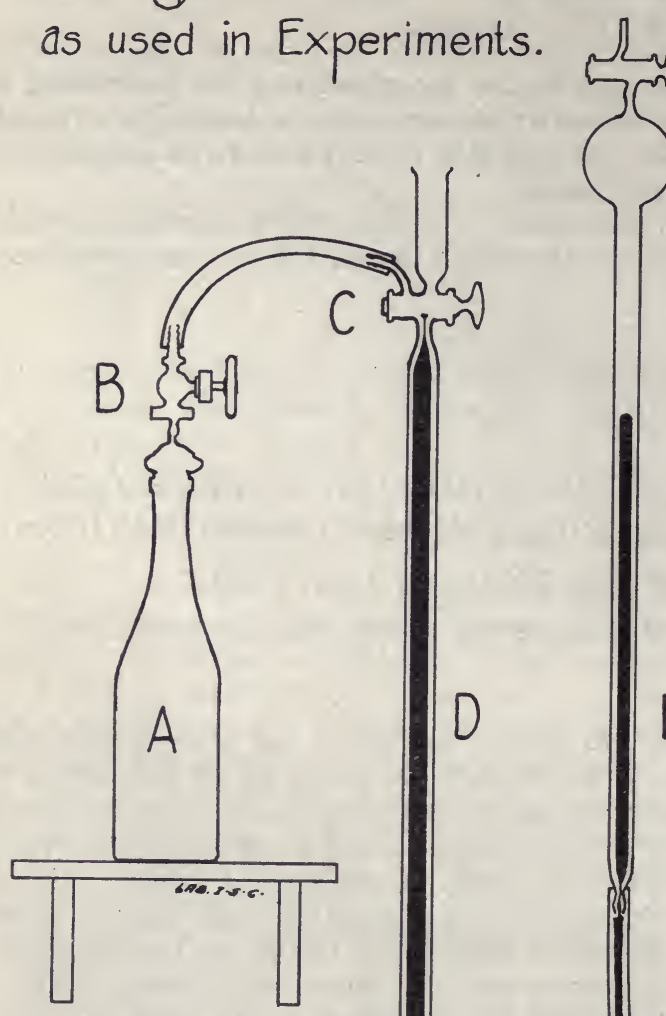

$3 \lim ^{2}$
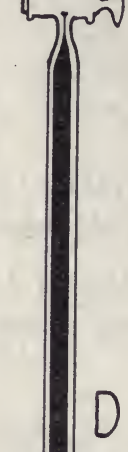
In comparing various champagnes, it was noted that the rate of effervescence was extremely variable with different wines having approximately the same internal pressure. Three bottles, each with an internal pressure of five and one-half atmospheres discharged their gases in variable ways. These wines were, however, of different composition and suggested a series of experiments on our part to determine whether the composition of a champagne exerted any influence on the effervescence of the gas. The preliminary experiments of this series are described below.

The champagnes used were prepared by Mr. Charles Jadeau at the Italian Swiss Colony's champagne cellars at Asti, California. They were normal sparkling wines of a single cuvee, the composition being modified after disgorging, the time at which the "dosage" is ordinarily practiced.

The experiments were divided into series according to the modification. The various series of bottles were modified as follows:

\begin{tabular}{|c|c|c|c|c|}
\hline eries & 1-Varying & amounts. & & suga \\
\hline “ & 2 & $"$ & “ & tartaric acid. \\
\hline “ & 3 & “ & “ & citric acid. \\
\hline “ & “ & “ & "6 & tannin. \\
\hline “ & “ & “ & “ & glycerine. \\
\hline “ & “ & “ & “ & extract. \\
\hline
\end{tabular}

Three bottles were left untreated to serve as "witnesses." The average of these three bottles was obtained and used as a basis of comparison.

After treatment, the bottles were allowed to rest at a temperature of $43^{\circ} \mathrm{F}$. for about a month and the rate of effervescence of the gas was then determined. The cork was pierced with the tap which connected with the measuring burette. The volume of gas was measured at stated intervals until the time of evolution totaled one hour. The remaining gas in the bottle (A-Figure 1) was then shaken out, and finally the bottle was warmed to $50^{\circ} \mathrm{C}$. to remove all possible traces of gas.

In order to represent the effervescence graphicaly curves were plotted in which the time was measured along the abscissa and the per cent of gas evolved on the ordinate. The per cent of effervescence was obtained by dividing the volume of gas given off in a certain time by the total volume of gas in the bottle.

The results, as obtained in the preliminary series, with the plotted curves graphically representing the "sparkle," follow in detail.

\section{Series 1. The Effect of Sugar (Liqueur).}

Varying amounts of liqueur were added to several bottles of the "brut" champagne so that they represented a "dosage" of 2, 4, 6 and 8 per cent, respectively. After allowing to stand, as previously stated, and measuring the gas, analysis of the wines was made. The results are here tabulated.

\begin{tabular}{|c|c|c|c|c|c|c|c|c|c|c|}
\hline \multirow{3}{*}{ 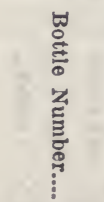 } & \multirow{3}{*}{ 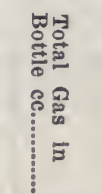 } & \multirow{3}{*}{ 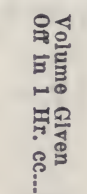 } & \multirow{3}{*}{ 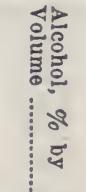 } & \multicolumn{7}{|c|}{ GMS. PER $100 \mathrm{cc}$. } \\
\hline & & & & & IDITY & & உ2ఐ & 02 & & \\
\hline & & & & 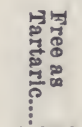 & 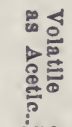 & 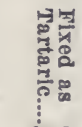 & 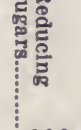 & 产 & 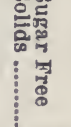 & \\
\hline & 1336 & 83 & 124 & 1.020 & .050 & .958 & .99 & 3.02 & 2.13 & .0 \\
\hline & & & & & & 1.0 & & & & \\
\hline & & & & & & 1 & & & & \\
\hline & & & & 1.116 & .0 & 1 & & 8.41 & 1.91 & \\
\hline 4 & & & & 1.130 & .051 & 1.066 & 8.400 & 9.89 & 1.59 & \\
\hline
\end{tabular}


Plate II is a graphic representation of the percentage of gas effervescence of the various bottles compared with the average of three untreated (brut) bottles.

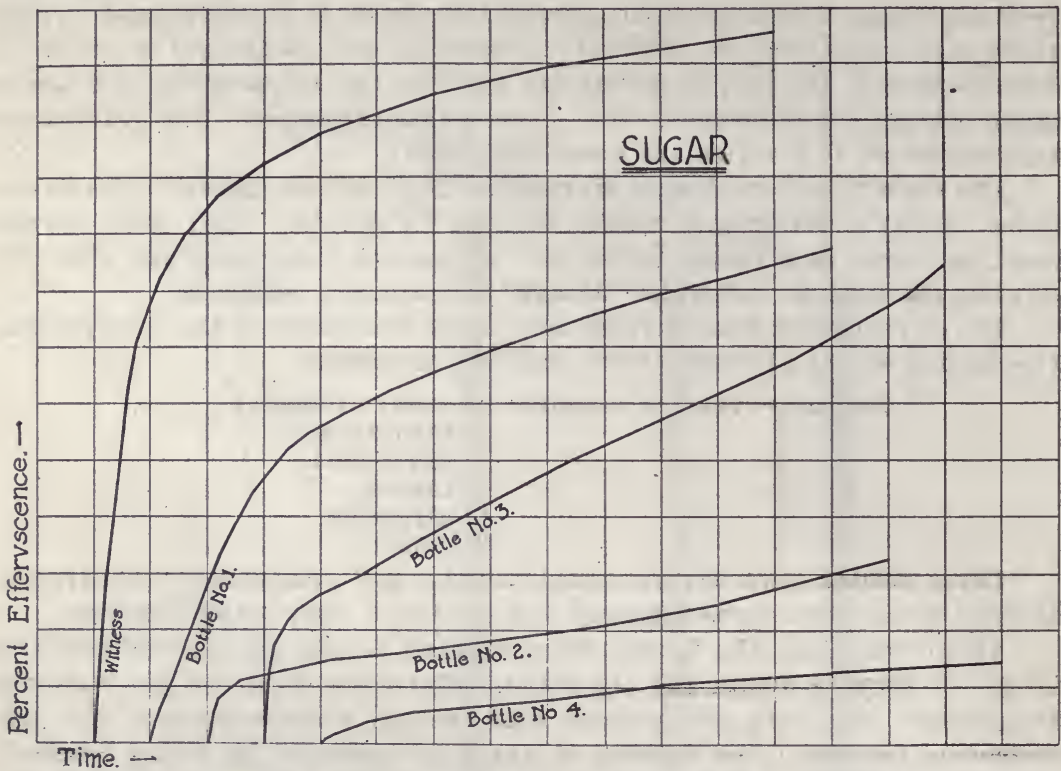

It may be readily seen from the above curves that sugar has a marked effect upon the rate of effervescence of the gas. The first rush of gas is markedly decrease where sugar has been added. With the exception of bottle 4, however, the effervescence in the last 20 minutes of the hour is faster than in the case of the witness.

\section{Series II. The Effect of Tartaric Acid.}

Instead of adding liqueur at the time of "dosage," as in the previous series, varying amounts of tartaric acid were added to different bottles. In order to prevent too great a modification of the composition of the wines, the tartaric acid was added in the form of crystals in preference to a solution. This made it very difficult to preserve a constant volume of gas in the various bottles since the crystals, before dissolving, caused a brisk ebullition of gas. This variation in gas content is shown in the first column of the analysis given below.

\begin{tabular}{|c|c|c|c|c|c|c|c|c|c|c|}
\hline \multirow{3}{*}{ 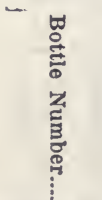 } & \multirow{3}{*}{ 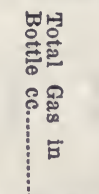 } & \multirow{3}{*}{ 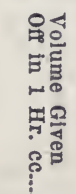 } & \multirow{3}{*}{ 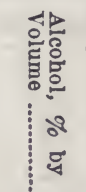 } & \multicolumn{7}{|c|}{ GMS. PER $100 \mathrm{cc}}$. \\
\hline & & & & \multicolumn{2}{|c|}{ ACIDITY } & & \multirow{2}{*}{ 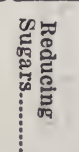 } & \multirow{2}{*}{ 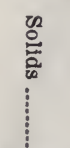 } & \multirow[b]{2}{*}{ 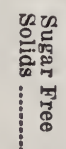 } & \multirow[b]{2}{*}{ 兽 } \\
\hline & & & & 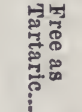 & 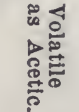 & 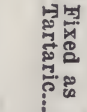 & & & & \\
\hline itness & 1336.4 & 837.6 & 12.43 & 1.020 & .050 & .958 & .99 & 3.02 & 2.13 & .019 \\
\hline 1 & 904.3 & 432 & 12. & 1.196 & .048 & 1.136 & 1.343 & 2.51 & 1.2 & .019 \\
\hline 2 & 1408.6 & & 12. & 1.497 & .049 & 1.436 & .280 & 2.69 & 2.5 & .024 \\
\hline 3 & & & & 1.585 & .049 & 1.524 & 1.137 & 3.69 & 2.65 & .020 \\
\hline 4 & 8 & & 12 & 2.077 & .050 & 1.963 & 1.025 & 4.03 & 3.11 & .014 \\
\hline
\end{tabular}


The percentages of effervescence, plotted as in Series I and comparable to them are shown on Plate III.

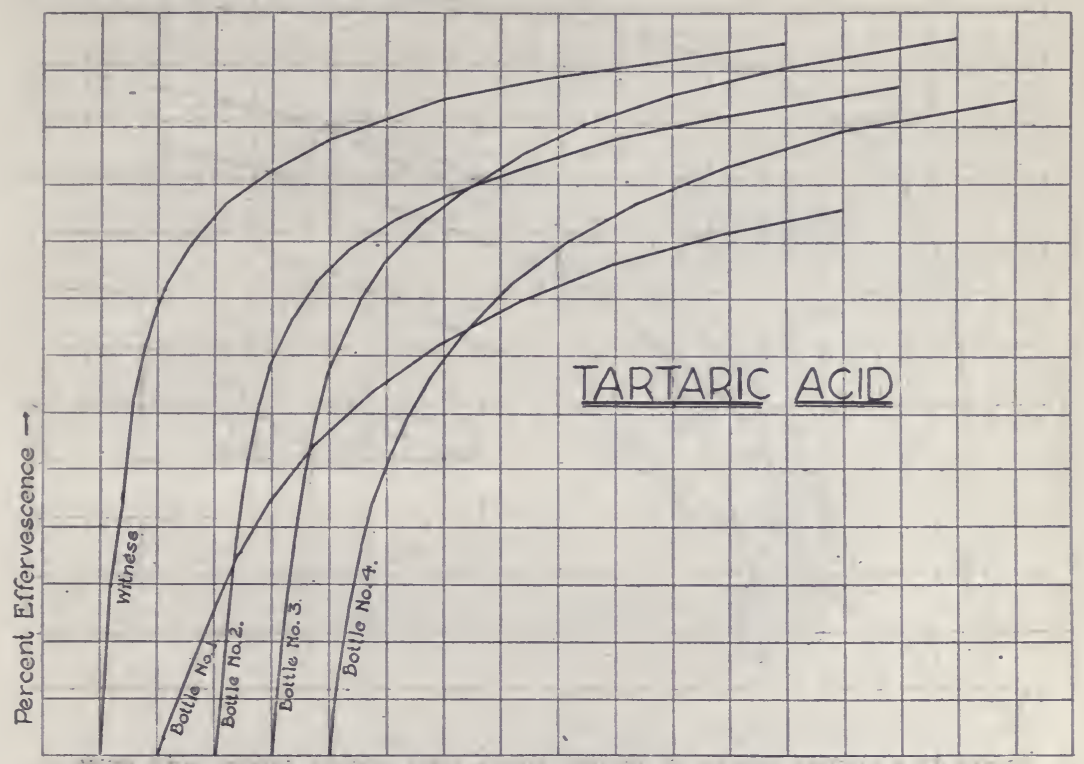

With the exception of bottle 1, the "sparkle" or first rush of gas is practically identical with that of the witness. It is probable, however, that the rate of effervescence at the start is governed chiefly by the total gas present in the bottle rather than any effect of added tartaric acid, as is shown by comparing bottle 2 with the witness. Again, this rapidity of effervescence just after opening may have been due to cream of tartar which precipitated out after storing in the ice chest, as it was noticed in several instances that gas broke readily from small particles in the wine. It would seem that the tartaric acid causes the "sparkle" to be prolonged even in the case of bottle 1 , where the total volume of gas is only about two-thirds that of the witness. In other words, with increased tartaric acid there is a less abrupt decrease in the rate of effervescence after the first ten minutes.

\section{Series III. The Effect of Citric Acid.}

Citric acid was added in the same manner as tartaric but no difficulty was encountered in maintaining a uniform gas content, as in the case of the latter. In the results given below the added citric acid has been calculated as tartaric for the sake of convenience.

\begin{tabular}{|c|c|c|c|c|c|c|c|c|c|c|}
\hline 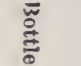 & 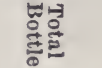 & 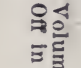 & 递 & & IDITY & & E2: & ש2 & & \\
\hline 줄 & 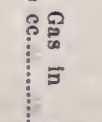 & $=$ & $\widetilde{20}$ & 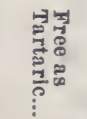 & 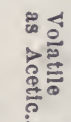 & 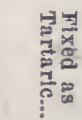 & 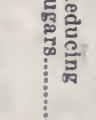 & $\begin{array}{r}\stackrel{0}{\bar{E}} \\
\vdots \\
\vdots \\
\vdots \\
\vdots\end{array}$ & 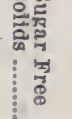 & $\frac{5}{5}$ \\
\hline es & 1336.4 & & 12.43 & 1.020 & .050 & .958 & .990 & 3.02 & 2.13 & .019 \\
\hline & & & & 1.1 & .0 & 1.1 & .26 & 2. & 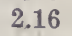 & .020 \\
\hline & & & & 1.321 & .0 & 1.261 & 1.000 & 3.36 & 2. & .017 \\
\hline & & & 12 & 1.696 & .049 & 1.635 & 1.062 & 3.62 & 2.66 & .014 \\
\hline & & & 12. & 2.011 & .049 & 1.950 & 1.125 & 4.17 & 3.15 & .014 \\
\hline
\end{tabular}




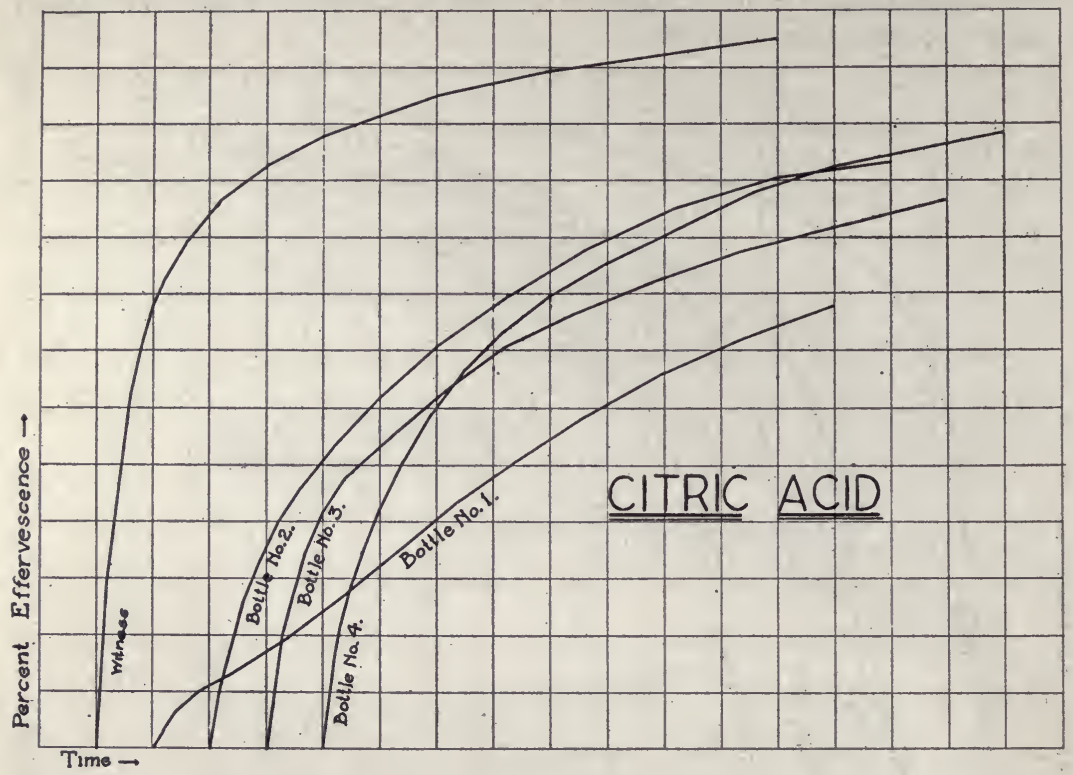

From the curves above it would seem that added citric acid causes a more even "sparkling." There is not such a marked first rush of gas, but the rate of effervescence is steadier throughout. It is interesting to note that the rate of effervescence during the last 20 minutes is in inverse proportion to the total amount of gas given off up to that time. In every case the citric acid appears to have caused a higher rate of effervescence at the end of one hour than in the case of the witness.

\section{Series IV. The Effect of Tannin.}

The tannin was added in the form of a solution because only a slight increase of tannin content was desired. The analyses are here tabulated.

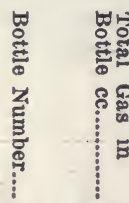

Witness.. 1336.4

1

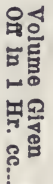

837.6

912.5

82.3

749.6

208.1

1418.7

1662.6

638.6

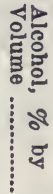

12.43

12.48

12.50

12.32

12.18

12.10

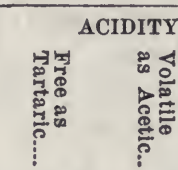

1.020

1.028

1.013

1.028

1.020

1.028

.050

.048

.048

GMS. PER $100 \mathrm{cc}$

\begin{tabular}{|c|c|c|c|}
\hline 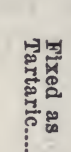 & 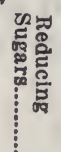 & 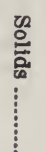 & 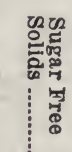 \\
\hline
\end{tabular}

.958

.990

3.02

2.13

.019

.968

.260

2.47

2.31

.041

.953 


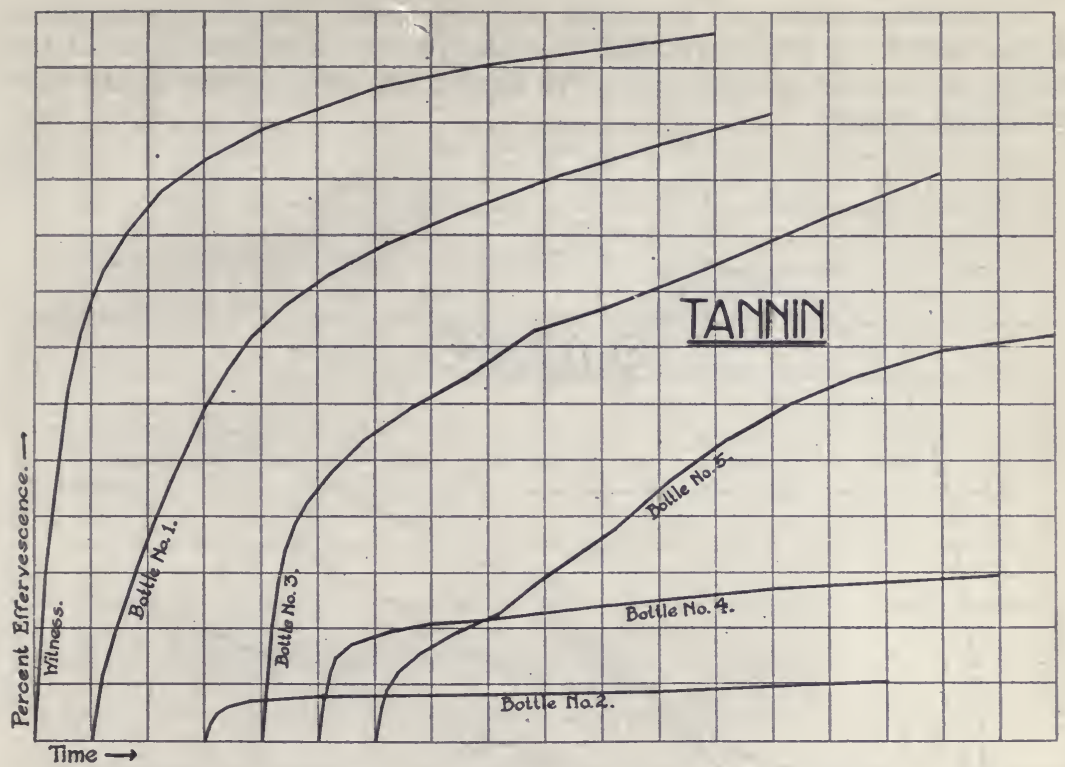

It is apparent from the curves that tannin exerts a retardative action on the rate of effervescence, but no definite conclusions can be drawn from the data obtained as to the effect of varying amounts. Bottles 3 and 5 were not prepared at the same time nor under the same conditions as the others and this renders it impossible to deduce anything of real value. It must be noted however, that bottles 1,3 and 5 are very much lower in sugar than 2 and 4 and in all three bottles the rate of effervescence was much faster.

\section{Series V. The Effect of Glycerine.}

Owing to the fact that the law prohibits the addition of glycerine these results are of no practical value and were conducted merely to note its effect for the sake of possible interest.

\begin{tabular}{|c|c|c|c|c|c|c|c|c|c|}
\hline 행붕 & & & & & MS. & 100 & E. & & \\
\hline हृ & $B$ & \% & & IDITY & & & (2) & & $\mapsto$ \\
\hline 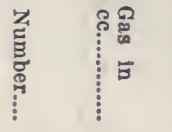 & 붕용 & $\begin{array}{l}0=0 \\
8 \\
0 \\
4\end{array}$ & 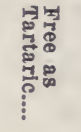 & 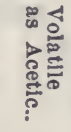 & 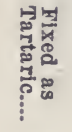 & 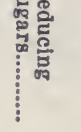 & $\begin{array}{c}\text { 兑 } \\
\vdots \\
\vdots\end{array}$ & 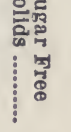 & $\begin{array}{l}0 \\
\vdots \\
\vdots \\
\vdots \\
\vdots \\
\vdots \\
\vdots\end{array}$ \\
\hline ... 1336.4 & 837.6 & 12.43 & 1.020 & .050 & .958 & .990 & 3.02 & 2.13 & .019 \\
\hline 35 & 5030 & 12.3 & 1.006 & .049 & .945 & .850 & 4.09 & 3.34 & .024 \\
\hline & & & 1.006 & .050 & .944 & .780 & 4.52 & 3.84 & .024 \\
\hline & & 12 & .991 & .048 & .931 & .6 & 5.58 & 5.07 & .022 \\
\hline 105 & 274.9 & 11 & .991 & .047 & .932 & 1.050 & 7.88 & 6.93 & .022 \\
\hline
\end{tabular}


The determination of glycerine was not made, but the approximate amount added can be ascertained by deducting the sugar-free solids of the witness from those of this series. The percentage effervescence of the various bottles follows:

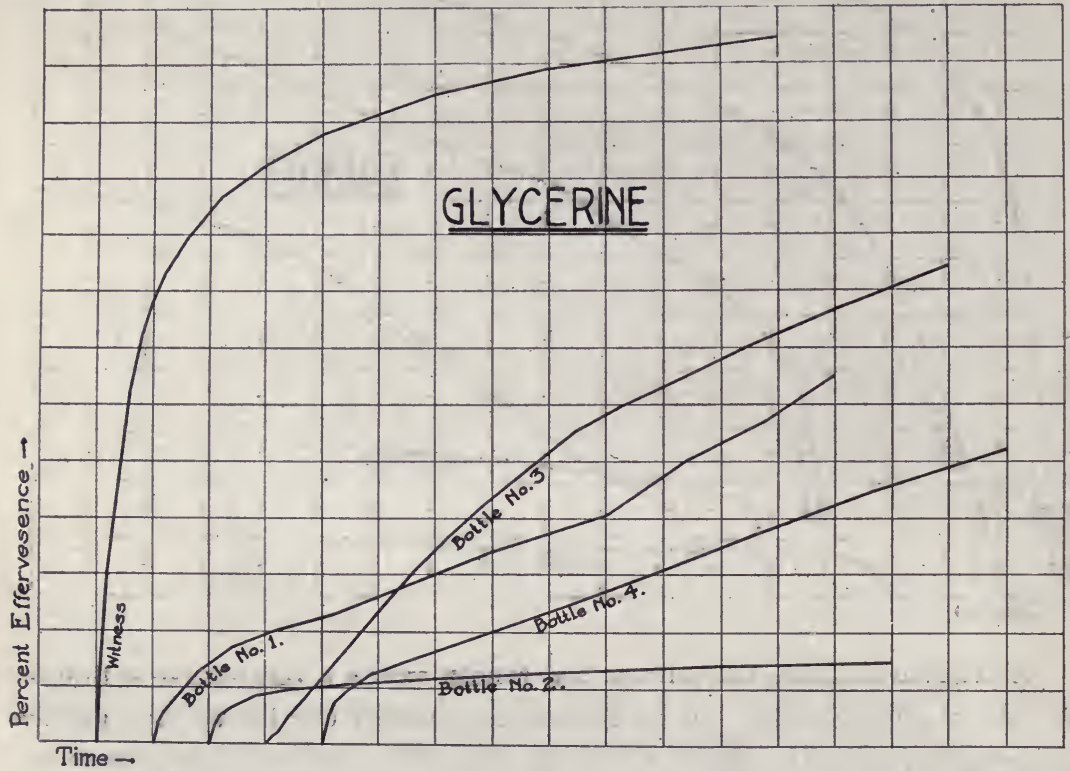

The great retardative action of glycerine is clearly shown in the above curves.

The sugar in bottle 3 , which had the highest rate of effervescence, is much lower than the others. This is in accordance with previous data which showed the retardative influence of the sugar.

\section{Series VI. The Effect of Increased Solids.}

The amounts of solids in the different bottles was increased by adding varying amounts of a white wine previously boiled down to about $1 / 15$ the original volume. This series is really a check on those that have preceded since the wine added contained everything except the alcohol and most of the water.

\begin{tabular}{|c|c|c|c|c|c|c|c|c|c|c|}
\hline \multirow{3}{*}{ 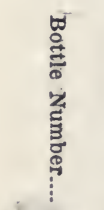 } & \multirow{3}{*}{ 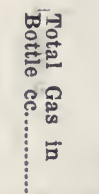 } & \multirow{3}{*}{ 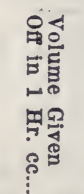 } & \multirow{3}{*}{ 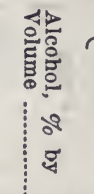 } & \multicolumn{7}{|c|}{ GMS. PER $100 \mathrm{cc}$. } \\
\hline & & & & \multicolumn{2}{|c|}{ ACIDITY } & & \multirow{2}{*}{ 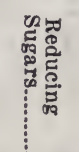 } & \multirow[b]{2}{*}{$\begin{array}{c}\mathscr{T} \\
\stackrel{\Xi}{0} \\
\vdots \\
\vdots\end{array}$} & \multirow[b]{2}{*}{ 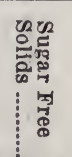 } & \multirow[b]{2}{*}{ 島 } \\
\hline & & & & 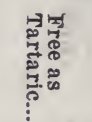 & 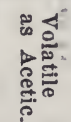 & 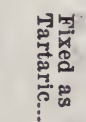 & & & & \\
\hline Witness.. & 1336.4 & 837.6 & 12.43 & 1.020 & .050 & .958 & .990 & 3.02 & 2.13 & .019 \\
\hline 1 & 1130.8 & 523.5 & 12.27 & 1.189 & .053 & 1.123 & 1.062 & 3.74 & 2.78 & .026 \\
\hline 2 & 1273.3 & 724.9 & 12.29 & 1.284 & .055 & 1.215 & .988 & 3.99 & 3.10 & .032 \\
\hline 3 & 1169.9 & 646.7 . & 11.90 & 1.387 & .056 & 1.317 & .920 & 4.35 & 3.53 & .034 \\
\hline 4 & 900.6 & 214.2 & 11.85 & 1.615 & .064 & 1.535 & 1.000 & 6.18 & 5.28 . & .040 \\
\hline
\end{tabular}




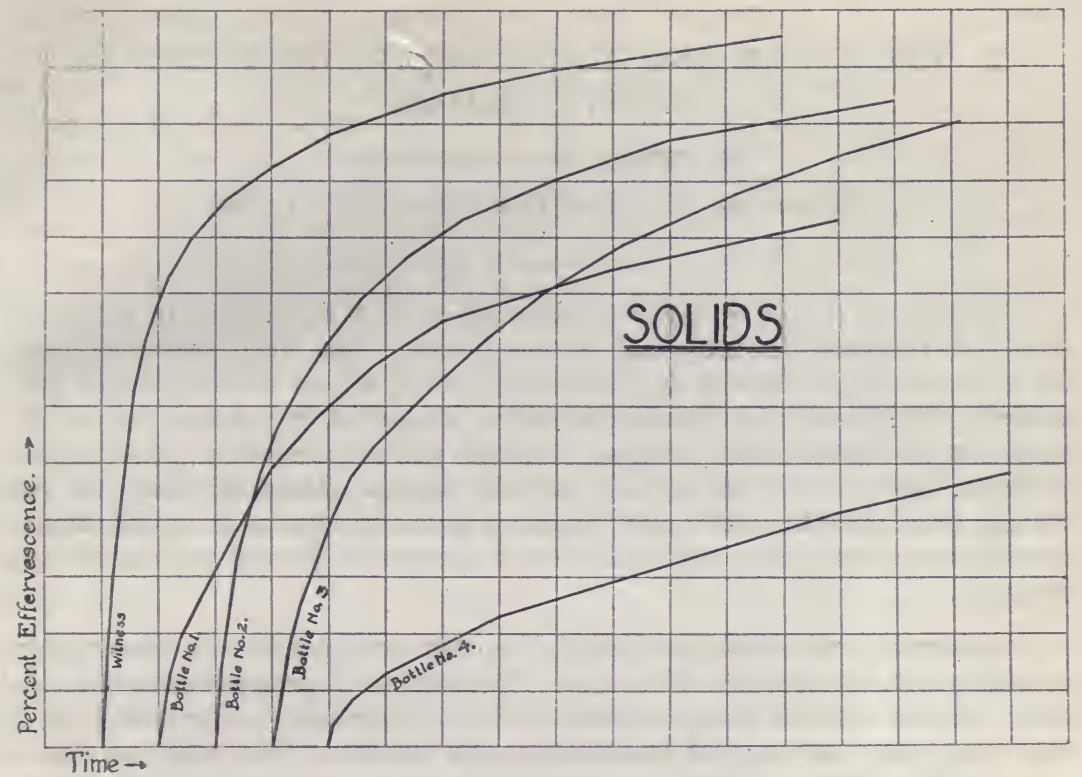

The sugar content is highest in bottle 1 and a comparison of this curve with that of bottle 1 , series 1 , shows a marked similiarity. In the last 20 minutes of the hour the rate of effervescence in bottle 1 is faster than in bottle 2, while 3 is the fastest of all. The sugar is lowest in bottle 3 . The tannin content is practically the same in bottles 2 and 3 , while in 3 the acidity is highest. From the previous data we would expect the effervescence in bottle 3 to be faster than the others, which it is.

Bottle 4 is highest in tannin and slightly higher in sugar than the other bottles of this series. If previous results are correct, the gas evolution should be slow. By reference to the curve (Plate VII), it will be noted that such is the case.

Since the experiments described were merely of a preliminary nature, no definite conclusions can be drawn. It would seem, however, that sugar, tannin and glycerine exert a marked retardative action on the effervescence, while with the tartaric and citric acids, the effervescence seems to be prolonged and not hastened. The fixed acidity of the wines used in the experiments was already exceptionally high so that any effect due to acidity may not have been so noticeable as it would have otherwise been. 


\title{
I. THE SUGAR AND ACID CONTENT OF AMERICAN NATIVE GRAPES.
}

\author{
By WILLIAM B. ALWOOD,
}

Stonehenge, Rio Road, Charlottesville, Virginia.

For several years the writer has carried on an investigation to determine the sugar and acid content of our native grapes. This work was done under the direction of the Bureau of Chemistry, United States Department of Agriculture. The results have been published somewhat in extenso by the Department of Agriculture. This paper deals with a summary of the results for sugar and acid in ripe grapes and the varying ratios of these two substances from year to year. Only eight varieties are included in this discussion because these comprise those most generally grown for commercial purposes.

The fruit of the grape as a food, or as raw material for the manufacture of wine, or of unfermented grape juice, is valuable in proportion to the total sugar content and the balanced ratio of its acid content to the sugar. It is true that there are special qualities in the nature of the fruit, as flavor, etc., which contribute to its palatability for food as fresh fruit, or for the manufacture of wine or unfermented grape juice, but the essential value, after all, is most readily based upon the sugar content and the proper balance of the acid and sugar. The question of acceptable or non-acceptable flavor of the fruit is usually settled at the very inception of a new variety. Those which have not sufficiently desirable flavors are not propagated or widely disseminated for commercial purposes.

Prior to the commencement of this investigation in 1907, there was very little data on the composition of American native grapes available.

The purpose in undertaking this work was not abstract investigation but to furnish information of practical value. The chemical examination of the fresh fruit was carried on principally at Sandusky, Ohio, but also a considerable number of samples were analyzed at Charlottesville, Va. The samples have been secured from growers direct and also from the stock as it arrived at the wine cellars and juice factories. Records of the samples have been kept in such manner as to identify the variety and in nearly every instance the farm where grown. While samples were examined from all the eastern grape growing districts, this paper includes data only of fruit grown in two districts, viz: Northern Ohio including the islands in Lake Erie, and samples from Charlottesville, Va. The reason for using only these results is that the sampling was more perfectly done within this territory and experiments in making pure wines were confined to grapes grown in those two districts.

The sample taken for analysis consisted of about four pounds of fruit, which was crushed by hand in a porcelain dish and then the juice strained off through a double thickness of cheese cloth and eventually the pulp was pressed firmly by hand until it was as dry as usually pressed at the wine 
cellars for securing the pure juice of the fruit. A portion of this expressed juice was then taken for the sample. The determinations made in all cases comprise a Brix reading at $20^{\circ} \mathrm{C}$., specific gravity determination in weighed pycnometer at $15.6^{\circ} \mathrm{C}$., total acid as tartaric by titration with $\mathrm{N} / 10 \mathrm{NaOH}$, using litmus solution on a spot plate for indicator, and the total sugar was determined as invert. Fairly complete ash analyses have been made for a considerable number of samples and the tartaric acid, fixed and free, as well as cream of tartar have also been determined on many samples. But the main study has been on sugar and acid content and we confine this paper to a simple treatment of the question of total acid and sugar content in its relation to by-products from the grape.

A large number of varieties have been analyzed in fact every sort found in cultivation in the territory covered thus far. For these complete results, the Government publication should be consulted. Most of the varieties herein considered have been analyzed each season during four years, and a sufficient number of samples taken to warrant the belief that the results are fairly conclusive.

The analytical results brought together in the table cover three years when the crop was rated as good, viz: 1908, 1910 and 1911, and one year, viz: 1909, when the growers in the northern grape belt rated the crop very poor as to quality though abundant in quantity. The results obtained in this investigation tend to overthrow the statements commonly made in the past concerning the quality of our native grapes. It has been freely stated that the native varieties do not produce a fruit rich enough in sugar and of proper acid-sugar ratio for the manufacture of pure wines. Acting on this dictum it has become very common to gallize arbitrarily the wines made from the native American grapes. The question now arises, is this practice necessary?

As to richness in sugar content, the eight varieties here presented, barring Concord and Ives, show. a sugar content equal to the average fruit grown in the best wine districts of Europe, and Concord and Ives do not fall below a very large amount of the European fruit. However, it must be admitted that the acid content is excessive in the fresh juice of a number of these varieties. But the acid in the finished wine must be taken into account when attempting to determine the general question of gallization.

The analytical results on composition of each variety are arranged consecutively by years for ready reference and does not require special discussion. The specific gravity given is, in all cases, where more than one sample was analyzed, the average of all the determinations made, and the total solids were also in like manner found by average, hence it will occur that these figures in a few instances do not agree to the last decimal with the table giving extracts in wines, Bureau of Chemistry, Bulletin 107, revised, page 218. All the other data given are averaged in like manner out are essentially accurate. The acid content and the sugar free solids for samples examined in 1908 are in many instances low. The fruit that year was of very fine character, but also the juice samples stood sometime before final aralysis and thus, by reason of precipitation of tartar, the acids and solids were affected. It is noticeable that the acid and sugar free solids are 
in most cases high for 1909. The fruit for that year was poorly ripened in many instances, and the analyses were made promptly before precipitation could occur. The analytical work for the years 1910 and 1911 was completed promptly on the unaltered sample.

The average sugar content of the several varieties given in the table are remarkably constant for each kind barring samples from Northern Ohio for 1909 , but the acid content is not so stable as the sugar content. It is quite probable that the acid is much more readily affected by climatic conditions, vigor of plants, healthfulness of foliage, etc., than the sugar content. These comparisons should not be made between the different districts but on samples from the same district. Note this point as to samples of Norton from Northern Ohio and Virginia. The acid-sugar ratio illustrates sharply the variation in the relation of these most important constituents.

While I am not prepared to propose at this time any final conclusion as to the limits within which the acid-sugar ratio may vary and yet produce a potable wine or unfermented grape juice for beverage purposes, I am quite certain that this cannot be arbitrarily fixed for the several varieties given in the table. Surely when we have sufficient data it will be comparatively simple to fix the ratio within reasonable limits for any particular variety. But because of the fact that the acid properties of the grape juice will vary much in constitution, the resultant by-products will vary likewise in the diminution of acid strength which will result from proper handling of the product. That is, the reduction of acid by precipitation of tartar and the breaking up of malic acid, must necessarily depend upon the percentage of these substances in the total acid properties of the fruit must.

The bearing on this point on the wine produced is brought out in the subsequent discussion under "Composition of Pure Wines from American Native Grapes."

Table I which follows presents the average composition, as to the more important organic elements, of eight of our native grapes. 
范

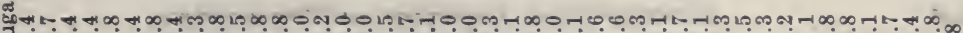
फ โ $\frac{4}{4}$

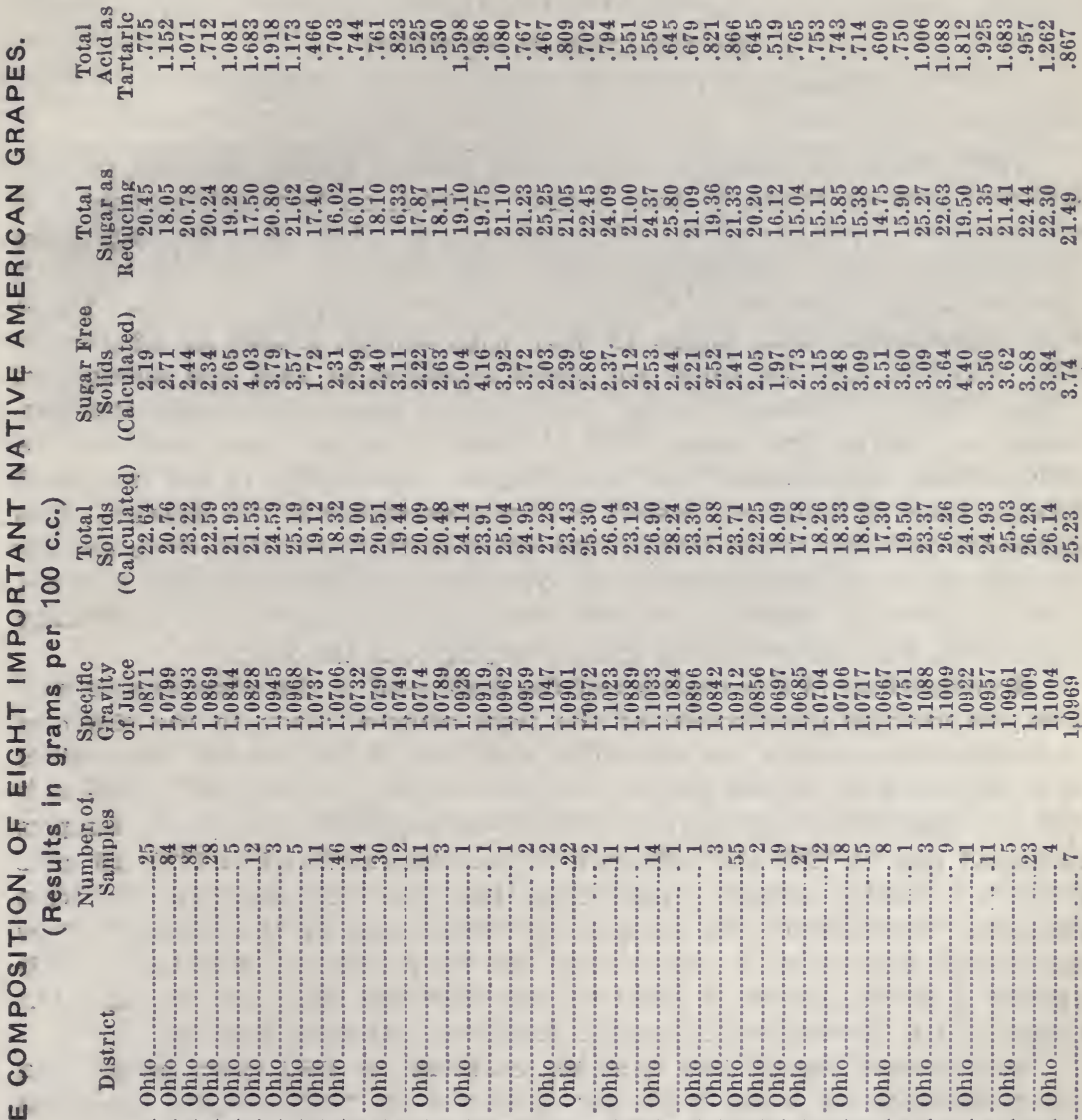

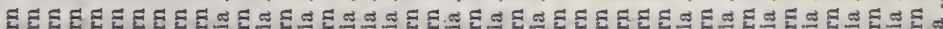

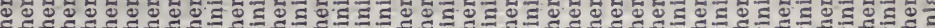

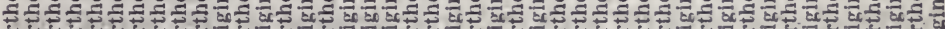

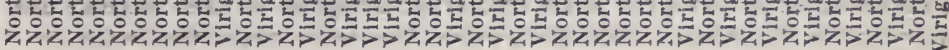

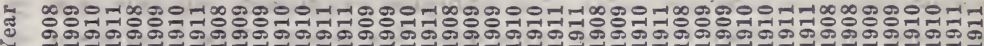

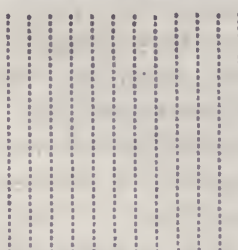

مّ 


\title{
II. THE COMPOSITION OF PURE WINE FROM AMERICAN NATIVE GRAPES.
}

\author{
By WILLIAM B. ALWOOD,
}

Stonehenge, Rio Road, Charlottesville, Virginia.

The chemical composition of the ripe fruit of grapes does not furnish sufficient data on which to base a final decision as to whether such fruit will produce a potable wine. This fact was in mind when we began the investigation of the composition of the fruit, therefore, wine was made in commercial quantities from a number of the more important varieties. These wine experiments were begun in 1907 with Norton grapes at Charlottesville, Virginia, and the work was much extended in 1909 and subsequent years, chiefly at Sandusky, Ohio. The fruit for these experiments was purchased as regular first grade fruit obtained from the stock found at the wine cellars, or purchased from the growers. The quality of the fruit used was the same as could be secured by any wine maker in the district. This statement does not imply that all the crops of these districts were equally as good as those purchased by us, but that the fruit we used was not specially selected. Naturally, it will occur that a greater or less percentage of the fruit will fall below first grade, varying with the year.

A comparison of the analyses of the fruit used in the wine experiments with the average composition of the fruit samples given in the study of varieties, shows clearly the relation of this fruit to the average composition of a large number of samples for the same year. From these analyses it will be seen that the 25 samples of Catawba examined in 1908, 84 samples examined both in 1909 and 1910, and 28 samples examined in 1911, all gave a slightly better average composition than the fruit used for the wine samples. The Clinton fruit samples for these years on the contrary, show an average quite a little poorer than the wine sample. The fact is, this variety is grown only in a small way in Northern Ohio, and samples furnished us by growers were, in some instances, not fully wine ripe.

For Concord the 48 fruit samples, examined in 1909, were better than the fruit used for wine, while for 1910 the 30 fruit samples examined as fresh fruit averaged poorer in sugar than the crop used for wine. The Cynthiana crop used for wine and fruit samples of this variety for 1911 are practically identical. For Delaware the crop used for wine in 1909 was better than the average of 22 fruit samples examined, but for 1910 the fruit samples were better than the crop used for wine. The Ives crop used for wine was better than the average of fruit samples for 1909 and 1910 , but the fruit used for wine in 1911 was poorer than the average of the fruit samples of that year. The stock used for Ives wine each year was bought on the floor of the same winery and sent to us without selection.

In case of Norton both at Sandusky and Charlottesville the fruit used for wine and the average composition of the fruit samples are practically alike. Thus it would appear that the variety samples examined for fruit composition and the fruit used for the wine experiments, vary as might be expected within reasonable limits, but show clearly that the experimental wines were not made from fruit of exceptional quality. 
The wines presented in the table comprise samples from all the varieties of grapes treated in the paper on chemical composition of American grapes, but in most cases we have not made wine from all these varieties each year. However, in a number of instances we have made several wine samples with the same variety in a season. The data given is from an experimental wine which, in all particulars, is typical of ordinary wine manufacture.

In these experiments the fruit was crushed by machines like those used in the regular wine plants. In case of white wine, the must was expressed on a power hydraulic press. A dial gauge was used to register the pressure, and the pulp was exhausted as completely as possible at 1,500 pounds direct pressure. The fresh must, both free and press musts, were then assembled in casks in the cellar, where the fermentation was carried to completion practically, as is customary, in the cellars. After precipitation was well completed the young wine was racked from the lees and transferred to clean casks. The quantity of the original must used in an experiment varied from 50 to 100 gallons and in some instances more.

In case of red wines the fruit was crushed on machines as given above and the pulp with the must was transferred to vats on the first floor of the building. Here the fermentation was carried on to a point of attenuation such as was thought proper to produce the normal wine from the variety in question. The sugar remaining in the pomace varied from .5 per cent to 1.8 per cent of the pressed pomace. The chemical sample of the fresh fruit used for both white and red wines was obtained by taking frequent portions of the pulp and juice as it was transferred to the vat. These portions were mixed and then a chemical sample taken.

The young wine was drawn from the vats when the fermentation had reached the point desired and the pulp was pressed thoroughly on the hydraulic press at 1,500 pounds pressure. Both the free run and the press wine were united in casks in the cellar as the experimental wine. The casks were given the ordinary care usual in wine cellars, and each sample was racked from the lees, after sedimentation, during the first winter. After this the wines were racked as conditions required to remove them from any sediment which precipitated. None of these samples have been fined, filtered, or treated in any wise to ameliorate or alter their condition. They have been held strictly as chemical samples for the purpose of technical study.

The full investigation comprised a study of the organic properties of these wines and complete ash analyses, but for the present purpose I present only the data on specific gravity, alcohol, solids, sugar and total acid. Ratios of acid-sugar in the fresh fruit, acid-alcohol and sugar-alcohol in the dry wines are given. My reason for limiting the data presented at this time is that I wish to treat only the organic composition of these wines in relation to the fruit from which they are derived without introducing other particulars.

The table presents first, the data on the composition of the fruit used for each wine sample, and then two analyses of the wine produced from this fruit. The first analysis of each wine represents the young wine as soon as fairly well sedimented and the second analysis given represents the dry wine. The analytical results on the wines are given only for solids, sugar, alcohol and total acid. Or, in other words, each analysis covers these elements given in the analyses of the fruit, with the addition of the determination of the alcohol derived from the sugar. 
The analyses of the wines show, by noting the sugar content, that fermentation was completed promptly and that all the wines were apparently sound and normal. The alcoholic strength is as high as experience has found necessary for proper conservation of the wine in handling, except for one sample of Concord and three samples of Ives. But these four exceptions show alcohol strength sufficient for "ordinary" wine and we have been able to hold such wines in wood for two years without material damage from acetic fermentation. The Delaware samples show alcoholic strength beyond all needs for preservation. These samples represent the complete range of alcoholic strength of normal wines from American native grapes, and cover a series of years, hence we conclude that our grapes will produce sufficient alcohol. There is a legitimate demand for low grade wines such as are produced from Concord and Ives and their blends.

The total acid found in the dry wines of these experiments is of the most vital importance as affecting their potable qualities. For the white wines, Catawba, Delaware and Iona, we know definitely the acid content of the composite of must from which they were made. Therefore, the changes which occurred in total acid are clearly shown by the figures given for total acid found in fresh must and that for the wine at the last analysis. In every sample of the white wines the acid has declined during the fermentation and development of the wine. This amounts in one instance to .26 grams per 100 c.c. (2.6 parts per mille) and though less for the other samples there is a very sensible decrease.

The acid content of the red wines, Clinton, Concord, Cynthiana, Ives and Norton, do not show in every case a less quantity in the dry wine than the young wine, but the exceptions are slight and apply only to Concord 1910 , Cynthiana 1911, Ives 1910 and Norton 1907. This exception is only apparent. If we had an acid determination of every sample just as drawn from the vat, it would show a higher acidity than shown by the analysis of the young wine some weeks later. The acid determined in the fruit used, never shows the actual acid of a red wine as drawn from the fermenting vat because the process of fermentation extracts more perfectly the acid from the pulp than can be done in pressing a fresh sample.

To bring out the relation of total acid to alcohol in the dry wines, a ratio is given for each analysis. This ratio is between total acid grams per 100 c.c. and the volume per cent of alcohol. If the acid were reduced to percentage the ratio would be still more striking, but as all the ratios are calculated on the same basis it appears to fairly illustrate the point desired, to use the ratio between gram weight of acid and volume per cent of alcohol per 100 c.c. of the wine. Volume per cent of alcohol is invariably understood by wine makers when speaking of the strength of their wines, and it is almost the universal custom of chemists to report results on acid and sugar in grams per 100 c.c., hence the reason for using, in this ratio, the determinations as above expressed.

In the white wines the acid-alcohol ratios show a very consistent relation for the Catawba samples covering the four years of the experiments. The sample for 1909 falls below the other years, and the sample for 1911 shows the widest ratio. This latter crop was the best wine stock of Catawba we have thus far examined. Iona gives an acid-alcohol ratio similar to Catawba, but Delaware shows a much wider ratio. In fact this grape is rather deficient 
in acid for a sprightly, agreeable wine. The ratio for this wine is about the same as some of the richest wines of the German Palatinate. For the red wines, the acid-alcohol ratios vary decidedly; in case of Clinton ranging in the dry wine from $1: 11.6$ to $1: 18.1$. Evidently this variety does not ripen its fruit as evenly as Catawba in Northern Ohio or else the foliage fails to resist insect pests and fungus diseases and, therefore, we have the variation in quality of fruit. The sample for 1911, however, shows a very favorable ratio of acid to alcohol. Clinton must, when well handled, gives a very marked precipitation of tartar during fermentation and aging, and consequent high loss of acid. Concord was only used for wine experiments during two years, and as 1909 was a poor year for quality we have not sufficient data for comparison. It is important to note, however, that this wine does not appear to precipitate much of its acid properties during aging.

Cynthiana was only used for wine one year, viz: 1911, which was the most favorable year of the series. Nothing can be said further than to call attention to its wide acid-alcohol ratio. This is very favorable to its use as a stock for blending with more acid wines. Ives was used for three years in the experiments and shows a very narrow acid-alcohol ratio in the dry wine. This variety, like Concord, does not appear to precipitate much of the acid properties. Such wines naturally remain harsh.

Norton was used for wine experiments for two years at Sandusky and three years at Charlottesville. The 1909 sample at Sandusky was made from fruit showing 1.816 grams of total acid, yet the dry wine shows only .885 grams of acid and gives an acid-alcohol ratio of 1:12.5. This is too narrow but shows remarkable precipitation of acid properties during fermentation and maturing. The 1911 Norton at Sandusky is a remarkably good sample and shows acid-alcohol ratio of 1:18.6. The three samples of Norton wine made at Charlottesville show a favorable acid-alcohol ratio, but in the sample for 1907 the narrowing of the ratio in the dry wine is due to increase of acid from development of a small amount of volatile acid and a slight reduction of alcohol. The two other samples show a very favorable acid-alcohol ratio. The acid-alcohol ratios of these red wines are again quite as favorable as the natural German wines and equal to some of the French wines. The question of what is normal, or rather an acceptable acid-alcohol ratio for a potable wine, presents itself forcibly in this connection. Certainly there is no arbitrary ratio which can be applied to all wines. But we should be able to arrive at fairly definite maximum and minimum ratios for wines of each general class which would be accepted by the palate as agreeable and satisfying.

The composition of a large number of German wines covering a series of years as given by Koenig, Volume I, 4th edition, pages 1182-1246, vary in acid-alcohol ratio from 1:10.4 for Lothringer white wines to 1.16 .8 for Pfalzer white wines, and for red wines the ratio varies from 1:9.0 for Oberhessische to 1:24.6 for Rheinhessische wines. A very large number of analyses of German wines are given by Koenig, but the averages of districts only were compared. It is well known that very many of these German wines are sugared. The acid-alcohol ratios of these German wines are so confusing by reason of their wide range that one cannot draw conclusions from them. I have at hand only a few analyses of French white and red dry wines of the Bordeaux district and these show average acid-alcohol ratios of 1:18.1 
for white wines and 1:17.7 for red wines. On the whole these ratios of French wines conform closely with what the average taste of wine users demands.

As a tentative proposition for dry still wines, I suggest as minimum and maximum ratios $1: 16.0$ to $1: 20.0$. A full bodied heavy wine will naturally carry the narrower acid-alcohol ratio while a light thin wine should have the wider ratio. Judged on the proposition advanced above, the pure dry wines we have made from American native grapes are not as a whole excessively acid. Therefore their amelioration ought not to be a difficult matter. The use of a reasonable amount of sugar solution to accomplish amelioration when needed is warranted, but should be allowed, only under control of some adequate authority in order to protect the legitimate producer as well as the user.

As a final comparison there is given the ratio between the original sugar determined in the must and the alcohol determined at the last analysis of the wine. This sugar-alcohol ratio of the wine is most interesting. It shows that in most instances where a variety has been used for wine in different years we have produced an almost identical quantity of alcohol for the sugar found in the original must. The value of such a comparison in these experiments is that it furnishes a check upon the accuracy and similarity of technic observed in making and handling the wines.

The exceptions to be noted in regard to the uniformity of this ratio are, in case of Concords, Ives and Norton where a few aberrations appear. The most striking variant is the Ives wine for 1909. No explanation of these variations can be offered at this time. It is noticeable that the white wines ferment drier than the red and give a slightly higher alcohol factor.

The theoretical alcohol to be derived is found if the percent of sugar in the must be multiplied by .598. The result of this calculation is the alcohol volume per cent which should be produced in the wine. Our experiments show that this factor cannot be exactly relied upon in practice. 
Sug.-Alco. Ratio, $\vdots: \vdots$ :

แ

Acid-sugar Ratio : \#

of Fruit used, :สู

Sugar/Acid ....

Acid-Alcohol

Ratio of Wine, : N

Alcohol, vol. \% : :

$: \because \infty$

$: \because n \pi$ :

Acid, gms........ : $\because \ddot{\sim}$

$: \frac{10}{16}$

$:$ :

$\infty \infty$

:

:

$\because+\frac{1}{2}:$

$\operatorname{sen}:$

Acid

Total Acid asto Tartaric, gms. per 100 c.c. ...

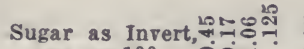

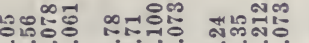
gms. per 100 c.c.

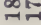

ㅇํㅇ

จิ่า

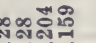

우유

-ini-ininini |

O

Sugar Free Solid 유요 gms. per 100 c.c. งi ioi

든ำ

ZNOT:

저요

독

ㄷำ

뚜ำ

ฟืกิัตับ

กิ่ง

ลี่ง

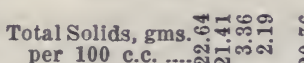

๑ตผ

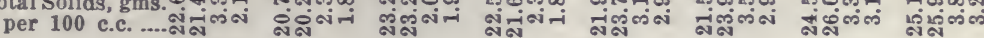

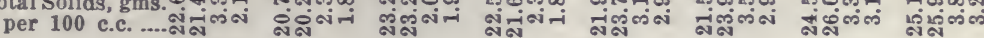

$\sin =0$

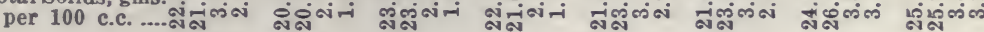

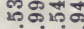

-icio

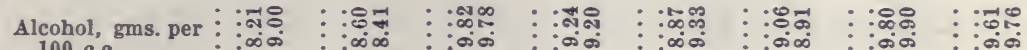
100 c.c.

Alcohol, Per Cent:

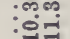

$: 108: \infty 0^{\infty}$

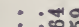

$\cdot \infty \infty$

$:$ :퍼워

$:: \operatorname{lng}$

:च7

4

山

$\frac{1}{5}$

Specific Gravity, 청ำ

$200^{25}$

: จูปส

:

$: \approx=$

: च्च

:งิ่ง

:จำ

$\infty$

15.6/15.6 ...

:

๓งติ

$+\infty \infty$

ㅍㅇ

พำㄴำ

100250

$\infty \infty 8 \%$ \%ం\%ా

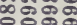

(-i.

कㅇํㅇ

i-i.

융요

-i.

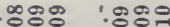

$:$ 크우

:

:용요

:우우그

'므무궈

:

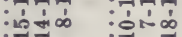

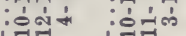

: เo

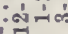

$: \infty \infty$

:อ் ஸेé

- $-1+\infty$

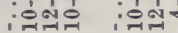

ผ

우웅ㅇㅇㅡ

تनー1 $\infty \infty \infty \infty$

양융요요

แั

$\frac{2}{0}$

$=$

0

氙志

हैं :

क्षे

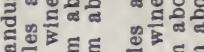

क

के के क

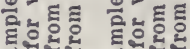

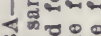

象影

ต็

ศึ년

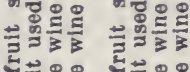

도는연

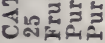

更=

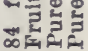

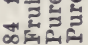

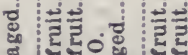

ङ

क

ज行

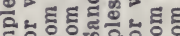

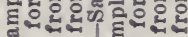

ฆ๊

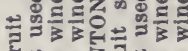

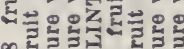

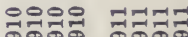

-

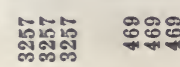

禹

就矛

웅

요요

क क ल

릉ㅇㅇ윤유

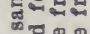

क马्ष

혼

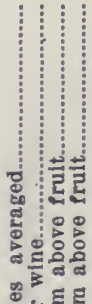

: :

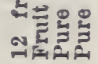

들운현

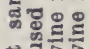

$\doteq \beth \frac{7}{B}$

론혼일

ชุ.

\&

范

क लै क

훙ํㅇㄹㅠ

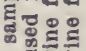

$+\underset{B}{ }$

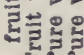

꾸윰유

ణॅణ 
Sug.-Alco. Ratio

Alcohol, vol. \%

Total Sug. gms.

$\underset{0}{4}$

Acid-sugar Ratio :-: :

กา

$\because:$

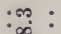

$: \infty:$

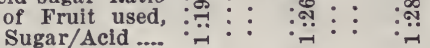

Acid-Alcohol

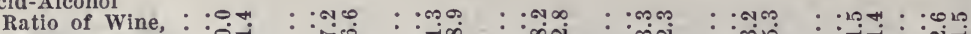

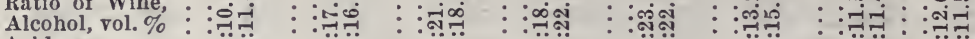

Acid, gms....... : : $\because \ddot{\sim} \ddot{-1}$

$\because \ddot{-1}$

$\because \ddot{-1}$

Total Acid as Tartaric, gms. ㄴ. per 100 c.c. ...

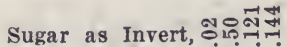

은ำำ

๓๒อ

$\stackrel{\infty}{\infty}$ gms. per 100 c.c. $\stackrel{\oplus}{ \pm}$

$\infty$ 여

तี่

สี่ส่

ปี่

लैन्त्र

ธีคิ

4

$\frac{11}{5}$

Sugar Free Solids 닦

웡ำ

노ำำ

ాణజలో

का

क्ष-

15:

gms. per 100 c.c. ง

งก่งก่

लें⿰ตัต

बioint

बisini-i

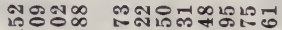

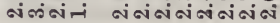

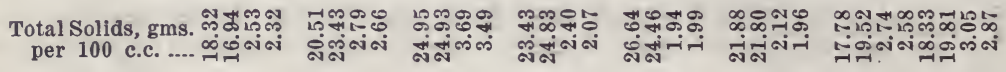

II

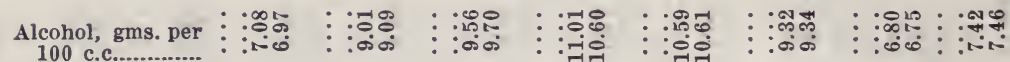

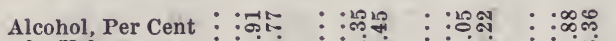

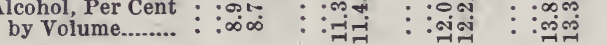

$:: \operatorname{lng}:: 105::$ : :

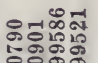

Speciflc Grävity, 15.6/15.6

대.

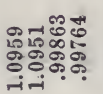

\section{ำ क्र० \\ พํํํํํㅇํㅇ 이용}

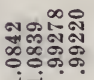

ผูพ ㄴ. 215

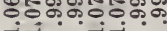

100N

1月ー7 180

1000 -in i-i.

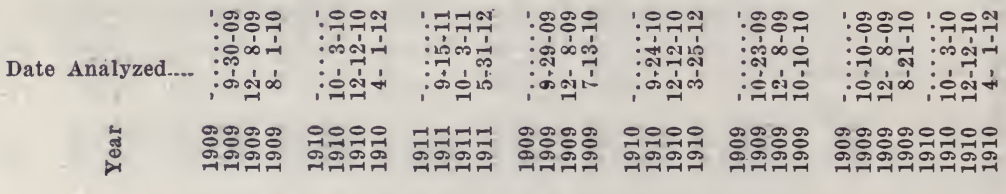

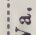

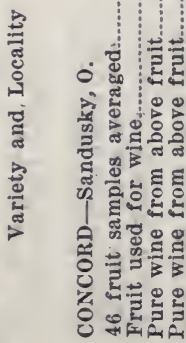

造 편 ๘

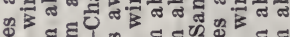

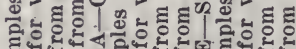
क็

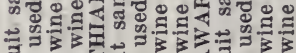

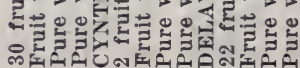

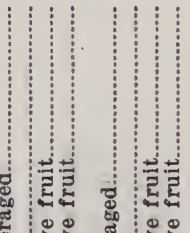

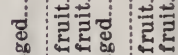
\% 00 政 0

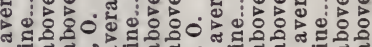

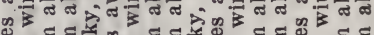

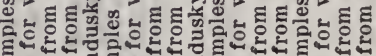
స్

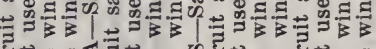

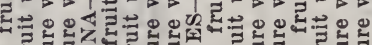

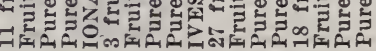


Sug.-Alco. Ratio, Alcohol, vol. \%

Total Sug.gms.

क

$\frac{1}{4}$

$\frac{a}{a}$

$\frac{11}{2}$

Acid-sugar Ratio of Fruit used, Sugar/Acld ...

Acld-Alcohol

Ratio of Wine,

Alcohol, vol. \%

$\operatorname{ing}$

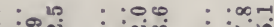

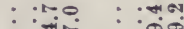
Acid, gms..... $: \div$ $\because \because \pi$ $\lim _{-10}^{\infty}$

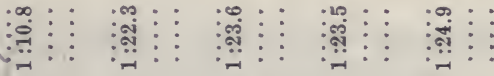

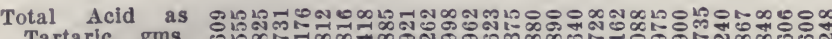
Tartaric, gms. 100 c.c....

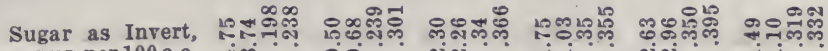
gms.per 100 c.c. ปี่

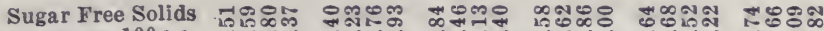

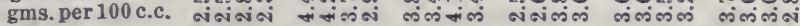

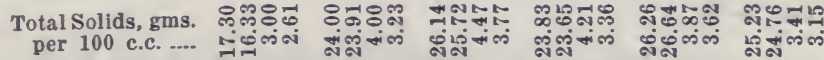

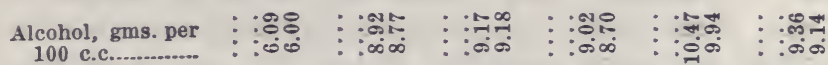

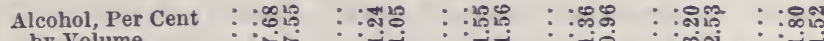
by Volume...... : :

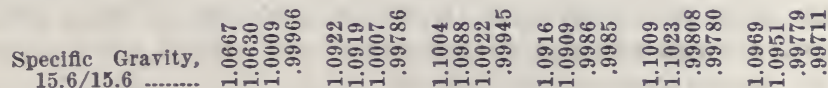

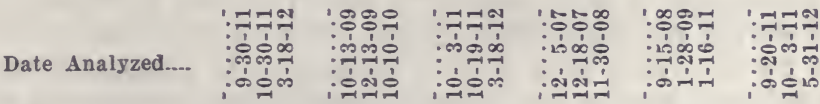

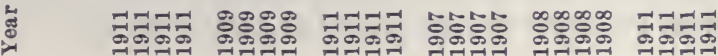

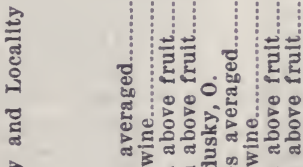

: :

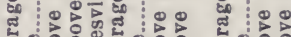

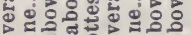

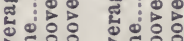
๘ क न ๘

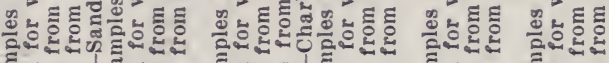
๗ँ.

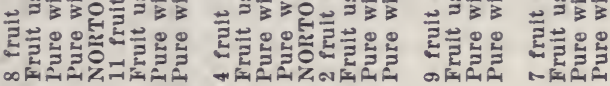




\title{
IMPORTANT FACTORS GOVERNING THE SUCCESSFUL TRANSPORTATION OF TABLE GRAPES.
}

\author{
By A. V. STUBENRAUCH,
}

Professor Pomology in the University of California and Consulting Pomologist of the United States Department of Agriculture.

\section{INTRODUCTION.}

The investigations which form the basis of the discussions in this paper were carried on while the writer was associated with and in charge of the pomological investigations of the Bureau of Plant Industry, United States Department of Agriculture. They should, therefore, be credited to the activities of the National Department of Agriculture rather than to those of the University of California. It is only fair that this acknowledgment be made at this time.

The table grape industry of California, like all of the fruit industries of the State, is dependent upon a wide distribution of the product for the profitable sale of the crop. The volume of production has long ago passed the point where any large, proportion of the crop can be consumed in the markets of the State or of neighboring States. The plantings are confined to the vinifera or European type of grapes mostly of the Flame Tokay, Malaga and Red Emperor varieties. California has almost a monopoly of the production of this class of fruit in the United States. The problems of transporting the crops to market are, therefore, problems of wide distribution, and the factors which underlie the successful shipment of the fruit are of the most urgent importance to the growers.

The production of table grapes in California has increased at a very rapid rate during the past fifteen years. Table I gives the record of the shipments for the years 1902 to 1914, inclusive. In computing the number of crates 980 was used as the average number per carload, and 26 pounds as the weight per crate to determine the number of tons.

\section{Table I. Shipments of Fresh Grapes from California, 1902-14, Inclusive.}

\begin{tabular}{|c|c|c|c|}
\hline Crop Year & Carloads & No. of $25-1 b$. Crates & Tons. \\
\hline 1902. & ........ 1,033 & $1,012,340$ & 13,160 \\
\hline $1903 \ldots$ & .... 1,804 & $1,767,920$ & 22,982 \\
\hline $1904 \ldots$ & 1,451 & $1,421,980$ & 18,485 \\
\hline $1905 \ldots$ & 1,602 & $1,569,960$ & 20,409 \\
\hline $1906 .$. & 2,052 & $2,010,960$ & 26,142 \\
\hline $1907 \ldots$ & …. 3,460 & $3,390,800$ & 44,080 \\
\hline $1908 \ldots$ & 3,816 & $3,739,680$ & 48,615 \\
\hline 1909. & 5,875 & $5,757,500$ & 74,848 \\
\hline 1910. & 4,948 & $4,849,040$ & 63,038 \\
\hline $1911 \ldots \ldots$ & 6,375 & $6,247,500$ & 81,218 \\
\hline $1912 \ldots \ldots$ & 6,355 & $6,227,900$ & 80,963 \\
\hline $1913 \ldots$ & ... 6,363 & $6,235,740$ & 81,065 \\
\hline $1914 \ldots \ldots$ & 8,773 & $8,597,540$ & 111,768 \\
\hline
\end{tabular}


When the present acreage of young vines reaches full bearing and the new plantings come into bearing the volume of shipments may exceed 10,000 carloads or about 125,000 tons per annum. The bulk of these enormous shipments must be handled within a period of six weeks to two months. The importance of finding available markets for these large crops becomes more pressing as production increases. It becomes necessary to extend the area over which the fruit may be distributed and also as far as possible to lengthen the marketing season through cold storage.

There are two requisites for the successful shipment and sale of fruit: (1) It must reach the primary market in sound condition; (2) it must have sufficient market-holding quality after arrival in market to enable it to be distributed through the various channels of the wholesale and retail trade, and reach the consumer in sound condition. It will be seen then that not only must the fruit carry to market in good condition, but it must remain sound for a considerable length of time after it arrives. Fruit which must be sold and consumed quickly after it arrives has only a limited sale in the primary or wholesale market; fruit which can be held long enough to be redistributed to surrounding small towns has a tremendous advantage; buyers are eager to obtain such fruit and are willing to pay extra prices for it.

Experience in the past has shown that California table grapes cannot be shipped to a number of markets in the United States and Canada on account of the fact that the fruit does not remain sound long enough to make the trip. Experience has also shown that during certain seasons, or from certain districts of the State the grapes arrive with heavy percentages of decay. The time required for the trip from California to the principal eastern cities ranges from eight to ten days. Sometimes seventeen days are required to make the trip from California to New York. The last is exceptional, however, and due to abnormal conditions on the transportation lines. In order to reach the southeastern portion of the country, a longer time is necessary, and the shipment of grapes into this territory is considered a risky undertaking.

\section{Table Grape Transportation Investigations of the United States Department of Agriculture.}

A few years ago the grape growers and shippers of California appealed to the United States Department of Agriculture to make a careful study of the conditions under which the fruit was being handled and shipped with a view to determining the causes of the heavy losses from decay that frequently occurred. The workers of the Office of Field Investigations in Pomology of the Bureau of Plant Industry were detailed for this work, and a thorough study of the methods of handling the fruit was made through four successive seasons. The influence of the character of the handling given the fruit in preparing it for shipment was studied and a large number of demonstration shipments were made. This work formed a part of the fruit transportation and storage investigations of the Bureau of Plant Industry which have been under way for a number of years. At the time the grape investigations were begun in California investigations of the causes of the decay in shipments of apples, peaches, oranges, and lemons had been made with the result that a definite relationship 
had been found to exist between the character of the handling given these fruits in preparing them for shipment and their behavior while in transit, in market or in storage. It was found that the decay occurring in fruits was very largely due to molds of the type of "blue mold," which have not the power of penetrating the sound, healthy skin of a fruit. By far the greater part of the decay was found to be due to common blue mold (Penicillium), and very careful study and experiment showed that this fungus is dependent upon a bruise, abrasion, break or weakness of some kind in the skin of the fruit to gain entrance into and develop within the tissues. In the citrus industry of California, careful attention to the handling of the fruit, and the management of the picking and packing operations in such a way that injury was avoided resulted in the practical elimination of the decay loss.

While it was realized from the start that the character of table grapes is very different from that of citrus and other fruits, requiring different treatment, there was sufficient evidence to indicate that the occurrence of decay in grapes was also largely dependent upon the presence of injuries in the grape berries, the methods of handling them and preparing them for shipment; as well as, possibly, upon the type of package used. There was no reason to believe that grapes were an exception to the rule of relationship between handling and carrying quality.

A careful and systematic investigation of all phases of grape handling and shipping was made at Lodi, California, where the Flame Tokay forms the bulk of the shipments. The work was continued through several seasons in order to overcome the results of seasonal variation. The method of carrying out the work consisted in making a careful comparison of grapes care. fully picked and packed by the Department workers with the same fruit picked, packed and handled by the ordinary workmen. Both these lots of grapes were packed in the ordinary open crate, containing four five-pound or two ten-pound splint baskets without a filler of any kind. There were also included in the experimental shipments lots of carefully handled grapes packed in tight boxes with a filler in order to determine whether the use of a filler is necessary to overcome decay, or whether care in handling is sufficient to eliminate the occurrence of the mold. The effect of holding the fruit two or three days before shipping was also studied, these shipments being designated as "delayed shipments." The determination of the effect of this treatment was necessary because of the widespread practice of holding the grapes for a day or two in order to allow them to wilt, under the supposition that this greatly facilitates packing. A number of these experimental series of crates and packages of grapes packed with a filler of ground cork or redwood sawdust were prepared at different vineyards, located in representative sections of the district. The fruit picked and packed by the ordinary workmen was designated as "commercially handled," and that prepared by the Department workers as "carefully hand'ed." The packages were all loaded into cars being shipped to New York, each car having crates and boxes on the top and bottom tiers of the load. Upon arrival at New York, the experimental lots were received by a representative of the Department and carefully inspected by him. The inspection consisted in cutting apart the bunches and carefully segregating the decayed and injuried berries and those which had dropped from the stems, the last being designated as "shelled 
berries." The percentages of the decayed, injured berries, and shelled berries were determined by weight. At first sight the determination by weight may appear to be only a fair approximation. A comparison of percentages by count and by weight showed, however, that there was only a very slight, if any, difference. Any inequalities due to the method of determining the decay practically disappear in the large number of shipments made. From twenty to thirty series were shipped each season. Inspections were made on the day the fruit arrived in New York and on the third, fifth and seventh days after arrival, the fruit being held, in the meantime, under ordinary open market conditions. In this way the effect of the different methods of treatment upon the market-holding qualities as well as upon the shipping qualities was studied.

\section{Results of the United States Department Investigations.}

Table II gives a summary of three seasons' shipping experiments and shows the percentages of decay found in the different lots of grapes on the day of arrival, and on the third and fifth days after arrival. After the first season, the use of redwood sawdust was substituted for ground cork in the lots packed with a filler.

TABLE II.-Results of experiental shipments of Tokay grapes during three successive seasons, from Lodi, California, to New York City, showing the average percentages of decay in all shipments of commercially handled and carefully handled fruit on arrival and on the third and fifth days after arrival.

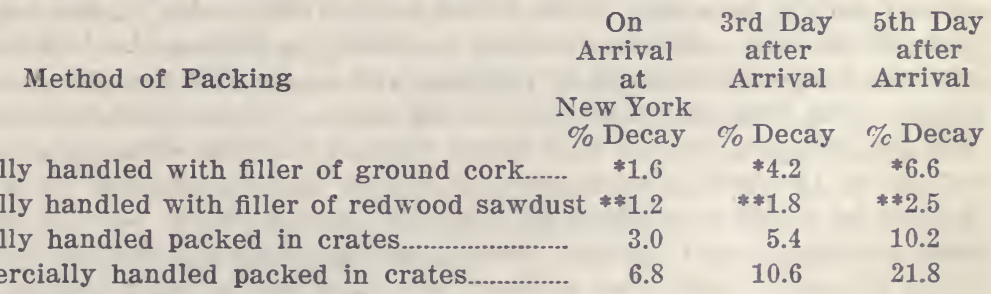

* Ground cork used only during one season.

**Average of two seasons.

The figures are significant in that they indicate the close relationship existing between the type of handling given the fruit in preparing it for shipment, the type of package used and the occurrence of decay while in transit to market and after arrival in market. The results also show that the effect of careful handling persists after the fruit arrives in the market. thus giving the lots packed without appreciable injury a tremendous advantage over those arriving with considerable deterioration. Careful observation of a large number of the crates under investigation shows that five per cent decay is about the limit of commercial soundness. Percentages of decay ranging from five to ten per cent are noticeable; above ten per cent indicates that the fruit must be used immediately and therefore must be disposed of at a forced sale. Above fifteen per cent decay is beyond the limits of marketable condition and packages showing more than this proportion of decay will not find sale except at a heavy discount. 
The lowest percentages of decay were found in the lots packed with a filler, those with the sawdust filler arriving with less decay and holding in much better condition than those packed in ground cork. This result is consistent with experiences in the use of this filler as compared with ground cork in a comprehensive study of the storage of grapes.*

A comparison of the carefully handled and the commercially handled lots packed in crates shows that the former arrived with less than half the percentage of decay, or three per cent for the carefully handled as compared with 6.8 per cent for the commercially handled. On the third day after arrival, the carefuly handled lots had developed 5.4 per cent, about the limit for marketable condition at a fair price. On the fifth day after arrival, the carefully handled fruit had reached the limit 10.2 per cent while the commercially handled had passed far beyond the limits of commercial sale. These figures, while very impressive; do not really tell the whole story. Included in the averages, of the commercially handled are the extremes of ordinary handling. Many of these reached as high as fifteen and some showed twenty per cent decay on arrival, while there were also a few commercial lots which arrived with as low or even lower percentages of decay than developed in the special lots handled by the department investigators.

\section{The Value of Careful Handling.}

Two questions naturally arise: What constitutes careful handling and will it pay to go to extra trouble and expense in preparing the fruit for shipment? In carrying out the investigations, nothing was attempted in the special careful handling which would not be practicable in ordinary commercial practice. Careful handling consisted in picking the bunches with some care to avoid bruising or crushing and all the lifting or moving of the bunches was done by means of the main stems. The bunches were carefully laid, not dropped, into the field boxes, which were filled only one layer deep. In moving the field trays or boxes, care was used to set them down gently instead of roughly dropping or otherwise jolting them. All hauling was done on wagons with springs. Special care was used in "culling" to remove every injured or otherwise unsound berry and not to injure others, always as far as possible handling the bunches by holding the main stems. The culling carefully done, the bunches were carefully but firmly placed in the baskets, always avoiding crushing or bruising. About ninety per cent of the injuries to grapes occur at the pedicels of the berries; in some varieties a slight bending aside of the berry being all that is necessary to cause a crack or break to occur beneath or at the side of the pedicel. A very slight injury is sufficient to allow the decay fungus to gain entrance into the fruit.

The most impressive answer to the question relating to the practicability of careful handling under commercial conditions is the fact that many growers are handling as carefully as the Department investigators and their fruit arrives in the market in sound condition.

In order to show the relationship existing between careful handling and soundness under actual commercial conditions, the data shown in Table III are presented.

* The results of the grape storage investigations were published a year ago in Eulletin 35 of the U. S. Dept. of Agriculture. 
TABLE III.-Percentages of decay in Tokay grapes, packed by careful and careless handlers, on arrival at New York, and after holding in market one week.

Careful Commercial Careless Commercial Handling. $\%$ Decay

On arrival at New York 1.0 Handling.

Three days after arrival $\%$ Decay

Five days after arrival.

Seven days after arrival

The figures presented were all obtained from shipments of grapes packed under commercial conditions by the ordinary packers and handlers. The lots were divided into two classes, the subdivision being based upon the character of the work being performed. The same number (5) of growers or packers are represented in each lot; therefore the figures are not the extremes of individual handling but are the averages found in the different vineyards. Those represented in the class of careless handlers were found to be so by close observations and those included under the category of "careful" handlers were likewise found to be doing careful work. In this connection it should be mentioned that the growers represented in the "careless" class consistently receive poor returns and their fruit was rated as being of poor carrying quality, while the fruit of the growers represented in the "careful" class had a reputation for uniformly good carrying qualities, and the return to the growers were likewise high.

The figures presented in the table show a consistent relationship between the carrying and market-holding qualities of the fruit handled and packed by the different growers. The fruit shipped by the careful growers arrive in New York with only one per cent decay, while that of the careless packers showed 8.9 per cent decay. The former is well within the limit of commercial soundness, while the carelessly handled lots with an average of 8.9 per cent are near the limit of commercial sale, and would have to be sold immediately and consumed quickly. Such fruit would not find ready sale except at a low price.

The after-arrival behavior of the two classes of fruit is of greater importance than the condition on arrival, from the standpoint of the possibility of marketing the different lots to advantage. The lots packed by the careful handlers had barely reached the commercial limit of soundness five days after arrival, while after the same length of time the carelessly handled lots had gone far beyond a condition of marketability. After holding a week, the carefully handled fruit had not reached the condition of decay shown by the carelessly handled on arrival. The influence of careful handling upon market-holding quality after arrival is thus effectively shown. The advantage of this superior market-holding quality cannot be too strongly emphasized.

Naturally, an increase in the cost of handling is necessary in order to obtain careful work. Just how great an increase is necessary could not be determined, but the cost is insignificant when the benefits obtained are considered. If the matter be considered from the standpoint of the difference in decay between careful and commercial handling, the quantity of fruit actually saved will more than compensate for any increased cost. Using the 
average percentages shown in Table II, the difference between careful and average commercial handling is 3.8 per cent. This means a saving of nearly the equivalent in four crates of fruit in each hundred shipped. In a carload the saving would be about thirty-six crates, or expressing it in terms of carloads, the difference amounts to a loss of fruit equal to one car-load in twenty-seven and a half. If the figures given in Table III are used in making a similar comparison, the showing is even more impressive, especially as the data were all obtained from lots of fruit handled under actual commercial conditions. The difference in the average percentages of decay found in the carefully and carelessly handled lots of Table III is 7.9 per cent, or a saving of nearly eight crates in each hundred, nearly seventy-eight crates in each car-load, or a loss of one car-load in twelve and a half. The savings by avoiding these losses can be computed in terms of money value, but a much larger return is obtained in the value of a good reputation for soundness which lots arriving consistently with only slight decay and holding in sound condition after arrival soon attain with the buyers. The value of such a reputation cannot be determined in actual money value. It is easy to see, however, that it means a premium either in increased demand or a price in excess of ordinary market quotations. Instead of doubting the profitableness or wisdom of handling with sufficient care to insure arrival in sound condition, one may wonder whether in the long run it will pay to handle in any other way.

\section{Influence of Handling Methods on the Occurrence of Decay in Different Parts of the Refrigerator Car.}

The data obtained from the experimental shipments may be analyzed from the standpoint of the relationship between handling methods and decay found in different parts of the car. As is well known, fruit which is shipped in the upper tiers of the load do not carry as well as that which is placed at or near the floor. The commercial grape crate measures five inches in depth or height, and in order to obtain the minimum car-load weight required by the transportation lines, the crates must be stacked nine high. These layers are designated as tiers, those on the floor are known as the first tier, those on top the ninth or top tier. In the experimental shipments each series had crates on the first and ninth tiers or on the bottom and top tiers of the load.

On account of the limitations of traffic requirements and expense, it has not been practicable to construct refrigerator cars for general use along the most efficient lines, or to use the highest type of insulation. In the cars at present in use, there is a considerable heat leakage through the walls of the car and this heat affects the air of the car, the warmer air rising to the top and accumulating in a stratum above the fruit. The difference in temperature between the top and bottom of the car is further aggravated by the sluggish circulation of the air within the car. The refrigeration or cooling of the car and its contents depends upon the natural circulation of the air within the car due to the difference in temperature of the air currents in the ice bunkers and in the body of the car. The refrigerator cars now in use in the United States are equipped with end ice bunkers of a combined capacity of five tons of ice. When the bunkers are filled with ice, the cold air within the bunkers flows downward, creating a current through the ice. This cold 
current flows outward along the floor of the car, and absorbs heat from the fruit packages. As it warms it rises to the top of the car and circulates back to the ice bunkers where it is again cooled by the ice. The rapidity of the circulation of the air currents within the car is thus greatest at the beginning when the difference in temperature of the car within the bunker and the car body is greatest. As the fruit cools this temperature difference becomes less, and the movement of the air currents becomes more sluggish. The temperature of the air is always considerably $\left(5^{\circ}\right.$ to $\left.10^{\circ}\right)$ higher at the top of the load, and the fruit on the top tiers of the load is thus subjected to a considerably higher temperature while en route than the fruit on or near the floor.

The fruit from the top tiers frequently arrives in market showing considerable deterioration while that from the bottom tiers may be in sound condition. For this reason, growers prefer to have their fruit loaded on the bottom layers or tiers, and shipping companies have difficulty at times in satisfying all their patrons. Obviously, all can not have their crates placed in the lower part of the load. When the investigations of the decay in grapes were begun, some objections were made by shipping companies against a study of the behavior of fruit loaded on the bottom and on the top tiers, on the ground that the results might increase their difficulty in satisfying the owners of fruit which had to be loaded on the top layers. Instead of increasing the difficulty of shippers in this respect, the results are really beneficial in that they show that the difference in temperature is not the only factor governing the difference in the condition of the fruit. This is conclusively shown when the results are analyzed. Table IV shows the average percentages of decay found in crates of Tokay grapes loaded on the bottom and top tiers of the loads in all the shipments made during an entire shipping season. The "Commercially Handled" lots were those obtained from ordinary shipments, the "Carefully Handled" were picked and packed by the Department investigators.

TABLE IV.-Average percentages of decay in commercially handled and carefully handled Tokay grapes, packed in crates, loaded on the bottom and top tiers in refrigerator cars, and shipped to New York City.

\begin{tabular}{|c|c|c|c|}
\hline \multicolumn{2}{|c|}{ Carefully Handled } & \multicolumn{2}{|c|}{ Commercially Handled } \\
\hline Bottom & Top & Bottom & Top \\
\hline Tier & Tier & Tier & Tier \\
\hline$\%$ Decay & $\%$ Decay & \% Decay & \% Decay \\
\hline 0.6 & 1.4 & 3.6 & 8.4 \\
\hline 1.8 & 3.2 & 7.2 & 11.1 \\
\hline 3.5 & 6.7 & 12.0 & 19.2 \\
\hline 5.0 & 12.5 & 15.2 & 19.8 \\
\hline
\end{tabular}

The figures shown in Table IV are presented to establish the general principle that the type of handling given the fruit in preparing it for shipment has an important influence upon its behavior under the varying conditions of temperature within a refrigerator car. While there is higher decay on the top tier of the load both in the fruit given ordinary commercial handling and that handled with special care, the results obtained from the experimental shipments show that the difference between top- and bottom-tier 
fruit is much greater under ordinary commercial handling than in the carefully handled lots. The latter arrived in excellent condition on the top tier (0.6 per cent) as well as on the bottom (1.4 per cent). Under ordinary commercial handling only the packages loaded on the bottom tiers arrived with a decay percentage (3.6 per cent) below the commercial limit. The toptier fruit with 8.4 per cent decay was beyond the five per cent limit, and was fit for only immediate sale and consumption. Looking at the figures presented from another standpoint it will be seen that the carefully handled fruit carried better and held in market after arrival in much better condition when loaded on the top tier than the commercially handled lots loaded in the more favorable position at the floor of the car.

TABLE V.-Average percentages of decay in Tokay grapes under careful and careless commercial handling loaded on the top and bottom tiers of refrigerator cars and shipped to New York.

Careful Commercial

\begin{tabular}{ccc}
\multicolumn{2}{c}{ Handling } \\
Bottom & Top \\
Tier & Tier \\
$\%$ Decay & $\%$ & Decay
\end{tabular}

On arrival at New York

Three days after arrival

Five days after arrival.

Seven days after arrival

$\begin{array}{ll}1.3 & 1.8 \\ 2.2 & 4.8 \\ 4.3 & 7.1 \\ 7.3 & 9.3\end{array}$

Careless Commercial

Handling

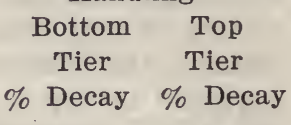

6.7

12.1

10.5

17.3

14.3

28.9

25.2

35.2

Table $\mathrm{V}$ is compiled from the records obtained entirely from shipments of fruit given ordinary commercial handling. The lots were divided into two classes, those from packers handling carefully and those packed by more or less careless growers and packers. The same number of shipments from the same number of growers are included in each class. A glance at the figures in the table is sufficient to indicate the consistency of the results with those presented in Table IV. There is a very wide difference between carelessly handled fruit loaded at the top and bottom tiers of the car, while the difference is much less or only slight with carefully handled lots.

These figures show the important influence the type of handling given the grapes in preparing them for shipment has upon their carrying and market-holding qualities. Moreover, the effect of the higher temperature at the top of the car is more unfavorable in fruit under conditions of careless handling than is the case with carefully handled fruit. In other words the difference between the top and bottom tiers in the cars becomes of less importance when the fruit is packed without injury. From the standpoint of the commercial shipper, these results are of the greatest importance. If he could be sure that all of the grapes offered him for shipment were packed without appreciable injury, he need not question whether they were placed on the bottom or top tiers of the load. 


\section{PRE-COOLING.}

The term "Pre-cooling" has been applied to a system of preparing fruits for shipment in which the initial temperature is reduced promptly and rapidly in advance of shipment. Probably no innovation in the handling of a food product has received wider discussion than has the use of pre-cooling since the work of the United States Department of Agriculture first brought it prominently to the attention of fruit growers about eleven years ago. The first application of pre-cooling to fruits was made by Parker Earle, the pioneer shipper of fruits under refrigeration in 1866, in cooling strawberries before loading them for shipment from southern Illinois to Chicago. This first work was done by placing the packages of berries in an iced chamber until they were thoroughly chilled. Mr. Earle reports that his first efforts along this line were very satisfactory, but on account of the lack of refrigerator car equipment, the extension of the process was not very rapid. The next step in the application of pre-cooling to fruit shipments was begun by Powell, then in charge of the United States Department Fruit Transportation and Storage Investigations, in the experimental pre-cooling of peaches shipped from Georgia. This work was begun in 1904. The results were very encouraging and showed that with proper cooling and equipment peaches from Georgia could be transported to New York with minimum decay and deterioration. The investigations of the Department of Agriculture were later extended to oranges and other fruits in California, and the work is still in progress with other fruits. The process of pre-cooling has received rather wide commercial application, especially in California, where both the Southern Pacific and the Santa Fe Railway Systems have constructed large plants for the pre-cooling of fruit after loading on the cars. In addition, a number of plants designed to pre-cool the fruit before loading have been erected by associations of fruit growers, chiefly in southern California for the precooling of oranges.

\section{Systems of Pre-cooling.}

There are two systems of pre-cooling: (1) Car Pre-cooling, and Warehouse Pre-cooling.

In the car pre-cooling system, the cooling is accomplished by forcing large volumes of very cold air through the loaded cars.

The warehouse system derives its name from the fact that the cooling is done in warehouse rooms, with special refrigerating capacity, before the fruit is loaded.

It will not be possible to give a detailed discussion of the relative merits of the two systems. It will be easily seen that the car pre-cooling system is the function of the transportation lines, as it necessarily involves the handling, switching, and movement of cars and trains. It also requires machinery of very large capacity in order to do the work as rapidly as possible.

The warehouse system is the only one which can be operated advantageously by the grower or packer or associations of growers or packers. Its only disadvantage lies in the fact that the fruit must be given an extra 
handling. This is wholly overcome, however, by the advantage of more uniform cooling and more prompt application of the process than is practicable with the car cooling system.

\section{Investigations of the Effect of Pre-cooling on Table Grapes.}

The effect of pre-cooling on grapes was thoroughly studied by the Department investigators during several seasons at Lodi, and one season at Fresno, California. During three seasons at Lodi, the pre-cooling was accomplished by means of a portable refrigerating outfit constructed by the Department. The work of these three seasons was confined to car pre-cooling. The plan followed was to circulate cold air through the loaded car until the average temperature of the fruit in the car reached about $40^{\circ} \mathrm{F}$. In each car cooled by the Department men, a series of marked crates were placed, some on the bottom and some on the top tiers of the load. After the cooling was finished the cars were forwarded to New York, where the marked crates were carefully inspected by Department representatives and the decay was carefully determined. Duplicate series of crates of grapes from the same vineyards were placed and shipped in non-precooled cars to serve as checks. Not less than ten cars were thus handled each year.

In Table VI the data obtained from the three years shipments are presented together with the corresponding records obtained from the non-precooled check shipments. The percentages of decay found on arrival at New York and two and three days after arrival are shown, the fruit being held in the meantime under ordinary market conditions.

TABLE VI.-Average percentages of decay in pre-cooled and non-pre-cooled commercially handled Tokay grapes, shipped during three seasons from Lodi, California, to New York City.

\begin{tabular}{|c|c|c|c|c|c|}
\hline & Pre-Coolir & & & n-Pre-Co & led \\
\hline & 2 Days & 4 Days & & 2 Days & 4 Days \\
\hline On & After & After & On & After & After \\
\hline Arrival & Arrival & Arrival & Arrival & Arrival & Arrival \\
\hline$\%$ Decay & $\%$ Decay & $\%$ Decay & $\%$ Decay & \% Decay & $\%$ Decay \\
\hline First Season........ 6.6 & 12.7 & 16.8 & 7.5 & 10.9 & 15.1 \\
\hline Second Season..... 7.5 & 11.1 & 15.1 & 8.7 & 12.2 & 17.5 \\
\hline Third Season....... 6.5 & 12.2 & 16.7 & 8.1 & 12.8 & 17.0 \\
\hline Averages........ 6.5 & 12.0 & 16.2 & 8.1 & 12.0 & 16.5 \\
\hline
\end{tabular}

Only the records obtained from the cooling and shipment of commercially handled crates are presented because it is the effect of the treatment upon the carrying and market-holding qualities of the fruit handled under ordinary methods of packing that interests the growers. It has already been shown what can be accomplished through the medium of careful handling alone. The additional application of pre-cooling to carefully handled grapes is an added safe-guard. But the effect on fruit packed and shipped under ordinary commercial conditions is the crucial test of the value of the work. 
The averages for the three seasons show remarkable uniformity throughout. The grand averages for all shipments of the three years are an index of the effect of the pre-cooling treatment upon this class of fruit. The differences in percentages of decay are only slight, although in favor of the pre-cooled lots. The decay in all lots is too high for good marketable condition. The average percentages found in the fruit two days after arrival are identical, and after four days very nearly identical in pre-cooled and nonpre-cooled shipments. The slight difference between 6.5 per cent and 8.1 per cent in favor of the pre-cooled shipments on arrival is not sufficient to justify the extra expense of the pre-cooling process, from the standpoint of the effect upon the carrying quality of the fruit. In fact, in a number of individual shipments the average percentages of decay were actually higher than was found in corresponding non-pre-cooled shipments. This does not necessarily mean that the pre-cooling of grapes is harmful. It does mean that there are other factors which must be taken into consideration, and precooling alone cannot be depended upon to avoid excessive deterioration in grape shipments.

One possible explanation for the increase in decay in pre-cooled shipments over non-pre-cooled and the slight differences shown in the averages was thought to be the uneven cooling which necessarily takes place in the cooling of the different parts of the car after it is loaded. It is easy to see that it is practically impossible to have the air blast reach uniformly to all parts of the load. The crates must be closely stacked, thus interfering materially with the circulation of the air currents within the car. The fruit most exposed to the blast will be cooled below the freezing point of the fruit long before the crates in the body of the load are materially affected. Therefore, as soon as the exposed crates reach the danger point, the work must cease. Equalization of the temperature conditions must then be depended upon to bring the average temperature of the load down to the desired point. It is conceivable that the extra cooling and following rise in temperature might be detrimental to the keeping quality of the affected packages. It has not been possible actually to test this hypothesis by experimental data. During one season, however, a comparison of car pre-cooling with the warehouse system was made, but the results did not show that there was any material gain by handling the fruit in this way.

Later investigations of the temperature conditions within the refrigerator cars while en route indicate that the relative inefficiency of the insulation used in the cars may be responsible for the inconsistent results. Temperature records taken of cars en route show that there is a considerable leakage of heat through the insulation, resulting in a rather rapid warmingup of the fruit on the top tiers. The rise in temperature on these top tiers is sufficient to account for the increase in the decay, especially where the fruit has not been handled with sufficient care to prevent injury. A better type of refrigerator car with better insulation is a necessity before the full benefits of pre-cooling can be obtained.

The most impressive lesson to be derived from these rather negative results, however, is the fact that pre-cooling cannot replace proper handling. It cannot be depended upon to offset the decay which inevitably follows injuries to the fruit. It is more expensive than careful handling, and in addition is less efficient in preventing decay. Pre-cooling is, however, a legiti- 
mate and effective added insurance against decay due to many unforeseen conditions arising while the car is in transit, and from that standpoint is alone worth while; but in no sense can it be regarded as a substitute for proper, careful handling methods.

\section{Local Demonstrations.}

A duplicate of each of the experimental series shipped to New York was prepared and held in a refrigerator car side-tracked at Lodi, and iced as far as possible to imitate actual transit conditions. The different lots were held in the iced car for a period of ten days, the average time of the transcontinental trip. The series were then withdrawn and a careful inspection and determination of the decay, injuries and shelled berries were made just as was done in New York with the fruit actually shipped. Inspections were likewise made on the third, fifth and seventh days after withdrawal from the car. This local demonstration was made in order to enable the growers and packers actually to see the condition of the fruit handled in different ways. The plan followed was to invite the growers and packers to see the inspections and demonstrations. Very few of the growers and fewer of the packers ever have the opportunity of seeing the condition of their fruit after it has been through the period necessary to reach distant markets. Many expressed disbelief in the occurrence of decay in their fruit, thinking that the reports of losses due to this cause were mere subterfuges on the part of the receivers and purchasers of the fruit to depress the prices paid the producer.

The demonstrations of packed fruit handled in different ways were attended by hundreds of growers and packers during the shipping seasons, and for the time being, at least, the great differences shown in the lots handled in different ways served as very impressive object lessons.

This form of local demonstration was found to be an effective means of impressing upon the various agencies engaged in the activities of grape growing, packing and shipping the importance and significance of the lessons learned from the results of the work. As stated above, many doubted the existence or occurrence of decay. Those who were in a position to know that decay occurred, frequently accepted it as the inevitable, which like the Scourges of Old were to be accepted with Christian fortitude and meekness. It is safe to say that little or no impression could have been made upon the industry without those engaged in the various operations having an opportunity actually to see the results and judge for themselves the importance of the various factors brought out. There is nothing like an ocular demonstration in impressing the layman.

It was thus the policy of the Department investigators to keep the industry fully acquainted with the progress of the work and the results were imparted just as rapidly as accurate and consistent records were obtained. In addition to the ocular demonstrations referred to, meetings were held at the close of the seasons, and in these sessions the results were fully explained to the assembled growers. The data were carefully analyzed and systematized and the importance of the various facts resulting therefrom were fully discussed. Graphic presentations of the data, arranged and compared from different viewpoints were used in the discussion. This was found to be a most effective method of presentation as in no other way could the relationships of the various factors be so clearly shown. 


\title{
THE INTELLIGENT BLENDING OF WINES.
}

\author{
By HIRAM S. DEWEY,
}

President of the American Wine Growers' Association.

The blending of wines is really the art of wine-making, which comes to a few men after many years of practical experience. I once heard a German, 80 years old, who had been a wine-maker all his life, say, "A man must live with his wines as a mother lives with her baby, to know them thoroughly. Wine is ever changing as a baby does as it grows."

I $a m^{\circ}$ not referring to wines which are made in great vats of thousands of gallons, but wines that are made in small quantities, such as Château wines of France, or the Schloss wines of Germany or private estate wines of Italy, where grapes are gathered, sorted and stemmed most carefully, then fermented in small standards where they can be turned three times daily to thoroughly dissolve the pulp and skins, in order to extract the proper color, acid and tannin and watch the development of the Oenanthic ethers, which come suddenly, and when they come the juice must be pressed at once (not to lie over night) as these ethers pass off quickly, then your wine will be soft and delicate in bouquet. This is not determined by chemistry.

Understand me, I am not underrating the advantages or requirements of the chemist, for his science is absolutely necessary in the large wine cellars, but quoting from Prof. Bigelow, the first assistant chemist of Dr. H. W. Wiley, while he was the head of the United States Food Laboratory, Prof. Bigelow remarked to me:

"What we need greatly in this laboratory is a wine-maker with a cultivated taste and smell. Chemistry carries us just so far and no farther, when we are dropped off as from a precipice. We require a cultivated sense of smell and taste to determine the excess or lack of different properties in a wine, and what different varieties of grapes or wines will blend or marry, so as to develop into a fine wine."

We should realize the necessity of blending wines from different sections. California grapes in general are high in saccharine and low in acid; some grapes are very strong in bouquet, others flat. So with Eastern grapes, most of them are high in tartaric acid and disproportionately low in saccharine.

Our most valuable grapes in the East, for which we pay $\$ 80$ to $\$ 100$ a ton, are very small berries with large seeds and very little juice, where it takes from eighteen to twenty pounds to get one gallon of juice. This I know astonishes some of the gentlemen within the sound of my voice. They may say how foolish to pay such prices for grapes. No, gentlemen, we are not foolish. This wine is our doctor, it is not good alone, but how a little of it helps and lifts up the weakling, experience of years only can tell. The American wine business will never reach the high standard and reputation of European wines until we realize that fine wines must be made and aged with constant watchful care and blending in small quantities. 
Many of you remember how your former president, Mr. Percy T. Morgan, spent years in selecting choice wines and had them given the most careful and watchful care, then had them bottled and stored away in one of your cellars here in San Francisco, to age in the bottle, when your dreadful fire destroyed all of his years of labor. That was one of the greatest calamities that ever visited the California wine business, as he intended to distribute these choice wines in the large cities, in wine stores, not saloons. This is what we have been doing for years.

I wish to quote a few extracts from the official report of Cav. Guido Rossati, Minister of Agriculture and Horticulture, who spent several years in America under pay of the Italian government, to report on the grape growing and wine making of America.

"I was surprised at the fineness of two types, which I must confess I never expected to find in wines made from American grapes. One is a Burgundy, eight or ten years old, made from Cynthiana grapes, the equal of which I never found in any part of the United States. The other is a Port, greatly superior to those produced in any other part of the United States.

"By the most careful and strict cleanliness in the fermentation, wine making and technical operation, and by long aging of their product, thus helping and not coercing nature, or substituting artificial means, which experience has proved of limited benefit and not desirable.

"They have in a special way the merit of having succeeded in making fine and delicate wines from American grapes, which is greatly to their honor and credit. To this they came by a very careful and wise choosing of vineyard cultivation of grapes.

"Besides these types they produce exquisite white wines of Rhine, Moselle and Sauterne type, also Clarets, Burgundy, Sweet Wines and Unfermented Grape Juice.

"I found their Superior Old Port delightful. It has several great advantages over other Ports. It has a brighter color and it can stand aging better. This wine compares favorably with some of the very best wines of the Douro Valley in Spain."

Some of our Eastern wines are improved by blending with a little California wines; not all, but some. There are few large wine cellars in the East which do not use.some California wines for blending, and right here I wish to state that the time is not far off when you gentlemen will require some of our Eastern wines to blend for the highest types of wines you will produce.

It was our privilege only a month ago, at one of our monthly luncheons, to drink some white and red wines which Mr. Morgan had bottled before the fire, and I want to state that they would grace the table of any gentleman. Make such wines and then ask a price to justify the expense and you will have a great market.

In conclusion let me extend to you the hand of fellowship and let the East and West come closer together with confidence, not distrust or jealousy, but for the uplifting and honor of our industry. 


\section{A NEW UTILIZATION OF A BY-PRODUCT OF THE GRAPE.}

By GUIDO ROSSATI.

Enotecnico Governativo Italiano at New York, N. Y.

It is a fact, often recurring in industrial enterprises working on a narrow margin, either because of competition or of other factors, that the manufacturer depends for his profit more from the by-products than from the primary product itself of his industry. The meat packers of Chicago, of whom it is proverbially said that they utilize everything of the hog except the squeal, afford, perhaps, one of the most striking examples of thorough utilization of such valuable material as they operate with.

The wine industry, with which I am concerned for my subject, is fortunately one of those that, notwithstanding the inevitable great variability of cost of its staple product, depending chiefly on the outcome of the crop, maintains in comparison with other agricultural industries, fairly satisfactory returns on the basis of its main product, viz., wine, provided vinification is accomplished by rational methods, so as to insure a sound article, of standard quality.

Yet it must be recognized that, where wine making is carried on on an important. scale, a rational utilization of the by-products of the grape can add considerably to the balance sheet of the wine maker. And when it is considered that, in this case, with the economic welfare of the wine maker is concerned to a certain extent that of other industries, such as the tartaric, for which the grape is as yet the only source of supply of the necessary prime material, while the consumption of tartaric products is constantly developing, it is apparent how desirable it is that of the precious ampelidae nothing should go to waste, or to less remunerative forms of utilization than modern ingenuity can suggest or devise.

It is not within the province of my subject to treat either of the distillation of grape and wine residues, for the production of alcohol or brandy, or of the extraction of cream of tartar, or tartaric acid, from the pomace and wine lees, neither of the manufacture of oil and tannic acid from the grape seeds, nor of the preparation of feed cake for cattle frum the grape pomace, etc., which are the usual forms of utilization of the resicues of vinification. Each of these lines of industrial exploitation would require more space and time than is possible to give within the limt of a short paper, like this, in order to be either adequately treated, or even only fairly touched upon.

I shall, therefore, confine myself to a suggestion in connection with the utilization of one of the by-products of the grape, that seems to be feasible, and upon which, so far as I am aware, no one before has called the attention of the wine makers. I mean the utilization of grape stems in the manufacture of paper.

The grape stem is essentially a fibrous material, containing, when green, about 20 per cent of fiber, and when dry, about 40 , while its branching conformation and wiry consistency, sharing in this particular the character of 
the vine tendrils, with which it bears a certain morphologic analogy, would appear to make it a desirable material for the purpose stated. A summary average analysis of grape stems shows their composition to be as follows:

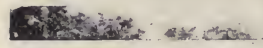

GREEN STEMS (1).

Per Cent

Fiber (about) 20

Tannic acid from 1 to 2

Resinous matters (about) 1.5

Potassium bitartrate from

Free acids. from.

Mineral matter. from

Moisture

from

0.6 to 1.2

0.3 to 0.9

2 to 2.5

74.9 to 73.4

DRY STEMS '(2).

Fiber of cellulose.

Tannic acid

Pectous matter

Sugars

Cream of tartar.

Free tartaric acid.

Mineral matter

Moisture

Total

100.00

Grape stems are not utilized at present for any particular purpose, and end usually in the manure heap, save when they are not separated from the pomace in wine making, in which case the pomace after having been pressed, goes to the distillery for distillation and subsequent treatment for extracting the raw cream of tartar, of which grape stems contain, if green, according to Ottavi Marescalchi, from 0.6 to 1.2 per cent; if dry, according to Girard \& Lindet, about 3.37 per cent.

In rational wine making the separation of the stems, the presence of which in the fermenting mass is undesirable, chiefly because of their imparting greenness and unpleasant acidity (racemic and tannic acids) to the resulting wine, is a recognized necessity and an established fact, the stems being separated by means of a stemmer, usually attached to the grape crusher. As a rule the stemming, crushing, and, if necessary, the cutting of the grapes, is accomplished in one operation by one single machine, the separated stems being conveyed, through a chute, outside of the crushing room, where they gather in a heap, which is removed from time to time.

Stems represent, as a rule, from 3.5 to 4.5 per cent of the grapes vintaged, while skins, seeds and other solid matter of the grapes, before they are fermented, represent from 12 to 18 per cent of the mass; the total solid matter of the grapes averaging thus from 15.5 to 22.5 of the whole mass.

The dry pomace of unstemmed grapes contains on an average 28 per cent of stems, 40 per cent of skin and 24 per cent of seeds; while the dry pomace of stemmed grapes is made up of 33 per cent of seeds and 67 per cent of skins.

(1) Ottavi Marescalchi, I residui della vinificazione, Casale 1901, p. 6.

(2) Girard \& Lindet (Acc. od Sciences, 1898). 
Fermented pomace, as it comes from the wine press, contains usually from 40 to 50 per cent of solid matter, the balance being represented by wine; the same, not pressed, contains about 35 per cent of solid matter and about 65 per cent of wine.

On the above stated average bases, which, of course, vary more or less according to variety of grape, climate and vintage, it will be easy to estimate in each particular instance the amount of stems obtainable.

Any idea of the theoretical world supply of this raw material, at present practically wasted, which, of course, would represent a far greater amount than actual supply, and, needless to state, is of impossible realization for obvious reasons, and chiefly because stemming is not yet the rule in wine making, while in many cases the freight problem would also be an unsurmountable difficulty, is given by the following table, in which the theoretical supply is estimated, for the sake of argument, on the basis of the wine production in the various wine growing countries of the world, as indicated in year 1909, representing an all round average year.

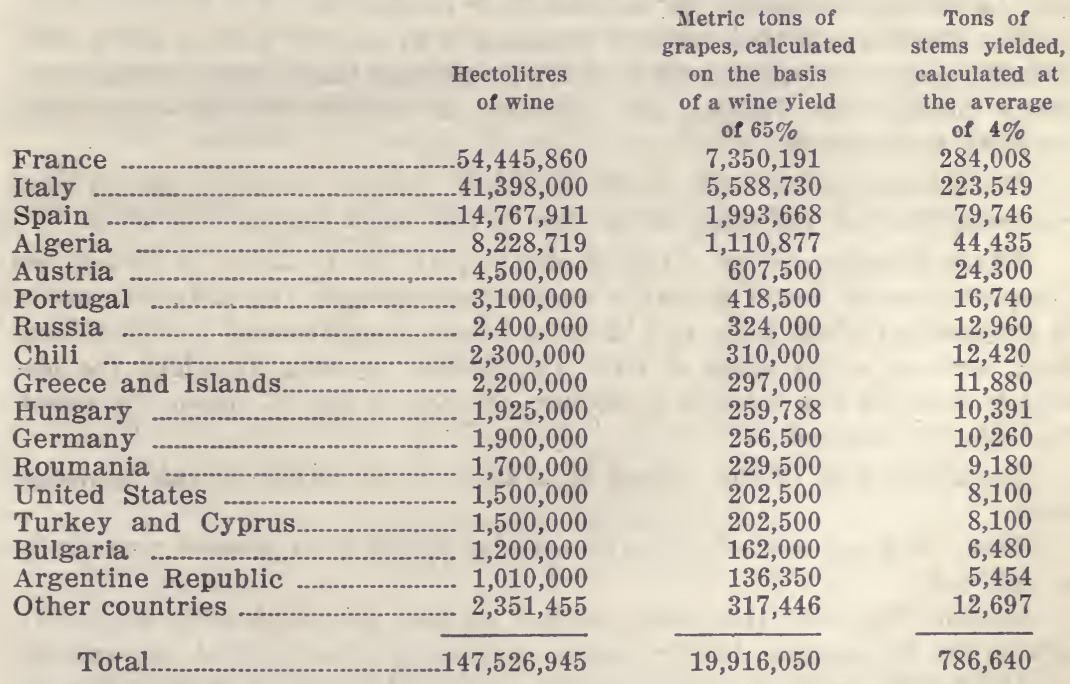

The (practically) 800,000 tons of theoretical supply of this raw material would mean, on the basis of a 20 per cent content, a supply of 160,000 tons of cellulose.

Freight, which represents an important item in the suggested utilization, so much so as to be possible only where paper mills exist in or within convenient distance of the district of supply, could be reduced in two ways:

First-by a partial drying of the material, such as is obtainable through natural agents, viz: sun and air drying, which reduces its bulkiness.

Second-By pressing the stems into bales, which could be done either by means of the same presses used for pressing the fermented grapes, or by special hydraulic presses, as used in pressing hay, esparto grass, and similar products. 
The treatment of such material at the paper mill for its conversion into pulp would not differ practically from that followed in the working of esparto.

The stems, before being digested with caustic soda, could be boiled for some time in the digester, in order to recover the cream of tartar, which they contain, and which, upon cooling and standing of the liquor, would crystallize out in the usual way, as in the case of the working of pomace for the same purpose. The mother-liquor, if fuel is to be had cheaply, after it has deposited the cream of tartar, could be condensed for the preparation of tannic extract.

Supposing the stems have been packed in a dry condition, they would contain, according to Girard and Lindet's analysis, made on dry stems of the Aramon grape, 3.37 per cent of cream of tartar and 10.23 per cent of tannin; but a more conservative estimate based on Ottavi-Marescalchi's figures, would be from about 1 to about 2 per cent of cream of tartar, and from about 1.5 to about 3 per cent of tannin.

Of course, only part of these by-products could be recovered, but, I believe, in sufficient quantity to pay for their extraction.

The stems would then have to be boiled with caustic soda of convenient strength, under convenient pressure, for a sufficient time, to remove the nonfibrous constituents, leaving the cellulose in a more or less pure form, according to treatment.

The washing of the fiber in the hollander and the bleaching would next be accomplished in the same manner as in the case of esparto or straw.

Where sulphur can be obtained cheaply, as, for instance, in Sicily, the bi-sulphite process could probably replace conveniently the soda process in the preparation of the pulp, and likewise where electro-energy is within easy reach, such as in the north of Italy, the Kellner process, by which the material is digested in a solution of sodium chloride at $126^{\circ} \mathrm{C}$. under the action of an electric current.

The advantages of the suggested utilization lie mainly in the following facts:

First-The low cost of the raw material, which is at present practically not utilized.

Second-The fact that wineries are already provided with machinery suitable for its packing, thus reducing considerably the cost of its removal.

Third-The fairly abundant supply of said material in important wine producing countries, such as Italy, France, etc., and within a comparatively short radius.

Fourth-The possibility of extracting from the stems, without departing from the industrial process necessary for their transformation into pulp, the valuable by-products above stated, viz: cream of tartar and tannic acid.

Take, for instance, the case of a wine plant working, say, 300 tons of grapes daily for thirty days. There would be a production of 360 tons of stems, which, at nominal net price of $\$ 2.50$ per ton (a dollar more than its value in manure, and almost more than three times its value as represented by the price paid for grapes), would add something like $\$ 900$ to the revenue of the wine maker. Freight expenses would have to be added to this cost of origin. 
Estimating a yield of say 60 tons of cellulose, after allowing for a certain waste, and on the conservative assumption that the finished article should sell at the price of the cheapest wood pulp, to which revenue should be added the value of the cream of tartar and of the tannic acid extracted, there would, after defraying the expenses of production, be left in all probability a profit, provided freight was not above $\$ 2$ per ton, in the same manner as there is a margin the working of esparto, a material having an original cost from three to four times greater than the one I am speaking of, but yielding, of course, about two and one-half times as much fiber.

I have ventured the above as a suggestion, without going into the details, for which I am not prepared. This suggestion appears to me, however, worthy of being made the subject of further study and experiments, especially where grape stems could be concentrated at one point by cheaper water transportation.

While such utilization, as proposed, would increase the revenue of the winemaker and, by stimulating the elimination of the stems from the fermenting grapes, would improve the quality of the main product of the winery, viz: wine; it would also, in wine producing countries, assist, to a certain extent, in solving the engrossing problem of the scarcity of material suitable to the manufacture of paper.

I will conclude by leaving to the poet of the future the emotions of writing his verses on such inspiring paper as one so akin, in its origin, to the wherewithal he is wont to wet his lyre and to sing the success of this new industrial achievement.

\title{
RELATION OF THE MATURITY OF THE GRAPES TO THE QUANTITY AND QUALITY OF THE RAISINS.
}

\author{
By FREDERIC T. BIOLETTI,
}

University of California.

During a lecture to grape growers in 1912 at Fresno, the center of the world's raisin production, the speaker was asked: "At what degree of ripeness should raisin grapes be harvested?" Though posing as an expert, the speaker was obliged to acknowledge ignorance. The same question addressed to the audience, composed of many of the largest and oldest raisin growers of the region, met with a similar response. Opinions were advanced, but not facts.

According to some, the riper the grapes the higher the quality of the raisins. According to others, the degree of maturity made little difference, providing it had reached a certain minimum. In any case, it was claimed, the harvesting of the crop before the first rains and when labor was availble, were the controlling factors and quite overshadowed any slight difference of price that might be obtained by any possible increase of quality. No suggestion was made that the degree of maturity influenced, in any way, the amount of the crop. 


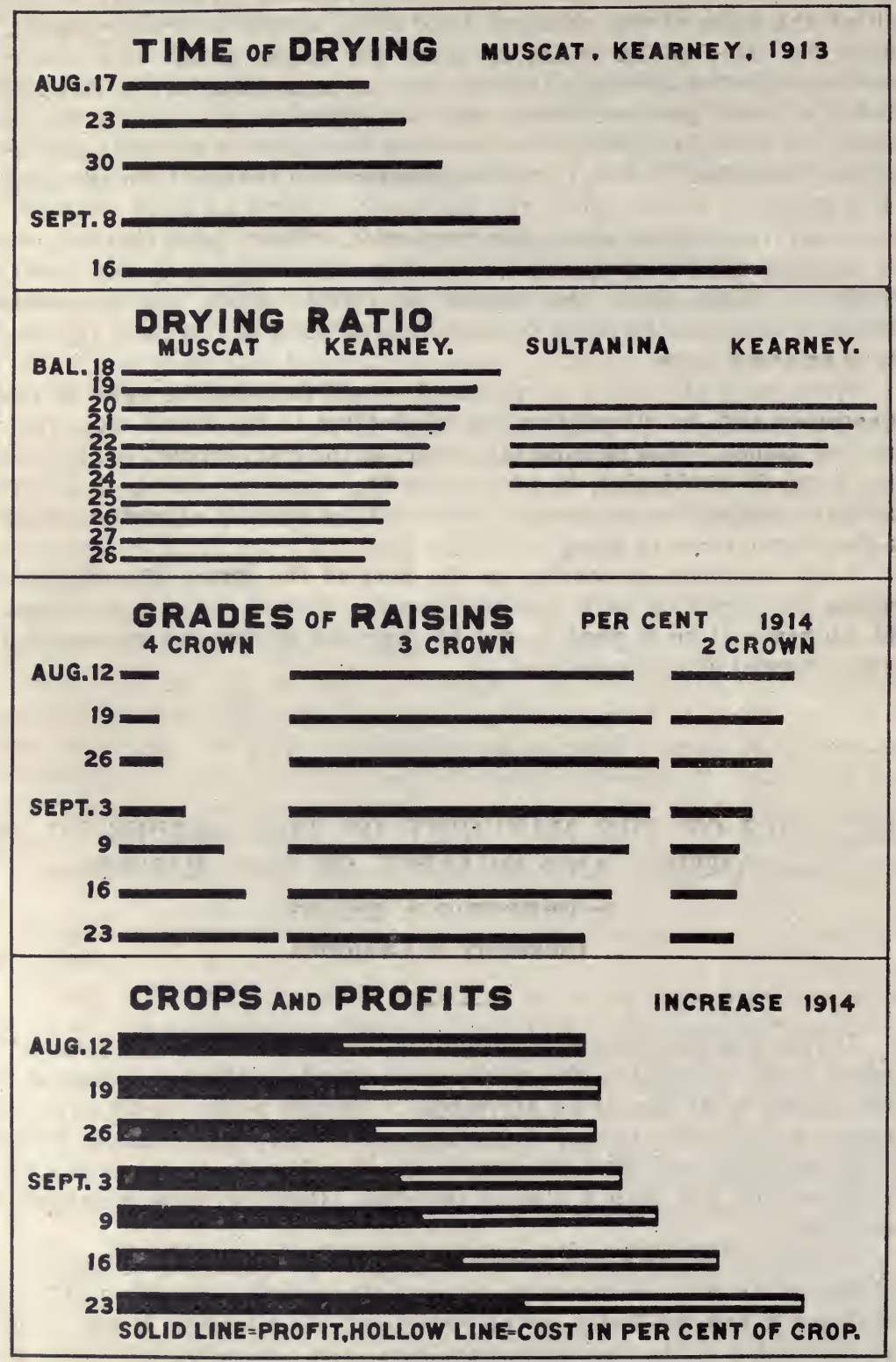


The concensus of opinion seemed to be that in a general way the riper the grapes the higher the quality and the higher the ratio of dried grapes to fresh. Whether this higher ratio represented an actual increase of dry matter or final crop, or simply a partial drying on the vine, was not discussed.

During the following season, 1913, an attempt was made by the California Agricultural Experiment Station to throw light on these doubtful points and, specifically, to determine the changes in drying ratio, time of drying, quality of raisins and quantity of crop with advancing maturity of the grapes.

The plan adopted was to gather five trays (110 pounds) of grapes when they reached about the minimum degree of ripeness at which it is ever attempted to make raisins, and to dry them by the usual methods adopted in the San Joaquin Valley. A similar amount was gathered thereafter every seven days and dried in the same way, as long as the weather permitted. These tests were carried out by Mr. A. E. Way at the Kearney Vineyard. The variety was the ordinary raisin grape, Muscat of Alexandria.

During the season of 1914 these tests were repeated at Kearney on a larger scale and similar tests at the same place made with Sultanina. Both varieties were tested in the same way also at Davis by Mr. F. Flossfeder.

1. Time of Drying. As the season progresses the days become cooler and the nights longer and as a consequence the time necessary for drying increases, as is shown by the following record.

\section{Table I-Muscat, Kearney, 1913.}

\begin{tabular}{|c|c|c|c|c|c|c|}
\hline & Bal. ${ }^{\circ}$ & $\begin{array}{c}\text { Date } \\
\text { Gathered }\end{array}$ & $\begin{array}{l}\text { Drying } \\
\text { Turned }\end{array}$ & $\begin{array}{l}\text { Time i } \\
\text { Stacked }\end{array}$ & $\begin{array}{l}\text { Days } \\
\text { Boxed }\end{array}$ & $\begin{array}{c}\text { Date } \\
\text { Finished }\end{array}$ \\
\hline$\ldots$ & 21.00 & Aug. 17 & 6 & .... & 13 & Aug. 30 \\
\hline $2 .$. & 23.90 & Aug. 23 & 6 & .... & 15 & Sept. 7 \\
\hline (................. & 25.50 & Aug. 30 & 9 & $\ldots$ & 17 & Sept. 16 \\
\hline - & 26.75 & Sept. 8 & 8 & 16 & 21 & Sept. 29 \\
\hline$(\ldots . . . .$. & 28.75 & Sept. 16 & 13 & 23 & 34 & Oct. \\
\hline
\end{tabular}

The process of drying required only about two weeks early in the season, but nearly five for the last picking in the middle of September. The drying of the last two pickings took place principally in the "stack," that is after the raisin trays had been placed one on top of another in piles of about ten trays. This, together with the cooler and shorter days, accounts for the greater time. Slow drying is favorable to quality as is also drying in the shade, such as occurs in the stack.

2. Drying Ratio. The number of pounds of fresh grapes required to make a pound of raisins is called the drying ratio. Estimates of the value of this ratio by various growers vary from 4.25 to 3.5. It depends on a number of factors. As the change of grapes into raisins consists essentially and principally in the evaporation of a large portion of the water, the chief factor is the degree of maturity of the grapes. The riper the grapes the more solid material they will contain and the less weight they will lose in drying. It is influenced also by the variety of grape, the compactness of the bunches, the percentage of stems and by the amount of loss in gathering, turning, boxing and hauling. 
Four series of tests were made at Kearney and at Davis with Muscat and Sultanina. The Muscats were gathered and dried at various degrees of ripeness from $18.6^{\circ} \mathrm{Bal}$. to $28.75^{\circ} \mathrm{Bal}$., the Sultaninas from $20.5^{\circ} \mathrm{Bal}$. to $25.6^{\circ} \mathrm{Bal}$. The results were fairly concordant except in the case of the Sultaninas where some of the raisins of the riper grapes were lost. The concordant results were averaged and the drying ratio at various degrees of ripeness calculated, as shown in the following table:

Table II. Drying Ratio-Grapes: Raisins (G/R).

(Calculated from experiment data.)

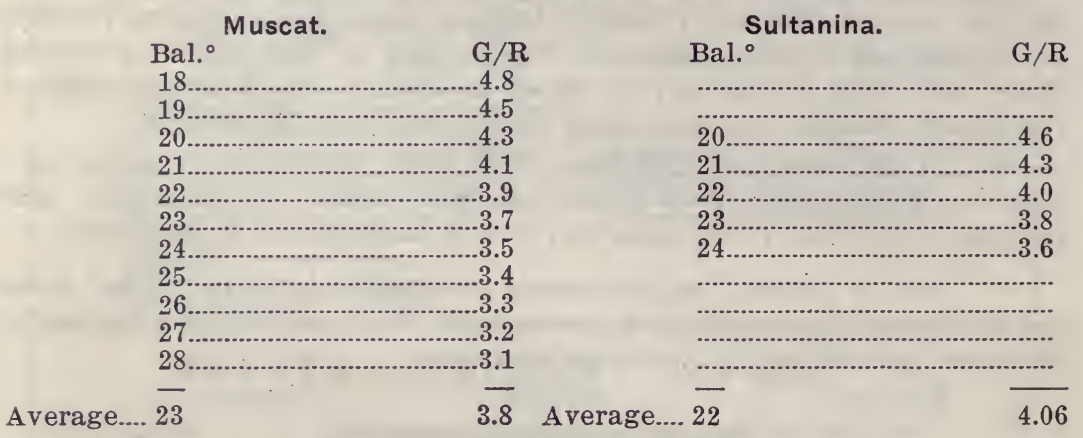

As very few of the raisins were lost in handling, these may be considered as minimum drying ratios at the various percentages of sugar. Under ordinary vineyard conditions the number indicating the ratios would be slightly higher, as it is difficult to avoid some loss of material during the various operations. The figures of the table include the weight of the stems according to the usual custom. The Muscat shows a slightly lower drying ratio than the Sultanina, owing probably to the presence of seeds in the former. The difference would amount to about 16 pounds of raisins per ton of fresh grapes in favor of the Muscat.

As the tests showed that first-class raisins cannot be made from the Muscats before they reach $25^{\circ}$ Balling, or from the Sultaninas below $23^{\circ}$ Balling, a drying ratio of 3.4 for the former and 3.8 for the latter should be the maximum. Ratios above these figures indicate either insufficient maturity of the grapes or losses of raisins in handling. If the gathering of the grapes is commenced when this degree of ripeness is attained they will be riper when the gathering is finished. The average drying ratio for the season should, therefore, be lower. An average drying ratio of about 3.2 for Muscat and of 3.6 for Sultanina may be considered excellent and indicating both full ripeness of the grapes and little loss in handling.

3. Quality. Variations in quality are much more difficult to estimate than those of quantity. From the point of view of the consumer there is no doubt that in all the tests the riper the grapes the higher the quality of the raisins. This was the unanimous verdict of all to whom samples were submitted. Samples were also submitted to expert raisin handlers and buyers. The opinions thus obtained were not quite so unanimous. All 
agreed that the Muscat raisins made from grapes below $25^{\circ} \mathrm{Bal}$. were more or less inferior. Some preferred those at $25^{\circ} \mathrm{Bal}$. and considered the raisins made from riper grapes less desirable commercially owing to their stickiness and deeper color. Others stated that there was little difference in value among those made after the grapes reached $25^{\circ} \mathrm{Bal}$. In the case of the Sultanina a similar difference of opinion was found.

The quality includes a number of factors, such as size, color, flavor and texture. Improvements in any of these factors usually accompany increase of size, if we confine our comparisons to the same variety of grape, the same locality and the same method of manufacture.

If we compare the various tests of Muscat raisins made at Kearney in 1914, in respect to the ratios of the various "crowns," or sizes produced, and use these ratios as measures of quality, we find a very regular increase of quality proportionate to the increase in ripeness of the grapes.

\section{Table III. Ratios of Grades ("Crowns") of Raisins (by Weight). Kearney, 1914.}

\begin{tabular}{|c|c|c|c|c|c|c|}
\hline Exp. & Bal. & $4 \mathrm{Cr}$. & $3 \mathrm{Cr}$. & $2 \mathrm{Cr}$. & Seedless & Waste \\
\hline $1 .$. & 18.6 & 7.45 & 65.95 & 23.32 & 1.62 & 2.10 \\
\hline 2. & 20.2 & 7.53 & 68.82 & 21.50 & 1.11 & 1.04 \\
\hline 3 & 21.8 & 8.26 & 70.19 & 19.03 & 1.51 & 1.03 \\
\hline 4 & 23.6 & 12.75 & 68.70 & 15.44 & 2.42 & .76 \\
\hline 5 & 24.0 & 20.26 & 64.76 & 13.00 & 1.41 & .57 \\
\hline 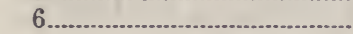 & 23.8 & 24.27 & 61.74 & 12.66 & .94 & .38 \\
\hline 7............................................... & 26.5 & 30.41 & 56.55 & 12.28 & .72 & .15 \\
\hline
\end{tabular}

Table IV. Average Weight of Various Grades (in Grams per 1000). Kearney, 1914.

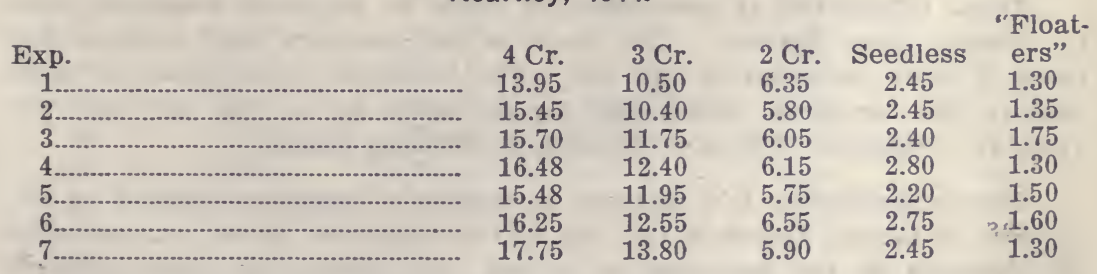

Improvement of quality with increasing ripeness is shown in Table III by an increase of over 300 per cent in the largest grade and a corresponding decrease in the smaller, particularly the smallest. This increase is both in size and in specific gravity, as it shown in Table IV by the regular increase of average weight of the $3 \mathrm{cr}$. and $4 \mathrm{cr}$. grades. In the smaller grades there is little or no change in specific gravity.

4. Increase of Crop. Thus as the grapes develop, they increase in size and in specific gravity, and the crop consequently increases in total weight. As the drying ratio at the same time diminishes, the increase in the weight of raisins is greater than in that of fresh grapes.

An estimate of the total increase of weight of raisins was made by weighing two average samples of 1,000 raisins taken from each drying test. 
Assuming that the total number of grapes does not vary during the ripening, the average weight of 1,000 raisins of each set should furnish a measure of the increase of crop.

Table V. Increase of Crop of Raisins with Increase of Ripeness of Grapes.

(Observed.)

\begin{tabular}{|c|c|c|}
\hline \multicolumn{3}{|c|}{ Muscat-Kearney, 1913.} \\
\hline Bal. ${ }^{\circ}$ & Lbs. per Acre & Per Cent \\
\hline 21.00 & 2,000 & 100.00 \\
\hline 23.90 & 2,365 & 118.25 \\
\hline 25.50 & 2,408 & 120.40 \\
\hline 26.75 & 2,648 & 132.40 \\
\hline 28.75 & 2,732 & 136.60 \\
\hline era & ncrease pe & $10^{\circ} 4$ \\
\hline Sul & anina-Kearne & 1914. \\
\hline Bal. ${ }^{\circ}$ & Lbs. per Acre & Per Cent \\
\hline 21.0 & 3,800 & 100.00 \\
\hline 21.8 & 4,244 & 111.68 \\
\hline 22.4 & 4,565 & 120.13 \\
\hline 23.0 & 4,565 & 120.13 \\
\hline 24.0 & 4,740 & 124.74 \\
\hline 23.6 & 4,686 & 123.32 \\
\hline 25.4 & 5,049 & 132.63 \\
\hline
\end{tabular}

Average increase per Bal. $^{\circ} 7.4 \%$

\begin{tabular}{|c|c|c|}
\hline \multicolumn{3}{|c|}{ Muscat-Kearney, 1914.} \\
\hline Bal. ${ }^{\circ}$ & Lbs. per Acre & Per Cent \\
\hline 18.6 & 2,950 & 100.00 \\
\hline 20.2 & 3,050 & 104.07 \\
\hline 21.8 & 3,032 & 102.78 \\
\hline 23.6 & 3,191 & 108:17 \\
\hline 4.0 & 3,414 & 119.12 \\
\hline 23.8 & 3,876 & 131.40 \\
\hline 26.5 & 4,363 & 147.80 \\
\hline
\end{tabular}

Average increase per $\mathrm{Bal}^{\circ} \overline{6.00 \%}$

\begin{tabular}{|c|c|c|}
\hline \multicolumn{3}{|c|}{ Muscat-Davis, 1914.} \\
\hline Bal. ${ }^{\circ}$ & Lbs. per Acre & Per Cent \\
\hline 21.4 & 2,000 & 100.00 \\
\hline 25.8 & 2,046 & 102.30 \\
\hline 26.1 & 2,074 & 103.70 \\
\hline 26.5 & 2,174 & 108.70 \\
\hline 28.7 & 2,244 & 112.20 \\
\hline
\end{tabular}

Average increase per $\mathrm{Bal}^{\circ} \mathrm{1.7 \%}$

These results are as concordant as could be expected, especially with the Muscat from Kearney. The vines in this case are very uniform and there is little variation in the soil. The Sultanina from Kearney show slightly less regularity, which may be accounted for by the fact that the vines are grafted on different varieties of resistant stocks.

The comparatively low increase in weight of raisins, compared to the increase in Balling degree in the case of the Muscat at Davis, can probably be explained by the gathering of second crop during the later pickings. This would decrease the average size of the raisins. The Balling tests of the grapes before picking were made on only first crop bunches. These tests are more liable to error than the other observations, as it is very difficult to choose a small sample of grapes that will give an exact measure of the ripeness of the whole crop. For this reason, the average increase per Balling degree has been calculated only on the samples at the ends of each series, as the greatest differences are liable to the smallest percentage of error.

The average increase of crop per Balling degree of sugar in the grapes, therefore, appears to be about 5.35 per cent with Muscat and 7.4 per cent with Sultanina in the San Joaquin Valley. This represents an average increase in crop per day of 1.18 per cent for the Muscat and .58 per cent for the Sultanina during the ripening period. 
5. Profits. In estimating the profits, we may assume that all the samples would bring the same price. This is approximately true under present market conditions for all, with the exception of some of the raisins made very early in the season which might be objected to by the dealers.

With this assumption, the gross returns would increase in the same ratio as the crop. The net profits, however, would increase in a greater ratio. The cost of raising the grapes would be the same and the cost of making the raisins larger in the total, but somewhat less per ton. The estimates of the following table have been calculated on this basis. A price of 5 cents per pound has been assumed for the Muscat raisins and 6 cents per pound for the Sultanina. A crop of 2,000 pounds at $20^{\circ} \mathrm{Bal}$, which is a low estimate for a well cared for vineyard in good soil. The cost of raising the grapes, including all fixed and running expenses, such as interest, taxes, depreciation and cultivation has been estimated at $\$ 37.50$ per acre. The cost of making the raisins, including all similar expenses, has been estimated at $\$ 12$ per ton for a crop of one ton per acre, with a suitable decrease for larger crops.

Table VI. Gross and Net Returns from a Muscat Vineyard (One Acre).

(Calculated from experiment data.)

$\begin{array}{cccccc}\text { Bal. } & \text { Lbs. per A. } & \text { Gross Returns } & \text { Cost } & \text { Net Profit } & \text { Increases } \\ 18 & 1,786 & \$ 89.30 & \$ 47.90 & \$ 41.40 & 0.00 \% \\ 19 & 1,893 & 94.65 & 48.70 & 45.95 & 8.57 \\ 20 & 2,000 & 100.00 & 49.50 & 50.50 & 21.98 \\ 21 & 2,107 & 105.35 & 50.19 & 55.16 & 33.24 \\ 22 & 2,214 & 110.70 & 50.88 & 59.82 & 44.49 \\ 23 & 2,321 & 116.05 & 51.57 & 64.48 & 55.75 \\ 24 & 2,428 & 121.40 & 52.26 & 69.14 & 67.00 \\ 25 & 2,535 & 126.75 & 52.95 & 73.80 & 78.26 \\ 26 & 2,642 & 132.10 & 53.64 & 78.46 & 89.52 \\ 27 & 2,749 & 137.45 & 54.33 & 83.12 & 100.77 \\ 28 & 2,856 & 142.80 & 55.02 & 87.78 & 112.03\end{array}$

These tests indicate that between the lowest degree of ripeness at which grapes are ever picked for raisin making, $18^{\circ}$ Bal., and the highest at which it is usually possible, $28^{\circ} \mathrm{Bal}$., there is an actual increase of weight of crop of about 60 per cent, representing an increase of profit, when the raisins will sell at 5 cents, from $\$ 41.40$ per acre to $\$ 87.78$ or 112 per cent. In the absence of extended observations of the degree of ripeness at which growers usually pick their grapes, it is impossible to estimate accurately how much of this profit is lost on the average. A few observations made in vineyards selected at hazard during the vintage of 1913 , however, indicate that it is large. The following table indicates the probable loss in the vineyards selected. A crop of 2,000 pounds of raisins is assumed in each case for a Balling degree of 20 and the crop and net profit estimated for the Balling degree at picking. This is compared with the crop which would have been obtained at $26^{\circ} \mathrm{Bal}$., calculated on the increase found in the experiments. 
Table VII. Loss of Crop by too Early Picking.

(Calculated for one acre.)

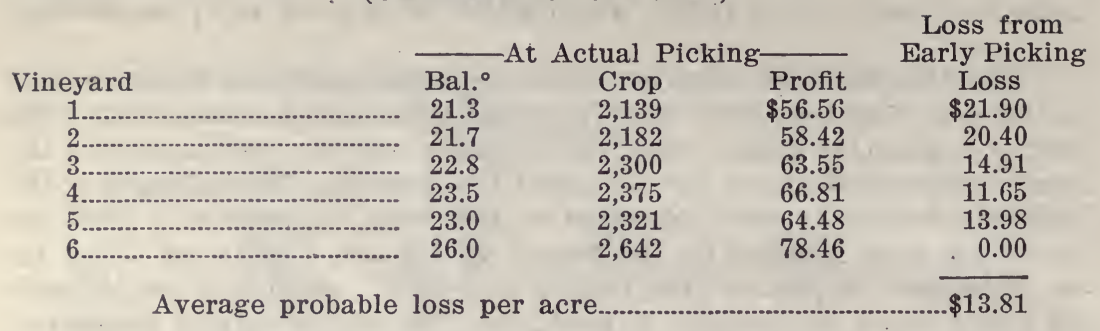

Out of six vineyards only one was found where the grapes were being picked at a sufficiently advanced stage of ripeness. The loss of profit in the others may be fairly estimated to be from $\$ 12$ to $\$ 22$ per acre, or an average of over $\$ 16$, not allowing anything for the inferior quality of the product. Some of this loss is probably unavoidable, owing to the necessity of harvesting the crop when labor for picking is available. Much of it is due, however, to fear of rain, which leads to early picking. If the extent of loss caused by premature harvesting were realized, however, it would be seen in most cases that it pays to run the risk of the expense of extra labor in stacking to protect the drying grapes.

The meteoriological records from 1882 to 1900 show an average monthly rainfall at Fresno in September of .26 inches and for October of .65. During this period the rainfall for September exceeded one inch only twice in the eighteen years and in October six times. Only once was the rainfall in October sufficiently heavy to make it likely that the raisins might not have been saved by stacking. The risk of expense in stacking would, therefore, seem to.be well insured against by the increased profit of allowing the grapes to remain on the vines two or three weeks later than is customary.

The presentation of papers closed with that of Mr. Hiram Dewey. In it he spoke of the port wine coming from a section of Spain. Mr. Manuel Roldan, Commissioner General to the Panama-Pacific International Exposition from Portugal, was in the audience and good-naturedly took exception to the identification of port wine with Spain. He spoke of his country, Portugal, in glowing terms and gave the Congress to understand that his native land was the home of port wine, and that the wine indeed had derived its name from the famous city of Oporto.

President Alwood asked for a word of greeting for the Congress from the representatives of foreign countries who were present.

Mr. I. Nagasawa, manager of the Fountain Grove Vineyard at Santa Rosa, California, who responded on behalf of Japan, spoke as follows:

"Mr. President and Distinguished Delegates to the International Congress of Viticulture. It gives me great pleasure to have this opportunity of welcoming you all to this wonderful exposition of great accomplishment and high ideals, and to this State of golden opportunities, where I have been engaged in the viticultural industry for the last forty years, where I have 
given the vitality of my whole life to the industry in which we are all interested. And as one born in Japan, I bring to you the best of greetings from the Island Empire across the Pacific. I bring greetings from the old country, where "sake" distilled from rice has constituted the national beverage for many, many centuries. Greetings to you from that country new in wine industry-new because they only learned the art of making. wine about a decade ago, though the neighborhood of Kofu, in Yamanashi Prefecture, has for some time been famed for the production of grapes for the table. Viticulture is yet in its infancy in Japan. Aside from the place just mentioned there are only two vineyards in all Japan worthy of mention: one at Iwahara, in the province of Echigo, cultivated by Kawakami Zembei, an enthusiast, who has been experimenting with about 300 different grapes he imported from France, and the other at Ushiku, in Chiba Prefecture, owned hy Kamiya Dembei. While the consumption of wine is steadily increasing in Japan, the wine industry has not made much headway on account of climatic disadvantages and for other reasons. Yet efforts are being made to overcome difficulties and surmount obstacles, as it has been the case with many things in which she has succeeded. Thus I bring greetings and good will to you all from the nation which has found supreme p'easure in overcoming difficulties with its ideals ever fixed upon the ethereal plane of success."

Mr. Manuel Roldan extended greetings in the name of the Government of Portugal. 


\section{AFTERNOON SESSION, JULY 13, 1915.}

Meeting called to order by the president, who introduced Mr. Charles A. Vogelsang, Exposition Commissioner.

Mr. Vogelsang: "I want to say on behalf of President Moore and the directors of the Panama-Pacific International Exposition that you are most welcome here. Congresses representing every line of human endeavor have been gathered here and are still to come. We feel that international congresses representing every line of human activity will not be frequent in the future. They may take some particular line, but here you have the honor and pleasure of gathering here at this time when we are celebrating in the United States an International Exposition commemorating an event that is without parallel so far as its physical and engineering achievement is concerned. You come here at a time when a realization of the dreams of Cabrillo and Balboa has come true. It was left to the American people to accomplish that end.

"This Viticultural Congress is one of the most successful that has been held at the Exposition. You represent a very important industry that had its beginning almost in the very dawn of civilization. Personally, I hope to see a continuance of it always.

"This Exposition desires to recognize the industry that you represent, that has a history dating so far back and this history contributing to the harmony, good feeling and friendliness of the human race should be properly recognized. We have had all kinds of congresses, educational, commercial, etc., and it seems to me that yours is just as important.

"On behalf of President Moore and the Exposition, and in commemoration of this day and this hour, because it is a momentous period in the world's history, to you who are assembled here in harmony and peace where all is music, flowers and architectural achievement, we welcome you. We want to show our respect for your organization and industry by presenting this little memento. It is not of diamonds or of gold, but of enduring quality - of bronze-and in commemoration of the Panama-Pacific International Exposition at San Francisco.

"I trust you will take this medal; keep it and preserve it in memory of this day and hour."

President Alwood: "On behalf of the International Commission of Viticulture, and on behalf of this Congress and all others here assembled, I receive this commemorative medal with great pleasure and we shall treasure it carefully and show it with pride to our brethren. who for very serious reasons cannot be with us here to receive it for themselves. It is a great pleasure for me to say that in my long experience as a member of the International Viticultural Commission never has such an event occurred; never has anybody, or State, or Government presented us with an emblem commemorative of such an occasion. We have been received frequently by royalty and given other honors, but as for enduring remembrances, these we have never before received. This testimonial in bronze will endure during our lives, and the lives of our children also. 
"It is also a great pleasure, Mr. Commissioner, for me to say that among all the surroundings where we have met in other countries it has never been our pleasure to meet in such surroundings as we have here. I have been present at nearly all the expositions for the past thirty years, and I wish to testify that you have created here a Wonderland, both in building and in landscape gardening. It is unsurpassed, and $\mathrm{I}$ do not believe that there will ever again be an exposition that can approach this wonderful Exposition. Therefore, amid this wonderful scene that shows the dreams of men come true, we accept with great pleasure the testimonial you have handed us."

The President called for the report of the Committee of Resolutions.

Mr. C. E. Bundschu, of San Francisco, chairman, presented the resolutions in the following order.

Whereas, This International Congress of Viticulture, assembled in San Francisco, July 12 th and 13th, 1915, learns with deep regret and sorrow of the untimely decease of Mr. Henry Lachman, of Mission San Jose, California, known and revered throughout the viticultural world as one of the foremost exponents of viticulture and its many branches; therefore, be it

Resolved, That the Secretary of the Internaional Congress of Viticulture express to the family of our departed and loved friend the great regret we feel at his taking away, and the sympathy we wish to extend to them and to the many friends who are with them in their bereavement.

Moved by Mr. George E. Lawrence, of Lodi, Cal., that the resolution be adopted. Motion seconded by Mr. Sophus Federspeil. Carried by a standing vote.

Mr. Lachman's death occurred on July 10 , on the eve of the assembling of the Congress.

\section{Resolution No. 2.}

Whereas, Since the American Commission of the International Viticultural Congress was organized, it has lost by death Mr. T. V. Munson, of Denison, Texas; Dr. Ludwig Basserman-Jordan, of Neudtadt-Rhein Pflaz, Germany; Dr. Clemente Grimaldi, of Modica, Sicily; M. Battanchon, Inspector General of Agriculture of France, and other of its distinguished and honored colleagues;

Resolved, By the members of the Congress assembled.in San Francisco, Califorria, July 12 th and 13 th, 1915 , that they hereby record their sincere regret.over this loss to their families and their countries, and also the loss to the viticultural industry of the world.

Moved by Mr. George E. Lawrence, of Lodi, Cal., that the resolution be adopted. Seconded by Mr. Sheridan Peterson, of Santa Rosa, Cal.

Adopted by a rising vote.

\section{Resolution No. 3.}

Whereas, On account of the great conflict now going on in Europe, many of our foreign colleagues are unable to attend this Congress as they had planned and expected to do; therefore, be it 
Resolved, That we deeply regret the enforced absence of our European associates, and we venture to express the hope that out of their present trouble will come lasting peace and unity.

Moved by Mr. E. M. Sheehan, of Sacramento, Cal., that the resolution be adopted. Seconded by Mr. Hiram Dewey, of New York.

Motion carried.

Resolution No. 4.

Whereas, The International Congress of Viticulture, in convention assembled in San Francisco, California, this 13th day of July, 1915, has had its official attention called to a condition existing in the United States inimical to the industrial welfare of grape growers and wine makers throughout the United States, resulting from the infliction by the Federal Government of an impessible tax on brandy used in the fortification of sweet wines; and

Whereas, After carefully listening to a statement of these conditions presented in paper No, 1 at this convention by Mr. E. M. Sheehan, Secretary of the California State Board of Viticultural Commissioners, followed by a thorough discussion of the subject by delegates attending the Congress, we believe that a great hardship has been placed on the viticultural interests of the United States, which, if continued, will result in the destruction of the sweet wine industry and great commercial depression in the dry wine, table grape and raisin producing sections of the entire country and of California particularly; therefore, be it

Resolved, That it is the sentiment of this International Congress of Viticulture that immediate steps be taken by all honorable and legitimate means to right the great wrong that has been done that we commend to fullest extent the effort that is being made under the auspices of the State Board of Viticultural Commissioners of California by way of prevailing on the Federal Government of the United States to repeal or amend the existing Emergency War Revenue Act of October 22, 1914; and that we pledge our earnest support and influence in the accomplishment of this great work which is aimed at saving the vineyard properties of this country.

Moved by Mr. Sheridan Peterson, of Santa Rosa, Cal., that the resolution be adopted as read. Seconded by Mr. Hiram Dewey, of New York.

Resolution adopted by a unanimous vote.

\section{Resolution No. 5 .}

Whereas, It has been the long established policy both of the State and Federal governments to extend every encouragement and help to the growers of grapes and makers of wine; and

Whereas, This policy has resulted in the development of viticulture in many States of the Union, thus adding greatly to the Nation's wealth, resources, employment and revenue; therefore, be it

Resolved, By the International Congress of Viticulture in meeting assembled that we appeal to the people of the United States to urge upon their representatives in the State Legislatures and in Congress to give increased support to the vineyard industry and technical investigations pertaining thereto. 
Moved by Mr. Lee J. Vance, of New York, that the resolution be adopted. Seconded by Mr. Lee Korbel, of Guerneville, Cal.

Resolution adopted.

Resolution No. 6 .

Whereas, Several States have recently passed prohibitory laws that make no distinction between light wines and the stronger liquors; and

Whereas, This legislation is based on a lack of knowledge by the voters and the legislators as to the true merits of wine as a food, a tonic and a beverage; therefore, be it

Resolved, By the International Congress of Viticulture in meeting assembled in Recital Hall, in Festival Hall, at the Panama-Pacific International Exposition, that we strongly recommend a campaign of education that shall teach the people of the United States the use of wine at the table with meals, the same as has been done for centuries by millions of people in Europe.

Moved by Mr. William B. Alwood, of Charlottesville, Va., that the resolution be adopted as read. Seconded by Mr. Sheridan Peterson, of Santa Rosa, Cal. Motion carried.

\section{Resolution No. 7.}

Whereas, A campaign of destruction against the growers of grapes and makers of wine is being waged by organizations led by professional agitators; and

Whereas, The effect of such agitation has resulted in the depreciation of millions of dollars of taxable property in the United States and has thrown out of employment thousands of men engaged in an agricultural pursuit; therefore, be it

Resolved, By the International Congress of Viticulture in meeting assembled in Recital Hall, at the Panama-Pacific International Exposition, that we denounce this so-called crusade, because it is practically a confiscation of property without just compensation.

Moved by Mr. George E. Lawrence, of Lodi, Cal., that the resolution be adopted. Seconded by Mr. R. W. Bettoli, of San Francisco.

Resolution adopted.

\section{Resolution No. 8}

Whereas, The members of the International Congress of Viticulture from the State of California extended such a splendid welcome and have shown such whole-souled hospitality; therefore, be it

Resolved, That the visiting delegates to the Congress hereby express their deep appreciation and their hearty thanks for all the many courtesies and entertainments offered by the California members, and they assure them that they will carry away the most delightful recollections of their visit and association with their California brethren.

Resolution introduced by Mr. Hiram Dewey, of New York:

Resolution adopted.

Mr. Federspiel. "I had the pleasure of meeting the Eastern delegation at Fresno, and on behalf of the California members I want to say a few words.

"It was our intention to show them what California can produce. Los Angeles and the southern part of the State had already shown them the 
beautiful vineyards and orange groves of Riverside and San Bernardino counties. I then told them that while they had seen the southern part of California, that we would undertake to show them the northern part, and I felt assured that they would be as pleased with the northern part of the State as they had been with the other districts. It has certainly been a pleasure to us Californians to welcome our Eastern guests, and I hope that they will carry away with them fondest recollections of the friends that they have made here, and that they will all have an opportunity of coming back to us some time in the future."

\section{UNFINISHED BUSINESS.}

Mr. Sheehan: "For the benefit of those who are present here today and did not attend the preliminary meeting of the officers of the Congress held last Sunday morning, I want to state that one matter of very vital importance was taken up at that meeting, and that was the publication of the proceedings of this Congress, including all of the papers submitted and read whether in full or by abstract or by title.

"At this meeting President Alwood, who has kept in touch with the finances of the Congress through the Treasurer, stated that there was not enough money in the treasury to pay for publishing a report; and that some means would have to be devised to raise this money.

"I think all of you will agree that every paper submitted at this Con. gress should appear later on in printed form in connection with a general report of the proceedings. I do not know of anything, for instance, that would be more useful in libraries, more up to date and more timely than a report of these proceedings, including the very excellent papers that have been delivered here. There is scarcely a question that might be asked in relation to viticulture that could not- be answered in one or more of the papers that have been submitted here.

"In California, a number of the wine makers imagine they are rich. At any rate, the State Board of Viticultural Commissioners believes that it is so important a topic at this time, and that the publication of the report should be assured without a doubt, that I have been asked to state to you that the furnishing of money necessary to affect the publication of this report will be guaranteed to the extent of $\$ 200$ by the State Board of Viticultural Commissioners of California."

President Alwood: "Mr. Secretary of the State Board of Viticultural Commissioners of California, I think the business of the Congress is finished and this order has been disposed of by the very generous action of your Board. I am relieved of the matter of begging, and we sincerely thank you."

President Alwood: “Dr. Cleonthes Vassardakis, Consul General for Greece and Commissioner to the Exposition, is the delegate from Greece to this convention. I have asked him at this time to say a word of greeting to us before we adjourn. I take great pleasure in introducing Mr. Vassardakis." 
Mr. Vassardakis: "It would have been unjustifiable had Greece not taken part in this International Congress of Viticulture to extend to you greetings and welcome. Our country was the first to make wine from the grape and the ancient Greeks for several centuries gave preference to wine made from dried to that made from fresh grapes. Theophrastus says that the islanders of Chio were the first to plant the vine and to make wine from the grape; an art which was imparted to them by Enopœos, the son of Bacchus, and which they afterward taught to other mortals.

"Ar.other legend has it that Bacchus taught the art to Icarus as a reward for his hospitality to the vine-garlanded god.

"I haven't time to tell you of the methods we employ in the making of wine and of the enemies that attack the vine. As you are probably aware, in my country only, and in a few aistricts of Greece, can the wholesome and delicious currant be grown, and that all attempts to transplant the currantvine in other lands of nearly similar climatic conditions, such as Asia Minor, Sicily, California, and others, have failed. In Greece itself it thrives only on a narrow strip of land. near the southern shore of the Gulf of Corinth, and on four of the Ionian Islands.

"Pliny, writing in the first century of the Christian era, mentions the tiny Greek grape, of fine quality and of thin skin. Be this as it may, the Greeks of the present day will hear of no other land as the mother of the currantvine than the classic plains of Corinth, from which the product derives its Greek name, meaning 'Corinthian Raisins,' of which the English word 'currants' is, no doubt, a slight corruption.

"In the name of my country I invite you cordially to hold your next meeting in Athens, in 1921. We will extend to you one of the most cordial of welcomes, and I hope this invitation will be accepted.

"I also invite you to be present tomorrow afternoon at the opening ceremonies of the Grecian Pavilion, where there will be a production by La Loie Fuller-a Grecian garden fete-around Phidias' statute of Pallas Athene, and concluding with a performance of the Worship of Pan."

President Alwood: "Before adjournment, I shall take time to say a few words.

"Possibly it may come in bad grace from me to say that the Congress, notwithstanding the unfortunate world disturbances that have hindered its proper organization, has proven a success. I wish someone else would say this, but as no one else seems inclined to do so, I must say it myself. It has not been what it might have been had we had with us our able colleagues from across the water, but we have shown that Americans can hold a viticultural congress.

"We have had with us our brother from Portugal, our brother from Greece, and our brother from Japan and are proud and glad, and if our colleagues from other foreign countries cou!d have been with us, we would have had a most successful congress indeed. 
"As it is, we are entitled to congratulate ourselves upon the matter that has been presented here, and in saying this I wish to mention especially the names of certain men who have performed a very useful part in this work.

"Of the California people, your able chairman, Mr. C. J. Wetmore, Mr. S. Federspiel, Mr. Stoll and Mr. Sheehan, and I am going to add Professor Bioletti, who insists that he is not one of the officers, but who has been a most potent factor in handling our program.

"Of the Eastern men, I may mention first of all the man whom all of you know, Mr. William Culman, who has been our very efficient treasurer and who has worked hard and loyally to make this Congress a success; Mr. H. S. Dewey, of New York, who has been a four-horse team in the work of this Congress; Messrs, Hildreth and Emerson, who could not attend; Mr. Lee J. Vance, who is always on time everywhere; Professor Hedrick, who largely arranged the program. He expected to be with us, but the opportunity to secure a long needed vacation occurred and he very properly accepted it. To these gentlemen, the moving spirits behind the scenes, belongs all the credit for making this Congress a success.

"I trust you will try to attend other Congresses in other countries where they may be held in the future. I am satisfied that if you would take part in these International Congresses it would help immensely to broaden your ideals of viticulture and give you new conceptions of the splendid work and the splendid position viticulture holds in the industries of the world. Gentlemen, I thank you sincerely for the courtesy you have given me."

Mr. E. M. Sheehan: "I move you that a special vote of thanks be given President Alwood for the able manner in which he has conducted the Congress at its deliberations here."

Motion carried by a standing vote.

President Alwood: "I thank you sincerely, and no other words are neces. sary. The Congress is adjourned." 


\section{ENTERTAINMENT OF DELEGA'TES \\ TO INTERNATIONAI, CONGRESS OF VITICILTURE.}

Elaborate preparations were made for the entertainment of the Eastern and foreign delegates who visted California to attend the International Congress of Viticulture, held in San Francisco, on July 12th and 13th.

In addition to seeing the Expositions at San Diego and San Francisco, they had an excellent opportunity to inspect important vineyards and wineries in Riverside, San Bernardino, Fresno, Contra Costa and Sonoma counties.

On their arrival at Los Angeles on July ith, the delegates were given their first taste of California hospitality at the banquet in the Hotel Alexandria, where many important grape growers, wine makers and public officials welcomed them to California.

On Thursday, July 8th, the delegates inspected the beauties of the Panama-California Exposition at San Diego, and bright and early the next morning they were back again in Los Angeles. At the depot they were met by automobiles and whisked out to the Chas. Stern \& Sons' winery, at Wineville, in Riverside County, and then taken to the Italian Vineyard Company's immense plant at Guasti, in San Bernardino County. There a novel luncheon was served in the huge storage cellars.

On Friday, July 9th, the delegates departed for Fresno, where they were shown not only the important sweet wine plants, but also the raisin grape vineyards and the big packing houses. In the evening a banquet was tendered them in the Hotel Fresno.

On Sunday morning, July 11th, the delegates reached San Francisco and were welcomed by a committee of Northern California wine men. At 10 o'clock the officers and chairmen of the various committees of the International Viticultural Congress met with Professor William B. Alwood, at the Hotel Bellevue, for a general conference, and after all details had been arranged the guests were taken in automobiles on a sightseeing trip around San Francisco.

On Tuesday evening, July 13th, about 300 delegates and their wives attended a notable banquet, given at Tait's Pavo Real. A number of distinguished city, State and foreign guests of honor were present and some excellent speeches were enjoyed. Only Californian wines were served. All sorts of novelties were planned for the banquet, and at 10 o'clock the floor was cleared and dancing was in order.

On Wednesday morning, July 14th, the visitors were taken on a trip around San Francisco Bay to Winehaven, where they inspected the great plant of the California Wine Association. At 1 o'clock they were landed at the 
Exposition grounds, met by Fadgl cars and taken to Old Faithful Inn for luncheon. About 200 guests were present. Impromptu speeches were given by leading wine men and Mrs. Abigail Scott Duniway, the most distinguished woman citizen of Oregon. A commemorative bronze medal was presented to the California Viticultural Exhibit Association by Charles E. Vogelsang, representing the Exposition.

Following the luncheon the delegates were taken to the Court of Ceres to witness an open air "Wine Day" program.

Later they visited the "Grape Temple" of the California Viticultural Exhibit Association in the Food Products Palace, where wine punch was served to over 10,000 people.

At 4.30 o'clock the Eastern delegates assembled in the service room of the "Grape Temple" to meet Thomas G. Stallsmith, Chief of Agriculture, who presented a commemorative bronze medal to the American Wine Growers' Association.

On Thursday morning, July 15th, at 7:45 o'clock, the delegates left for Asti, in Sonoma County. En route they stopped at Petaluma and inspected the Lachman \& Jacobi plant, enjoying a buffet luncheon on the lawn in the patio.

When the delegates reached Asti, they were first shown the important features of the Italian Swiss Colony winery, including the great storage tank with a capacity of 500,000 gallons, and the champagne plant, under the management of Charles Jadeau.

Luncheon was served under the great vine arbor in the grounds adjoining Cav. Andrea Sbarboro's Villa Pompeii, where moving pictures were taken of the assembled delegates.

The trip to Asti conc'uded the formal entertainment of the visitors, who during the next few days returned to their homes in the East and the different viticultural sections of California. 





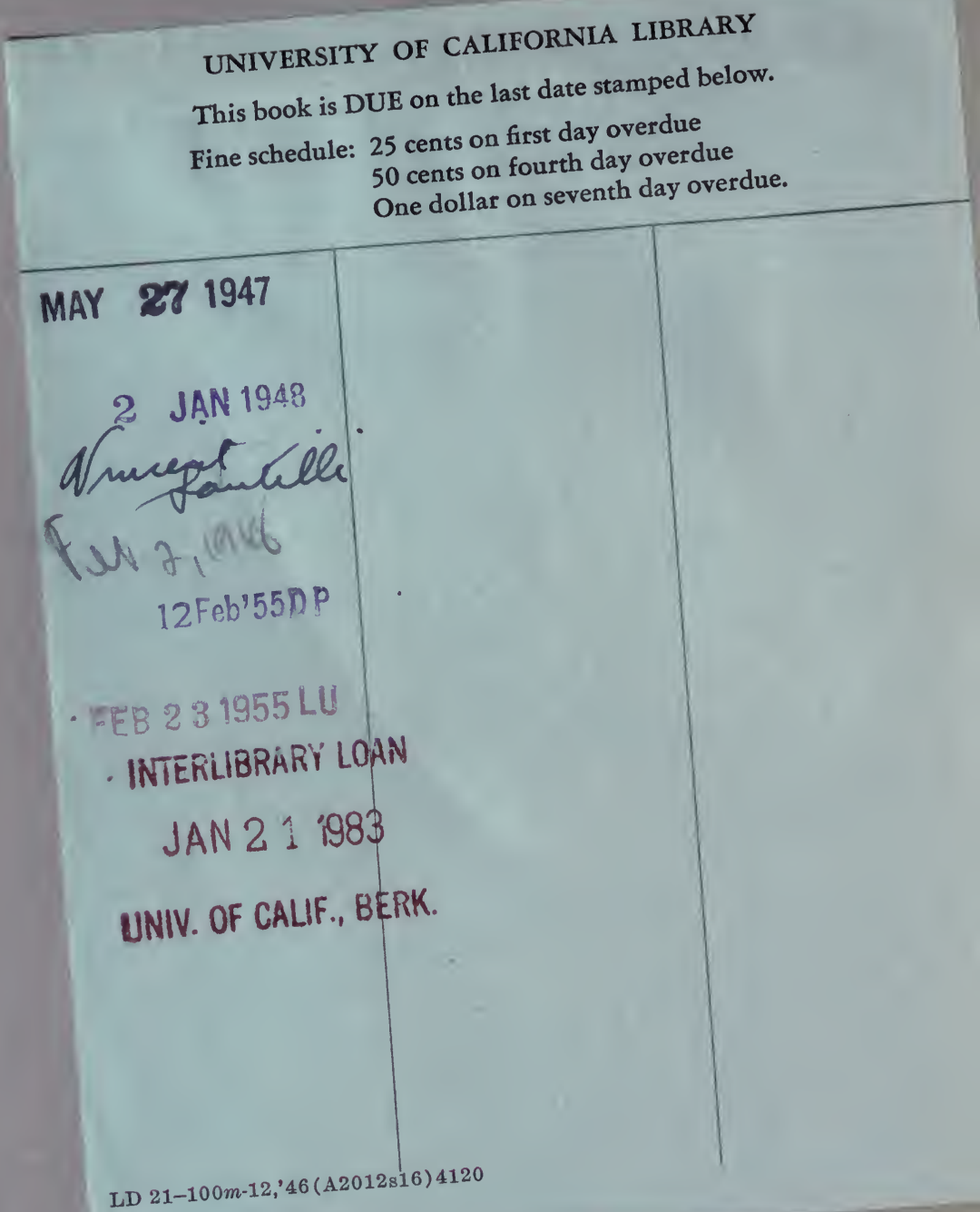




\section{YC 11811}

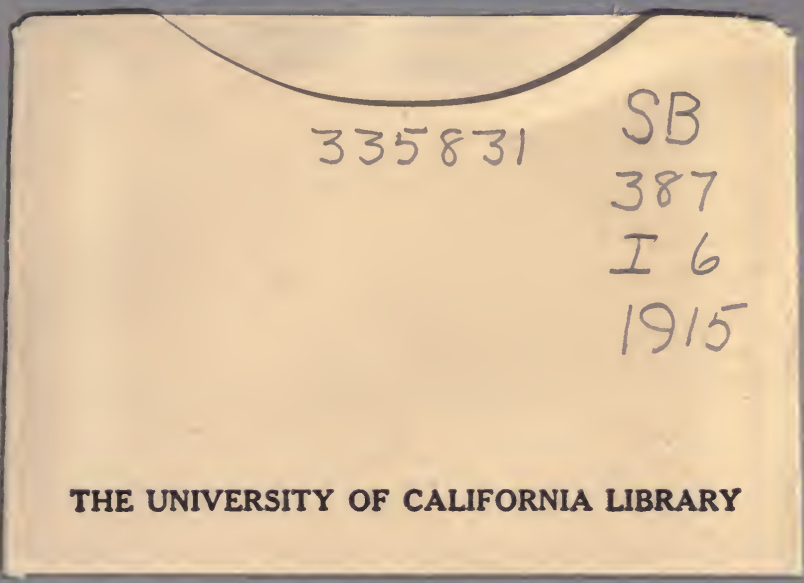


